\title{
A Study of Brine Treatment
}

\author{
EPRI ER-476 \\ Research Project 791-1 \\ LBL-6371 \\ UC-66d \\ TID-4500-R65
}

Final Report, November 1977

\section{Prepared by}

\section{LAWRENCE BERKELEY LABORATORY \\ University of California \\ Berkeley, California 94720}

(Operating under

U.S. Energy Research \& Development Administration

Contract No. W-7405-ENG-48)

Principal Investigators

Sidney L. Phillips

Ashwani K. Mathur

Raymond E. Doebler

This report was prepared as an account of work sponsored by the United States Government. Neither the

United States not the United States Department of

Energy, nor any of their employees, nor any of their

contractors, subcontractors, or their employees, makes

ny warranty, express or implied, or assumes any legal

liability or responsibility for the accuracy, completeness

or usefulness of any information, apparatus, product or

process disclosed, or represents that its use woutd not

infringe privately owned rights.

\section{Prepared for}

Electric Power Research Institute

3412 Hillview Avenue

Palo Alto, California 94304

EPRI Project Manager

Phillip N. La Mori 


\section{DISCLAIMER}

This report was prepared as an account of work sponsored by an agency of the United States Government. Neither the United States Government nor any agency Thereof, nor any of their employees, makes any warranty, express or implied, or assumes any legal liability or responsibility for the accuracy, completeness, or usefulness of any information, apparatus, product, or process disclosed, or represents that its use would not infringe privately owned rights. Reference herein to any specific commercial product, process, or service by trade name, trademark, manufacturer, or otherwise does not necessarily constitute or imply its endorsement, recommendation, or favoring by the United States Government or any agency thereof. The views and opinions of authors expressed herein do not necessarily state or reflect those of the United States Government or any agency thereof. 


\section{DISCLAIMER}

Portions of this document may be illegible in electronic image products. Images are produced from the best available original document. 
LEGAL NOTICE

This report was prepared by Lawrence Berkeley Laboratory (LBL), as an account of work sponsored by the Electric Power Research Institute, Inc. (EPRI). Neither EPRI, members of EPRI, LBL, nor any person acting on behalf of either: (a) makes any warranty or representation, express or implied, with respect to the accuracy, completeness, or usefulness of the information contained in this report, or that the use of any information, apparatus, method, or process disclosed in this report may not infringe privately owned rights; or (b) assumes any liabilities with respect to the use of, or for damages resulting from the use of, any information, apparatus, method, or process disclosed in this report.

Furthermore this report was done with support from the United States Energy Research and Development Administration. Any conclusions or opinions expressed in this report represent solely those of the author(s) and not necessarily those of The Regents of the University of California, the Lawrence Berkeley Laboratory or the United States Energy Research and Development Administration. 


\section{ABSTRACT}

The objective of this project was to collect the available information pertinent to the treatment of geothermal brines by literature search and then evaluate and summarize this information for use by the electric utility and geothermal industry.

The information used for this study was screened from the geothermal, oil and gas, wastewater disposal, and boiler water treatment industries. This information was evaluated and the current state of knowledge and methodology concerning the treatment of geothermal brines to control scaling and corrosion in geothermal electric power production was assessed. Currently, geothermal scale in pipes and wells is removed by physical or chemical methods. There is a growing effort on developing methods to control scale formation for both fresh and spent brines, including $\mathrm{pH}$ adjustment and application of an electrical potential for fresh fluids, and coagulation to treat spent fluids. Current methods of corrosion control center around planned replacement of piping and other plant components, with efforts focused primarily on development of materials with improved corrosion resistance. Recommendations for additional work to improve brine treatment include the following:

1) Chemical and physical characterization of brine and scale compositions

2) Basic data on the mechanism of scale formation and the effects of inhibitors

3) Development of instrumentation to monitor geothermal brine constituents

4) Correlation of laboratory results with field test data

5) Screening of currently available commercial inhibitors for application to geothermal brines

An annotated bibliography of the reference material used in this study is contained in this report. 


\section{ACKNOWLEDGMENT}

The authors are thankful to Arnold E. Greenberg, State of California Department of Health, Berkeley, CA; Phillip N. La Mori, Electric Power Research Institute, Palo Alto, CA; Daniel A. McLean, East Bay Municipal Utility District, Oakland, CA; Lawrence B. Owen, Lawrence Livermore Laboratory, Livermore, CA, and Donald W. Shannon, Battelle Pacific Northwest Laboratories, Richland, WA, for their comments. 


\section{CONTENTS}

Section

Page

1 INTRODUCTION

$1-1$

2 SCOPE OF STUDY

2-1

Brine Treatment for Scale Control

$2-1$

Brine Treatment for Corrosion Control

$2-2$

3 BRINE TREATMENT FOR SCALE CONTROL

3-1

Fresh Fluid Treatment

3-1

Silica Treatment Methods

$3-1$

Sulfide Treatment Methods

$3-7$

Calcite Treatment Methods

$3-10$

Spent Fluid Treatment

$3-12$

Silica Treatment Methods

$3-13$

Calcite Treatment Methods

4 BRINE TREATMENT FOR CORROSION CONTROL

4-1

Aeration and Degasification

4-3

Materials Selection

4-4

5 SCALE AND INCRUSTANTS REMOVAL

$5-1$

Acidizing

$5-1$

Addition of Base

$5-4$

Reaming

$5-4$

Cavitation Descaling and Hydroblasting

$5-5$

Thermal Shock

5-6

0 il Injection

$5-6$

Scaling Control by Magnetic Field

$5-9$

Summary

$5-9$

6 SUMMARY AND RECOMMENDATIONS

$6-1$

7 REFERENCES

$7-1$

8 GLOSSARY OF TYPICAL BRINE TREATMENT TERMS

$8-1$

APPENDIX A: Basic Water Treatment Processes

A-1

APPENDIX B: Annotated Bibliography

B-1 
$\ominus$

$\bullet$
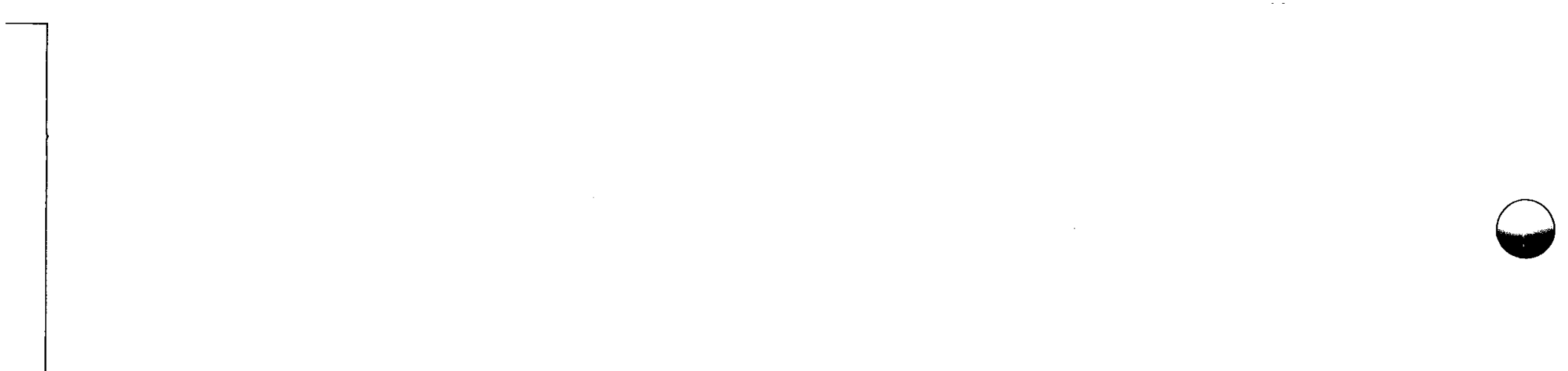


\section{FIGURES}

3-1 Solubilities of various silica phases along two-phase curve

(water plus vapor, $\mathrm{pH}=7.0$ ).

3-2 Solubility of silica in water $\left(25^{\circ} \mathrm{C}\right)$.

3-3 Schematic diagram of typical reactions in sulfide scale formation. 3-8

3-4 Thermometry and thickness of $\mathrm{CaCO}_{3}$ layer formed within 6 hours in a drillhole in the Bolshe-Banny area, Kamchatka, USSR.

3-5 Surface design for pretreatment of wastes where extensive treatment cleanup is required prior to subsurface injection.

3-6 Suspended-solids contact unit.

3-7 Sketch of pilot plant adapted for continuous operation in Broadlands, New Zealand.

3-8 Kinetics of silica solubility. Representative runs showing approach to the solubility equilibrium from both sides. Temperature $22-27^{\circ} \mathrm{C}$.

3-9 Experimental retaining tank to control silica scale in hot water pipes, Otake Geothermal Plant, Japan.

3-10 Effect of $\mathrm{pH}$ on chelating power of EDTA. 3-27

3-11 Influence of $\mathrm{pH}$ on the chelating power of some iror sequestrants. 3-29

3-12 Influence of $\mathrm{pH}$ on the chelating power of some calcium sequestrants. 3-29

4-1 Effect of catalysts on rate of oxygen-sulfite reaction. 4-4

5-1 Profile of scale in Well M-13, Cerro Prieto Geothermal Field, Mexico.

5-2 Part of the temperature record for Run 303 showing the thermal shock effecting descaling in Fig. 5-3.

5-3 Effect of thermal shock on scale resistance. Heat transfer scale resistance for Run 303 . 
$\bullet$

。

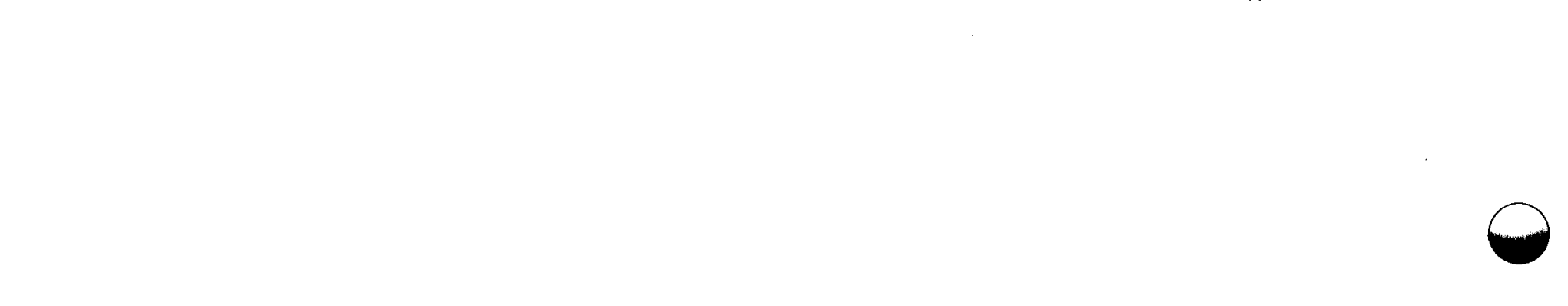




\section{TABLES}

1-1 Important parameters affecting scaling and corrosion in geothermal plants.

Page

$1-3$

1-2 Nominal concentrations of gases in geotherma' l brines (ppm). 1-3

1-3 Approximate concentrations of dissolved solids in selected geothermal waters compared with seawater and oilfield brines.

$1-4$

2-1 Description of typical brine as delivered to test unit from East Mesa Wel1 6-1 between $3 / 18 / 74$ and $4 / 9 / 74$.

2-2 Chemical composition of scales from East Mesa Well 6-1 brine. 2-3

2-3 Chemical compositions of geothermal water of No. 1 and No. 2 wells (ppm), Matsukawa, Japan.

2-4 Chemical compositions of scale in No. 1 and No. 2 wells (\%), Matsukawa Japan.

2-5 Chemical composition of scale (\%) in geothermal power plant, Matsukawa, Japan.

2-6 Chemical composition of the fluids flowing from the Cerro Prieto wells, Mexico.

2-7 Chemical analyses of well casing incrustations, Cerro Prieto, Mexico. 2-7

2-8 Chemical composition of scale in production pipe of Well M-9 (750731) at 147-170 meters, Cerro Prieto, Mexico.

3-1 Typical treatment methods to control scale formation; treatment methods for spent fluid disposal.

3-2 Spectrochemical analys is report.

3-3 Typical treatment methods for spent geothermal brines (suggested or used).

3-4 Common treatment chemicals. 3-14

3-5 Basic pretreatment steps.

3-6 Typical reactions of coagulants with alkaline substances in water. 3-17

3-7 Characteristics of typical coagulants. 3-18

3-8 Analyses of cooled discharge waters from Wairakei and Broadlands
bores, New Zealand. 
3-9 Analyses of discharge waters from Wairakei "mixed bores" (aged $2-1 / 2$ hours) after treatment with slaked lime.

$\underline{\text { Page }}$

$3-20$

3-10 Analyses of discharge waters from Broadlands Bore 22 (aged 1/2 hour) after treatment with slaked lime.

3-11 Chemical analysis of the hot water (ppm), Otake, Japan.

3-12 Analytical results of 0take scales.

3-13 Typical polymetaphosphates used for preventing scale formation.

3-14 Concentration of EDTA and its sodium salts necessary to complex $1 \mathrm{ppm}$ calcium ion, magnesium ion, and barium ion.

4-1 Surface corrosion rates of metals in geothermal media. 4-2

4-2 Corrosion data at $105^{\circ} \mathrm{C}$ and $1 \mathrm{~atm}, 15$ days.

4-3 Corrosion data in deaerated $\mathrm{Niland}(28 \mathrm{w} / \mathrm{O})$ brine at $232^{\circ} \mathrm{C}$, 15 days.

4-4 Corrosion resistant candidate materials for oxygen-free geothermal sys tems.

5-1 Typical treatment methods for scale removal. 
Section 1

INTRODUCTION

Utilization of geothermal energy for power production requires a fluid (e.g., brine) to extract heat from the earth. Major development of geothermal energy in the next 25 years will be in regions where the fluid occurs naturally and has been in contact with the country rocks for a considerable period of time. The chemical composition of the fluids will therefore reflect the composition of the country rock and in general be in chemical equilibrium with it. Because of the wide variety in rock types, the composition of geothermal fluids is expected to vary widely, ranging from several thousand to several hundred thousand $\mathrm{ppm}$ dissolved solids combined with dissolved gases (e.g., $\mathrm{CO}_{2}, \mathrm{H}_{2} \mathrm{~S}$ ) in an aqueous solution. The fresh fluids can react with the total geothermal power generation system to cause scaling and corrosion, and may plug injection wells and formations.

Treatment of the fluids by chemical or physical methods could reduce scaling in the power cycle and plugging in the injection cycle. The problem is compounded by the large volume of fluids required for geothermal power production. As a result many chemical treatment systems which can be devised to control scaling and corrosion could be uneconomic. The treatment techniques devised for geothermal brines will have to be of low cost, e.g., additions of ions, catalysts, electric charge, settling, coagulation.

The purpose of this study is to compile and evaluate the current information on brine treatment technology for use by the utility industry and EPRI. The current published worldwide literature on treatment of geothermal brines to control scaling and corrosion is sparse, with information widely scattered and incomplete. For this reason, we have also included in the compilation and drawn on the relevant data from other industries (e.g., boiler water, wastewater disposal, oilfield brines) to provide additional information which may be useful to geothermal brine treatment methodology. 
Scale incrustation is a fairly common occurrence that arises mainly from the deposition of soluble or suspended constituents of geothermal brines in piping and other components of power plants (Ref. 1,2). The interest in controlling scaling stems from two major concerns: (1) plugging of well casings and pipes transporting geothermal hot water, and (2) decrease in the efficiency of heat exchangers and other components. The other main problem related to geothermal hot water utilization covered here is corrosion of metallic components of power plants which are in contact with the fluid. The corrosion process is complicated and related to a number of parameters, including the following: material of construction, chloride concentration, $\mathrm{pH}, \mathrm{CO}_{2}$ partial pressure, $\mathrm{H}_{2} \mathrm{~S}$ partial pressure, and temperature of the brine. Current methods of dealing with corrosion center around either scheduled replacement of plant components or the selection and choice of suitable resistant materials (Ref. 3). Table 1-1 lists the principal parameters affecting geothermal scaling and corrosion.

Data on brine chemistry are important because scale and corrosion treatment methods must be designed on the basis of the brine constituent (e.g., sulfide content) that should be changed by the treatment to control scaling and corrosion. The dissolved solids and gases content of selected geothermal brines are listed in Table 1-2 and Table 1-3.

While it is our intent that this report be as comprehensive as possible, it is realized that no literature search can be totally complete. In this context, the reader is urged to communicate important omissions on geothermal brine treatment to the National Geothermal Information Resource, Lawrence Berkeley Laboratory, University of California, Berkeley, CA 94720. This additional information, together with new data, will be stored in our computer file for subsequent critical evaluation and general dissemination.

For additional background information on geothermal scaling and corrosion, the reader is referred to the following: Economic Impact of Corrosion and Scaling Problems in Geothermal Energy Systems (Ref. 2), Silicate Scale Control in Geothermal Brines--Final Report (Ref. 4), Scale Deposition and Control Research for Geothermal Utilization (Ref. 5), Materials Problems Associated with the Development of Geothermal Energy Resources (Ref. 6), Second Workshop on Materials Problems Associated with the Development of Geothermal Energy Systems (Ref. 7), and "Corrosion Encountered in Energy Extraction from Geothermal Brines and Steams" (Ref. 9). 
Table 1-1

IMPORTANT PARAMETERS AFFECTING SCALING AND CORROSION

IN GEOTHERMAL PLANTS

Scale and Incrustation

Brine composition

Temperature and temperature changes

Pressure changes, including partial pressure change in $\mathrm{CO}_{2}, \mathrm{H}_{2} \mathrm{~S}, \mathrm{NH}_{3}$

Velocity and turbulence

Residence time in each part of plant

Surface effects and surface to volume ratio effects

Fluid phase (steam or water)

Geometry of power plant components

Salt carryover in steam phase

Materials Corrosion

Brine composition

$\mathrm{pH}$ of fluid

Temperature and temperature changes

Fluid phase (steam or water)

Moisture and soluble salts carryover in steam phase

Partial pressures of $\mathrm{CO}_{2}, \mathrm{H}_{2} \mathrm{~S}, \mathrm{NH}_{3}, \mathrm{H}_{2}$

Atmospheric $\mathrm{O}_{2}$ leakage into plant sys tem (e.g., piping, condenser, heat exchanger)

Stress levels in materials and especially cyclic stresses

Crevices

Presence of scale deposits

Passive or active state of metal protective films

Velocity of fluid

Suspended solids content

Ionic strength of water

Galvanic coupling of dissimilar metals

Power plant material

Table 1-2

NOMINAL CONCENTRATIONS OF GASES IN GEOTHERMAL BRINES (PPM). DATA ARE FOR STANDARD TEMPERATURE AND PRESSURE. (REF. 10)

Iceland

Raft River Boise

New Zealand

(Idaho, USA)

$\begin{array}{lllll}\mathrm{CO}_{2} & 90 & 92 & 16.4 & 0.20 \\ \mathrm{H}_{2} \mathrm{~S} & 2.6 & 4.2 & -- & 0.005 \\ \mathrm{H}_{2} & 2.0 & 1.8 & 0.06 & -- \\ \mathrm{CH}_{4} & 0.03 & 0.9 & 0.01 & 0.065 \\ \mathrm{~N}_{2} & -- & -- & 100 . & 18.5 \\ \mathrm{Ar} & 4.43 & 0.3 & 2.6 & 0.62 \\ \mathrm{O}_{2} & 0.0 & -- & 0.02 & 0.003\end{array}$


Table $1-3$

APPROXIMATE CONCENTRATION OF DISSOLVED SOLIDS IN SELECTED GEOTHERMAL WATERS COMPARED WITH SEANATER AND OILFIELD BRINES

\begin{tabular}{|c|c|c|c|c|c|c|c|c|c|c|c|c|}
\hline & $\begin{array}{l}{ }^{\mathrm{a}} \text { Seawa ter } \\
(\mathrm{mg} / \mathrm{l})\end{array}$ & $\begin{array}{c}\text { Coilfield Brine } \\
(\mathrm{mg} / \mathrm{l})\end{array}$ & $\begin{array}{c}\text { East Mesa, } \\
\text { Calif. } \\
\text { (Holtvilie) } \\
\text { (opm) }\end{array}$ & $\begin{array}{c}\text { dEast Mesa } \\
\text { (Well 6-1) } \\
(\mathrm{mg} / 1)\end{array}$ & $\begin{array}{c}\text { bsalton Sea, } \\
\text { Calif. } \\
\text { (Sinclair \#3) } \\
\text { (ppm) }\end{array}$ & $\begin{array}{c}\text { bSal ton Sea } \\
\text { (Niland \#IID-2) } \\
\text { (ppm) }\end{array}$ & $\begin{array}{l}\text { b Salton Sea } \\
\text { (Woolsey \#1) } \\
(\mathrm{ppm})\end{array}$ & $\begin{array}{c}\text { bSalton Sea } \\
\text { (Magmamax } \# I) \\
(m g / 1)\end{array}$ & $\begin{array}{c}\text { Raft River, } \\
\text { I daho } \\
\text { (RRGE } \# 2) \\
\text { (DPM) }\end{array}$ & $\begin{array}{l}\text { boosevelt } \\
\text { Hot Springs, } \\
\text { Utah ( }(\# 3-1) \\
\text { (pRD) } \\
\end{array}$ & $\begin{array}{l}\text { ad Wairakei, } \\
\text { New Zealand } \\
\text { (ppm) }\end{array}$ & 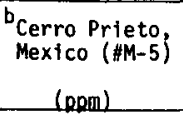 \\
\hline$T^{\circ} \mathrm{C}$ & $16-22$ & -- & $165-180$ & 138 & $280^{\star}$ & $330^{\star}$ & $238^{*}$ & 240 & 126 & $>205$ & 240 & 100 \\
\hline $\mathrm{pH}$ & 8.0 & -- & 7.6 & $5.6-6.0$ & 5.3 & 4.64 & 6.2 & 6.1 & 6.96 & 6.3 & 8.6 & 7.89 \\
\hline $\mathrm{SiO}_{2}$ & 7.0 & -- & 100 & 286 & 350 & 400 & 112 & 435 & 86.8 & 560 & 640 & 1,318 \\
\hline L1 & 0.1 & -- & 55 & 54 & 49 & 210 & 65.0 & 75.6 & 1.1 & 20.0 & 14 & 22.9 \\
\hline B & -- & -- & -- & -- & 210 & 390 & -- & -- & $-\cdot$ & 25.0 & -- & 17.7 \\
\hline $\mathrm{Na}$ & 10,561 & $12,000-150,000$ & 11,000 & 7,050 & 36,340 & 53,000 & 49,257 & 47,300 & 408 & 2,437 & 1,320 & 8,016 \\
\hline k & 380 & $30-4,000$ & 1,430 & 890 & 7,820 & 16,500 & 2,881 & 7,960 & 36 & 448 & 225 & 1,899 \\
\hline $\mathrm{Mg}$ & 1,272 & $500-25,000$ & 22 & 16 & 780 & 10 & 651 & 110 & 0.04 & 0.01 & 0.03 & 0.50 \\
\hline ca & 400 & $1,000-120,000$ & 1,370 & 770 & 14,550 & 27,800 & 8,550 & 23,600 & 27.5 & 8.0 & 17 & 504 \\
\hline $\mathrm{Sr}$ & 13 & -- & 226 & 135 & 360 & 440 & -- & 102 & 0.9 & -- & -- & 15.4 \\
\hline $\mathrm{Ba}$ & 0.05 & -- & 58 & -- & 540 & 250 & -- & 55.3 & $<4$ & -- & $-\cdot$ & 9.4 \\
\hline $\mathrm{F}$ & 1.4 & -- & 1.5 & -- & 2.4 & -- & -- & 12.0 & 7.4 & 5.0 & 8.3 & 2.0 \\
\hline Cl & 18,980 & $20,000-250,000$ & 18,000 & 14,000 & 93,650 & 155,000 & 59,015 & 123,390 & 678 & 4,090 & 8,730 & 14,828 \\
\hline I & -- & $1-300$ & -- & -- & -- & -- & -- & -- & -- & -- & -- & .74 \\
\hline $\mathrm{Br}$ & 380 & $50-5,000$ & 35 & -- & -. & -- & -- & -- & -. & -- & -- & 23.7 \\
\hline $\mathrm{SO}_{4}$ & 2,650 & $0-3,600$ & 16 & 173 & 58 & -- & -- & $<10.0$ & -- & 59 & 36 & 13.0 \\
\hline $\mathrm{HCO}_{3}$ & 140 & $0-1,200$ & -- & -- & 60 & -- & -- & 61.6 & 38 & 180 & 19 & 59.0 \\
\hline $\mathrm{CO}_{3}$ & -- & -- & -- & 300 & -- & 500 & - & -- & -- & -- & -- & 0.0 \\
\hline $\mathrm{NO}_{3}$ or $\mathrm{Bi}$ & -- & -- & -- & -- & -- & -- & -- & $B i=5.0$ & -- & $\mathrm{NO}_{3}=0.1$ & -- & -- \\
\hline $\mathrm{s}$ & -- & -- & $<1$ & $<1$ & -- & 30 & -- & -- & -- & -- & -- & $\cdots$ \\
\hline $\mathrm{NH}_{4}$ & 0.05 & -- & 39 & -- & 340 & -- & -- & 570 & 1.2 & -- & 0.2 & -- \\
\hline $\mathrm{Fe}$ & $10^{-9}$ & -- & 0.18 & $1-10$ & 166 & 2,000 & 84.0 & 172 & -. & -- & -- & 0.51 \\
\hline $\operatorname{mn}$ & 0.01 & -- & 0.9 & -- & 410 & 1,370 & 121.0 & -- & 0.55 & -- & -- & 0.88 \\
\hline $\mathrm{Ni}$ & -- & - & -- & -- & -- & -- & -- & 1.05 & 0.66 & -- & -- & $<0.01$ \\
\hline $\mathrm{BO}_{4}$ & - & -- & -- & 36 & -- & -- & -- & -- & -- & -- & -- & -- \\
\hline cs & -- & -- & -- & -- & - & 20 & -- & 250 & -- & -- & -- & 39.5 \\
\hline $\mathrm{Rb}$ & -- & -- & - & -- & -- & 70 & -- & 50.4 & -- & -- & -- & 11.2 \\
\hline $\mathrm{Pb}$ & -- & -- & -- & -- & 80 & 80 & -- & 36.2 & -- & -- & n & -- \\
\hline As & -- & -- & -- & - & 10.0 & -- & -- & .187 & -- & -- & -- & 1.5 \\
\hline Ag or $S n$ & -. & -- & -- & -- & -- & $\mathrm{Ag}<1$ & -- & $S_{n}=2.2$ & -- & -- & -- & -- \\
\hline $\mathrm{Zn}$ or $\mathrm{Cr}$ & -- & -- & -- & -- & -- & $\mathrm{Zn}=500$ & -- & $\mathrm{Zn}=283$ & -- & -- & -- & $\mathrm{Cr}<0.5$ \\
\hline Sb or $\mathrm{Cu}$ & -- & -- & -- & -- & $S b=0.2$ & $\mathrm{Cu}=3$ & -- & $S b=6.7$ & -- & -- & -- & -- \\
\hline $\begin{array}{l}\text { TOTAL } \\
\text { DISSOLVED } \\
\text { SOLIDS }\end{array}$ & -- & -- & -- & 24,800 & 153,300 & 259,000 & 120,735 & 203,410 & -- & 7,067 & -- & 25,429 \\
\hline
\end{tabular}

*Maximum well temperature; all other temperatures 1 isted are measured at the wellhead. 
Section 2

SCOPE OF STUDY

The scope of this study includes the current, proposed, or suggested means for the treatment of geothermal hot water with the purpose of controlling scaling and corrosion prior to (1) utilization of the fluid for electric power production, and (2) disposal of the spent fluid, e.g., to injection wells or holding ponds. Discussion of the treatment of geothermal fluids is based on available worldwide data and is intended to be comprehensive; selected methods are included from other technologies, principally boiler water, wastewater, and oilfield brine treatment.

BRINE TREATMENT FOR SCALE CONTROL

This section centers on the work to date covering mainly the following: (1) the methods of treatment of fresh geothermal brines to prevent scale formation prior to utilization in power production (e.g., pH adjustment); (2) methods that are or might be used to treat geothermal brines after power production utilization and prior to disposal, for example, coagulation.

The brine treatment study centers around the three principal forms of deposits which are commonly found in geothermal scales: silica, carbonate, and sulfide. It is recognized that a geothermal scale is likely to be composed of a mixture of these main deposits and lesser amounts of other substances (e.g., Fe, Pb), so that brine treatment methods specific to calcite, silica, or sulfides may have to be modified for application to mixed scales. Tables 2-1 through 2-8 1ist the compositions of some geothermal brines and the resulting scales. Since brine treatment methodology for geothermal applications is still in the experimental/development stage and since most scale and incrustants are by and large removed mechanically or chemicaliy, we have also included for completeness a section covering methods which are or might be used for the removal of scale once it has formed (e.g., reaming, acidizing).

Additional information on geothermal scaling may be obtained from the following: Silicate Scale Control in Geothermal Brines--Final Report (Ref. 4), Second Workshop 
on Materials Problems Associated with the Development of Geothermal Energy Systems (Ref. 7), and Conference on Scale Management in Geothermal Energy Development (Ref. 8).

BRINE TREATMENT FOR CORROSION CONTROL

This section covers mainly deaeration and materials selection which are the principal methods used or suggested to control the rate of corrosion for geothermal brines.

The reader is referred to the Extended Abstracts of the fall meeting of the Electrochemical Society (Ref. 9) for recent work on geothermal corrosion.

In summary, the literature on geothermal scaling and corrosion is not extensive. In other treatment technologies, we have found the following as useful sources for non-geothermal brine treatment data: Water quality and Treatment (Ref. 16); Brine Disposal Treatment Practices Relating to the 0 il Production Industry (Ref. 12); Subsurface Salt-Water Disposal (Ref. 17); Introduction to 0ilfield Water Technology (Ref. 18); Underground Waste Management and Environmental Implications (Ref. 19), and Salt Water Disposal, East Texas 0il Field (Ref. 20).

Table 2-1

DESCRIPTION OF TYPICAL BRINE AS DELIVERED TO TEST UNIT FROM EAST MESA WELL 6-1 BETWEEN 3/18/74 AND 4/9/74 (REF. 5)

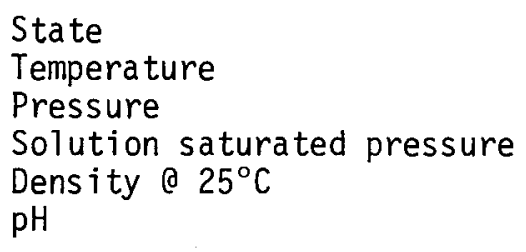

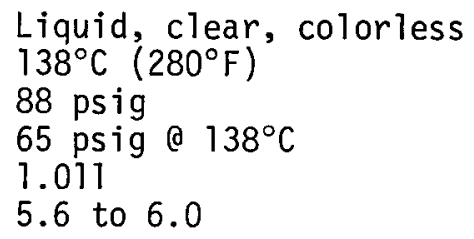

$\begin{array}{lr}\mathrm{Mg} & 16 \mathrm{mg} / 1 \\ \mathrm{SiO}_{2} & 286 \mathrm{mg} / 1 \\ \mathrm{CO}_{3} & 300 \mathrm{mg} / 1 \\ \mathrm{SO}_{4} & 173 \mathrm{mg} / 1 \\ \mathrm{~S} & <1 \mathrm{mg} / 1 \\ \mathrm{BO}_{4} & 36 \mathrm{mg} / 1\end{array}$


Table 2-2

CHEMICAL COMPOSITION OF SCALES FROM EAST MESA WELL 6-1 BRINE. ALL COMPONENTS IN WEIGHT PERCENT. (REF. 5)

\begin{tabular}{|c|c|c|c|c|c|c|c|c|c|c|c|c|c|c|c|}
\hline & RUN & $\mathbf{N a}$ & C1 & $\infty_{3}$ & $\mathrm{Ca}$ & $\mathbf{F e}$ & $\mathrm{SiO}_{2}$ & Sr & Mg & m & $\mathrm{SO}_{4}$ & $\mathbf{K}$ & $\mathbf{S}$ & $\operatorname{sum}^{(1)}$ & $\operatorname{sum}(2)$ \\
\hline $\begin{array}{l}\text { PKOBE } \\
\text { PROBE }\end{array}$ & 102 & 0.74 & 0.81 & 28.80 & 14.60 & 21.00 & 15.02 & 0.21 & 0.31 & 0.68 & - & 0.12 & 0.02 & 82.31 & 104.10 \\
\hline PROBE & 205 & 5.55 & - & - & 20.90 & 6.20 & 0.86 & 0.40 & 0.30 & - & - & - & - & & - \\
\hline PYREX PIPE & 205 & 0.43 & - & 56.81 & 31.50 & 6.70 & 0.10 & 0.40 & 0.10 & - & - & - & - & 96.04 & 100.18 \\
\hline CONIROL VALVE SIEM & 205 & 0.12 & - & 55.74 & 34.90 & 6.40 & 0.20 & 0.60 & 0.10 & - & - & - & - & 96.06 & 202.08 \\
\hline PROBE BOTTOM THLRD & 207 & 0.11 & 0.26 & 52.40 & 29.00 & 7.23 & 2.00 & 0.61 & 0.11 & 0.52 & 0.29 & 0.03 & - & 92.56 & 98.16 \\
\hline PROBE TOP THIRD & 207 & 0.13 & 0.24 & 54.18 & 30.30 & 6.33 & 1.20 & 0.62 & 0.10 & 0.52 & 0.32 & 0.02 & - & 93.96 & 98.53 \\
\hline SEPARAIOR ENITYY & 207 & 0.11 & 0.16 & 54.25 & 33.10 & 2.55 & 0.94 & 2.44 & 0.04 & 0.17 & 0.21 & 0.01 & - & 93.98 & 96.09 \\
\hline PROBE & 300 & 3.34 & 3.91 & 47.57 & 27.80 & 3.79 & 6.40 & 0.39 & 0.13 & - & - & - & 0.02 & 93.35 & 99.49 \\
\hline PPOBE, UNHEATED PART & 301 & 0.16 & 0.17 & 56.33 & 30.30 & 8.00 & 0.24 & 0.40 & 0.20 & 0.55 & - & 0.01 & 0.04 & 96.40 & 101.41 \\
\hline PROBE, HEATED PAPT & 301 & 0.09 & 0.11 & 57.40 & 30.70 & 7.62 & 0.11 & 0.44 & 0.20 & 0.51 & - & 0.01 & 0.02 & 97.21 & 101.92 \\
\hline PROBE & 302 & 0.87 & - & 11.48 & 6.11 & 24.50 & 29.80 & - & 0.20 & - & - & - & - & 72.96 & 105.73 \\
\hline PROBE TOP & 303 & 0.10 & 0.01 & 57.42 & 33.20 & 6.40 & 0.38 & 0.50 & 0.20 & - & - & - & - & 98.21 & 102.34 \\
\hline EXIT LTNE & $204 / 5$ & 1.50 & 0.02 & - & 0.87 & 27.20 & 28.20 & 0.10 & 0.30 & - & - & - & - & 58.19 & 91.64 \\
\hline MOLDCUIAR KEIGTT & - & 22.99 & 35.45 & 60.01 & 40.08 & 55.84 & 60.09 & 87.62 & 24.31 & 54.93 & 96.06 & 39.10 & 32.20 & - & - \\
\hline
\end{tabular}

(1) Of determined components listed in table

(2) Assuming 2.5 moles $\mathrm{OH}$ per mole $\mathrm{Fe}$ and 2 moles $\mathrm{H}_{2} \mathrm{O}$ per mole $\mathrm{SiO}_{2}$ 
Table 2-3

CHEMICAL COMPOSITIONS OF GEOTHERMAL WATER

OF NO. 1 AND NO. 2 WELLS (PPM), MATSUKAWA, JAPAN (REF. 13)

\begin{tabular}{cccccccccc}
$\begin{array}{c}\text { Thermal } \\
\text { water }\end{array}$ & $\mathrm{pH}$ & $\mathrm{SiO}_{2}$ & $\mathrm{Fe}$ & $\mathrm{Al}$ & $\mathrm{Ca}$ & $\mathrm{Mg}$ & $\mathrm{SO}_{4}$ & $\mathrm{Na}$ & $\mathrm{K}$ \\
\hline No. 1 & 5.0 & $1000-1500$ & $400-600$ & $10-15$ & $30-40$ & $10-15$ & $1500-1800$ & $200-300$ & $150-200$ \\
No. 2 & 7.5 & 2000 & 5 & $5-10$ & $10-15$ & 5 & 400 & $150-200$ & $40-50$
\end{tabular}

Table 2-4

CHEMICAL COMPOSITIONS OF SCALE IN NO. 1 AND NO. 2 WELLS $(\%)$, MATSUKAWA, JAPAN (REF. 13)

\begin{tabular}{llllllllll} 
Scale & $\mathrm{SiO}_{2}$ & $\mathrm{Fe}$ & $\mathrm{Al}$ & $\mathrm{CaO}$ & $\mathrm{MgO}$ & $\mathrm{SO}_{4}$ & $\mathrm{~S}$ & $\mathrm{Na}$ & $\mathrm{K}$ \\
\hline Well No. 1 & 17.75 & 12.20 & 0.83 & 0.30 & 0.21 & 40.84 & 3.20 & 9.25 & 5.05 \\
Well No. 2 & 90.45 & 0.35 & 0.84 & 0.59 & 0.30 & 2.25 & $\mathrm{Tr}$ & 1.50 & 0.50
\end{tabular}


Table 2-5

CHEMICAL COMPOSITION OF SCALE (\%) IN GEOTHERMAL POWER PLANT, MATSUKAWA, JAPAN (REF. 13)

\begin{tabular}{|c|c|c|c|c|c|c|c|c|c|c|c|}
\hline & & & $\mathrm{SiO}_{2}$ & $\mathrm{Fe}$ & Al & $\mathrm{CaO}$ & $\mathrm{MgO}$ & SO. & $\mathrm{s}$ & $\mathrm{Na}$ & $\mathrm{K}$ \\
\hline A & & & 69.85 & 4.25 & 17.34 & 0.40 & 0.23 & - & 3.74 & - & - \\
\hline $\begin{array}{l}\mathrm{B} \\
\mathrm{C} \\
\mathrm{D} \\
\mathrm{E}\end{array}$ & $\begin{array}{l}1 \\
1\end{array}$ & $\begin{array}{l}\text { No. } 1 \text { well } \\
\text { silencer }\end{array}$ & $\begin{array}{l}17.75 \\
16.20 \\
51.80 \\
14.0\end{array}$ & $\begin{array}{l}12.20 \\
13.96 \\
13.74 \\
16.5\end{array}$ & $\begin{array}{l}0.83 \\
0.27 \\
0.36 \\
1.5\end{array}$ & $\begin{array}{l}0.30 \\
0.40 \\
0.38 \\
1.4\end{array}$ & $\begin{array}{l}0.21 \\
0.65 \\
0.38 \\
1.1\end{array}$ & $\begin{array}{r}40.84 \\
41.45 \\
1.12 \\
51.99\end{array}$ & $\begin{array}{l}3.20 \\
4.25 \\
7.79 \\
0.1\end{array}$ & $\begin{array}{c}9.25 \\
= \\
=\end{array}$ & $\begin{array}{l}5.05 \\
= \\
=\end{array}$ \\
\hline $\mathrm{F}=$ & $T$ & & 59.0 & 7.0 & 0.8 & 1.7 & 1.2 & 13.8 & 0.05 & $\bar{T}$ & $\bar{T}$ \\
\hline $\begin{array}{l}\mathrm{G} \\
\mathrm{H}\end{array}$ & $i$ & Generator & $\begin{array}{l}\operatorname{Tr} \\
61.55\end{array}$ & $\begin{array}{r}46.90 \\
3.80\end{array}$ & $\begin{array}{l}\mathrm{Tr} \\
0.27\end{array}$ & $\begin{array}{l}\mathrm{Tr} \\
1.50\end{array}$ & $\begin{array}{l}\mathrm{Tr} \\
1.20\end{array}$ & $\begin{array}{c}\mathrm{Tr} \\
10.20\end{array}$ & $\begin{array}{r}53.10 \\
0.05\end{array}$ & $\begin{array}{l}\mathrm{Tr} \\
2.35\end{array}$ & $\begin{array}{l}\underset{0}{\mathrm{r}} \\
0.80\end{array}$ \\
\hline$I_{1}$ & & & 67.3 & 11.6 & 0.45 & 1.30 & 0.80 & 26.50 & $\mathrm{Tr}$ & 6.50 & 3.80 \\
\hline I $=$ & & & 90.45 & 0.35 & 0.84 & 0.59 & 0.30 & 2.25 & $\operatorname{Tr}$ & 1.50 & 0.50 \\
\hline $\mathrm{I}$ & 1 & & 58.5 & 16.3 & - & 0.6 & 0.3 & & -5 & -- & - \\
\hline${ }_{\mathrm{L}}^{\mathrm{K}}$ & 1 & Separator & $\begin{array}{l}70.82 \\
71.20\end{array}$ & $\begin{array}{l}4.46 \\
0.33\end{array}$ & $\begin{array}{l}3.77 \\
0.08\end{array}$ & $\begin{array}{l}8.06 \\
0.66\end{array}$ & $\begin{array}{l}3.07 \\
0.02\end{array}$ & $\begin{array}{r}3.50 \\
15.24\end{array}$ & $\begin{array}{l}0.25 \\
\mathrm{Tr}\end{array}$ & $\begin{array}{l}1.00 \\
5.90\end{array}$ & $\begin{array}{l}0.40 \\
3.00\end{array}$ \\
\hline$M$ & 1 & & 66.60 & 17.62 & 0.87 & 0.96 & $\mathrm{Tr}$ & 0.83 & 9.55 & $\mathrm{Tr}$ & $\operatorname{Tr}$ \\
\hline $\begin{array}{l}N \\
O\end{array}$ & $!$ & Header & $\begin{array}{l}50.42 \\
40.90\end{array}$ & $\begin{array}{l}28.14 \\
27.30\end{array}$ & $\begin{array}{l}4.21 \\
2.80\end{array}$ & $\begin{array}{l}0.12 \\
4.76\end{array}$ & $\begin{array}{c}\mathrm{Tr} \\
1.50\end{array}$ & $\begin{array}{r}0.32 \\
15.89\end{array}$ & 14.25 & $\operatorname{Tr}$ & $\operatorname{Tr}$ \\
\hline P & 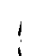 & Drain & 72.50 & $\begin{array}{l}6.03 \\
8.94\end{array}$ & 3.23 & $\begin{array}{l}4.20 \\
4.36\end{array}$ & 0.01 & 10.22 & 0.50 & 1.00 & 0.50 \\
\hline $\mathrm{Q}$ & & separator & 65.40 & & 2.13 & $\begin{array}{l}4.36 \\
1.33\end{array}$ & $\begin{array}{l}0.03 \\
0.17\end{array}$ & 8.50 & 0.80 & 1.10 & 1.00 \\
\hline $\mathrm{R}$ & & Main valve & 78.90 & 5.24 & 0.25 & 1.35 & 0.17 & 13.50 & $\mathrm{Tr}$ & 2.30 & 1.00 \\
\hline$S_{1}$ & 1 & & $\begin{array}{l}69.28 \\
44.40\end{array}$ & 1.00 & $\begin{array}{l}0.05 \\
1.84\end{array}$ & $\begin{array}{l}1.60 \\
1.30\end{array}$ & $\begin{array}{l}0.04 \\
0.55\end{array}$ & $\begin{array}{l}17.56 \\
32.82\end{array}$ & $\begin{array}{l}\mathrm{Tr} \\
\mathrm{Tr}\end{array}$ & $\begin{array}{l}6.10 \\
8.5\end{array}$ & $\begin{array}{l}3.80 \\
3.5\end{array}$ \\
\hline $\begin{array}{l}\mathrm{S}_{2} \\
\mathrm{~S}_{3}\end{array}$ & $i$ & Control valve & $\begin{array}{l}44.40 \\
+9.10\end{array}$ & $\begin{array}{l}2.01 \\
2.01\end{array}$ & $\begin{array}{l}1.84 \\
1.63\end{array}$ & $\begin{array}{l}1.30 \\
1.28\end{array}$ & $\begin{array}{l}0.55 \\
0.33\end{array}$ & $\begin{array}{l}32.82 \\
30.06\end{array}$ & $\begin{array}{l}\text { lr } \\
\text { Tr }\end{array}$ & 8.0 & 4.0 \\
\hline$T_{1}$ & 1 & & 24.00 & 10.20 & 0.53 & 1.14 & 0.30 & $\begin{array}{l}50.26 \\
7350\end{array}$ & $\begin{array}{l}0.38 \\
2.28\end{array}$ & 9.26 & 2.80 \\
\hline $\begin{array}{l}T_{2} \\
T_{3}\end{array}$ & $i$ & Rotor & $\begin{array}{r}11.30 \\
4.00\end{array}$ & $\begin{array}{l}50.83 \\
55.49\end{array}$ & $\begin{array}{l}0.20 \\
0.20\end{array}$ & $\begin{array}{l}0.35 \\
0.05\end{array}$ & $\underset{T r}{0.11}$ & $\begin{array}{l}23.50 \\
17.75\end{array}$ & $\begin{array}{l}2.28 \\
4.31\end{array}$ & $\begin{array}{l}2.30 \\
0.56\end{array}$ & $\begin{array}{l}0.60 \\
\text { Tr }\end{array}$ \\
\hline $\mathrm{U}_{3}$ & & & 58.60 & 1.45 & 0.11 & 3.44 & 0.13 & 24.05 & 0.20 & 7.2 & 4.7 \\
\hline $\mathrm{U}_{3}$ & i & Nozzle & 60.00 & 4.80 & 5.82 & 9.11 & 0.36 & 14.50 & $\mathrm{Tr}$ & 2.1 & 1.3 \\
\hline $\mathrm{v}$ & & Exhaust pipe & 6.00 & 55.85 & $\mathrm{Tr}$ & $\operatorname{Tr}$ & $\mathrm{Tr}$ & 2.90 & 7.70 & - & - \\
\hline w & & Ejector & 40.60 & 27.40 & 2.50 & $0.4 \mathrm{c}$ & 0.40 & 15.50 & 2.10 & 2.3 & 0.8 \\
\hline$T_{p 1}$ & $!$ & Trap & 31.40 & 32.50 & 1.80 & u.su & 0.41 & 18.40 & 3.20 & 3.25 & 1.80 \\
\hline$T_{p i}$ & $i$ & Irap & 80.52 & 6.20 & 0.85 & 0.49 & 0.18 & 8.80 & $\operatorname{Tr}$ & 2.0 & 0.8 \\
\hline
\end{tabular}

- $\operatorname{Tr}=$ traces 
Table 2-6

CHEMICAL COMPOSITION OF THE FLUIDS

FLOWING FROM THE CERRO PRIETO WELLS, MEXICO (REF. 14)

\begin{tabular}{|c|c|c|c|c|c|c|c|c|c|c|c|c|c|}
\hline \multirow{2}{*}{$\begin{array}{l}\text { Well } \\
\text { No. }\end{array}$} & \multirow{2}{*}{$\begin{array}{c}\text { Sampling } \\
\text { Date }\end{array}$} & \multirow{2}{*}{$\begin{array}{c}\text { Pressure } \\
\text { (psig) }\end{array}$} & \multicolumn{9}{|c|}{ Chemical composition in ppm } & \multicolumn{2}{|c|}{ Ratios } \\
\hline & & & $\mathrm{Na}$ & $k$ & $\mathrm{Li}$ & $\mathrm{Ca}$ & $\mathrm{Cl}$ & $B$ & $\mathrm{CO}_{3}$ & $\mathrm{HCO}_{3}$ & $\mathrm{SiO}_{2}$ & $\mathrm{Na} / \mathrm{K}$ & $\mathrm{Na} / \mathrm{Ca}$ \\
\hline${ }^{*} M-1 A$ & $12 / 72$ & 3 & 4175 & 575 & 11 & 212 & 7470 & 8 & 0 & 62 & 235 & 12.3 & 34 \\
\hline - $M-3$ & $8 / 72$ & 200 & 5875 & 1312 & 15 & 331 & 11261 & 11 & 13 & 64 & 507 & 7.6 & 31 \\
\hline M.5 & $6 / 73$ & 300 & 8300 & 2210 & 27 & 521 & 16431 & 15 & 6 & 44 & 864 & 6.4 & 28 \\
\hline - $M-6$ & $10 / 72$ & 10 & 4375 & 475 & 17 & 552 & 8141 & 6 & 0 & 836 & 162 & 15.6 & 14 \\
\hline${ }^{*} \mathrm{M}-7$ & $11 / 72$ & 71 & 5800 & 1175 & 16 & 316 & 10258 & 14 & 8 & 197 & 530 & 8.4 & 32 \\
\hline$M-8$ & $6 / 73$ & 232 & 7999 & 2125 & 24 & 427 & 15884 & 18 & 5 & 74 & 1218 & $\begin{array}{l}0.4 \\
6.4\end{array}$ & 32 \\
\hline M.9 & $6 / 73$ & 100 & 6331 & 1067 & 17 & 447 & 11459 & 11 & 8 & 65 & 495 & 10.1 & 25 \\
\hline$=\mathrm{M}-10$ & $12 / 72$ & 197 & 5500 & 1487 & 17 & 232 & 9910 & 14 & 13 & 179 & 675 & 6.3 & 41 \\
\hline$M-11$ & $6 / 73$ & 578 & 8281 & 1987 & 18 & 494 & 15965 & 17 & 0 & 59 & 870 & 7.1 & 29 \\
\hline $\mathrm{M}-13$ & $6 / 72$ & 148 & 8775 & 2200 & 26 & 448 & 16254 & 11 & 27 & 27 & 880 & 6.7 & 34 \\
\hline${ }^{*} M-15$ & $3 / 69$ & 315 & 5375 & 1587 & - & 260 & 9604 & 7 & 0 & 19 & 1231 & 5.7 & 36 \\
\hline $\mathrm{M}-15 \mathrm{~A}$ & $1 / 75$ & 212 & 6000 & 1125 & 15 & 321 & 11500 & 9 & 24 & 19 & 678 & 9.1 & 32.1 \\
\hline$M-19 A$ & $2 / 75$ & 415 & 8540 & 2124 & 20 & 547 & 16750 & 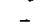 & - & - & 967 & 6.8 & 26.8 \\
\hline $\mathrm{M}-20$ & $1 / 74$ & 120 & 7100 & 1620 & 15 & 510 & 12800 & 13 & 5 & 58 & 800 & 7.4 & 25 \\
\hline$\cdot M-21$ & $10 / 72$ & 610 & 5525 & 1725 & 18 & 304 & 11437 & 10 & 13 & $\begin{array}{r}30 \\
106\end{array}$ & 675 & 5.4 & 32 \\
\hline$\cdot M-21 \mathrm{~A}$ & $4 / 74$ & 280 & 5803 & 1628 & 14 & 318 & 10301 & - & - & - & 804 & 6.0 & 34 \\
\hline M-25 & $1 / 74$ & 105 & 8650 & 2000 & 23 & 585 & 16900 & - & - & 44 & 900 & 7.3 & 28 \\
\hline$M-26$ & $1 / 74$ & 92 & 9050 & 2200 & 20 & 840 & 16800 & - & - & 40 & 1000 & 7.0 & 22 \\
\hline M. 29 & $2 / 74$ & 90 & 6450 & 1200 & 15 & 480 & 12100 & 13 & 16 & 55 & 500 & 9.1 & 23 \\
\hline$M-30$ & $1 / 74$ & 116 & 8500 & 1980 & 22 & 585 & 16400 & - & - & 36 & 950 & 7.3 & 25 \\
\hline$M-31$ & $1 / 74$ & 274 & 7700 & 1930 & 20 & 500 & 15400 & 14 & 11 & 48 & 850 & 6.7 & 26 \\
\hline$M-34$ & $2 / 74$ & 86 & 7100 & 1200 & 18 & 645 & 13100 & 11 & 0 & 48 & 600 & 10.0 & 19 \\
\hline M. -35 & $3 / 74$ & 290 & 9459 & 2557 & 20 & 545 & 17064 & - & - & - & - & 6.3 & 30 \\
\hline M. 38 & $10 / 72$ & 540 & 7050 & 1900 & 23 & 360 & 13984 & 15 & 8 & 58 & 755 & 6.3 & 34 \\
\hline M. 39 & $2 / 74$ & 90 & 6100 & 1080 & 14 & 455 & 11300 & 15 & 30 & 60 & 650 & 9.6 & 23 \\
\hline$=M .59$ & $4 / 74$ & 340 & 6180 & 1905 & 16 & 302 & 11184 & - & - & - & 785 & 5.5 & 35 \\
\hline$=\mathrm{M}-53$ & $11 / 74$ & 1088 & 7843 & 2742 & - & 341 & 16483 & - & 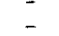 & - & 1441 & $\begin{array}{l}4.5 \\
4.8\end{array}$ & 39.5 \\
\hline
\end{tabular}

*Samples were obtained by bleeding the well through a small drainage line. 
Table 2-7

CHEMICAL ANALYSES OF WELL CASING INCRUSTATIONS, CERRO PRIETO, MEXICO (\% WEIGHT) (REF. 14)

\begin{tabular}{llccrr} 
Measurement & \multicolumn{1}{c}{ As } & $\mathrm{M}-5$ & $\mathrm{M}-6$ & $\mathrm{M}-7$ & $\mathrm{M}-10$ \\
\hline Silicon & $\mathrm{SiO}_{2}$ & 15.1 & $\mathrm{~T}$ & 1.8 & 19.5 \\
Iron & $\mathrm{FeS}$ & 83.4 & $\mathrm{~T}$ & 1.2 & 1.6 \\
Calcium & $\mathrm{CaCO}_{3}$ & 1.5 & 97.5 & 93.0 & 75.5 \\
Magnesium & $\mathrm{MgCO}_{3}$ & $\mathrm{~T}$ & 2.5 & 4.0 & 2.2 \\
Depth (m) & & 604 & -- & 200 & -- \\
& & & & &
\end{tabular}

Table 2-8

CHEMICAL COMPOSITION OF SCALE IN PRODUCTION PIPE

OF WELL M-9 (750731) AT 147-170 METERS, CERRO PRIETO, MEXICO (REF. 15)

$\begin{array}{lr}\mathrm{CaCO}_{3} & 75.56 \% \\ \mathrm{SiO}_{2} & 12.57 \% \\ \mathrm{NaCl} & 0.82 \% \\ \mathrm{FeS} & 9.46 \%\end{array}$


Section 3

BRINE TREATMENT FOR SCALE CONTROL

There is an active research and development effort on treating and handling geothermal brines to prevent scale formation. In this section, we describe typical methods either used or proposed for use to prevent silica, sulfide, and carbonate scale formation. We have found it convenient to organize the treatment methods into two broad categories: (1) those used to control scaling caused by fresh geothermal fluid prior to utilization for power production, and (2) methods used to control scaling by the spent fluid following power production and prior to disposal. See Table 3-l for a listing of treatment methods for scale control.

\section{A. FRESH FLUID TREATMENT}

The term fresh fluid as used here refers to the hot water from the producing wells which is used to drive a turbine for power generation.

\section{Silica Treatment Methods}

The mechanism of silica precipitation from a geothermal fluid to cause deposition can be complex as indicated in the following discussion:

A simple model is proposed to account for the precipitation of amorphous silica from SSGF [Salton Sea Geothermal Field] brines. Because of the lack of information bearing on the kinetics. of scale formation, the model should be viewed as a working hypothesis. As more data become available necessary refinements can be made. The ultimate goal will be to achieve a basic understanding of precipitation mechanisms, at which time it may be possible to devise methods for minimizing or preventing the problem.

As brine is expanded to the surface from a geothermal reservoir, it cools adiabatically. As pressure declines, dissolved gases and steam are evolved, and the residual brine salinity increases. The principal result of the evolution of $\mathrm{CO}_{2}$, the most abundant noncondensible gas in SSGF brine, and $\mathrm{H}_{2} \mathrm{~S}$ is an increase in brine $\mathrm{pH}$. As a consequence, sulfides (and probably hydroxides of multivalent elements, such as iron, aluminum, zinc, lead, possibly rare earths, etc.) begin precipitating. A suite of dispersed fine-grained sulfides (and hydroxides) induces the precipitation of dissolved silica either by serving as nucleation centers or by adsorption mechanisms. 
Table 3-1

TYPICAL TREATMENT METHODS TO CONTROL SCALE FORMATION

Scale Type

Silica

Silica

Silica

Mixed

Calcite in borehole

II

II
Treatment Method

$\mathrm{pH}$ adjustment (acid injection)

Injection of base $\left(\mathrm{NH}_{3}\right.$ or $\mathrm{NaOH})$

Dilution of the unflashed geothermal fluid

Application of electrical potential

Maintain $\mathrm{CO}_{2}$ pressure

Acid addition

Alkaline phosphate addition

\section{Comments}

Tested at Magmamax No. 1 well, Niland, California

Sinclair wells, California

Namafjall, Iceland

Sinclair Well No. 4, California

Tested at East Mesa Hell 6-1, California

Proposed method

Proposed method

TREATMENT METHODS FOR SPENT FLUID DISPOSAL

$\begin{array}{lll}\text { Silica and arsenic } & \begin{array}{l}\text { Sedimentation and coagulation } \\ \text { (addition of slaked lime, } \\ \text { hypochlorite, and flocculant) }\end{array} & \begin{array}{l}\text { Used at Wairakei and } \\ \text { Broadlands, New Zealand }\end{array} \\ \text { Silica } & \begin{array}{l}\text { Plain sedimentation; retention } \\ \text { tank }\end{array} & \begin{array}{l}\text { Used at Otake, Japan, and } \\ \text { Ahuachapan, El Salvador }\end{array} \\ \text { Calcite } & \begin{array}{l}\text { Addition of scale inhibitors } \\ \text { and sequestrants (polyphos- } \\ \text { phates, EDTA) }\end{array} & \text { Proposed method } \\ & \end{array}$


The presence of $\mathrm{NaCl}$ promotes the polymerization of monomerica silica in basic solutions. Simultaneous increase in pH and decrease in temperature coupled with high concentrations of $\mathrm{NaCl}, \mathrm{KCl}$, and $\mathrm{CaCl}_{2}$ probably induce polymerization of silica in SSGF brines when brine $\mathrm{pH}$ values exceed 4.5 . (Ref. 32)

The solubility of silica in water depends on a number of parameters, including form, temperature, and time. For example, as shown in Fig. 3-1, the solubility for the five forms given increases with temperature over the range $0^{\circ} \mathrm{C}$ to about $300^{\circ} \mathrm{C}$, then falls off markedly for both quartz and chalcedony. Fig. 3-2 shows the effect of pH on silica solubility at $25^{\circ} \mathrm{C}$. At other temperatures, the solubility of amorphous silica follows a logarithmic relation.

The solubility at the vapor pressure (v.p.) of the solution, from $0^{\circ}$ to $250^{\circ} \mathrm{C}$, is given by the equation:

$$
\log C=\frac{-731}{T}+4.52
$$

where $C$ is the silica concentration in ppm and $T$ is the absolute temperature. The maximum solubility at the v.p. of solution is $1660 \mathrm{ppm}$ at $340^{\circ}$ and the extrapolated solubility at the critical point is 890 ppm.

At a constant pressure of 1034 bars, the solubility from $0^{\circ}$ to $380^{\circ} \mathrm{C}$ is given by the equation:

$$
\log C=\frac{-810}{T}+4.82
$$

Solubilities intermediate between 1034 bars and the v.p. of the solution can be calculated using a plot of solubility vs. density of water. When the data are plotted in this way, solubilities at constant temperature and variable pressure lie along straight lines. (Ref. 33)

Silica is less soluble in $\mathrm{NaCl}$ solutions than in pure water. An increase in salinity decreases the activity of water $\left(a_{\mathrm{H}_{2}} \mathrm{O}\right)$ which in turn lowers silica solubility (Ref. 34).

a. pH Adjustment. This section includes a discussion of methods used to control silica scale formation by addition of acid or base to the hot water, thereby adjusting the $\mathrm{pH}$ to higher or lower values than that of the untreated fluid.

(1) Addition of Acid. In an experiment at Niland, California, Lawrence Livermore Laboratory found $\mathrm{HCl}$ injection beneficial in controlling scale formation:

A mobile field test unit has been established at the ERDA-SDG\&E test site in the southwestern part of the SSGF. Brine from the Magmamax No. 1 well was flowed through a steam separator that isolated vapor 


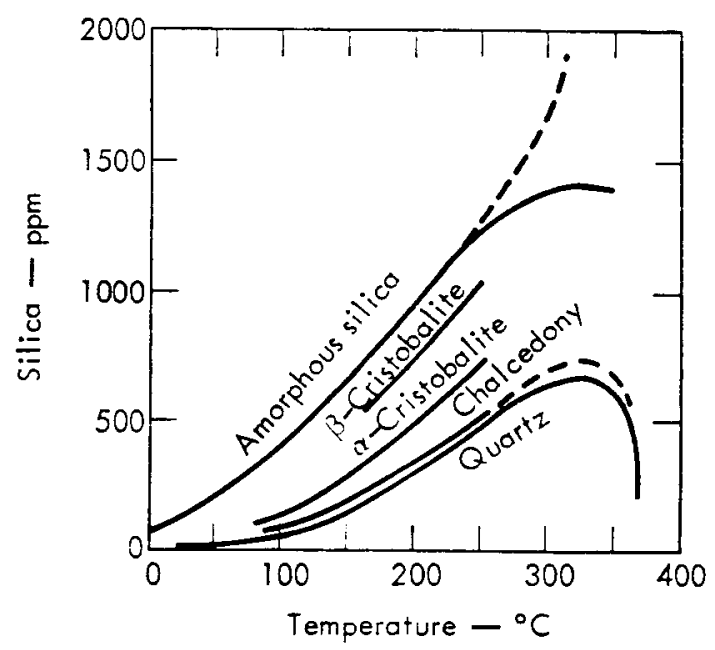

Fig. 3-1. Solubilities of various silica phases along two-phase curve (water plus vapor, $\mathrm{pH}=7.0$ ) (Ref. 35)

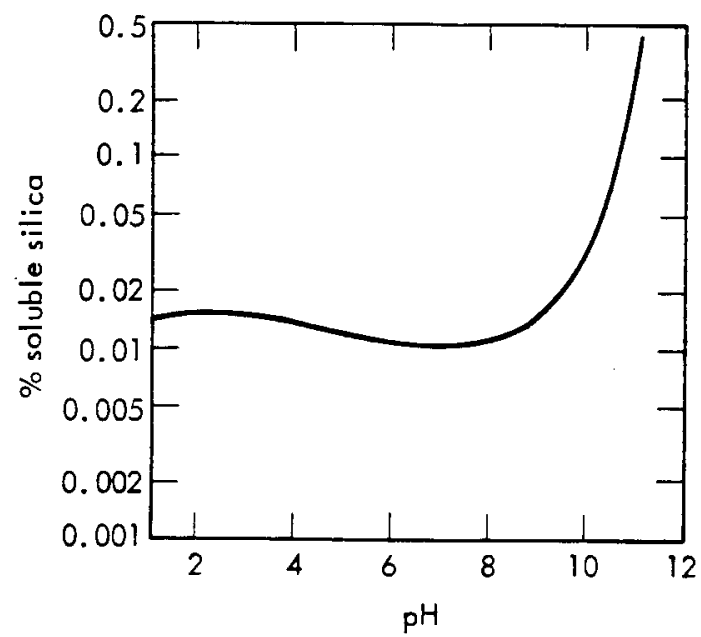

Fig. 3-2. Solubility of silica in water $\left(25^{\circ} \mathrm{C}\right.$ ) (Ref. 36 ) 
and liquid fractions formed as the brine moved from the geothermal reservoir, up the wellbore to the surface. Although the separated liquid phase was used for the initial brine modification experiments, subsequent work will involve remixing of liquid and vapor fractions prior to the chemical additions. Average temperature and pressure of the brine were about $220^{\circ} \mathrm{C}$ and $265 \mathrm{psi}$, respectively. System through-put varied between 18,000 and 24,000 pounds of brine per hour. Flow through nozzles (8:1 expansion ratio, $1 / 4$ inch diameter throat) was 1.25 pounds of brine per second. The nominal $\mathrm{pH}$ of unmodified brine flowing from the separator varied from 5.5 to 5.8. Dissolved solids content of the brine prior to and after expansion through nozzles was 18 weight percent to 22 weight percent, respectively. Nozzles and wearplates were fabricated from Ti-6Al-4V alloy. Three independent nozzles were operated simultaneously. During each acidification run, at least one nozzle was always operated as a control station flowing unmodified brine.

Thus far, four experiments, each of 20 hours duration, have been completed. Nominal scaling (copper sulfide, native silver, and iron-rich amorphous silica) from unmodified brine resulted in closure of up to $10 \%$ of the cross-sectional areas of nozzle throats. Thickness of scale formed on wearblades ranged between $0.019 \mathrm{~mm}$ to $0.04 \mathrm{~mm}$. However, when brine was acidified to $\mathrm{pH} 1.5,2.3$, and 4.0 , scaling in nozzles was eliminated and substantially reduced on wearblades. Acidified brine effluents remained clear several hours after collection. However, unmodified brine was slightly turbid when collected, with precipitates forming a few minutes after samples were taken. (Ref. 31)

(2) Addition of Base. Brine treatment methods for controlling silica scaling based on the addition of ammonia or sodium hydroxide have also been investigated. An attempt was made to control silica deposition at Sinclair wells by injecting ammonia, the idea being to alter the nature of the precipitate so that it would not adhere to surfaces. Results of laboratory experiments on ammonia injection indicate that silica precipitation cannot be prevented, but that it may be possible to control where precipitation will occur (Ref. 1).

The solubility of silica increases at pH 8.5 or higher because the dissociation products of silicic acid are more soluble than the undissociated monomer, $\mathrm{H}_{4} \mathrm{SiO}_{4}$.

In low-pH solutions, silica exists primarily in the form of monomers and polymers of silicic acid. Polymerization occurs rapidly at near neutral $\mathrm{pH}$. As the $\mathrm{pH}$ is further increased, soluble complex ions begin to form, as shown by the following equilibria:

$$
\begin{aligned}
\left(\mathrm{H}_{2} \mathrm{SiO}_{3}\right)_{\mathrm{m}} & =\mathrm{mH}_{2} \mathrm{SiO}_{3} \\
\mathrm{H}_{2} \mathrm{SiO}_{3}+\mathrm{mH}_{2} \mathrm{O} & =\mathrm{H}^{+}+\left(\mathrm{HSiO}_{3} \cdot \mathrm{nH}_{2} \mathrm{O}\right)^{2-} \\
\left(\mathrm{HSiO}_{3} \cdot \mathrm{nH}_{2} \mathrm{O}\right)^{-} & =\mathrm{H}^{+}+\left(\mathrm{SiO}_{3} \cdot \mathrm{nH}_{2} \mathrm{O}\right)^{2-} \\
\mathrm{H}^{+}+\mathrm{OH}^{-} & =\mathrm{H}_{2} \mathrm{O}
\end{aligned}
$$


As base $\left(\mathrm{OH}^{-}\right)$is added, $\mathrm{H}^{+}$will be removed as in Eq. (9) and the equilibria shown in Eqs. (7) and (8) will be shifted to the right. Thus, silica will be in soluble form. (Ref. 37)

However, increasing the $\mathrm{pH}$ can cause precipitation of heavy metal hydroxides (e.g., $\mathrm{Fe}(\mathrm{OH})_{2}$, $\left.\mathrm{Mn}(\mathrm{OH})_{2}\right)$, carbonates, and sulfides at $\mathrm{pH}$ 6-9 thereby requiring preutilization removal of the precipitates to control erosion. An additional parameter associated with addition of base is the buffering action of the brine which would require increased quantities of added base and hence increased cost of the brine treatment.

b. Water Dilution. Addition of water was successful in reducing silica scaling at Namafja11, Iceland. Before dilution, scale was deposited from $95^{\circ} \mathrm{C}$ water as loose, leaf-like flakes which grew to 15 to $30 \mathrm{~mm}$ inside an 8 inch pipe. The scaling was reduced by mixing unflashed fluid from the drillhole to a $35 \%$ dilution with cold water at atmospheric pressure. Addition of dilution water reduced the silica content of the fluid from $347 \mathrm{ppm}$ to $188 \mathrm{ppm}$ (Ref. 25).

Addition of dilution water should be approached with caution:

Before relying on dilution to reduce silica precipitation, one needs to consider that:

The dilutant must be chemically compatible with the brine. For instance, attempts by the San Diego Gas and Electric Company to reduce scaling in their GLEF at Niland by addition of steam condensate to brine actualiy resulted in higher rates of scale and solids formation. This was a result of the high ammonia and carbonate content of the condensate and its correspondingly high $\mathrm{pH}(9-10)$. The problem is that when steam containing noncondensibles is cooled, redistribution of species occurs with most of the ammonia redissolving. This raises the $\mathrm{pH}$ of condensate and promotes dissolution of $\mathrm{CO}_{2}$ into the condensate. (Ref. 38)

Other disadvantages of dilution water include the possible reduction in enthalpy of the geothermal brine and the quantity of clean water that may be required for dilution of the brine. Owen estimates for a typical well flow rate of $1.8 \times 10^{5} \mathrm{~kg} / \mathrm{hr}$ at the SSGF that $35 \%$ dilution would require about $6.3 \times 10^{4} \mathrm{~kg} / \mathrm{hr}$ of water (Ref. 38 ).

c. Magnesium Addition. In treatment of water for use in cooling, heating, and steam generation the addition of magnesium salts (e.g., dolomite) during hot-lime softening reduces the silica content of the water (Ref. 39). The reaction produces insoluble magnesium silicate:

$$
\mathrm{H}_{2} \mathrm{O}+2 \mathrm{Mg}^{++}+\mathrm{SiO}_{3}=\mathrm{Mg}_{2} \mathrm{SiO}_{4}+2 \mathrm{H}^{+}
$$


Optimum separation efficiency of silica using $\mathrm{MgO}_{2}$ or $\mathrm{MgCO}_{3}$ is achieved at a $\mathrm{pH}>9$, and about 15 minutes of residence time is required for efficient silica removal (Ref. 40, 41, 42). The method may have merit for fresh geothermal brines; however, the requirement for elevated $\mathrm{pH}$ will have the same shortcomings as noted previously under "Addition of Base." Furthermore, retaining the fluids for required residence times results in reduction of fluid enthalpy, and removal of solids (e.g., $\mathrm{Mg}_{2} \mathrm{SiO}_{4}$ ) may be required to control erosion effects.

d. Application of Electrical Potential. Experiments at Lawrence Livermore Laboratory on brine from a flowing geothermal well (Sinclair No. 4) studied the influence of electrical potential on scale deposition. Fluid from a $51 \mathrm{~mm}$ diameter pipe was flowed through a $6^{\circ}$ nozzle and was subsequently exposed to six spherical stainiess steel electrodes $(9.53 \mathrm{~mm}$ diameter) for periods of up to 2 hours. Experiments were run with +5 volts, -5 volts, and +30 volts applied potentials, and more scale formed on negative than on either positive or neutral electrodes. Table 3-2 shows that there are significant differences among $+5 \mathrm{~V},-5 \mathrm{~V}$, and neutral electrodes. The authors feel that the results of the preliminary experiments were encouraging: scale was formed on the electrodes (as opposed to corrosion) and there were decided differences produced by varying the charge on the electrode. According to the authors, the lack of a positive correlation between oppositely charged electrodes suggests that species $\left[\mathrm{e} . \mathrm{g} ., \mathrm{Pb}(\mathrm{OH})^{+},(\mathrm{FeOH})^{+}\right]$are being precipitated in the presence of an electric field which would remain in solution otherwise (Ref. 43).

\section{Sulfide Treatment Methods}

Fig. 3-3 is a schematic diagram proposed for typical reactions in sulfide scale formation (Ref. 44). While $\mathrm{Cu}_{2} \mathrm{~S}$ is illustrated, it is only one of other heavy metal sulfides that may be present (e.g., FeS, PbS); thus the number of reactions involved is undoubtedly greater than those illustrated. As seen, acid addition may result in removal of gaseous $\mathrm{H}_{2} \mathrm{~S}$, dissolution of $\mathrm{Cu}_{2} \mathrm{~S}$, and will shift the equilibrium to favor $\mathrm{CO}_{2}$ formation, as shown by equation 4 . Removal of $\mathrm{CO}_{2}$ and $\mathrm{H}_{2} \mathrm{~S}$ will limit subsequent precipitation of carbonates and sulfides.

a. $\mathrm{pH}$ Adjustment. Addition of acid to sulfide solutions favors formation of $\mathrm{H}_{2} \mathrm{~S}$ in solution, and the likelihood of an increase in the gas (noncondensible) phase. This and other pH-dependent reactions are iliustrated (Ref. 37):

$$
\begin{aligned}
& \mathrm{S}^{2-}+\mathrm{H}^{+}=\mathrm{HS}^{-} \\
& \mathrm{HS}^{-}+\mathrm{H}^{+}=\mathrm{H}_{2} \mathrm{~S} \text { (gas) }
\end{aligned}
$$


Table 3-2

SPECTROCHEMICAL ANALYSIS REPORT

Selected elements were examined for direct comparison of relative amounts in each sample. One sample (indicated by b) was selected as a reference for each element, and the values for other samples determined by relative intensity ratios. (Ref. 43)

\begin{tabular}{|c|c|c|c|c|c|c|c|c|c|c|c|}
\hline Charge & Si & $\mathrm{Fe}$ & $\mathrm{Cu}$ & $\mathrm{Ag}$ & A) & B & $\mathrm{Ga}$ & $\mathrm{Cr}$ & $\mathrm{Be}$ & $\mathrm{Ba}$ & $\mathrm{Pb}^{\mathrm{a}}$ \\
\hline$+5 V$ & $26 \%$ & $14 \%$ & $7 \%$ & $0.5 \%$ & $1 \%$ & $0.3 \%$ & $0.04 \%$ & $0.06 \%$ & $0.06 \%$ & $0.03 \%$ & \\
\hline$+5 V$ & 24 & 17 & $5^{b}$ & $0.3^{b}$ & 0.8 & 0.3 & 0.05 & 0.08 & 0.05 & 0.03 & \\
\hline$+5 V$ & 26 & 16 & 8 & 0.5 & 1 & 0.2 & 0.05 & 0.06 & 0.05 & 0.03 & \\
\hline 0 & 22 & 10 & 8 & 2 & 0.8 & 0.2 & 0.04 & 0.01 & 0.04 & 0.01 & \\
\hline 0 & 24 & 10 & 10 & 2 & 1 & 0.2 & 0.05 & 0.02 & 0.05 & 0.02 & \\
\hline 0 & 26 & 16 & 8 & 2 & 0.8 & 0.2 & 0.05 & 0.03 & 0.04 & 0.02 & \\
\hline$-5 v$ & $10^{b}$ & $5^{b}$ & 10 & 1 & $0.3^{b}$ & $0.1^{b}$ & $0.01^{b}$ & $0.02^{b}$ & $0.01^{b}$ & $0.01^{b}$ & \\
\hline$-5 v$ & 11 & 6 & 9 & 0.7 & 0.3 & 0.1 & 0.02 & 0.02 & 0.01 & 0.02 & \\
\hline$-5 v$ & 16 & 8 & 20 & 2 & 0.5 & 0.2 & 0.03 & 0.02 & 0.02 & 0.01 & \\
\hline Pipe & 10 & 8 & 6 & 0.0 & 0.3 & 0.1 & 0.03 & 0.01 & 0.01 & 0.02 & \\
\hline Nozzle & 12 & 6 & 6 & 1 & 0.6 & 0.09 & 0.02 & 0.05 & 0.01 & 0.01 & \\
\hline
\end{tabular}

${ }^{a}$ Differences in lead concentrations were too great to apply this method.

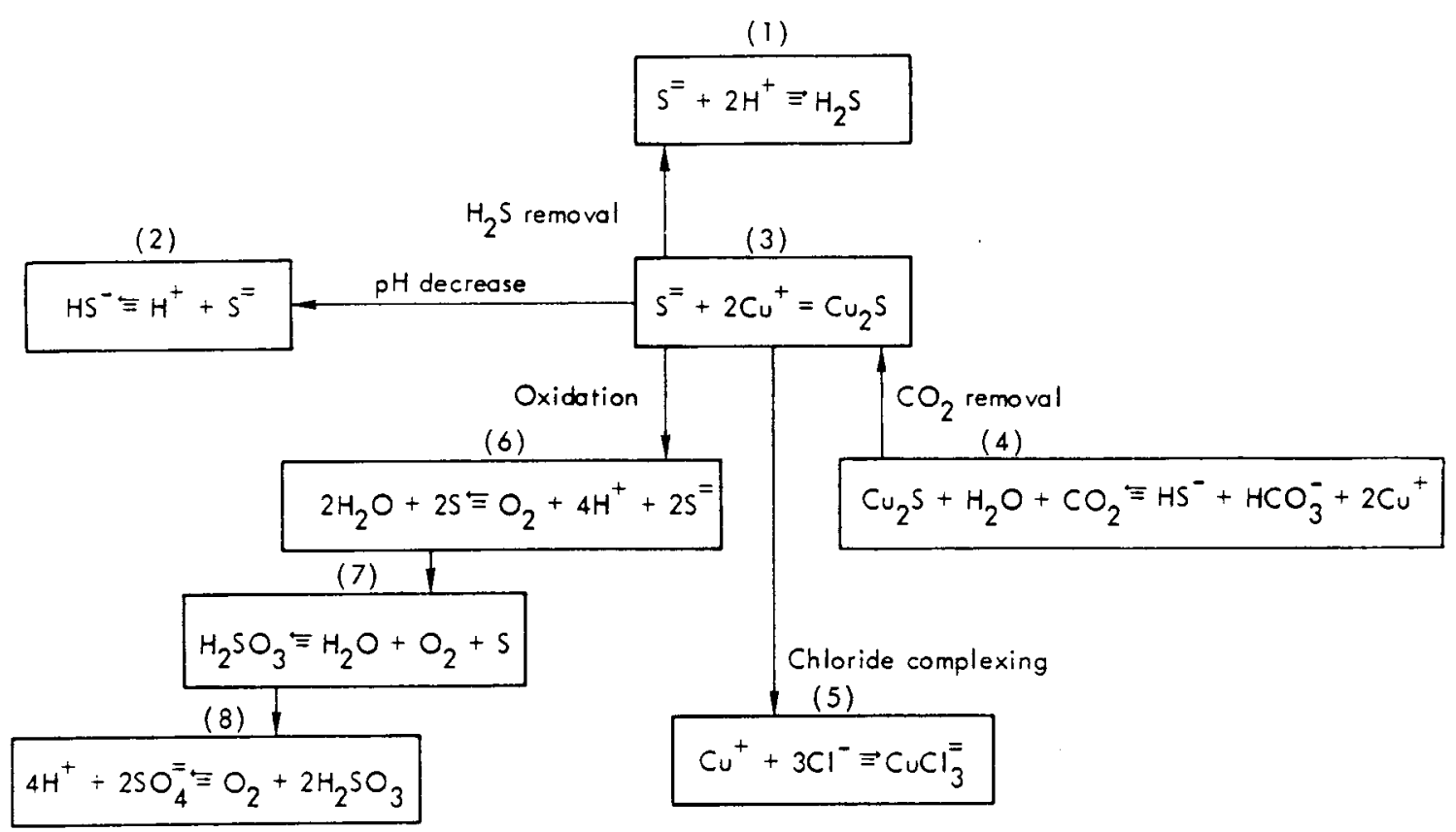

Fig. 3-3. Schematic diagram of typical reactions in sulfide scale formation (Ref. 44) 
As base is added, the $\mathrm{s}^{2-}$ concentration increases and insoluble sulfides start to precipitate as follows:

$$
2 M^{+x}+X S^{2-}=M_{2} S_{x}
$$

b. Oxidation. Oxidation of sulfide to sulfur or sulfate has been proposed as a means of controlling sulfide scale deposition (Ref. 44). The overall, simplified reaction is schematically:

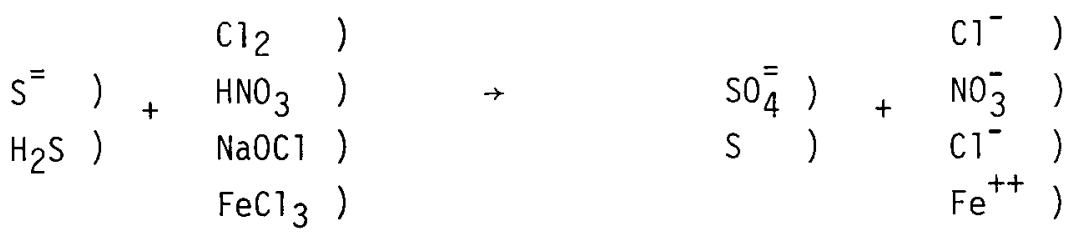

$$
\begin{aligned}
& \begin{array}{ll}
\text { oxidant } & \text { sulfur } \\
\text { product }
\end{array}
\end{aligned}
$$

A possible problem here is the formation of insoluble metal sulfates (e.g., $\mathrm{CaSO}_{4}$ ), as well as elemental sulfur which may cause erosion of piping and plugging of injection systems. Addition of a dispersing agent may be desirable to prevent the solids from settling out, or filtration may be required.

c. Diffused-Air Aerators. In water quality treatment, diffused-air aerators are used to remove gases such as $\mathrm{H}_{2} \mathrm{~S}$ and $\mathrm{CO}_{2}$. The method utilizes injection of compressed air through a perforated pipe or similar system to produce fine bubbles. The $\mathrm{H}_{2} \mathrm{~S}$ gas is exchanged from the water phase to the gas phase, according to the equations:

Gas absorption:

$$
C_{t}=S-\left(S-C_{0}\right) 10^{-k(A / V) t}
$$

Gas release:

$$
C_{t}=S+\left(C_{0}-S\right) 10^{-k(A / V)} t
$$

These formulas and the differential equations from which they are derived indicate that:

1. At any instant, the rate of gas transfer is directly proportional to the difference between the gas saturation concentration $S$ and the actual concentration $C_{t}$ in the water.

2. The rate of gas transfer is directly proportional to the ratio of the exposed area to the volume of water, A/V. 
3. The rate of gas transfer is directly proportional to the gas transfer coefficient $k$ which in turn is dependent on the diffusivity of the gas in question and the film resistance.

4. The total amount of gas transfer is greater as the time of aeration increases.

5. The percentage change in gas saturation deficit $S-C_{t}$ or surplus $C_{t}-S$ for any given time period $t$ is constant based on the deficit or surplus at the beginning of the time period.

6. Temperature and pressure are important factors because they influence gas solubility $\underline{S}$. Temperature also influences diffusivity and film resistance and hence the value of $\underline{k}$.

The term $\mathrm{C}_{0}$ is the concentration of gas originally present in the water. (Ref. 45)

An advantage of aeration for $\mathrm{H}_{2} \mathrm{~S}$ removal is the low cost of air used in aeration. However, aeration can cause formation of sulfate and subsequent deposition of insoluble metal sulfates.

\section{Calcite Treatment Methods}

Calcite, or calcium carbonate $\left(\mathrm{CaCO}_{3}\right)$, is a common scaling problem associated with water intended for cooling, heating, and steam generation purposes. The solubility of $\mathrm{CaCO}_{3}$ in water and brine depends on a number of parameters including the following: $\mathrm{CO}_{2}$ gas partial pressure, temperature, $\mathrm{pH}$, and the chemical composition of the brines. Methods for preventing $\mathrm{CaCO}_{3}$ scale formation are based on the suitable control of one or more of these parameters.

a. $\mathrm{CO}_{2}$ Pressure. As the brine flows in a geothermal well from the reservoir, it depressurizes and $\mathrm{CO}_{2}$ is released as a result of the fluid boiling. This release of $\mathrm{CO}_{2}$ causes an increase in brine $\mathrm{pH}$, thus increasing the possibility of depositing calcite (Ref. 46).

Fig. 3-4 shows the results of allowing a geothermal brine containing a high concentration of dissolved $\mathrm{CO}_{2}$ to flash in a well. Note that the deposition of calcite scale begins immediately above the point of flashing and that the maximum thickness of the $\mathrm{CaCO}_{3}$ scaling inside the well is just above the flash point.

Experiments at the East Mesa test site using brine from Wel1 6-1 indicate that no scale was formed until the brine was allowed to flash (Ref. 4).

In summary, maintaining a $\mathrm{CO}_{2}$ pressure may have merit in minimizing calcite precipitation. However, a disadvantage of maintaining a high back pressure on the well 
TEMPERATURE, ${ }^{\circ} \mathrm{C}$

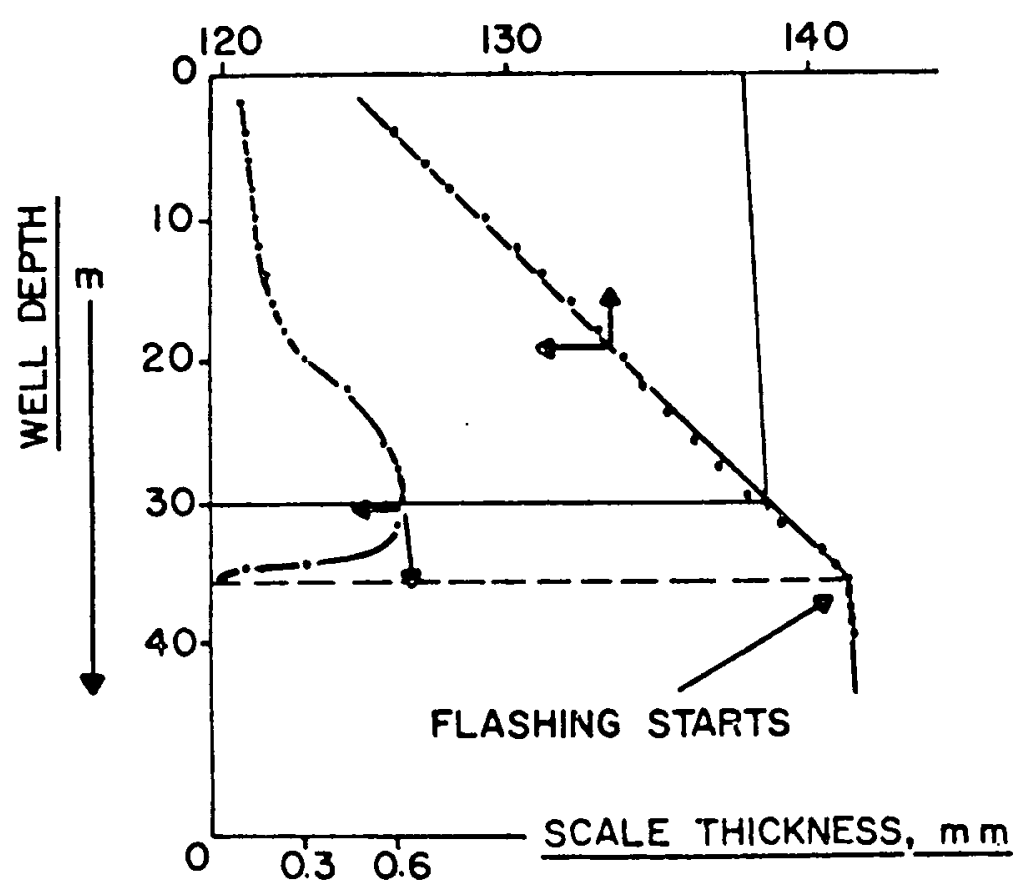

Fig. 3-4. Thermometry and thickness of $\mathrm{CaCO}_{3}$ layer formed within 6 hours in a drillhole in the Bolshe-Banny area, Kamchatka, USSR (Ref. 48)

is that the flow rate will be reduced considerably below that of a free flowing we11. This disadvantage may possibly be overcome by use of a downhole pump (Ref. 47).

b. $\mathrm{pH}$ Adjustment. Addition of acid favors removal of carbonate by formation of $\mathrm{CO}_{2}$ according to the reactions:

$$
\begin{aligned}
\mathrm{CO}_{3}{ }^{2-}+\mathrm{H}^{+} & =\mathrm{HCO}_{3}^{-} \\
\mathrm{HCO}_{3}{ }^{-}+\mathrm{H}^{+} & =\mathrm{H}_{2} \mathrm{CO}_{3} \\
\mathrm{H}_{2} \mathrm{CO}_{3} & =\mathrm{H}_{2} \mathrm{O}+\mathrm{CO}_{2}^{-} \text {(gas) }
\end{aligned}
$$

Removal of carbonate prevents formation of calcite; however, large amounts of acid may be required due to any buffering action by the brine.

c. Phosphate Addition. In steam generating systems, calcium is precipitated in the form of a sludge by addition of alkaline phosphate (Ref. 49). This sludge is often removed by subsequent settling or filtration.

$$
10 \mathrm{Ca}^{++}+6 \mathrm{PO}_{4}^{\overline{\overline{4}}}+2 \mathrm{OH}^{-} \rightarrow \underset{3}{\left.3 \mathrm{Ca}_{3}\left(\mathrm{PO}_{4}\right)_{2}\right)_{2}^{\mathrm{Ca}}(\mathrm{OH})_{2}}
$$


The sludge formed is less likely to scale than $\mathrm{CaCO}_{3}$ because it is relatively nonadherent to boiler metals and is easily removed by manual blowdown. Sometimes a synthetic polymer is included to enhance flocculation and settling and to make the sludge less adherent and more easily dispersed. A disadvantage of this method is the possibility of precipitation of insoluble substances (e.g., sulfides, hydroxides, carbonates) at the elevated $\mathrm{pH}$ required for phosphate precipitation.

d. Sulfate Addition. This method of controlling scale in boiler water is based on the hundredfold greater solubility of $\mathrm{CaSO}_{4}$ as compared to $\mathrm{CaCO}_{3}$ (Ref. 50, 51):

$$
\mathrm{Ca}\left(\mathrm{HCO}_{3}\right)_{2}+\mathrm{H}_{2} \mathrm{SO}_{4} \rightarrow \mathrm{CaSO}_{4}+2 \mathrm{CO}_{2}+2 \mathrm{H}_{2} \mathrm{O}
$$

A disadvantage in application to geothermal brines is the formation of other insoluble sulfates (e.g., $\mathrm{BaSO}_{4}$ ) which may form scales, and plugging of injection systems by the formed $\mathrm{CaSO}_{4}$.

\section{B. SPENT FLUID TREATMENT}

Fluid production from a geothermal field for power generation will be in large volumes (e.g., $1.8 \times 10^{5} \mathrm{~kg} / \mathrm{hr} /$ well in SSGF) which contain silica, carbonates, chlorides of sodium, potassium, and calcium, and various undesirable elements, e.g., $\mathrm{B}, \mathrm{CO}_{2}, \mathrm{H}_{2} \mathrm{~S}, \mathrm{NH}_{3}$, As, $\mathrm{Hg}$. Disposal of geothermal effluents poses a problem of environmental pollution in the development of geothermal resources. Methods for disposal of geothermal effluents could include: surface disposal in local waterways, evaporation ponds, or subsurface injection. Disposal by injection has some advantages over other forms of disposal, for example elimination of therma 7 and chemical pollution of the environment and reduction of ground subsidence. Injection of wastewaters and brines through wells has been frequently used by the industrial wastewater and oilfield industries. In several geothermal fields, e.g., the Geysers steam field and Niland area of the Imperial Valley, Valles Caldera in New Mexico, Ahuachapan in El Salvador, and Hachimantai in Japan, disposal of effluents through injection has been or is being tried experimentally. The problem of scale formation in pipes and reservoir rocks, however, may be a serious long-term limitation (Ref. 52).

In the oilfield industry, brine is treated prior to injection so that it is chemically compatible with the receiving rock formation; otherwise, formation plugging will necessitate high injection pressures. 
In this section, we discuss existing geothermal and other methods used to treat spent brines prior to disposal. Currently, spent geothermal brines are not treated to a significant extent and little data is available on the effectiveness of the various treatment steps. Thus, this section draws on oilfield and industrial wastewater treatment techniques which appear appropriate for application to geothermal fluids, for example, the use of closed systems, coagulation, filtration, and sedimentation. See Table 3-3 for a listing of current geothermal spent brine treatment methods. Spent geothermal fluids will have a lower temperature than fresh geothermal fluids; thus some oilfield treatment techniques, e.g., addition of decomposable sequestrants, may be applicable and are included here. Table 3-4 gives a listing of common chemicals and their uses in the treatment of industrial wastewater. In evaluating geothermal effluent treatment possibilities, however, one will have to consider a variety of parameters including chemical compatibility of the additive with brine, mechanical requirements for removal of solids (precipitates), and cost. Economic analys is of various treatment methods is beyond the scope of this report and hence not presented.

A complete brine treatment system could include the following: aeration, closed systems, sedimentation and coagulation, filtration, chlorination, and sequestration. See Table 3-5 and Fig. 3-5. For additional information, the reader is referred to Subsurface Salt-Water Disposal (Ref. 17), Brine Disposal Practices Relating to the $0 i 1$ Production Industry (Ref. 12), and Underground Waste Management and Environmental Implications (Ref. 19).

\section{Silica Treatment Methods}

This section covers mainly a discussion of wastewater treatment methods that have been applied to spent geothermal hot waters to remove silica.

Table 3-3

TYPICAL TREATMENT METHODS FOR SPENT GEOTHERMAL BRINES (SUGGESTED OR USED)

$\begin{array}{lllc}\text { Treatment Objective } & \text { Treatment Method } & \text { Comment } & \text { Reference } \\ \begin{array}{l}\text { Calcite }\left(\mathrm{CaCO}_{3}\right) \text { bore } \\ \text { plugging prevention }\end{array} & \begin{array}{l}\text { Exclude air (closed } \\ \text { system); maintain } \mathrm{CO}_{2} \\ \text { pressure }\end{array} & -- & \begin{array}{l}\text { Ref. } 2 \\ \text { Ref. } 4\end{array} \\ \begin{array}{l}\text { Formation plugging } \\ \text { prevention }\end{array} & \begin{array}{l}\text { Sedimentation in } \\ \text { holding pond }\end{array} & \text { Gravity } & \text { Ref. } 2 \\ \begin{array}{l}\text { Silica and arsenic } \\ \text { removal }\end{array} & \text { Add slaked lime } \\ \begin{array}{l}\text { CaCO } 3 \text { downhole deposits } \\ \text { removal }\end{array} & \begin{array}{l}\text { Pump 15\% } \mathrm{HCl} \text { into } \\ \text { injection well }\end{array} & \text { Acidizing } & \text { Ref. } 21\end{array}$




\begin{tabular}{|c|}
\hline Chemical \\
\hline Alum \\
\hline Sodium Aluminate \\
\hline Ferric Salts \\
\hline Lime (Hydrated) \\
\hline Soda Ash (Crystalline) \\
\hline Soda Ash (Anhydrous) \\
\hline Caustic Soda \\
\hline $\begin{array}{l}\text { Acid Feed } \\
\left(\mathrm{H}_{2} \mathrm{SO}_{4}\right) \\
\left(\mathrm{H}_{3} \mathrm{PO}_{4}\right) \\
\left(\mathrm{NaHSO}_{4}\right)\end{array}$ \\
\hline Surface Active Phosphates \\
\hline $\begin{array}{l}\text { Ortho-phos phates } \\
\text { (Monosodium Phosphate) } \\
\text { (Disodium Phosphate) } \\
\text { (Trisodium Phosphate) }\end{array}$ \\
\hline Sodium Sulfite \\
\hline Sodium Nitrate \\
\hline $\begin{array}{l}\text { Sodium and Potassium } \\
\text { Chromates }\end{array}$ \\
\hline $\begin{array}{l}\text { Reactive Colloids } \\
\text { (Sodium Manuronate) } \\
\text { Protective Colloids } \\
\text { (Starches) (Tannins) }\end{array}$ \\
\hline $\begin{array}{l}\text { Amines and Related Organic } \\
\text { Compounds }\end{array}$ \\
\hline
\end{tabular}

Process Use

coagulation color removal

coagulation

coagulation

color removal

oil removal

$\mathrm{pH}$ adjus tment softening

$\mathrm{pH}$ adjus tment

$\mathrm{pH}$ and alkalinity adjus tment sof tening

$\mathrm{pH}$ adjustment alkalinity adjustment softening

$\mathrm{pH}$ adjustment reduction of alkalinity

prevent calcium carbonate deposits eliminate "red water"

prevent scale in boilers

prevent corrosion due to oxygen in boilers, feedlines, economizers

inhibition of embrittlement

corrosion inhibitor

coagulation particle absorption and adsorption

prevention of return line corrosion
Points of Application

Coagulation and sedimentation sys tems; prior to pressure filters for removal of suspended matter and oil.

Usually added with soda ash to softeners; used to some extent for internal boiler water treatment.

Prior to coagulation and filtration sys tems.

Prior to coagulation systems; to softeners; to treated water lines for adjustment of $\mathrm{pH}$.

Prior to pressure filters.

To domestic systems, feed lines, softeners, coagulation and filtration systems; boilers.

To softeners; oil removal systems; domestic water systems; boilers

Treated water lines, prior to degassifiers or de-aerating heaters: $\mathrm{H}_{3} \mathrm{PO}_{4}$ to phosphate softeners (for both softening and alkalinity reduction).

Treated water lines.

Added continuous ly to boiler drums; shotfed to drums or boiler feed line.

Storage section of de-aerating heater; suction or pressure side of boiler feed pumps .

Any point in boiler feed lines or direct to boilers.

To brine systems and various circulating cooling and hot water systems.

To boiler feed lines; circulating cooling sys tems.

Application depends upon material used. Some materials may be added to boilers and volatilize with steam; others are added to steam line direct, requiring pumps. 
Table 3-5

BASIC PRETREATMENT STEPS (REF. 55)

I. Raw-waste storage--open, closed

II. Corrosion control--pH, inhibitors

III. Solids separation--settling, coagulation

IV. Filtration--fine, medium, coarse

V. Slime control--bactericides, shock

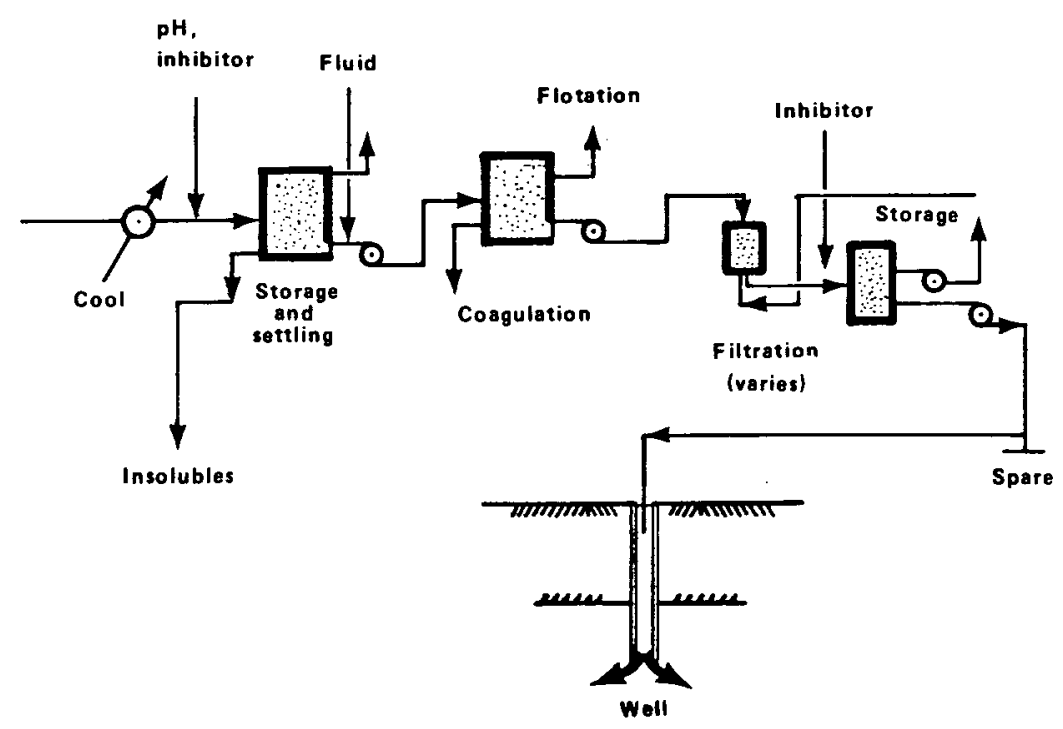

Fig. 3-5. Surface design for pretreatment of wastes where extensive treatment cleanup is required prior to subsurface injection (Ref. 55).

a. Sedimentation and Coagulation. Sedimentation is a commonly used wastewater treatment practice in which suspended materials settle from the fluid under the influence of gravity. This settling process, or "plain sedimentation," usually takes place in specially designed circular or rectangular basins with either horizontal or vertical fluid flow. The design of the settling basin depends on the overflow rate of the basin, $V$, which is expressed as

$$
V=\frac{Q}{A}=\frac{\text { inflow rate, cu. ft. } / \mathrm{hr} \text {. }}{\text { surface area of the settling basin, sq. ft. }}
$$

(ft./hr.) 
The overflow rate of the basin is a function of the specific gravity and viscosity of the wastewater, and the specific gravity, size, shape, and concentration of the particles which will settle out:

$$
\begin{aligned}
V=\frac{64.4(\sigma-\rho) D^{2}}{\mu} & D=\text { particle diameter, } \mathrm{mm} \\
(\mathrm{ft} / \mathrm{hr}) & \rho=\text { fluid density, } \mathrm{g} / \mathrm{cm}^{3} \\
& \sigma=\text { particle density, } \mathrm{g} / \mathrm{cm}^{3} \\
\mu & =\text { liquid viscosity, poise }
\end{aligned}
$$

This equation holds rigorously for spherical particles undergoing free settling by gravity at low Reynolds numbers with viscous resistance to settling. See Ref. 56 .

In coagulation, chemicals are added to the wastewater prior to settling process, with the idea to gather all suspended particles (e.g., colloids), enhance settling, and prevent the small particles from passing through or plugging filters. The addition of a coagulant essentially enlarges the small particles by causing the aggregation of fine particles to produce a floc which settles rapidly, thus increasing the efficiency of the sedimentation process. Coagulation-sedimentation is beneficial in that it requires smaller sedimentation basins and lower initial cost than plain sedimentation.

In a coagulation process, coagulant is added to the water with initial rapid mixing, followed by a slow mixing speed once floc has formed; the coagulated material separates from the fluid by gravity (see Fig. 3-6). Coagulation of turbid water depends on several factors; for example, the kind and quantity of coagulant used, extent of mixing, $\mathrm{pH}$ of the water, and water temperature.

The most commonly used coagulants, composed of iron or aluminum compounds, include ferric sulfate, ferrous sulfate, ferric chloride, aluminum sulfate (alum), sodium aluminate. The coagulant on reaction with a turbid water neutralizes the negative charge of the impurities and produces positively charged colloidal hydrous oxide flocs. These flocs attract and adsorb negatively charged colloidal impurities, forming still larger floc particles. The chemical reactions of various coagulants with turbid waters are shown in Table 3-6.

The optimum pH range for effective coagulation is shown in Table 3-7; for aluminum sulfate, the optimum is 6-7. The $\mathrm{pH}$ of the water may be adjusted by the addition of hydrated lime. Where coagulating agents alone do not give satisfactory results, compounds called coagulation aids (e.g., activated silica, organic polyelectrolytes) which by themselves are not necessarily effective coagulants are added to form larger flocs. 


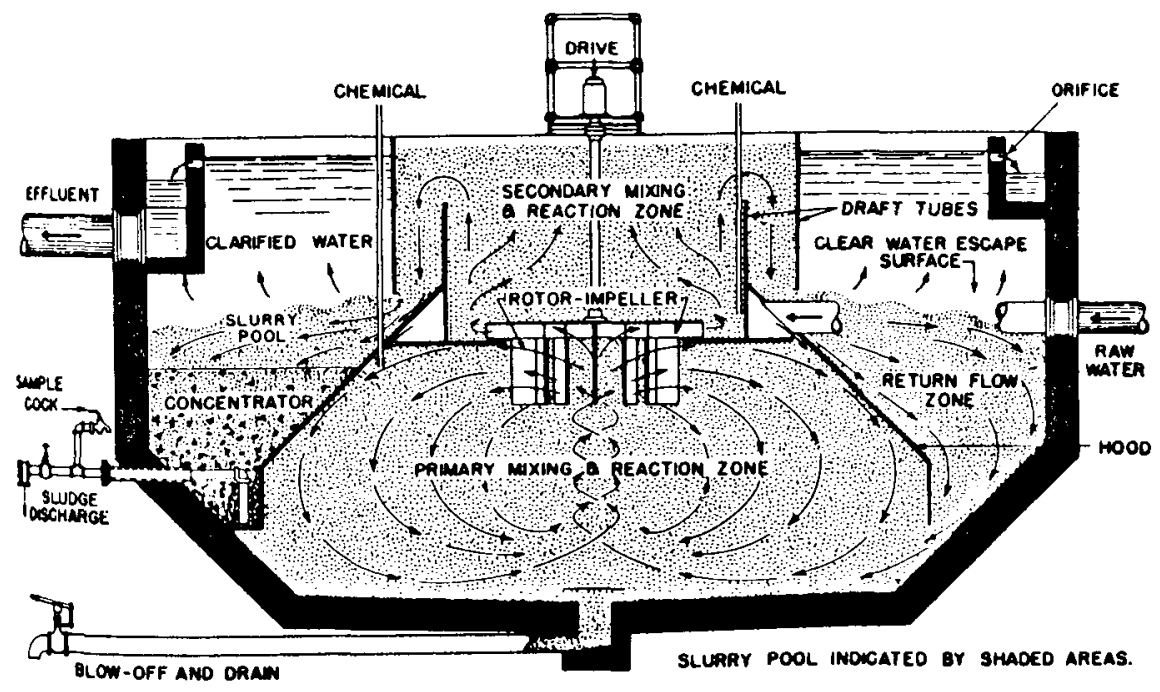

Fig. 3-6. Suspended-solids contact unit (Ref. 18). (This is for a single stage unit which is most often used for low flow situations. Separate coagulation, flocculation, and sedimentation basins are usually used for large flows.)

Table 3-6

TYPICAL REACTIONS OF COAGULANTS WITH ALKALINE SUBSTANCES IN WATER (REF. 18)

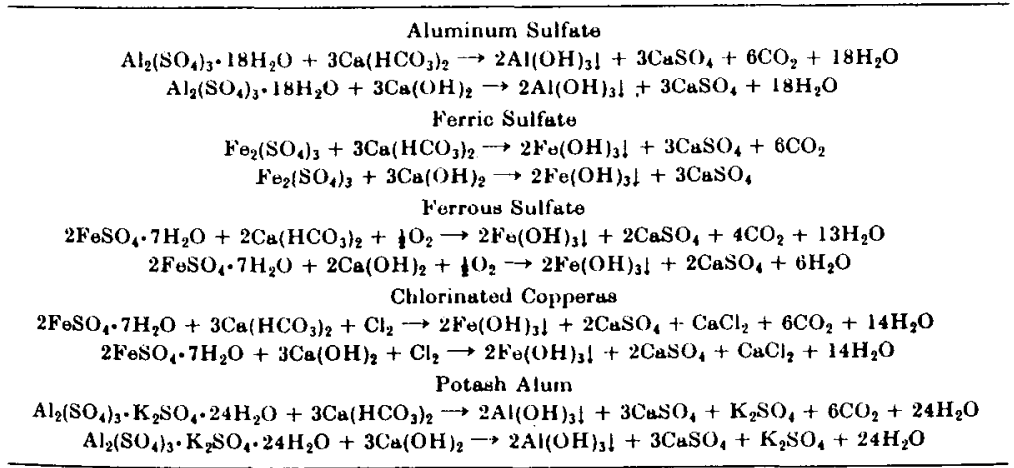


Table 3-7

CHARACTERISTICS OF TYPICAL COAGULANTS (REF. 57)

\begin{tabular}{|c|c|c|c|c|c|c|c|}
\hline Coagulant & $\begin{array}{c}\text { Common } \\
\text { name }\end{array}$ & Purpose & Normal dosage & $\mathrm{pH}$ range & Charge & Precipitate produced & Remarks \\
\hline $\begin{array}{l}\text { Aluminium } \\
\text { sulfate }\end{array}$ & filter alum & $\begin{array}{l}\text { main coagulant } \\
\text { to assist coagulation } \\
\text { with sodium } \\
\text { aluminate }\end{array}$ & $\begin{array}{l}5-50 \\
2-20\end{array}$ & $\begin{array}{c}5.5-8.0 \\
\text { (optimum : 6-7) }\end{array}$ & positive & bydrated alumina & $\begin{array}{l}\text { Floc is relatively light and will generally not } \\
\text { settle against an upward flow greater than } \\
\text { about } 3 \mathrm{ft} / \mathrm{h} \text {. Higher rates are obtainable, } \\
\text { however, in a sludge-blanket type of } \\
\text { plant. }\end{array}$ \\
\hline $\begin{array}{l}\text { Sodium } \\
\text { aluminate }\end{array}$ & - & $\begin{array}{l}\text { main coagulant } \\
\text { to assist coagulation } \\
\text { with aluminium } \\
\text { sulphate }\end{array}$ & $\begin{array}{c}5-15 \\
2 \text { or } \\
0.1-0.05 \text { of } \\
\text { alum dosage }\end{array}$ & $4.0-7.0$ & negative & hydrated slumins & $\begin{array}{l}\text { Floc formed by double congulation ususlly } \\
\text { coarser than that from flter alum alone. } \\
\text { Aluminate should be added } 2-2 \text { min } \\
\text { before alum. Sometimes useful as main } \\
\text { coagulant for surface waters of variable } \\
\text { composition. }\end{array}$ \\
\hline $\begin{array}{l}\text { Ferrous } \\
\text { sulfate }\end{array}$ & copperes & main coagulant & $5-50$ & $4.0-11.0$ & positive* & $\begin{array}{l}\text { hydrated fertic } \\
\text { oxide }\end{array}$ & $\begin{array}{l}\text { At low pH values oxidation to ferric state } \\
\text { may not be complete and treated water } \\
\text { may contain residual iron. Floc hesvier } \\
\text { than that of alumina and settles faster. }\end{array}$ \\
\hline $\begin{array}{l}\text { Ferric } \\
\text { chloride }\end{array}$ & - & main coagulant & $5-50$ & $4.0-11.0$ & positive* & $\begin{array}{l}\text { hydrated ferric } \\
\text { oride }\end{array}$ & $\begin{array}{l}\text { Floc heavier than that of slumina and } \\
\text { settles faster. }\end{array}$ \\
\hline $\begin{array}{l}\text { Ferric } \\
\text { chloride/ } \\
\text { ferric } \\
\text { Sulfate }\end{array}$ & $\begin{array}{l}\text { chlorinsted } \\
\text { copperas }\end{array}$ & main congulant & $5-50$ & $4.0-11.0$ & positive* & $\begin{array}{l}\text { hydrated ferric } \\
\text { oxide }\end{array}$ & $\begin{array}{l}\text { Floc heavier then that of alumina and } \\
\text { settles faster. Reagent oolution prepared } \\
\text { as required by passing chlorine into } \\
\text { ferrous aulfate polution. }\end{array}$ \\
\hline $\begin{array}{l}\text { Activated } \\
\text { silica sol }\end{array}$ & - & $\begin{array}{l}\text { to assist coagualtion } \\
\text { with aluminium } \\
\text { Bulfate }\end{array}$ & $\begin{array}{c}\text { 1-15 } \\
\text { (expressed } \\
\text { as silica) }\end{array}$ & $5.5-8.0$ & negative & hydrated silice & $\begin{array}{l}\text { Used as coegulant aid in conjunction with } \\
\text { aluminium sulfate repidly produces } \\
\text { strong, coarse floc which oettles quickly. } \\
\text { May give effective treatment during } \\
\text { periods of spate and at low temperatures. }\end{array}$ \\
\hline $\begin{array}{l}\text { Bentonite or } \\
\text { other clays }\end{array}$ & $\ldots$ & $\begin{array}{l}\text { main coagulant or to } \\
\text { essist coagulation } \\
\text { with aluminium } \\
\text { sulfate }\end{array}$ & $2-12$ & - & - & - & $\begin{array}{l}\text { Increases density of floc formed from filter } \\
\text { slum and thus gives faster settling. } \\
\text { Should be added to water before filter } \\
\text { slum. }\end{array}$ \\
\hline $\begin{array}{l}\text { Calcium } \\
\text { carbonate }\end{array}$ & chalk & $\begin{array}{l}\text { to assiat coagulation } \\
\text { with aluminium } \\
\text { gulfate }\end{array}$ & - & - & - & - & $\begin{array}{l}\text { Increases density of floc formed from filter } \\
\text { slum and thus gives faster settling. } \\
\text { Should be added to water before filter } \\
\text { slum. }\end{array}$ \\
\hline $\mathrm{Na}]_{\mathrm{co}} 600$ & - & main coagulant & 1 & - & - & - & Cationic polyelectrolyte. \\
\hline
\end{tabular}

- May be negative at high $\mathrm{pH}$ valuea.

The coagulation treatment method was applied to remove both silica and arsenic from cooled $\left(90^{\circ} \mathrm{C}\right)$ geothermal discharge waters at Wairakei and Broadlands by addition of slaked lime:

A pilot plant was built for studying this process on a continuous basis. Discharge water at $90^{\circ} \mathrm{C}$ is first "aged" to allow silica to polymerize; addition of slaked lime to the water then rapidly precipitates a flocculent, hydrated calcium silicate gel, which is readily separated in settling tanks. If arsenic has been preoxidized to the pentavalent state, most of it is coprecipitated.

Optimum operating conditions for a water containing about $1000 \mathrm{~g} /$ tonne silica involve addition of $700 \mathrm{~g} /$ tonne quick-lime; the resulting calcium silicate filtered well to give a gel with $30 \%$ solid content. This could be dried with geothermal heat to give an amorphous powder, having a bulk 
density of $0.20 \mathrm{~g} / \mathrm{cm}^{3}$ and a $\mathrm{SiO}_{2} / \mathrm{CaO}$ ratio of 1.7 , which can find uses in wallboards or insulants. Smaller lime-addition rates remove part of the silica as a silica-rich calcium silicate, while higher lime-addition rates give almost quantitative silica and arsenic removal as a calciumrich calcium silicate. (Ref. 53).

The untreated cooled discharge waters had the composition shown in Table 3-8; the effect of treatment with slaked lime, hypochlorite, and added flocculant is shown in Tables 3-9 and 3-10. The cost of this chemical treatment process is approximately $\$ 20,000$ per annum which is the same figure that was expended previously for mechanically cleaning the discharge drains (Ref. 1).

Fig. 3-7 is a sketch of the pilot plant used for continuous brine treatment at Broadlands.

\section{Table 3-8}

ANALYSES OF COOLED DISCHARGE WATERS FROM WAIRAKEI AND BROADLANDS BORES, NEW ZEALAND (ALL FIGURES EXCEPT pH IN g/TONNE) (REF. 53)

\begin{tabular}{|c|c|c|c|}
\hline & $\begin{array}{l}\text { Wairakei } \\
\text { Bore } 67 \\
\end{array}$ & $\begin{array}{c}\text { Wairakei } \\
\text { "mixed" bores } \\
\end{array}$ & $\begin{array}{l}\text { Broadl ands } \\
\text { Bore } 22 \\
\end{array}$ \\
\hline $\mathrm{pH}$ at $20^{\circ} \mathrm{C}$ & 7.8 & 7.9 & 8.6 \\
\hline $\mathrm{SiO}_{2}($ total $)$ & 650 & 560 & 980 \\
\hline (monomeric) & 100 & 115 & 110 \\
\hline (M.W. 200 to 150000$)$ & 0 & n.a. & 0 \\
\hline (M.W. over 150000 approx.) & 500 & n.a. & 700 \\
\hline $\mathrm{Na}$ & 1230 & 1190 & 1054 \\
\hline k & 194 & 185 & 228 \\
\hline Li & 12 & 11 & 13 \\
\hline $\mathrm{Rb}$ & 2.5 & n.a. & 2.0 \\
\hline Cs & 2.4 & n.a. & 2.0 \\
\hline $\mathrm{Ca}$ & 18 & 23 & 2.6 \\
\hline $\mathrm{Mg}$ & 0.06 & n.a. & 0.03 \\
\hline Cl & 2126 & 2100 & 1873 \\
\hline $\mathrm{SO}_{4}$ & 31 & 32 & 10 \\
\hline B & 29 & 28 & 60 \\
\hline As & 4.5 & 4.3 & 4.3 \\
\hline Dissolved $\mathrm{CO}_{2}$ & 20 & 13 & 150 \\
\hline
\end{tabular}


Table 3-9

ANALYSES OF DISCHARGE WATERS FROM WAIRAKEI "MIXED BORES" (AGED 2- l/2 HOURS) AFTER TREATMENT WITH SLAKED LIME. (ALL QUANTITIES IN g/TONNE) (REF. 53)

\begin{tabular}{|c|c|c|c|c|c|c|c|c|}
\hline $\begin{array}{c}\text { Added } \\
\mathrm{CaO}\end{array}$ & $\begin{array}{c}\text { Added } \\
\text { active } \\
\text { chlorine las } \\
\text { hypochloritel }\end{array}$ & $\begin{array}{l}\text { Added } \\
\text { flocculant } \\
\text { (polyflok } \\
90 \mathrm{AP} \text { ) }\end{array}$ & $\begin{array}{c}\text { Monomeric } \\
\mathrm{SiO}_{2}\end{array}$ & $\begin{array}{l}\text { Total } \\
\mathrm{SiO}_{2}\end{array}$ & $\mathrm{CaO}$ & As & B & $\mathrm{pH}$ \\
\hline 0 & 0 & 0 & 390 & 560 & 32 & 4.30 & 28 & 7.9 \\
\hline 350 & 0 & 0 & 167 & 136 & 210 & 2.50 & ก.a. & 11.2 \\
\hline 350 & 10 & 0 & 159 & 117 & 221 & 0.45 & n.a. & 11.3 \\
\hline 410 & 0 & 0 & 94 & 87 & 216 & 2.03 & 25 & 11.4 \\
\hline 425 & 0 & 1 & 75 & 73 & 210 & 1.55 & n.a. & 11.5 \\
\hline 580 & 0 & 0 & 37 & 33 & 255 & 0.51 & 22 & 11.6 \\
\hline 780 & 0 & 0 & 15 & 15 & 435 & 0.13 & n.a. & 11.7 \\
\hline 985 & 0 & 0 & 6 & 6 & 575 & 0.06 & n.a. & 11.9 \\
\hline 1000 & 0 & 1 & 10 & 10 & 545 & 0.12 & 20 & 12.0 \\
\hline
\end{tabular}

n.a. = not analysed

Table $3-10$

ANALYSES OF DISCHARGE WATERS FROM BROADLANDS BORE 22 (AGED $1 / 2$ HOUR) AFTER TREATMENT WITH SLAKED LIME (REF. 53)

\begin{tabular}{|c|c|c|c|c|c|c|c|c|c|}
\hline $\begin{array}{c}\text { Added } \\
\mathrm{CaO} \\
\text { (g/tonne) }\end{array}$ & $\begin{array}{l}\text { Added } \\
\text { active } \\
\text { chlorine } \\
\text { (g/tonne) }\end{array}$ & $\begin{array}{l}\text { Length } \\
\text { of } \\
\text { run } \\
\text { (hours) }\end{array}$ & $\begin{array}{l}\text { Mono- } \\
\text { meric } \\
\mathrm{SiO}_{2}\end{array}$ & $\begin{array}{l}\text { Total } \\
\mathrm{SiO}_{2}\end{array}$ & $\begin{array}{l}\mathrm{CaO} \\
\text { (All q }\end{array}$ & $\begin{array}{l}\text { As } \\
\text { (chemical) } \\
\text { tities in } \mathrm{g} / \text { tonne) }\end{array}$ & $\begin{array}{c}\text { As (V) } \\
\text { (polarog.) }\end{array}$ & B & $\begin{array}{c}\mathrm{pH} \\
\text { value }\end{array}$ \\
\hline 0 & 0 & - & 410 & 910 & 2 & 4.3 & 1.5 & 60 & 8.6 \\
\hline \multirow[t]{4}{*}{460} & 0 & & 280 & 258 & 170 & 3.3 & 0.3 & 55 & 10.3 \\
\hline & 5 & $41 / 2$ & 290 & 263 & 170 & 2.8 & 0.2 & n.a. & 10.3 \\
\hline & 10 & & 250 & 237 & 172 & 1.6 & 0.0 & n.a. & 10.4 \\
\hline & 20 & & 240 & 230 & 172 & 1.4 & 0.1 & n.a. & 10.4 \\
\hline 605 & 0 & 3 & 165 & 165 & 196 & 2.6 & 0.8 & n.a. & 11.1 \\
\hline \multirow[t]{4}{*}{685} & $0)$ & & 95 & 93 & 208 & 2.0 & 0.2 & 52 & 11.4 \\
\hline & 51 & & 130 & 126 & 190 & 2.2 & 0.3 & n.a. & 11.3 \\
\hline & 10 & $43 / 4$ & 120 & 116 & 190 & 1.7 & 0.2 & n.a. & 11.3 \\
\hline & $20)$ & & 120 & 115 & 190 & 0.9 & 0.2 & п.a. & 11.3 \\
\hline 815 & 0 & $11 / 4$ & 70 & 70 & 228 & 1.2 & 0.0 & n.a. & 11.5 \\
\hline 1120 & 0 & $21 / 2$ & 6 & 7 & 440 & 0.1 & 0.0 & 49 & 12.0 \\
\hline
\end{tabular}

$\mathrm{n}$. $\mathrm{a}$ = not analysed 


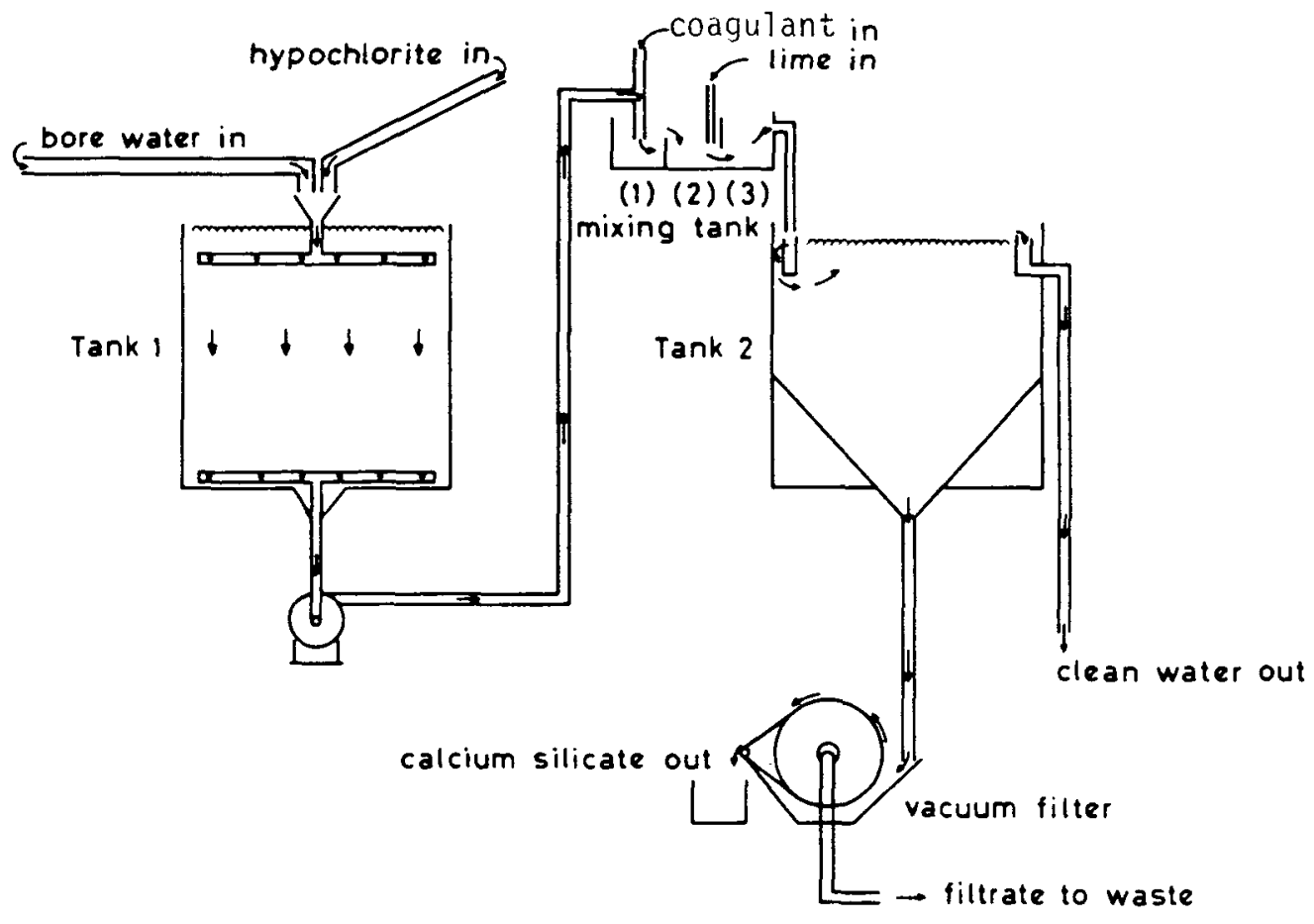

Fig. 3-7. Sketch of pilot plant adapted for continuous operation in Broadlands, New Zealand (Ref. 53)

b. Holding Tank. This illustrates application of plain sedimentation treatment to silica control. The precipitation of silica from supersaturated solution is a progressive process in which a colloidal silica is produced which gradually forms gel or precipitate. Fig. 3-8 shows the rate of precipitation and the rate of dissolution of silica at 22 to $27^{\circ} \mathrm{C}$. As can be seen, several days or weeks may be required to reach equilibrium in this temperature range. Because of the slowness of precipitation, geothermal brines which appear clear become cloudy after standing at ambient temperatures for a few hours. This cloudiness may turn into a heavy precipitate which subsequently settles (Ref. 4).

A retention tank with a series of baffles was used at the Otake geothermal plant in Japan to control silica scale in hot water pipes (Ref. 58, 59). See Fig. 3-9. It was found that one hour retention was sufficient to reduce silica scale formation before discharging the brines to pipelines. This delay in time permitted the 


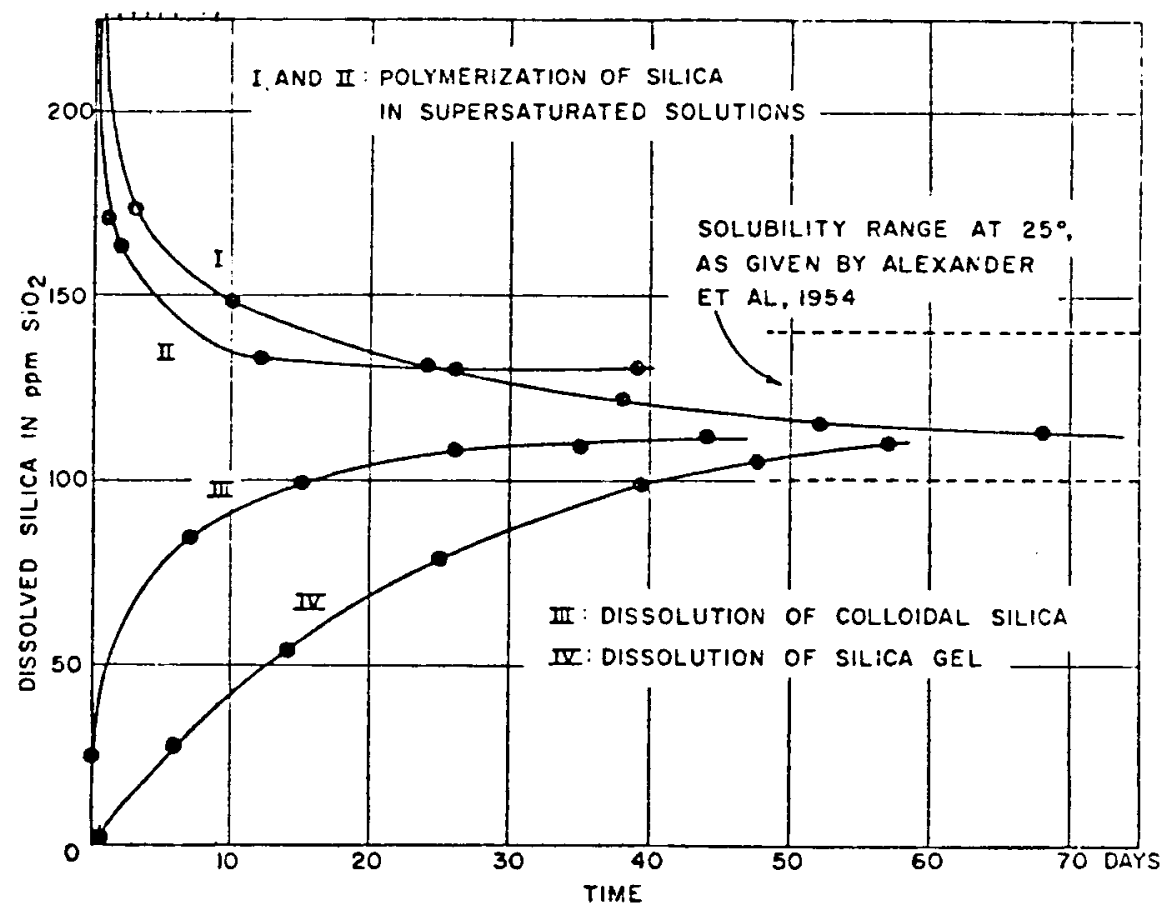

Curve I: Hot-spring water boiled to dissolve most of the silica. Initial total $\mathrm{SiO}_{2} 320 \mathrm{ppm}$; initial dissolved $\mathrm{SiO}_{2} 284 \mathrm{ppm}$; $\mathrm{pH}$ during run $7.7-8.3$.

Curve II: $\mathrm{Na}_{2} \mathrm{SiO}_{3}$ solution neutralized with $\mathrm{HCl}$. Initial total $\mathrm{SiO}_{2}$ $975 \mathrm{ppm}$; initial soluble $\mathrm{SiO}_{2} 544 \mathrm{ppm}$; pH during run 7.3-7.9.

Curve III: $\mathrm{Na}_{2} \mathrm{SiO}_{3}$ solution neutralized with $\mathrm{HCl}$, aged and diluted. Initial $\mathrm{SiO}_{2} 187 \mathrm{ppm}$; initial dissolved $\mathrm{SiO}_{2} 25 \mathrm{ppm}$; $\mathrm{pH}$ 8.3-7.4.

Curve IV: Silica gel in distilled water. $\mathrm{pH}$ 5.2-5.6.

Fig. 3-8. Kinetics of silica solubility. Representative runs showing approach to the solubility equilibrium from both sides.

Temperature $22-27^{\circ} \mathrm{C}$. (Ref. 60) 


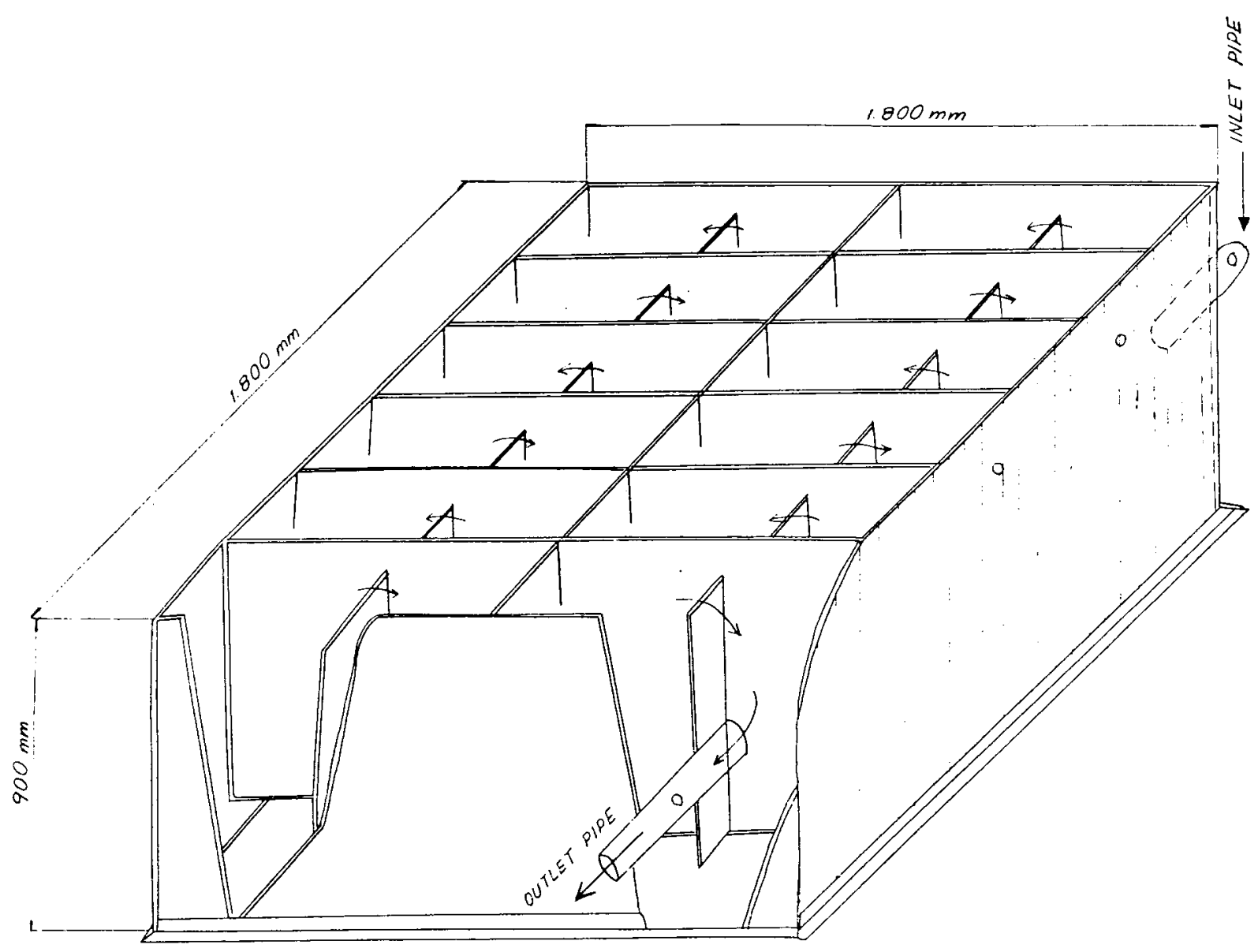

Fig. 3-9. Experimental retaining tank to control silica scale in hot water pipes, Otake Geothermal Plant, Japan (Ref. 58) 
silica to change from the monomeric state to the amorphous settleable state, where it deposited on the walls of the concrete holding tank. See Tables 3-11 and 3-12 for water and scale composition. Similar methods were used at Ahuachapan, El Salvador, to prevent silica deposition in a disposal culvert (Ref. 61).

c. Filtration. Filtration is a process for separating undissolved solids from turbid waters using a porous or filter medium. It is used to remove colloidal silica and other floc particles which are not removed in a sedimentation process. The filters generally operate at constant rate and constant pressure; however, the pressure drop across the filter increases as the filter loads up. In oilfield brine treatment, both slow and rapid sand filters are commonly used.

Slow sand filters contain sand bedding with the top layer used as the filtering media. The disadvantages of slow sand filters are that they require large filter area, have low filtration rates per square foot of filter surface, have high initial cost, and the sand bedding material cannot be backwashed to permit unclogging. Rapid sand filters have a layer of sand on layers of coarser gravel (sometimes anthracite coal and sometimes graded sand), use smaller filter area, and have provision for backwashing. They may be gravity or pressure operated.

Gravity filters are usually open to the atmosphere and have operating rates for municipal water supplies of 4-5 gal/min per sq. $\mathrm{ft}$. of bed area, with a maximum of 8-10 gal/min per sq. ft. (Ref. 51).

Pressure sand filters are most widely used in industry and are particularly applicable in closed water systems. Filtering under pressure increases the filtration rate by a factor of about 1.5 and has the advantage over gravity filters in higher capacity and requiring less area. For details on the design of these and other filters, the reader is referred to Ref. 18, 51 , and 56 .

\section{Calcite Treatment Methods}

Calcite can also be removed by sedimentation and coagulation processes, using methods similar to those discussed under silica treatment. In this section, other methods to prevent calcium carbonate scales are discussed.

a. Scale Inhibitors and Sequestrants. Sequestration is the process of maintaining scale-forming cations (e.g., calcium, barium, iron) as soluble complex metallic ions by addition of chelating or sequestering agents to the wastewater. The most 
Table 3-11

CHEMICAL ANALYSIS OF THE HOT WATER (PPM), OTAKE, JAPAN (REF. 58)

Chemical

Composition

$\mathrm{Li}^{+}$

$\mathrm{K}^{+}$

$\mathrm{Na}^{+}$

$\mathrm{NH}_{4}{ }^{+}$

$\mathrm{Ca}^{++}$

$\mathrm{Mg}^{++}$

$\mathrm{Fe}^{++}$

$\mathrm{Al}^{+++}$

$\mathrm{Mn}^{++}$

$\mathrm{F}^{-}$

$\mathrm{Cl}^{-}$

$\mathrm{Br}^{-}$

$\mathrm{I}^{-}$

$\mathrm{SO}_{4}^{--}$

$\mathrm{HCO}_{3}{ }^{-}$

$\mathrm{CO}_{3}{ }^{--}$

$\mathrm{pH}$

\begin{tabular}{|c|c|c|c|}
\hline \multicolumn{3}{|c|}{ Wells } & \multirow{2}{*}{ No. 10} \\
\hline No. 7 & No. 8 & No. 9 & \\
\hline 4.50 & 4.35 & 5.15 & 5.68 \\
\hline 105 & 108 & 131 & 143 \\
\hline 846 & 805 & 936 & 1098 \\
\hline 0.11 & 0.05 & 0.06 & 0.15 \\
\hline 9.9 & 19.8 & 12.3 & 20.1 \\
\hline 0.025 & 0.055 & 0.190 & 0.010 \\
\hline 0.05 & 0.05 & 0.03 & 0.06 \\
\hline 0.09 & 0.02 & 0.02 & 0.03 \\
\hline 0.00 & 0.00 & 0.00 & 0.00 \\
\hline 3.80 & 4.18 & 4.65 & 4.20 \\
\hline 1279 & 1243 & 1474 & 1753 \\
\hline 2.48 & 2.82 & 3.40 & 4.15 \\
\hline 0.26 & 0.22 & 0.26 & 0.33 \\
\hline 214 & 202 & 136 & 112 \\
\hline 76 & 65 & 46 & 66 \\
\hline 2.10 & 1.80 & 1.44 & 1.86 \\
\hline 8.4 & 8.4 & 8.2 & 8.4 \\
\hline
\end{tabular}

Table 3-12

ANALYTICAL RESULTS OF OTAKE SCALES (REF. 58)

Distance from the

\begin{tabular}{|c|c|c|c|c|c|c|}
\hline $\begin{array}{l}\text { Sample } \\
\text { No. }\end{array}$ & $\begin{array}{c}\text { entrance of the pipeline } \\
\text { (in meters) }\end{array}$ & $\begin{array}{l}\mathrm{SiO}_{2} \\
(\%)^{2} \\
\end{array}$ & $\begin{array}{c}\mathrm{A}]_{2} \mathrm{O}_{3} \\
(\%) \\
\end{array}$ & $\begin{array}{l}\mathrm{Fe}_{2} \mathrm{O}_{3} \\
(\%)\end{array}$ & $\begin{array}{l}\mathrm{TiO}_{2} \\
(\%) \\
\end{array}$ & $\begin{array}{l}\mathrm{H}_{2} \mathrm{O} \\
(\%) \\
\end{array}$ \\
\hline 1 & 0 & 78.45 & 4.62 & 3.22 & 0.34 & 8.34 \\
\hline 2 & 950 & 87.98 & 2.36 & 0.66 & 0.07 & 7.31 \\
\hline 3 & 3863 & 93.25 & 0.99 & 0.15 & 0.11 & 4.60 \\
\hline
\end{tabular}


popular sequestering agents in water treatment are inorganic polymetaphosphates; see, for example, Table 3-13. These adsorb on the surface of existing scale and cause the scale to redissolve. Care should be taken to avoid using acids along with polymetaphosphates since acids promote formation of orthophosphate ion which reacts with calcium in the water to form insoluble calcium phosphate (Ref. 62).

Scale formed on downhole oilwell tubing and pumps has been controlled by introducing phosphates in one of the following ways: (1) lowering a wire basket containing the phosphates on the bottom of the tubing string; (2) passing the produced water through a feeder containing the phosphate, and then recycling it through the annulus, and (3) fracturing the formation of a producing we 11 with sand, $0 i 1$, and 12 to 40 mesh phosphate (Ref. 63). A dosage of 2 to $10 \mathrm{ppm}$ of phosphate in the produced water is usually sufficient to prevent scale formation.

Ethylenediaminetetraacetic acid (EDTA) and its sodium salts are used as scale inhibitors in boiler water treatment. EDTA forms stable soluble complexes with nearly all metallic ions, e.g., $\mathrm{Mg}^{++}, \mathrm{Ca}^{++}, \mathrm{Sn}^{++}, \mathrm{Ba}^{++}$, and has an advantage over polymetaphosphate in not hydrolyzing. The maximum complexing or chelating efficiency of EDTA for $\mathrm{Ca}$ is obtained at $\mathrm{pH} 6$, and thereafter remains nearly constant (Fig. 3-10). Other metals are effectively complexed at lower pH (Ref. 64). Table 3-14 gives some data on the solubility of EDTA salts in water and the quantity of various EDTA salts necessary to complex $1 \mathrm{ppm}$ of calcium. The higher cost of EDTA as compared to polymetaphosphates may limit its use (Ref. 64, 65).

Citric acid and gluconic acid and their sodium salts are used as sequestering agents for calcium and ferric iron. The effectiveness of the free acids is enhanced by an increase in the solution pH. Fig. 3-11 shows the effect of pH on the ironsequestering power of sodium tetraphosphate, sodium citrate, and sodium gluconate; Fig. 3-12 shows the effect of pH change on the chelating power of selected calcium sequestrants.

An additive based on polymeric carboxylic acid (trade name Belgard EV) for controlling scale deposition in high temperature multistage flash commercial desalting plants has been developed. It prevents hard scale formation by threshold effect retarding the precipitation and by crystal distortion and is reported to be effective for use with brines up to $121^{\circ} \mathrm{C}\left(250^{\circ} \mathrm{F}\right)$ or higher temperature (Ref. 78). 
Table 3-13

TYPICAL POLYMETAPHOSPHATES USED FOR PREVENTING SCALE FORMATION (REF. 18)

Name of Phosphate

Tetrasodium pyrophosphate

Sodium triphosphate

Trisodium tripolyphosphate

Hexasodium hexametaphosphate

Sodium-calcium phosphate

Sodium-magnesium phosphate

Sodium-zinc phosphate
Formula

$\mathrm{Na}_{4} \mathrm{P}_{2} \mathrm{O}_{7}$

$\mathrm{Na}_{5} \mathrm{P}_{3} \mathrm{O}_{10}$

$\mathrm{Na}_{3} \mathrm{P}_{3} \mathrm{O}_{9}$

$\mathrm{Na}_{6} \mathrm{P}_{6} \mathrm{O}_{18}$

$\mathrm{Na}_{2} \mathrm{O} \cdot \mathrm{CaO} \cdot \mathrm{P}_{2} \mathrm{O}_{5}$

$\mathrm{Na}_{2} \mathrm{O} \cdot \mathrm{MgO} \cdot \mathrm{P}_{2} \mathrm{O}_{5}$

$\mathrm{Na}_{2} \mathrm{O} \cdot \mathrm{ZnO} \cdot \mathrm{P}_{2} \mathrm{O}_{5}$

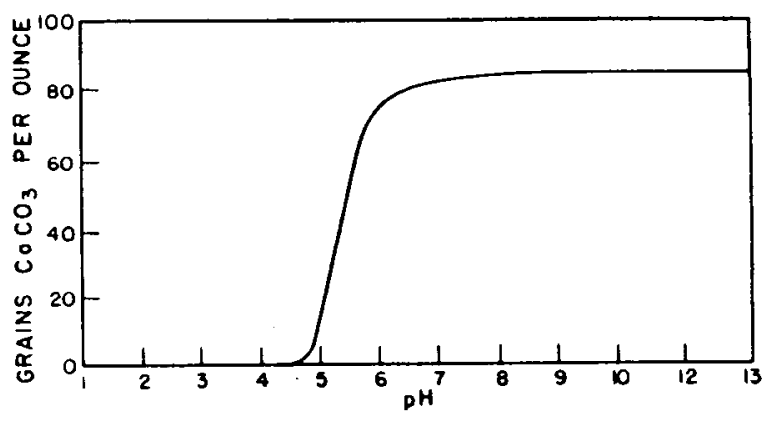

Fig. 3-10. Effect of pH on chelating power of EDTA (Ref. 66); (This is for Ca only. pH curves for other metals vary.) 
Table 3-14

CONCENTRATION OF EDTA AND ITS SODIUM SALTS

NECESSARY TO COMPLEX I PPM CALCIUM ION,

MAGNESIUM ION, AND BARIUM ION (REF. 18)

Solubility $\quad \mathrm{pH}$ of $\mathrm{g} / 100 \mathrm{CC} \mathrm{H}_{2} \mathrm{O}$ Water Q $26^{\circ} \mathrm{C}\left(79^{\circ} \mathrm{F}\right)$ Solution ppm necessary to complex $1 \mathrm{ppm}$ of Alkaline Earth Metal
$\mathrm{Ca}^{++}$

$\mathrm{Ba}^{++}$

\begin{tabular}{|c|c|c|c|c|c|}
\hline $\begin{array}{l}\text { Ethylenediaminetetra- } \\
\text { acetic acid }\end{array}$ & 0.02 & 2.3 & 12.0 & 7.4 & 2.1 \\
\hline $\begin{array}{l}\text { Disodium ethylenediaminetetra- } \\
\text { acetate dihydrate }\end{array}$ & 11.1 & 5.0 & 15.4 & 9.5 & 2.7 \\
\hline $\begin{array}{l}\text { Trisodium ethylenediaminetetra- } \\
\text { acetate monohydrate }\end{array}$ & 57.0 & 8.4 & 15.6 & 9.6 & 2.8 \\
\hline $\begin{array}{l}\text { Tetrasodium ethylenediamine- } \\
\text { tetraacetate dihydrate }\end{array}$ & 103.0 & 10.3 & 16.9 & 10.4 & 3.0 \\
\hline
\end{tabular}

b. Closed Treatment Systems. A closed treatment system has the objective to exclude atmospheric oxygen and thereby aid in maintaining a constant wastewater composition. The closed system also minimizes escape of $\mathrm{CO}_{2}$ gas from the water causing undesirable chemical reactions; for example, loss of $\mathrm{CO}_{2}$ will increase the likelihood of $\mathrm{CaCO}_{3}$ formation.

In oilfield brine treatment, a blanket of natural gas is maintained in the brinecontaining vessels to insure the absence of air. Here, closed systems were found effective in maintaining brine chemistry, but success of the method depends partially on gathering brine from only a few wells and minimizing leaks in piping and other equipment (Ref. 20).

\section{Treatment for Controlling Microorganisms}

Growth of algae and bacteria is controlled by use of oxidizing agents such as chlorine. Chlorination is used to control microorganisms in flow lines, filters, cooling towers, ion exchange units, condensers, and water storage. In oilfield 


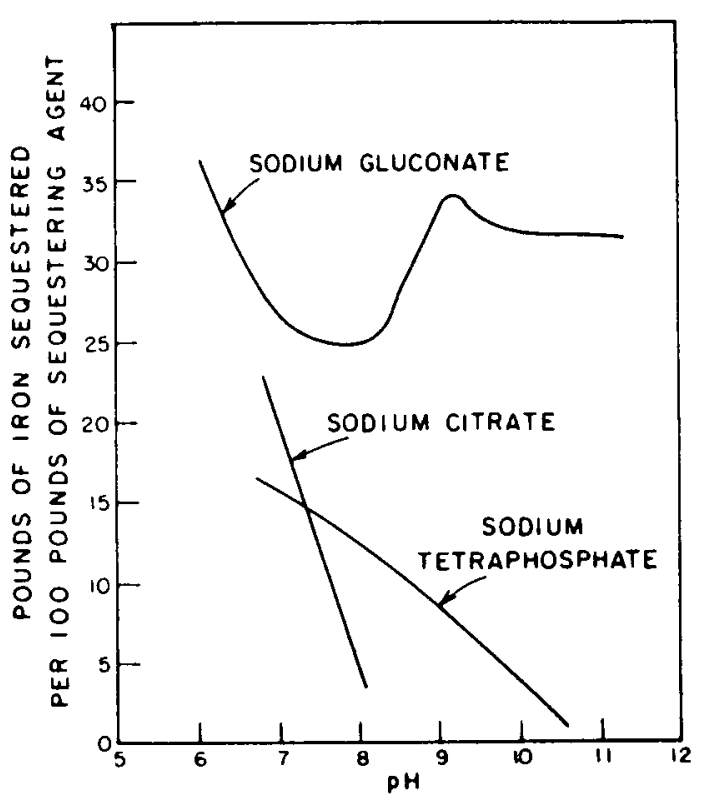

Fig. 3-11. Influence of $\mathrm{pH}$ on the chelating power of some iron seques trants (Ref. 67)

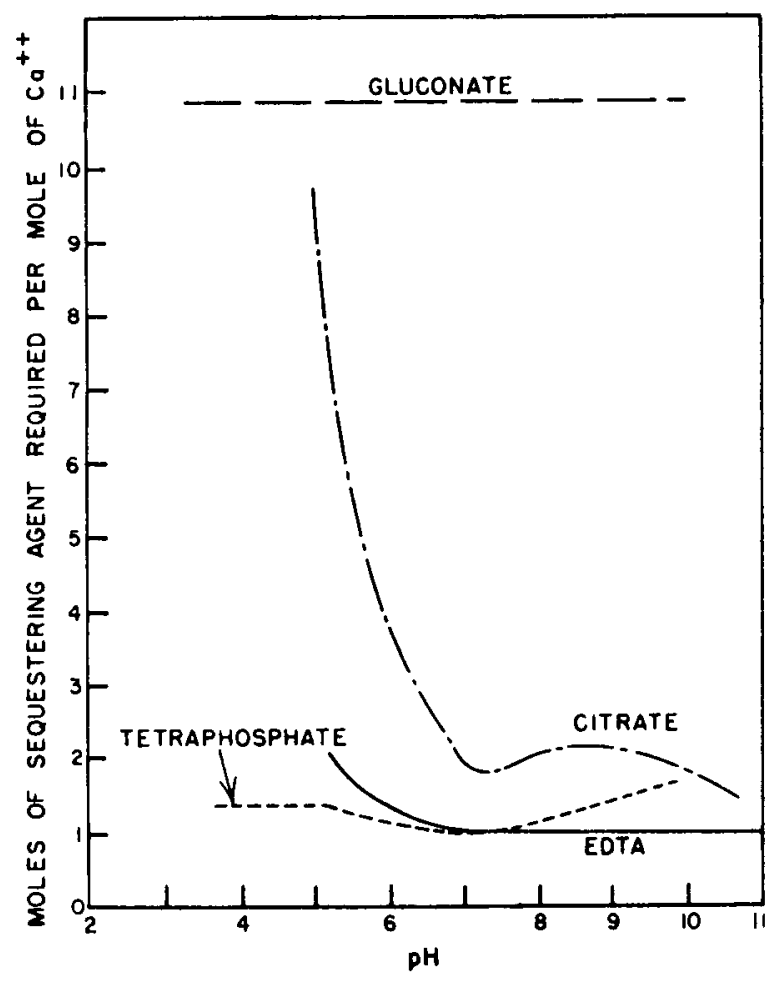

Fig. 3-12. Influence of $\mathrm{pH}$ on the chelating power of some calcium sequestrants (Ref. 68) 
treatment chlorine may be added as a liquid, or generated in situ by electrolysis of the brine (Ref. 20). Chlorine added to water hydrolyzes to form hypochlorous and hydrochloric acids, as shown below:

$$
\begin{aligned}
\mathrm{H}_{2} \mathrm{O}+\mathrm{Cl}_{2} & \rightleftarrows \mathrm{H}^{+}+\mathrm{Cl}^{-}+\mathrm{HOCl} \\
\mathrm{HOCl} & \rightleftarrows \mathrm{H}^{+}+\mathrm{OCl}^{-}
\end{aligned}
$$

The above reaction is influenced by $\mathrm{pH}$ and temperature. Chlorine is a strong oxidizing agent and converts any ferrous iron present in the water to the ferric form. This may eventually hydrolyze to insoluble $\mathrm{Fe}(\mathrm{OH})_{3}$. Chlorination oxidizes hydrogen sulfide present in the water to $\mathrm{SO}_{4}$ or sulfur.

Excessive amounts of residual chlorine may cause corrosion and should be avoided. Normally $0.2 \mathrm{ppm}$ residual chlorine is sufficient to control microorganisms in water. Besides chlorine, other inorganic bactericides used are chromates and silver or mercury compounds.

At Cerro Prieto geothermal power plant, excessive corrosive bacteria proliferation caused a lowering in brine $\mathrm{pH}$ and an increase in sulfates in the cooling water. This was controlled using biocides containing organotin, bithiocyanite, polychlorophenol, and dispersants, and by periodic hand removal of the deposits (Ref. 14).

Sodium hypochlorite was used as an oxidizing agent to preoxidize As(III) to As(V), thereby substantially improving the efficiency of arsenic removal by coagulation from geothermal discharge waters in New Zealand (Ref. 53). 


\section{Section 4}

BRINE TREATMENT FOR - CORROSION CONTROL

The following section covers methods currently in use, or which may be useful in controlling geothermal corrosion. The methods generally fall into one of two categories: (1) removal of brine constituents which cause corrosion (e.g., $\mathrm{CO}_{2}, \mathrm{H}_{2} \mathrm{~S}$ ), and (2) development of corrosion-resistant materials.

\section{Geothermal fluids contain appreciable quantities of dissolved salts and gases} that are generally more corrosive to materials of construction than other standard environments for the production of electrical power. In a geothermal power system corrosion takes place in well casings (downhole corrosion), surface lines, separators, turbines, heat exchangers, cooling towers, and discharge lines. Corrosion rates in geothermal plants are dependent primarily on fluid pH, mineral content, temperature, flow rate (velocity), partial pressures of $\mathrm{CO}_{2}, \mathrm{H}_{2} \mathrm{~S}, \mathrm{NH}_{3}$, and $\mathrm{H}_{2}$, and the oxygen content of the system. (See Table 1-1.) Because geothermal fluids vary in composition from one field to another, treatment to prevent corrosion may require extensive tests and analyses of brine data for each geothermal site.

The forms of corrosion damage to metals commonly occuring in a geothermal environment include the following:

- Uniform surface corrosion--ordinary rusting on the surface of the metal resulting in reduction of metal thickness by a uniform amount. See Table 4-1.

- Pitting corrosion--a localized corrosive attack resulting in the formation of a shallow or deep pit.

- Stress corrosion and sulfide stress cracking--cracking of a metal due to constant tensile stresses in a corrosive environment.

- Erosion-corrosion due to mechanical abrasion of the passive film on a metal resulting in corrosion. This is traceable to the high velocity entrained particulate matter (e.g., sand or precipitated solids) in the geothermal fluids, and is particularly important where wearing is maximized due to high fluid velocity. 
Table 4-1

SURFACE CORROSION RATES OF METALS IN GEOTHERMAL MEDIA (REF. 68)

\begin{tabular}{|c|c|c|c|c|c|c|c|}
\hline Metel & $\begin{array}{l}\text { Bore water" } \\
>200^{\circ} \mathrm{C}\end{array}$ & $\begin{array}{l}\text { Wotor" } \\
-12 !^{\circ} \mathrm{C}\end{array}$ & $\begin{array}{l}\text { Steatn" } \\
100-200^{\circ} \mathrm{C}\end{array}$ & $\begin{array}{l}\text { Aeratod } \\
\text { steam" } \\
\sim 100^{\circ} \mathrm{C}\end{array}$ & $\begin{array}{c}\text { Condensate" } \\
\sim 70^{\circ} \mathrm{C}\end{array}$ & $\begin{array}{l}\text { Condeneated } \\
\text { freth water } \\
\text { mixture' } \\
\sim 50^{\circ} \mathrm{C}\end{array}$ & $\begin{array}{l}\text { Higbly ceid } \\
\text { tbermal waver" }\end{array}$ \\
\hline Titanium & 0 & 0 & 0 & $\mathbf{0}$ & - & - & $\mathbf{0}$ \\
\hline Chromium (plating on steel) & 0 & & 0 & $\mathbf{0}$ & - & - & - \\
\hline Aluminium & I & $0.8-\mathrm{P}$ & O-P-I & O-P & 0.2 & 9 & 28 \\
\hline Zinc (costing on steel) & $S^{14}$ & 1 & O-I-P & $\mathbf{S}$ & - & $\mathbf{S}$ & - \\
\hline Austenitic stainiess steels' & 0.1 & $\mathbf{0}$ & 1 & 0 & $\mathbf{0}$ & $\mathbf{0}$ & 22 \\
\hline Ferritic stainless steels ${ }^{10}$ & $0-0.1$ & $0.1-\mathrm{P}$ & \multirow{2}{*}{$\begin{array}{l}0-0.3-P \\
0.3-6\end{array}$} & 1-P & $0.1 \cdot \mathrm{P}$ & $0-0.5$ & - \\
\hline Carbon and low alloy stoels & $0.3-0.4$ & $0.3-0.5$ & & 20 & 3 & $30-170$ & 1,000 \\
\hline Grey cast iron & 1 & 0.4 & $1 \cdot 3$ & 10 & - & 90 & - \\
\hline High silicon cast iron & 一 & - & 0.5 & 1 & - & - & 8 \\
\hline Brasses" & 5 & 0.3 & $0.3-0.6$ & 40 & 0.2 & - & - \\
\hline Bronze & 20 & - & 2 & 9 & - & - & - \\
\hline Aluminium bronzes & 10 & - & $2-3$ & 10 & 1 & - & - \\
\hline Silicon bronze & - & - & 3 & 20 & - & - & - \\
\hline Cupronickel & 9 & - & 2 & - & - & - & - \\
\hline Beryllium copper & 10 & - & 4 & - & - & - & - \\
\hline Copper & 20 & 10 & 2 & 40 & 5 & - & - \\
\hline Nickel & 6 & - & 1 & 8 & 2 & - & - \\
\hline Monel and $\mathrm{K}$ Monel & $8-10$ & 1 & $2-4$ & 10 & 4 & - & 14 \\
\hline Nimonic 75 & 0.3 & - & 0 & - & - & - & - \\
\hline Inconel & 1 & 0 & $0-0.3$ & 80 & - & - & 20 \\
\hline Lead, antimonial lead & - & - & 0.5 & 2.5-P & - & 1 & 6 \\
\hline \multicolumn{3}{|c|}{ 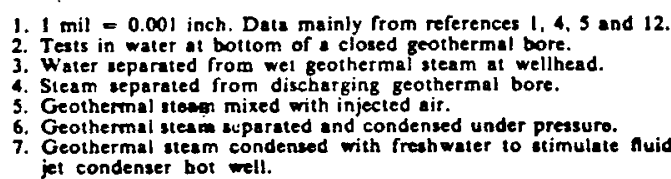 } & \multicolumn{5}{|c|}{ 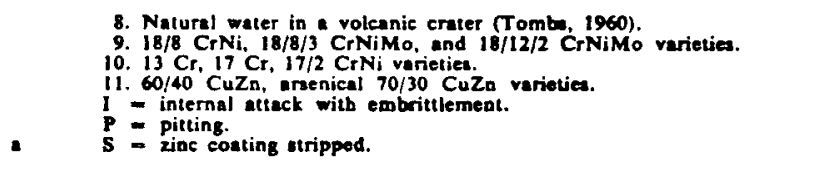 } \\
\hline
\end{tabular}


In addition to the above, corrosion fatigue, hydrogen infusion, galvanic corrosion, and hydrogen-induced delayed fracture are also common in a geothermal environment. For additional details, see Ref. 2, 68, and 69.

\section{A. AERATION AND DEGASIFICATION}

Aeration is a process used in "open-type" systems involving a mass transfer between the water and gas phases. Aeration speeds up the rate of interchange between air and water by producing a large contact surface area, and is effective in removing acidic gases (e.g., $\mathrm{H}_{2} \mathrm{~S}$ and $\mathrm{CO}_{2}$ ).

$$
\mathrm{H}_{2} \mathrm{~S}+\frac{1}{2} \mathrm{O}_{2} \rightleftarrows \mathrm{H}_{2} \mathrm{O}+\mathrm{S}
$$

Typical aeration equipment includes cooling towers, spray nozzles, and forced draft blowers where air flows countercurrent to a flow of water cascading over splash trays.

However, over-aeration causes additional corrosion due to introduction of excess dissolved oxygen, probably the main cause of corrosion in oilfield brines (Ref. 12).

Degasification is a chemical process with the objective mainly to remove dissolved oxygen from water. The equipment used for oxygen removal includes open heaters, deaerating heaters, spray type deaerating heaters, tray type deaerating heaters, vacuum deaerators. For details of deaerators, see Ref. 18 and 56.

Chemical degasification is used to remove oxygen selectively from the water by adding a chemical such as sodium sulfite or hydrazine to remove $\mathrm{O}_{2}$ from oilfield brines and boiler feed water. Sodium sulfite reacts with dissolved oxygen to form sulfate as follows:

$$
\frac{1}{2} \mathrm{O}_{2}+\mathrm{Na}_{2} \mathrm{SO}_{3} \rightarrow \mathrm{Na}_{2} \mathrm{SO}_{4}
$$

The rate of the reaction is slow at ambient temperatures, requiring the use of catalysts ( $\mathrm{Mn}, \mathrm{Cu}, \mathrm{CO}, \mathrm{Ni}, \mathrm{Fe}$ ) to increase the reaction rate. See Fig. 4-1. Addition of a catalyst reduces the cost of treatment by about $25 \%$ (Ref. 18).

As discussed earlier, production of sulfate causes undesired precipitation of insoluble metal sulfates. Another problem with sodium sulfite is that it decomposes into corrosive $\mathrm{SO}_{2}$ at high temperatures. Hydrazine $\left(\mathrm{N}_{2} \mathrm{H}_{4}\right)$ is effective for reducing oxygen even at high temperatures. The reaction with $\mathrm{O}_{2}$ is as follows: 


$$
\mathrm{N}_{2} \mathrm{H}_{4}+\mathrm{O}_{2} \rightarrow \mathrm{N}_{2}+2 \mathrm{H}_{2} \mathrm{O}
$$

In one experiment, hydrazine removed $81 \%$ of the oxygen from boiler feed water at $47^{\circ} \mathrm{C}\left(117^{\circ} \mathrm{F}\right)$; the removal increased to $94 \%$ when the feed water temperature was raised to $54^{\circ} \mathrm{C}\left(130^{\circ} \mathrm{F}\right)$. The presence of a catalyst (e.g., $\left.\mathrm{Cu}^{++}, \mathrm{Mn}^{++}\right)$increases the reaction rates (Ref. 71 ).

Sodium sulfite $\left(10 \mathrm{ppm} \mathrm{Na} 2 \mathrm{SO}_{3}\right.$ per $1 \mathrm{ppm} \mathrm{O}_{2}$ ) was added to the $86^{\circ} \mathrm{C}$ water in the Reykjavik Municipal Heating System, Iceland, to reduce oxygen and thereby control internal corrosion of metals in the heating system (Ref. 72).

Tables 4-2 and 4-3 show the effect of air-aeration and degasification of geothermal brines on corrosion of various metals tested.

\section{B. MATERIALS SELECTION}

There is an active research and development effort centered on developing alloys with resistance to geothermal corrosion. The current status of this work is summarized in tabular form in Table 4-4. The reader is referred to Ref. 73 and 10 for a thorough review of corrosion resistance of metals in hot brines.

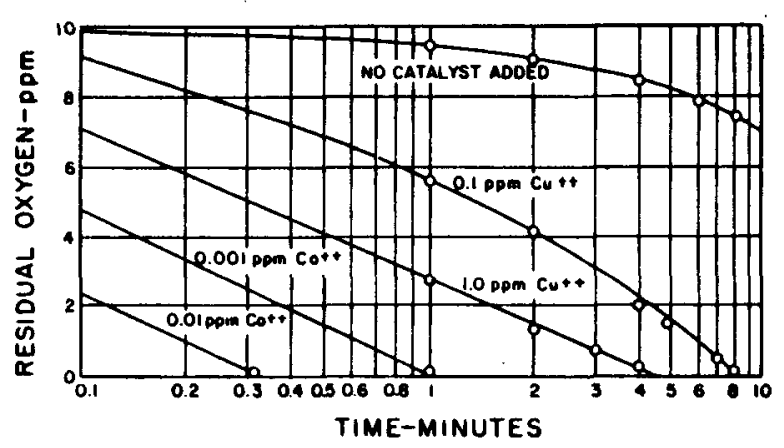

Fig. 4-1. Effect of catalysts on rate of oxygen-sulfite reaction (Ref. 70) 
Table 4-2

CORROSION DATA AT $105^{\circ} \mathrm{C}$ AND 1 ATM, 15 DAYS (REF. 74) ${ }^{1}$

\begin{tabular}{|c|c|c|c|c|c|c|c|c|}
\hline & \multicolumn{4}{|c|}{ General corrosion, mpy } & \multicolumn{4}{|c|}{ Crevice corrosion $^{2}$} \\
\hline & \multicolumn{2}{|c|}{ Air-aerated } & \multicolumn{2}{|c|}{ Deaerated } & \multicolumn{2}{|c|}{ Air-aerated } & \multicolumn{2}{|c|}{ Deaerated } \\
\hline & $\begin{array}{l}\text { Holt- } \\
\text { ville } \\
\text { brine } \\
(3 w / 0) \\
\end{array}$ & $\begin{array}{l}\text { Niland } \\
\text { brine } \\
(28 w / 0)\end{array}$ & $\begin{array}{l}\text { Holt- } \\
\text { ville } \\
\text { brine } \\
(3 w / 0) \\
\end{array}$ & $\begin{array}{l}\text { Niland } \\
\text { brine } \\
(28 w / 0)\end{array}$ & $\begin{array}{l}\text { Holt- } \\
\text { ville } \\
\text { brine } \\
(3 w / 0) \\
\end{array}$ & $\begin{array}{l}\text { Niland } \\
\text { brine } \\
(28 \mathrm{w} / 0)^{\circ}\end{array}$ & $\begin{array}{l}\text { Hoit- } \\
\text { vi } 11 \mathrm{e} \\
\text { brine } \\
(3 w / 0) \\
\end{array}$ & $\begin{array}{l}\text { Ni Tand } \\
\text { brine } \\
(28 w / 0)\end{array}$ \\
\hline Iron Base: & & & & & & & & \\
\hline Carbon stee 1 & 40.9 & 5.8 & 17.3 & 4.2 & -- & -- & -- & -- \\
\hline 4130 s tee 1 & 10.7 & -- & 0.2 & -- & 1 & -- & 1 & -- \\
\hline Sandvik 3RE-60 & 0.1 & 0.9 & .4 & 0.0 & 3 & 6 & 1 & 2 \\
\hline E-Brite 26-1 & .0 & 3.6 & .0 & .0 & 1 & 1 & 1 & 1 \\
\hline Type 302 ss & .1 & -- & .0 & -- & 2 & -- & 1 & -- \\
\hline Type $316 \mathrm{~L}$ sS & .0 & 4.0 & .0 & 0.0 & 2 & 6 & 2 & 2 \\
\hline Carpenter 20 ss & .2 & 2.2 & .1 & .0 & 1 & 5 & 1 & 2 \\
\hline \multicolumn{9}{|l|}{ Nickel Base: } \\
\hline Monel 400 & 2.5 & 3.7 & 0.2 & 2.8 & 4 & 5 & 1 & 4 \\
\hline Inconel $\mathrm{X}-750$ & 0.1 & 3.4 & 0.0 & 0.0 & -- & 5 & -- & 3 \\
\hline Inconel 625 & .0 & 0.0 & .0 & .0 & 1 & 1 & 1 & 1 \\
\hline Hastelloy $\mathrm{S}$ & .1 & .0 & .1 & .0 & 1 & 4 & 1 & 1 \\
\hline Hastelloy G & .1 & .1 & .1 & .0 & 1 & 4 & 1 & 1 \\
\hline Haste11oy C-276 & .1 & .0 & .1 & .0 & 1 & 1 & 1 & 1 \\
\hline \multicolumn{9}{|l|}{ Copper Base: } \\
\hline Copper & 63.1 & 12.5 & 1.9 & 3.1 & -- & 1 & -- & 1 \\
\hline Copper-2Iron & 11.6 & 13.3 & 3.7 & 2.7 & -- & -- & -- & - \\
\hline $90-10$ brass & 3.6 & -- & 2.2 & -- & 4 & -- & 1 & -- \\
\hline $70-30$ brass & 4.3 & -- & 1.2 & -- & 4 & -- & 1 & -- \\
\hline 90-10 cupronickel & 3.7 & -- & 0.9 & -- & 1 & -- & 1 & -- \\
\hline 70-30 cupronicke1 & 17.9 & 5.8 & 5.7 & 0.6 & -- & 4 & -- & 3 \\
\hline \multicolumn{9}{|l|}{ Titanium Base: } \\
\hline Titanium & 0.0 & 0.0 & 0.0 & 0.0 & 2 & 2 & 1 & 1 \\
\hline Titanium-1.7W & .0 & .0 & .0 & .0 & 1 & 1 & 1 & 1 \\
\hline Titanium-2Ni & .1 & .0 & .0 & .0 & -- & 1 & -- & 1 \\
\hline Titanium-10V & .0 & .0 & .0 & .0 & -- & 1 & -- & 1 \\
\hline \multicolumn{9}{|l|}{ Aluminum Base: } \\
\hline $2024-T 3$ & ${ }^{3} 45.4$ & 34.9 & 4.9 & ${ }^{3} 1.3$ & -- & 6 & -- & 6 \\
\hline $6061-T 6$ & 2.1 & 56.6 & 2.1 & ${ }^{3} 30.4$ & -- & 1 & -- & 1 \\
\hline \multicolumn{9}{|l|}{ Molybdenum Base: } \\
\hline$T Z M$ & 3.0 & 1.4 & 0.2 & 0.0 & -- & 5 & -- & 1 \\
\hline
\end{tabular}

${ }^{1}$ Dashes (--) indicate that metal was not tested.

${ }^{2}$ Numbers indicate extent of corrosion as follows:

1. Not detected

2. Very slight $(<0.1 \mathrm{mpy})$

3. Slight $(>0.1$ mpy but $<1$ mpy)

${ }^{3}$ pits 60 mils deep.
4. Moderate ( $>1$ mpy but $<5$ mpy)

5. Severe (> 5 mpy but < $50 \mathrm{mpy}$ )

6. Very severe $(>50 \mathrm{mpy})$. 
Table 4-3

CORROSION DATA IN DEAERATED NILAND (28 W/O) BRINE

AT $232^{\circ} \mathrm{C}, 15$ DAYS (REF. 74 )

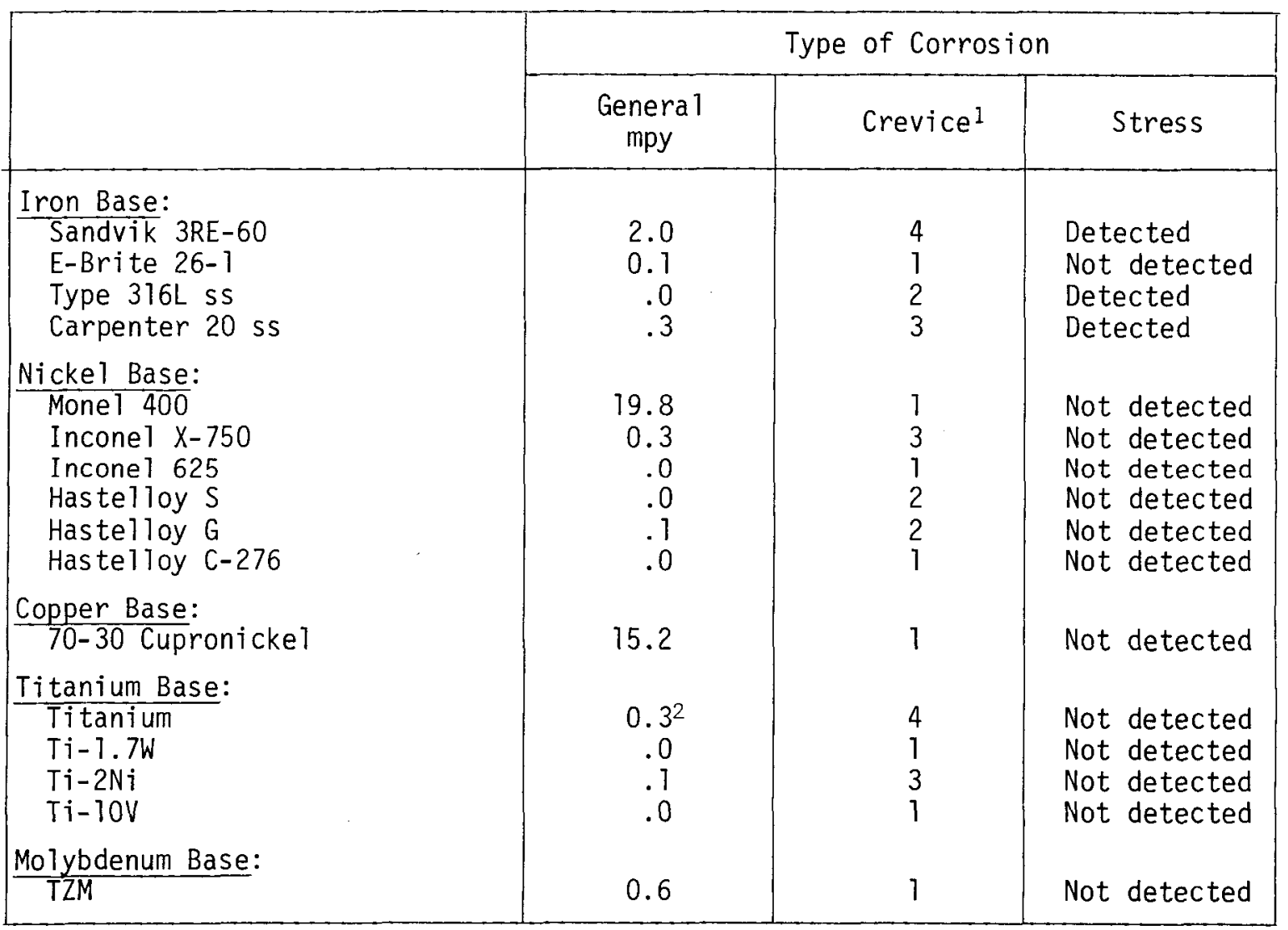

1 Numbers indicate extent of corrosion as follows:

1. Not detected

2. Slight $(<1$ mpy)

3. Moderate ( $>1$ mpy but $<5$ mpy)

4. Severe (> 5 mpy)

2 Pitting 2.0 to $6.0 \mathrm{mils}$ deep. 
Table 4-4

CORROSION RESISTANT CANDIDATE MATERIALS FOR OXYGEN-FREE GEOTHERMAL SYSTEMS (REF. 75)

\begin{tabular}{|c|c|c|c|c|c|c|}
\hline \multicolumn{3}{|c|}{$\underline{120^{\circ} \mathrm{C}\left(250^{\circ} \mathrm{F}\right)}$} & \multicolumn{2}{|c|}{$120^{\circ} \mathrm{C}-180^{\circ} \mathrm{C}\left(250^{\circ} \mathrm{F}-350^{\circ} \mathrm{F}\right)$} & \multicolumn{2}{|c|}{$180^{\circ} \mathrm{C}\left(>350^{\circ} \mathrm{F}\right)$} \\
\hline & Material & Problems & Material & Problems & Yaterial & Problew \\
\hline \multirow[t]{2}{*}{ Dry steam } & $\begin{array}{l}\text { Carbon Steel } \\
\text { Low alloy steels } \\
12 \mathrm{cr} \text { ateel }\end{array}$ & $\begin{array}{l}\text { Corrosion fatigue } \\
\text { Erosion } \\
\text { High corrosion if } \\
\text { steam condenses }\end{array}$ & $\begin{array}{l}\text { Carbon Steel } \\
\text { Low alloy steels } \\
12 \mathrm{cr} \text { steel } \\
\text { Titanium } \\
\text { Zirconium }\end{array}$ & $\begin{array}{l}\text { Corrosion fatigue } \\
\text { Erosion } \\
\text { Specify corrosion } \\
\text { allowance }\end{array}$ & 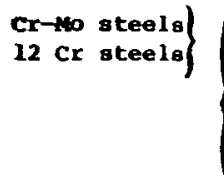 & $\left\{\begin{array}{l}\text { Corrosion fatigue } \\
\text { Erosion } \\
\text { Specify significant } \\
\text { corrosion allowance } \\
\text { R\&D on turbine } \\
\text { materials }\end{array}\right.$ \\
\hline & & & & & $\left.\begin{array}{l}\text { zirconium } \\
\text { Titanium }\end{array}\right\}$ & Lack of data \\
\hline \multicolumn{7}{|l|}{ Water } \\
\hline $\mathrm{pH}>\theta$ & Carbon steel & Erosion & $\begin{array}{l}\text { Carbon steel } \\
\text { Low alloy steels }\end{array}$ & $\left\{\begin{array}{l}\text { Hydrogen } \\
\text { embrittlement } \\
\text { Erosion } \\
\text { specify corrosion } \\
\text { allowance }\end{array}\right.$ & $\begin{array}{l}\text { Alloy steels } \\
\text { (for strength }\end{array}$ & $\begin{array}{l}\text { Hydrogen } \\
\text { embrittlement } \\
\text { Erosion } \\
\text { Specify corrosion } \\
\text { allowance } \\
\text { Need R\&D for data }\end{array}$ \\
\hline
\end{tabular}

PH 6-8 Carbon steel Erosion

\begin{tabular}{l|l} 
carbon steel & Low alloy steels
\end{tabular} \mid $\begin{aligned} & \text { Erosion } \\
& \text { Specify corrosion } \\
& \text { allowance }\end{aligned}$

RED Required

Aluminum Test for pitting

A

est for pitting

Alumi num

316 SST

$<50$ ppm $\mathrm{Cl}^{-}$

Titanium

Test for pitting

Test for pitting

and crevice

corrosion (especially

$56 \mathrm{Ni}-15 \mathrm{Cr}-16 \mathrm{MO}$

in brines)

$\begin{array}{llll}\text { pH 4-6 Carbon steel } & \begin{array}{c}\text { Short life } \\ \text { uses only }\end{array} & \\ \text { Aluminum } & \text { Test for pitting } & \text { Aluminum } & \text { Pitting Test } \\ \text { Titanium } & & \text { Titanium } & \text { required } \\ \text { zirconium } & & \text { zirconium } & \end{array}$

316 SST

$<50 \mathrm{ppm} \mathrm{C1}^{-}$

$56 \mathrm{Ni}-16 \mathrm{Cr}-16 \mathrm{MO}^{*}$

$56 \mathrm{Ni}-15 \mathrm{Cr}-16 \mathrm{MO} *$

pH 4 Titanium

Titanium

RED Required

$56 \mathrm{Ni}-15 \mathrm{Cr}-16 \mathrm{MO} *$ 


\section{Section 5}

SCALE AND INCRUSTANTS REMOVAL

In this section, we discuss methods currently being used or proposed for removal of scale once it has been formed in production wells, power plant equipment, and injection wells (Fig. 5-1). There are several approaches for removing deposited scale, depending on its location and composition. Commonly used methods to remove deposits are described below. See Table 5-1 for a listing of typical methods of scale removal.

\section{A. ACIDIZING}

Acidizing is a method used to clean boreholes of scale by injecting an acid into the borehole. The type of acid used depends on the composition of the deposit, e.g., $\mathrm{HCl}$ for $\mathrm{CaCO}_{3}$ deposits, $\mathrm{HF}$ for sand or silica. Calcite reacts with $\mathrm{HCl}$ to form soluble $\mathrm{CaCl}_{2}$ according to the reaction:

$$
\mathrm{CaCO}_{3}+2 \mathrm{HCl} \rightarrow \mathrm{Ca}^{++}+\mathrm{H}_{2} \mathrm{O}+\mathrm{CO}_{2} \uparrow+2 \mathrm{Cl}^{-}
$$

Acid cleaning of $\mathrm{CaCO}_{3}$ deposits with $\mathrm{HCl}$ was accomplished in East Mesa Well 5- 1 by pumping 19,000 liters of inhibited 15\% $\mathrm{HCl}$ into the bore (Ref. 21). East Mesa 5- 1 has the following casing parameters:

\begin{tabular}{|c|c|c|c|}
\hline $\begin{array}{c}\text { Casing } \\
\text { (0.D., inches) } \\
\end{array}$ & $\begin{array}{c}\text { Depth Interval } \\
\text { (meters) }\end{array}$ & $\begin{array}{c}\text { Slotted Interval } \\
\text { (meters) }\end{array}$ & $\begin{array}{l}\text { Average Saraband } \\
\text { Sand Permeability }\end{array}$ \\
\hline 20 & $0-18$ & - & - \\
\hline $13-3 / 8$ & $0-312$ & -- & -- \\
\hline $7-5 / 8$ & $0-1830$ & $1525-1830$ & 69 millidarcies \\
\hline
\end{tabular}

On acidizing, sufficient deposit was removed to permit lowering of small diameter downhole instruments into the bore; this previously was prevented by the $\mathrm{CaCO}_{3}$ scale.

Acidizing appears to be fairly common practice in the geothermal industry. For example, acid treatment to descale well casings is practiced in Hungary (Ref. 22) 


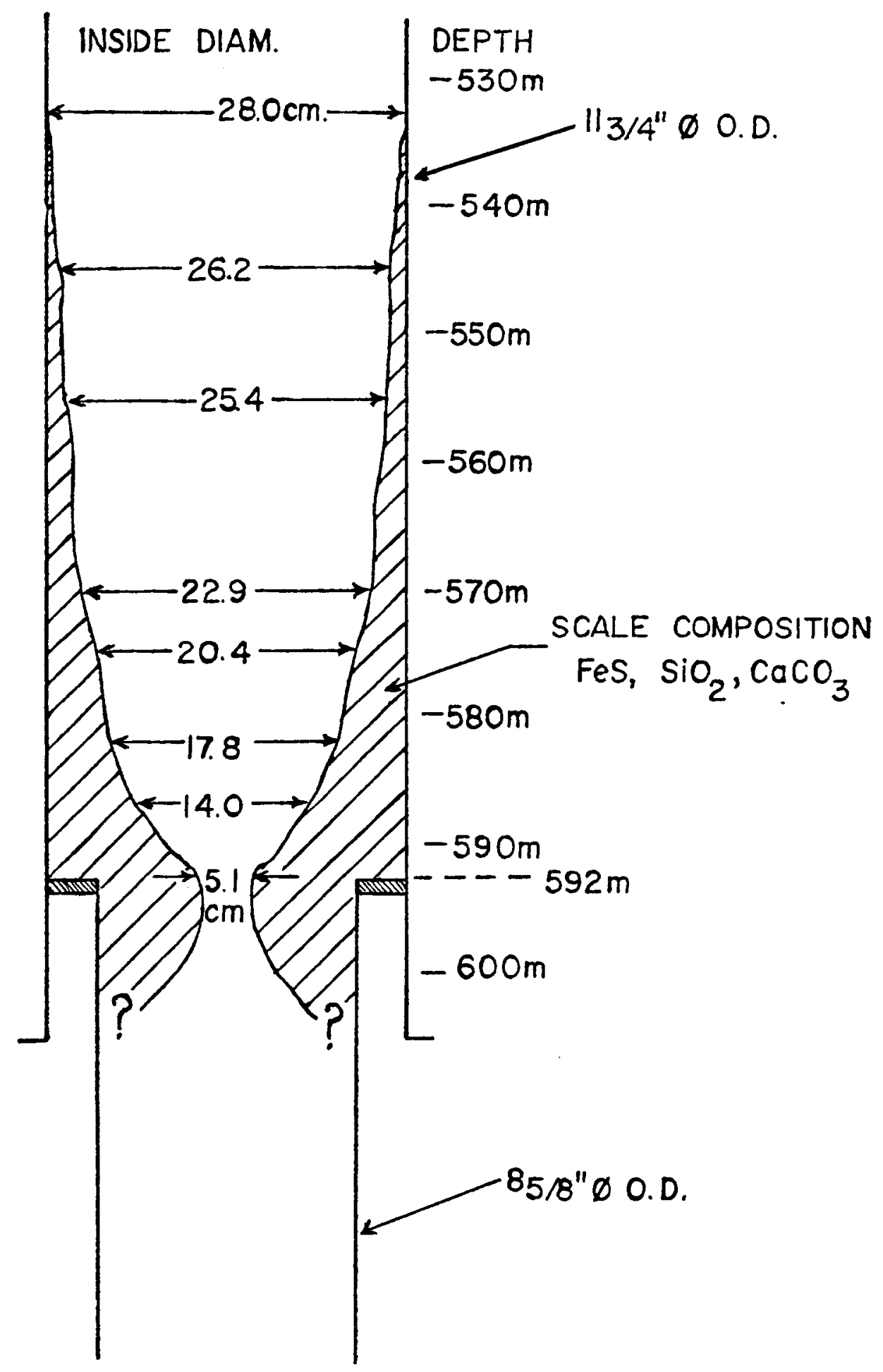

Fig. 5-1. Profile of scale in Well M-13, Cerro Prieto Geothermal Field, Mexico (Ref. 15). 
Table 5-1

TYPICAL TREATMENT METHODS FOR SCALE REMOVAL

Scale Type

Calcite in well casings

Silica in flow control

equipment and heat

exchangers

Silica in borehole

Calcite in borehole

Mixed scales in turbine components

Mixed scales in injection and brine drain lines

Mixed scales in heat exchanger tubing and piping Calcite scale (test probe)
Treatment Method

CURRENT METHODS:

Pump inhibited $\mathrm{HC} 1$ into the well

Wash with inhibited $\mathrm{HC} 1$

Wash with ammonium bifluoride

Pump $\mathrm{NaOH}$ solution into the well

Reaming or redrilling

Spaced injection of heavy diesel oils

Hydroblasting followed by water flush

DEVELOPING METHODS:

Cavitation descaling

Application of thermal Laboratory experiments

\section{Comments}

Acidizing used at East Mesa We11 5-1 and Otake, Japan

Used in Hungary and Kawerau, New Zealand

Acidizing, used at Hveragerdi, Iceland

Used at Matsukawa, Japan

Used in New Zealand, Hungary, and Mexico

Used at Lardere110, Italy

Used at Niland Geothermal Test Facility, California

Laboratory experiments shock 
and inhibited hydrochloric acid has been used with minor success in the Kawerau Geothermal Field in New Zealand to remove calcite deposits from well casing slots (Ref. 23). In 0take, Japan, acid cleaning of a bore choked at a depth of 260 meters with calcite scale was carried out using $5000 \mathrm{~kg}$ of $35 \% \mathrm{HCl}$ containing $75 \mathrm{~kg}$ of inhibitor (Ref. 24). Water was injected into the well to maintain a 3-5\% acid concentration. Although the deposit was not removed completely, the discharge from the well approximately doubled as shown in the following table:

\begin{tabular}{lcccc} 
& $\begin{array}{l}\text { Separator } \\
\text { Pressure } \\
\mathrm{kg} / \mathrm{cm}^{2} \mathrm{G}^{*}\end{array}$ & $\begin{array}{c}\text { Steam } \\
\mathrm{t} / \mathrm{h}\end{array}$ & $\begin{array}{c}\text { Hot Water } \\
\mathrm{t} / \mathrm{h}\end{array}$ & $\begin{array}{c}\text { Shut In } \\
\text { Pressure } \\
\mathrm{kg} / \mathrm{cm}^{2} \mathrm{G}^{*}\end{array}$ \\
\cline { 2 - 5 } before acid cleaning & 2.1 & 4 & 25 & 2.2 \\
\hline after acid cleaning & 2.1 & 8 & 56 & 2.8 \\
\hline${ }^{*} \mathrm{G}=$ Gauge & & & &
\end{tabular}

Chemical cleaning to remove silica scale from flow control equipment and heat exchangers using ammonium bifiuoride has been tried with fair success at Hveraqerdi, Iceland (Ref. 25). Caution is required in use of the acid; injected HF reacts with certain metals (e.g., Ca) to form insoluble fluorides which could precipitate within the borehole.

\section{B. ADDITION OF BASE}

Though very insoluble in water and acid, silica scale dissolves in sodium hydroxide solutions to form soluble silicate:

$$
\mathrm{SiO}_{2}+2 \mathrm{OH}^{-}+\mathrm{SiO}_{3}^{=}+\mathrm{H}_{2} \mathrm{O}
$$

Scale containing $90 \%$ silica was removed from a well in Matsukawa, Jaban, using sodium hydroxide $(\mathrm{NaOH})$ as follows: $125 \mathrm{~kg}$ of $\mathrm{NaOH}$ was dissolved in 300 liters of water. The solution was put into the wellhead for 8 minutes while maintaining high temperature and pressure. The wellhead was then washed with pure water for 15 minutes and the process was repeated. The scale was completely removed in 30 minutes" (Ref. 13).

A disadvantage in scale removal with $\mathrm{NaOH}$ is the possibility of precipitating metal hydroxides in the formation. These precipitates, if formed, would require addition of acid (e.g., $\mathrm{HCl}$ ) for their removal.

\section{REAMING}

As used here, reaming is defined as use of mechanical means such as scratching to clean scale deposits from the wall or casing of a well and from pipelines. In a 
well, the scratcher or reamer is lowered into the bore and deposits scratched by simultaneous rotary and transverse motion of the reamer.

Reaming of geothermal wells to remove calcite has been tried with limited success in New Zealand (Ref. 23), Hungary (Ref. 22), and Mexico. A 1974 estimate of the cost of reaming is obtained from the following data: Low enthalpy wells $(\sim 400 \mathrm{Btu} / 1 \mathrm{~b})$ at Cerro Prieto are expected to plug with calcite in about one year, and the high enthalpy wells $(-650 \mathrm{Btu} / \mathrm{lb})$ with silica in three to four years. Reaming a typical plugged-up well involving redrilling takes five to ten days at Cerro Prieto and costs about $\$ 1200 /$ day. Based on these figures, a rework cost of $\$ 10,000$ to $\$ 30,000$ is estimated in a Salton Sea we11, assuming that the rework rig was available with no move-in or mobilization charge (Ref. 2).

Scrapers are used to remove scales formed in pipelines by running them through the lines at regular intervals; they are inserted and removed at inlet and outlet scraper traps. The scrapers frequently used in salt-water gathering systems are variously called steel-balls, chained rubber-balls, plugs and wire-brushes, godevils, and spiral-brush pigs. A disadvantage of scrapers is the possibility of damage to any plastic lining of the pipes and mechanical abrasion of the pipe itself.

\section{CAVITATION DESCALING AND HYDROBLASTING}

Cavitation descaling employs pulsating high pressure jets of water which are directed against the scale surfaces. If the water velocity is such that repetitive low- and high-pressure areas are developed, bubbles form and collapse at the solid-liquid interface. This phenomenon is termed cavitation (Ref. 26). The collapse of these bubbles or cavities results in shock pressures reaching several hundred atmospheres in localized areas. The resultant impact tears out sections of porous or brittle material adhering to pipes.

Application of waterjet or cavitation descaling to remove scale from geothermal heat exchanger tubing and pipes is currently being investigated by studying the cleaning rates of various scale-filled pipes as a function of nozzle and jet parameters. In tests conducted so far, a 2 inch inside diameter pipe which had been reduced to 1-1/4 inches by an iron-rich silica scale was cleaned out completely by a cavitation hydrojet (Ref. 27, 76). Hydroblasting was used to clean portions of the reinjection line and brine drain lines at Niland Geothermal Loop Experimental Facility (GLEF), California. Approximately 1,200 feet of the reinjection line was 
cleaned by hydroblasting. Depending upon drainage and length of the line, the hydroblasting was followed by a water flush. Several combinations of hydroblast nozzle geometries, number and size of orifices, high pressure pump flows and pressures were tried. The best cleaning was generally achieved with a low number of orifices, moderately high pressure (5,000 psig), high pump flow rates, and an impingement angle of $30^{\circ}$ from the pipe center line (Ref. 77).

\section{E. THERMAL SHOCK}

In tests conducted at the East Mesa KGRA on brine from Well 6-1, a thermal shock method was used to remove calcite scale from a test probe in a simulated vertical tube evaporator. See Tables 2-1 and 2-2 for brine and scale composition. An electrically heated probe was placed inside a test section of pyrex pipe through which geothermal brine was flowing at a constant rate. Buildup of scale on the probe was monitored by measuring the change in heat transfer due to scale buildup. The scaled system was subjected to a thermal shock by closing the liquid flow to the test section, thus causing the temperature of the probe to rise. See Fig. 5-2. During this temperature rise, boiling of the liquid caused slugs of vapor to move up the test section and the liquid to flow down, which may have increased the thermal shock effect. Differential expansion of the metal probe and scale along with the rapid vaporization of moisture in the scale next to the heated probe is thought to be partly responsible for the effectiveness of thermal shock in scale removal. About 30 to $40 \%$ of this scale fell free leaving the probe clear and wet. The result on heat transfer resistance is shown in Fig. 5-3, which appears to indicate that a larger percentage of the scale was removed than was estimated from a visual observation (Ref. 4 ).

\section{F. OIL INJECTION}

The injection of heavy diesel oils was used to aid in scale removal from turbine blades at Larderello:

Scaling can occur anywhere in the turbine. The components are always the same: iron sulfide, clay, ammonium, calcium and alkaline metal salts of boric, sulfuric, hydrochloric and carbonic acid. As a rule, iron sulfide prevails in the first row of blades, whereas later rows show partially hydrated ammonium borates, silica and various silicates. These scales are up to $5 \mathrm{~mm}$ thick and show a crystal consistency and structure that suggests an actual separation by supersaturation crystallization. Since it is impossible to prevent their formation, practical methods are used to diminish their danger such as, for instance, the spaced injection of heavy diesel oils into the turbine to make the scales softer and easy to remove. (Ref. 28) 

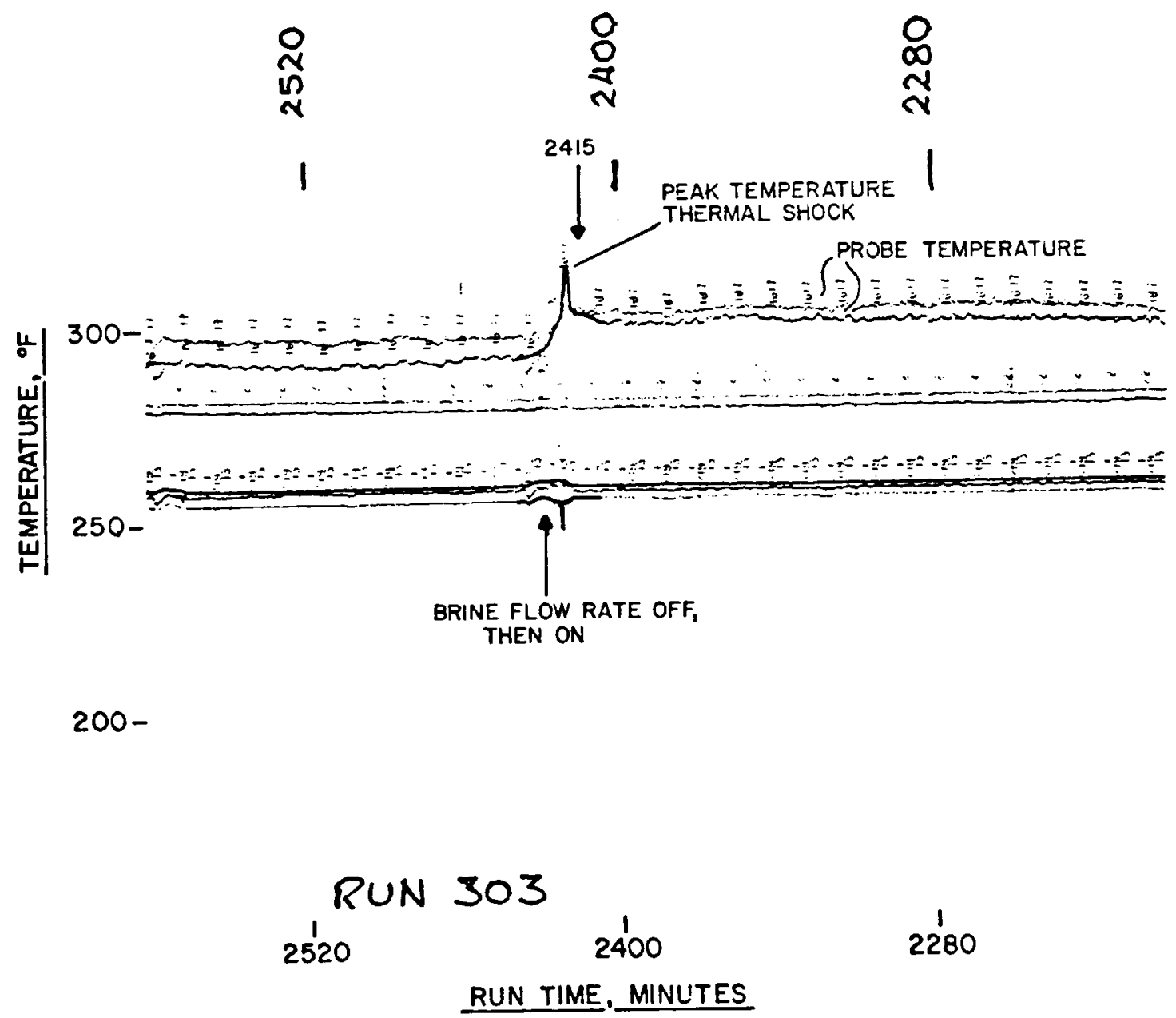

Fig. 5-2. Part of the temperature record for Run 303 showing the thermal shock effecting descaling in Fig. 5-3 (Ref. 4). 


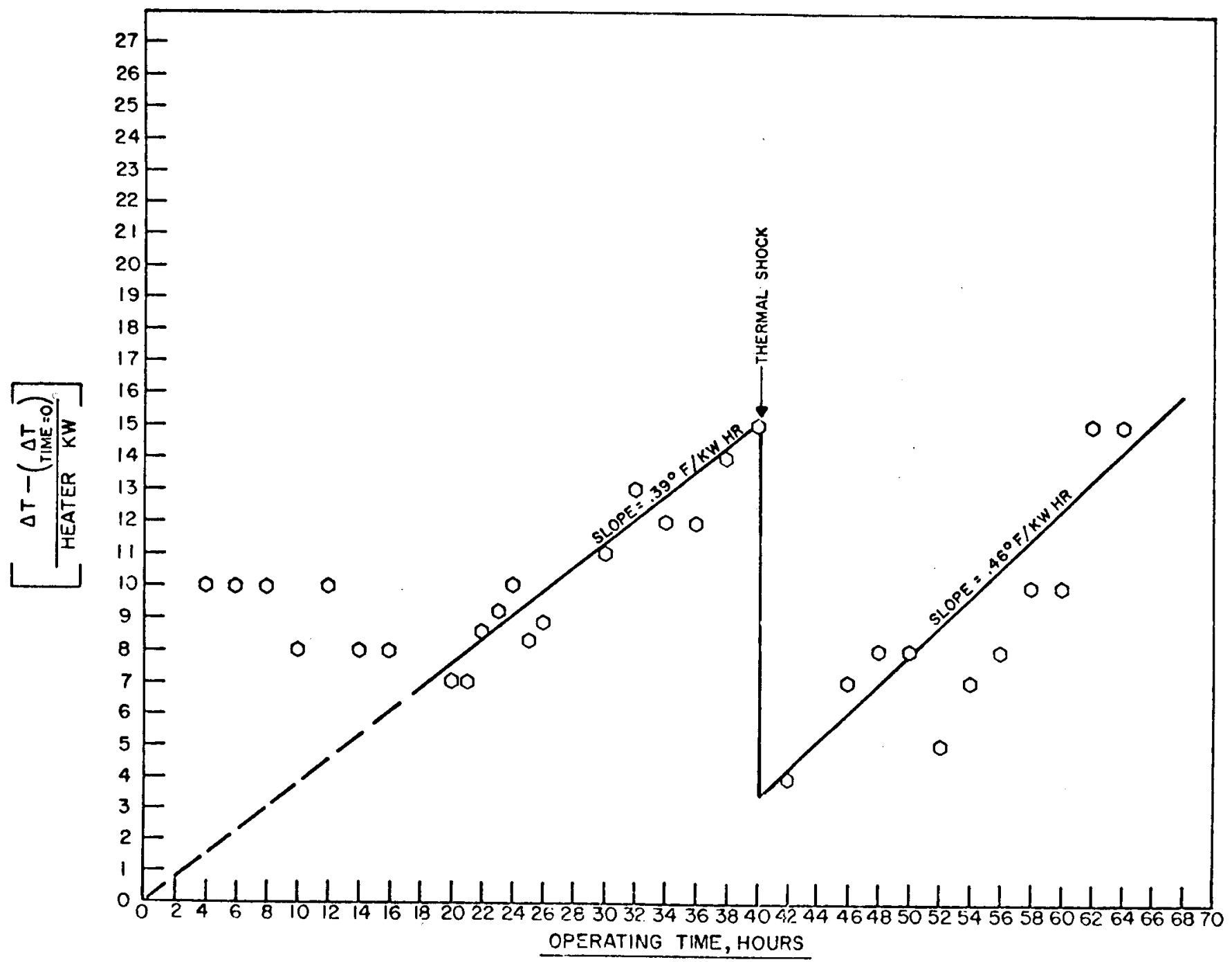

Fig. 5-3. Effect of thermal shock on scale resistance. Heat transfer scale resistance for Run 303. (Ref. 4) 


\section{G. SCALING CONTROL BY MAGNETIC FIELD}

CEPI of Belgium has proposed an apparatus using magnetic field for removal of scaling:

The device consists essentially of a permanent magnet where the core is an iron cylinder 40 to $50 \mathrm{~cm}$ long and 10 to $20 \mathrm{~cm}$ in diameter. Water flows through the system and the crystal structure of the precipitate is modified under the influence of the magnetic field and as a consequence can be easily removed from the pipeline. Unfortunately, this method is unsuitable for scaling control in thermal water wells as its setting into the well at about 40 to $50 \mathrm{~m}$ depth is very difficult due to its outer diameter. (Ref. 29)

H. SUMMARY

In summary, scale is removed by either mechanical (e.g., reaming) or chemical (e.g., acidizing) methods. An advantage of mechanical methods is that most scales can be removed. Disadvantages of mechanical methods include the following: (1) removal of scale from wellbores requires a drill rig and can be expensive; (2) the well or piping system must be shut down prior to reaming; (3) in a well, only the bore itself is cleaned so that any deposits in the formation are untouched; (4) dril1 cuttings may be squeezed into any pipe perforations, causing an impermeable layer to form and hot water production to fall off; (5) mechanical removal from a plugged slotted liner is very difficult; (6) plastic pipe lining may be damaged. Because of these factors, chemical methods are preferred in the oilfield industry (Ref. 30).

Depending on scale composition, chemical treatment such as acidizing is generally economical and effective in removing scale from boreholes. A disadvantage of chemical treatment is the possible "eating a hole" through the scale, thereby leaking the chemical into the formation without dissolving scale.

Although the methods of scale cleanup described above are satisfactory in some respects, they have at least four significant drawbacks associated with these "after the fact" solutions:

- The well must be taken out of service to perform cleanout.

- Frequency of cleanout for some wells may be prohibitively high.

- Scale buildup causes gradual reduction of pressure and flow with time during the interval between cleaning.

- Chemical or mechanical methods of cleaning may damage well casings and piping.

For additional information on scale removal, see the papers, "0ilfield Scale--Can We Handle It?" (Ref. 30) and "Inhibiting Deposition of Siliceous Scale" (Ref. 31). 


\section{Section 6}

\section{SUMMARY AND RECOMMENDATIONS}

Present methods for controlling scale deposition and materials corrosion in the geothermal industry are mainly cleanup and replacement of pipes and other components on an as-required basis. Scale or incrustations due to deposition of scales (e.g., silica, sulfide) from hot brines are usually removed from boreholes by acidizing or reaming; that in piping is mechanically removed by wire-brushing or by using scrapers. Materials rendered unserviceable by corrosion are replaced with new parts.

There is a current effort focused on geothermal brine treatment with the purpose of minimizing silica, sulfide, and calcite deposition from fresh brine, and to remove arsenic and silica prior to spent brine disposal. Examples of some of the methods used to control scaling at geothermal installations include the following: At Namafja11, Iceland, addition of cold dilution water to fresh fluid was effective in reducing silica scale. At Otake, Japan, a holding tank for spent brines was included as part of a treatment system to allow formation of colloidal silica in the retention tank so that the silica deposition in the transport lines or in the injection well is minimized. At Wairakei and Broadlands, New Zealand, a coagulation treatment was used to remove arsenic and silica from spent fluid prior to disposal of the fluid to the Waikato River. However, detailed investigation of the economics of these as well as the other methods described in this report is necessary for assessing the commercial feasibility of one or the other method of brine treatment.

It is clear that utilization of geothermal hot water for electric power production will be aided by adequate brine treatment methods. Research and development activities centered around geothermal scale and corrosion control by treatment of brines have been increasing within the past two years. An ideal brine treatment program would include the following:

1. Characterization of brine chemistry and deposited scales in order to determine the causes and possible means of control. The scale and corrosion products 
reflect the variable brine composition for different geothermal areas. Brine treatment methods can then be devised for the particular production fluid and for the particular method of disposal under consideration.

2. Basic laboratory investigations on the mechanisms and rates of scale formation due to corrosion or scale deposition. Basic data are transferable to all geothermal sites and will be needed to select, for example, additives and materials which would control scaling and corrosion.

3. Development of additives (e.g., inhibitors, sequestrants) and instruments to monitor the important geothermal brine scale and corrosion parameters (e.g., silica, $\left.\mathrm{pH}, \mathrm{H}_{2} \mathrm{~S}\right)$. The instrument sensors should be sufficiently rugged to monitor geothermal fresh fluids in a reliable manner.

4. Correlation of laboratory test results with actual tests in field conditions. In this way, feedback on the predictions based on laboratory results can be quickly verified and incorporated into brine treatment programs.

5. Development of laboratory screening methods for commercially available scale and corrosion inhibitors, with the idea to evaluate their effectiveness under geothermal conditions. The inhibitors should be effective at the elevated temperatures and pressures encountered in geothermal systems and should not react with brine constituents either to form harmful products or to reduce the effectiveness of the additive. 


\section{Section 7}

\section{REFERENCES}

1. Hoffman, M.R., Brine Chemistry--Scaling and Corrosion, EQL Memorandum No. 14, California Institute of Technology, Pasadena (July 1975).

2. Shannon, D.W., Economic Impact of Corrosion and Scaling Problems in Geothermal Energy Systems, Report \#BNWL-1866 UC-4, Batte11e Pacific Northwest Labs., Richland, Wash. (January 1975).

3. Lyon, R.N., and Kolstad, G.A., A Recommended Research Program in Geothermal Chemistry, Report \#WASH-1344, USAEC, Washington, D.C. (October 1974).

4. Wahl, E.F., Yen, I.K., and Bartel, W.J., Silicate Scale Control in Geothermal Brines--Final Report, Report \#GR\&D 74-048, Garrett Research and Development Co., Inc., LaVerne, Calif. (September 1974).

5. Wahl, E.F. and Yen, I.K., Scale Deposition and Control Research for Geothermal Utilization, Report \#GRD 75-050, Garrett Research and Development Co., Inc., LaVerne, Calif. (May 1975).

6. Materials Problems Associated with the Development of Geothermal Energy Resources, USBM Grant \#P0150296, B.A. Ha11 (ed.), Geotherma7 Resources Council, Davis, Calif. (May 1975).

7. Second Workshop on Materials Problems Associated with the Development of Geothermal Energy Sys tems. Proceedings of the Workshop Held May 16-18, 1975 at E1 Centro, California, USBM Grant \#P0152088, B.A. Ha11 (ed.), Geothermal Resources Council, Davis, Calif. (1976).

8. Conference on Scale Management in Geothermal Energy Development, San Diego, California, August 2-4, 1976, Report \#C00-2607-4, Energy Research and Development Administration (Division of Geothermal Energy), Washington, D.C. (1976).

9. "Corrosion Encountered in Energy Extraction from Geothermal Brines and Steams," Extended Abstracts of 150th Society Meeting, Las Vegas, Nevada, October 17-22, 1976, The Electrochemical Society, Inc., Princeton, N.J., Vol. 76-2, p. 289$\overline{327}(1976)$.

10. Miller, R.L., Corrosion Engineering in the Utilization of the Raft River Geothermal Resource, Report \#ANCR-1342, Idaho National Engineering Lab., Idaho Fal1s (August 1976).

11. Compilation of Geothermal Wel1 Fluid Data, Report \#LBL-5936, Lawrence Berkeley Lab., Univ. of California, Berkeley (To Be Published).

12. Reid, G.W., Streebin, L.E., Canter, L.W., and Smith, J.R., Brine Disposal

Treatment Practices Relating to the 011 Production Industry, Report \#EPA 660/2-74-0, Environmental Protection Agency, Washington, D.C. (May 1974). 
13. Ozawa, T., and Fujii, Y., "A Phenomenon of Scaling in Production Wells and the Geothermal Power Plant in the Matsukawa Area," Geothermics, Special Issue 2, 2(2), 1613-1618 (1970).

14. Mercado, S.G., "Cerro Prieto Geothermoelectric Project: Pollution and Basic Protection," Proceedings Second United Nations Symposium on the Development and Use of Geothermal Resources, San Francisco, California, May 20-29, 1975, Lawrence Berkeley Lab., Univ. of California, Berkeley, VoT. 2, p. 1417-1425, (1976).

15. Mercado, S., and Guiza, J., "Problems of Silica Scaling at.Cerro Prieto Geothermal Field," Conference on Scale Management in Geothermal Energy Development, San Diego, California, August 2-4, 1976, Report \#C00-2607-4, Energy Research and Development Administration (Division of Geothermal Energy), Washington, D.C., p. 59-87 (1976).

16. Water Quality and Treatment--A Handbook of Public Water Supplies, 3rd edition, McGraw-Hil1 Book Co., New York (1971).

17. Subsurface Salt-Water Disposal--Book 3 of the Vocational Training Series, American Petroleum Institute (Production Division), Dallas, Texas (1960).

18. Ostroff, A. G., Introduction to Oilfield Water Technology, Prentice-Ha11, Inc., Englewood Cliffs, N.J. (1965).

19. Underground Waste Management and Environmental Implications. Proceedings of the Symposium held December 6-9, 1971, in Houston, Texas, Memoir 18, T.D. Cook (ed.), American Association of Petroleum Geologists, Tulsa, Okla. (1972).

20. Salt Water Disposal--East Texas 0il Field, 2nd edition, Petroleum Extension Service, Univ. of Texas, Austin (1958).

21. Mathias, K.E., "The Mesa Geothermal Field--A Preliminary Evaluation of Five Geothermal Wells," Proceedings Second United Nations Symposium on the Development and Use of Geothermal Resources, San Francisco, California, May 20-29, 1975, Lawrence Berkeley Lab., Univ. of California, Berkeley, Vo1. 2, p. 1741$1747(1976)$.

22. Facca, G., "The Status of World Geothermal Development," Geothermics, Special Issue $2, \underline{1}, 8-23(1970)$.

23. Smith, J.H., "Geothermal Development in New Zealand," Geothermics, Special Issue 2, 2(1), 232-247 (1970).

24. Hayashida, T., and Ezima, Y., "Development of Otake Geothermal Field," Geothermics, Special Issue 2, 2(1), 208-220 (1970).

25. Thorhallsson, S., Ragnars, K., Arnorsson, S., and Kristmanndottir, H., "Rapid Scaling of Silica in Two District Heating Systems," Proceedings Second United Nations Symposium on the Development and Use of Geothermal Resources, San Francisco, California, May 20-29, 1975, Lawrence Berkeley Lab., Univ. of California, Berkeley, Vo1. 2, p. 1445-1449 (1976).

26. Uhlig, H.H., Corrosion and Corrosion Control--An Introduction to Corrosion Science and Engineering, 2nd edition, John Wiley \& Sons, Inc., New York (1971). 
27. "Task of Developing Cavitation Descaling Techniques and Hardware for Scaled-up and Stopped-up Geothermal Heat Exchanger Tubing and Pipes...," Geothermal Report, $\underline{5}(21)$, 3-4 (November 1976).

28. Allegrini, G., and Benvenuti, G., "Corrosion Characteristics and Geothermal Power Plant Protection (Collateral Processes of Abrasion, Erosion, and Scaling)," Geothermics, Special Issue 2, 2(1), 865-881 (1970).

29. Belteky, L., Probiems Related to Operating Thermal Wells Subject to Scaling in Hungary;" Geothermics, 4(1-4), 57-65 (1975).

30. Vetter, 0.J., "0ilfield Scale--Can We Handle It?", J. Pet. Technol., 28, 14021048 (1976).

31. Grens, J.Z., and Owen, L.B., "Inhibiting Deposition of Siliceous Scale," Conference on Scale Management in Geothermal Energy Development, San Diego, California, August 2-4, 1976, Report \#C00-2607-4, Energy Research and Deve 1opment Administration (Division of Geothermal Energy), Washington, D.C., p. 167$168(1976)$.

32. Owen, L.B., Precipitation of Amorphous Silica from High Temperature HyperSal ine Geothermal Brines, Report \#UCRL-51866, Lawrence Livermore Lab., Univ. of California, Livermore (June 1975).

33. Fournier, R.0., "The Solubility of Amorphous Silica at High Temperatures and High Pressures," Conference on Scale Management in Geothermal Energy Development, San Diego, California, August 2-4, 1976, Report \#C00-2607-4, Energy Research and Development Administration (Division of Geothermal Energy), Washington, D.C., p. 19-23 (1976).

34. Barnes, H.L., and Rimstidt, J.D., "Chemistry of Silica Scale Formation," Second Workshop on Materials Problems Associated with the Development of Geothermal Energy Systems. Proceedings of the Workshop Held May 16-18, 1975 at E1 Centro, California, USBM Grant \#P0152088, B.A. Ha11 (ed.), Geothermal Resources Counci1, Davis, Calif., p. 1-13 (1976).

35. Fournier, R.0., "Silica in Thermal Waters: Laboratory and Field Investigations," Proceedings of Symposium on Hydrogeochemistry and Biogeochemistry, Tokyo, Japan, September 7-9, 1970, The Clarke Company, Washington, D.C., Vol 1 (Hydrogeochemistry), p. 122-139 (1973).

36. Alexander, G.B., Heston, W.M., and Iler, R.K., "The Solubility of Amorphous Silica in Water," J. Phys. Chem., 58, 453-455 (1954).

37. Catalano, E., and Hill, J.H., Comments on the Possible Effects of Additives on Scaling by Geothermal Brines, Report. \#UCRL-51756, Lawrence Livermore Lab., Univ. of California, Livermore (February 1975).

38. Owen, L.B., Private Communication (March 1977).

39. Sussman, S., "Treatment of Water for Cooling, Heating, and Steam Generation" (Chapter 16), Water Quality and Treatment--A Handbook of Public Water Supplies, 3rd edition, McGraw-Hi11 Book Co., New York, p. 499-525 (1971):

40. Betz, L.D., Noll, C.A., and Maguire, J.J., "Removal of Silica from Water by Cold Processes," Ind. Eng. Chem., 32, 1320-1323 (1940). 
41. Betz, L.D., Noll, C.A., and Maguire, J.J., "Removal of Silica from Water by Hot Processes," Ind. Eng. Chem., 32, 1320-1.323 (1940).

42. Behrman, A.S., and Gustafson, H., "Removal of Silica from Water," Ind. Eng. Chem., 32, 468-472 (1940).

43. Schock, R.N., and Duba, A., The Effect of Electrical Potential on Scale Formation in Salton Sea Brine, Report \#UCRL-51944, Lawrence Livermore Lab., Univ. of California, Livermore (November 1975).

44. Jackson, D.D., and Hi17, J.J., Possibilities for Controlling Heavy Metal Sulfides in Scale from Geotherma.] Brines, Report \#UCRL-51977, Lawrence Livermore Lab., Univ. of California, Livermore (January 1976).

45. Scott, G.R., "Aeration" (Chapter 2), Water Quality and Treatment--A Handbook of Public Water Supplies, 3rd edition, McGraw-Hi17 Book Co., New York, p. 52-65 $(1971)$.

46. Holland, D.E., "Gangue Minerals in Hydrothermal Deposits" (Chapter 9), Geochemistry of Hydrothermal Ore Deposits, H.L. Barnes (ed.), Holt, Rinehart and Winston, Inc., New York, p. 382-436 (1967).

47. Matthews, H.B., and McBee, W.D., "Geothermal Down-Well Pumping System," Proceedings of the Conference on Research for the Development of Geothermal Energy Resources, Pasadena, California, September 23-25, 1974, Report \#NSF-RA-N-74-159, California Institute of Technology, Pasadena, p. 281-291 (1974).

48. Kryukov, P.A., and Larionov, E.G., "Physico-chemical Sampling of High-Temperature Wells in Connection with Their Encrustation by Calcium Carbonate," Geothermics, Special Issue 2, 2(2), 1624-1628 (1970).

49. Gelosa, L.R., and Andrade, R.C., "Water Treatment Programs for Steam Generating Systems," Ind. Water Eng., 14(2), 18-22 (1976).

50. Gaupp, R.H., and Nygren, J.A., "Corrosion and Scale Control," Ind. Water Eng., 1] (3), 18-20 (1974).

51. Weber, W.J., Physicochemical Processes for Water Quality Control, WileyInterscience, New York (1972).

52. Einarsson, S.S., Vides, A.R., and Cuellar, G., "Disposal of Geothermal Waste Water by Reinjection," Proceedings Second United Nations Symposium on the Development and Use of Geothermal Resources, San Francisco, California, May 2029, 1975, Lawrence Berkeley Lab., Univ. of California, Berkeley, Vol. 2, p. 1349-1363 (1976).

53. Rothbaum, H.P., and Anderton, B.H., "Removal of Silica and Arsenic from Geothermal Discharge Waters by Precipitation of Useful Calcium Silicates," Proceedings Second United Nations Symposium on the Development and Use of Geothermal Resources, San Francisco, California, May 20-29, 1975, Lawrence Berkeley Lab. , Univ. of California, Berkeley, Vol. 2, p. 1417-1425 (1976).

54. Betz Handbook of Industrial Water Conditioning, 6th edition, Betz Lab., PhiTadelphia (1962). 
55. Sadow, R.D., "Pretreatment of Industrial Waste Waters for Subsurface Injection," Underground Waste Management and Environmental Implications. Proceedings of the Symposium held December 6-9, 1971, in Houston, Texas, Memoir 18, T.D. Cook (ed.), American Association of Petroleum Geologists, Tulsa, Okla., p. 93-101 (1972).

56. Fair, G.M., Geyer, J.C., and Okun, D.A., Water and Wastewater Engineering, John Wiley \& Sons, New York (1968).

57. Hamer, P., Jackson, J., and Thurston, E.F., Industrial Water Treatment Practice, Butterworth \& Co., London, 514 p. (196T).

58. Yanagase, T., Suginohara, Y., and Yanagase, K., "The Properties of Scales and Methods To Prevent Them," Geothermics, Special Issue 2, 2(2), 1619-1623 (1970).

59. James, R., "Collection and Transmission of Geothermal Fluids," Geothermics, Special Issue 2, 1, 99-105 (1970).

60. Krauskopf, K.B., "The Geochemistry of Silica in Sedimentary Environments," Soc. Econ. Paleontol. Mineral., Spec. Publ. 7, 4-19 (1959).

61. Ceullar, G., "Behavior of Silica in Geothermal Waste Waters," Proceedings Second United Nations Symposium on the Development and Use of Geothermal Resources, San Francisco, California, May 20-29, 1975, Lawrence Berkeley Lab., Univ. of California, Berkeley, Vol. 2, p. 1343-1347 (1976).

62. VanWazer, J.R., Phosphorus and Its Compounds, Interscience Publishers, New York, Vol. 1 (1958).

63. Earllougher, R.C., and Love, W.W., "Sequestering Agents for Prevention of Scale Deposition in 0il Wells," J. Pet. Technol., 9, 17-20 (1957).

64. Welcher, F.J., The Analytical Uses of Ethylenediaminetetraacetic Acid, D. Van Nostrand, Princeton, N.J. (1958).

65. Chaberek, S., and Marte11, A.E., Organic Sequestering Agents, John Wiley \& Sons, Inc., New York (1959).

66. Martell, A.E., and Calvin, M., Chemistry of the Metal Chelate Compounds, Prentice-Hall, Inc., Englewood Cliffs, N.J. (1952).

67. Ostroff, A.G., Introduction to 0ilfield Water Technology, Prentice-Hall, Inc., Englewood Cliffs, N.J., p. 90 (1965).

68. Marshall, T., and Braithwaite, W.R., "Corrosion Control in Geothermal Systems," Geothermal Energy, Earth Sciences Series No. 12, H.C.H. Arms tead (ed.), UNESCO, Paris, p. 151-160 (1973).

69. Foster, P.K., Marshal1, T., and Tombs, A., "Corrosion Investigations in Hydrothermal Media at Wairakei, New Zealand," New Sources of Energy. Proceedings of the Conference, Rome, 21-31 August 1967, United Nations, New York, VoT. 3 (Geotherma T Energy: II), p. 186-195 (1964).

70. Pye, D.J., "Chemical Fixation of Oxygen," J. Am. Hater Works Assoc., 39, $1121-1127$ (1947). 
71. Leichester, J., "The Chemical Deaeration of Boiler Water--The Use of Hydrazine Compounds," Trans. ASME, $\underline{78}, 273$ (1956).

72. Hermannsson, S., "Corrosion of Metals and the Forming of a Protective Coating on the Inside of Pipes Carrying Thermal Waters Used by the Reykjavik Municipal District Heating Service," Geothermics, Special Issue 2, 2(2), 1602-1612 (1970).

73. Banning, L.H., and Oden, L.L., Corrosion Resistance of Meta is in Hot Brines--A Literature Review, Report \#IC-8607, U.S. Bureau of Mines, Washington, D.C. (1973).

74. Carter, J.P., and Cramer, S.D., "Corrosion Resistance of Some Commercially Available Metals and Alloys to Geothermal Brines," Corrosion Problems in Energy Conversion and Generation, The Electrochemical Society, Princeton, N.J., p. 240-250 (1974).

75. Kukacka, L.E., Fontane, J., Horn, W., and Amars, J., Concrete-Polymer Materials for Geothermal Applications, Progress Report \#8, January-March 1976, Informal Report, Report \#BNL-21244, Brookhaven National Lab., Upton, N.Y., 18 pp. (1976).

76. Thiruvengadem, A.P., "Cavitation Descaling Techniques for Geothermal Applications," Conference on Scale Management in Geothermal Energy Development, San Diego, California, August 2-4, 1976, Report \#C00-2607-4, Energy Research and Development Administration (Division of Geothermal Energy), Washington, D.C., p. 247-256 (1976).

77. Geothermal Loop Experimental Facility, Report \#SAN/1137-5, San Diego Gas and Electric, San Diego, Calif. (March 1977).

78. Technical Service Bulletin WT 10.0, Industrial Chemicals Division, CIBA-Geigy (UK) Ltd., Manchester, England, 8 p., (July 1975).

79. Glossary--Water and Wastewater Control Engineering, American Public Health Association, American Society of Civil Engineers, American Water Works Association, and Water Pollution Control Federation (1969).

80. Webster's Third New International Dictionary (1961).

81. Chambers Dictionary of Science and Technology, T.C. Collocott edition, Barnes and Noble, New York (1972).

82. Water Quality Criteria 1972, A Report of the Committee on water Quality Criteria, Report \#EPA.R3.73.033 March 1973, Environmenta] Protection Agency, Washington, D.C., p. 372-375 (1972). 


\section{Section 8}

\section{GLOSSARY OF TYPICAL BRINE TREATMENT TERMS}

Unless noted otherwise, the following are from Reference 79.

Acidizing--A chemical scrubbing process which consists of pumping an acid (e.g., $\mathrm{HCl}, \mathrm{HF}$ ) into a bore. (Ref. 1)

Aeration--The bringing about of intimate contact between air and a liquid by one or more of the following methods: (1) spraying the liquid in the air; (2) bubbling air through the liquid; (3) agitating the liquid to promote surface absorption of air.

Aeration period--(1) The theoretical time, usually expressed in hours, during which mixed liquor is subjected to aeration in an aeration tank, while undergoing activated sludge treatment. It is equal to the volume of the tank divided by the volumetric rate of flow of the wastewater and return sludge. (2) The theoretical time during which water is subjected to aeration.

Aeration tank--A tank in which sludge, wastewater, or other liquid is aerated.

Alkaline water--(1) Water having a pH greater than 7.0. (2) Water high in percent sodium (approaching and exceeding 60), but relatively low in total dissolved solids.

Alum--A common name, in the water and wastewater treatment field, for commercialgrade aluminum sulfate.

Aluminum sulfate--A chemical, formerly sometimes called "waterworks alum" in water or wastewater treatment, prepared by combining a mineral known as bauxite with sulfuric acid.

Brine--Concentrated salt solution containing more than $36,000 \mathrm{mg} / 1$ of total dissolved solids.

Cavitation--(1) The action resulting from forcing a flowing stream to change direction in which reduced internal pressure causes dissolved gases to expand, creating negative pressure. Cavitation frequently causes pitting of the hydraulic structure affected. (2) The formation of a cavity between the downstream surface of a moving body, for example, the blade of a propeller, and a liquid normally in contact with it.

Coagulation--In water and wastewater treatment, the destabilization and initial aggregation of colloidal and finely divided suspended matter by the addition of a floc-forming chemical or by biological processes.

Corrosion--The gradual deterioration or destruction of a substance or material by chemical action, frequently induced by electrochemical processes. The action proceeds inward from the surface. 
Corrosion control--(1) In water treatment, any method that keeps the discharge of the metaliic ions of a conduit from going into solution, such as increasing the $\mathrm{pH}$ of the water, removing free oxygen from the water, or controlling the carbonate balance of the water. (2) The sequestration of metallic ions and the formation of protective films on metal surfaces by chemical treatment.

Dispersion--(1) Scattering and mixing. (2) The mixing of polluted fluids with a large volume of water in a stream or other body of water. (3) The outward percolation of water from an artesian basin or aquifier through confining formations.

(4) The repelling action of an electric potential on fine particles in suspension in water, as in a stream carrying clay. This dispersion usually is ended by contact with ocean water which causes flocculation and precipitation of the clay, a common cause of shoaling in harbors. (5) In a continuous flow treatment unit, the phenomenon of short-circuiting. (6) The breaking down of soil aggregates, resulting in a single grain structure.

Disposal by dilution--A method of disposing of wastewater or treated effluent by discharging it into a stream or body of water.

Dissolved oxygen--The oxygen dissolved in water, wastewater, or other liquid, usually expressed in milligrams per liter, parts per million, or percent of saturation. Abbreviated DO.

Dissolved-oxygen sag curve--A curve that represents the profile of dissolved oxygen content along the course of a stream resulting from deoxygenation associated with biochemical oxidation of organic matter and reoxygenation through the absorption of atmospheric oxygen and biological photosynthesis. Also called oxygen-sag curve.

Dissolved solids--Theoretically, the anhydrous residues of the dissolved constituents in water. Actually, the term is defined by the method used in determination. In water and wastewater treatment, the Standard Methods tests are used.

Erosion--Surface destruction of a metal or refractory material effected by the airasive action of a moving liquid or gas and often accelerated by solid particles in suspension. (Ref. 80)

Effluent--(1) A liquid which flows out of a containing space. (2) Wastewater or other liquid, partially or completely treated, or in its natural state, flowing out of a reservoir basin, treatment plant, or industrial treatment plant, or part thereof. (3) An outflowing branch of a main stream or lake.

Evaporation--The process by which water becomes a vapor at a temperature below the boiling point. (2) The quantity of water that is evaporated; the rate is expressed in depth of water, measured as liquid water, removed from a specified surface per unit of time, generally in inches or centimeters per day, month, or year.

Evaporation area--The surface area of a body of water and of any adjacent moist 7and to which water was supplied from the body of water, from which water is lost to the atmosphere by evaporation.

Evaporation discharge--Discharge into the atmosphere, in the gaseous state, of water derived from the saturation zone. Evaporation discharge may be divided into vegetal discharge and soil discharge.

Evaporation gage--A means of measuring evaporation.

Evaporation opportunity--The ratio of the rate of evaporation from a land or water surface in contact with the atmosphere to the evaporativity under the existing atmospheric conditions; that is, the ratio of the actual to the potential rate of evaporation. Also called relative evaporation. 
Evaporation pan--A pan used to hold water during observations for the determination of the quantity of evaporation at a given location. Such pans are of various sizes and shapes, the most commonly used being circular or square.

Filter--A device or structure for removing solid or colloidal material, usually of a type that cannot be removed by sedimentation, from water, wastewater, or other liquid. The liquid is passed through a filtering medium, usually a granular material but sometimes finely woven cloth, unglazed porcelain, or specially prepared paper. There are many types of filters used in water or wastewater treatment.

Filter bed-- (1) A type of bank revetment consisting of layers of filtering medium of which the particles gradually increase in size from the bottom upward. Such a filter allows the groundwater to flow freely, but it prevents even the smallest soil particles from being washed out. (2) A tank for water filtration having a false bottom covered with sand, as a rapid sand filter. (3) A pond with sand bedding, as a sand filter or slow sand filter.

Filter bottom--(1) The underdrainage system for collecting the water that has passed through a rapid sand filter and for distributing the wash water that cleans the filtering medium. (2) The underdrainage system supporting the graded gravel of a biological bed. It may consist of specially fabricated tile or concrete blocks containing waterways and slots in the top for convening the underdrainage, or it may consist of inverted half tile.

Floc--Small gelatinous masses formed in a liquid by the reaction of a coagulant added thereto, through biochemical processes, or by agglomeration.

Flocculating tank--A tank used for the formation of floc by the gentle agitation of liquid suspensions, with or without the aid of chemicals.

Flocculation--In water and wastewater treatment, the agglomeration of colloidal and finely divided suspended matter after coagulation by gentle stirring by either mechanical or hydraulic means. In biological wastewater treatment where coagulation is not used, agglomeration may be accomplished biologically.

Flocculation agent--A coagulating substance which, when added to water, forms a flocculent precipitate which will entrain suspended matter and expedite sedimentation; examples are alum, ferrous sulfate, and lime.

Flocculation limit--The water content of a soil when it is in the condition of a deflocculated sediment.

Flocculation ratio--The void ratio of a soil when it is in the condition of a deflocculated sediment.

Flocculator--(1) A mechanical device to enhance the formation of floc in a liquid. (2) An apparatus for the formation of floc in water and wastewater.

Incrustants--Dense solids formed as a crust on the inside surface of a pipe as a result of hardness and other characteristics of the water carried.

Mechanical aeration--(1) The mixing, by mechanical means, of wastewater and activated sludge in the aeration tank of the activated sludge process to bring fresh surfaces of liquid into contact with the atmosphere. (2) The introduction of atmospheric oxygen into a liquid by the mechanical action of paddle, paddle wheel, spray, or turbine mechanisms. 
Mechanical aerator--A mechanical device for the introduction of atmospheric oxygen into a liquid. See mechanical aeration.

Mechanical agitation--The introduction of atmospheric oxygen into a liquid by the mechanical action of paddle, paddle wheel, spray, or turbine mechanism. Also see mechanical aeration.

Noncondensable--Gaseous matter not liquified under the existing conditions.

Nozzle--(1) A short, cone-shaped tube used as an outlet for a hose or pipe. The velocity of the merging stream of water is increased by the reduction in crosssectional area of the nozzle. (2) A short piece of pipe with a flange on one end and a saddle flange on the other end. (3) A side outlet attached to a pipe by means such as riveting, brazing, or welding.

$\mathrm{pH}--$ The logarithm of the reciprocal of the hydrogen-ion activity or $10 \mathrm{~g}$ (1/hydrogenion activity). Pure neutral water has a $\mathrm{pH}$ of 7 , acids a $\mathrm{pH}$ value of less than 7 , and alkalies a pH of more than 7 .

Rapid sand filter--A filter for the purification of water, in which water that has been previously treated, usually by coagulation and sedimentation, is passed downward through a filtering medium. The medium consists of a layer of sand, prepared anthracite coal, or other suitable material, usually 24-30 in. thick, resting on a supporting bed of gravel or a porous medium such as carborundum. The filtrate is removed by an underdrainage system which also distributes the wash water. The fi1ter is cleaned periodically by reversing the flow of the water upward through the filtering medium, sometimes supplementing by mechanical or air agitation during washing, to remove mud and other impurities which have lodged in the sand. It is characterized by a rapid rate of filtration, commonly from two to three gallons per minute per square foot of filter area.

Rapid sand filter rating--The design rate at which water is to be passed through a rapid sand filter.

Rapid sand filter strainer--A perforated device inserted in the underdrains of a rapid sand filter through which the filtered water is collected and through which the wash water is distributed when the filter is washed. Also called strainer head.

Saline water--Water containing dissolved salts--usually from 10,000 to $33,000 \mathrm{mg} / 1$.

Salinity--(1) The relative concentration of salts, usually sodium chloride, in a given water. It is usually expressed in terms of the number of parts per million of chlorine (C1). (2) A measure of the concentration of dissolved mineral substances in water.

Sand filter--A filter in which sand is used as a filtering medium. Also see rapid sand filter, slow sand filter.

Scale--(1) An accumulation of solid material precipitated out of waters containing certain mineral salts in solution and formed on interior surfaces, such as those of pipelines, tanks, boilers, under certain physical conditions. May also be formed from interaction of water with metallic pipe. (2) Loose, thin fragments of rock threatening to break or fall from either roof or wall. (3) A series of graduations representing lengths or distances on a map, drawing, or rule. (4) The dimension of a drawing, map, or model relative to the actual dimension of the object, usually expressed as a ratio, as $1: 100$. (5) To remove scale. 
Scraper-- (1) A device for insertion in pipelines that is pushed or hauled through by some method or device such as water pressure, rope, cable, to remove accumulated organic or mineral deposits. Scrapers are used principally in pipes too small for access by man and are of various designs and sizes. (2) A device used in the bottom of a sedimentation tank to move settled sludge to a discharge port. (3) A blade used to separate accumulated sediment from filter or screen surfaces.

Screen--(1) A device with openings, generally of uniform size, used to retain or remove suspended or floating solids in flowing water or wastewater and to prevent them from entering an intake or passing a given point in a conduit. The screening element may consist of parallel bars, rods, wires, grating, wire mesh, or perforated plate, and the openings may be of any shape, although they are usually circular or rectangular. (2) A device used to segregate granular material such as sand, crushed rock, and soil into various sizes.

Seawater--Water in the seas containing from 33,000 to $36,000 \mathrm{mg} / 1$ of total dissolved solids.

Sedimentation--(1) The process of subsidence and deposition of suspended matter carried by water, wastewater, or other liquids, by gravity. It is usually accomplished by reducing the velocity of the liquid below the point at which it can transport the suspended material. Also called settling. (2) In geology, sedimentation consists of five fundamental processes: weathering, erosion, transportation, deposition, and diagnesis or consolidation into rock.

Sedimentation basin--A basin or tank in which water or wastewater containing settleable solids is retained to remove by gravity a part of the suspended matter. Also called sedimentation tank, settling basin, settling tank.

Sedimentation compartment--(1) The portion of a water or wastewater treatment tank used as a settling tank; for example, the flowing-through chamber of an Imhoff tank. (2) The settling section of a chemical flocculation and sedimentation unit.

Sedimentation tank--A basin or tank in which water or wastewater containing settleable solids is retained to remove by gravity a part of the suspended matter. Also called sedimentation basin, settling basin, settling tank.

Sediment concentration--The ratio of the weight of the sediment in a water-sediment mixture to the total weight of the mixture. Sometimes expressed as the ratio of the volume of sediment to the volume of mixture. It is dimensionless and is usually expressed in percentage for high values of concentrations and in parts per milition for low values.

Sequester--To form a stable, water-soluble complex.

Sequestering agent--A chemical that causes the coordination complex of certain phosphates with metallic ions in solution so that they may no longer be precipitated. Hexametaphosphates are an example: calcium soap precipitates are not produced from hard water treated with them. Also, any agent that prevents an ion from exhibiting its usual properties because of close combination with an added material.

Sequestration--The inactivation of an ion by addition of a reagent that combines it and, in effect, prevents it from participating in other reactions. Also called complexation. 
Settling--The process of subsidence and deposition of suspended matter carried by water, wastewater, or other liquids, by gravity. It is usually accomplished by reducing the velocity of the liquid below the point at which it can transport the suspended material. Also called sedimentation.

Settling basin--A basin or tank in which water or wastewater containing settleable solids is retained to remove by gravity a part of the suspended matter. Also called sedimentation basin, sedimentation tank, settling tank.

Settling chamber-- (1) A basin or tank in which water or wastewater containing settleable solids is retained to remove by gravity a part of the suspended matter. (2) The second or final element of the so-called biolytic tank, which is a combination of a flocculating tank and a settling tank. (3) Sometimes, the sedimentation compartment of a two-story tank, as in the case of an Imhoff tank.

Settling solids--Solids that are settling in sedimentation tanks or sedimentation chambers and other such tanks that are constructed for the purpose of removing this fraction of suspended solids.

Settling tank--A basin or tank in which water or wastewater containing settleable solids is retained to remove by gravity a part of the suspended matter. Also called sedimentation basin, sedimentation tank, settling basin.

Settling velocity--The velocity at which subsidence and deposition of the settleable suspended solids in water and was tewater will occur.

Slake--To become mixed with water so that a true chemical combination takes place, as in the slaking of lime.

Slow sand filter--A filter for the purification of water in which water without previous treatment is passed downward through a filtering medium consisting of a layer of sand or other suitable material, usually finer than for a rapid sand filter and from 24 to $40 \mathrm{in}$. thick. The filtrate is removed by an underdrainage system and the filter is cleaned by scraping off and replacing the clogged layer. It is characterized by a slow rate of filtration, commonly 3-6 mgd/acre of filter area.

Sludge--(1) The accumulated solids separated from liquids, such as water or wastewater, during processing, or deposits on bottoms of streams or other bodies of water. (2) The precipitate resulting from chemical treatment, coagulation, or sedimentation of water or wastewater.

Standard methods--(1) Methods for the examination of water and wastewater published jointly by the American Public Health Associacion, the American Water Works Association, and the Water Pollution Control Federation. (2) Methods published by professional organizations and agencies covering specific fields. These include, among others: American Public Health Association, American Public Works Association, American Society of Civil Engineers, American Society of Mechanical Engineers, American Society for Testing and Materials, American Water Works Association, United States Bureau of Standards, United States of America Standards Institute (formerly American Standards Association), United States Public Health Service, Water Pollution Control Federation.

Standard oxidation-reduction potential (Eh)--The potential established at an inert electrode dipping into a solution containing equimolecular amounts of an ion or molecule in two states of oxidation. (Ref. 81) 
Suspended matter--(1) Solids in suspension in water, wastewater, or effluent. (2) Solids in suspension that can be removed readily by standard filtering procedures in a laboratory. See suspended solids.

Suspended sediment--The very fine soil particles that remain in suspension in water for a considerable period of time without contact with the solid-fluid boundary at or near the bottom. They are maintained in suspension by the upward components of turbulent currents or may be fine enough to form a colloidal suspension.

Suspended solids--(1) Solids that either float on the surface of, or are in suspension in, water, wastewater, or other liquids, and which are largely removable by laboratory filtering. See suspended matter. (2) The quantity of material removed from wastewater in a laboratory test, as prescribed in "Standard Methods for the Examination of Water and Wastewater" and referred to as nonfilterable residue.

Vacuum deaeration--Equipment operating under vacuum to remove dissolved gases from Tiquid.

Waste--Something that is superfluous or rejected; something that can no longer be used for its originaliy intended purpose.

Waste-disposal plant--(1) A plant equipped for treatment and disposal of waste. (2) An arrangement of devices and structures for treating wastewater, industrial wastes, and sludge.

Waste treatment--Any process to which wastewater or industrial waste is subjected to make it suitable for subsequent use.

Waste water--In a legal sense, water that is not needed or that has been used and is permitted to escape, or that unavoidably escapes from ditches, canals, or other conduits, or reservoirs of the lawful owners of such structures. 


\section{BASIC WATER TREATMENT PROCESSES}

A wide range of treatment processes is available to produce water of the required quality for industry at the point of use. Treatment methods fall into two general categories: external and internal. External treatment refers to processes utilized in altering water quality prior to the point of use. The typical household water softening unit is an external treatment. Internal treatment refers to processes limited basically to chemical additives utilized to alter water quality at the point of use or within the process. Water softening compounds used in laundering are forms of internal treatment. Water treatment processes are in themselves users of water. Normally, 2 to 10 per cent of the feed water ends up as waste generated by treatment processes (see Table VI-3). Thus, the actual water intake is greater than the treated water produced.

\section{EXTERNAL WATER TREATMENT PROCESSES}

Figure VI-1 is a schematic diagram of the most common external water treatment processes. Properly applied, alone or in various combinations, these processes can convert any incoming water quality to a usable quality. A dramatic example is the conversion of brackish water to a water that exceeds the quality of distilled water.

Note that the flow chart illustrates many processes and that a particular process is applied to remove a particular contaminant. If that contaminant does not appear in the water or is harmless for the intended use of the water, that process would not be used. For example, a clear well water might not need filtration prior to further treatment. In addition, the water use determines the extent of treatment. For example, to use Mississippi River water for cooling, rough screening to remove the floating debris may be sufficient for some applications, whereas clarification and filtration may be required for other uses. To use that same water for makeup for a super critical pressure boiler would require further treatment by ion exchange, perhaps strong cation, strong anion, and mixed bed exchangers.

As previously stated, industry's need for water can be met even under the poorest conditions. However, the use of water treatment systems is not without consequence. External water treatment processes concentrate a particular contaminant or contaminants. Thus, in the quest for pure water, a waste product is generated. The waste product is a pollutant and the cost of its disposal must be considered as part of the overall cost of water treatment.

The estimates of waste volume and solids in Table VI-3 are based on treating a water with an analysis such as shown in Table V1-4. Table VI-4 also illustrates an analysis of several common forms of water treatment. The estimates are thus typical only of the water described and will vary with different water supplies. Waste volumes are stated as a percentage of inlet flow. Thus, a 2,000 gallon per minute (gpm) clarifier will discharge 40 to $100 \mathrm{gpm}$ of sludge.

The following paragraphs briefly describe the available treatment methods, outline their capabilities, and combined with Table VI-3, provide a general idea of the waste produced. (The groupings $\mathrm{A}, \mathrm{B}$, and $\mathrm{C}$ do not imply treatment schemes or necessarily indicate a sequence of treatment.) The processes are applicable to various water characteristics; it is immaterial whether the supply is surface or ground water. Since the equipment used can be of appreciable size, available land area can be an important factor in the selection of a particular process.

\section{Group A Processes}

Rough Screens Generally installed at the actual point of intake, rough screens are simple bars or mesh screens used to trap large objects and prevent damage to pumps and other mechanical equipment.

Sedimentation This process takes place in large open basins used to reduce the water velocity so that heavier suspended particles can settle out.

Clarification Chemical additives (e.g., aluminum salts, iron salts, lime) are used in large open basins so that practically all suspended matter, color, odors, and organic compounds can be removed efficiently.

Lime Softening (cold) The equipment used here is 
similar to that used for clarification. In addition to flocculent chemicals, lime and sometimes soda ash are used in large open basins. Clarification is obtained, and a large portion of the calcium and magnesium bicarbonates are removed.

Lime Softening (hot) The process is, in general, the same as cold except that it is carried out at or above $212 \mathrm{~F}$. The results are the same but with the added benefit of silica removal. The characteristics of wastes are the same but at a high temperature. Note that further treatment of hot lime

TABLE VI-3-Waste Generated by Treatment Processes

\begin{tabular}{|c|c|c|c|}
\hline Trentment proceso & Character of waste produced & $\begin{array}{l}\text { Waste volume } \\
\text { percentuge flow }\end{array}$ & $\begin{array}{l}\text { Example of waste } \\
\text { weighte ory basis } \\
\text { pounds solits' } 1,000 \\
\text { ral processed }\end{array}$ \\
\hline Routh sereens. & Line objects, debris & & \\
\hline 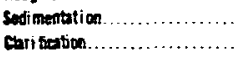 & $\begin{array}{l}\text { Sind, mud surry } \\
\text { Usually atidit thamiel slodge } \\
\text { and settied mutter }\end{array}$ & $\begin{array}{l}5-10 \\
2-5\end{array}$ & 1.3 \\
\hline Cold time softening. & $\begin{array}{l}\text { Wkaline chemieal sludge and } \\
\text { settled matter }\end{array}$ & $2-5$ & 1.7 \\
\hline Hot bme sol tering $(+212$ F). & $\begin{array}{l}\text { Alkaline ekemiesl sludga and } \\
\text { sottled matter }\end{array}$ & $2-5$ & 1.7 \\
\hline Meration. & $\begin{array}{l}\text { Gaseous, possible air pollutant, } \\
\text { such as hydrozen sulide }\end{array}$ & & \\
\hline Filtration, errvity, $\alpha$ pressure. & Studge, suspended solids & $\begin{array}{c}2-5 \\
\text { (for pocked bed units) }\end{array}$ & $0.1-0.2$ \\
\hline $\begin{array}{l}\text { Adsorption, actirnted carbon tor } \\
\text { odors, tuster, color, orpenies }\end{array}$ & $\begin{array}{l}\text { Exhousted carbon it not re. } \\
\text { cenerated. Smalf amounts } \\
\text { carbon fines and other solids } \\
\text { can appear in backwash. } \\
\text { Carbon rezenera tian is seps. } \\
\text { rate process (usually thermal) } \\
\text { in which air pollution prob. } \\
\text { lams must be met. }\end{array}$ & $2-5$ & \\
\hline $\begin{array}{l}\text { Mangantse zedite, for iton } \\
\text { remave! }\end{array}$ & Iren oxide suspended solids & $\begin{array}{l}\text { Simibr to other } \\
\text { fitrution prodesses }\end{array}$ & \\
\hline $\begin{array}{l}\text { Missetlaneous, e.g., precoat, } \\
\text { meembrane, dual media flturs. } \\
\text { tion fine straining }\end{array}$ & $\begin{array}{l}\text { As in other fillers Precosat } \\
\text { wrste insludes procoat ma- } \\
\text { torials. }\end{array}$ & $1-5$ & $\begin{array}{l}0.1-0.2 \\
\text { (olus precoat ma- } \\
\text { terials when used) }\end{array}$ \\
\hline Roverse osmosise... & $\begin{array}{l}\text { Suspended and 50-99 percent } \\
\text { of dissolved solids plus chem- } \\
\text { iel pretreatment if required }\end{array}$ & $10-50$ & $1.0-2.0$ \\
\hline Enctrodialycis $x$ & $\begin{array}{l}\text { Suspended and } 80-95 \text { percent } \\
\text { of dissotred solids ptus chem- } \\
\text { ival pretreatment if resuired }\end{array}$ & $10-50$ & $1.0-2.0$ \\
\hline Distillation... & $\begin{array}{l}\text { Concentrated dissolved and } \\
\text { wspended solids }\end{array}$ & $10-75$ & 1.5 \\
\hline \multicolumn{4}{|l|}{ Lox extiange processesd } \\
\hline Sodium eation. . & $\begin{array}{l}\text { Dissolved encium, magnesium } \\
\text { and sodium chlorides }\end{array}$ & $\leftrightarrow$ & 1.3 \\
\hline 2-bes deniperalization. & $\begin{array}{l}\text { Dissolved solids froca faed plus } \\
\text { rogenerants }\end{array}$ & $10-14$ & 45 \\
\hline Wired bed deminartination .... & $\begin{array}{l}\text { Dissolved sotids trom laed plus } \\
\text { rezenerants }\end{array}$ & $10-14$ & $>5$ \\
\hline Itterai processes. & 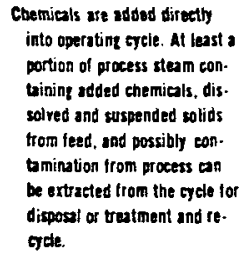 & & \\
\hline
\end{tabular}

- Processer are used alone or in nrious conabinations, dependiag upoon noed.

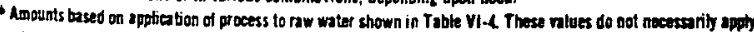
when these processes are used in combinations. - Fed must be relativaly tree of suspended matter.

- Twen are many ritialions Listed here are a low of the most important.
TABLE VI-4-Typical Raw Water Analyses and Operating Results (mg/l, unless otherwise indicated)

\begin{tabular}{|c|c|c|c|c|c|c|}
\hline Constituent & $\begin{array}{c}\text { Expressed } \\
\text { n }\end{array}$ & Raw watero & $\begin{array}{l}\text { After } \\
\text { chrifieation } \\
\text { and } \\
\text { oftration }\end{array}$ & $\begin{array}{l}\text { After } \\
\text { cold time } \\
\text { seftening } \\
\text { and } \\
\text { nitration }\end{array}$ & $\begin{array}{c}\text { After } \\
\text { clarifiention, } \\
\text { fltration, } \\
\text { ant sodiun. } \\
\text { ation } \\
\text { exchunge } \\
\text { coftening }\end{array}$ & $\begin{array}{l}\text { Alter } \\
\text { chrification } \\
\text { filtrabion, } \\
\text { and } \\
\text { deminerali } \\
\text { ation }\end{array}$ \\
\hline \multicolumn{7}{|l|}{ Cationso } \\
\hline Gateium. & $\mathrm{CaCO}_{3}$ & 51.5 & $\$ 1.5$ & 38.7 & 1.0 & 0 \\
\hline Magnesium. & " & 19.5 & 19.5 & 17.5 & 1.0 & 0 \\
\hline Sottivm...... & $"$ & 18.6 & 18.6 & to. 6 & 8.6 & $1-2$ \\
\hline Potersium $\ldots \ldots \ldots \ldots \ldots \ldots$ & $"$ & 1.8 & 1.8 & 1.8 & 1.8 & 0 \\
\hline Total Cutions. & $"$ & 91.1 & 91.4 & E. 6 & 91.4 & $1-2$ \\
\hline \multicolumn{7}{|l|}{ Anions: } \\
\hline Biearbonate. & $"$ & 56.1 & 47.8 & 0 & 47.8 & 0 \\
\hline Carbonate. & $"$ & 0 & 0 & 33.0 & 0 & 0 \\
\hline Hydroxide & $"$ & 0 & 0 & 0. & 0 & $1-2$ \\
\hline Sultate & $"$ & 21.8 & 30.8 & 30.8 & 30.8 & 0 \\
\hline Chloride & $"$ & 12.0 & 12.0 & 12.0 & 12.0 & 0 \\
\hline Mitrate. & $"$ & 0.1 & 0.8 & 0.1 & 0.8 & 0 \\
\hline Total Anions. & $"$ & 91.4 & 91.1 & 76.6 & 91.4 & $1-2$ \\
\hline Irona. & $\mathbf{F e}$ & 0.16 & Mit & Mil & Mil & Mil \\
\hline Siliear. & sio: & 9.0 & 9.0 & 9.0 & 9.0 & 0.01 \\
\hline Color? & units & 15.0 & $2-5$ & $2-5$ & Nil & Mil \\
\hline Turbidity ${ }^{i}$. & $"$ & 100.0 & $a-2$ & $0-2$ & Nil & Mil \\
\hline $\mathrm{pH}^{a} \ldots \ldots$ & $"$ & $6.5-7.5$ & $6.0-8.0$ & 9. $0-11,0$ & $6.0-8.0$ & $7.0-9.0$ \\
\hline
\end{tabular}

- Taken trom Livingstone 1963"; adjusted slightly for ien talanee and for expression as $\mathrm{CaCO}_{3}$ equivaients. - Developed by the Panel for illustrative purposes.

effluent is generally limited to filtration and sodium cation exchange.

Aeration This process, which can be in several different physical forms, is applied to reduce the concentration of carbon dioxide, thereby reducing the chemicals required for cold lime softening. Aeration oxidizes iron and manganese to allow their removal by clarification, lime softening, or filtration. No solid wastes flow from an aerator, but released gases such as hydrogen sulfide can present a problem.

Miscellaneous There are other special variations of all the primary treatment methods that can be applied under specific circumstances.

\section{Group B Processes}

Filtration This process uses gravity or pressure units in which traces of suspended matter are removed by passage through a bed of sand, anthracite coal, or other granular material. In general, the effluent at the primary stage must be filtered prior to further treatment. Some waters can be filtered without primary treatment. A filter is cleaned by reversing the direction of the water flow (backwashing).

Adsorption This is a separation process designed primarily to remove dissolved organic materials including odor, taste, and color-producing compounds. Activated carbon is generally used for this purpose. Backwashing of fixed adsorption units produces small amounts of solids as the feed has generally been filtered prior to passage over the carbon. Expanded bed adsorption units do not require regular backwashing. Chemical or thermal regeneration of 
(Jtems not enclosed in boxes indicate typical water uses for treatment methods shown.)

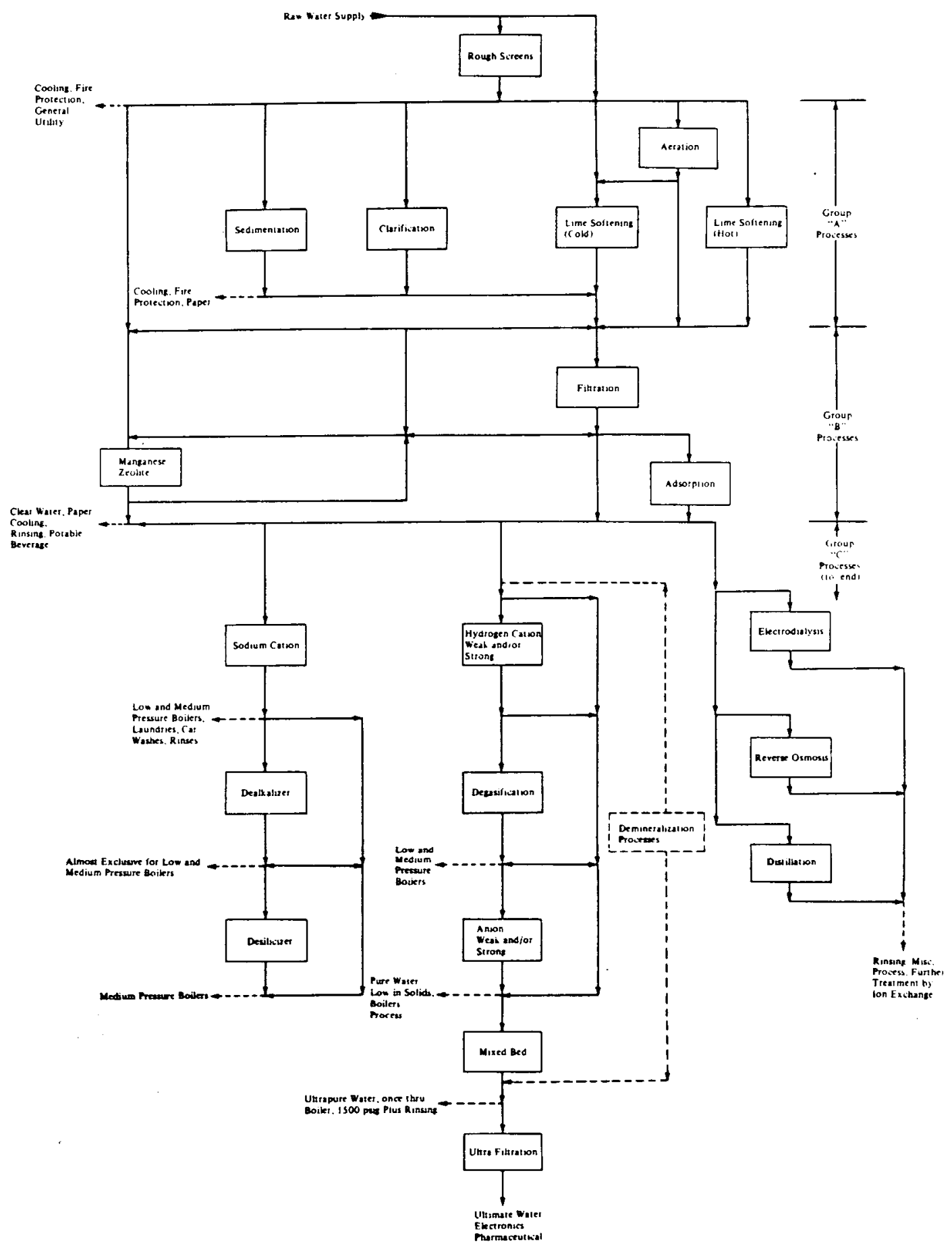

FIGURE VI-1-External Water Treatment Processes

(Items not enclosed in boxes indicate typical water uses for treatment methods shown.) 
carbon can remove adsorbed impurities and restore adsorptive efficiency and capacity.

Manganese Zeolite This process, specifically used for iron removal, is a special combined form of oxidation and filtration with a feed of potassium permanganate.

Miscellaneous Many specialized forms applicable to specific conditions are available. These include precoated filters, membrane filters, strainers, and dual media filters.

\section{Group C Processes}

Ultrafiltration Various types of pressure filters including membranes, cartridges, and discs can remove suspended solids larger than 0.1 to 1.0 micron, depending on the application

Reverse Osmosis This relatively new development uses high pressures to force water through a membrane, preventing the passage of all suspended matter and up to 90 99 per cent of dissolved solids. The product water can be used directly or may require further treatment by ion exchange. The influent must be essentially free of suspended solids.

Electrodialysis A relatively new development, this process uses cationic and anionic membranes with applied direct current to remove dissolved solids. The product water can be used directly or may require further treatment by ion exchange. The feed must be essentially free of suspended matter.

Distillation This process uses thermal evaporation and condensation of water so that the condensate is free of suspended solids and 98-99 per cent of the dissolved solids are removed. Certain conditions mav require the addition of special chemicals. The product water can be used directly or may require further treatment by ion exchange. The feed must be relatively free of suspended matter.

Ion Exchange Ion exchange is a versatile process with several dozen variations. Ion exchange technology is rapidly advancing. New resins, regeneration techniques, and operation modes are being introduced. Some of the more common applications are shown in Table VI-3. The exact arrangement of an ion exchange system depends upon raw water quality, desired treated water quality, flow rate, and economics. Total demineralization can remove in excess of 99 per cent of dissolved solids with feeds as high as 2,000 parts per million (ppm) or more. The waste produced by an ion exchanger includes the backwash and rinse waters, the regeneration effluent containing the exchanged ions, and the excess regenerative chemical. In general, the feed to any ion exchanger should contain no or only small quantities of suspended matter, color, and organics.

Cation Cation exchange removes cations from the water and replaces them with other cations from an ion exchanger. When in the hydrogen or acid form, strong cation (i.e., strong acid) can exchange hydrogen ions for the cations of either weak or strong acids, whereas weak cation (i.e., weak acid) exchanges hydrogen only for that fraction of cations equivalent to the weakly acidic anions present, such as bicarbonate.

Sodium Cation This is the simplest form of ion exchange. Sodium ions are exchanged for hardness ions (e.g., calcium, magnesium)

Anion Anion exchange removes anions from the water and replaces them with other anions from the ion exchanger. When in the base form, strong anion exchangers are capable of exchanging hydroxyl ions for the anions of either weak or strong acids, whereas weak anion exchangers exchange only with anions of strong acids.

Demineralization In industrial water treatment, demineralization refers to a sequence of cation exchange in which hydrogen ions are substituted for other cations followed by anion exchange in which hydroxyl ions are substituted for other anions. The product is $\mathrm{H}^{+}$plus $\mathrm{OH}^{-}$; i.e., water.

Mixed Bed Mixed bed exchange provides complete demineralization in one step by the use of an intimate mixture of cation and anion resin in one unit. It is generally used for the polishing service step of high purity water. A cation-anion exchange system might produce a water con. taining $1.0 \mathrm{ppm}$ of dissolved solids. After treatment by mixed bed, the solids would be down as low as $0.01 \mathrm{ppm}$.

Miscellaneous There are several specialty ion exchangers including: dealkalizers-chloride anion exchange for the removal of alkalinity; desilicizers-hydroxide anion exchange for the removal of silica (without previous hydrogen cation). Degasification equipment is used to remove carbon dioxide in order to reduce the work of the strong anion units that follow.

\section{INTERNAL WATER TREATMENT PROCESSES}

Internal water treatment processes are numerous. They include the addition of acid and alkali for $\mathrm{pH}$ control; polyphosphates, phosphonates, or polyelectrolytes for scale control; polymers for dispersal of sediment; phosphates and alkali for precipitation of hardness; amines, chromates, zinc, or silicates for corrosion control; sulfites or hydrazine for oxygen scavenging; and polyphosphates for sequestration of iron or manganese. Here again, the chemical feed is determined by the requirements. The industrial user produces the water quality that is needed, but a problem can be created when the user must dispose of all or part of the treated water. The choice of chemicals added to water must be considered in light of their potential as pollutants. 
APPENDIX B

ANNOTATED BIBLIOGRAPHY

1

EARLOW 72

BR INE TREATMENT/SFENT FLUIC CISPOSAL

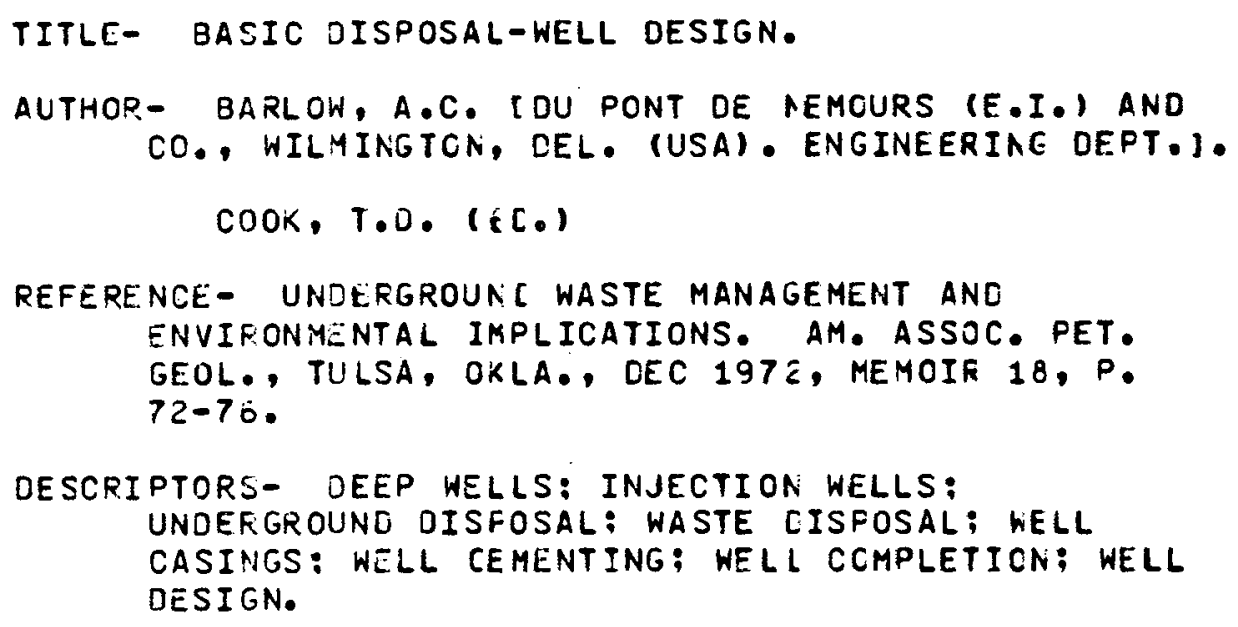

TITLE- WATER-MINEFAL FEACTIONS RELATED TO PCTENTIAL FLUIC-INJECIION PPOBLEMS.

AUTHOR- BARNES, I. (GEOLOGICAL SURVEY, MENLO PARK, CALIF. (USA), hATER RESOURCES DIV.1.

COOK, T.O: (EL.)

REFERENCE - UNDERGROUN C WASTE MANAGEMENT AND ENVIRONMENTAL IMPLICATIONS. AM. ASSOC. FET. GEOL., TULSA, OKLA.. DEC 1972, MEMCIF 18, P. $294-297$. 
DESCRIPTORS- CARBONATES: CHEMICAL ANALYSIS: CHEMICAL REACTIONS: CLAY MINERALS; FREE ENERGY;

HYOROXIDES; INJECTION WELLS; LIQUIO WASTES;

ROCK-FLUID INTERACTIONS: SILICATES: SULFIDES: THERMODYNAMICS: UNDERGROUNO OISPOSAL.

BERESTROM 68

BR INE TREATMENT/SFENT FLUIC CISPOSAL

TITLE- FEASIBILITY OF SUBSURFACE DISPOSAL OF INDUSTRIAL WAS IES IN ILLINCIS.

AUTHOR- BERGSTROM, F.E. IILLINOIS STATE EEOLCGICAL SURVEY, URBANA, ILL. (USA)].

REFERENCE- FEASIBILITY OF SUBSURFACE OISPCSAL OF INDUSTRIAL WASTES IN ILLINOIS. CIRCULAF 426, ILL. STATE GEOICGICAL SURVEY, UREANA, ILL., 1968,18 P..

OESCRIPTORS - AQUIFERS: DEEP WELLS: FEASIBILITY STUDIES: GEOLCGY; HYDROLOGY: INJECTION WELLS; LIMESTONE; LIQUI C WASTES: LITHOLOGY; PERMEABILITY; FCLLUTION: PCROSITY; REELLATIONS; ROCKS; SANDSTONE; UNDERGROUND OISPOSAL; WATER POLLUTION: WATER QUALITY: ILLINCIS; ILLINOIS BASIN.

4

TITLE- FINAL DISPOSAL OF EFFLUENT BRINES FRCM INLAND DESALTING PLANTS.

AUTHOR - BOOTH, J.R., JR. : SHEPHERO, B.P.: MCILHENNY, W.F. COOW CHEMICAL CO.. FREEFORT, TEX. (USA)].

REFERENCE- FINAL OISFCSAL OF EFFLUENT BRINES FROM INLAND DESALTING PLANTS. INT-OSW-RDPR-72-817, OFFICE OF SALINE WATER, WASHINGTON, MAY 1972, ¿81 P..

DESCRIPTORS- $\triangle$ QUIFEFS: BIOLOGICAL FCULING: EFINE TREATMENT: BRINES: CASE HISTCFIES: CHEYICAL ANALYSIS: CHEMICAL COMPOSITION: CRYSTALLIZATIOA; DEEP WELLS; CESALINATICN; DESALTING PLANTS: DISPOSAL FCRMATIONS; 
DISSOLVEO SOLIJS: DOLOMITE RCCKS; ECCNCNICS; ELECTRODIALYSIS: ENVIRONMENTAL EFFECTS; EVAPORATION PONCS; RESERVOIR PRESSURE: GE OLOGY; GRAVEL PACKING; INJECTION WELLS; LEGAL ASPECTS: LIQUID WASTES: LITHOLOGY: PERMEABILITY: PERMEABILITY RESTORATION: PG VALUE; PORCSITY; REVERSE OSMOSIS; SANDSTONE; STRATIGRAPHY; UNDEFGROUND OISFOSAL: WASTE GISFOSAL; RELL DESIGN; WELL L CGGING: SAN JUAN BASIN; KANSAS; COLORADO: TEXAS: NEW MEXICO; NORTH CAKCTA.

5

CAVIS 72

BR INE TPEATMENT/SFENT FLUIC CISPOSAL

TITLE- CONTROI- OF UNC CNSOLIDATED SANGS IN WASTE-DISPOSAL MELLS.

AUTHOR- DAVIS, K.E.;FLNK, R.J. I SUESURFACE IISPOSAL CORPORATION, HOUSTON, TEX. (USA)].

COOK, T.D. (E[.)

REFERENCE - UNDERGROUN C WASTE MANAGEMENT AND ENVIRONMENTAL IRPLICATIONS. AM. ASSOC. FET. GEOL., TULSA, OKLA., DEC 1972, MEMCIF 18, P. $112-118$.

DESCRIPTORS- CASE HISTORIES: DEEP WELLS: DISFOSAL FORMATIONS: EXPERIMENTAL RESULTS; FIELO STUDERGROUND DISPOSAL: WASTE DISPOSAL; WELL COMPLETION: WELL DESIGN: TEXAS; LOUISIANA; IES; FORMATION CAPACITY; GRAVEL PACKING; OILFIELD BRINES: SAND CONTROL: SANOSTONE; UNDFE

$$
S C=\text { DONALOSON } 72 .
$$

6

BR INE TREATMENT/SFENT FLUIO DISPOSAL

TITLE- INJECTION HELLS AND OPERATIONS TODAY.

AUTHOR- DONALOSON, E.C. IBUREAU OF MINES, BARTLES VILLE, OKLA. (USA), BARTLESVILLE ENERGY RESEARCH CENTEF].

COOK, T.O. (E[.)

REFERENCE- UNOERGROUN C WASTE MANAGEMENT ANO

ENVIRONMENTAL IMPLICATIONS. AM. ASSOC. PET. GEOL., TULSA, OKLA., DEC 1972, MEMOIR 18, P. $24-46$. 
DESCRIPTORS- $\triangle$ CIOIZATION: BACTERIA; CASE HISTORIES: CHEMICAL ANALYSIS: CHEMICAL CCMPATIEILITY; CHEMICAL COMFOSITION: CLAY MINERALS; CCEROSICN; CORROSION INHIBITORS: DEEP WELLS; DISFCSAL FORMATIONS: OOLCPITE ROCKS: ECONCMICS: ENVIRONMINTAL EFFECTS: FILTRATION; FLUIC MECHANICS; FLOCCLLATING AGENTS; FLOW RATE; GEOLOGY: GFOUNO HATER: HYORAULIC FRACTURING: INOUSTRIAL WASTE:: INJECTION WELLS: LIHESTONE; LIQUID WASTES; LITHOLOGY: MATHEMATICAL MCOELS; MEASURING METHOCS: OILFIELO ERINES:

PERMEABILITY; PH ADJUSTMENT: PH VALUE; PLUGGING: POROSITY: PRECIPITATION;

PRE-INJEOTION TKEATMENT: RESERVOIR PFOPERTIES:

SANDSTONE: ; SCALING; SCALING CCNTROL: SFECIFIC INJECTIVITY INOEX; SURFACE EQUIPMENT; SLSPENCEC SOLICS: THEORETICAL TREATMENTS: TRANSMISSIVITY: UNDEKGROUND OISFOSAL: WASTE CISFOSAL: WASTE MANAGEMENT; WASTE WATER; WELL CASINGS •

TITLE- SUBSURFACE RASTE INJECTION IN THE UNITED STATES. FIFTEEN CASE HISTORIES.

AUTHOR- DONALOSCN, E. C.:THOMAS, R.D. ; JOHASTON, K. H. [BARTLESVILLE ENERGY RESEARCH CENTER, BARTLESVILLE, CKLA, (USA) 1.

REFERENCE- SUSSURFACE WASTE INJECTION IN THE LNITED STATES. FIFTEEN CASE HISTORIES. INFOFHATION CIRCULAR 8636 , EUREAU OF MINES, WASHINGTON,D.C. , 1974,72 P..

DESCRIPTORS- ACIOIZATION: AQUIFEFS; BIOLCGICAL FOULING; CASE HISTORIES: CHEMICAL COMPATIBILITY: CHEMICAL REACIIONS: CLAY MINERALS: CORROS ION: DEEP WELLS: DISPOSAL FORMATIONS; DOLCPITE ROCKS; ECCNOMICS; FILTRATION: FL CCCULATION; FLOW RATE: GECLOGY; GROUND WATER; HYORAULIC FRACTURING; HYDRAULICS: HYORODYNAMICS; HYDROGEOLOGY; HYOROLOGY; HYOROOYNAMIC GRALIENT: INDUSTRIAL WASTES; INJECTION PRESSLRE: INJECTICN RATES; INJECTICN WELLS; LEGAL ASFECTS: LIMESTCNE; LIQUIC WASTES; LITHOLOGY; PERMEABILITY; PH ACJUSTMENT; PLUGGING; POLLUTION; POROSITY; PRECIFITATION: PRE-INJECTION TKEATMENT; RESERVOIR PFOFERTIES; RESERVOIR PRESSULE: SANDSTONE; SEOIMENTATION; SHALE; STORAGE CAPACITY: STRATIGRAPHY; 
SUBSURFACE RESER VOIRS; SURFACE EQUIPMENT; SUSPENOED SOLIOS: UNOERGROUNC OISPOSAL; WASTE DISPOSAL.

8

EHFLICH 72

BR INE TREATMENT/SFENT FLUID OISPOSAL

TITLE- ROLE OF BIOTA IN UNDERGROUNO WASTE INJECTICN AND STORAGE.

AUTHOR- EHRLICH, G.G. [GEOLOGICAL SURVEY, MENLO PARK, CALIF. (USA)J.

COOK, T.O. (E[.)

REFERENCE- UNDERGRCUN L WASTE MANAGEMENT AND ENVIPONMENTAL IKPLICATIONS. AM. ASSOC. FET. GEOL., TULSA, OKLA., DEC 1972, MEMOIR 18, P. $298-307$.

DESCRIPTORS- BACTERIA; BIOLOGICAL EFFECTS: BIOLOGICAL FOULING: CHEMICAL REACTICNS; CORROSION; GROUN [ WATER; INJECIION WELLS; MICROORGANISMS; OILFIELD BRINES: PETROLEUM INOUSTPY: PLUGEIAG: UNOERGROUNO DISFCSAL: WASTE DISPOSAL.

TITLE- RESPONSE OF HYUROLOGIC SYSTEMS TO HASTE STORAGE.

AUTHOR - FLRRIS, J.G. [GEOLOGICAL SLRVEY, WASHINGTCN, D.C. (USA). HATER RESOURCES OIV.1.

COOK, T.D. (E[.)

REFEPSNCE- UNJERGROUN W WASTE MANAGEMENT AND ENVIFONMENTAL IKPLICATIONS. AM. ASSOC. PET. GEOL., TULSA, CKLA., DEC 1972, MEMCIR 18, P. 126-132.

DESCRIPTOPS- AQUIFERS: AQUITAROS: CEEP WELLS:

ENVIFOHMENTAL EFFECTS: FLUID MECHANICS; FLOW

RATE: GEOLOGY: GFOUNO WATER: HYOROLOGY: 
INJECTION PRESSLRE: LIQUIC WASTES:

PERMEABILITY; FRESSURE BUILDLP; TRANSMISSIVITY; UNDEFGROUND OISFOSAL; WASTE OISPOSAL; KASTE FRONT.

10

FRYEERGER 72

BRINE TREATMENT/SFENT FLUIC OISPCSAL

TITLE- REHABILITATICA OF A BRINE-FOLLUTED AQUIFER.

AUTHOR - FRYBERGER, J.S. [ENGINEERINE ENTERPEISES, NORMAN, OKLA, (USA) J.

REFERENCE- REHABILITATION OF A BRINE-POLLUTEC AQUIFER. EPA-R2-72-014, ENV JFONMENTAL PROTECTION AGENCY, WASHINGTOA, DEC 1972, 61 P..

DESCPIPTORS- AQUIFER FEHABILITATION; AQUIFERS:

BRINES: CHEMICAL COMPOSITION; CHEMICAL

REACTIONS ; DEEF WELLS; DESALINATION: ECONOMICS:

ENVIRONMENTAL EFFECTS: EVAPORATICN PCNES:

FEASIBILITY STUOJES; FLOW RATE: GEOLOGY: GROUNO

WATER; HYCRAULICS; HYOROLOGY; INJECTION WELLS;

OILFIELD BRINES: POLLUTION; FOLLUTICN

REGULATIONS; STRATIGPAPHY; UNCERGROUND

DISPOSAL; WASTE CISPOSAL; WATER CHEMISTRY;

WATER POLLUTIOIN WELL OESIGN; ARKANSAS.

11

GALLEY 72

BRINE TREATMENT/SFENT FLUIC CISPOSAL

TITLE- GEOLOGIC FRAMEWORK FOR SUCCESSFUL UNCERGROUND WASTL MANAGEMENT.

AUTHOR- GALLEY, J.E. [GEOLOGICAL CONSULTANT, KERRVILLE, TEX. (USA)].

COOK, T.O. (EC.)

REFERENCE - UNDEFGROUN [ WASTE MANAGEMENT AND

ENVIRONMENTAL IMPLICATIONS. AM. ASSCC. PET. GEOL., TULSA, CKLA., DEC 1972, MEMOIF 18, P. $119-125$. 


\begin{abstract}
DESCRIPTORS- AQUIFERS: CHEMICAL ANALYSIS: CHEMICAL COMPATIBILITY; CHEMICAL REACIIONS; CLAY MINERALS: DEEP WELLS: DISPOSAL FORMATICNS; DOLOMITE ROCKS: LCONOMICS: ENVIRONMENTAL EFFECTS: FLOW FATE: GEOLCGY: GROUNO WATEE: HYOROGEOLOGY; HYOROLOGY: HYOFCOYNAMIC GRAOIENT: LIMESTONE; LIQUIL WASTES; LITHCLOGY; PERMEABILITY: PCFOSITY: POROUS MEOIA: FESEFVCIR PR.OPTRTIES: ROCK S; SANDSTONE; SEDIMENTARY ROCKS: SEISMCLCGY: SHALF; SUESURFACE RESFFVOIRS: UNCERGROUNO DISFCSAL; WASTE DISPOSAL: WASTE RANAGEMENT; WELL DRILLING; WELL INTERFERENCE: HELL LOGGING.
\end{abstract}

12

GFEENFIELC 72 ERINE TREATMENT/SFENT FLLIC CISPOSAL

TITLE- EPA--THE ENVIRONMENTAL WATCHMAN.

AUTHOR - GREENFIELD, S.M. IENVIRONMENTAL PROTECTION AGLNCY, WASHINGTCN, D.C. (USA)].

COOK, T.O. (EO.)

REFERENCE- UNOERGROUND WASTE MANAGEMENT ANO ENVIFONMENTAL IMPLICATIONS. AM. ASSOC. FET. GEOL., TULSA, CKLA., DEC 1972, MEMCIF 18, P. $14-18$.

DESCEIPTORS- CASE HISTORIES: DEEP RELLS: DISFCSAL FORMATIONS; EAFTRQUAKES: ENVIFONMENTAL EFFECTS; ENVIRONME NTAL PFCTECTION AGENCY: EVAPCRATION PONDS: GROUNE WATER; INJECTION WELLS; MONITORING: POLLLTION; POLLUTION REGULATIONS; UNDERGROUNO OISFOSAL; WASTE OISFOSAL.

TITLE- COMPATIBILITY CF SUBSURFACE RESEFUCIFS WITH INJECTED LIQUIC WASTES.

AUTHOR - GRUBBS, D.M.:HAYNES, C.D.:HUGHES, T.H.:STOW, S.H. [ALABAMA UNIV., UNIVERSITY. (USA), NATURAL RESOURCES CENTEFI. 


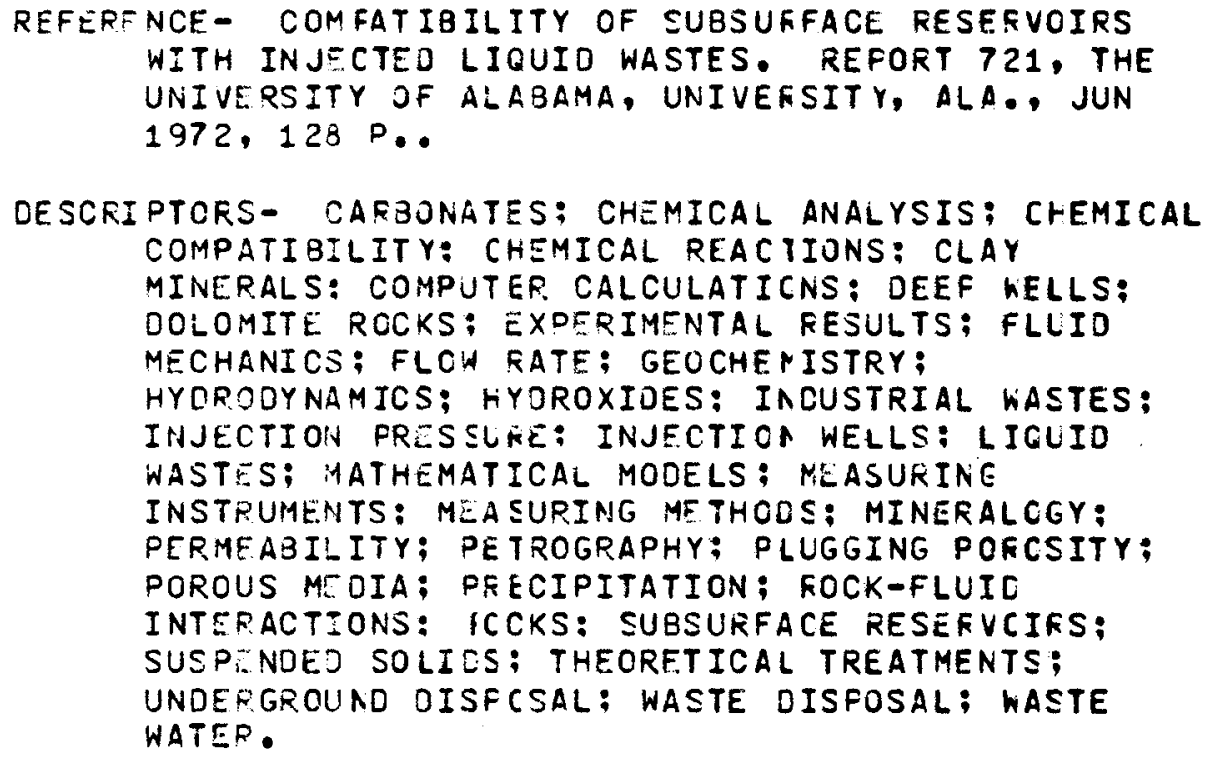

TITLE- PERMEABILITY RESTORATION IN UNDERGROLNC OISPCSAL RESERVCIRS.

AUTHOR - GFUBBS, D.M.:HAYNES, C.D.;WHITTLE, E.F. [ ALAGAMA UNIV., UNIVERSITY (USA). NATURAL RESOURCES CENTER].

REFERENCE- PFRMEABILITY RESTORATICN IN UNCEFGFOUNO DISPOSAL RESERVCIRS. REFORT 733, THE UNIVERSITY OF ALABAMA, UNIVEFSITY, ALA., SEP 1973,138 P..

DESCRIPTORS - ABRASION: ACIOIZATICN; BKINES; CARBONATES: CHEMICAL ANALYSIS: CHEMICAL REACTIONS: CLAY MINERALS; COMFUTER CALCULATIONS; CEEP WELLS: DISFCSAL FORMATIONS; ECONOMICS: FLCW FATE: HYORAULIC FRACTUEING: INJECTION PRESSLFE: INJECTIOA WELLS; LIQUIO WASTES: MEASURINE INSTRUMENTS; MEASURING METHODS: PERMEAEILITY: PERMEABILITY RESTORATION: PF ADJUSTMENT: FLUGGING; PFECIPITATION; FFESSURE. BUILDUP: REAMING; ROCKS: SANOSTONE: SCALING: UNDERGROUNC DISPOSAL: WASTE FROCESSING. 
HANSHAW 72

BRINE TREATMENT/SFENT FLUIC OISPOSAL

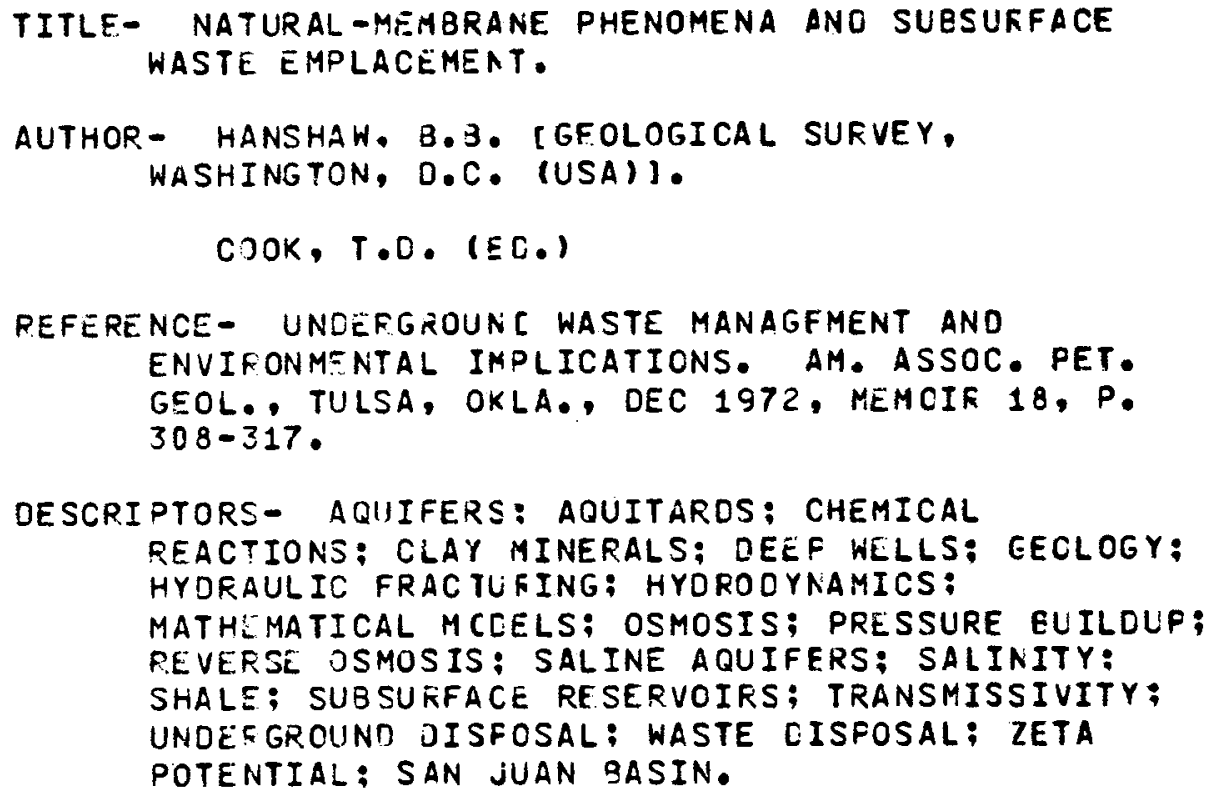

TITLE- FEDERAL REGULATIONS AS THEY RELATE TO UNDEFGROUND WASTE MANAGEMENT.

AUTHOR- HARRISON, T.F., II IENVIRCAMENTAL PRCTECTION AGENCY, DALLAS, IEX. (USA)).

$$
\text { COOK, T.D. (EC.) }
$$

REFERENCE - UNOERGROUR [ WASTE MANAGEMENT ANC ENVIFONMENTAL IMPLICATIONS. AM. ASSOC. PET. GEOL., TULSA, OKLA., DEC 1972, MEMOIF $18, P$. $376-380$.

OESCRIPTORS - ENVIRONFCNTAL EFFECTS: ENVIFONMENTAL PROTLCTION AGENCY: INJECTION WELLS: LEGAL ASPECTS: POLLUTICN LAWS: POLLUTION REEULATIONS; REGULATIOAS; UNOERGROUNO OISFOSAL; WASTE MANAGEMENT: WATEF POLLUTION. 
TITLE- DESIGN AND COST OF LIQUIC-WASTE DISPOSAL SYSTEMS.

AUTHOR - HAYNES, C.D.:GRUBBS, D.M. [ALABAMA UNIV., UNIVERSITY (USA). NATURAL RESCURCES CEATERI.

REFERENCE- DESIGN ANC COST OF LIQUIO-WASTE CISPOSAL SYSTEMS. REPORT 692, UNIVERSITY OF ALAEAMA, UNIVERSITY, ALA ., DEC 1969, 120 P..

DESCRI PTORS- BRINES; CHEMICAL COMFATIBILITY: CHEMICAL FEACTICNS: COMPUTER CALCULATICNS; CORROSION: CORFCSION INHIBITORS; DEEF KELLS: DISPOSAL FORMATICNS: ECONOMICS: FEASIBILITY STUDIES: FILTRATION: HYOROOYNAMICS; INJECTION WELLS; LIQUIO WASTES: OILFIELC BRINES; PERMPABILITY: PIPELINES: PRECIPITATION; PRE-INJECTION TFEATMENT; SUBSURFACE RESERVOIRS; SURFACE EQUIPMENT: SUSPENDED SOLIDS; UNDERGROUND DISFCSAL: WASTE CISPOSAL: WELL CASINGS: WELL CE PENTING; WELL DATA; WELL DESIGN; WELL LOEGING; ALABAMA.

TITLE- CIRCULATION FATTEFNS OF SALINE GROUNCWATER AFFECTED BY GEOTHFRMAL HEATING--AS RELATED TO WASTE OISPCSAL.

AUTHOR.- HENRY, H.R. [ALABAMA UNIV ., TUSCALCCSA, ALA. (USA). DEPT. CF CIVIL AND MINERAL ENEINEERINGI.

KOHOUT, F.A. [GEOLOGICAL SURVEY, HASHINGTON, D.C. (USA)].

CCOK, T.D. (E[.)

REFERENCE- UNDERGROUN [ WASTE MANAGEMENT ANO ENVIRONMENTAL IPPLICATIONS. AM. ASSCC. FET. GEOL., TULSA, OKLA., OEC 197 C, MEMOIF 18, P. 202-221.

OESCRIPTORS- AQUIFEFS: COMPUTER CALCULATICNS: CONVECTION: DEEF WELLS: DIFFUSION: OISFCSAL FORMATIONS; DOLCPITE ROCKS; ENVIRONMENTAL 
EFFECTS: EXPERIMENTAL RESULTS; FLOW RATE; GEOLOGY: GEOTHERMAL ENERGY: GROUND WATEF: HYDRAULICS: HYOFCGEOLOGY: INJECTION HELLS: LIMESTONE: LIQUI [ WASTES: MATHEMATICAL MCDELS: SALINE AQUIFERS: SALINITY; TEMPEKATUFE LCGGING; THEOFETICAL TREATMENTS; TEMPERATURE ERACIEATS: UNDERGROUND OISFCSAL: WASTE CISFOSAL: WATER CHEMISTRY; FLOFIOA.

BR INE TREATMENT/SFENT FLUIC IISPOSAL

TITLE- REGULATION CF SUBSURFACE DISFOSAL IN TEXAS.

AUTHOF- HILL, R. CTEXAS WATER QUALITY BOAFC, AUSTIN, TEX. (USA)I.

COOK, T.O. (E[.)

REFERENCF- UNDERGROUN [ WASTE MANAGEMENT AND ENVIFIONMENTAL IMPLICATIONS. AM. ASSOC. PET. GEOL., TULSA, OKLA, DEC 1972, MEMOIR 18, P. $381-385$.

DESCRIPTORS- DEEP WELLS: ENVIRONMENTAL EFFECTS: GEOLOGY: GROUNC HATER: HYCROLCGY: INJECTION WELLS: LEGAL ASFECTS: LIQUID WASTES: LITHOLOGY; MONITORING: CILFIELD BRINES: PRESSURE ELILDUF; REGULATIONS: SUESURFACE RESEFVCIRS: UNCERGROUND DISPCSAL: WASTE IISPOSAL: WASTE PROCESSIAG: WELL COMPLETION; WELL DATA: LELL DESIGN; TEXAS.

20

HOOVER 69

BR INE TREATMENT/SPENT FLUIC CISPOSAL

TITLE- SEISMIC ACTIVITY DURING THE 1968 TEST PUMPING AT THE RJCKY MOLNTAIN ARSENAL OISPOSAL RELL.

AUTHOR- HOOVER, D.B,: EIETRICH, J.A. IGEOLCGICAL SURVEY, CARMEL, CALIF. (USA)].

REFERENCE - SEISMIC ACIIVITY DURING THE 1968 TEST PUMPING AT THE FCCKY MOUNTAIN ARSENAL CISPOSAL WELL. CIRCULAR 613, GEOLOGICAL SURVEY, WASHINGTON, 1969, 35 P.. 


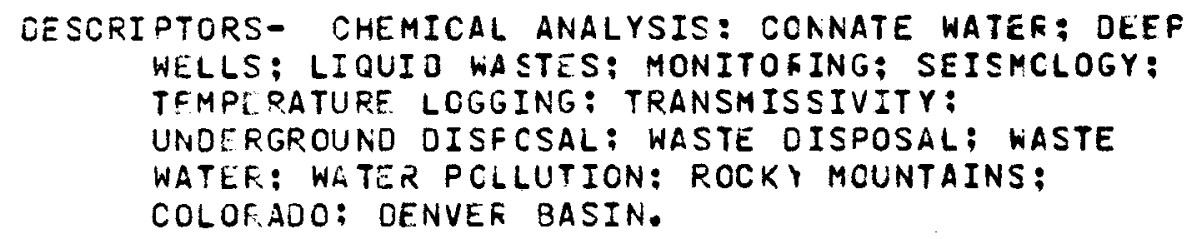

TITLE- COMPATIBILITY OF INJECTION FLUIDS WITH FTSERVOIF COMPONENTS.

AUTHOP- HOWFE, W.F.:LISATER, R.M.;MIHKAM, F.G. [HALLIBURTON SEF VICES, DUNCAN, OKLA. (USA)].

COOK, T.D. ( $\left(C_{0}\right)$

REFERENCE- UNDERGROUN I WASTE MANAGEMENT ANC ENVIRONME NTAL INFLICATIONS. AM. ASSOC. PET. GEOL., TULSA, OKLA., DEC 1972, MEMCIF 18, P. $287-293$.

DESCRIPTORS- 3ACTERIA; BIOLOGICAL FCULING: ERINES: CARBONATES: CASE HISTORIES: CHEMICAL COMPATIBILITY; CHEMICAL REACTIONS: CLAY MINEFALS; DEEP RELLS; HYORAULIC FRACTUFING; INJECTION WELLS: LIQUID WASTES; PERMEAEILITY: PERMEABILITY RES TOF.ATION: PH AOJUSTMENT: PH VALUE: PLUGEING; PRECIPITATICN; PRE-INJECTION TREATMENT: RESËRVOIR PROPERTIES: ROCK-FLUID INTERACTIONS; SANDSTONE; SILICA MINERALS; SUBSURFACE RESEKVOIRS; SUSPEACED SCLIDS; UNOERGROUND DISFOSAL: WASTE CISPOSAL.

22

LACEY 71

BRIAE TREATMENT/SFENT FLUIC CISPOSAL

TITLE- DEMINERALIZATICN OF WASTEWATER BY THE TRANSPORT - DEPLETION PROCESS.

AUTHOR- LACEY, R.E. :HUFFMAN, E.L. ISOUTHERN RESEARCH INST., BIRMINGHAM, ALA. IUSAIJ. 


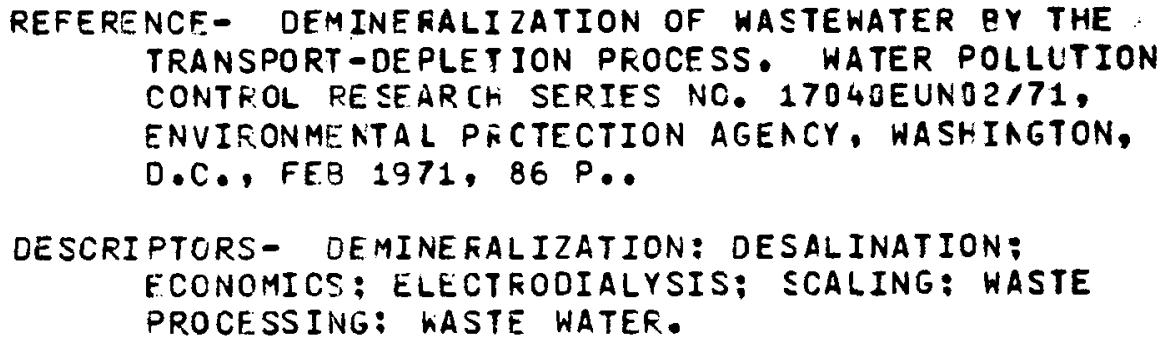

TITLE- A STUDY OF DEEF-WELL OISPOSAL OF DESALINATION BRINE WASTE.

AUTHOR - LFGROS, P.G.; GUSTAFSON, C.E.;NEVILL, G.L.:MAJESKE, E. C.:MATHEWS, F.O.:TALECT, J.S. :MCILHENAY, W.F. [DOW CHEMICAL CC., MIDLAND, MICH. (USA)).

REFERENCE - A STUOY OF DEEP-WELL CISPOSAL CF DESALINATION BFINE WASTE. RESEARCH ANO DEVELOPMENT PRCERESS REPORT NC. 456, OFFICE OF SALINE WATER, WASHINGTON, JUA $19 E 9,259$ P..

DESCRI PTORS- BRINES: CASE HISTCRIES; CHEMICAL ANALYSIS: DEEP WELLS; DESALIAATION; OISFOSAL FORMATIONS: ECCNOMICS: EVAPOFATION PCNOS: FEASIBILITY STUCIES; GEOLOGY; INJECTICN PRESSURE: INUE CTION WELLS: LEGAL ASFECTS: MONITORING; SUFFACE EQUIPMENT; UNDERGRCUND OISPOSAL: WASTE CISPOSAL: WELL DESIGN; OKLAHOMA: TEXAS: KANSAS: COLOFADO; SOUTH DAKOTA.

TITLE- DISPOSAL-WELL CIMENSIONS-IAJECTION RATES ANC COST RESPGASES.

AUTHOR- MALINA, J.F., JP. ITEXAS UNIV., AUSTIN (USA). DEPT. OF CIVIL ENGINEERINGI. 
MOSELEY, J.C., II COIV. OF COORDINATION ANO PLANNING OFFICE OF THE GOVERHOF OF TEXAS, AUSTIN (USA)].

$$
\text { COOK, T.O. (E. E.) }
$$

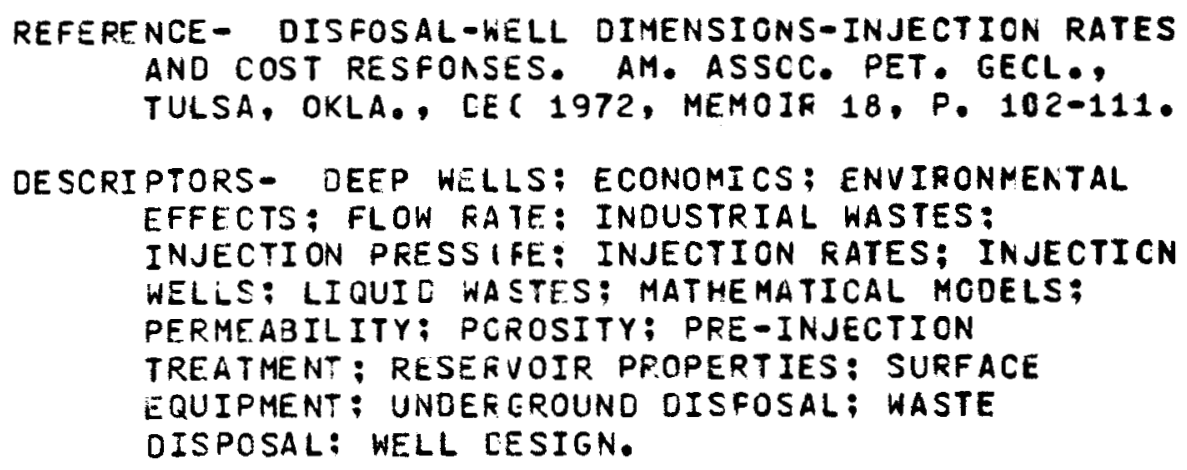

\section{BRINE TREATMENT/SFENT FLUIC OISPOSAL}

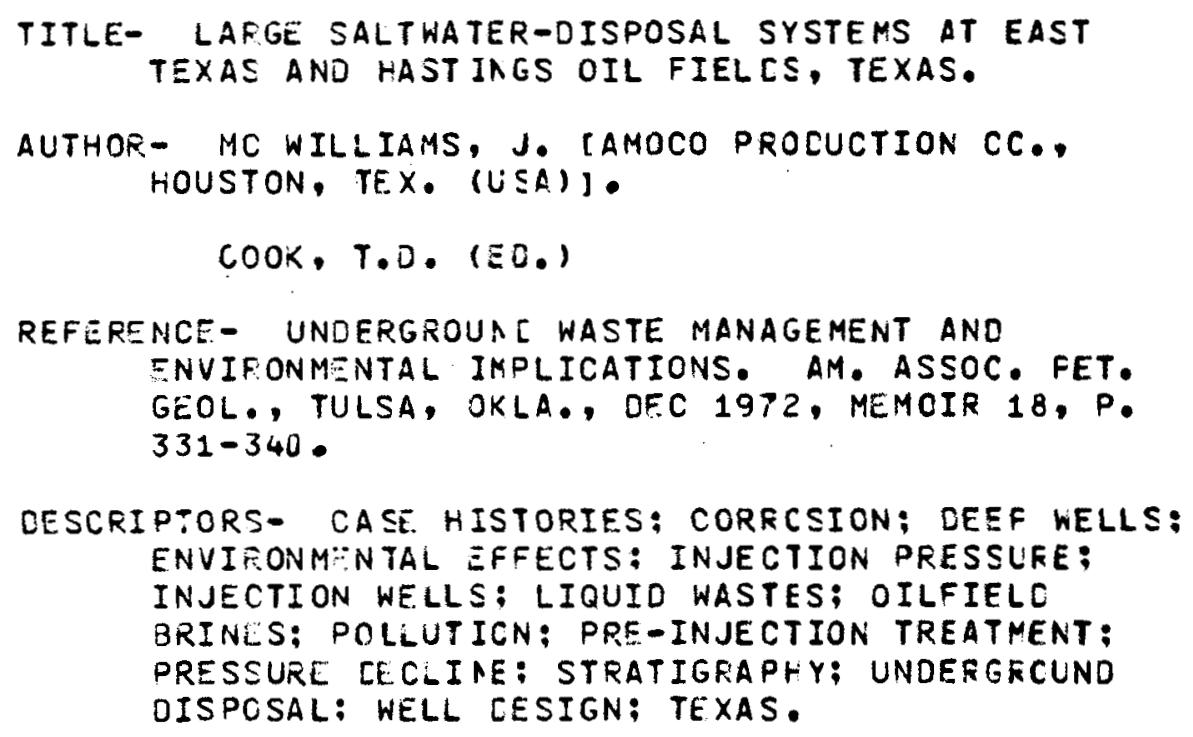




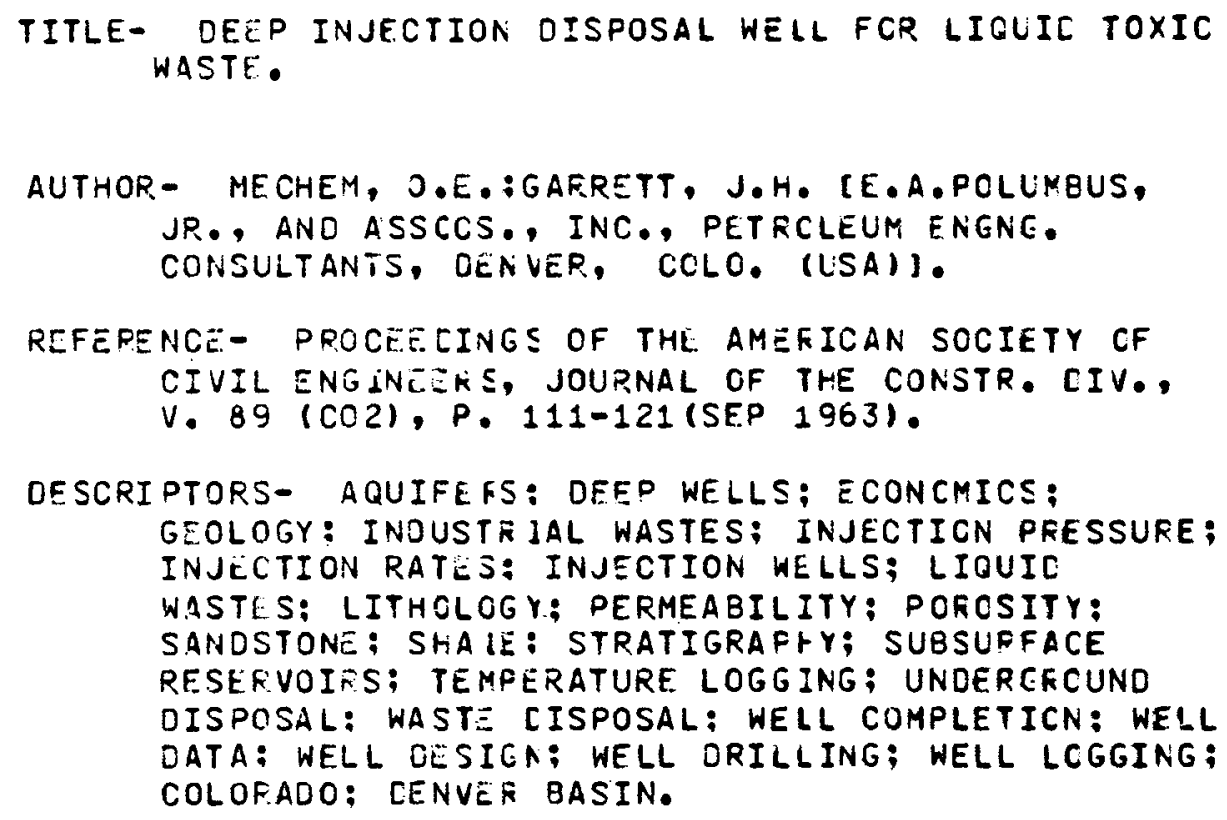

BR INE TREATMENT/SFENT FLUIC CISPOSAL

TITLF- UNOERGPOUNO INJECTION OF WASTEWATERS IN THE OHIO VALLEY REGION.

AUTHOR- OHIO RIVER VALLEY WATER SANITATICN COMMISSION, OR SANCO AOVISORY COMMITTEE ON UNDEFGROUND INJECTION OF WASTEWATERS. CINCINNATI, OHIC.

REFERENCE- UNDERGROUNC INJECTICN CF WASTEWATERS IN THE UHIO VALLEY REGION. OHIO RIVER VALLEY WATEF SANITATICN COMMISSION, CINCINNATI, AUG 1973,63 P..

OESCRIPTORS- AQUIFERS: GEOLOGY: GROUND WATER: HYDRODYNAMICS; HYDROGEOLOGY: INJECTION WELLS; LEGAL ASPECTS: MINERALS; MONITORING; SEISMOLOGY: SURFACE EQUIPMENT: UNDEREROUND DISPOSAL: WASTE FROCESSING; WELL DESIGA; WELL DRILLING: OHIO. 
BRINE TREATMEAT/SFENT FLUIC OISPOSAL

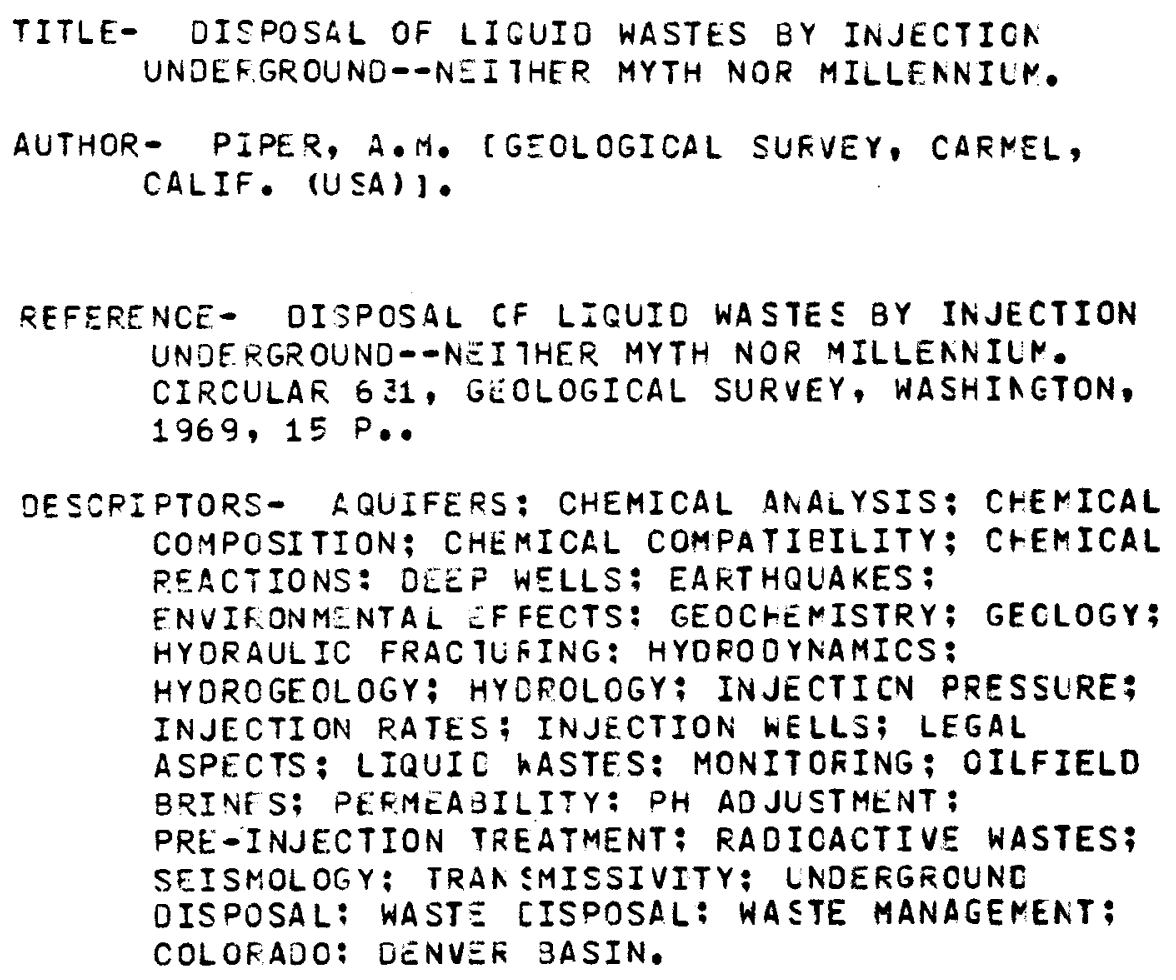

TITLE- EARTHQUAKES ANC FLUIO INJECTICN.

AUTHOR- RALEIGH, C.B. CGEOLOGICAL SURVEY, MENLO PARK, CALIF. (USA). NATIONAL CENTER FCF

EARTHQUAKE RESEARCH].

COOK, T.D. (E[.)

REFERENCE- UNDERGROUNC WASTE MANAGEMENT ANC ENVIRONMENTAL IMPLICATIONS. AM. ASSOC. FET. GEOL., TULSA, OKLA,, DEC 1972, MEMCIR 18, P. 273-279. 
DESCRIPTORS - AQUITARES: DEEP WELLS: EARTHOUAKES:

FAULT ACTIVATICN: HYORAULIC FRACTURINE:

INJFCTION WELLS: LIQUIO WASTES; MONITCRING;

PORE PRESSURE; FRESSURE BUILCUP; RESERVCIR

PROPERTIES: SANESTONE: SEISMCLOGY: SUESURFACE

RESERVOIPS: UNCERGROUND DISFOSAL; WASTE

DISPOSAL: COLOFACO; DENVER BASIN.

SAOOW 72

BRINE TRFATMENT/SFENT FLUIC OISPOSAL

TITLE- PRETREATMENT CF INDUSTRIAL WASTE WATERS FOF SUBSURFACE INJECTION.

AUTHOR - SADOW, R.D. IMONSANTO POLYMEFS ANO

PETROCHEMICALS COMPANY, TEXAS CITY, TEX. CUSAI\}.

COOK, T.O. (E..)

REFERENCE- UNOERGROUNE WASTE MANAGEMENT AND

ENVIRONMF NTAL IMFLICATIONS. AM. ASSOC. FET. GEOL., TULSA, CKLA., DEC 1972, MEMOIF 18, P. 93-101.

DESCRIPTORS- BACTERIA: BIOLOGICAL FOULING: CHEMICAL COMPATIBILITY; CORROSION: CORFOSION INHIEITORS; CORROSION RESISTANT ALLOYS; CCRROSIVE EFFECTS: DEEP WELLS; DISFCSAL FORMATICNS: FILTRATION: GEOLOGY; INDUSTEIAL WASTES: INJECTION PRESSURE; INJECTIOH RATES; OILFIELO BRINES; PERMEABILITY; PH ADJUSTMENT: FH VALUE: PLUGGING; POLYMERIZATION: FOROSITY; PRECIPITATICA; PRE-INJECTION TREATMENT; PRESSURE BUILDUF; SUPFACE Z QUIPMEN 1: SUSPENDEO SOLIDS: UHDEFGROUNO DISFOSAL: WASTE CISPOSAL; WASTE WATEF; WELL DESIGN; TEXAS.

31

SCEVA 68

BRINE TREATMENT/SPENT FLUID CISPOSAL

TITLE- LIQUID WASTE CISPOSAL In the lava tefaAne cF CENTKAL OREGCN.

AUTHOR- SCEVA, J.E. IFEOERAL WATEF POLLUTICA CONTROL ADMINISTRATION, NORTHWEST REGION, CORVALLIS, OREG. (USA). PACIFIC NORTHWEST WATER LAE.J. 


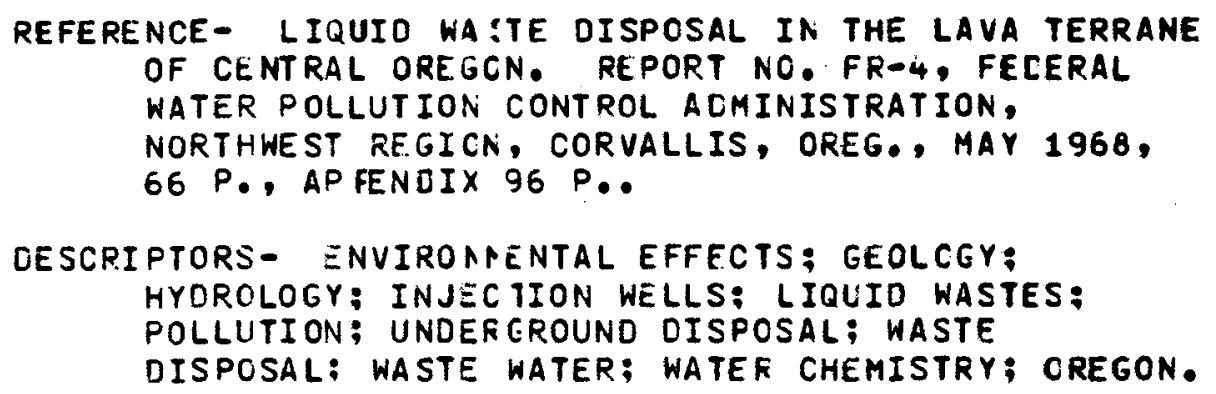

TITLE- CHEMICAL EFFEC IS OF PORE FLUICS ON ROCK PROPFRTIES.

AUTHOP- SWOLFS, H.S. ITERRA TEK, INC., SALT LAKE CITY, UTAH (USA)].

COOK, T.D. (E[.)

REFERENCE- UNDERGROUN L WASTE MANAGEMENT AND ENVIKONMFNTAL IMPLICATIONS. AM. ASSOC. FET. GEOL., TULSA, OKLA., DEC 1972, MEMOIR 18, P. 224-234.

DESCRIPTORS- CHEMICAL RFACTIONS; FREE ENERGY; GROUND SUBSIDENCE: LI CLID WASTES; MECHANICAL PROPERTIES: POKE PRESSURE; PRESSURE BUILCUP; ROCK-FLUID INTEFACTIONS: ROCK MECHANICS; ROCK PROPERTIES; SANCSTONE; UNOERGROUNO CISFCSAL; WASTE OISPOSAL: ZETA POTENTIAL.

TITLE- REQUIREMENTS FCR THE MONITORING OF INCLSTRIAL DEEP-WE LL WASTE-[ISPOSAL SYSTEMS.

AUTHOR- TALBOT, J.S. [DOW CHEMICAL CO., HCUSTCN, TEX.: (USA) l. COOK, T.O. (E[.) 


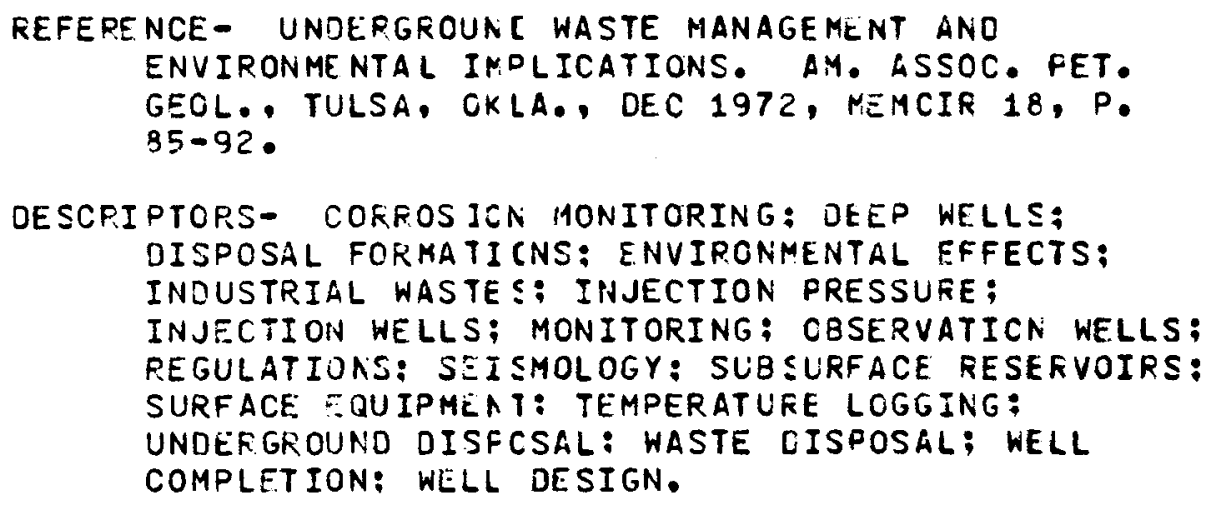

34

TWQB 72

BE INE TREATMENTISFENT FLUIC OISPOSAL

TITLE- THE OISPCSAL hELL ACT.

AUTHOR- TEXAS WATER GLALITY BOARO (USA).

REFERENCE- THE OISPCSAL WELL ACT ACENCY

PUBLICATION NUMEER 72-C1, TEXAS WATER GUALITY

BOARD, FEB $197 \mathrm{Z}, 15 \mathrm{P}$..

DESCRIPTORS- INJECTICN WELLS: LEGAL ASPECTS:

OILFIEL O BFINES: REGULATIONS: UNDERGROLNC

OISPOSAL: WASTE [ISPOSAL: WASTE WATER: WATER

QUALITY: TEXAS.

TITLE- SUBSURFACE OISFOSAL OF WASTE IN CANACA. INJECTION OF LIQUID INDUSTRIAL WASTE IA CEEP WELLS-AA PRELININARY APPRAISAL.

AUTHOR - VAN EVERDINGEN, R.O.IFREEZE, R.A. [DEPART MENT OF THE ENVIRONMENT, OTTAHA, ONTARIO (CANADA). INLANE WATERS BRANCH].

REFERENCE- SUSSURFACE DISPOSAL OF WASTE IN CANADA. INJECTION OF LIQUIO INDUSTRIAL WASTE IN OEEP WELLS--A PRELIMINARY APPRAISAL. TECHNICAL BULLETIN NC. 49, DEPT. OF THE ENVIRONMENT, INLANO WATERS BRANCH, OTTAWA (CANADA), 1971, 64 


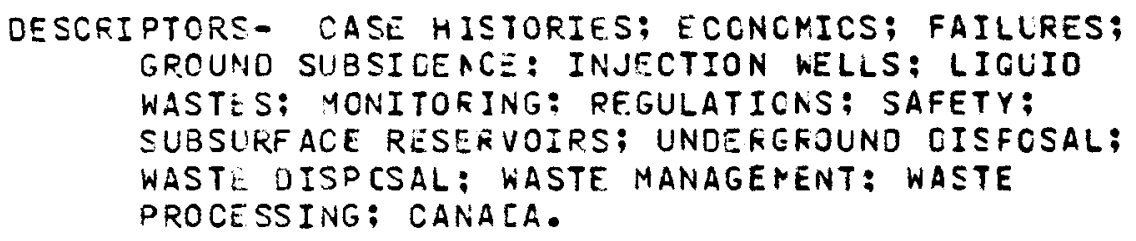

TITLE- PRELIMINARY FËSULTS OF INJECTING HIGHLY TREATED SEWAGE-FLANT EFFLUENT INTO A CEEF SAND AQUIFER AT BAY FARK. NEW YORK. DEEF-WELL ARTIF ICIEL RECHAFGE EXPEPIMENTS AT EAY FARK, LONG ISLAND, NEW YORK.

AUTHOR- VTCCHIOLI, ..;KU, H.F.H. IGEOLOGICAL SURVEY, WASHINGTON, O.C. (USA)I.

REFERENCE - PRTLIMINAFY RESULTS OF INJECTING HIGHLY TREATEE SEWAGE-FLANT EFFLUENT INTO A DEEP SANE AQUIFER GT BAY PARK. NEW YORK. DEEP-WELL ARTIFICIAL RECHARGE EXPERIMENTS AT EAY FARK, LONG ISLAND, NEA YORK. PROFESSIONAL PAFER 751-A, GTOLOGICAL SURVEY, WASHINGTON, 1972, 14

DESCRIPTORS- AQUIFERS: ARTIFICIAL RECTARGE; BACTERIA: BIOLOGICAL FOULING; CHEMICAL GNALYSIS: CHEMICAL COMPOSITION; DEEP WFLLS; DEGASIFICA IION; FILTRATION; FLOW RATE; GRAVEL PACKING: HYORAULICS: INJFCTION RATES: INJECTION WELLS; LIQUIO WASTES: MATHEMATICAL MOCELS; OBSEFVATION WELLS; PLUGGING: FRECIFITATICN: PRT-INJECTION TREATMENT: PRESSURE BUILCLF: SANOSTONE:; SUSFENOEO SOLIOS; THEORETICAL TREATMENTS; LNDERGROUND DISFCSAL; WASTE DISPCSAL: WASTE WATER: WATER CHEMISTRY: WELL COMPLETION; WELL DESIGN: NEW YORK.

TITLE- DEEP WELL INJECTION OF LIOUIO WASTE. A REVIEW OF EXISTING KNOWLEDGE ANO AN EVALUATION OF RESEARCH NEEDS. 


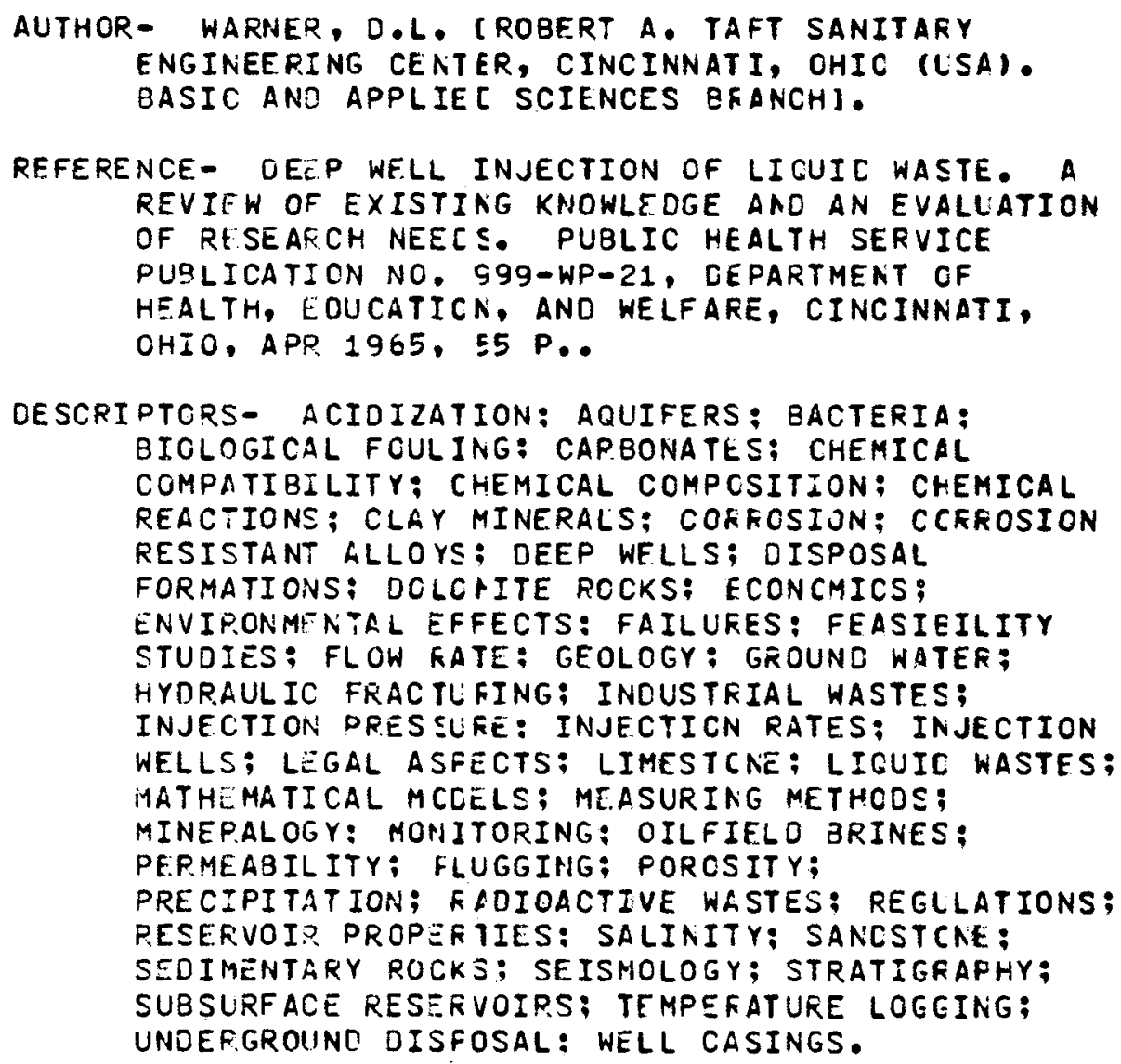

TITLE- DEEP WELLS FOF INOUSTRIAL WASTE INJECTION IN THE UNITFO STATES. SUMMARY OF OATA.

ALTHOR - WARNER, 3.L. CFEDEPAL WATER POLLUTICN CONTFOL ADMINISTRATION, CINCINNATI, OHIC (USA). WATER RESEARCH LAB.I.

REFERENCE- CËP WELLS FOK INDUSTRIAL WASTE INJECTION IN THE UNITED STATES. SUMMAFY OF DATA. WATER POLLUTION CONTFCL DESEARCH SERIES PLELICATION NO. WP-20-10, FELERAL WATER PCLLUTICN CCNTROL AOMINISTRATICN, CINCINNATI, CHIO, NOV 1967, 45 P..

CESCRIPTORS- CEEP WELLS: DISPOSAL FCRMATIONS: DOLOMITE ROCKS: EEOLOGY: INDLSTFIAL WASTES: INJECTION PRESSUFE; INJECTION RATES: INJECTION WELLS; LIMESTONË; LIQUID WASTES; SANO; SANDSTONE: UNDEFGROUND DISFOSAL: WASTE OISPCSAL; WELL CATA; USA. 
WARNER 72

BRINE TREATMENT/SFENT FLUIC CISPOSAL

\section{TITLE- SUBSURFACE INCUSTRIAL WASTERATER INJECTION IN ILLINOIS.}
AUTHOR- WARNER, D.L. COHIO RIVER VALLEY SANITATION COMMITTEE ON SUE SURFACE INOUSTRIAL WASTEWATER INJECTION (USA)I.

REFERENCE- SUSSURFACE INOUSTRIAL WASTEWATER INJECTION IN ILLINOIS. I IEQ DOCUMENT NC. 72-2, ILLINOIS INSTITUTE FOR ENVIRCAMENTAL QUALITY, CHICAGO, FEB 1972,116 P..

DESCRIPTORS- AQUIFEFS: BRINES; CHEMICAL CCMFCSITION; DEEP WELLS: OISPOSAL FORMATICAS: DCLOMITE ROCKS: ECCNOMICS: ENVIRONMENTAL PROTECTICN AGENCY; GEOLOGY; GROUND WATEF; HYORAULIC FRACTURING: HYCE CGEOLOGY; HYCFOLOGY; INOUSTRIAL WASTES: INJECTICN PRESSURE: INJECTICN RATES: INJECTI ON WELLS: LIMESTONE: MCNITORING: PERMEABILITY; PCLLUTION REGULATIONS; PCECSITY; REGULATIONS: RESERVOIF PF,OPERTIES: SALIKE AQUIFERS: SAND; SANCSTONE; SECIMENTAFY RCCKS; STRATIGRAPHY; SLESURFACE RESERVOIRS; SLFFACE EQUIPMENT; SUSFENDED SOLIDS: TEMPERATURE LOGGING; UNDERGFCUND DISPOSAL; WASTE OISFOSAL; WASTE WATER: WELL CEMENTING: WELL CHAFECTERISTICS: WELL COMPLETION; WELL CESIGN: ILLINOIS: NEW YCRK; ILLINOIS EASIN: USA.

40

\section{WILSON 71 \\ BRINE TREATMENT/SFENT FLUIC CISPOSAL}

TITLE- INUESTIGATIONS ON THE SUBSURFACE CISFOSAL OF WASTE EFFLUERTS AT INLAND SITES.

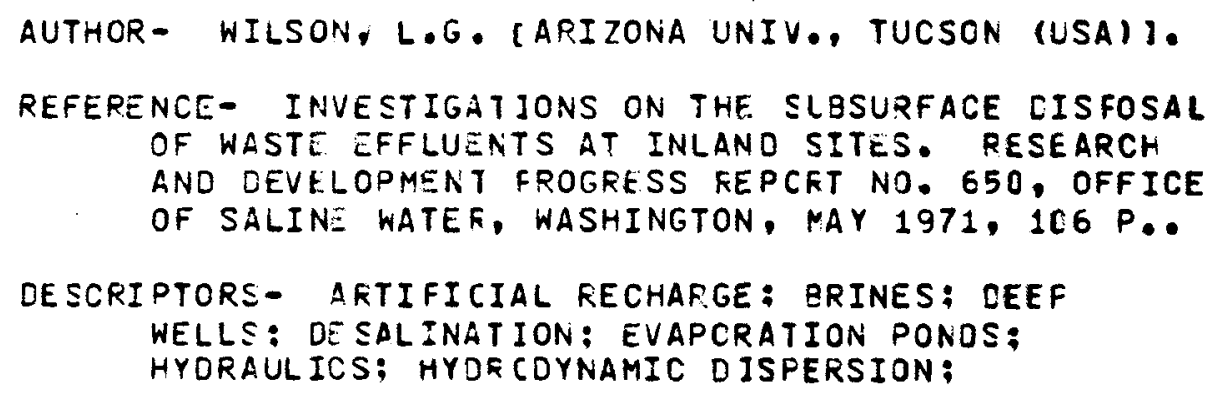


HYDRODYNAMICS: HYOROGEOLOGY; INJECTION WELLS: OBSERVATION WELLS: POROUS MECIA: UNOEREFCUND OISPOSAL: hASTE CISPOSAL; WELL CESIGN.

41

\section{WITHERSPOON 72 \\ BRINE TREATMENT/SFENT FLUIC OISPOSAL}

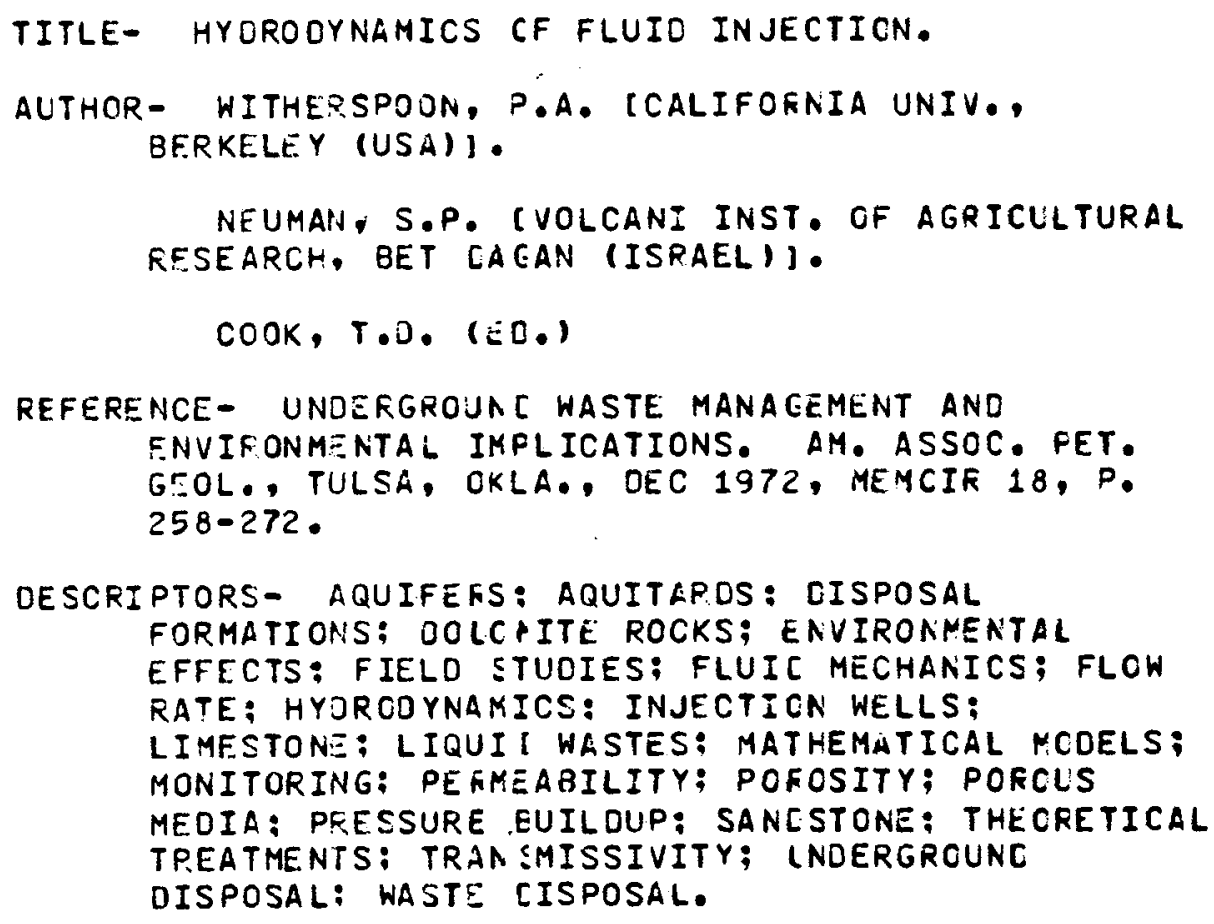

42

EROWN 73

BR INE TREATMENT/SFENT FLUID CISPCSAL

TITLE- ARTIFICIAL RECHARGE--STATE OF THE ART.

AUTHOR- BROWN, K.F. ;SIGNOR, D.C. CGEOLDGICAL SURVEY, LUBBOCK, TEX. (LSA) I.

BPAUNSTEIN, J. (EO.)

REFERENCE- UNDERGROUNC WASTE MANAGEMENT AND

ARTIFICIAL RECHARGE. AMERICAN ASSOCIATION OF PETROLEUM GECLCGISTS, TULSA, OKLA., 1973, V. 2 , P. 668-686. 
DESCRIPTORS- AGUIFERS: APTIFICIAL RECHARGE:

BACTERIA: BIOLCGICAL EFFECTS; BIOLOGICAL

FOULING: CARBONGTES: CHEMICAL REACTIONS;

CHEMICAL CCMPATIEILITY; CLAY MINERALS: CISFOSAL

FORMATIONS: ECCNCMICS: EXPERIMENTAL FESLLTS;

FEASIBILITY STUEIES: FLOW RATE; GEOLOGY; GROUND WATEP: HYOFODYAAMIC DISPEFSICN; HYDFOGECLOGY; HYORCLOGY; INJECTION WELLS; LIMESTONE;

LITHCLOGY; MEASLEING METHODS: MICROORGANISMS;

PERMEABILITY: PLUGGING: PRE-INJECTION

TREATMENT: RESERVOIR PROPEFTIES; SANOSTCNE: SUBSURFACE RESERVOIRS; SUSPENCEO SCLICS; TRACE AMOUNTS: UNDEFGFCUND DISPCSAL; WASTE DISFOSAL: WASTE STORAGE; WATER POLLUTION; WATER GLALITY; ISRAEL: USA: UNITED KINGDCM; JAMAICA; FRANCE; FLEMENTS.

43

ERIGGS68

BRINE TREATMENT/SFENT FLUIC DISPCSAL

TITLE- GEOLOGY OF SUESURFACE WASTE OISPOSAL IN MICHIGAN BASIN.

AUTHOR- 8RIGGS, L.I. JR. [MICHIGAN UNIV., ANA AREOR (USA) ].

GALLEY, J,E, (ED.)

REFERENCE- SUBSURFACË OISPOSAL IN GEOLOGIC EASINS--A STUDY OF RESERVCIR STFATA. AM. ASSOC. FET. GEOL. , TULSA, OKLA,, AUG 1968, MEMOIF 10, P. $128-153$.

DESCRIPTORS- $\triangle$ ACIOIZATION; CAFBONATES: DEEP WELLS: DISPCSAL FOR PATICNS: DOLOMITE ROCKS; EXPERIMENTAL RESULTS: GEOLOGY: HYDRAULIC FRACTURING: HYUK COYNAMICS: INJECTION PRESSURE: INJECTION FATES: INJECTION HELLS: LIMESTCNE: LIQUID WASTES; LITHOLOGY: MEASURING METHODS; MINEFALOGY; PERNEABILITY: PETROGRAPHY: POROSITY; RADIOACTIVE WASTES; RESEFVOIF PROPERT IFS; SANCSTONE; SEDIMENTARY ROCKS; SHALE: STFATIGFAFHY: SUBSURFACE RESEFVCIFS: UNDERGROUND OISFOSAL: WASTE DISPOSAL: MICHIGAN; MICHIGAN EASIN. 
TITLE- PERSPECTIVE CN THE REGULATICN CF UNDERGROUNO INJECTION OF WASTEWATERS.

AUTHOR - CLEAFY, E.J. IOHIO RIVER VALLEY WATER SANITATION COMMISSION, CINCINNATI, CHIC (USA)).

WARNEP, D.L. [MISSOURI UNIV., ROLLA (USA)].

REFERENCE- PEPSFECTIVE ON THE REGULATION OF UNDERGROUND INJECTION OF WASTEWATERS. CHIO RIVER VALLEY WATER SANITATION COMMISSION, CINCINNATI, OHIC, DEC 1969, 88 P..

DESCRIPTORS- DEEP WELLS; GEOLOGY; HYORODYNAMICS; HYOROLOGY: INJECTION WELLS: LEGAL ASPECTS; PLUGGING: RE UULA IIONS: SE ISMCLOGY: UNCERGROUNO DISPOSAL: WASTE CISPOSAL: WASTE WATER: CHIO.

TITLE- HYDRCGEOLOGIC AND ECONOMIC FACTORS IN DECISION MAKINE UNOER UNCERTAINTY FCR NORMATIVE SUSSURFACE DISPOSAL OF FLLIC KASTES, NORTHERN WILLISTCN SASIN, SASKATCHEWAN, CANADA.

AUTHOR- DLNNISON, E.G.:SIMPSON, F. ISASKATCHEWAN DEPT. OF MINERAL RESOURCES, FEGINA (CANACA)].

$$
\text { BRAUNSTEIN, J. (ED.) }
$$

REFERENCE- UNDERGROUNL WASTE MANAGEMENT ANC ARTIFICIAL RECHARGE. AMERICAN ASSOCIATION OF PETROLEUM GECLCGISTS, TULSA, OKLA., 1973, V. 2 , P. 879-927.

DESCFIPTORS- AQUIFERS: BRINES: CAREONATES: CHEMICAL COMPATIBILITY: CEEP WELLS: OISPOSAL FCFNATIONS; ECONOMICS; ENVIFCNMENTAL EFFECTS; GEOLOEY; HYORAUL ICS: HYOFOGEOLCGY; INCUSTRIAL WASTES: INJECTION PRESSLRE: INJECTICN RATES; INJECTION WELLS; LCGAL ASFECTS; LIQUIO WASTES: LITHOLOGY; MONITORING: OBSEFVATION WELLS: OILFIELC ERINES: OIL WELLS; PERNEABILITY; POROSITY; REGULATIONS; 
SALINE AQUIFERS; SANDSTONE; SEDIMENTARY ROCKS; STRATIGRAPHY; SLESURFACE RESERVOIRS: SUIFFACE EQUIPMENT; UNDEREROUND DISPOSAL; WASTE OISPOSAL: WELL CASINGS; WELL CEMENTING; WELL COMPLETION: WELL DESIGN; WELL LOGGING;

WILLISTON BASIN; CANADA.

46

ECMUNC 68

BR INE TREATMENT/SPENT FLUIC CISPOSAL

TITLE- SUBSURFACE WASIE-DISPOSAL FOTENTIAL IN SALINA BASIN OF KANSAS.

AUTHOR- ECMUND, R.W. IAUGUSTANA COLLEGE, ROCK ISLAND, ILL. (USA)].

GOEBEL, E.D. [KANSAS STATE GEOLOEICAL SURVEY, LAWRENCE, KAN. (USA) I.

GALLEY, J.E. (E.,)

REFERENCE- SUBSURFACE DISFOSAL IN GEOLOGIC EASINS--A STUDY OF RESEP.VCIR STRATA. AM. ASSCC. PET. GEOL., TULSA, OKLA., AUG 1968, MEMOIR 10, P. 154-164.

DESCRIPTORS - AQUIFERS: GEOLOGY: HYDROGEOLOEY; HYDROLOGY: LIMES 1ONE: SALINE AQUIFEKS: SANOSTONE; SALT CEPOSITS: SEOIMENTAFY FOCKS; SHALE; STFATIGFAPHY: SUBSURFACE RESERVCIRS; TRANSMISSIVITY; LNDERGROUNO OISFOSAL: WASTE DISPOSAL; KANSAS; SALINA BASIA.

47

EPA 74

BRINE TREATMENT/SFENT FLUIC OISPOSAL

TITLE- COMPILATION OF INDUSTRIAL AND MUNICIFAL

INJECTION WELLS IN THE. UNITEC STATES.

AUTHOP. - WASHINGTON, C.C. (USA), OFFICE OF WATER PROGRAM OPERAT ICNS.

REFERENCE- COMPILATICP OF INOUSTRIAL AND MUNICIPAL INJECTION WELLS IN THE UNITEC STATES. EPA-520/9-74-0 80 , ENVIRONMENTAL PROTECTION AGENCY, WASHINGTCN, D.C., OCT $1974, V, 1,23$ 
DESCRIPTORS - AQUIFERS; CARBONATES; DEEP WELLS: ENVIRONMENTAL PFCTECTION AGEACY; GECLOGY: HYOROGEOLOGY: INJECTION WELLS: LIQUIO WASTES: SAFETY; SANDST CAE; SUPFACE EGUIPMENT; WASTE

DISPOSAL: WELL CATA; WELL DESIGN; USA.

48

EALLEY 68

BRINE TREATMENT/SFENT FLUIO OISPOSAL

TITLE- ECONOMIC AND INOUSTRIAL PCTENTIAL CF GEOLOGIC EASINS AND RESEKVOIR STRATA.

AUTHOR- GALLEY, J.E. (ED.) (GEGLCGICAL CCNSULTANT, KERRVILLE, TEX. (USA) ).

REFERENCE- SUBSURFACE OISFOSAL IN GEOLOGIC EASINS--A STUOY OF RESERVCIR STRATA. IM. ASSOC. PET. GEOL., TULSA, OILA., AUG 1968 , MEMOIR 10, P. $1-10$.

DESCRIPTORS- AQUIFERS; CHEMICAL CCMPATIBILITY; DEEF WELLS: DISPOSAL FORMATIONS: ECONOMICS:

ENVIRONMENTAL EFFECTS: GEOLCEY; HYORAULIC FRACTURING; HYORCOYNAMICS: INCUSTRIAL KASTES; INJECTION WELLS: LIOUID. WASTES; OILFIELC BRINES: PLUGGINE; RAOIOACTI VE WASTES; RESEFVOIR PROPERTIES: SALT DEPOSITS: SEISMOLOGY; SHALE; STRATIGRAPHY: SLESURFACE RESERVOIRS: UNDERGROUND DISFCSAL: WASTE CISPOSAL.

GAREARINI 68
BR INE TREATMENT / SFENT FLUIC DISPOSAL

TITLE- POTENTIAL GF CENVER BASIN FOF DISPOSAL OF LIQUID WASTES.

AUTHOR- GARBARINI, G.S. [SUN OIL CC., DENVER, COLO. (USA)].

VEAL, H.K. [WOLF EXPLORATICN CO., DALLAS, TEX. (USA)I.

GALLEY, J.E. (ED.) 


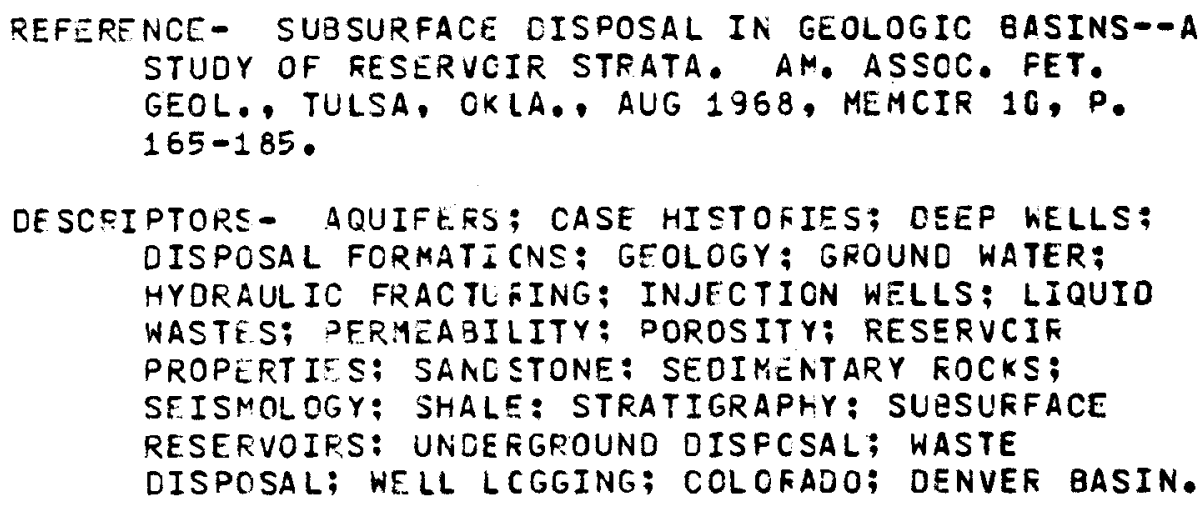

TITLE- ARTIFICIAL RECHARGE OF TREATED WASTE WATERS AND FAINFALL RUNCFF INTO DEEF SALINE AGLIFERS OF PFNINSULA CF FLORIDA.

AUTHOR - GARCIA-BENGCCHEA, J.I. ISFFCUL, C.R. IELACK, CROW AND EIDSNES S, INC., GAINESVILLE, FLA. (USA)].

VERNON, R.O.;WOOOARO, H.J. [FLORIOA STATE DEPARTMENT OF IATURAL RESOURCES, TALLAFASSEE (USA). DIV. OF INTERIOR RESOURCES).

BRAUNSTEIN, S. (ED.)

REFERENCE- UNDERGROUN L WASTE MANAGEMENT ANO ARTIFICIAL RECHARGE. AMERICAN ASSCCIATION OF PETROLEUM GEOLCGISTS, TULSA, CKLA.. 1973, V. 1, P. 5C5-525.

DESCRIPTORS- A GUICLUCES: AQUIFERS; ARTIFICIAL RECHARGE: CASE HISTORIES: CHEMICAL COMFCSITICN: DEEP WELLS: DCLCHITE ROCKS; ENVIRONMENTAL EFFECTS: GROUNC WATER; HYDROGEOLUGY; INJECTION PRESSURE: INJECTION RATES: IAJECTION WELLS; LIMESTONE: MEASLIING INSTRUMEATS: MEASURING METHODS: MONITCEING; PH VALUE; PRE-INJECTION TREATMENT: SALINE AQUIFERS: TKANSMISSIVITY: UNDERGROUND OISFCSAL: WASTE WATER: WATEK QUALITY; WELL CASINGS; WELL OATA: WELL ORILLING: WELL LCGGING: FLOFICA. 
HALL 73

BRINE TREATMENT/SPENT FLUIC DISPOSAL

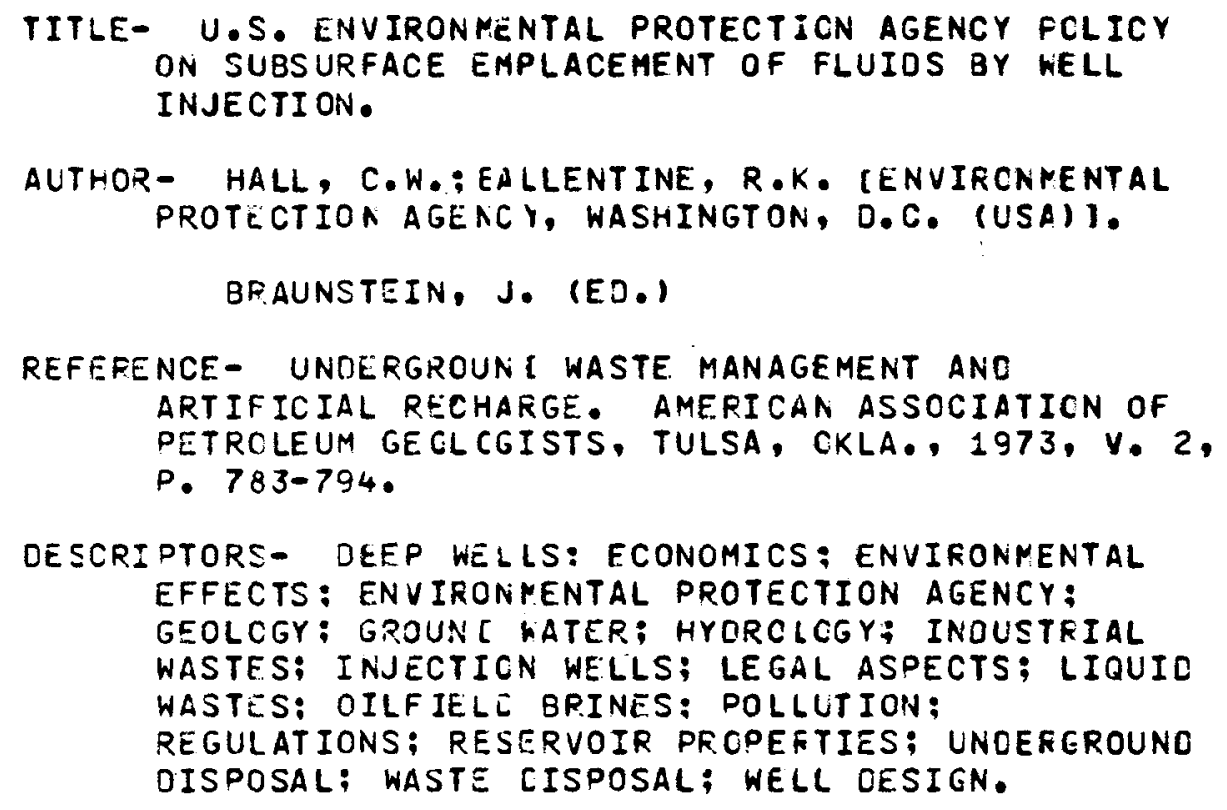

BRINE TREATMENT/SFENT FLUIC CISPOSAL

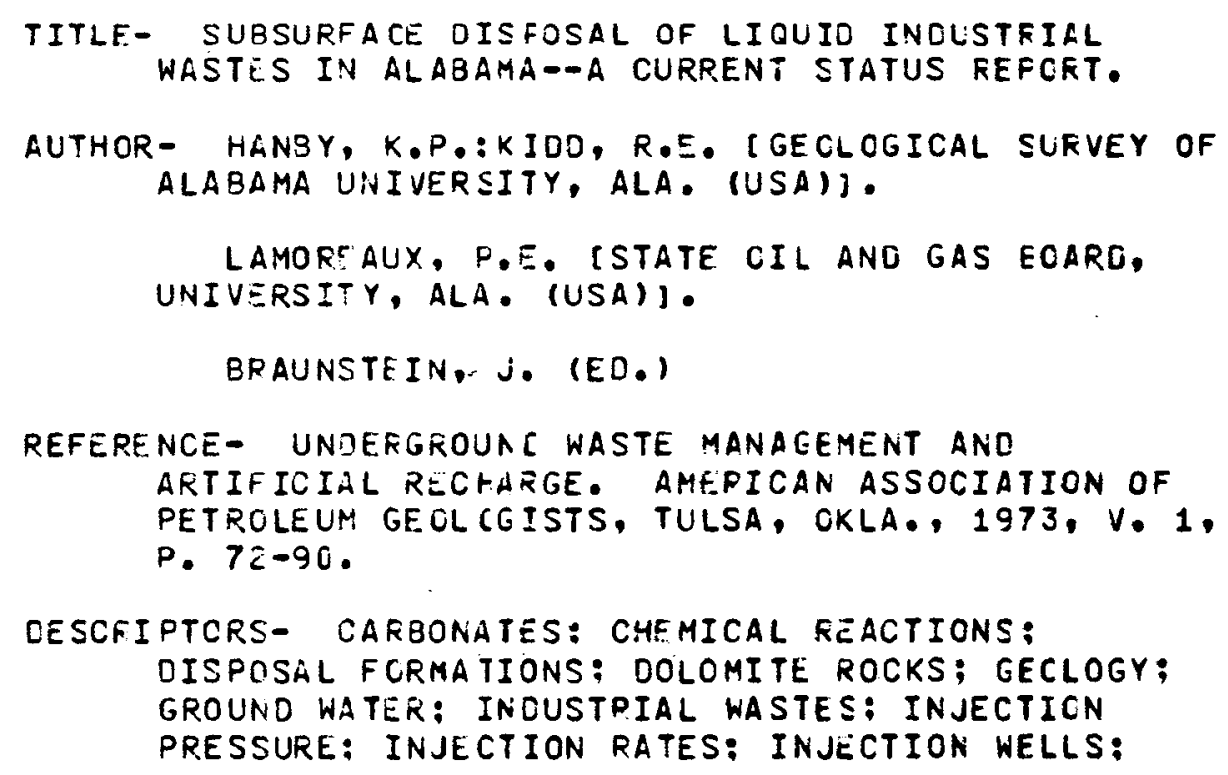


LIQUID WASTES; IITHOLOGY: MONITORING:

PERMEABILITY: PLLGGING; POROSITY; PRE-INJECTION TREATMENT: SANDS IONE: SURFACE EQUIPMENT: UNDERGROUND OISFOSAL; WASTE CISPOSAL: WELL CEMENTING; WELL COMPLETION; HELL ORILLING; ALABAMA; BLACK WARRIOR BASIN.

53

HARCAMAY 68 BR INE TREATMENT/SFENT FLUIC DISPOSAL

TITLE- POSSIBILITIES FOR SUBSURFACE WASTE DISFOSAL IN A STRUCTURAL SYNCLINE IN FENNSYLVANIA.

AUTHOR- HARDAWAY, J.E. [ISOTAPES-TELEDYNE, WESTWOOD, N.J. (USA)].

GALLEY, J.E. (ED.)

REFERENCE- SUBSURFACE DISPOSAL. IN GEOLOGIC EASINS--A STUDY OF RESERVCIR STRATA. AM. ASSOC • PET. GEOL., TULSA, OKLA., AUG 1968, MEMOIF 10, P. 93-127.

DESCRIPTORS- $\triangle$ QUUFERS: BRINES; CHEMICAL ANALYSIS: CONNATE WATER; CEEP WELLS: GEOLOGY: HYGFAULIC FRACTURING: HYDFCOYNAMICS: HYOROLOGY: INJECTION WELLS; LIQUI C WASTES: LITHOLCGY: POROSITY: SALINE AOUIFERS: SANOSTONE: SHALE: STRATIGRAPHY : SLESURFACE RESERVOIRS : UNDEFGROUND DISFCSAL: WASTE CISPOSAL: WELL LOGGING: PENNSYLVANIA.

54

HEIDARI 74 BRINE TREATMENT/SFENT FLUIC OISPOSAL

TITLF- ANALYSIS OF LIQUID-WASTE INJECTION WELLS IN ILLINOIS EY MATHEMATICAL MOOELS.

AUTHOR - HEIDARI, M. :CARTWRIGHT, K. CILLINCIS STATE GEOLOGICAL SURVEY (USA) I.

SAYLOR, P.E. (ILLINOIS UNIV., URBANA (USA). DEPT. OF COMPUTEF SCIENCEJ.

REFERENCF- ANALYSIS GF LIQUID-WASTE INJECTICN WELLS IN ILLINOIS 3Y MATHEMATICAL MCDELS. WRC RESEARCH REPORT NO. 77, ILLINCIS UNIV,, NATER RESOURCES CENTEF, URBANA, JAA 1974,114 P.. 


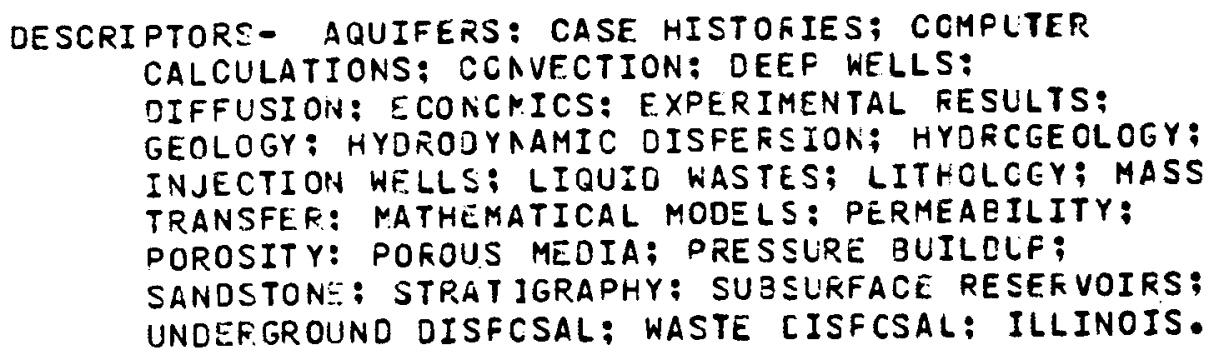

55

HICALGO 73

BR INE TREATMENT/SFENT FLUIC CISPOSAL

TITLE- EOP AS AN AIC FOR OECISION MAKING IN SUBSURFACE INJECTION OF LIQUIO WASTES.

AUTHOR - HIDALGO, R.V.;WOODFORK, L.D. (WEST VIRGINIA GEOLOGICAL SURVEY, MORGANTOWA (USA)].

BRAUNSTEIN, J. (ED.)

REFERENCE - UNOERGROUNC WASTE MANAGEMENT AND

ARTIFICIAL RECHARGE. AMERICAN ASSOCIATICN OF PETROLEUM GECLCEISTS, TULLSA, CKLA, 1973, V. 1 , P. 133-146.

DESCRIPTORS- CCMPUTER CALCULATIONS: OISPOSAL FORMATIONS: ECONOMICS: FEASIBILITY STUCIES; GEOLOGY: GROUND WATER; HYDRAULIC FRACTLEING; INDUSTRIAL WASTES: INJECTION WELLS: LIGLID WASTES: SUBSURFACF RESERVOIRS; UNDERGROLND DISPOSAL; WASTE CISPOSAL; WELL DATA; WELL LOGGING: WEST VIFGINIA.

56

BR INE TREATMENT/SPENT FLUIC OISPOSAL

TITLE- APPLICATION CF HYPERFILTRATION TO TREATMENT OF MUNICIPAL SEMAGE EFFLUENTS.

AUTHOR- KRAUS, K.A. IOAK RIDGE NATIONAL LAE., TENN. (USA) ].

REFERENCE - APPLICATICN OF HYPERFILTRATION TC TREATMENT OF MUNICIPAL SEWAGE EFFLUENTS. WATER POLLUTION CONTRCL RESFARCH SERIES ORO-17030EOH O1/70. FEDERAL WATER QUALITY ADMINISTRATION, WASHINGTON, D.C.. JAN 1970,71 P.. 
DESCRIPTORS- AODITIVES: POLLUTICN; REVERSE CSMOSIS: WASTE PROCESSINE; WASTE WATEF. TOPEKA (USA) l.

BEAUNSTEIN, J. (EO.)

REFERENCE- UNDEFGR̈OUNL WASTE MANAGEMENT AND ARTIFICIOL RECHARGE. AMERICAN ASSOCIATION OF PETRCLEUM GECLCEISTS, TULSA, CKLA., 1973, V. 1 , P. $622-633$.

DESCRIPTORS- ACIOIZATION: APEAL EXTENT: BRINES: CHEMICAL COMPATIBILITY: CORFCSION: CORROSION IHHIBITORS: DEEF WELLS: DISFCSAL FCKMATIONS: DOLOMITE ROCKS: FAILUFES; GFCUNO WATER; INDUSTRIAL WASTES: INJECTION FRESSURE; INJECTION WELLS: LEGAL ASPECTS: LIMESTCNE; LIQUID WASTES; LITHOLOGY; OILFIELO BRINES: PERMEABILITY: PLUGGING: POLLUTION: POLLLTION LAWS: PORCSITY; PRECIPITATICN: PRE-INJECTION TREATMENT; REGULATIONS; SALT DEPOSITS: SANDSTONE: SUE.FACE WATERS: UNCERGROUNC DISPCSAL; WASTE CISPOSAL; WELL COMPLETICN; WELL DESIGN; WELL LOGGING; WELL OFERATION: KANSAS.

TITLE- HAZARDS OF WASTE DISPOSAL IN GROUNCWATER BASINS.

AUTHOR - LOFGREN, B.E. [GEOLOGICAL SURVEY, SACRAMENTO, CALIF. (USA)I.

BRAUNSTEIN, J. (ED.)

REFERENCE- UNDERGROUN C WASTE MANAGEMENT AND

ARTIFICIAL RECHARGE. AMERI CAN ASSOCIATICN OF PETROLEUM GECLCGISTS, TULSA, OKLA., 1973, V. 2 , P. 715-728. 
DESCRIPTORS- AQUIFEFS: AQUITAROS: ENVIRONKENTAL EFFECTS: EXPERIMENTAL RESULTS: FAILURES: GROUNC SUBSIDENCE: GROUND WATER: HYERAULICS; HYDROGEOLOGY; INJECTION WELLS; MEASURING INSTRUMENTS: MCNITORING: SOIL MECHANICS: UNDERGROUND OISFOSAL: WASTE OISPOSAL; hATER POLLUTION: CALIFCRNIA.

\author{
59 \\ MC CANN 68 \\ BR INE TREATMENT/SFENT FLUIC DISPOSAL
}

TITLE- POSSIBILITIES FOR DISPOSAL OF INDUSTRIAL WASTES IN SUESURFACE ROCKS ON NORTH FLAAK OF APPALACHIAN BASIA IN NEW YOKK.

AUTHOR- MC CANN, T.P. [SHELL CANACIAN EXPLORATION

CO.. HOUSTON, TEX. (USA)].

PRIVRASKY, N.C. (TIDEWATEF CIL CC., PITTSBURGH, PA. (USA)].

STEAD, F.L. (CONSULTING GEOLOGIST, MAGNOLIA, ARKKANSAS (USA)].

HILSON, J.E. (CONSOLIDATED GAS SUFPLY

CORPORATION, C.LAFKSBURG, W. VA. (USA)].

GALLEY, J.E. (ED.)

REFERENCE- SUBSURFACE OISPOSAL IN GECLOGIC EASINS--A STUDY OF RESER VCIR STRATA. GM. ASSCC. FET. GEOL., TULSA, OKLA.. AUG 1968, MEMCIR 10, P. $43-92$.

OESCRIPTORE- CHEMICAL COMPOSITION: CEEP WELLS; OISPDSAL FORYATICNS: DOLOMITE FOCKS; EARTHQUAKES: FEASIBILITY STULIES; GEOLCEY; HYORAULIC FRACTLIING: HYOROOYNAMICS: INCLSTRIAL WASTES; INJECTICN WELLS: LIMESTCNE; LICLIO WASTES: PERMEABILITY: PH VALLE: PORCSITY; RESERVOIR PR.CPEFTIES: SALT CEPOSITS: SANCSTONE: SEDIMENTARY ROCKS; SEISMOLOGY; SHALE; STRATIGKAFHY; SL ESURFACE RESERVCIRS; WELL DATA; NEW YORK: APPALACHIAN BASIN.

60

MEERS 73

GR INE TREATMENT/SPENT FLUIL OISPCSAL

TITLE- OFSIGN, DFILLING ANO COMPLETICN, CPERATICN, AND COST OF UNCERGROUNO WASTE-CISPOSAL hELLS IN GULF COAST REGICA OF TEXAS AND LCUISIANA. 


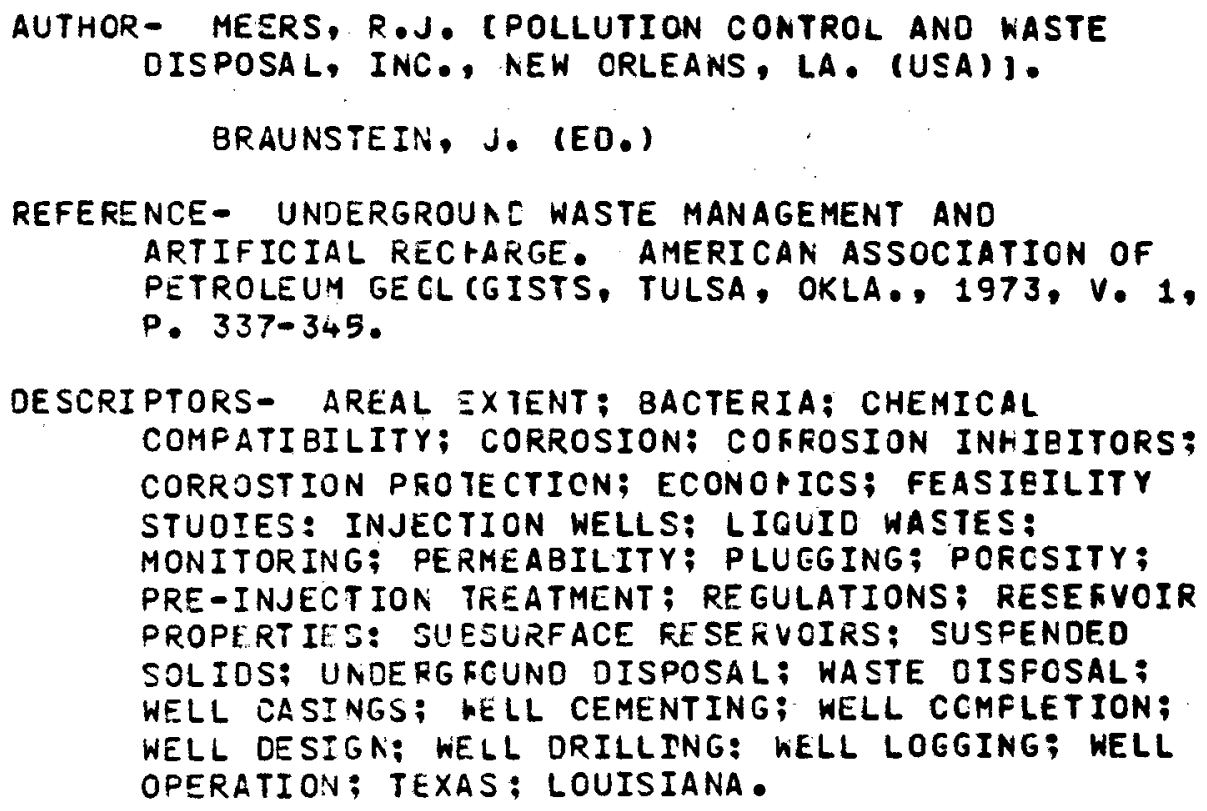

DESCRIPTORS- BRINE TFEATMENT; DEEP WELLS: ECONOMICS: FEASIBILITY STUCJES; INOUSTFIAL WASTES; INJECTION WELLS: LIQUIO WASTES: MATHEMATICAL MODELS: PEGULAIICNS: UNDERGRCUND OISPOSAL: WASTE OISPCSAL; WASTE MANAGENENT. 


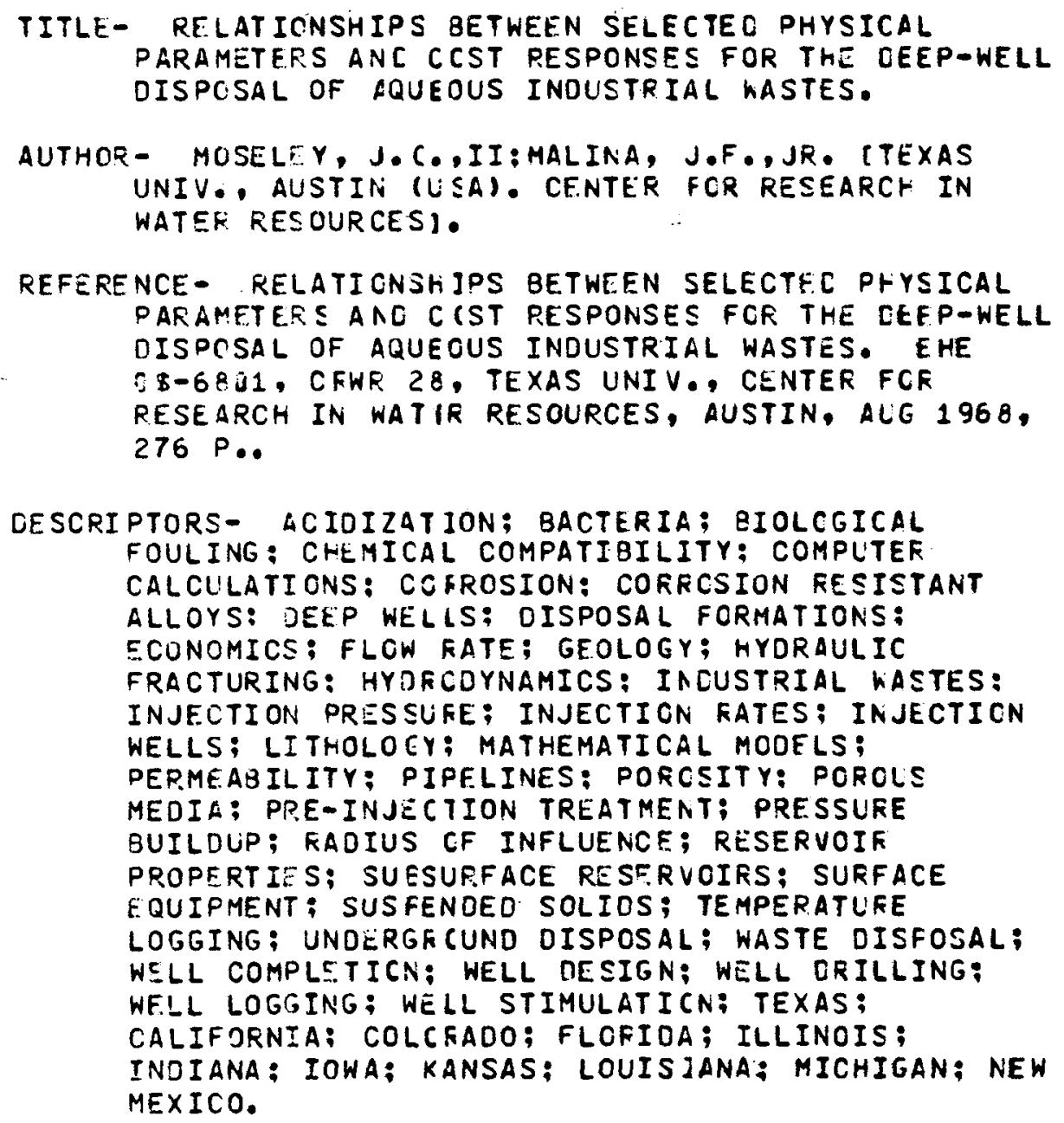

DESCRIPTORS- $\quad$ CIOIZATION; BACTERIA; BIOLCGICAL FOULING: CHEMICAL COMPATIBILITY; COMPLTER CALCULATIONS: CORROSION: CORRCSION RESISTANT ALLOYS: DEEP WELLS: OISPOSAL FORMATIONS: ECONOMICS: FLOW RATE; GEOLOGY; HYDRAULIC FRACTURING: HYOFCDYNAMICS: IACUSTRIAL KASTES: INJECTION PRES SURE; INJECTION RATES; INJECTICN WELLS; LITHOLOEY; MATHEMATICAL MOOELS; PERMEABILITY; PIFELINES: PORCSITY: POROLS MEDIA: PPE-INJECIION TREATMENT; PRESSURE BUILDLP; FAOIUS CF INFLUENCE; RESERVOIF PROPERTIES; SUESURFACE RESFRVOIRS: SURFACE EQUIPMENT; SUSFENOEO SOLIOS; TEMPERATUFE LOGGING: UNDERGF CUND OISPOSAL; WASTE DISFOSAL; WELL COMPLETICN; WELL OESIGN; WELL ORILLING: WE.LL LOGGING: WELL STIMULATICN: TEXAS; CALIFORNIA: COLCFADO; FLOFIOA; ILLINOIS: INDIANA: IOWA; KANSAS; LOUISIANA: MICHIGAN; NEW MEXICO.

TITLE- SEOIMENTARY HISTORY AND ECCNOMIC GEOLCGY OF SAN JUAN BASIN, NEW MEXICO ATI COLORACO.

AUTHOR- PETERSON, J.A. [MONTANA UNIV., MISSCLLA (USA) ).

LOLEIT. A.J.: ULLRICH, R.A. LEL FASC NATURAL GAS CO.. FARMINGTON, N. MEX. (USA) J.

SPENCER, C.W. [TEXACO, INC.].

GALLEY, J.E. (EO.) 


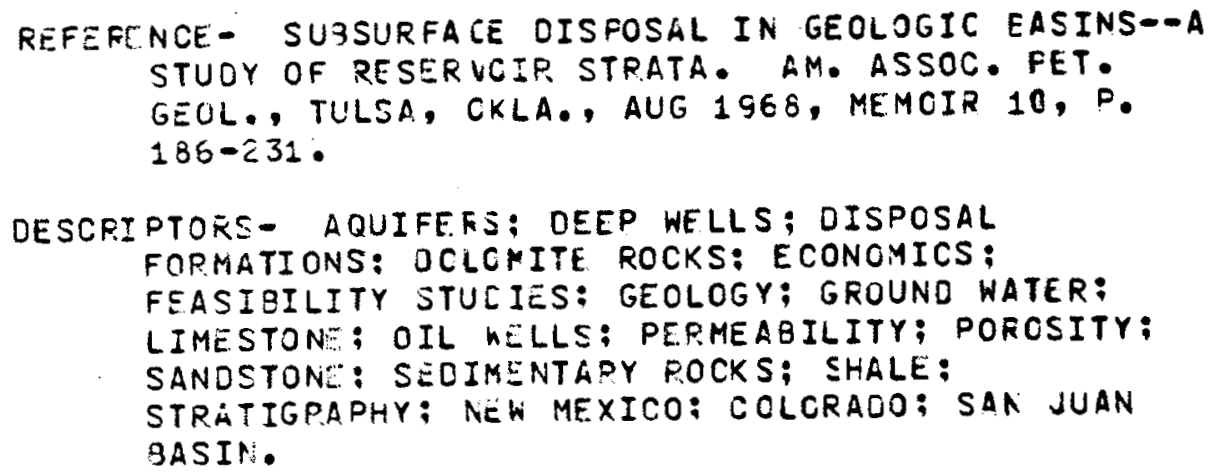

SCHICHT 73

GR INE TREATMENT/SPENT FLUIC DISPOSAL

TITLE- DEEP-WELL INJECTION OF DESALTING-PLANT WASTE
BRINE.

AUTHOR- SCHICHT, R.J. [ILLINOIS STATE WATEF SLRVEY, UPBANA (USA)I.

ERAUNSTEIN, J. (ED.)

REFERENCE - UNDEFGROUNL WASTE MANAGEMENT ANC ARTIFICIAL RECHAFGE. AMERICAN ASSOCIATION OF PETROLEUM GEOLCGISTS, TULSA, CKLA, , 1973, V. 1 , P. 652-663.

DESCRIPTORS- $A Q U I F E R S:$ BRINE TREATMENT: BRINES: CHEMICAL ANALYSIS; DEEP WELLS: DESALINATION; ECONOMICS; ELECTFODIALYSIS: ENVIRONMENTAL EFFECTS; FEASIBILITY STUDIES; GFOUNO WATER: HYDRAULICS: HYOFCLOGY: INJECTION PRESSUFE: INJECTION RATES: INJECTION WELLS; LIQUID WASTES: MATHEMATICAL MODELS: PRESSURE ELILDUF; PEVERSE OSMOSIS; SANDSTONE: STRATIGRAPHY: TRANSMISSIVITY: UNOERGRQUND OISPOSAL: WASTE OISPOSAL: WATER QUALITY: WELL CASINGS; WELL DESIGN: ILLINOIS.

65

VAN EVERCINGEN 68

BR INE TREATMENT/SFENT FLUIO DISPOSAL

TITLE- FLUID MECHANICS OF DEEP-HELL DISFCSALS. 


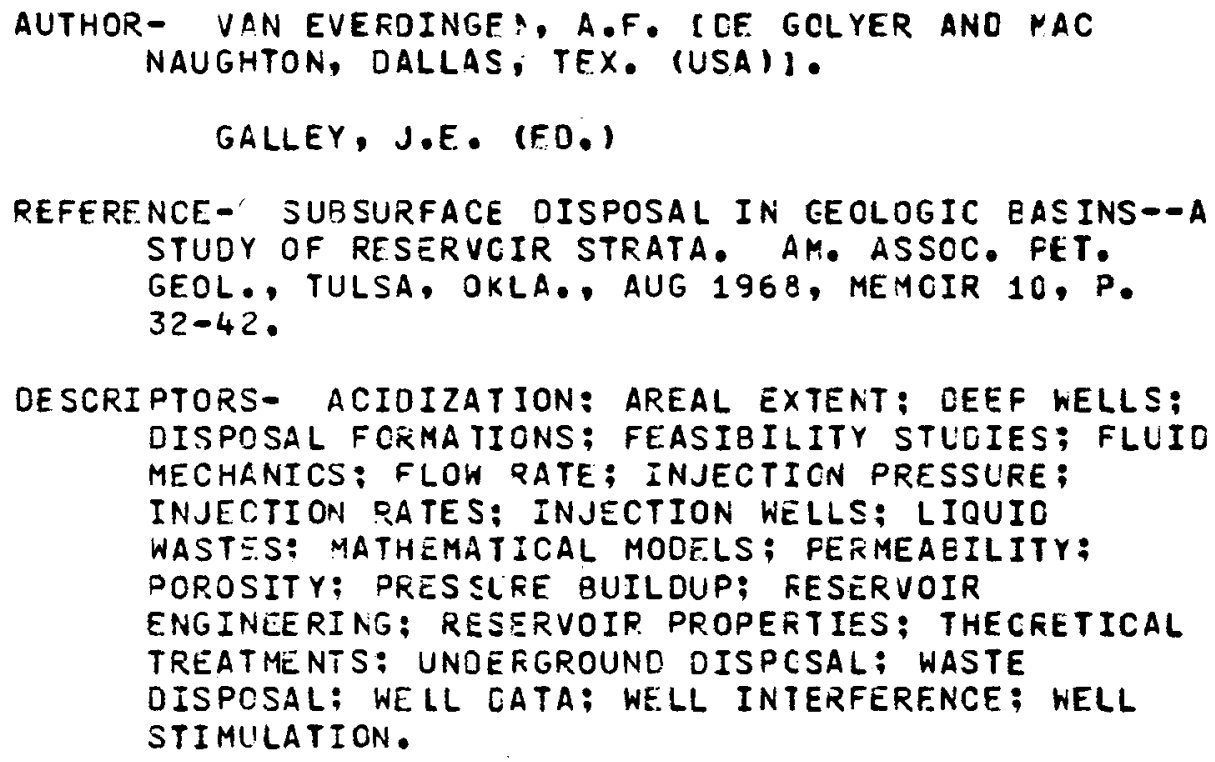

66

WALKER 73

ER INE TREATMENT/SFENT FLUIC CISPCSAL

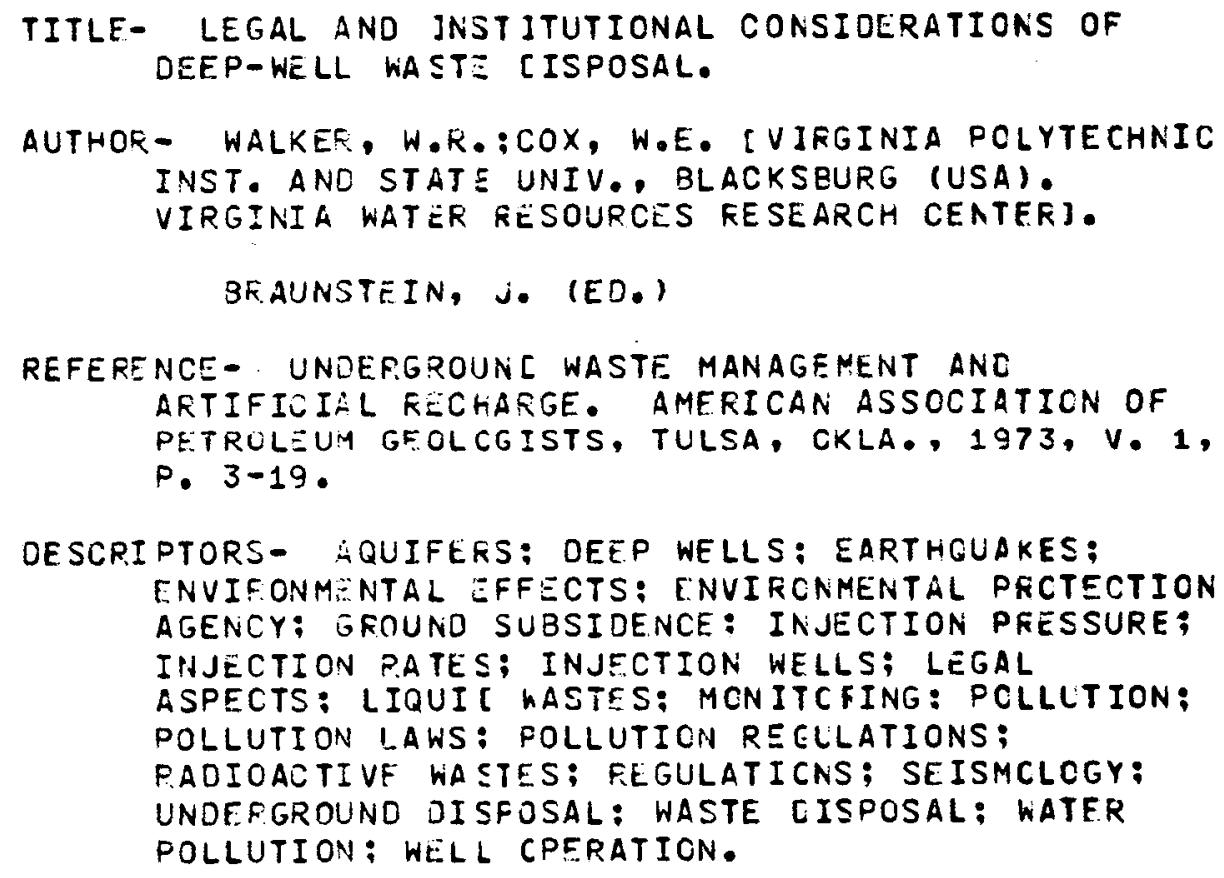




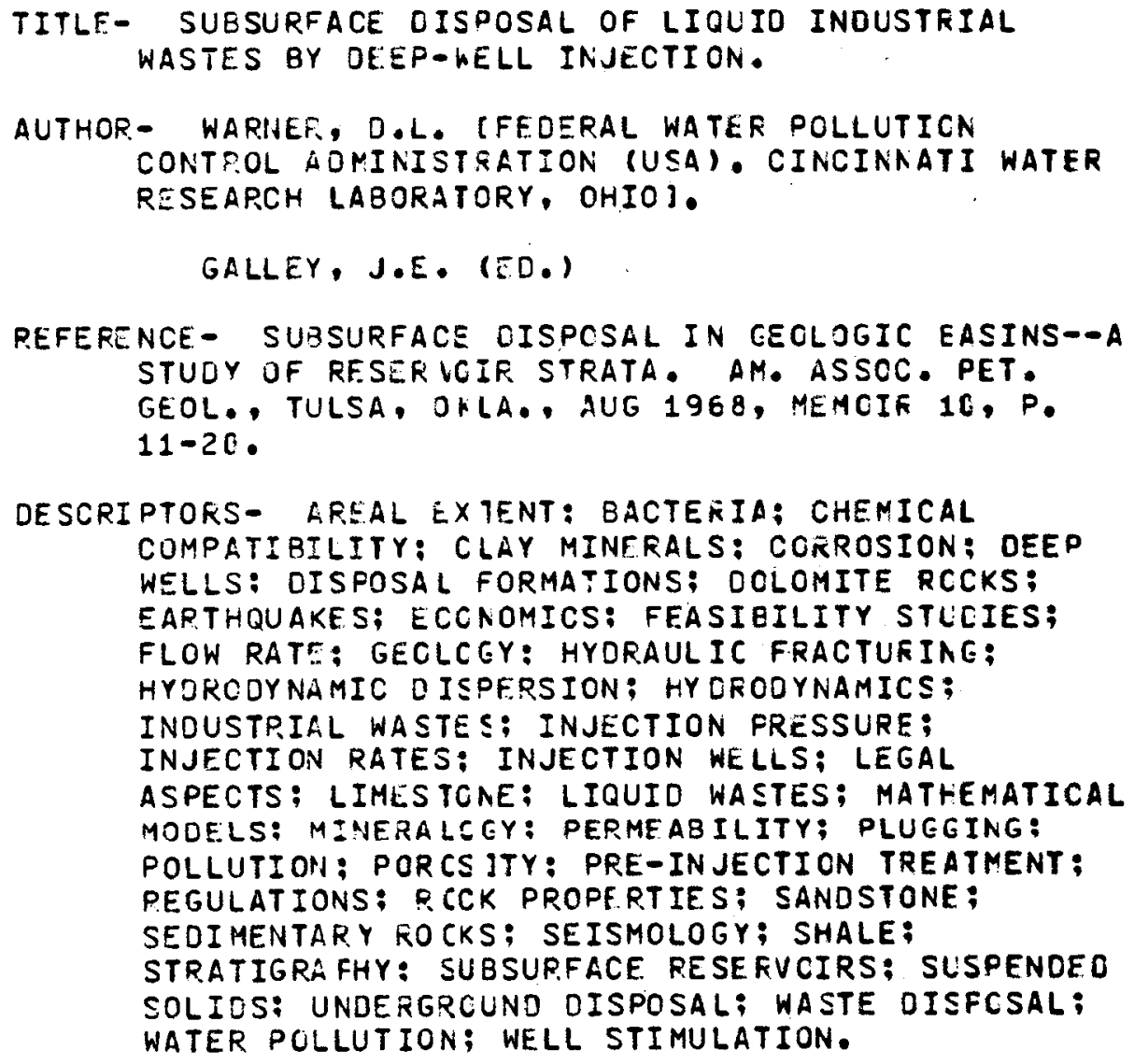

68

TITLE- INDUSTFIAL WASIEWATER-INJECTION WELLS IN UNITED STATES--STATUS OF USE AND REGULATION, 1973.

AUTHOR- WARNER, D.L. [MISSOURI UNIV., ROLLA (USA)]. (USA)].

OFCUTT, D.H. [WAPORA, INC., WASHINGTCN, D.C.

$$
\text { BRAUNSTEIN, J. (ED.) }
$$

REFERENCE- UNOERGROUNC WASTE MANAGEMENT AND ARTIFICIAL RECHAFGE. AMERICAN ASSOCIATION OF PETROLEUM GE CLUGISTS, TULSA, OKLA., 1973, V. 2 , P. 687-697. 
DESCRIPTORS - CHEMICAL COMPATIBILITY; DEEF WELLS; DOLOMITE ROCKS: EARTHQUAKES: ENVIRONMENTAL EFFECTS; FAILUFES; GROUND WATER; HYOROLCGY; INDUSTRIAL WASTE S; INJECTION PRESSURE: INJECTION RATES; INJECTION WELLS; LEGAL ASPECTS: LIMESTCNE: LIQUID HASTES: OILFIELD BRINES: POLLUTICN LAWS; POLLUTION REGULATIONS; REGULATIONS; SALINE AQUIFERS: SAND; SANCSTONE; UNDERGROUND DISFCSAL: WASTE [ISFOSAL; WATER POLLUTION: USA.

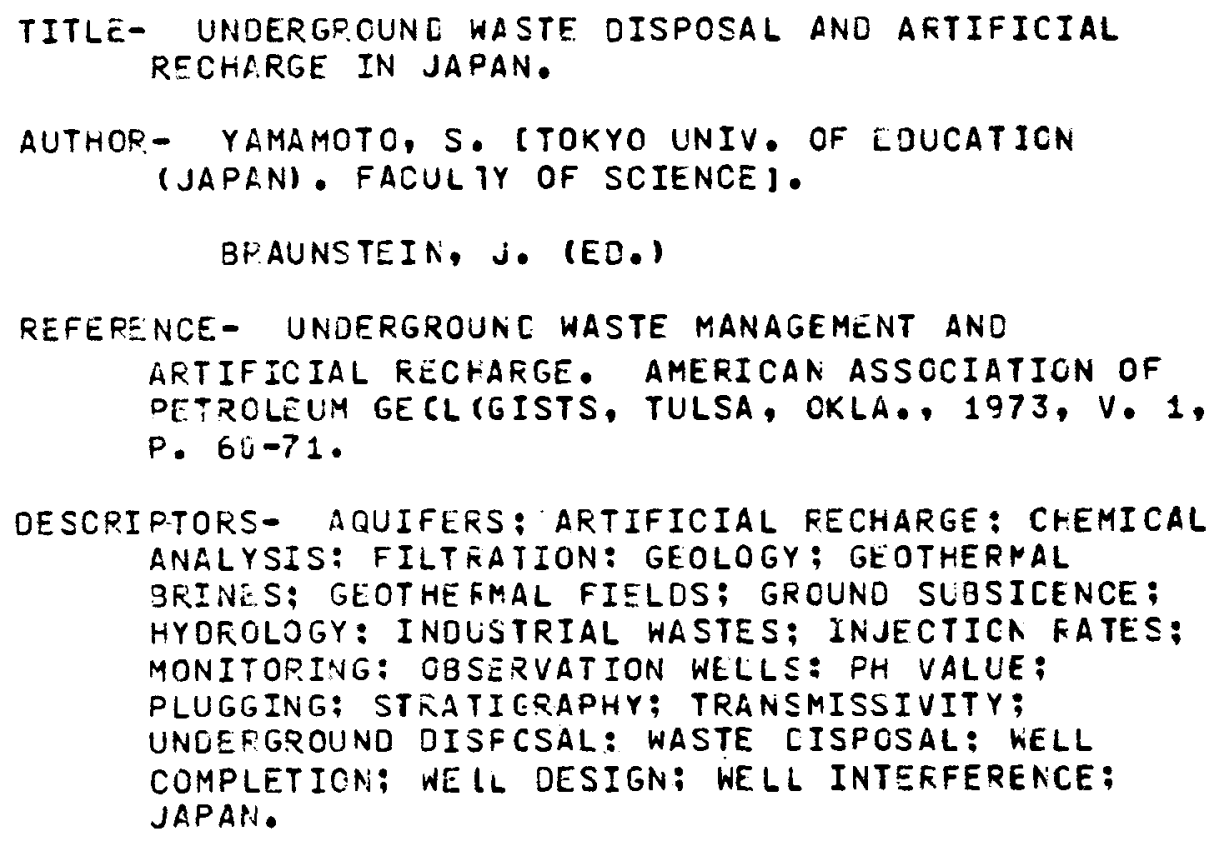

BR INE TREATMENT/SFENT FLUIC OISPCSAL

TITLE- SUBSURFACE. SALT-WATER DISFOSAL. ROCK 3 OF THE VOCATIGNAL TFAINING SERIES.

AUTHOR- AMERICAN PETF CLEUM INSTITUTE, OALLAS, TEXAS.

REFERENCR - SUBSURFACE SALT-WATER OISFOSAL. EOOK 3

OF THE VOCATIONAL TRAINING SERIES. AMERICAN 


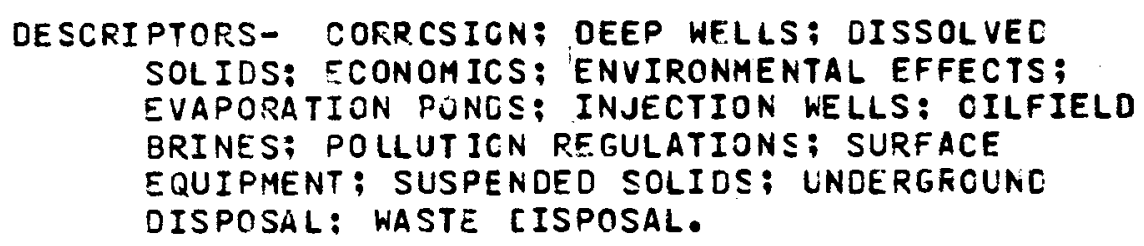

BR INE TREATMENT / SPENT FLC

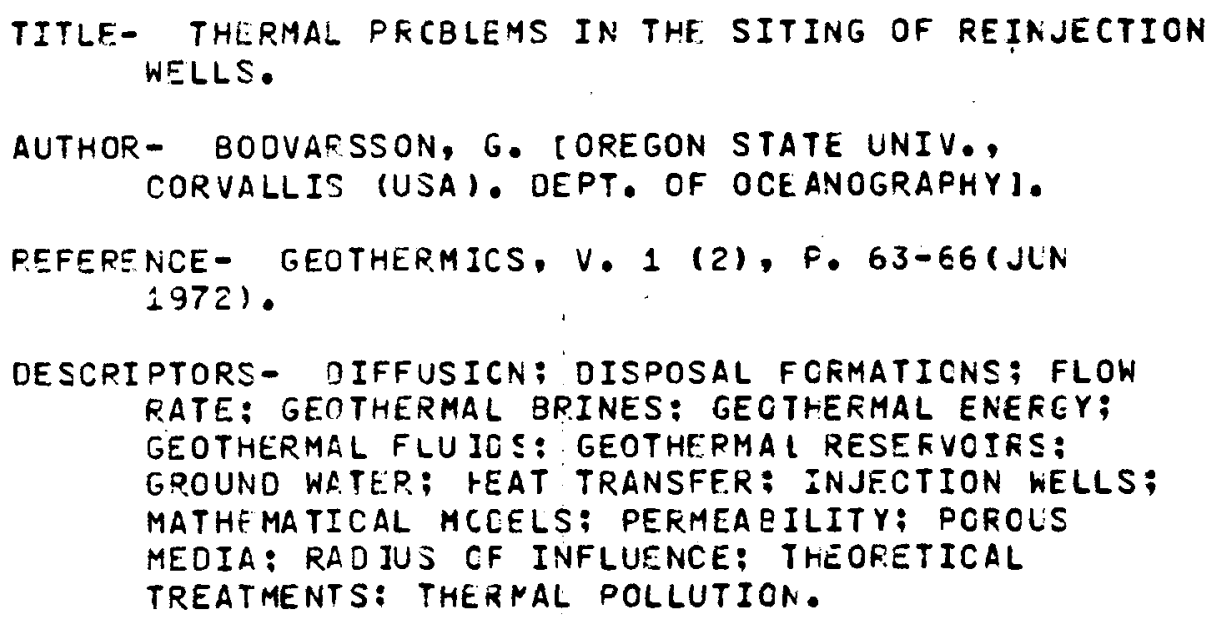

74

TITLE- A PEINJECTION EXPERIMENT IN THE VICO 1 WELL.

AUTHOR- CALAMAI, A.;CERON, P.:FERKARA, G.:MANETTI, G. IENEL, DIREZIONE STUDI E RICERCHE, FISA

(ITALY). CENTKC LI RFCER.CA GEOTERMICA).

REFERENCE- GEOTHERMICS, V. $2(3-4), P$. 117-118 (SEP-OEC 1973).

DESCRIPTOFS- AQUIFERS: CARBONATES: CHEMICAL ANALYSIS: DISPOSAL FCRMATIONS: OISSCLVEC SOLIOS: ENVIROAMENTAL EFFECTS; EXPERIMENTAL P.ESULTS: FLOW TATE: GEOTHERMAL ERINES: GEOTHEFMAL FLUICS: GEOTHEFMAL RESERVCIRS; HYDROGE.OLOGY; IA EECTION PRESSLRE; INJECTION WELLS; LITHOLOGY: PERMEABILITY: POROSITY: 
SEISMOLOGY: TEPPERATURE LOGEING: THERMAL EFFLUENTS; UNDERGROUND DISFOSAL; WASTE OISPOSAL: ITALY.

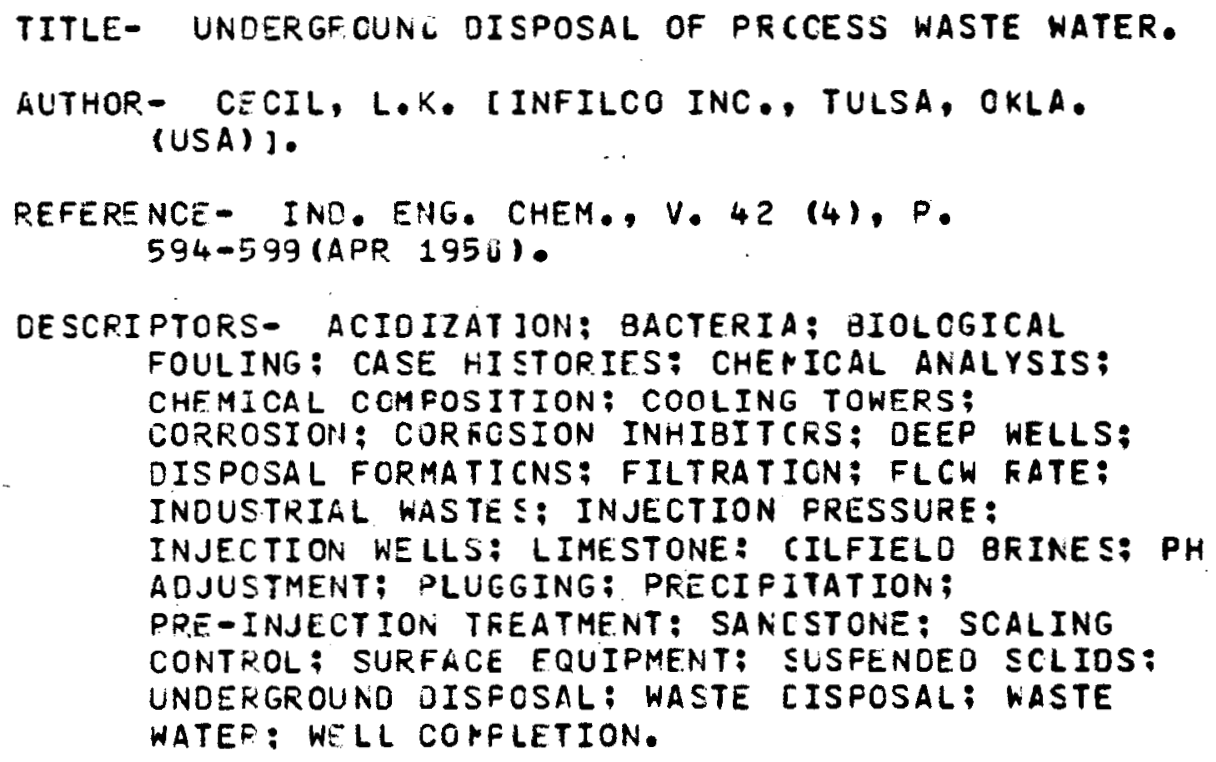

TITLE- GEOTHEPMAL STEAM CONOENSATE REINJECTION.

AUTHOR- CHASTEEN, A.J. [UNION CIL CO., SANTA ROSA, CALIF. (USA)].

REFERENCE - PROCEECINGS- CONFERENCE ON RESEARCH FOR THE- CEVELOFMENT OF GEOTHERMAI ENERGY RESCURCES. JET PROPULSION LAB. /CALIF. INST. OF TECH.. PASAUENA, CALIF., DEC 1974, P. 340-344.

DESCRIPTORS - CASE HISTORIES: CCCLIRG TOWERS; CORROSION; DEEP WELLS: OISFOSAL FORMATICNS; FLOW RATE: GEO IHERMAL BRINES: GEOTHEXTMAL RESEFVOIRS: INJECTION PRESSUFE; INJECTICN WELLS; MONITCEING; PERMEABILITY; PIPELINES; PLUGGING: SEISMCLOGY: SUBSURFACE RESERVCIRS: 
SURFACE EQUIPMEAT: UNDERGROUNC OISFOSAL: WASTE OISPOSAL: WASTE WATER; WELL DESIGN; GEYSERS GEOTHERMAL FIELC: IMPERIAL VALLEY: VALLES CALOERA GEOTHERMAL FIELD: CALIFOFNIA; NEW

77

COLLINS 70

GRINE TREATMENT/SFENT FLUIC CISPOSAL

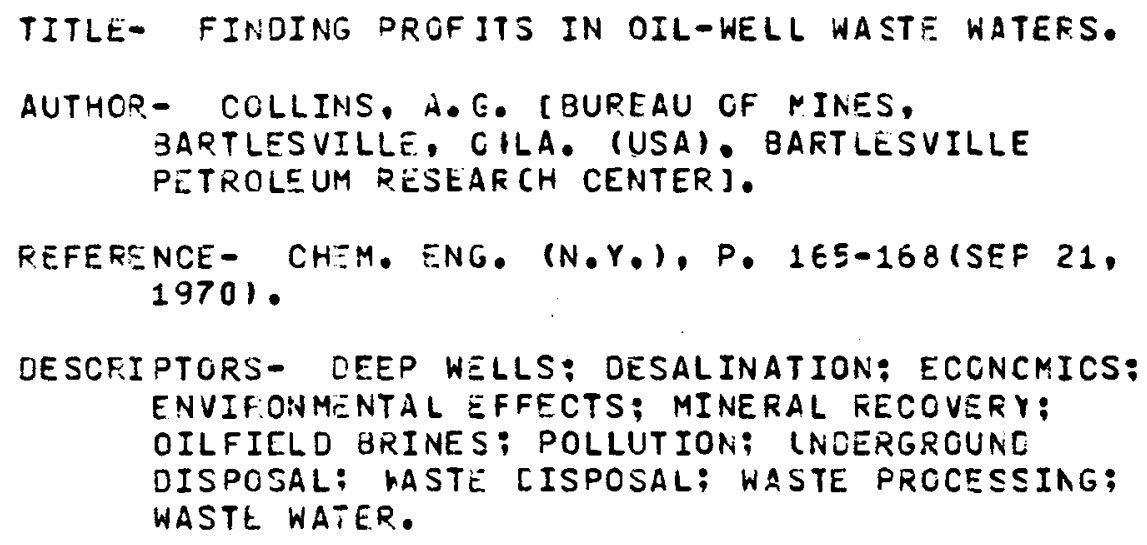

COLLINS 74

BR INE TFEATMENT/SFENT FLUIC CISPCSAL

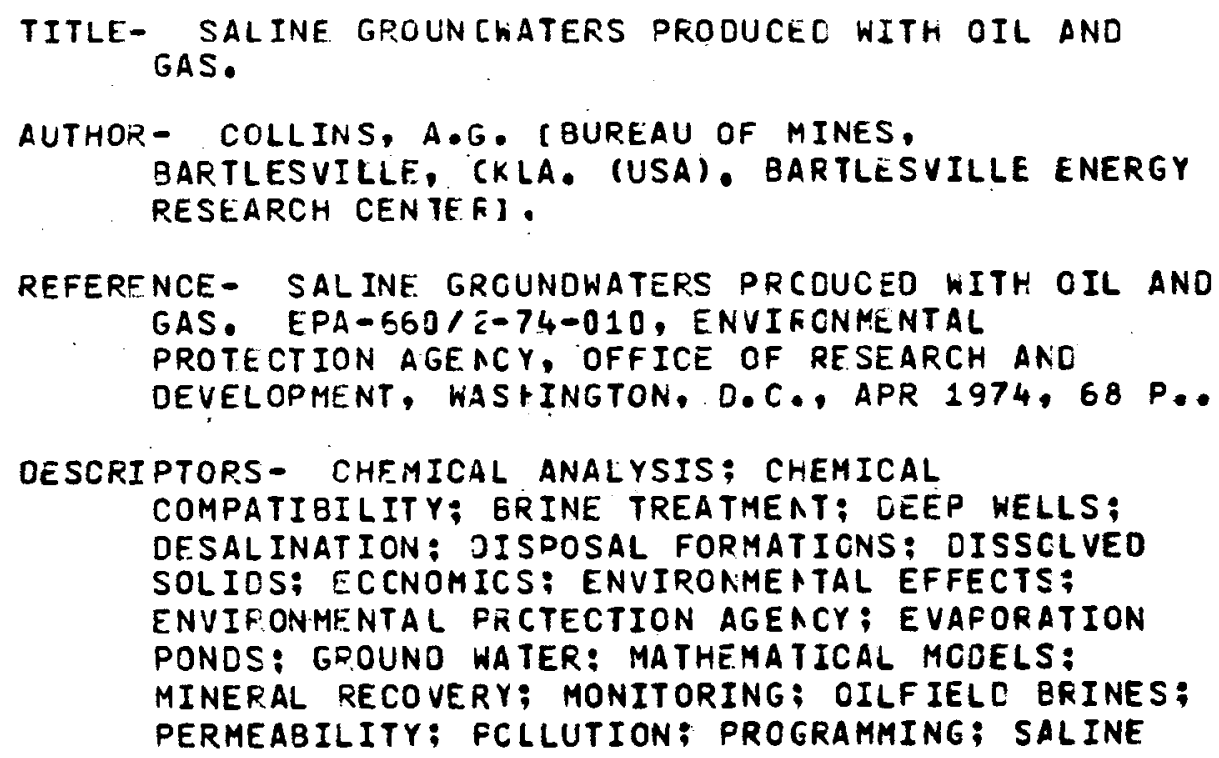


AQUIFERS: SALINITY: SALINITY MAPS: SCALING CONTFOL: SEOIMEATARY ROCKS; LNOERGRCLNC DISPOSAL: WATER ANALYSIS; WELL DESIGN; TEXAS; ANADAKRO BASIN: WILLISTON BASIN: USA.

$8 \mathrm{C}$

GARG 75

GRINE TREATMENT/SFENT FLUIC CISPOSAL

TITLE- SIMULATION OF FLUID-ROCK INTERACTIONS IN A GEOTHERMAL BASIA.

AUTHOR - GARG, S.K.;BLAKE, T.K.;BROWNELL, O.H., JR.: NAYFEH, A.H.:PRITCHETT, J.W. [SYSTEMS, SCIENCE AND SOFTWARE, LA JOLLA, CALIF. (USA)].

REFERENCE- SIMULATION OF FLUID-ROCK INTERACTICNS IN A GEOTHERMAL BASIN. SSS-R-76-2734, SYSTEMS, SCIENCE AND SOFTWARE, LA JOLLA, CALIF, (USA), SEP 1975,63 P..

DESCRIPTORS - COMPUTER CALCULATIONS; CONVECTION; GEOTHERMAL RESERVOIRS: GROUNC SUBSIOENCE; HEAT TRANSFER: HEAT TFANSFER COEFFICIENT: HYOROOYNAMIC OISPERSION; MATHEMATICAL MCOELS; PERMEABILITY; PCFOSITY; POROUS MEOIA; ROCK-FLUIC INTERACTIONS: THECRETICAL TREATMENTS• 


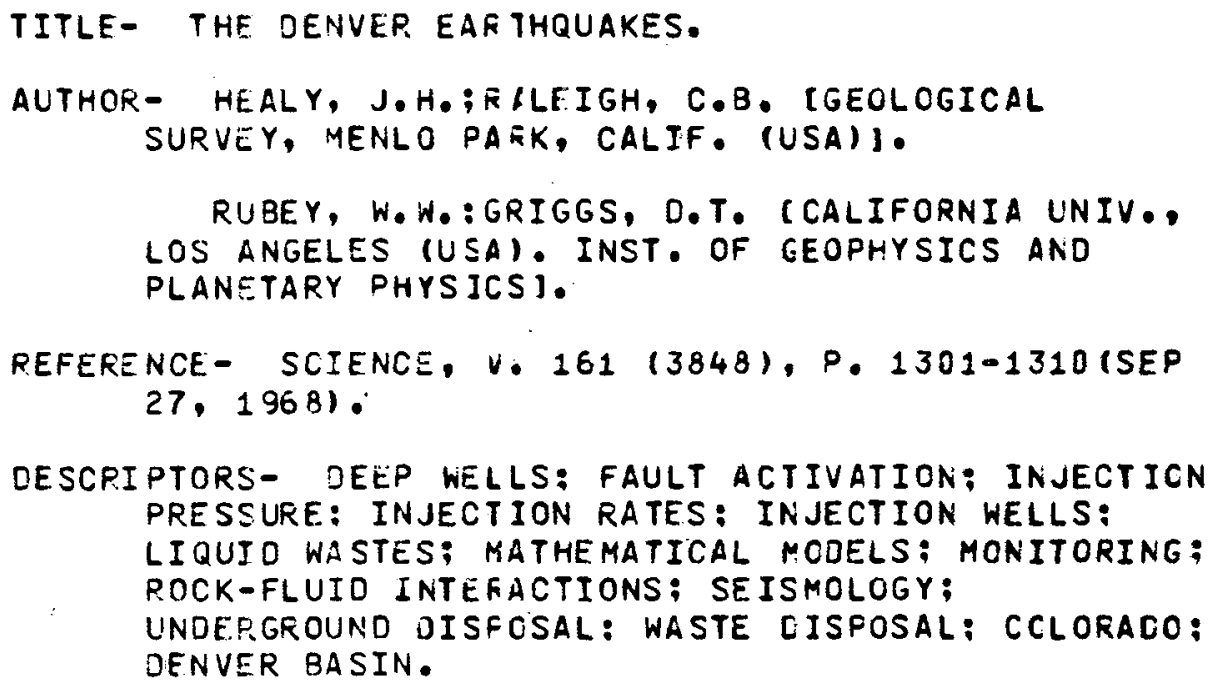

TITLE- SUBSURFACE DISFOSAL OF OIL FIELO ERINES. 


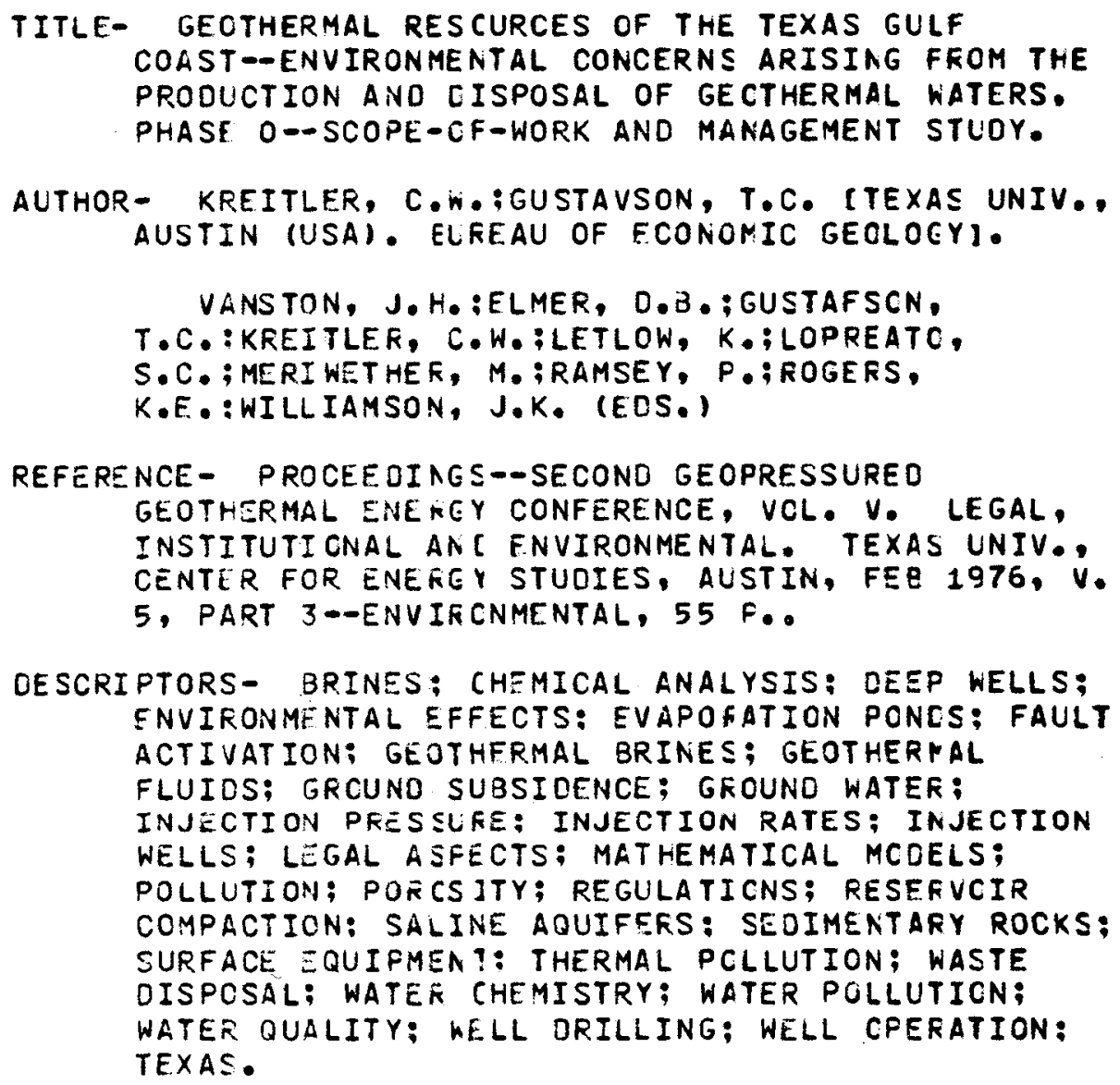
COAST--ENVIRONMENTAL CONCERNS ARISING FROM THE PRODUCTION AND CISPOSAL OF GECTHERMAL WATERS. PHASF O-OSCOPE-CF-WORK AND MANAGEMENT STUDY.

AUTHOR - KREITLER, C.WH.;GUSTAVSON, T.C. CTEXAS UNIV., AUSTIN (USA). ELREAU OF ECONOMIC GEOLOCYI.

VANSTON, J.H.:ELMER, D.B. ;GUSTAFSCN, T.C.:KREITLEF, C.W.:LETLOW, K.;LOPREATC, S.C.;MERI WETHEF, M.;RAMSEY, P.;ROGERS, K.E.: WI LLIAMSON, J.K. (EOS,)

REFERENCE - PROCEEDINGS--SECOND GEOPRESSURED GEOTHERMAL ENEREY CONFERENCE, VCL. V. LEGAL, INSTITUTICNAL ANC ENVIRONMENTAL. TEXAS UNIV., CENTER FOR ENEREY STUDIES, AUSTIN, FEE 1976, $V$. 5. PART 3--ENVIFCNMENTAL, 55 F..

OESCRIPTORS - BRINES; CHEMICAL ANALYSIS: DEEP WELLS; ENVIRONMENTAL EFFECTS: EVAPOFATION PONCS; FAULT ACTIVATION: GEOTHFRMAL BRINES; GEOTHERMAL FLUIDS: GRCUNO SUBSIDENCE; GFOUND WATER: INJECTION PRES SLRE: INJECTION RATES; INJECTION WELLS; LEGAL ASFECTS; MATHEMATICAL MCOELS; POLLUTION; POFCSITY; REGULATICNS; RESEFVCIR COMPACTION: SALINE AOUIFERS: SEOIMENTARY ROCKS: SURFACE EQUIFMEN?: THERMAL PCLLUTION; WASTE OISPOSAL; WATEE CHEMISTRY; WATER POLLUTICN; WATER QUALITY; HELL ORILLING; WELL CFERATION: TEXAS.

TITLE- THF.OW YOUR WASTES DOWN A WELL.

ALTHOP- LFE, J.A. (EE.)

REFERENCF- CHEM. ENG. (N.Y.), P. 137-139(SEF 1950).

OESCRIPTORS- ACIDIZATION; BACTERIA; EIOLCGICAL EFFECTS: BIOLOGICAL FOULING: CASE HISTCFIES: CHEMICAL COMPA IIEILITY; CORRCSION; DEEF WELLS; OISPOSAL FORMATICNS; ECONOMICS; FLOW RATE: INOUSTRIAL WASTE:; INJECTION WELLS; LEGAL ASPECTS: LIMESTCAE; LIQUIC WASTES; CILFIELO BRINES: PLUGEIAG: POLLUTICN REGULATIONS: SANOSTONE: SUSFENDEO SOLIOS: UNDERGRCUNO DISPCSAL: WASTE CISPOSAL; WASTE WATER; WELL STIMULATION. 


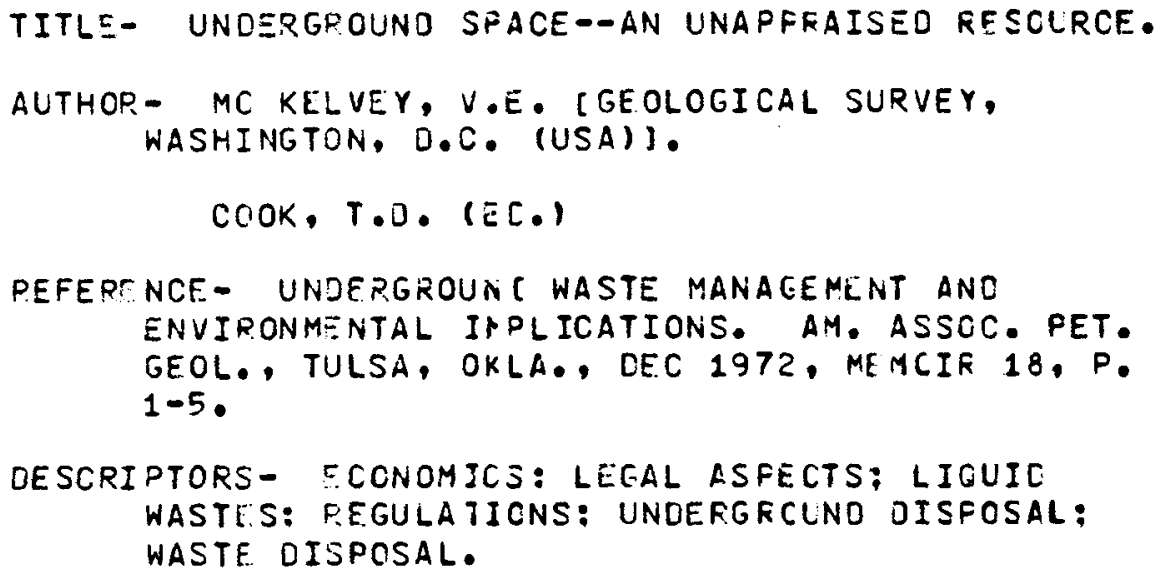

TITLE- LET ENGINEER ING KNOW-HOW SCLVE SALT-PCLLUTION PROBLEMS.

AUTHOR- RASCHKE, A. :SPITH, J.E.:WILLS, M.E. [RAILROAD COMMISSION OF TEXAS (USA)].

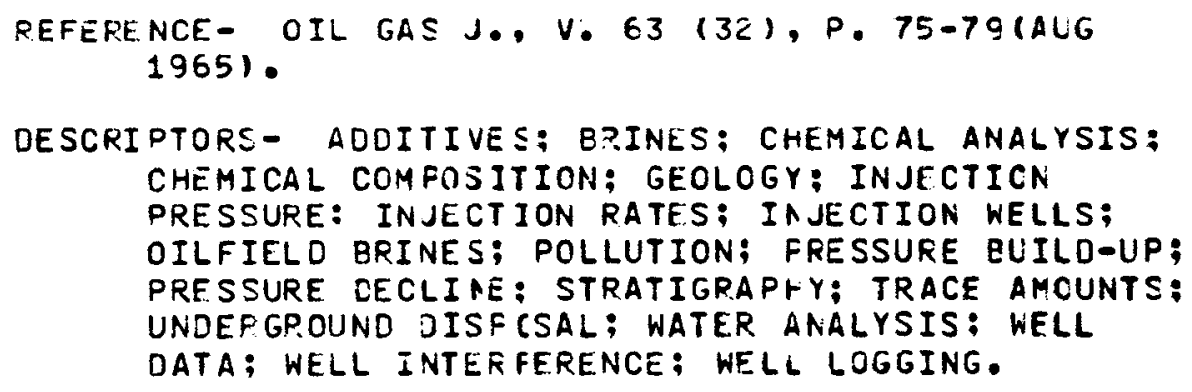




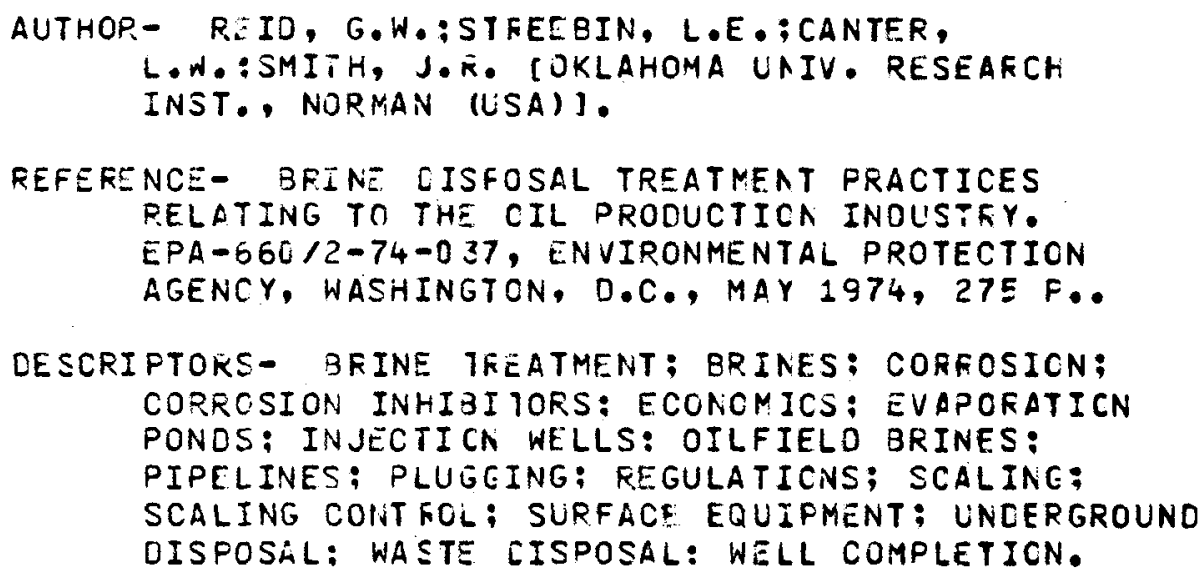

TITLE- DELP WELL DISFOSAL OF IMOUSTRIAL RASTES.

AUTHOR- SELM, R.F.; HLLSE, B.T.

REFERENCE- CHEM. ENG. PROG., V. 56 (5), P. $138-144$ (IIAY $19 E 0)$.

DESCRIPTORS- BACTERIA; BIOLOGICAL FOULING; CHEMICAL COMPATIBILITY: GEFP WELLS; ECCNOMICS; FLCW RATE: INDUSTRIAL WASTES; LEGAL ASPECTS; OILFIELD BRINES; PLUGGING; PRE-INJECTION TREATMENT: SUS FENDED SOLIDS; UNOERGROUNC OISPOSAL: WASTE CISPOSAL: WELL DESIGN.

BRINE TREATMENT/SFENT FLUIC OISPOSAL BR INE TREATMEAT/SCALINE BRINE TREATMENT/CCREOSION

TITLE- ECONOMIC IMPACI OF CORROSION AND SCALING PROBLEMS IN GECTHERMAL ENERGY SYSTEMS.

AUTHOR- SHANNON, C.W. T3ATTELLE FACIFIC NORTHWEST LABS. RICHLAND, WASH. (USA). $A C=9 \quad 5000221$.

REFERENCE- ECONOMIC IMPACT OF CORFOSION AND SCALING PROBLEMS IN GECTHERMAL ENERGY SYSTEMS. 


\author{
BNWL-1866, UC-4, BATTELLE PACIFIC NORTHLEST \\ LABS., RIC RLANC, WASH., JAN 1975, 115 P.. \\ OESCRIPTORS- AQUIFEKS; ARTIFICIAL RECHARGE; \\ BACTERIA: CARBONATES: CHEMICAL REACTIONS: BRINE \\ TREATMENT: CHLOFIDES; CORROSION: COREOSICN \\ PROTECTION: CORECSION RESISTANT ALLCYS: \\ CORROSI VE EFFECTS; DEEP WELLS; DESALINATION; \\ ECONCMICS; FILTFATION; ELECTROCHEMICAL \\ CORROSION: GEOTHERMAL BRINES; GEOTHERMAL \\ ENERGY; GEOTHERMAL FLUIDS; GEOTHERMAL HELLS; \\ INJECTI ON PRES SLRE: INJECTION WELLS: IRCN \\ OXIDES; PERHEABILITY: PH VALUE; PITTINE \\ CORROSION: PLUGGING: PRECIPITATION: \\ PRE-INJECTION TREATMENT; SCALING; SCRUEEERS; \\ SILICA MINERALS; STEAM SCRUEEFRS; STEAY \\ SEPAFATORS; STRESS CORROSION; SURFACE \\ EQUIPMENT: SUSFENDED SOLIDS: TUREINE ELACES: \\ UNDERGROUNO OISFCSAL: WASTE HATER; WATER \\ CHEMISTRY. \\ 90 \\ SHELCRICK $6 \%$ \\ BR INE TREATMENT/SFENT FLUIC CISPOSAL \\ TITLE- DEEP-WELL DISFCSAL-ARE SAFEGUARDS REING \\ I GNOREO . \\ AUTHOR - SHELORICK, M.G. (EO.) \\ REFERENCE- CHEM. ENG. (N.Y.), P. 74-78(APR 7, 19691 . \\ DESCRIPTORS- CASE HISTORIES; OEEP HELLS; IISFCSAL \\ FORMATIONS: ENIIFONMENTAL EFFECTS; FAILLEES; \\ GEOLCGY: GROUNI HATER; HYDROLCGY; INJECTION \\ PRESSURE: INJECTION WELLS: LEGAL ASPECTS; \\ LIQUIO WASTES; MCNITORING: FCLLUTION; \\ REGULATIONS: SAFETY; SEDIMENTARY ROCKS; \\ SEISMOLOGY: UNCERGFOUND OISPCSAL; WASTE
}

TITLE- OIL FIELDS YIELD NEH DEEP-WELL DISFOSAL TECHRIIQUE.

AUTHOR- SLAGLE, K.A.: STOGNER, J.M. IHALLIEURTON 


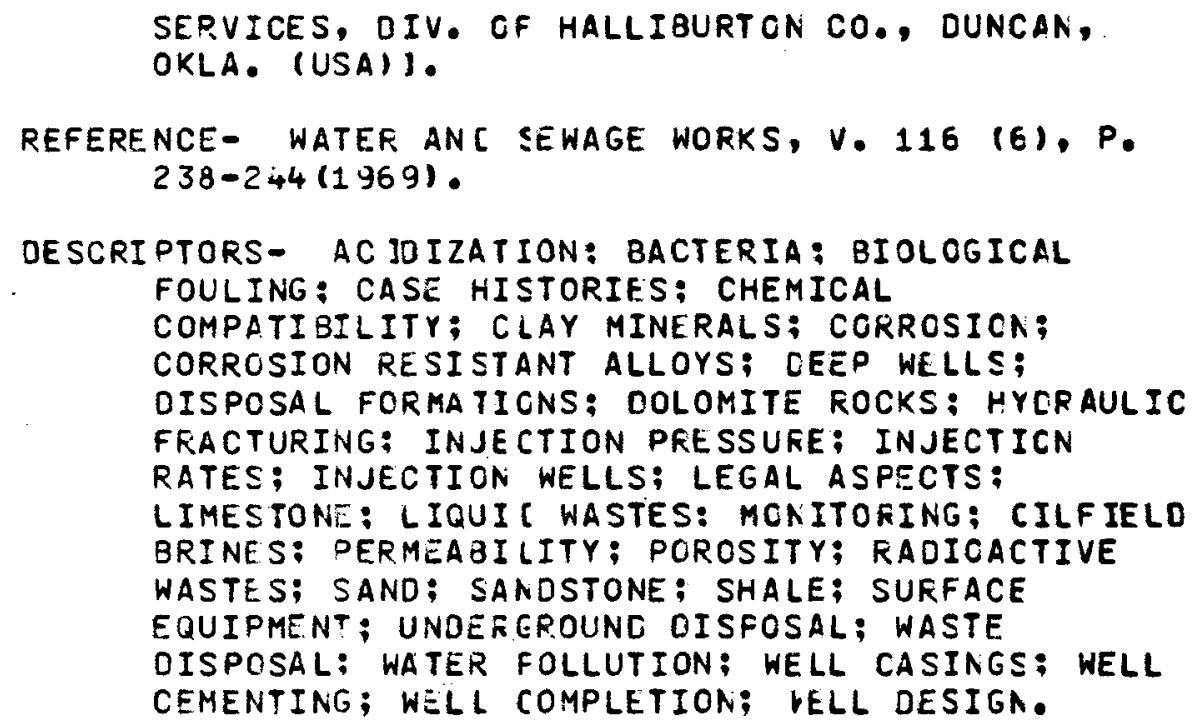

TITLE- THE DEEF WELL METHOD OF INGLSTRIAL WASTE DISPCSAL.

AUTHOR- TALBOT, J.S. IDOWELL SLUMEERGER, PAFIS (FRANCE)). 


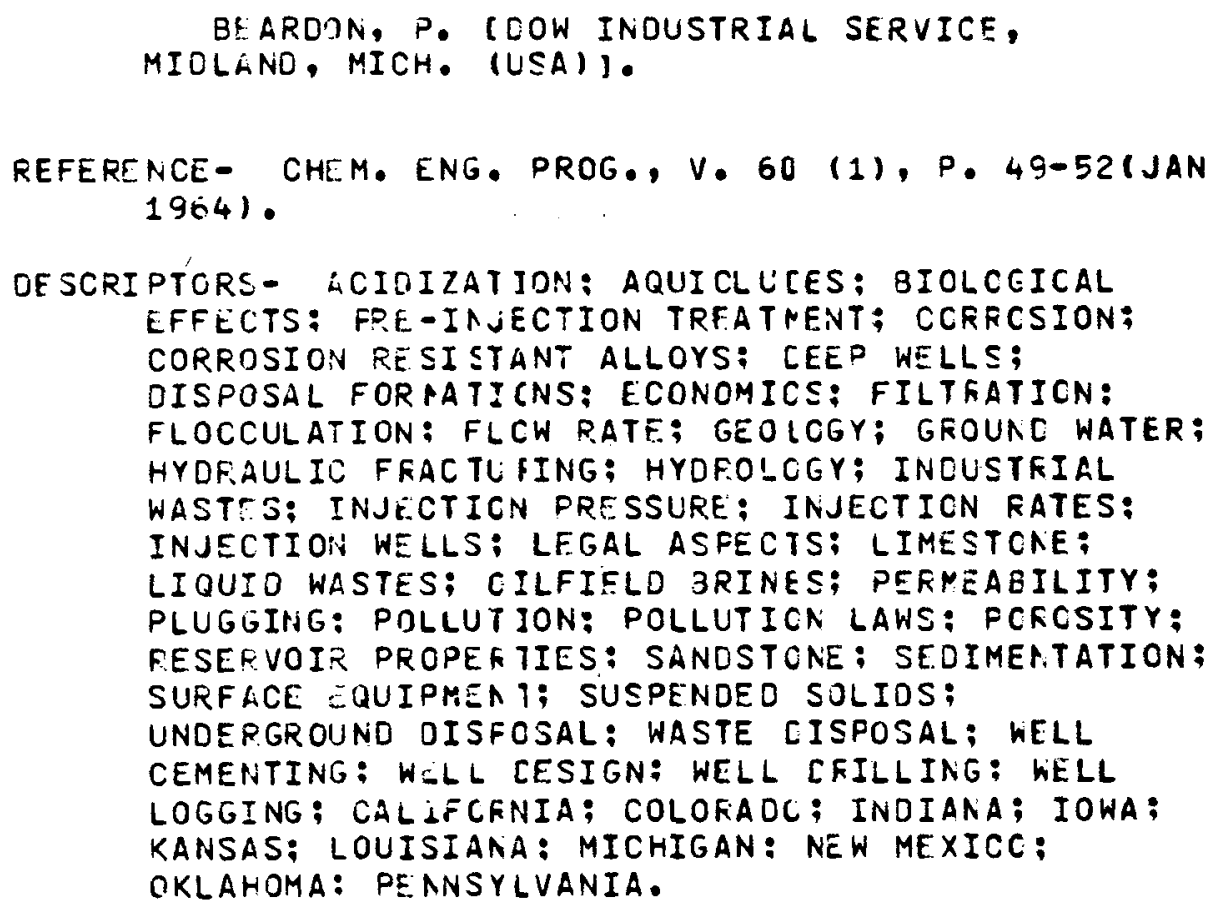

94

CIL CAS J. 76

BR INE TREATMENT/SPENT FLUIO OISPOSAL

TITLE- NEW TEXAS HZS RULE COVERS MANY FIELO OPERATIONS.

AUTHOR - OIL GAS J.

REFERENCE- OIL GAS J., V. 74 (16), P. 60-62(AFR 19761 .

DESCRI PTORS- DEEP WËLLS: FLOW RATE; HYOROGEN SULFIDES: INJECTION WELLS: FCLLUTION: FCLLUTION LAWS; R.EGULATICAS; SURFACE EQLIPMENT; KELL DRILLING: TEXAS.

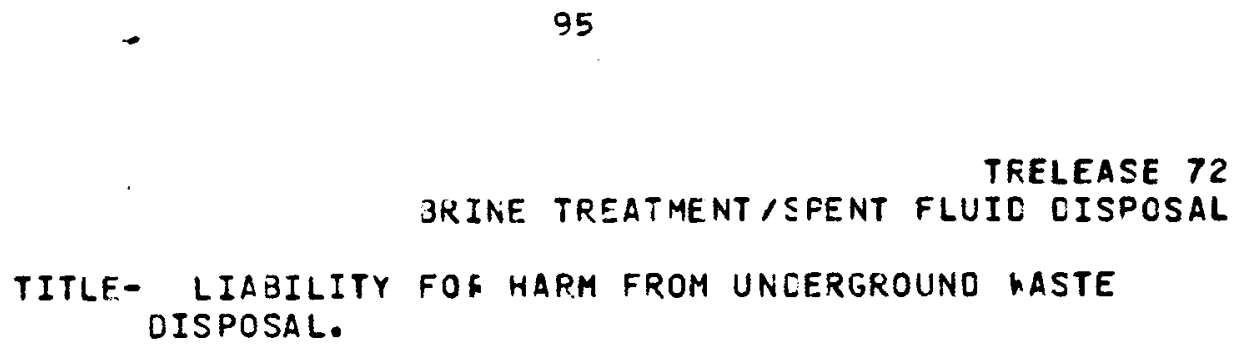




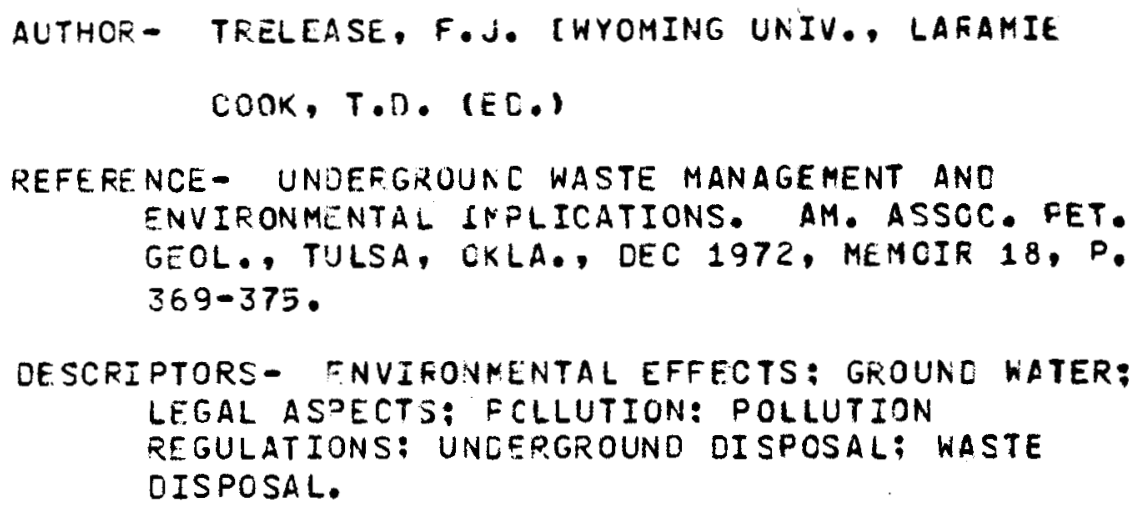

TITLE- BRINE DISPUSAL, CHAPTER VIII.

AUTHOR- UNDERHILL, G.K.:CARLSON, F.A.:CLENOINNING, W.A.:ERDOS, J.:GAULT, J.:HALL, J.W. ;JCNES, R.L.: MICHAEL, \& .K.:POWELL, P.H.:RIEMANN, C.F.:RIOS-CASTELLON, L.;SHEPHERD, B.F.:WILSON, J.S. (EDS.)

REFERENCE- PROCEEDINES--SECOND GECFRESSUFEO GEOTHERMAL ENERGY CONFERENCE, VOL. IV. SURFACE TECHNOLOGY AND FESOURCF UTILIZATION. TEXAS UNIV., CENTEF FCF ENERGY, STUCIES, AUSTIN, TEX., FEB 1976. V. 4, P. 183-191.

DESCRIPTORS- AOUIFERS; BRINES: CORFOSION: CCFROSION INHIBITORS; DEEF WELLS: DISFCSAL FCRMATIONS; ECONOMICS; ENVIFCNMENTAL EFFECTS; GECLOGY: GEOTHERMAL BRINES: GEOTHERMAL FLUIDS: INJECTION PRESSURE: INJECTION RATES; INJECTION WELLS; OILFIELD BRINES: PERMEABILITY: PH AOJUSTMENT: POROSITY; RESERVOIR ENGINFERING; SURFACE EQUIPMENT; SLSFENDEO SOLIDS: THERMAL PCLLUTION: UNDERGROUND DISFCSAL; WASTE CISFOSAL: KELL DATA: WELL DESIEA.

97 


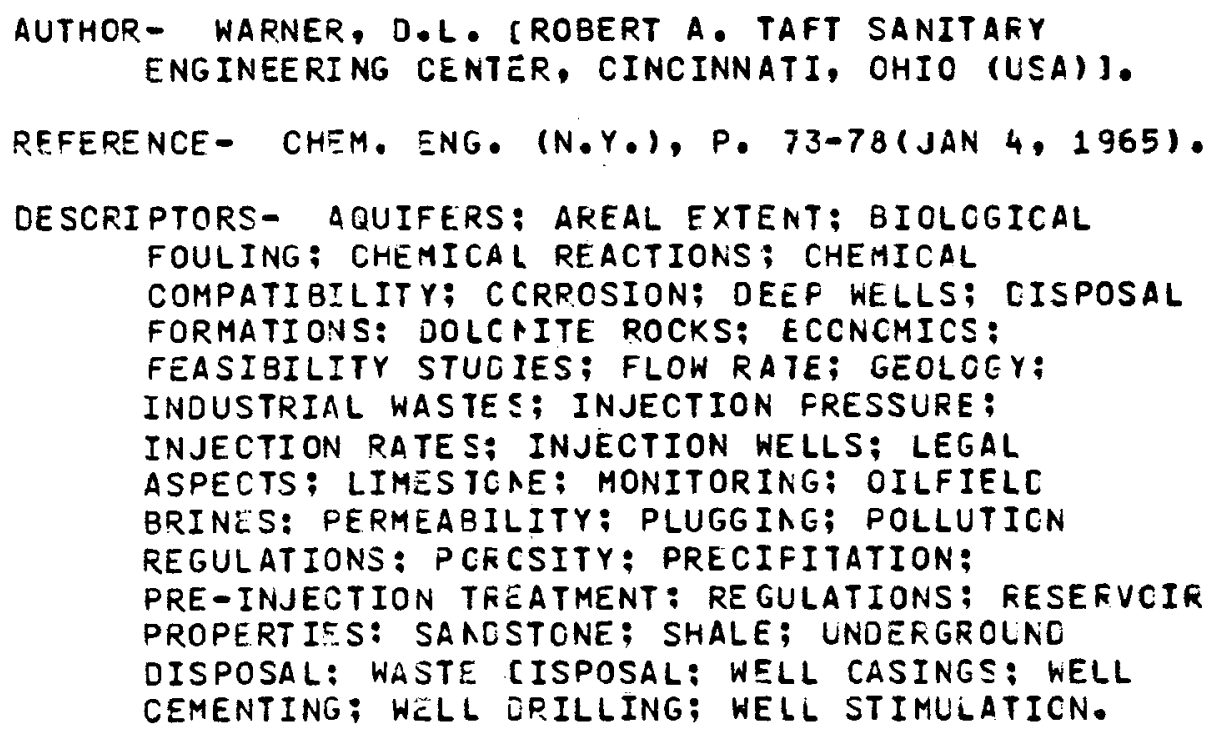

98

WARNEF 66

BRINE TEEATMENT/SFENT FLUIC CISPOSAL

TITLE- DEEP WILL RASTE INJECTION--FEACTION WITH AQUIFER WATER.

AUTHOR - WARNEQ, D.L. [FEOERAL WATEF POLLUTICN CONTFOL ADMINISTFATION, CINCINAATI, CHIC (USA). WATER. PESEARCH LAB.].

REFERENCE - J. SANIT. ENG. OIV., AR. SOC. CIV. ENG., V. 92 (SA I), P. 45-6g(AUG 19EE).

OESCRIPTORS- AQUIFERS; CHEMICAL ANALYSIS; CHEMICAL COMPATIBILITY: CHEMICAL REACTIONS: DEEF WELLS; ECONGMICS; HYORCOYNAMIC OISFERSION; INJECTION WELLS: LIOUIC KASTES: MEASURING INSTFUMENTS; MEASURING METHCLS: PERMEABILITY; PLUEGING: POROUS MEDIA; FEECIPITATION: FADIUS OF INFLUENC: RESERVOIR PROPERTIES; SANCSTCAE; THEOFETICAL TFEA IMENTS: UNDEFGROUNO OISFOSAL: WASTE DISPOSAL. 
TITLE- ANALYTICAL METHODS OF TESTING WATERS TO BE. INJECTED INTO SLESURFACE OIL-PRODUCTIVE STRATA.

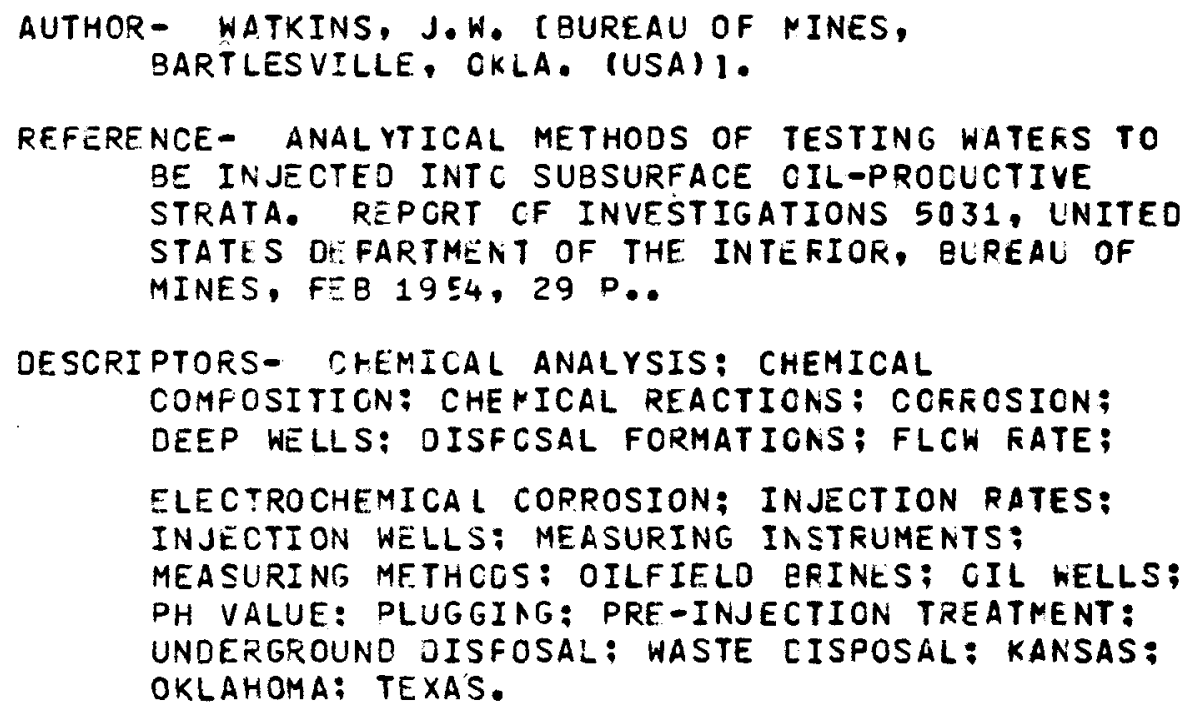




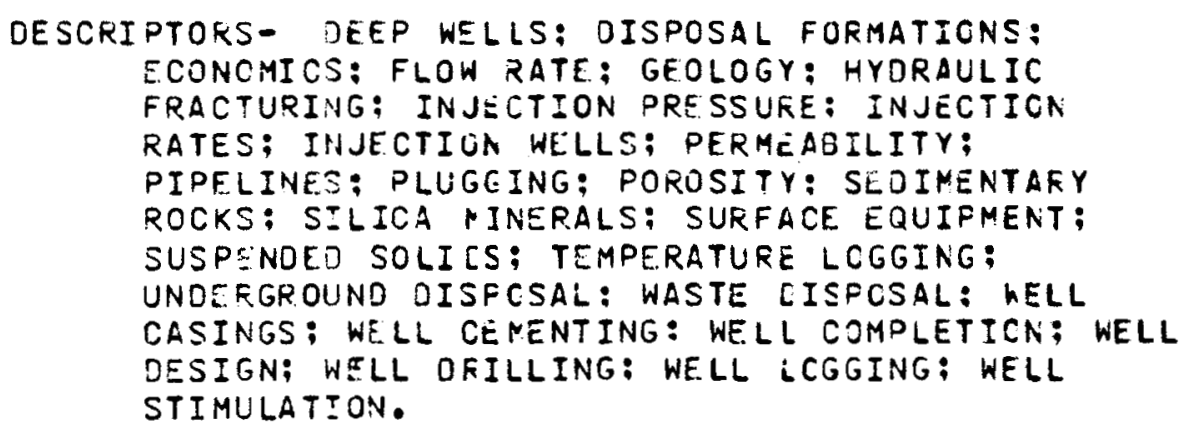

161

WOOC 74

BRINE TREATMENT/SFENT FLLIL CISPOSAL

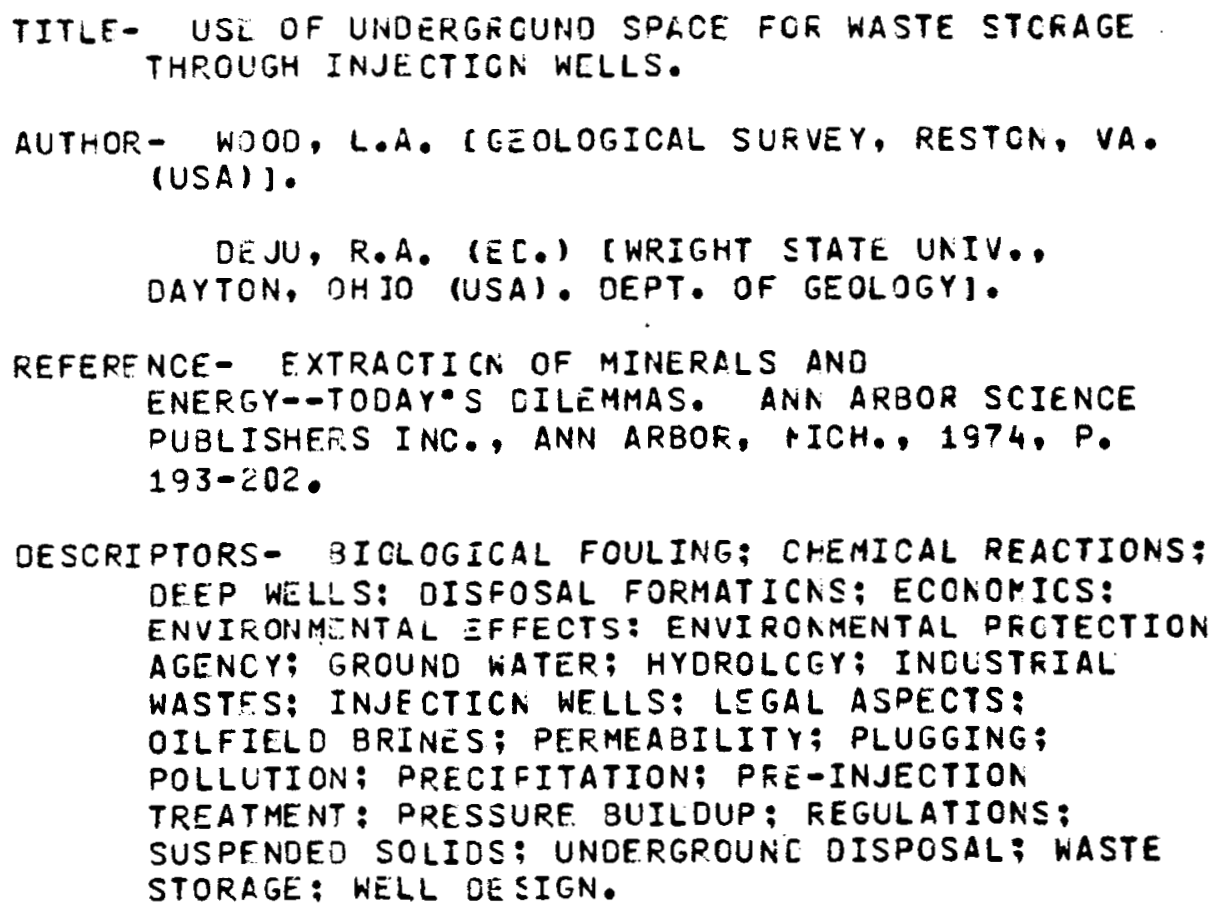

102

WATER WELL JCLRNAL 65 BRINE, TREATMENT/SPENT FLUIC OISPOSAL

TITLE- OPERATION DEEF WELL.

AUTHOR- WATER WELL J. 


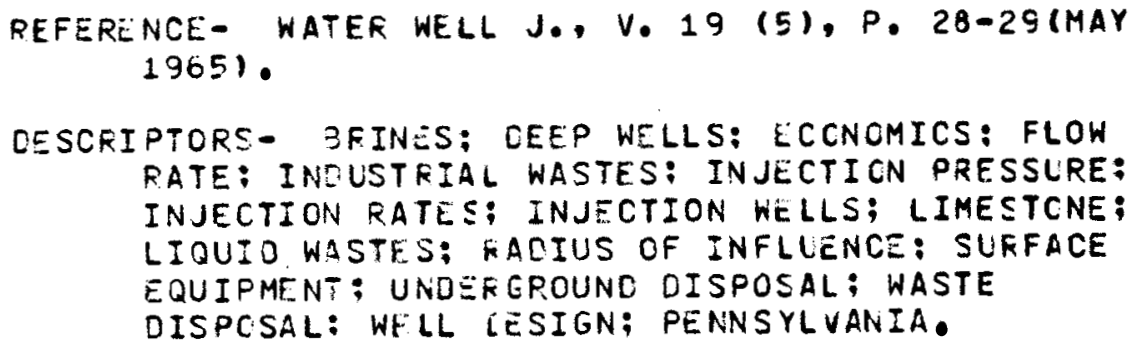

103

BEINE TREATMENT/SFENT FLUIO CISPOSAL

TITLE- INJECTION WELL EXPERIENCE AT RIVERHEAC, N.Y..

AUTHOR- BKFFA, J.J. [JOHN J. BAFFA CONSULTING

ENGINEERS, NEW YORK, N.Y. (USA)).

REFERENCE- J. AM. WATER WORKS ASSOC, V. 62 (1), P. 41-46 (JAN $197 C$ ).

DESCRIPTORS- ARTIFICIAL RECHAFGE ; EXPERIMENTAL RESULTS: FLOW RATE: GRAVEL PACKING; GRCLND WATEF: HYDFAULICS; INJECTION RATES; INJECTION WELLS: MEASUFING INSTRUMENTS: MEASURING MFTHODS: OESERVATION WELLS: FLUGGING: WASTE WATEE: WELL DESIGN; NEW YORK.

104

BRINE TREATMEAT/SFENT FLUIC CISPOSAL

TITLE- WASTE INJECTICN INTO A CEEF LIMESTCNE IN NORTHWESTERN FLCFIOA.

AUTHOR- BARRACLCUGH, J.T. CGEOLOGICAL SURVEY, ICAHO FALLS, IDAHO (USA)).

REFERENCE- GROUND WATER, V. L (1), P. 22-24(1966).

OESCRIPTORS - AQUICLUOES; AQUIFERS; CASE HISTCRIES; CHEMICAL ANALYSIS: CLAY MINERALS; DEEF HELLS; FLOW RATE: GEO ICGY; HYDRAULICS; HYOROLCGY; INDUSTRIAL WASTES; INJECTION FRESSURE; INJECTION RATES; INJECTION WELLS; LIMESTCNE; LIQUID WASTES: MCNITORING: OESERYATION WELLS; SHALE; STRATIGRAFHY; SUSPENDED SOLIOS; 
UNDFRGROUNO OISFOSAL; WASTE DISFOSAL; FLGRIDA; ALABAMA.

105

\section{EERESTROM $68 \mathrm{E}$ \\ GRINE TREATMENT/SFENT FLLIL CISPOSAL}

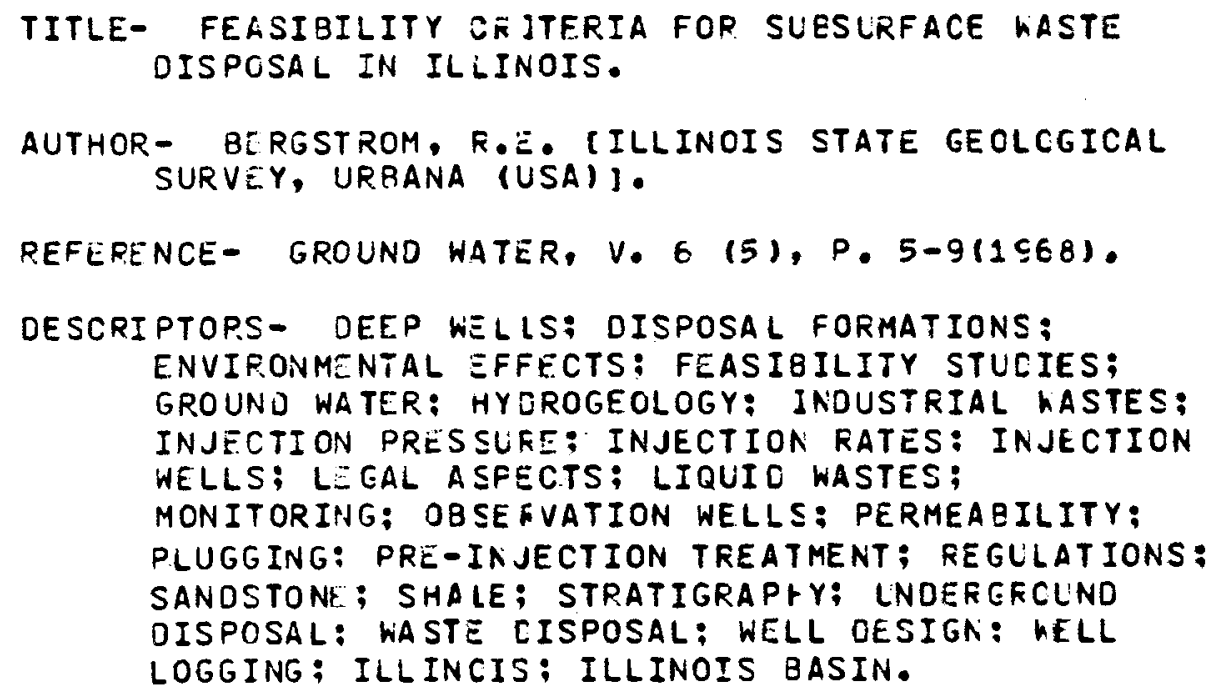

106

CAMELI 76

BFINE TREATMENT/SFENT FLUIC CISPOSAL

TITLE- SEISMIC CONTROL DURING A RËINJECTION EXPERIMENT IA THE VITERBO REGION (CEATKAL ITALYI.

AUTHOR- CAMELI, G.M. IENTE NAZIONALE PER L ENERGIA ELETTRICA, PISA (ITALY). CENTFO OI RICERCA GEOTERMICA .

CARABELLLI, E. IISTITUTO CI GEOFISICA APPLICATA DEL PCLITECNICO DE MILANO (ITALYI).

REFERENCE- PROCEECIACS-OSECOND UNITED NATIONS SYMPOSIUM ON THE LEVFLOPMENT ANO USE OF GEOTHERMAL RES CLRCES. LAWRENCE BERKELEY LABOFATOPY, UNIVERSITY OF CALIFORNIA, EERKELEY, 1976, V. Z, P. 1329-1334. 


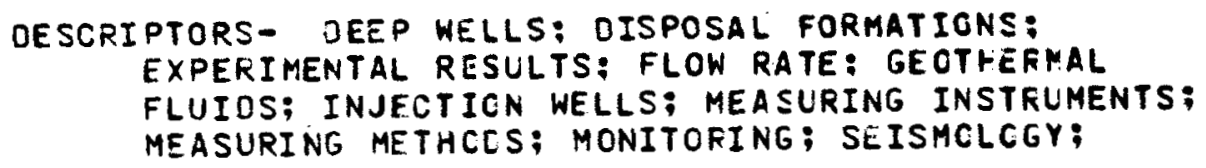

107

CLELLAR 76

BR INE TREATMENT/SFENT FLLIC CISPOSAL

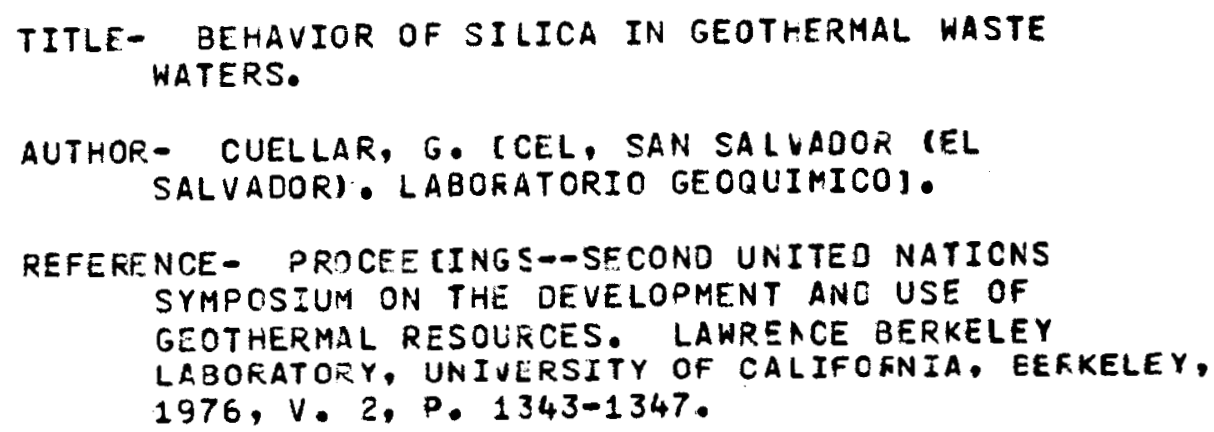

DESCRIPTORS- CHEMICAL ANALYSIS: CHEMICAL COMPOSITION: DEEF WELLS: DESALINATION: ECONOMICS; EVAPCAATION PONOS: EXPERIMENTAL RESULTS: FEASIBILITY STUOTES: FLOW RATE: GEOTHERMAL BRINES; GEOTHERMAL FLUIOS: GEOTHERMAL RESEFVOIRS; INJECTION PRESSLRE; INJFCTION WELLS: LIQUIO WASTES: MEASURING INSTRUMENTS: MEA SURING METHOOS: MINERAL RECOVERY; PERMEAEILITY; PH ACUUSTMENT: PRE-INJECTION TREATMENT: SCALING: SILICA MINERALS: SUFFACE EQUIPMENT: UNDERGROUND DISPOSAL; WASTE IISPOSAL: WASTE WATER: AHUACHAPAN GEOTHERMAL FIELD: EL SALVACCF.

108

BRINE TREATMENT/SFENT FLUIC CISPOSAL

TITLE- OISPOSAL OF GEOTHERMAL WASTE WATER EY REINJECTION.

AUTHOR - EINARSSON, S.S. COTC, UNITEO NATIONS, MANAGUA (NICARAGUA)).

VIOES, A.R.;CUELLAR, G. CCOMISION EJECUTIVA HIDROELECTRICA CEL RIO LEMPA, SAN SALVACOR (EL SALVADORI 1 . 


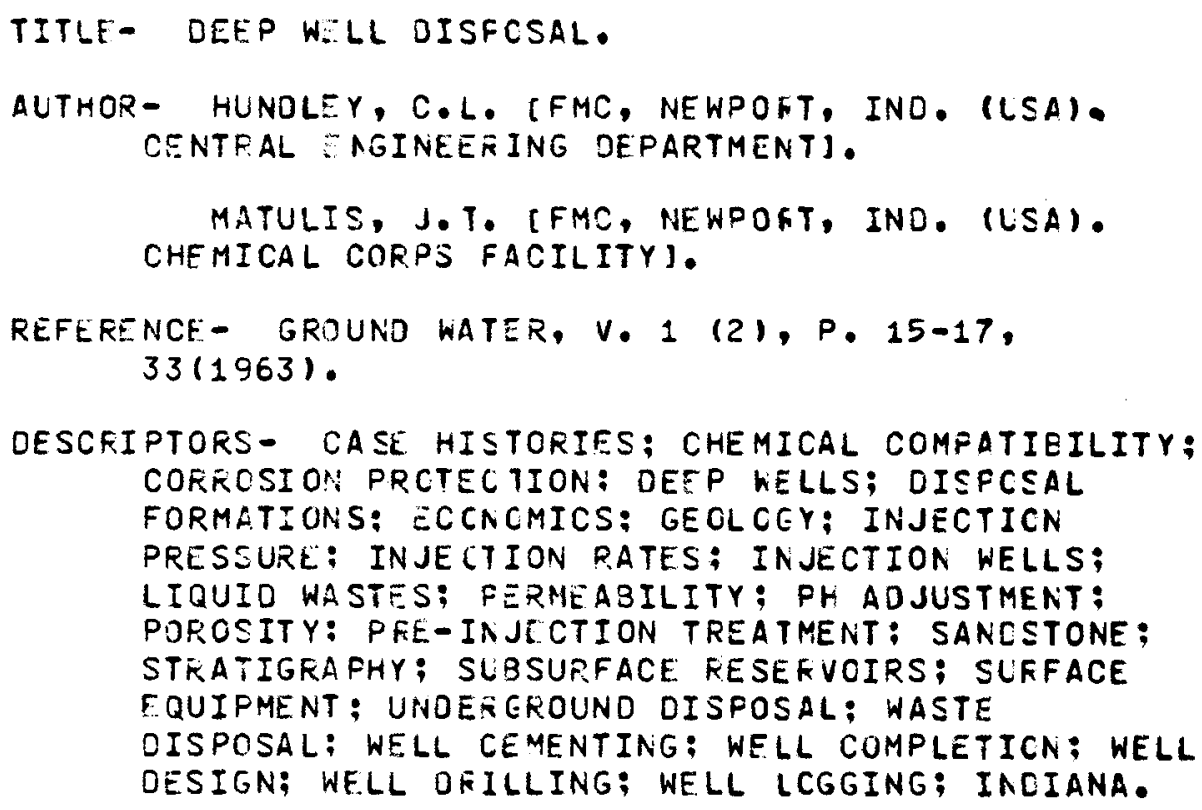

TITLE- REINJECTION CF GEOTHEPMAL HCT WATER AT THE OTAKE GEOTHERMAL FIELD.

AUTHOR - KUBOTA, K.:ACSAKI, K. [KYUSHU ELECTKIC POWER CO., INC., FUKUCKA (JAPAN), RESEARCH DEFT. 1.

REFERENCE - PROCEECIAGS--SECOND UNITED NATIONS SYMPOSIUM ON THE DEVELOPMENT ANE USE OF GEOTHERMAL RESOLRCES. LAWRENCE BERKELEY LABCFATORY, UNIVERSITY OF CALIFCFNIA, EEFKELEY, $1976, V .2, P .1379-1383$.

DESCRIPTORS- CASE HISTORIES: DEEP WELLS: DISFOSAL FORMATIONS; FLOW RATE; GEOLOEY; GEOTHEFMAL BRINES: GEOTHERMAL FIELOS; GEOTHERMAL FLLIDS; GEOTHERMAL RESERVOIPS; INJECTION PRESSURE: INJECTION WELLS: SCALING; SEISMOLOGY; SILICA MINERALS: UNOEREROUND DISFOSAL; WASTE CISPOSAL; WELL CASINGS; WELL DESIGN: OTAKE GECTHEFMAL FIELD; JAPAN. 
MARSH 68

BR INE TREATMENT/SFENT FLUIC DISPOSAL

TITLE- DFSIGN OF WASTE DISPOSAL WELLS.

AUTHCR- MARSH, J.H. LUOP JOHNSON LIVISION, SAINT

PAUL, MINN. (USA)).

REFERENCE- GROUND WATER, V. 6 (2), P. 4-8(1968).

DESCPIPTORS- ACIOIZATION: AQUICLUIES; CASE

HISTORIES: CHEMICAL ANALYSIS; CLAY MINEKALS;

CORROSIOH: CORFCSION INHIBITCES; COFFOSICN

PROTECTION: CORFCSION PESISTANT ALLCYS; CEEP

WELLS; ECCNOMICS: GRAVEL PACKING; INOUSTRIAL

WASTES: INJECTICN WELLS; LIQUIO WASTES;

PLUGGING: SAND; SAND CONTROL; SUSPENCEC SOLIOS:

UNOERGROUND JISFOSAL; WASTE DISPOSAL; WELL

CASINGS; WELL CEMENTING; WELL COMPLETICN; WELL

DESIGN: WELL LOGGING; WELL SCREENS: PH:

ADJUSTMENT.

113

ANGINO 70

BRINE TREATMENT/SFENT FLUIC OISPCSAL

TITLE- SELECTIVE ELEMENT RECOVERY FRCM CIL FIELD BRINSS.

AUTHOR- ANGINO, E.E. [KANSAS UNIV., LAWRENCE (USA)],

REFERENCE- WATER RESOUR, RES, $V_{0} 6(5)$, P.

$1501-15 C 4(O C T$ 19:0).

OESCPIPTORS - BRINE TFEATMENT: BRINES: CHEMICAL COMPOSITION: CHERICAL REACTICNS; DESALINAT ION;

ECONOMICS; MINEFAL RECOVERY; CILFIELO ERINES.

114

GARCIA-EENECCHEA 70

BR INE TPEATMEAT/SPENT FLUIC CISPOSAL

TITLE- DEEP WELL OISFCSAL OF WASTE WATERS IN SALINE AQUIFERS CF SOUTH FLORIDA. 


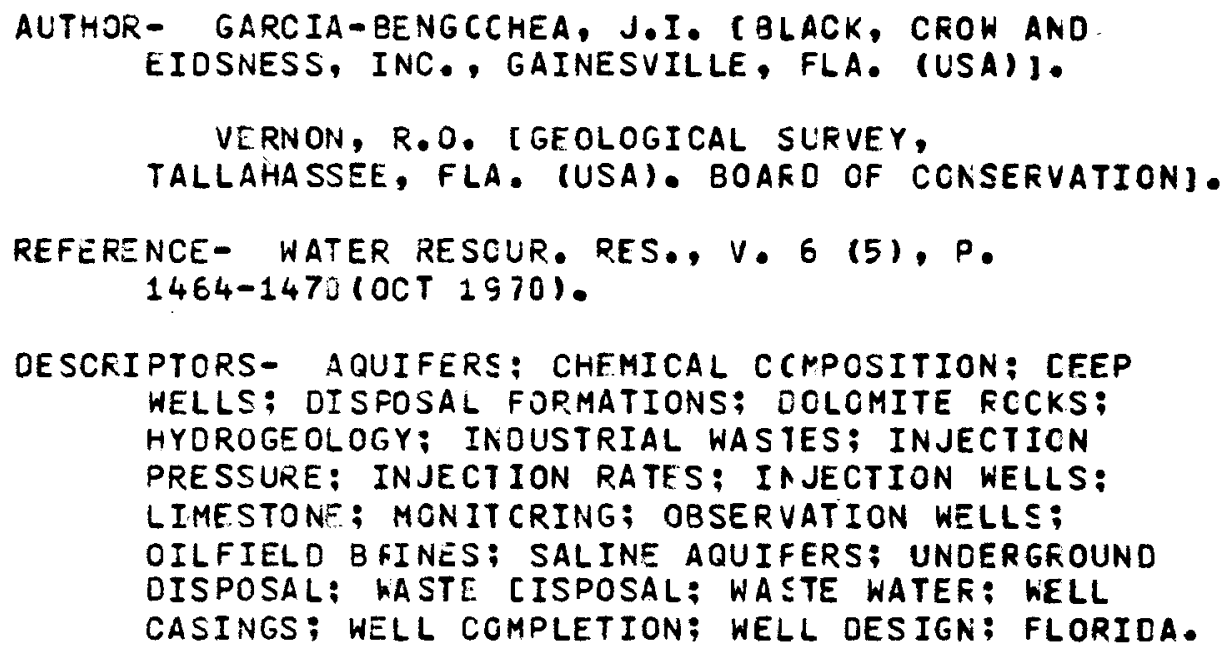

115

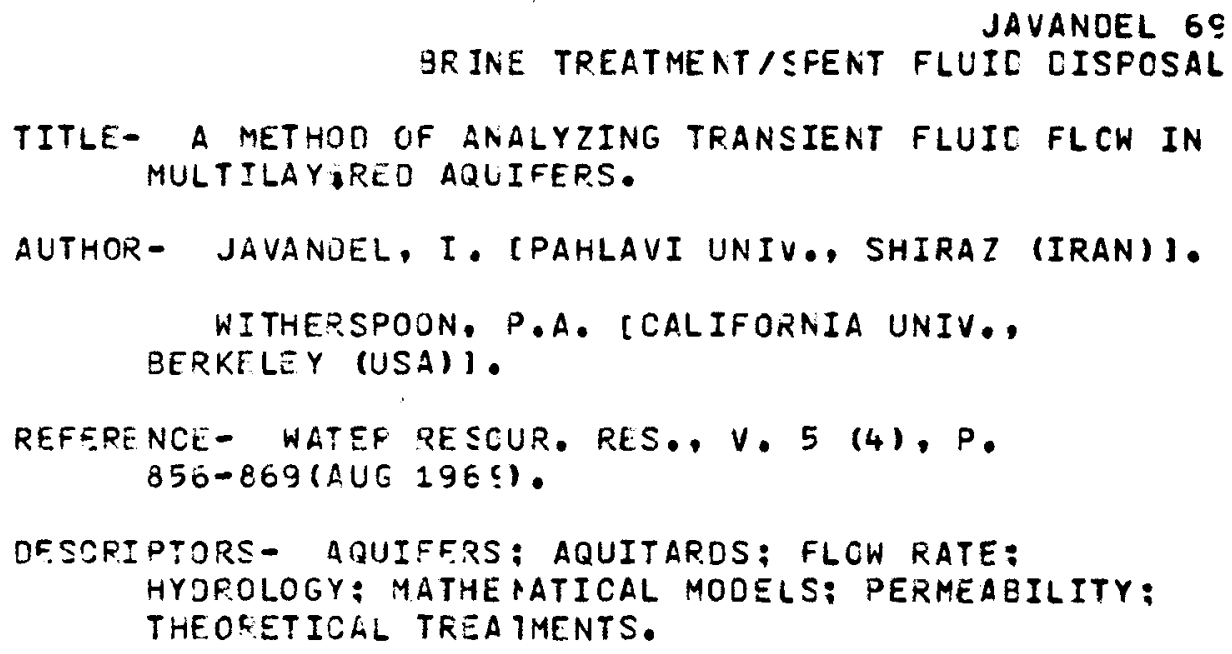

116

NEUMAN 69

BRINE TREATMENT/SPENT FLUIC DISPOSAL

TITLE- THIORY OF FLCW IN A CONFINEO TWO AQUIFER SYSTEM.

AUTHOR - NEUMAN, S.P.: HITHERSPOON, F.A. ICALIFORNIA UNIV., BERKE LFY (USA)).

REFEFENCE - WATER RESOUR. RES,, V. $5(4), P$. $803-816$ (AUG 1969). 


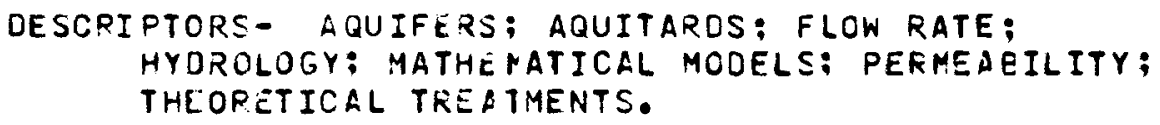

\author{
BRINE TREATMENT/SPENT FLUIO CISPOSAL
}

NELMAN 698

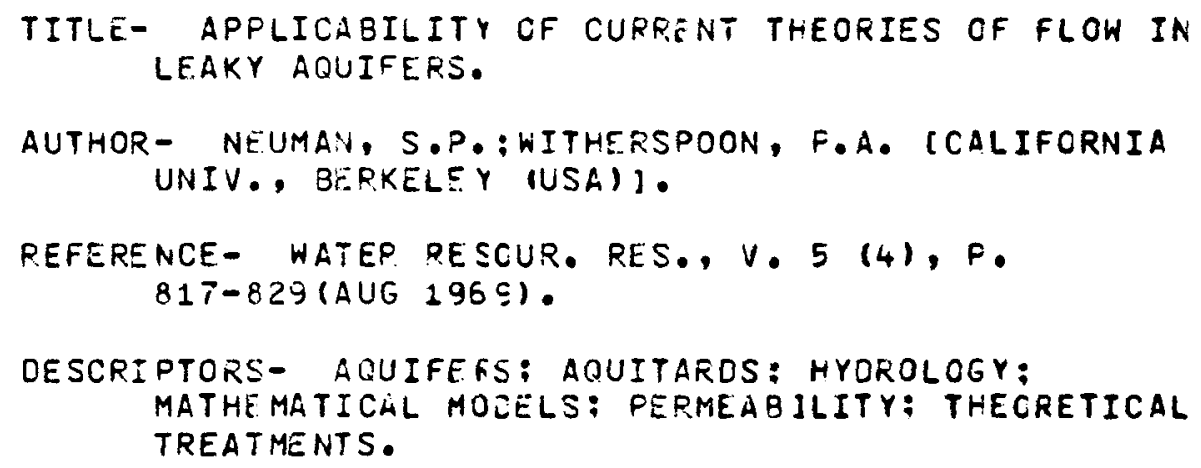


REBHUN 68

BRINE TREATMENT/SFENT FLUIC CISPCSAL

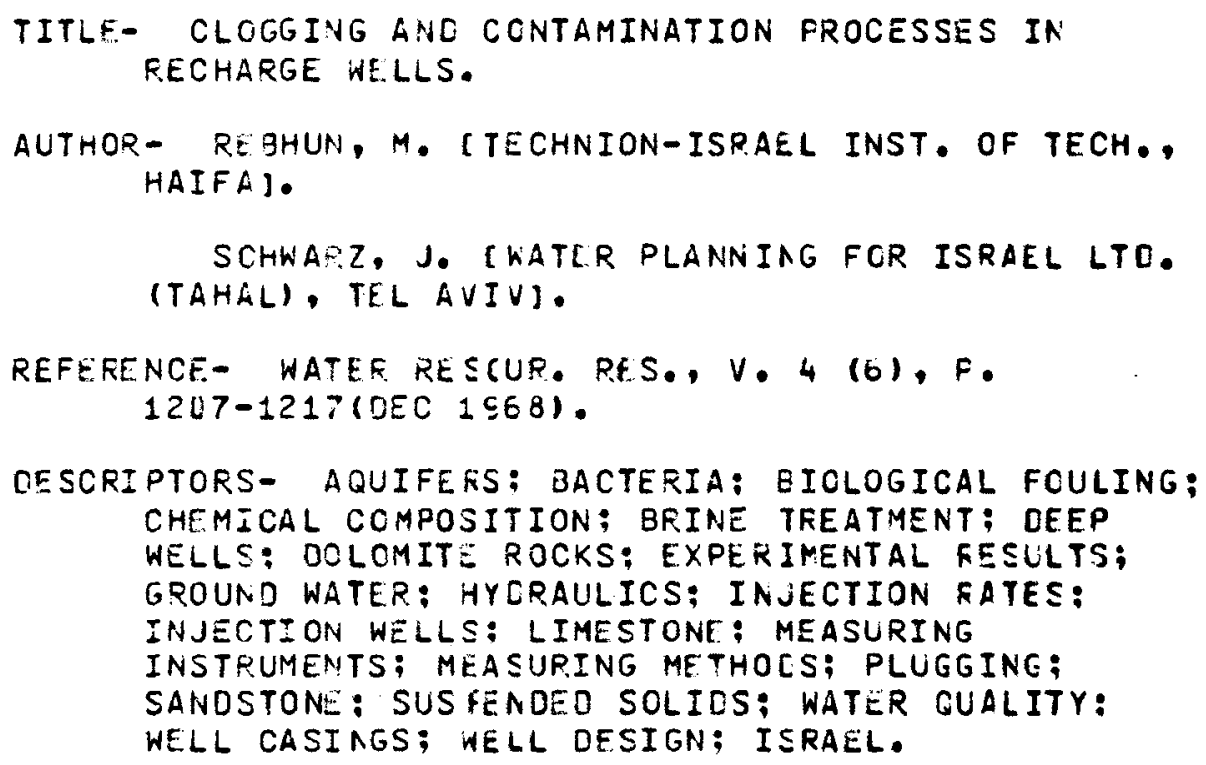


WARNER 70

GKINE TREATMENT/SFENT FLUIC DISPOSAL

TITLE- REGULATORY ASPECTS OF LIQLID WASTE INJECTION INTO SALINE AQUIFERS.

AUTHOR- WARNER, D.L. [MISSOURI UNIV., ROLLA (USA)]. REFERENCE- WATER RESOUR. RES., V. 6 (5), P. $1458-1463$ (CCT 1970$)$.

DESCRIPTORS - CHEMICAL COMPATIBILITY: CORFOSICN: DEEP WELLS: ECONOMICS: FEASIBILITY STUDIES; FILTRATION: GEOLCGY: HYDROGECLOGY; INCUSTRIAL WASTES: INJECTICN PEESSURE; INJECTION RATES; INJECTION WELLS: LIQUID WASTES: MONITORING: PRE-INJECTION TREATMENT: RADIOACTIVE WASTES: REGULATIONS; SALINE AQUIFERS; SEOIMENTATION; SUBSURFACE RESERVOIRS: SURFACE EQUIPMENT; WELL CASINGS: WELL CEMCNTING; WELL COMPLETICN; WELL DESIGN; WELL LGGGING; WELL OFEFATION.

122

MAHON $6 E$ BRINE TREATMENT/SCALINE

TITLE- SILICA IN HOT WATER DISCHAFGED FROM DRILLHOL:S AT KAIRAKEI, NEW ZEALAND.

ALTHOR- MAHON, W.A.J. IDEPARTMENT CF SCIENTIFIC ANO INOUSTRIAL RESEARCH, (NEW ZEALAND) . CHEMISTRY DIV.J.

REFERFNCE- N.Z.J. SCI., V. 9, F. 135-144(MAF 1966).

DESCRIPTORS- CHEMICAL ANALYSIS: CCNCENTRATICN

OEPFNDENCE: DEEF WELLS: GEOTHERMAL FIELES; GEOTHERMAL WELLS: MEASURING INSTRUMENTS: MEASURING METHOCS: MONITOFING: QUARTZ; SILICA MINEFALS: SILICA SOLUBILITY; TEMPERATURE DEPENDENCE: TEMFERATURE LOGGING: WELL HEAD PRESSURE: WAIRAKEI GEOTHERMAL FIELO: NEH 
INSTRUMEITS; MEA SURING METHOOS; QUAFTZ; SILICA MINFRALS: SILICA CHEMISTRY; SILICA SOLLEILITY; SOLUBILITY: TEMFERATURE DEPEACENCE: TIME DEPENDENCE.

TITLE- THE SOLUEILITY OF AMORPHOUS SILICA AT 25 DEGREES $C$.

AUTHOR- MOREY, G.W.:FCURNIER, R..C.;ROWE, J.J. [GEOLOGICAL SURVEY, WASHINGTCA, D.C. (LSA)].

REFERENCE - J. GEOPHYS . RES, V. 69 (1E), P. 1995-2002 (MAY $1 S E 4)$.

DESCRIPTORS - AMORPHCLS SILICA; AQUEOUS SOLUTICNS: CRISTOSALITE: E>FFRIMENTAL RESULTS: FREE ENERGY; GEOTHEKMAL FLUIOS; MEASURING METHOOS; PH VALUE; PH CEFENCENCE; QUAFTZ; SILICA MINERALS: SILICA CHEMISTRY; SILICA SOLUEILITY; TEMPERATURE DE FE RDENCE; TIME OEPENDENCE.

TITLE- PRECIPITATION CF AMORPHOUS SILICA FRCM HIGH-TEMPERATURE HYPERSALINE GEOTHERMAL ERINES.

AUTHOR- OWEN, L.B. (CALIFORNIA UNIV., LIVERMCRE (USA). LAWFENCE IIVERMORE. LAB.).

REFEPENCE - PRECIPITATION OF AMORPHOUS SILICA FROM HIGH-TEMPERATUKE HYPERSALINE GECTHERMAL ERINES. UCRL-51866, CALIFORNIA UNIV., LAWRENCE LIVERMORE. LAB., LIVERMORE, CALIF., JUN 1975, 20 D..

DESCRIPTORS- AMORPHCLS SILICA: $A Q U E O U S$ SOLUTICNS; CHALCEDONY: CHENICAL REACTIONS: CONCENTFATION DEPENDENCE； CRISTOBALITE; ECCNOMICS; GECTHERMAL BRINES; HYOROXICES; METALS; OPALINE SCALE; PH ADJUSTMENT; PH VALUE: PH DEPENDENCE; POLYMIRIZATICN: PRECIPITATION: PRESSURE DEPENDENCE: QUAFTZ; SALINITY; SCALING; SILICA MINERALS: SILIC/ CHEMISTRY: SILICA SCLUEILITY; 
SUSPENDED SOLIOS: TEMPERATURE DEPENCENCE; TIME DEPENDENCE; SALTCN SEA GECTHERMAL FIELC.

TITLE- A PHENOMENCIN UF SCALING IN PROOUCTION WELLS AND THE GEOTHERMAL POWER. PLANT IN THE MATSUKAHA AREA.

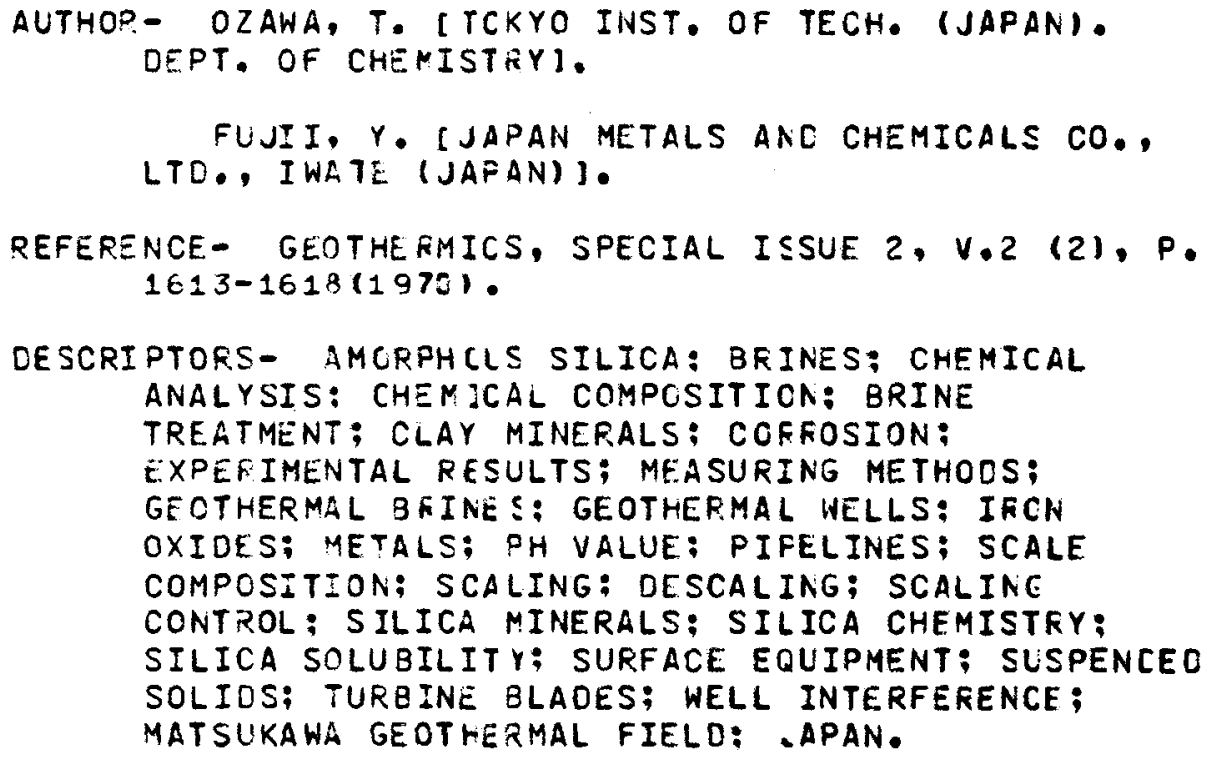

TITLE- THE EFFECT OF ELECTRICAL FOTENTIAL ON SCALE FORMATION IN SAL ION SEA BRINE.

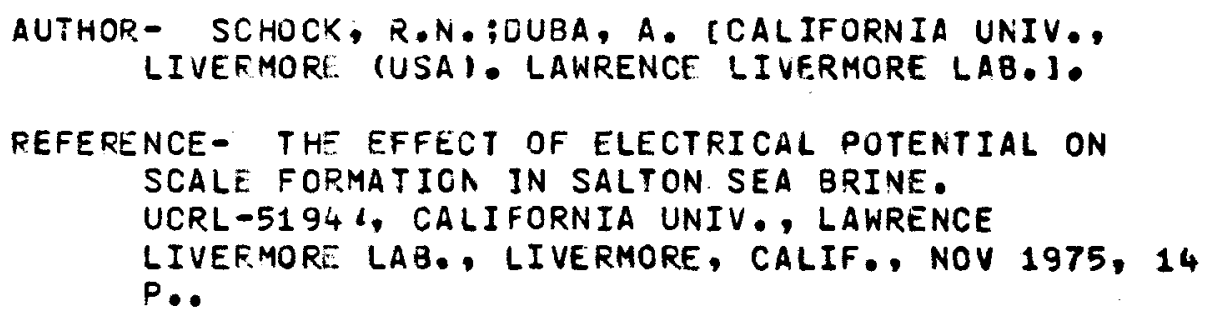


OESCRIPTORS- BRINES: CHEMICAL ANALYSIS: EXPEFIMENTAL RESULTS: GEOTHERMAL BRINES: MEASURING

INSTRUMENTS; MEA SURING METHOCS; SCALINE; SILICA MINERALS: SILICA SOLUBILITY; SALTON SEA

GEOTHERMAL FIELE.

129

TCLIVIA 70

BRINE TREATMENT/CCREOSION

TITLE- CORROSION MEASUREMENTS IN A GEOTHERMAL ENVIRON MENT •

AUTHOR - TOLIVIA, E. P. IGEOTHERMAL ENERGY COMMISSION, MEXICO CITY (MEXICO). CHEMICAL INVESTIGATION SECTION].

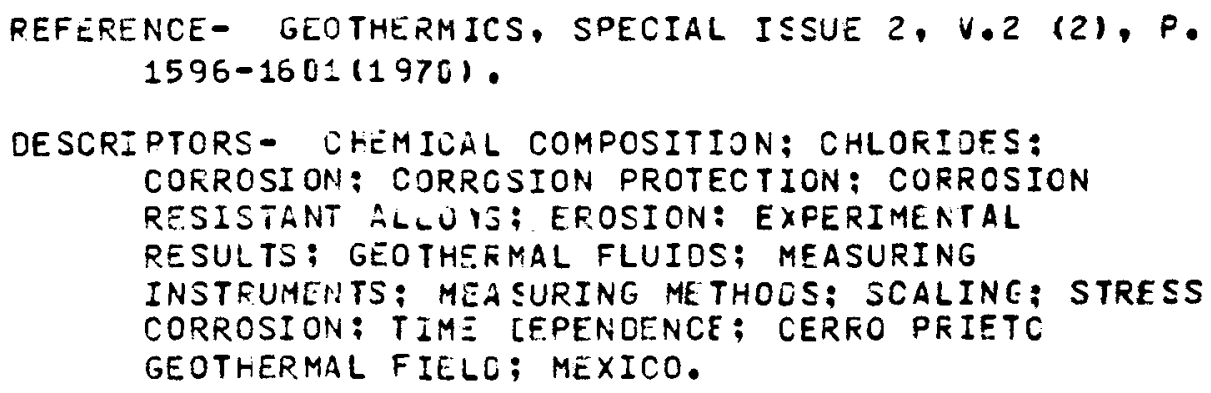

130

TREAC WELL 35

BRINE TREATMENT/SCALING

TITLE- POLYME?ISATION OF PHENOMENA OF SILICIC ACIO.

AUTHOR- TREAOWELL, W.C. [EIOGFNOESSISCHE TECHAISCHE HOCHSCHULE, ZURIEH (SWITZERLAND). INOREANIC LAB.J.

REFERENCE - TRANS. FAFADAY SOC., $V_{0} 31, \mathrm{P}$. $297-304(1 \subseteq 35)$.

DESCRIPTORS- CHEMICAL REACTIONS; ELECTRODIALYSIS: EXPEFIMENTAL RESULTS: MEASURING INSTRUPENTS: MEASURING METHOCS: FH ADJUSTRENT; PH DEPENDENCE; POLYMERIZATION; SILICA CHEMISTRY; TIME DEPENDENCE. 


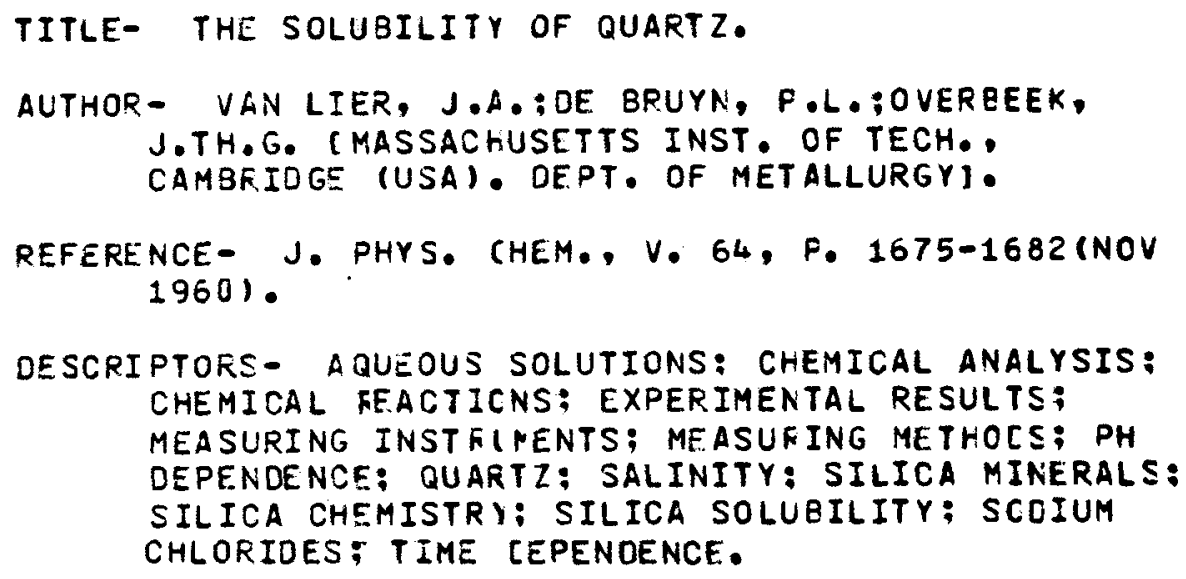

132

WAHL 74

BRINE TREATMENT/SCALING

TITLE- SILICATE SCALE CONTROL IN GEOTHERMAL BRINES--FINAL REPORT.

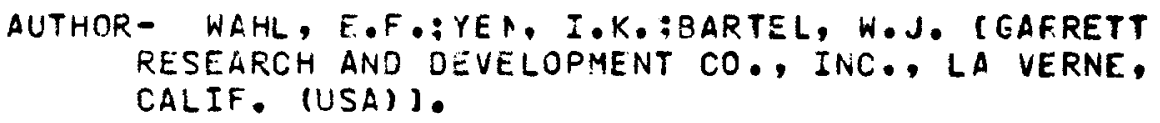

PEFERENCE- SILICATE SCALE CONTROL IN GEOTHEFMAL BRINES-F INAL REPORT. GR-D 74-048, GAFFETT RESEARCH ANO CEVELOPMENT COMPANY, INC., LA VERNE, CALIF., SEP 1974, $122 \mathrm{~F} .$.

DESCRIPTORS- ABRASION; AMORPHOUS SILICA; AQLECUS SOLUTIONS: BRINES: CARBCNATES: CHEMICAL ANALYSIS: CHALCE CONY: CHEMICAL COMPOSITICN; CHEMICAL FEACTICNS: BRINE TREATMENT; CONCENTRATION CE FENDENCE; CRYSTAL SEEDING; CRISTOBALITE: EXFERIMENTAL FESULTS; FLCW RATE; GEOTHERMAL BÑIAES: HEAT FLOW; HEAT TRANSFER; HEAT TRANSFER CGEFFICIENT; HYDROXIDES; MATHEMATICAL MOCELS: MEASURIAG INSTRUMENTS; MEASURING METHOCS: MONITOFING: PH ADJUSTMENT; PH VALUE: PH DEFENDENCE; PIPELINES; POLYMERIZATICN: PRECIPITATION: QUARTZ: SANO: SCALE COMPOSITION; SCALING: SCALING CCNTROL; SILICA MINERALS; SILICA CHEMISTRY: SILICA SOLURILITY: SILICATES; SURFACE EQUIPMENT; 
TEMPERATURE DEFENDENCE: TEMPERATURE LOEGING:

THEORETICAL TREATMENTS: TIME OEPENDEACE;

TRIDYMITE: WELL CHARACTERISTICS; WELL LCGGING;

WELL OPERATION: EAST MESA KGRA: CALIFOFNIA.

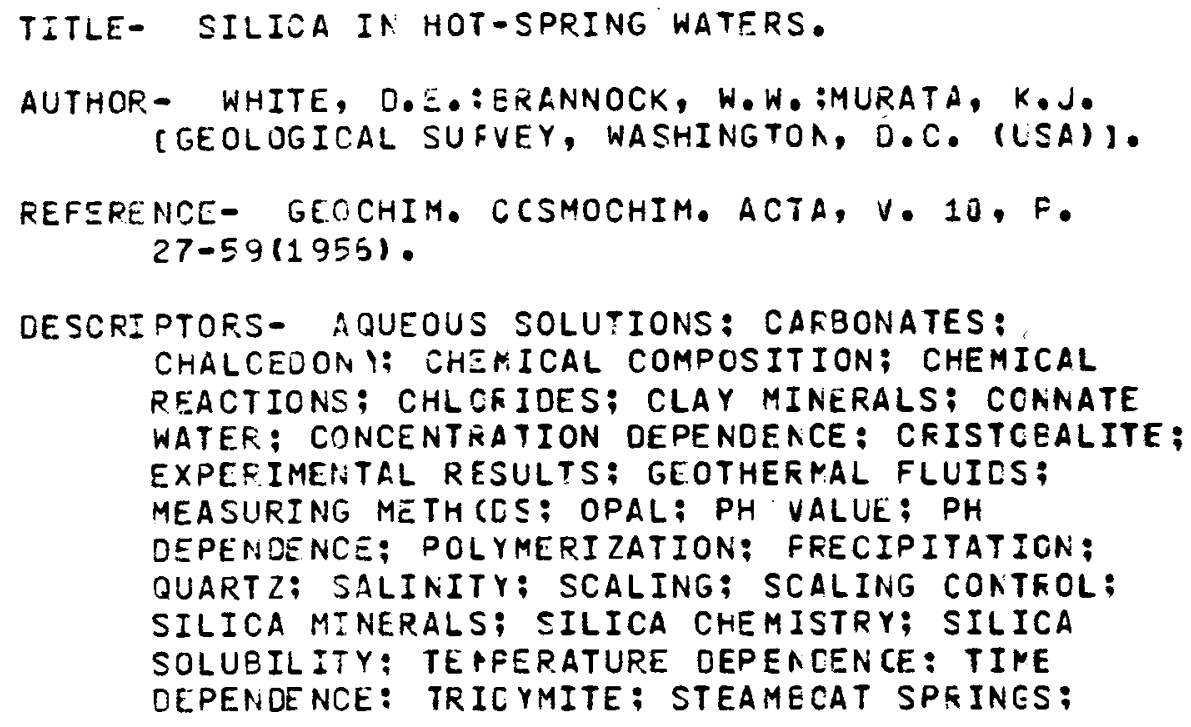

134

WILSON 74

BR INE TREATMENT/SCALING

BF: INE TREATMENT/CCRROSION

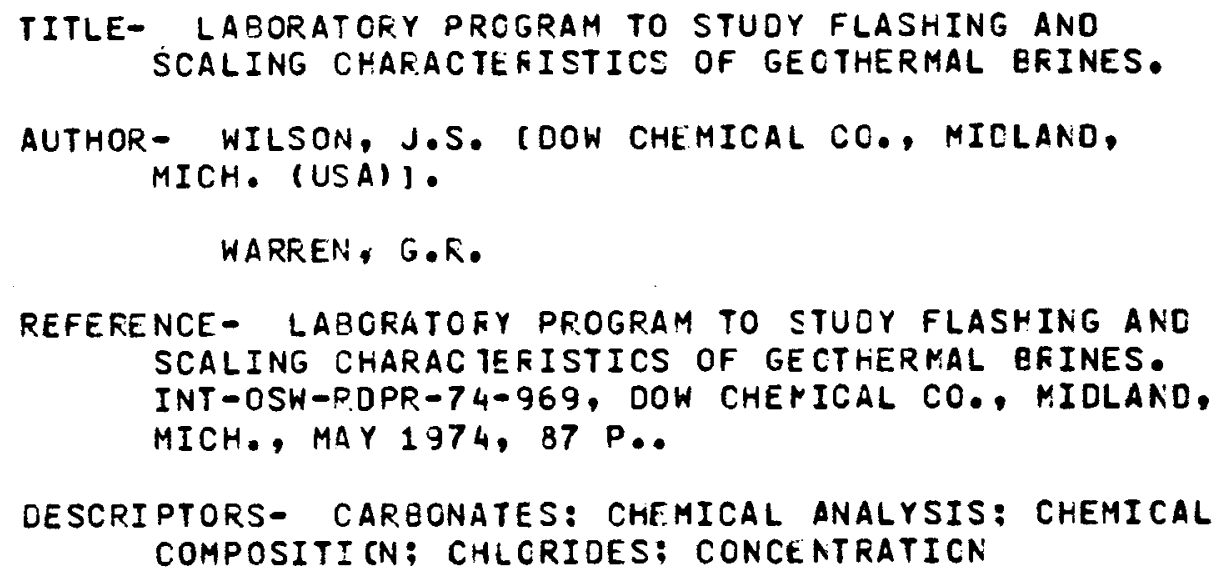


DEPENDENCE: CORFOSION; CORROSION RESISTANT ALLOYS: JESALINATION: EXPERIMENTAL RESULTS: FILTRATION; FLAS ING: FLOCCULATION; FLCW RATE; GEOTHERMAL BEINES; GEOTHERMAL FLUIDS; GROUND SUBSIDENCE: HYOROGEN SULFIOES; INJECTICN WELLS; MEASURING INSTRLLENTS; ME ASURING METHOCS; PH AOJUSTMENT; PH VALUE; PH DEFENDENCE; PITTING CORRCSION: PRE SSURE DEPENCENCE; SCALINE; SILICA MINEFALS: SILICA CHEMISTRY: SILICA SOLLEILITY; SULFIOES: SUSPENIED SOLIDS; TEMFERATURE DEPENDENCE: TIME OEPENDENCE: UNDERGROUNC DISPOSAL: WAST $=$ CISPOSAL: WASTE WATER: IYPERIAL VALLEY; CALIFCFNIA.

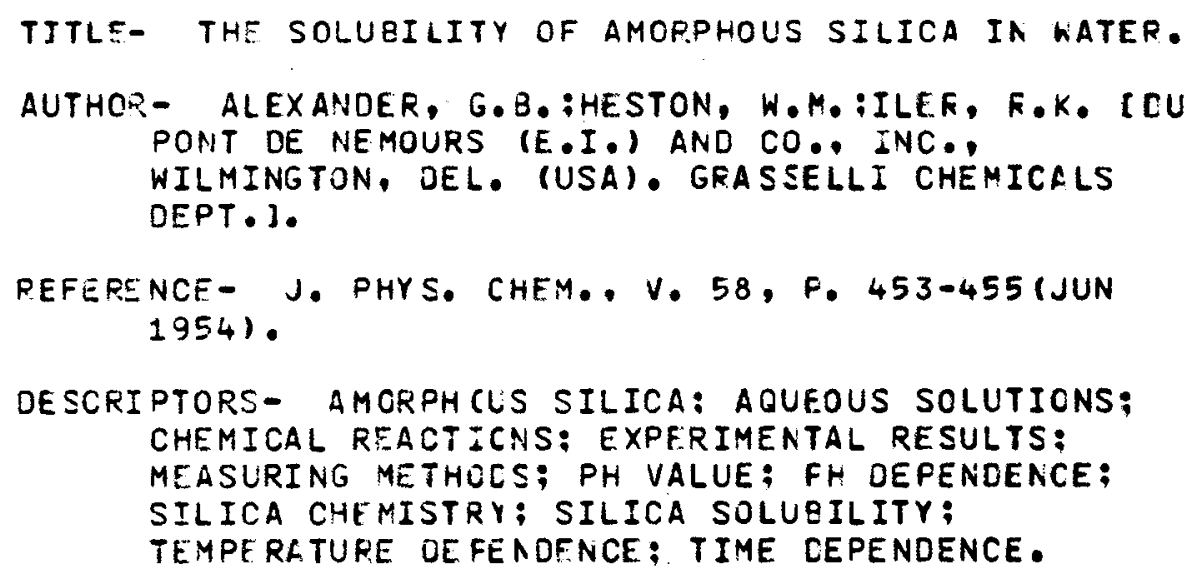

136

\section{ALEXANOER $54 B$}

BRINE TREATMENT/SCALING

TITLE- THE POLYMERIZAIION OF MONOSILICIC ACIC.

AUTHOR- ALEXANCER, G.B. (OU PONT CE NEMOURS (E.I.) AND CO.. INC., WILMINGTON, DEL. (USA). GRASSELLI CHEMICALS DEPT. \}.

REFERENCE - AM. CHEM, SOC, J., V. 16, P. 2094-2C 96 (APF 1954). 


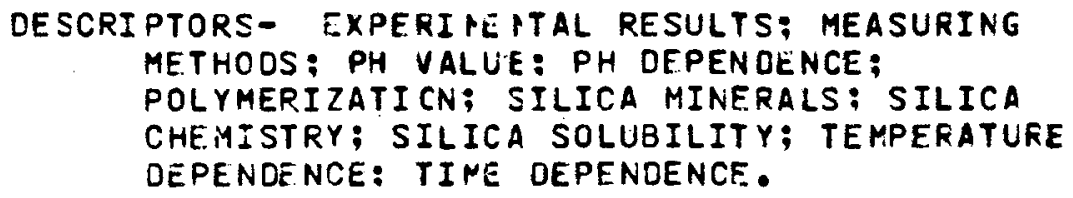

137

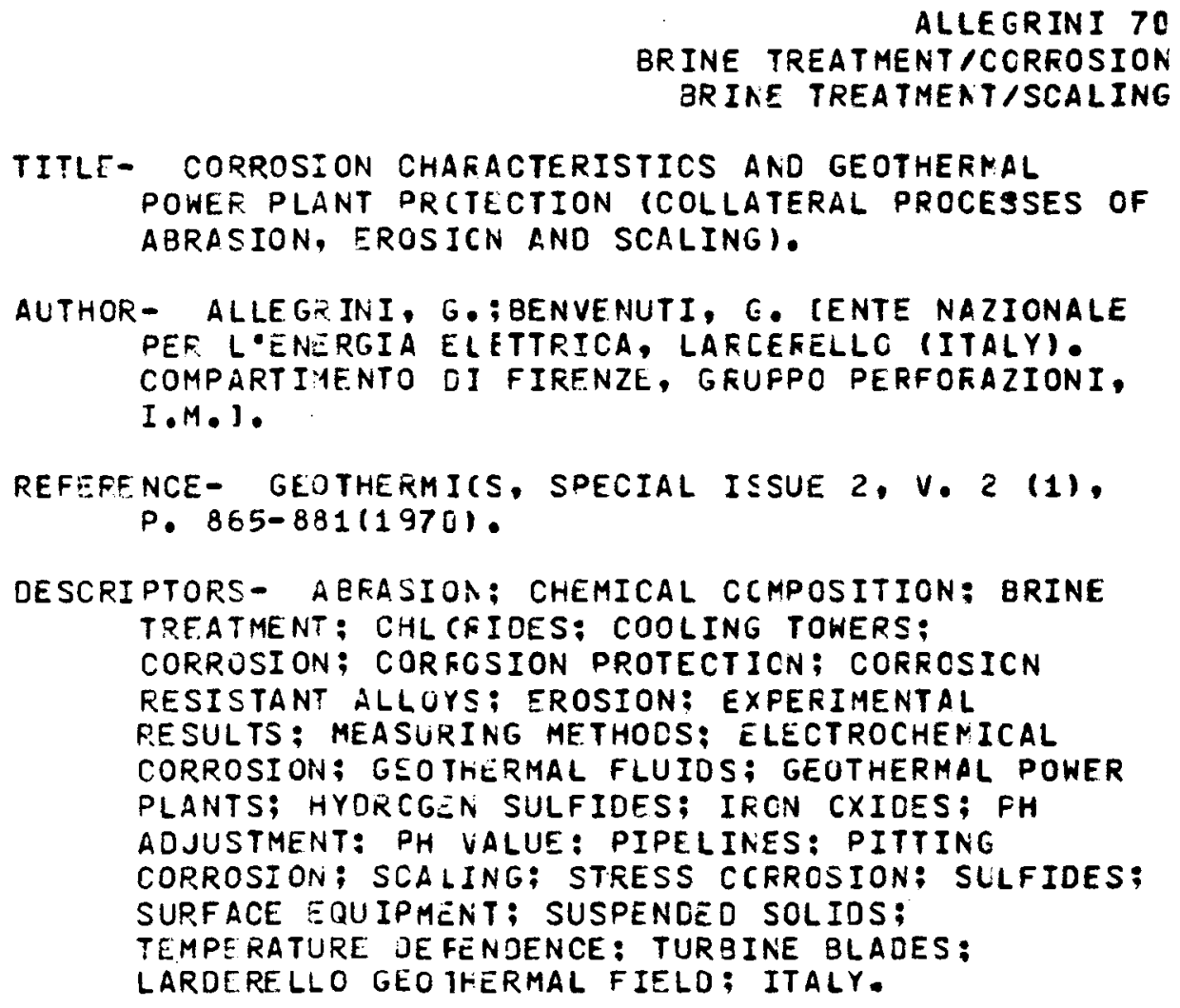

ALLEGRINI 70

BR INE TREATMENT/CCRROSION BR INE TREATMEAT/SCALING

TITLE- CORROSIOA RESISTANCE OF METALS IN HOT BRINES-A LITERATURE REVIEW.

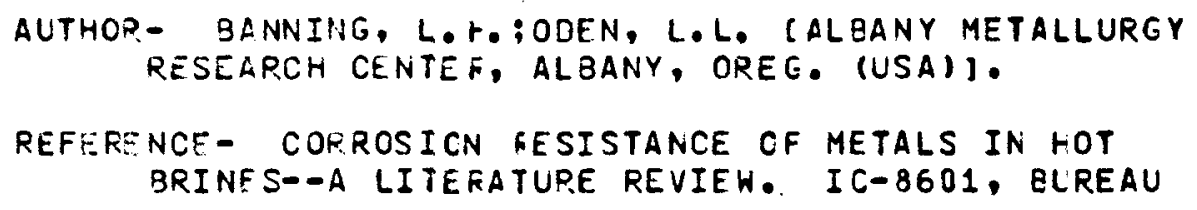




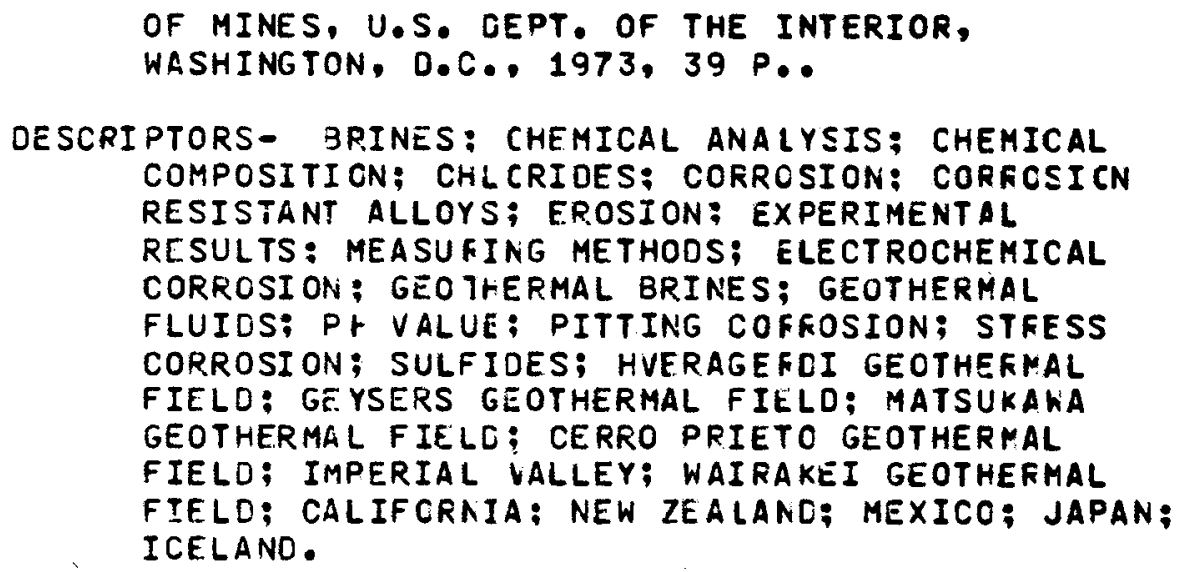

139

EEHRMAN 40

BRINE TREATMENT/SCALING

TITLE- REMOVAL OF SILICA FROM WATER.

AUTHOR- BEHRMAN, A.S.;GUSTAFSON, H. [INTERNATIONAL

FILTER CO.. CHICAGO, ILL. (USA)].

REFERENCE- IND. ENG. CHEM., V. 32 (4), P.

$468-472$ (APR 1940$)$.

DESCRIPTORS - BRINE TREATMENT: EXPERIMENTAL RESULTS: MEASURING METHOCS; FLOCCULATION; FLCCCLLATING AGENTS: HEAT TRANSFER: HYDROXIDES: IFON CXIDES: METALS; PH AOJUSTMENT; PRECIFITATION; SCALING; OESCALING; SILICA MINERALS.

140

TITLE- COMMENTS ON THE POSSIBLE EFFECTS OF ACCITIVES ON SCALINE BY GECTHERMAL BRINES.

AUTHCF- CATALANC, E.: IILL, J.H. CCALIFORNIA UNIV., LIVERMORE (USA). LAWRENCE LIVERPORE LAE.I•

REFERENCE- COMMENTS CN THE POSSIBLE EFFECTS CF ADOITIVES ON SCALING BY GEOTHERMAL BRINES. M.S. . UCQL-5175E, CALIFORNIA UNIV. . LAWRENCE LIVERMORE LAB., LIVERMORE (USA), FEE 1975, 7 


\begin{abstract}
DESCPIPTORS - ADOITI VES:; CARBONATES: CHEMICAL REACTIONS; CORFCSION; GEOTHEKMAL BRINES; HYDROXIDES: 11ETALS: PH ADJUSTMENT: PH DEPENDENCE: FOLYMERIZATION; FRECIPITATICN; SCALING; SCALINE CONTROL; SILICA MINERALS; SILICA CHEMISTFY; SLLFIOES; THERMODYNAMICS.
\end{abstract}

\author{
ELLIS E4 \\ BRINE TREATMENT/SCALING \\ TITLE- NATURAL HYOROTHERMAL SYSTEMS AND EXPERIMENTAL \\ HOT-WATER/ROCK IATERACTIONS. \\ AUTHOR- ELLIS, A.J.:MAHON, W.A.J. CCEFARTMENT OF \\ SCIENTIFIC AND INDUSTRIAL RESEARCH, PETCNE (NEW \\ ZEALANDI. CHEMI!TRY OIVISIONI. \\ REFERENCE- GEOCHIM. COSMOCHIM. ACTA, V. $28, F$. \\ $1323-1357(1964)$. \\ DESCRIPTORS- AMGRPHOIS SILICA: CHEMICAL ANALYSIS; \\ CHEMICAL COMFOSITION; CHLORIDES; CONCENTRATION \\ DEPENOENCE: CRISTOBALITE: ELEVATEO PRESSURE: \\ EXPERIMENTAL RESULTS: GEOTHERRAL BRINES; \\ HYDROGEN SULFIUES; MEASURING METHOOS; GLARTZ; \\ ROCK-FLUID INTERACTIONS: ROCKS: SILICA \\ MINEFALS: SILICA CHEMISTRY; SILICA SOLLEILITY; \\ ELEVATED TEMPERATURE; TEMPERATURE DEFENCENCE; \\ TIME DEPLNDENCE; NEW ZEALANO.
}

142

FCSTER 61

BRINE TREAT MENT/CORROSION

\author{
TITLE- COFROSION INVESTIGATIONS IN HYDROTHERMAL \\ MEDIA AT WAIRAKEI, NEW ZEALAND.
AUTHOR- FOSTER, P.K.:MARSHALL, T.;TOMBS, A. COEPARTMENT OF SCIENTIFIC ANO INOUSTRIAL RESEARCH, WELLIKGTON (NEW ZEALANDI. OCRINION LAB. J. \\ REFERENCE- PROCEECIAGS OF THE UNITEO MATIONS \\ CONFERENCE ON NEW SOURCES OF ENERGY. VOLUME 3 , \\ GEOTHERMAL ENERG I--II. UNITEO NATICNS, NEW \\ YORK, $1964, V .3$, GEOTHERMAL ENERGY--II, \\ P.18E-195. \\ DESCRIPTORS- CARBONATES: CATHOOIC DEPOLARIZATION: \\ CHLORIDES; CORFCSION: CORROSICN PROTECTION: \\ CORROSION RESI STANT ALLOYS; EROSION;
}


EXPEF.IMENTAL RESULTS; GEOTHERMAL BRINES; HYDROGEN SULFIDES: MEASURING METHODS: MCDERATE PRESSURE: PITTING CORROSION: STRESS CORFOSION; SULFIDES: ELEVATED TEMPERATURE; MODERATE TEMPERATURE; TEMIERATURE CEPENDENCE: TIME DEPENDENCE; TUREINE BLADES; WAIRAKEI GECTHERMAL FIELD: NEW ZEALAND.

143

FCURNIER 62

BRIAE. TREATMENT/SCALING

\author{
TITLE- THE SOLUEILITY OF CRISTOBALITE ALCNE THE \\ THREE-PHASE CUFVE, GAS PLUS LIQUID PLUS \\ CRISTOBALITE. \\ AUTHOR- FOURNIER, R.O.:ROWE, J.J. [GEOLOGICAL \\ SURVEY, WASHINGTCN, D.C. (USA)]. \\ REFERENCE- AM. MINERAL., V. 47, P. 897-912(19E2). \\ OESCRIPTORS - CRISTOAALITE: EXPERIMENTAL RESULTS: \\ FREE ENERGY; MEA SURING METHOCS; SILICA \\ MINERALS: SILICA SOLUBILITY: MODERATE \\ TEMPERATURE: ELEVATED TEMPERATURE: TEMFERATURE \\ DEPENDENCE; THERMODYNAMICS.
}

144

HCFFMANN 75

BR INE TREATMENT/SCALING

BRINE TREATMENT/CCRROSION

TITLE- BRINE CHEMISTFY--SCALING AND CORFCSICN. GEOTHEKMAL RESEARCH STUDY IN THE SALTON SEA REGION OF CALIFCFNIA.

AUTHOR - HOFFMANN, M.F. [CALIFORNIA INST. OF TECH., PASADENA (USA). ENVIRONMFNTAL QUALITY LAB.).

REFERENCE- BRINE CHEMISTRY--SCALING AND CORFOSION. GEOTHERMAL RESEARCH STUDY IN THE SALTOA SEA REGION OF CALIFCENIA. EQL MEMORANOUM NC. 14, CALIFORNIA INST. OF TECH. , ENVIRONMENTAL QUALITY LAB., PASADENA, CALIF. (USA), JUL 1975, 48 P..

DESCRIPTORS- BINAFY FLUID SYSTEMS; BRINES; CARBONATES: CATHODIC DEPOLARIZATION: CHEMICAL 
COMPOSITION; CHERICAL REACTIONS: BRINE

TREATMENT; CHL CFIDES: CORROSION; CORROSICN RESISTANT ALLOYS; CRYSTAL SEECING; ECONCMICS; EXPERIMENTAL RESULTS: MEASURING METHOCS: FLOCCULATING AGENTS; FLOW RATE; GEOCHEMISTRY; GEOTHEP.MAL BEINES: GEOTHERMAL FLUIDS; GEOTHERMAL RESER VOIRS: GEOTHERMAL WELLS: HYDROGEN SULFICES; LEGAL ASPECTS; MINERAL RECOVERY; OPALINE SCALE; PH VALUE; FITTING CORROSION: PRECIFITATION: RESERVOIR PROFERTIES: SCALING: SCALING CONTROL; SCFUBEERS; SILICA. MINEPALS; SILICA CHEMISTRY; SILICA SOLUBILITY; STRESS CORROSICN: TEMPERATURE DEPENDENCE: TOTAL FLOW SYSTEM: TUREINE BLAOES; SALTON SEA GEOTHERMAL FIELC; CALIFORNIA.

145

HUANE 75

BRINE TREATMENT/SCALING

TITLE- THE REMOVAL OF AQUEOUS SILICA FROM CILLTE AQUEOUS SOLUTICN.

AUTHOR- HUANG, C.P. (DELAWARE UNIV., NEWARK (USA). DEPT. OF CIVIL (NGINEERING).

REFERENCE- EAPTH PLANET. SCI. LETT., V. 27, F. $265-274(1975)$.

DESCRIPTORS- $A Q U E C U S$ SOLUTIONS: CHEMICAL REACTIONS; CONCENTRATION DE FENUENCE; EXFE.RIMENTAL RESULTS; FREE ENERGY; MEA SURING INSTRUMENTS: MEASURING METHODS: FH VALUE: PH DEPENCENCE; SILICA MINERALS; SILICA CHEMISTRY: SILICA SOLUEILITY; SILICATES; SUSFENDED SOLIOS.

146

ILEF 55

BR INE TREATMENT/SCALING

TITLE- THE COLLOID CHEMISTRY OF SILICA AND SILICATES.

AUTHOR- ILER, R.K. CCORNELL UNIV., ITHACA,

REFERENCE- THE COLLCID CHEMISTRY OF SILICA ANO SILICATES: CORNELL UNIVERSITY PRESS, ITHACA, NEW YORK, 1955, $\$ 24$ P.. 


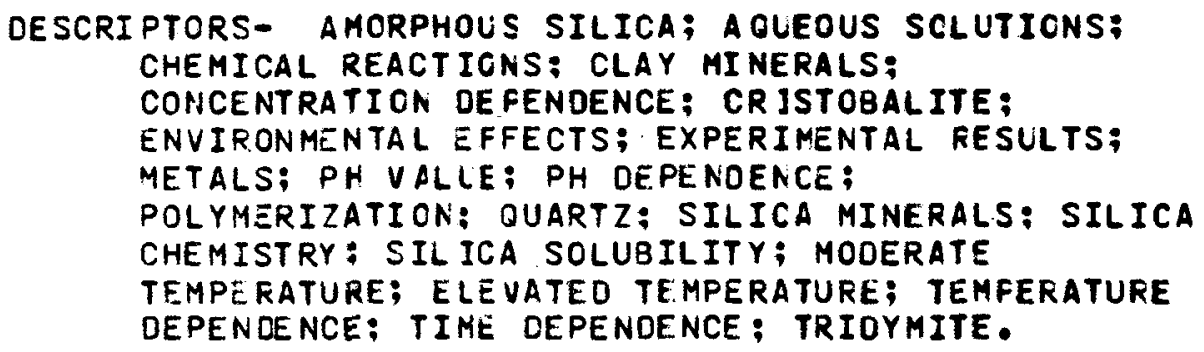

147

JACKSON 76

BEINE TREATMENT/SCALING

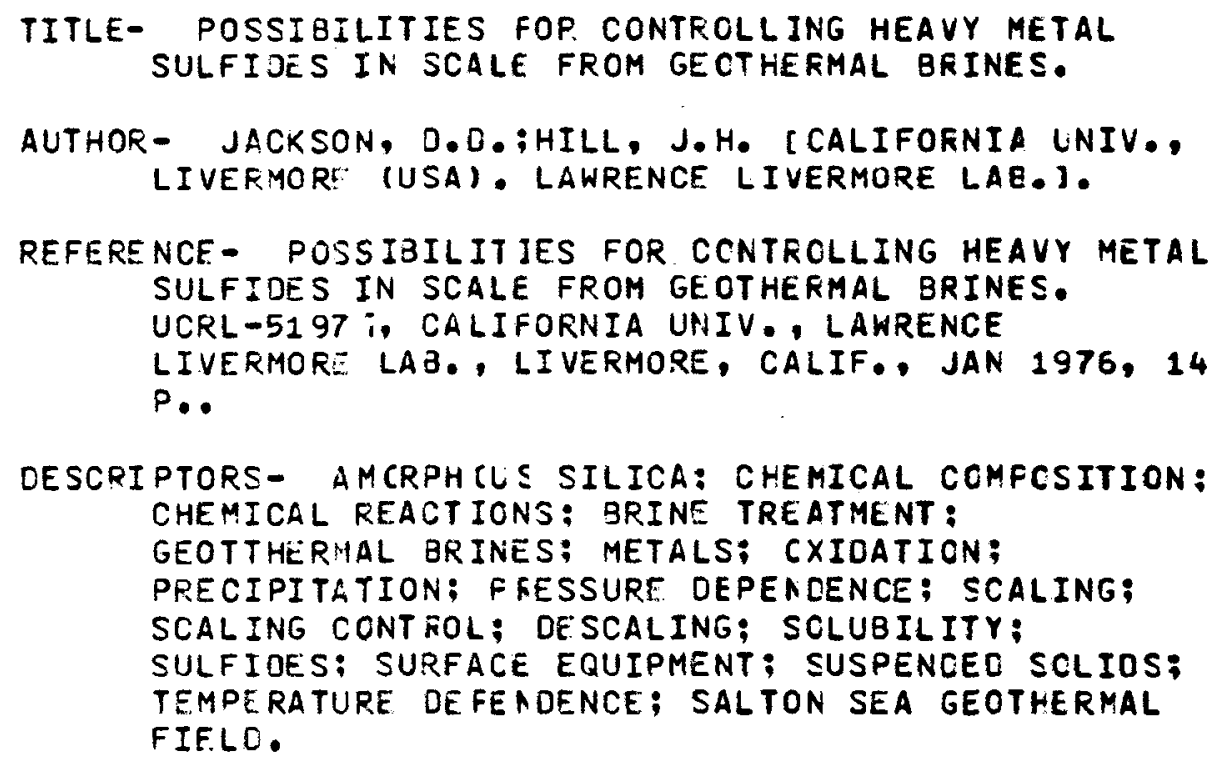

DESCRIPTORS - AMCRPHCLS SILICA: CHEMICAL COMFCSITION: CHEMICAL REACTIONS: BRINE TREATMENT: GEOTTHERMAL BRINES; METALS; CXIDATION; PRECIPITATION; FRESSURE OEPENDENCE; SCALING; SCALING CONTFOL; DESCALING; SCLUBILITY; SULFIOES; SURFACE EQUIPMENT; SUSPENCED SCLIOS; TEMPERATURE DEFEADENCE; SALTON SEA GEOTHERMAL FIELO.

148

TITLE- A PORTION CF THE SYSTEM SILICA-WATER.

ALTHOR - KENNEDY, G.C. [HARVARD UNIV., CAMBFILGE, MASS. (USA). GECLOGICAL MUSEUM).

REFERENCF- ECON. GEOL., V. 45, P. 629-653(1950).

DESCRIPTORS- AMCRPHCLS SILICA: ACLEOUS SOLUTICNS;

ELEVATED PRESSUFE: EXPERIMENTAL RESULTS;

GEOLOGY; GEOTHERMAL FLUIOS; HIGH PRESSURE; 
MEASURING INSTRLMENTS: MEASURING METHCCS: MODERATE PRESSURE: PRESSURE OEPENDENCE; GUARTZ; SILICA MINERALS; SILICA CHEMISTRY; SILICA SOLUBILITY: ELEVATED TEMPERATLRE; HIGH TEMPERATURE; TEMFERATURE CEFENDENCE; TIME DEPENDENCE.

149

KITAHARA 60

BRINE TREATMENT/SCALING

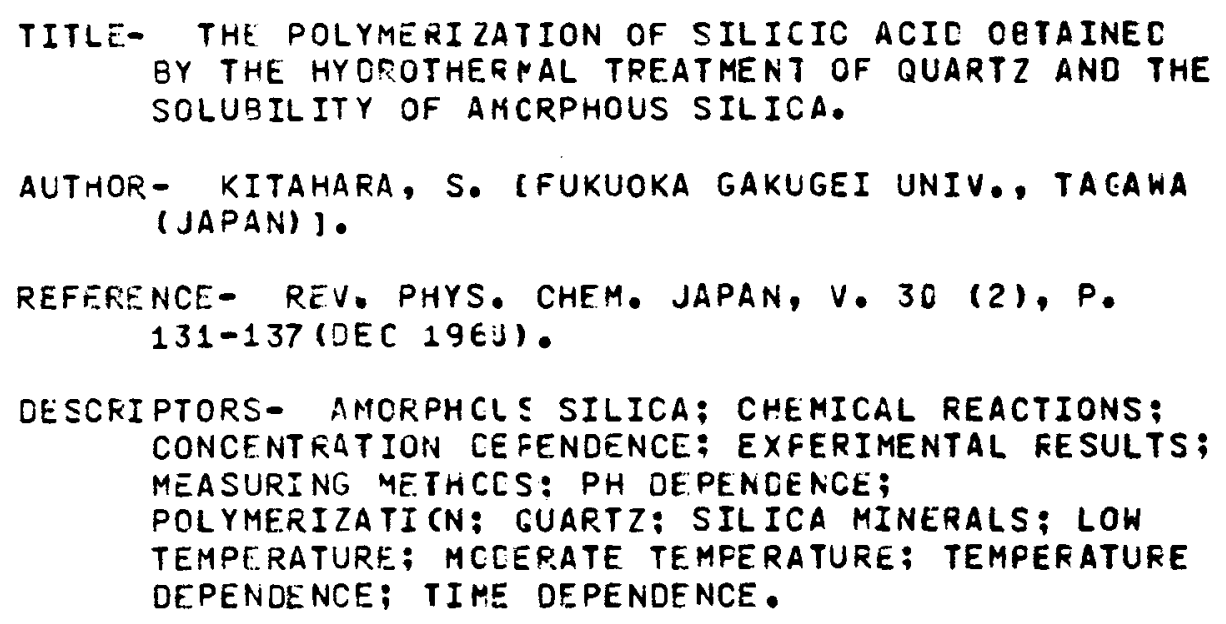

150

KITATARA 608

BR INE TREATMENT/SCALING

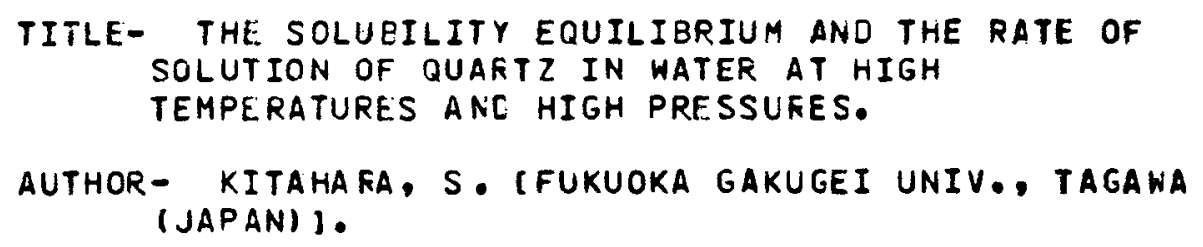

DESCRIPTURS- AQUEOUS SOLUTIONS: CHEMICAL REACTIONS: CONCENTRATION CE FENDENCE; ELEVATED PRESSURE: EXPERIMENTAL RESULTS; HIGH PFESSURE; MEASURING METHODS; PFESSUFE DEPENOENCE; QUARTZ; SILICA SOLUBILITY: SODIUM CHLORIDES; HIGH TEMFERATURE; TEMPERATURE DEFE ADENCE; TIME DEPENDENCE. 


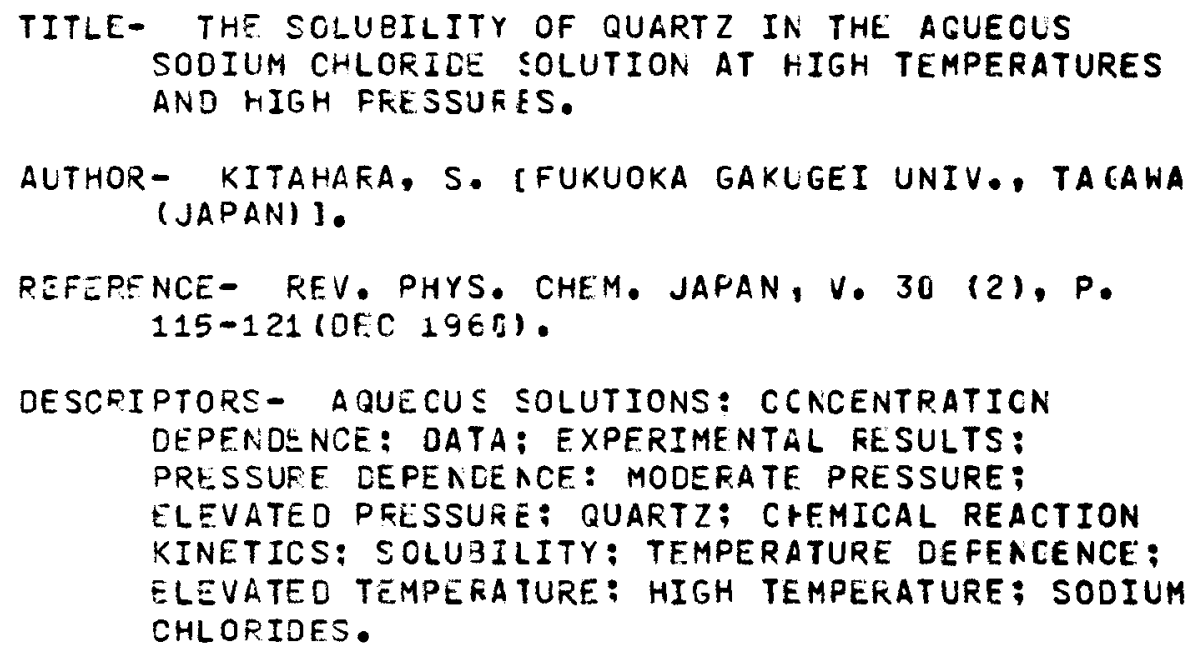

152

KRALSKOPF 56

BRINE TKEATMENT/SCALING

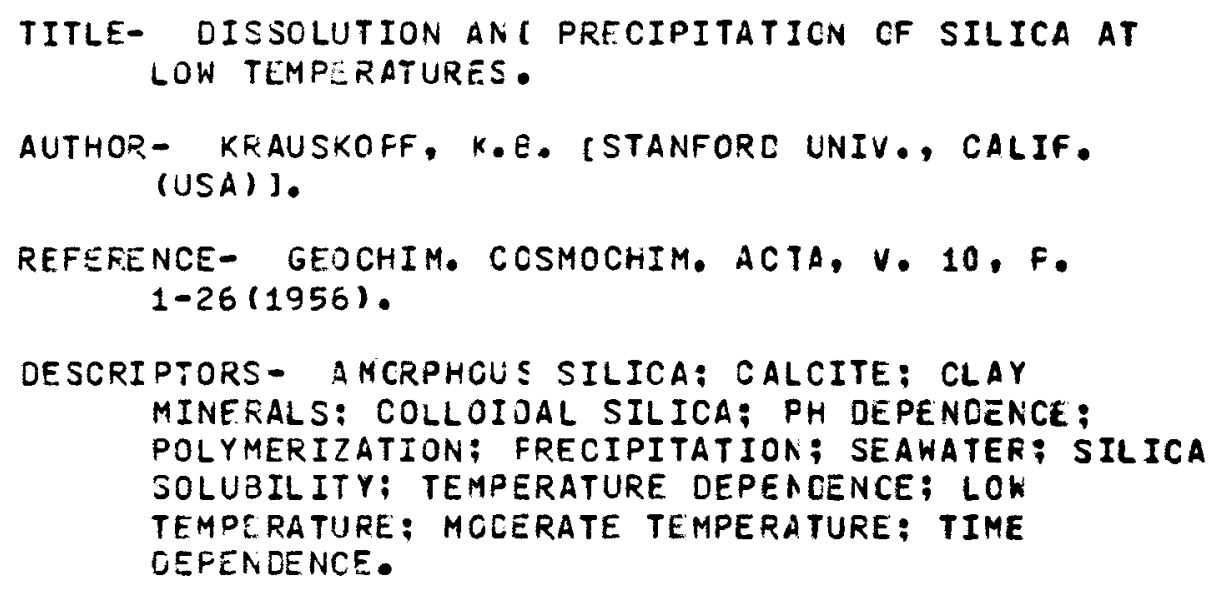


FLORKE 76

BR INE TREATMENT/SCALING

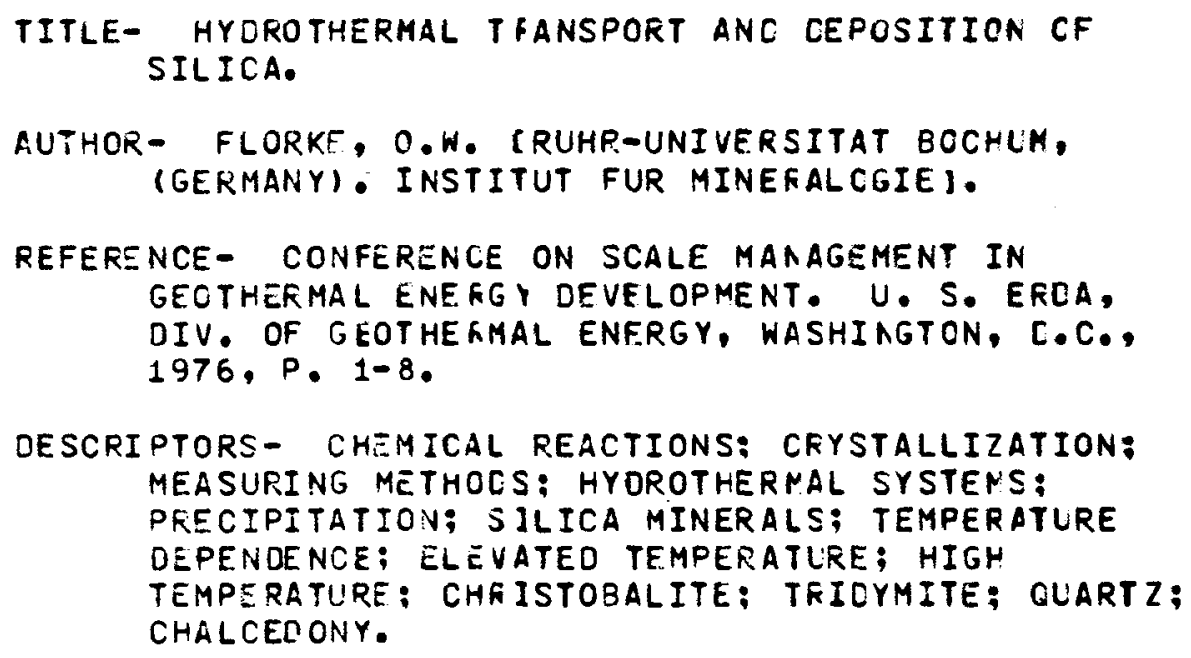

154

DOWNS 76

BR INE TREATMENT/SCALING

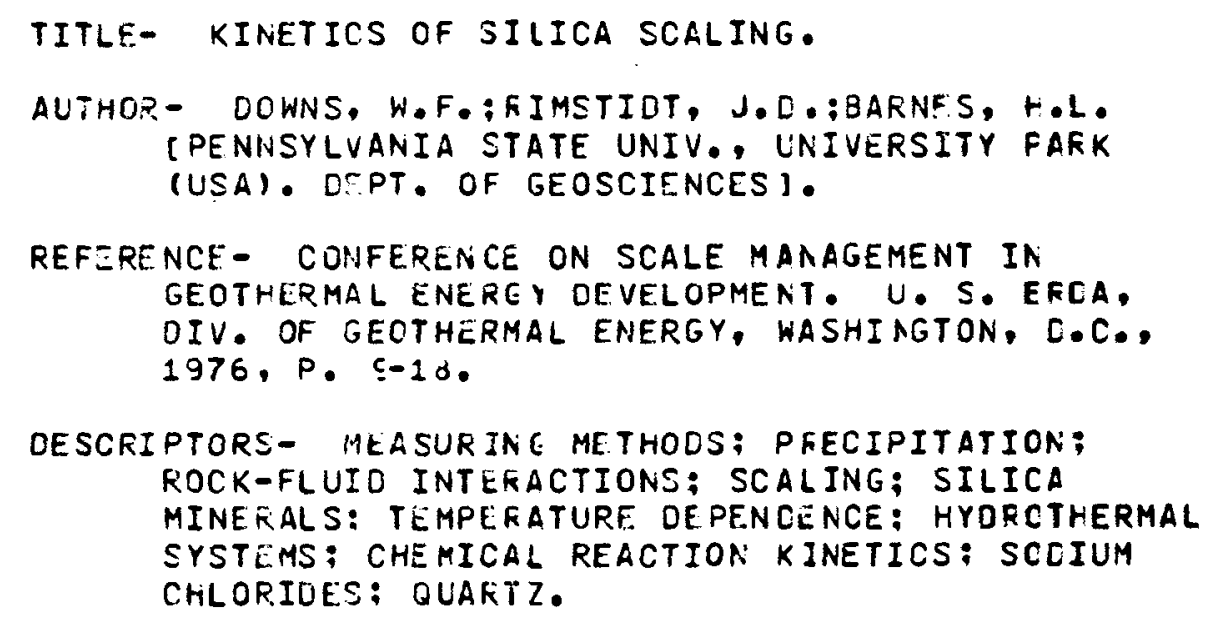


TITLE- THE SOLUEILITY OF AMORPHOUS SILICA AT HIGH TEMPERATURES ANC HIGH PRESSURES.

AUTHOR- FOURNIER, R.O. IGEOLOGICAL SURVEY, MENLO PARK, CALIF. (USAI).

PEFERENCE - CONFERENCE ON SCALE MANAGEMENT IN GEOTHERMAL ENERGY DEVELOPMENT. U. S. ERDA, DIV. OF GEOTHERMAL ENERGY, KASHINGTON, D.C.. 1976, P. 19-24.

DESCRIPTORS- AMORPHCUS SILICA; MEASURING METHODS; PRESSURE CEPENDENCE: HIGH PRESSURE; SILICA SOLUEILITY: TE FFERATURE DEPENCENCE; MOCERATE TEMPERATURE; ELE VATED TEMPERATURE.

156

HARVEY 76

BRINE TREATMENT/SCALING

TITLE- KINETICS OF SILICA CONDENSATION IN REINES.

AUTHOR- HARVEY, W.W.;MAKRIDES, A.C.;SLAUGHTER, J.;TURNER, M.J. IEIC CORPORATION, NEWTCA, MASS. (USA)).

REFERENCE- CONFERENCE ON SCALE MANAGEMENT IN GEOTHERMAL ENEFGY DEVELOPMENT. U. S. EROA, DIV. OF GEOTHERMAL ENERGY, WASHINGTON, C.C.. $1976, P .25-36$.

OESCRIPTORS- BRINES: MEASURING METHOOS: EEOTHERMAL FLUIOS: HUCLEATION: PRECIPITATION: SILICA MINEFALS: CHEMICAL REACTION KINETICS: PH DEPENDENCE; CONCENTRATION DEPENDENCE; TEMPERATURE DEPENDENCE: SILICIC ACID.

157

MESHER 76

BR INE TREATMENT/SCALING

\footnotetext{
TITLE- STUDIES ON THE IONIZATION EQUILIBRIA CF SILICIC ACID ANC POLYSILICATE EQUILIBRIA IN HIGH TEMPERATURE BFINES.

AUTHOR- ME SMEF, R.E.;EUSEY, F.H. COAK RICGE NATIONAL LAB.. TENN. (USA) I.
} 


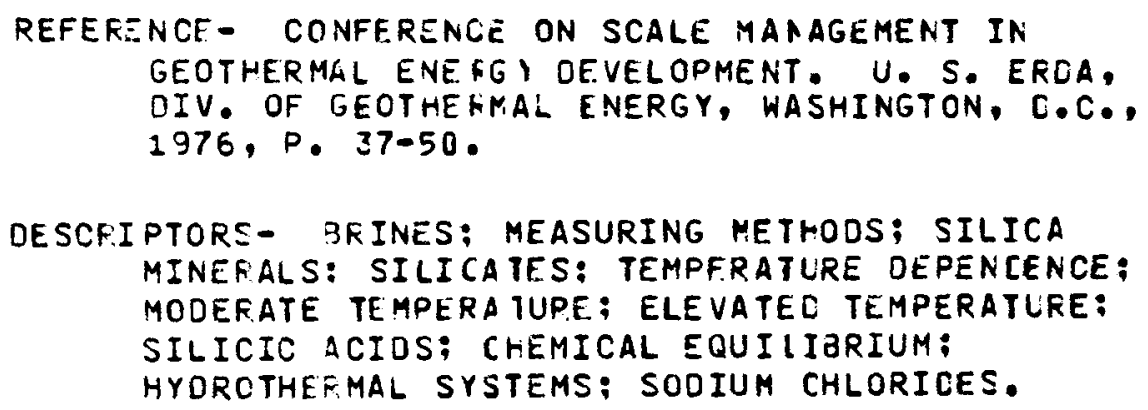

158

MICHELS 76

BRINE TREATMENT/SCALING

TITLE- MOLECULAR MECHANISMS OF SCALE CEFOSITION.

AUTHOP- MICHELS, C.E.:KEISER, C.D. [IDAHC NATIONAL ENGINEERING LAB.. IDAHO FALLS (USA)].

REFERENCE- CONFERENCE ON SCALE MANAGEMENT IN GEOTHERMAL ENERE, DEVELOPMENT. U. S. EROA, OIV. OF GEOTHE FMAL ENERGY, WASHINGTCN, C.C., 1976 , P. E1-58.

OESCRIPTORS- CRYSTALLIZATION: NUCLEATION; PRECIPITATION: SCALING: SURFACE PROPERTIES: FOULING; GEOLOGIC STRUCTURES: MOLECULAR STPUCTURE:

TITLE- PROBLFMS OF SILICA SCALING AT CERRO FEIETO GEOTHERMAL PCWER STATION.

AUTHOR- MERCAOO, S.;GLIZA, J. CCOMISION FEDERAL DE ELECTRICIDAD, PE XICO CITY (MEXICO)) •

REFERENCE- CONFERENCE ON SCALE MANAGEMENT IN GEOTHERMAL ENEREI DEVELOPMENT. U. S. ERCA, DIV. OF GEOTHERMAL ENERGY, HASHINGTON, D.C., 1976, P. 59-88.

DESCRIPTORS - GEOTHERMAL FLUTOS; SCALING; SILICA MINERALS: TURBINE BLADES: CERRO PRIETO GEOTHERAL FIELD; FOULING. 


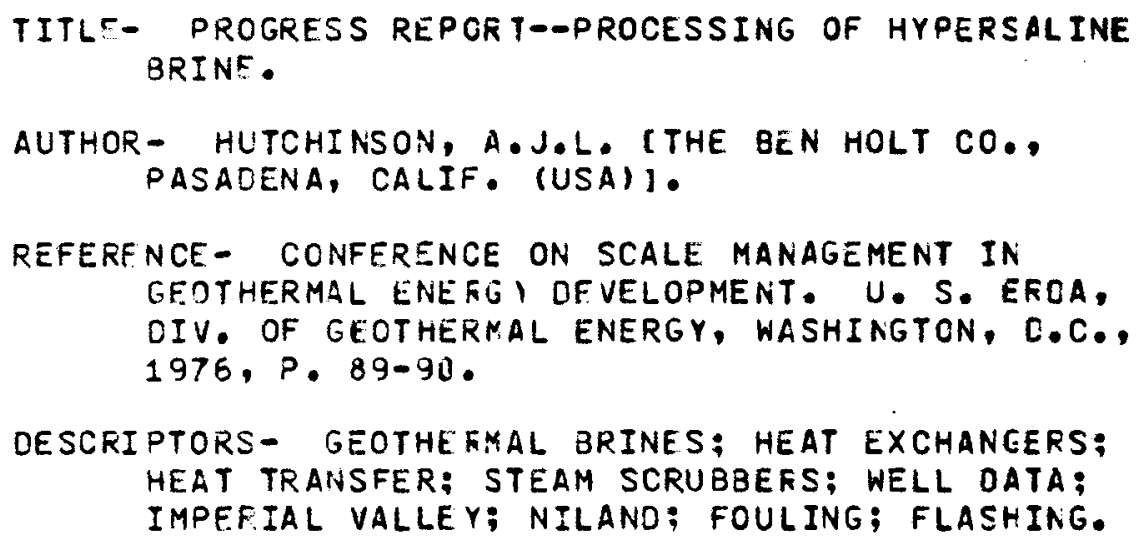

161

MC KAY 76

BRIAE TREATMENT/SCALING

TITLE- EXPERIENCE, FLANS, ANO A MIXED FLCW EXPANDER.

AUTHOR- MC KAY, R.A. (JET PROPULSICN LAB., FASAOENA, CALIF. (USA)I.

SPRANKLE, R.S. [HYOROTHERMAL POWER CO., LTD., MISSION VIEJO, CALIF, IUSAIJ.

REFERENCE- CONFERENCE ON SCALE MAAAGEMENT IN

GEOTHERMAL ENERG Y DEVELOPMENT. U. S. ERDA, DIV. OF GEOTHERMAL ENERGY, WASHINGTCN, C.C., 1976, P. \$1-10 C.

DESCRIPTORS - CORROS ICN PROTECTION; OISSOLVEO SOLIDS; EROSION: GEOTHERMAL FLUIDS; FRECIPITATICN; SCALING: SCALIAG CONTROL: FLOW EXPANDER: TURBINES; MEXICO; FLUID FLOW; GEOTHERMAL POWER PLANTS; PILOT FLANTS. 


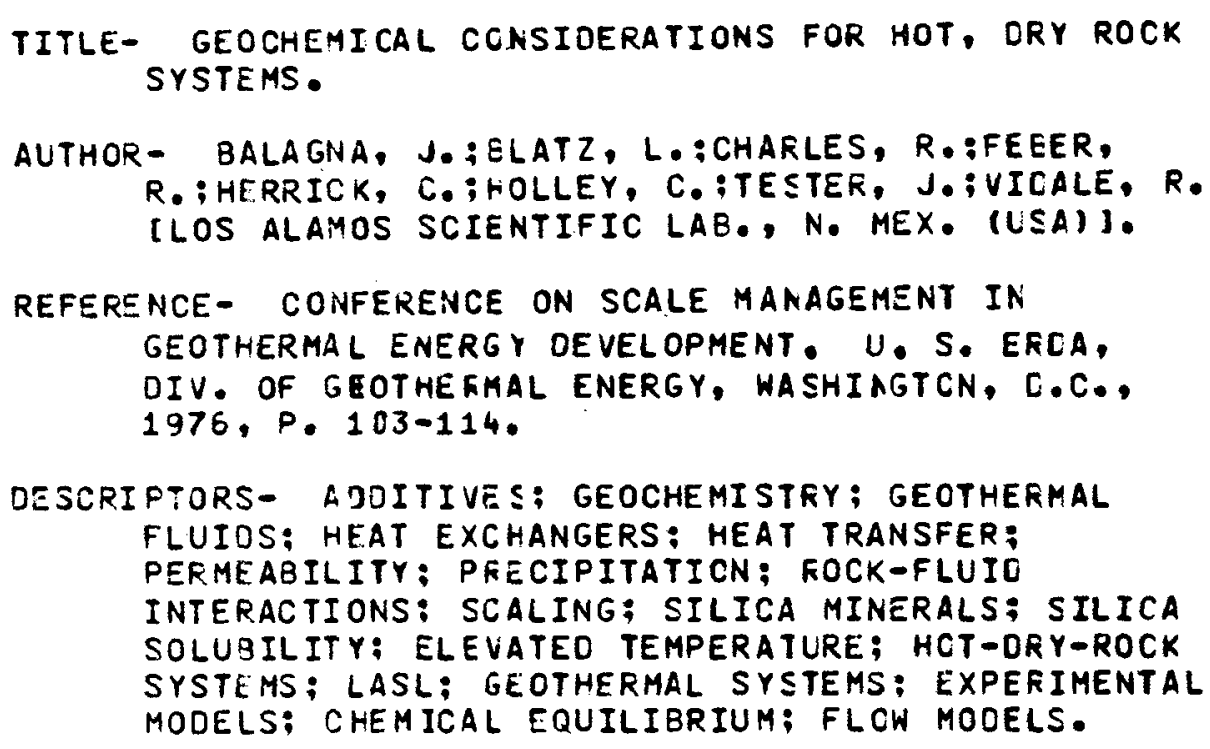

163

COLLINS 76

BRINE TREATMENT/SCALING

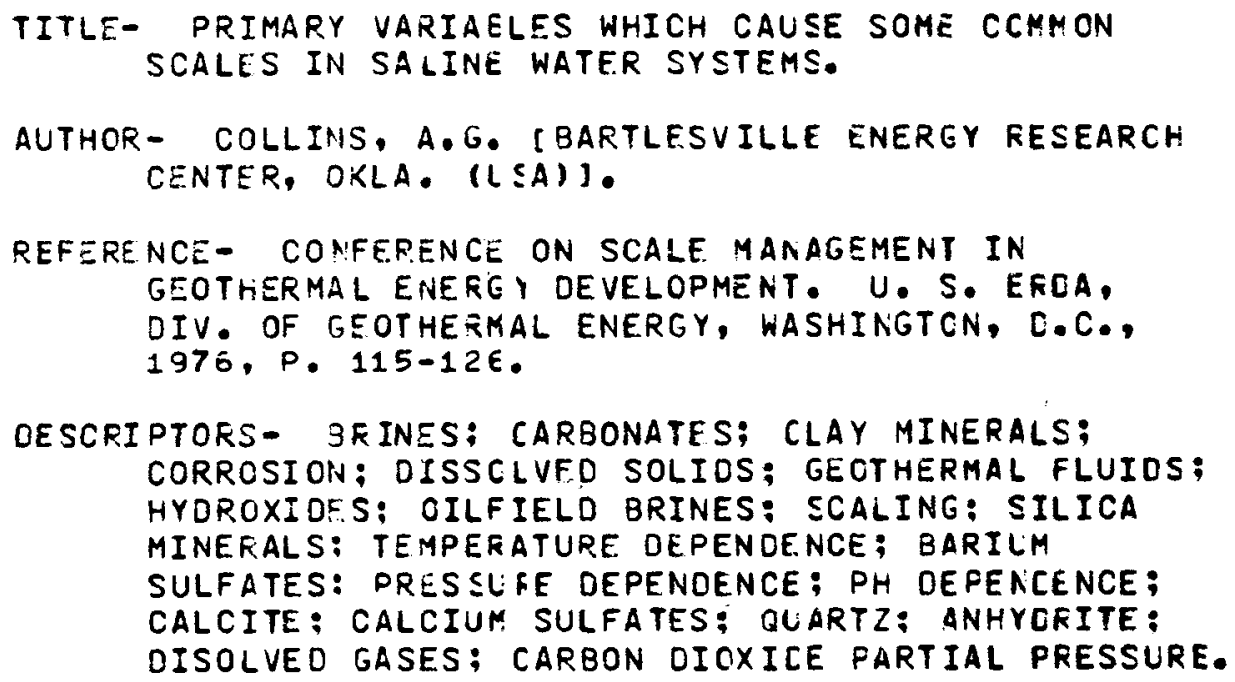

OESCRIPTORS - 3FINES: CARBONATES; CLAY MINERALS; CORROSION: DISSCLVFO SOLIOS; GEOTHERMAL FLUIOS; HYDROXIDES; OILFIELD BRINES: SCALING: SILICA MINERALS: TEMPERATURE DEPENDENCE; BARILIM SULFATES: PRES SLIFE DEPENDENCE; PH DEFENCENCE; CALCITE: CALCIUN SULFATES: QUARTZ: ANHYORITE: DISOLVEO GASES; CARBON OIOXILE FARTIAL PRESSURE.

164

NEE DHAM 76

BRIAE TREATMENT/SCALING

TITLE- SCALING IN B CTH HIGH-ANO LCK-SALINITY ERINES. 


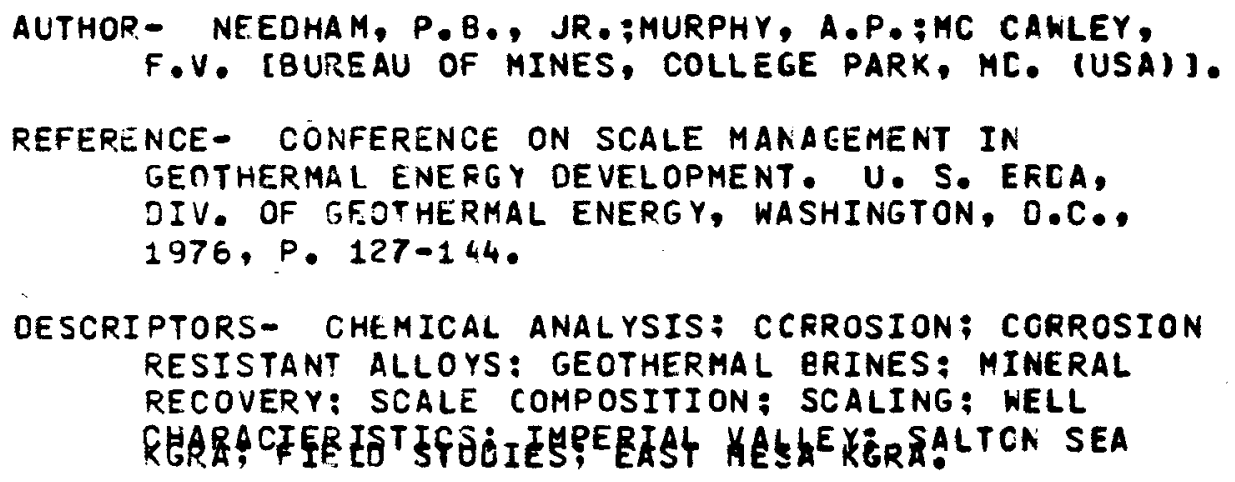

165

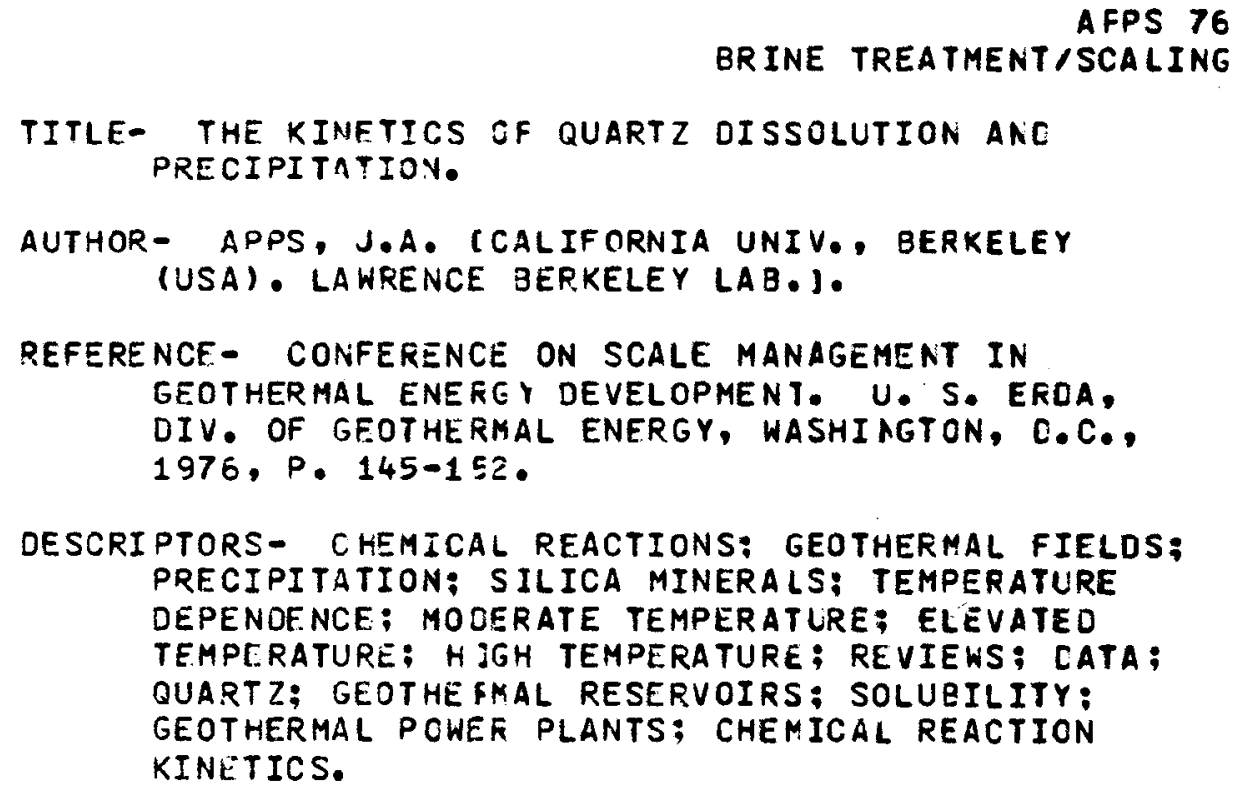

166

TITLE- CHEMICAL CONTEOLS ON THE. OFAL-A TO OFAL-CT TRANSFORMATION.

AUTHOR- KASTNER, M. :KEENE, J.B. ISCRIPPS INST: OF OCEANOGRAPHY, LA JOLLA, CALIF• (USA)). 


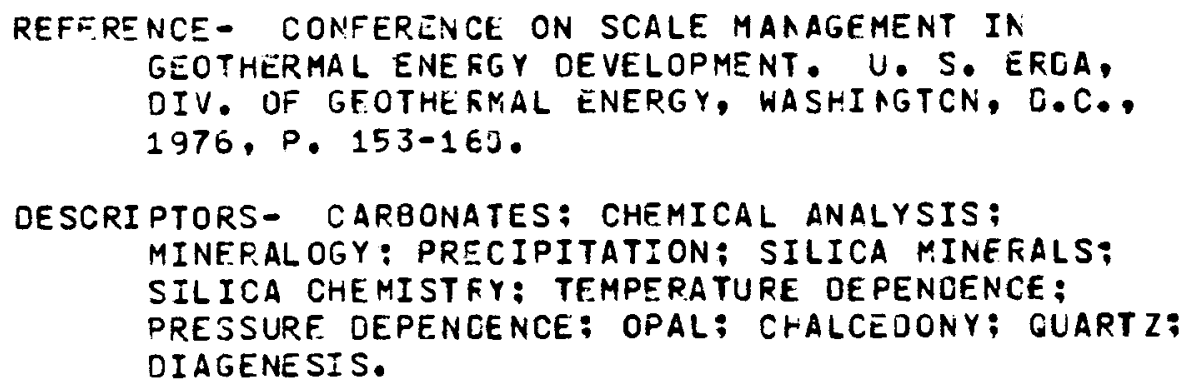

167

GRENS 76

BRINE TREATMENT/SCALING

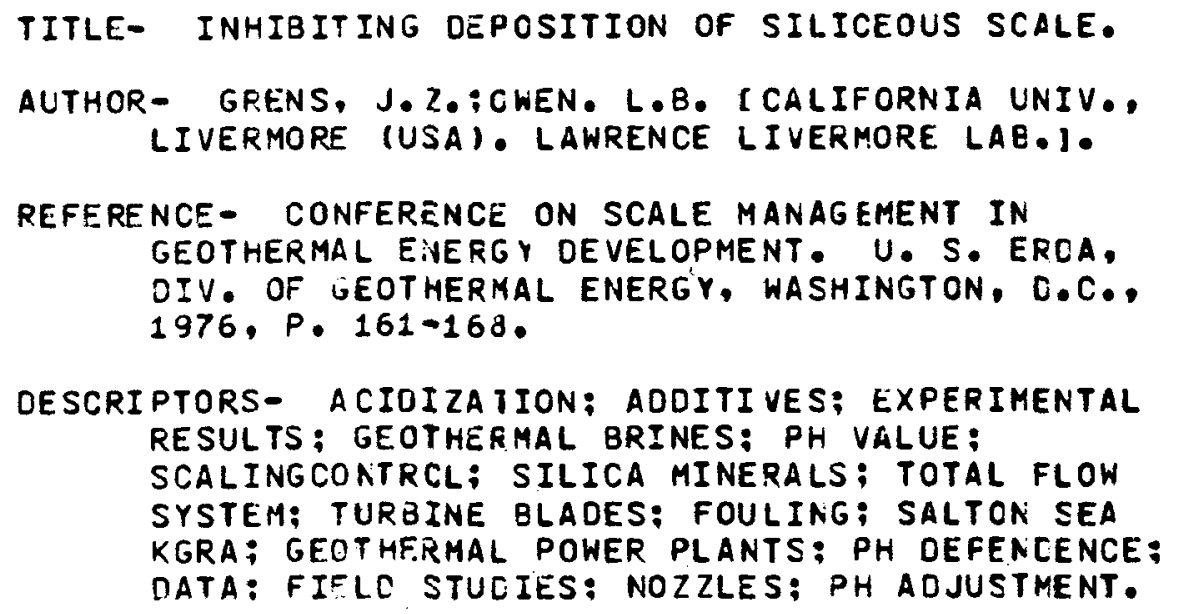

168

VETTER 76

BRINE TREATMENT/SCALING

TITLE- WHAT WE DO NOT KNOW ABOUT SCALING.

AUTHOR- VETTER; O. [LNION OIL FESEARCH CENTER, BREA, CALIF. (USA)].

REFERENCE- CONFERENCE ON SCALE MANAGEMENT IN GEOTHERMAL ENERG Y DEVELOPMENT. U. S. ERDA, OIV. OF GEOTHERMAL ENERGY, WASHINGTCN, C.C., 1976, P. $169-170$.

DESCRIPTORS - ECONOMICS: GEOTHERMAL FLUIOS: SCALING; SCALING CONTKOL; FIELO STUOIES; DATA. 
TITLE- SILICA PRECIPITATION AND SCALING IN CYNAMIC GEOTHERMAL SYSTERS.

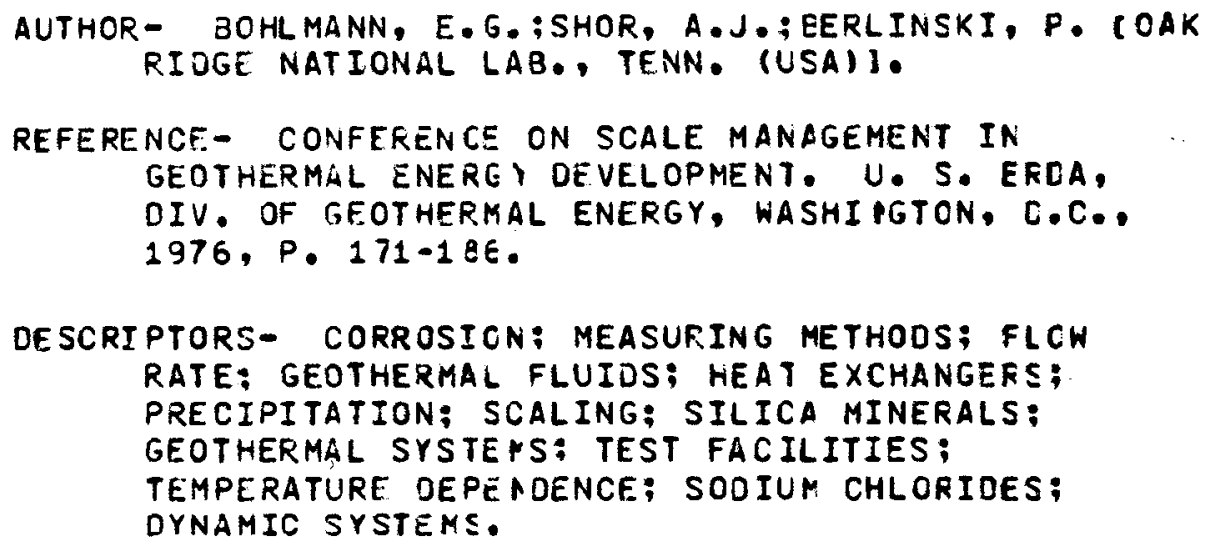

170

\section{BRINE TREATMENT/SCALING}

TITLE- THE DEVELOPMENI OF LIQUID-FLUIOIZED FEC HEAT EXCHANGEFS FOR CONTROLLING THE OEPOSITION OF SCALE IN GEOTHERHAL APPLICATIONS.

AUTHOR- ALLEN, C.A.;ERIMMETT, E.S•:MC ATEE, F.E. [IDAHO NATIONAL ENGINEERING LAB., IOAHO FALLS (USA) ].

REFERENCE- CONFERENCE ON SCALE MANAGEMENT IN GEOTHERMAL ENEFGY DEVELOPMENT . U. S. ERCA, DIV. OF GLOTHERMAL ENERGY, WASHINGTON, C.C., 1976 , P 187-1 ऽ8.

DESCRIPTORS- ECONOMICS: EXPERIMENTAL RESULTS; HEAT TRANSFER; HEAT TRANSFER COEFFICIENT; SCALING; SCALING CONTROL; GEOTHERMAL SYSTEMS: FLLIDIZED BED HEAT EXCHANGER; P.AFT RIVEF KGRA: EAST MESA KGRA; TEST FAC ILITIES. 


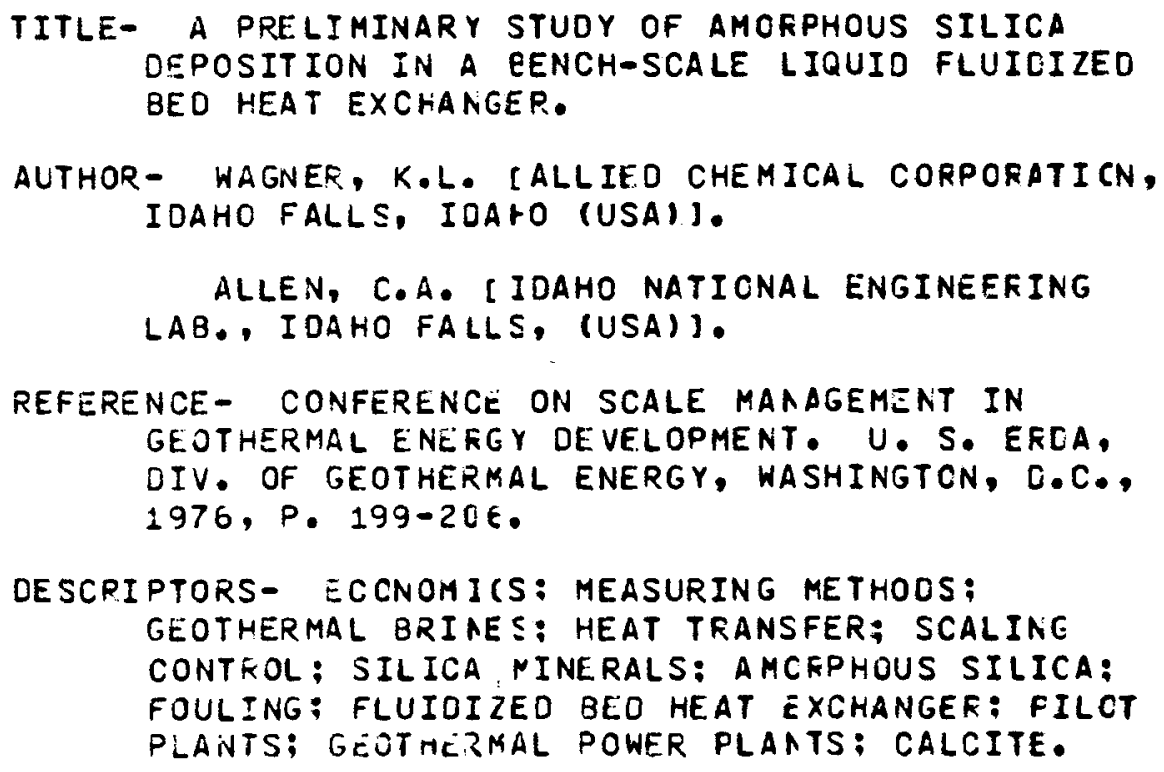

172

WILSON 76

BRINE TKEATMENT/SCALING

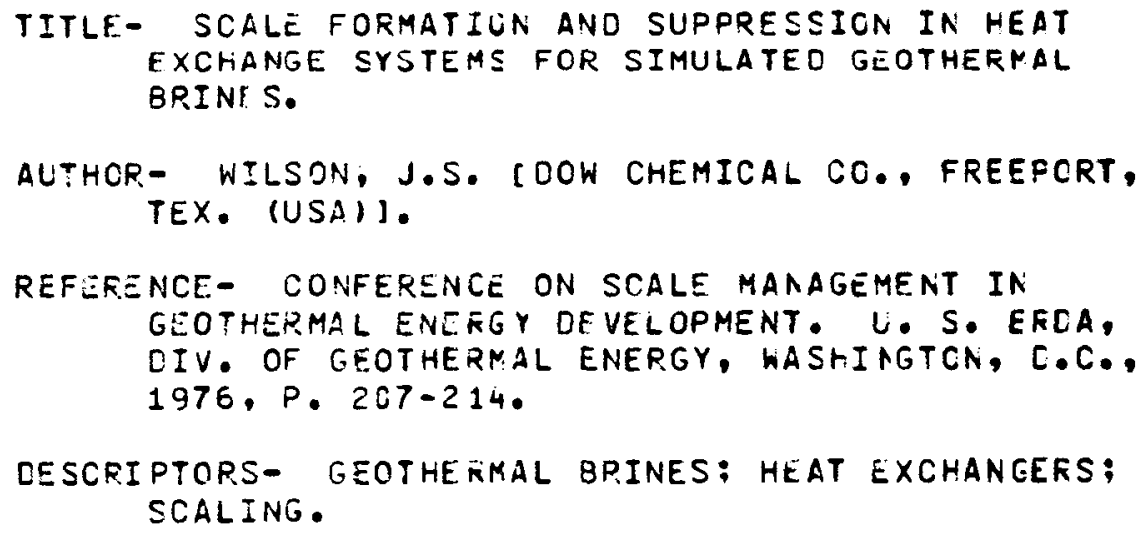




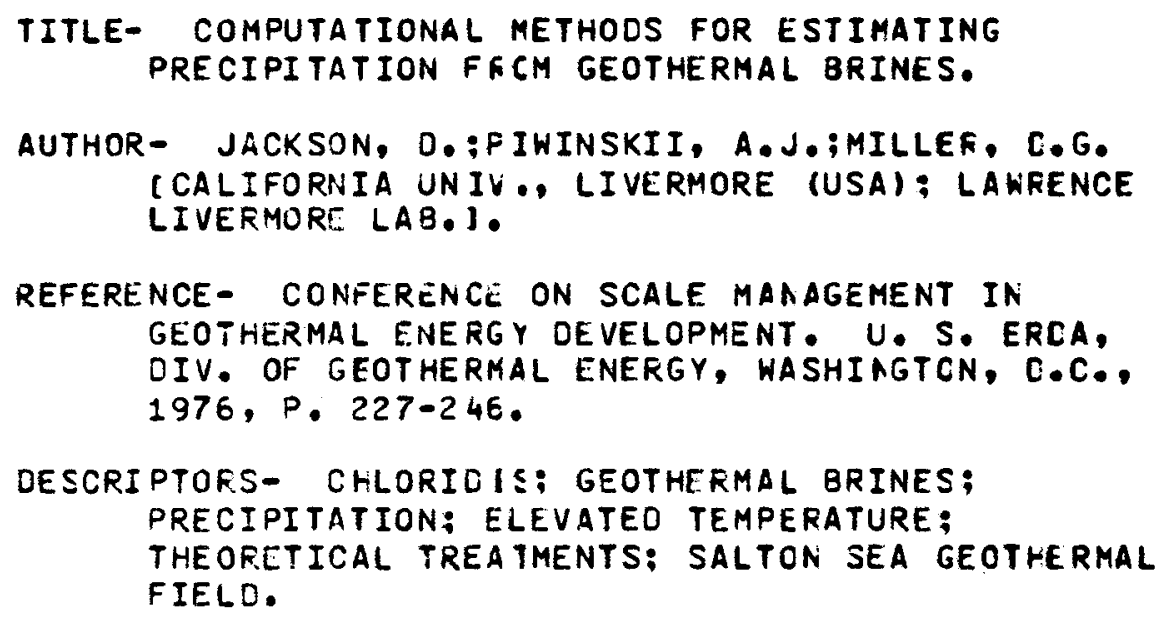

174

TITLE- THE GEOSCALE COMPUTER MCOEL FOR GEOTHEFMAL PLAIT SCALINE ANI CORROSION ANALYSES.

AUTHOR - SHANNON, C.N.;WALTER, R.A.:LESSOR, O.L. [BATTELLE PACIFIC NORTHWEST LAB., RICHLAND, WASH. (USA)].

REFERENCE- CONFERENCE ON SCALE MANLGEMENT IN GEOTHERMAL ENERG, DEVELOPMENT. U. S. ERDA. DIV. OF GEOTHEFMAL ENERGY, WASHINGTCN, O.C., $1976, P .215-2$ CE.

DESCPIPTORS - CHEMICAL COMFCSITION: COMPUTER CALCULATIONS: COFROSION: GEOTHERMAL BRINES: GEOTHERMAL POWER PLANTS; MATHEMATICAL MOCELS; SCALING.

TITLE- CAVITATION CESCALING TECHNIQUES FCR GEOTHERMAL APPLICATIONS.

AUTHOR- THIRUVENGADAM, A.P. IOAECALEAN ASSOCIATES, INC.. WOOCBINE, MD. (USA)]. 


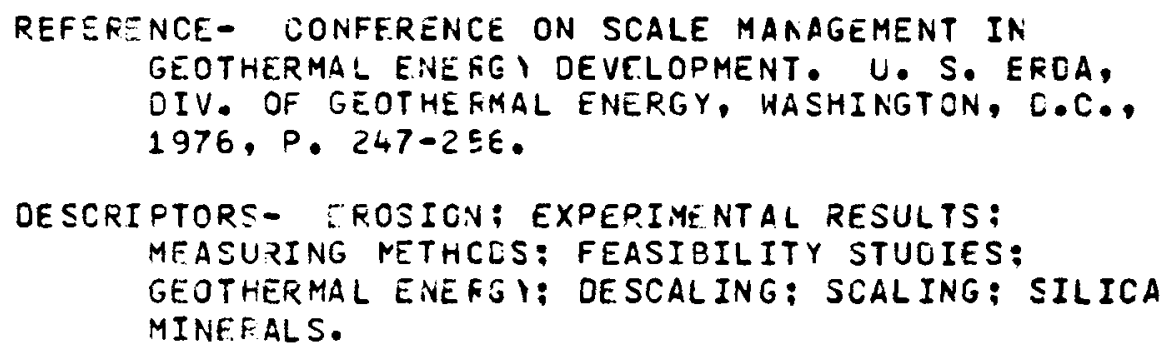

176

REEBEF 76

BRINE TREATMENT/SCALINE

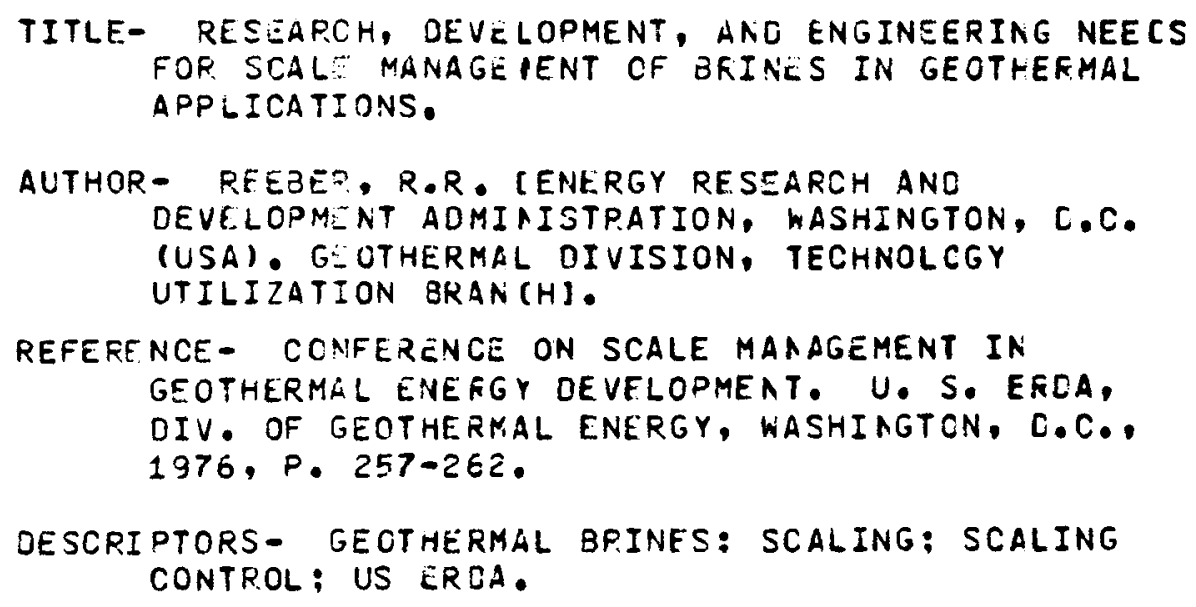

TITLE- TASK OF OEVELCPING CAVITATION DESCALINE TECHNIOUES AND HARDWARE FOR SCALED-UP AND STOPPED-UP GEOTHERMAL HEAT EXCHANGER TUEING AND PIPES......

AUTHOR - SMITH, R.A. (ED.)

REFERENCE- GEOTHERMAL REPORT, V. 5 (21), P. 3-4 (NOV 1. 19761 .

DESCRIPTORS- CAVITATIIN EROSION; GEOTHERMAL ERINES; GEOTHCRMAL ENEFGY: HEAT EXCHANGERS; DESCALING; SCALING: SCALING CONTROL: SILICA MINERALS; NILAND. 
WANG 74

GRIN: TREATMENT/SFENT FLUIC CISPOSAL

BRINE TREATMENT/SCALINE

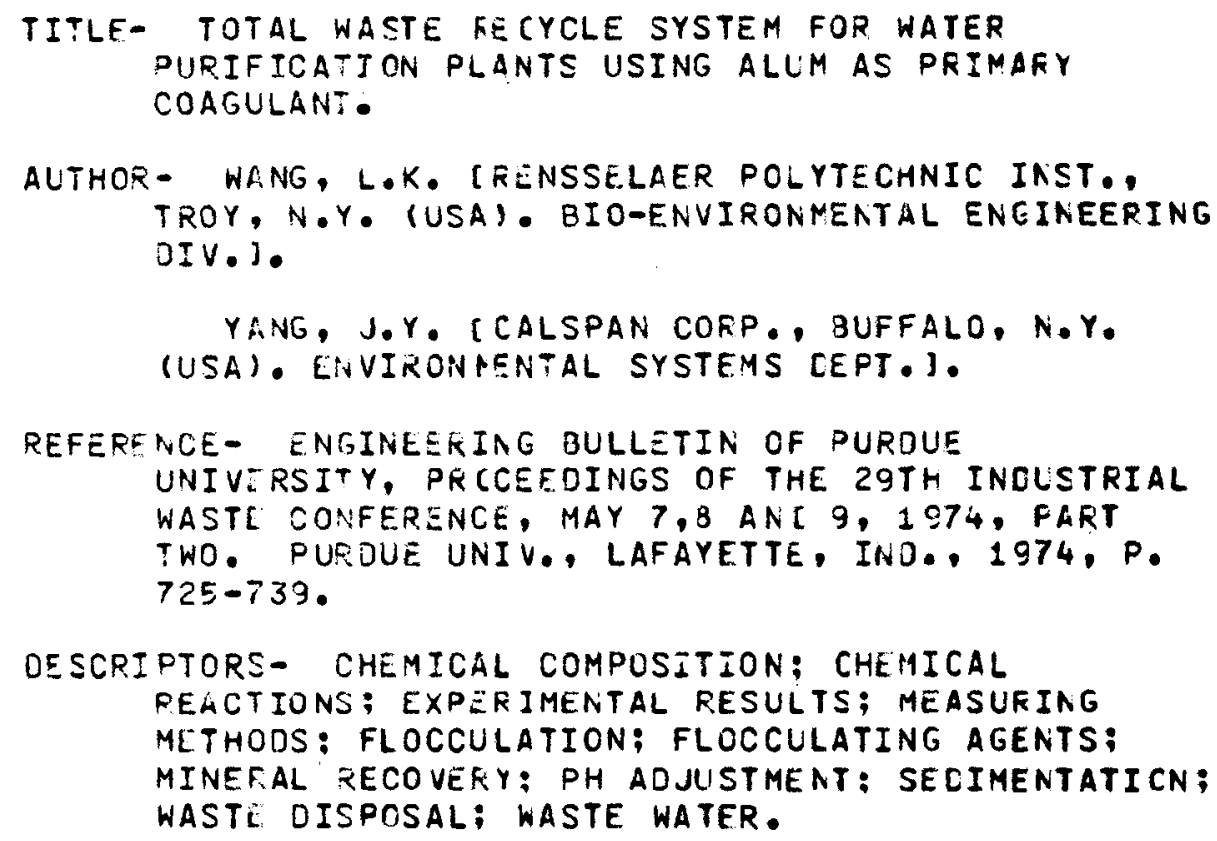

179

TITLE- GEOTHERMAL CHEMICAL ENGINEEFING.

AUTHOF - AXTMANN, F.C.:PECK, L.B. [FRINCETON UNIV., N.J. (USA): DEFT. OF CHEMICAL ENGINEERINGI.

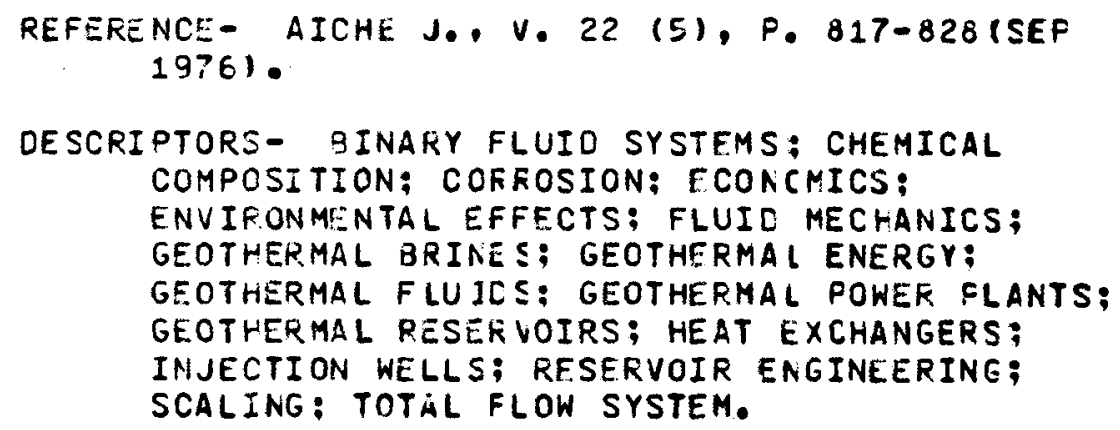




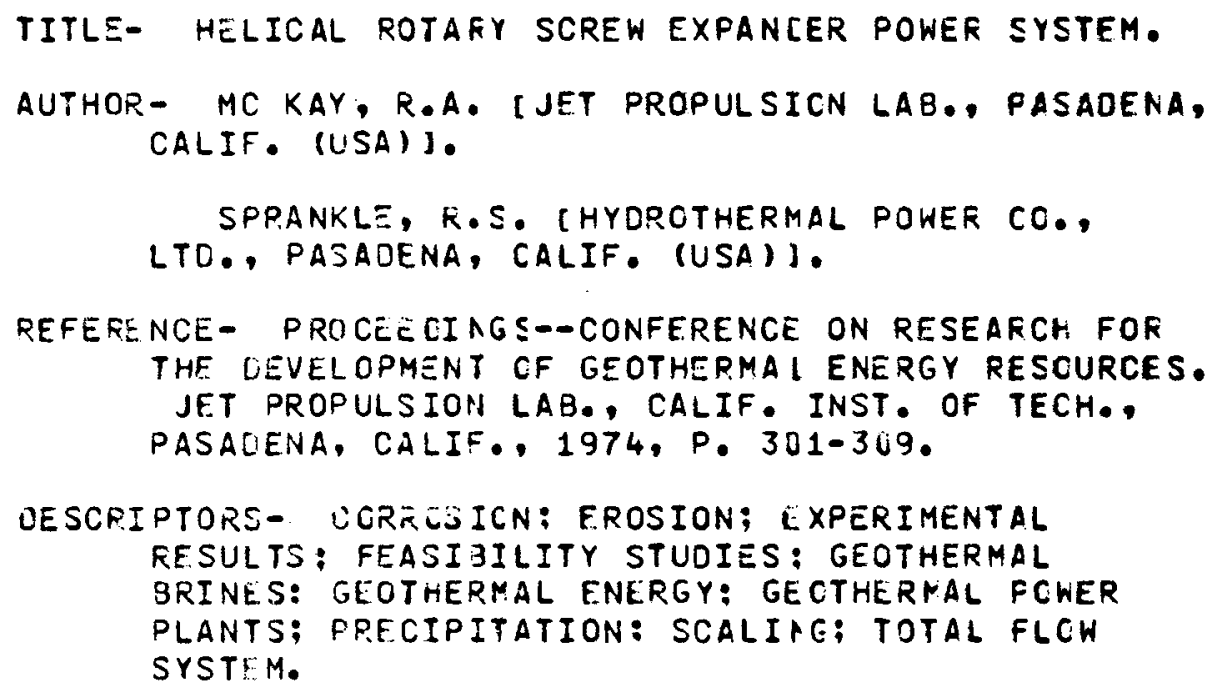

181

MATTHEWS 74

BR INE TREATMENT/SCALINE

TITLE- GEOTHERMAL OCWA-WELL PUMPING SYSTER.

AUTHOR- MATTHEWS, H.A.:MC BEE, W.O. [SPEGRY FAND RESEARCH CENTER, SUDBURY, MASS, (USA)] •

REFEREN NCE- PROCEECIAGS- CONFERENCE ON RESEARCF FOF THE OEVELOPMENT CF GEOTHEPMAL ENERGY RESCURCES. JET PROPULSION LAB., CALIF. INST. CF TECH., PASACENA, CALIF., 1974, ?. 281-291.

DESCFIPTORS- CARBONATES: MEASUFINE METHOOS: FEASIBILITY STUEIES: FIELD STLDIES: FLASHING: FLOW RATC: GEOTHERMAL POWER FLANTS: GECTHERMAL WELLS; HEAT EXCH.ANGEPS; HEAT TFANSFEE: PRECIPITATION; S ILICA MINERALS: SUFFACE EQUIPMENT: WELL CASINGS: WELL DESIGN: WELL OPERATION. 


\section{AUSTIN 74 \\ BRINE TREATMENT/SCALING}

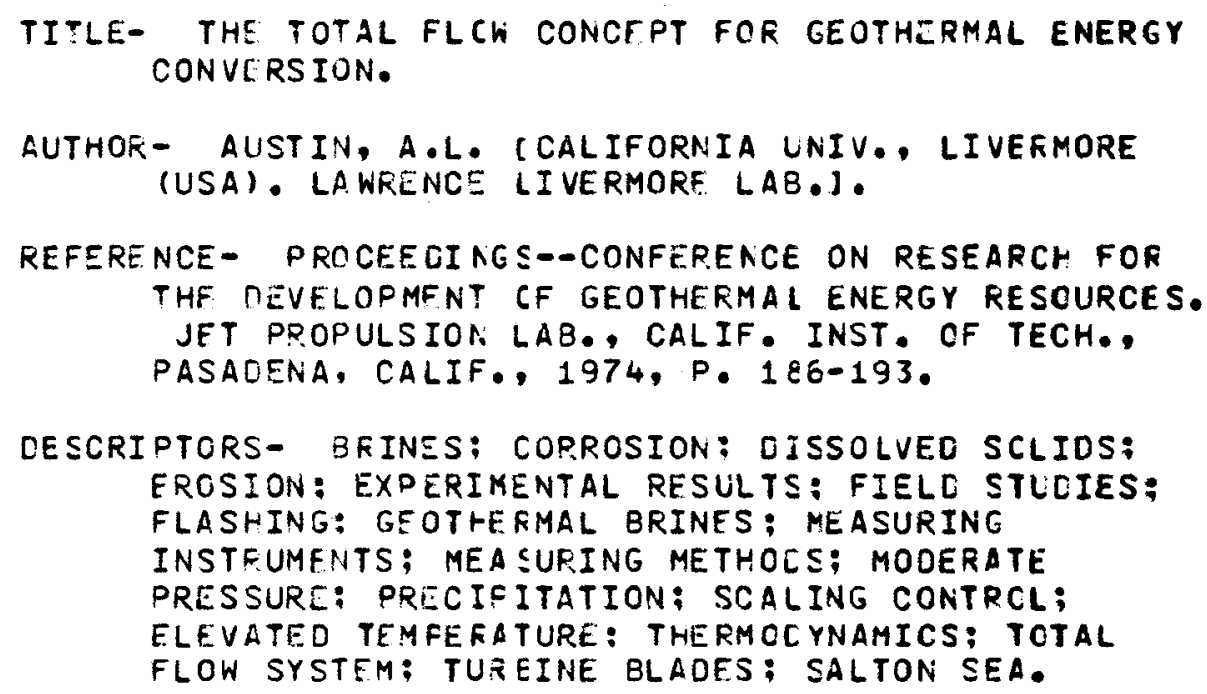

183

HOLT 74

ERINE TREATMENT/SCALINE

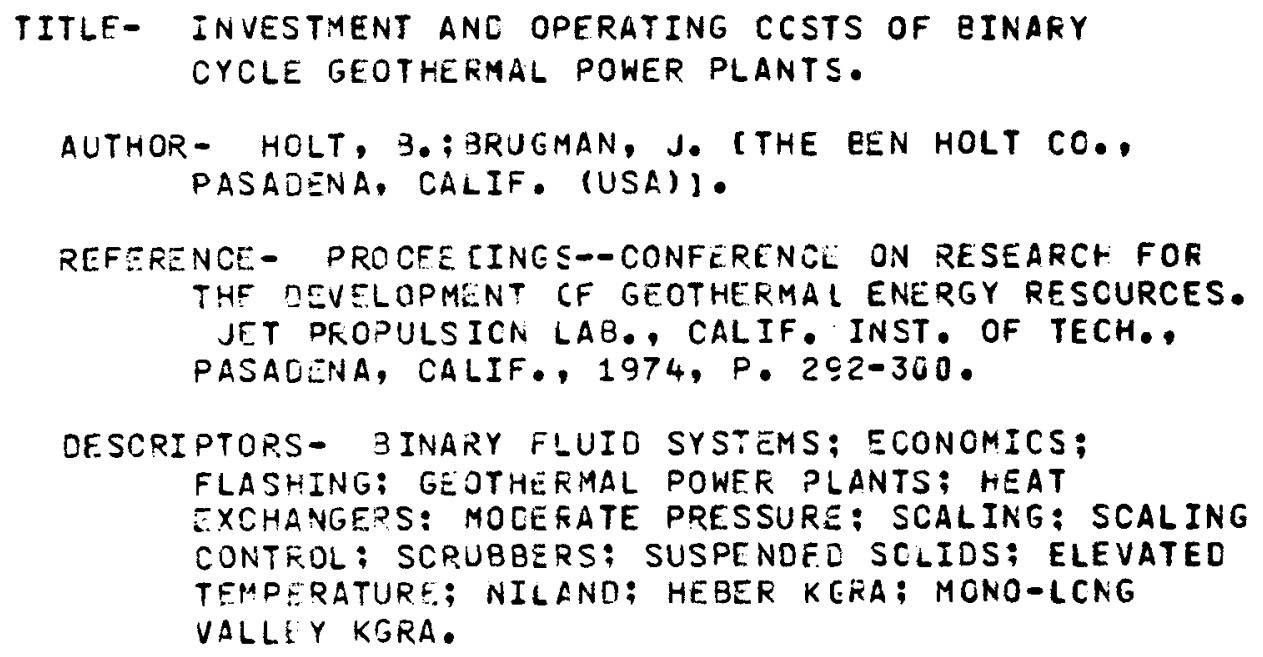




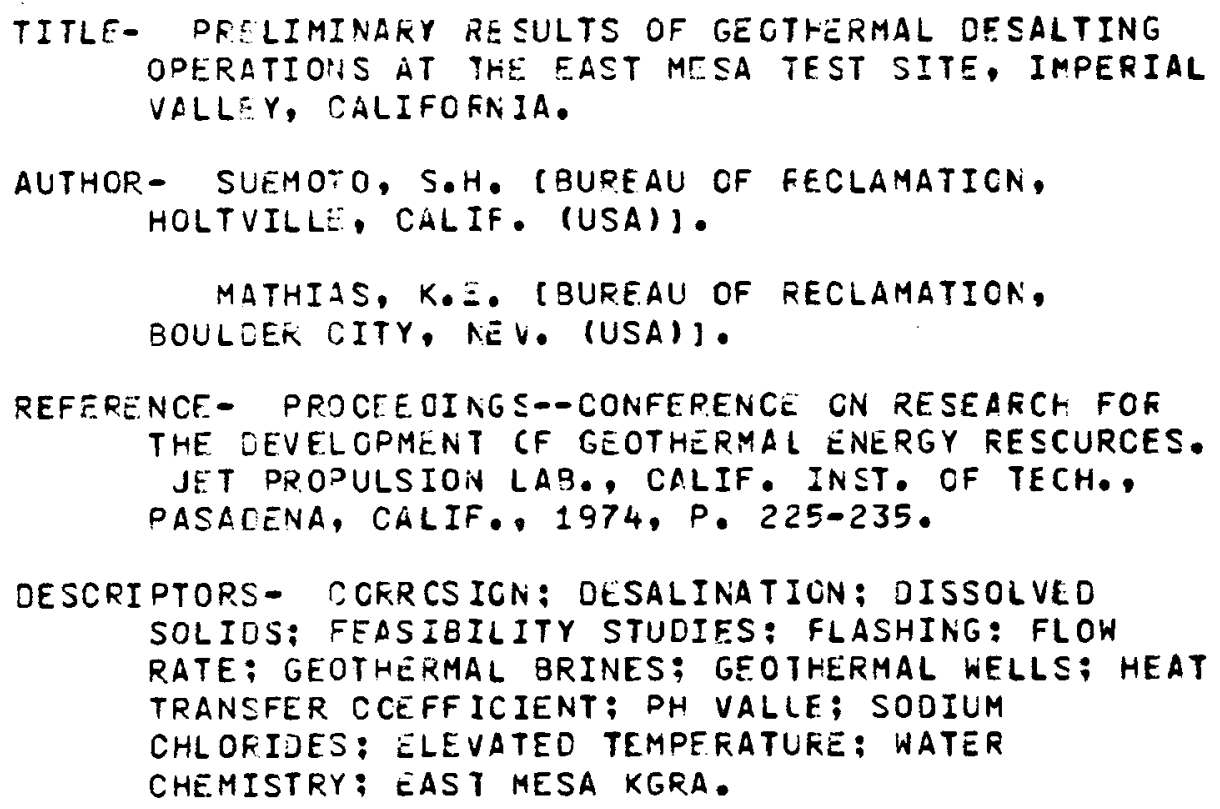

185

TITLE- THC FEASIBILITY OF DEEP-WELL INJECTION OF WASTE BRINE FRCM INLAND DESALTING PLANTS.

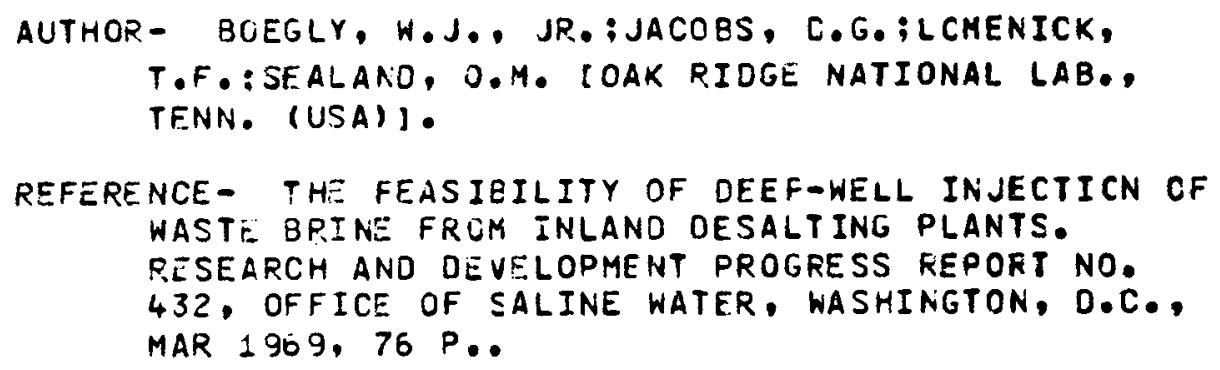




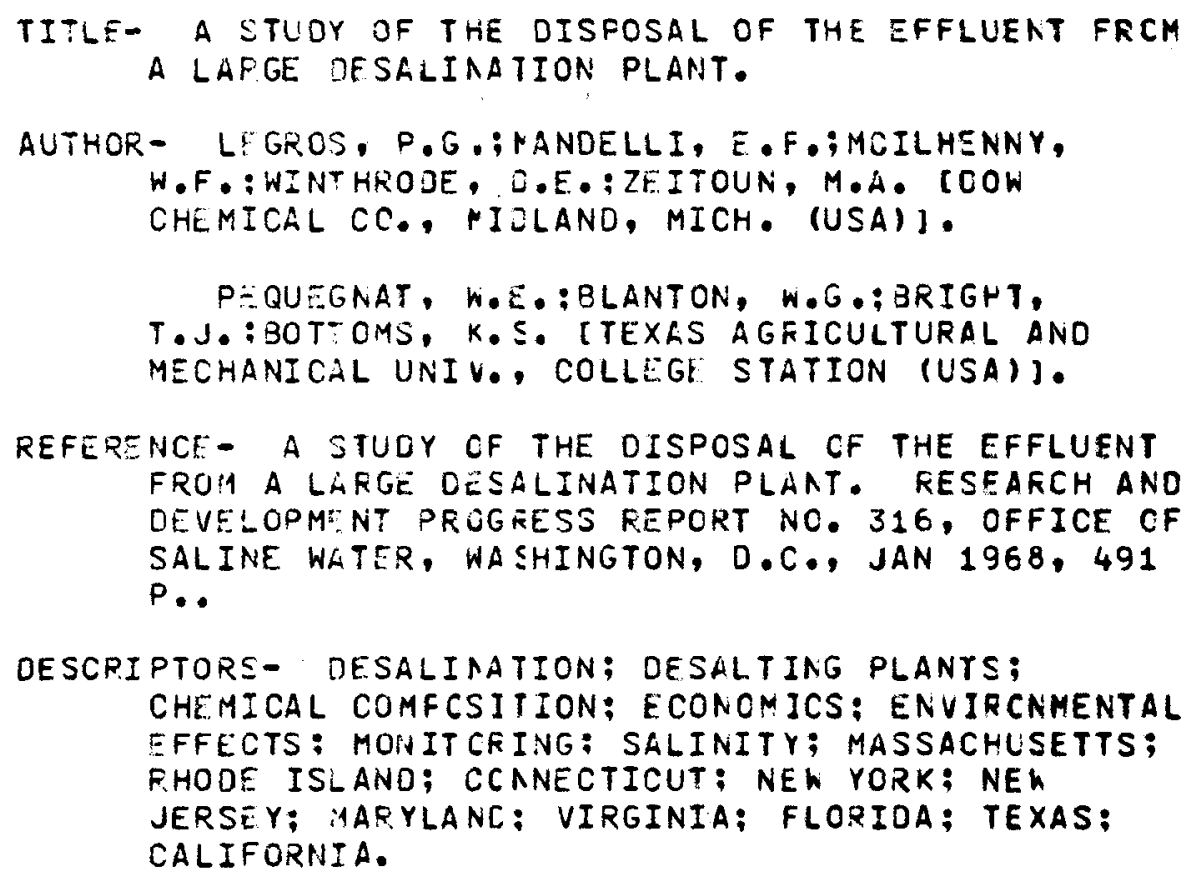

TITLE- SYETEMS ANALYSIS OF BRINE CISPOSAL FRCM REVEFSE JSMOSIS FLANTS.

AUTHOR- LEGRCS, P.G.: IEUSTAFSON, C.E.;SHEFHERE, B.P.: MCILHENNEY, W.F. CDOW CHEMICAL CO.. MIOLAND, MICH. (USA)J.

FEFEFENCE- SYSTEMS ANALYSIS OF BRINE OISPOSAL FROM REVERSE OSMOSIS PLANTS. RESEARCH ANC DEVELOPMENT PRCGRESS REPORT NC. 587 , OFFICE OF SALINE WATER, WESHINGTON, D.C., AUG 1970, 201 P..

DESCRIPTORS- DESALINATION; DESALTING PLANTS; REVERSE OSMOSIS: ECONOMICS: PRE-INJECTION TREATMENT; INJECTION WELLS: WASTE DISPOSAL; EVAPORATICN PONDS. 
CCLLINS 75

BRINE TREATMENT/SFENT FLUIC CISPOSAL BRINE TREATMENT/SCALING BRINE TREATMENT/CCRFOSION

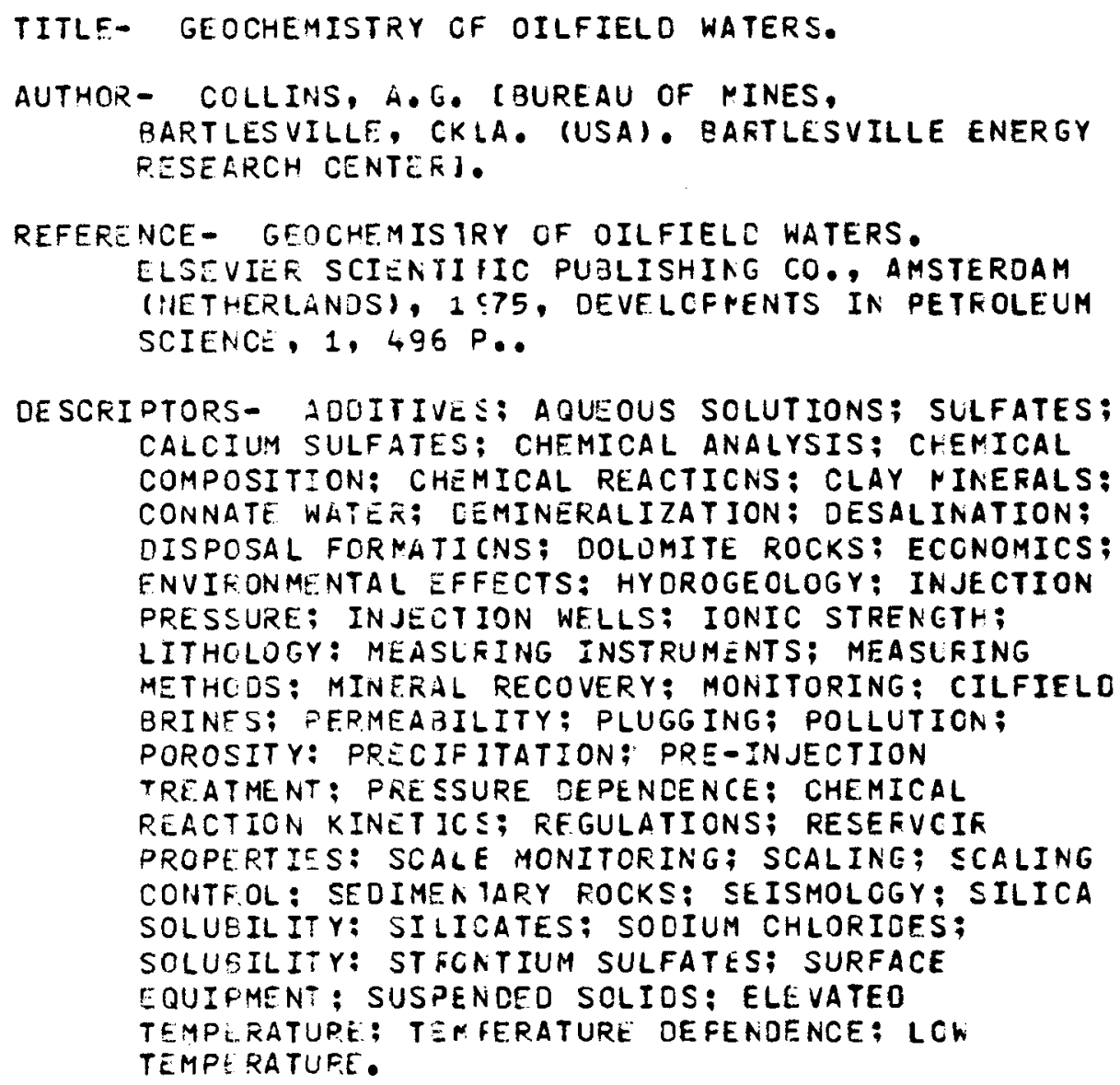

OESCRIPTORS- ADOITIVES: AQUEOUS SOLUTIONS; SLLFATES; CALCIUM SULFATES; CHEMICAL ANALYSIS; CHEMICAL COMPOSITION: CHEMICAL REACTICNS: CLAY MINEFALS: CONNATE WATER̈; CEMINERALIZATION; DESALINATION; DISPOSAL FORMATICNS; DOLUMITE ROCKS; ECONOMICS; FNVIFONMENTAL EFFECTS: HYOROGEOLOGY; INJECTION PRESSURE; INJECTION WELLS; IONIC STRENGTH; LITHOLOGY: MEASLFING INSTRUMENTS; MEASLFING METHCDS: MINERAL RECOVERY; MONITORING: CILFIELO BRINES: PERMEABILITY: PLUGGING: POLLUTICN; POROSITY: PRECIFITATION: PRE-INJECTION TREATMENT: PRE SSURE OEPENCENCE; CHEMICAL REACTION KINET ICS; REGULATIONS; RESEFVCIF PROPERTIES: SCALE MONITORING; SCALING; SCALING CONTFOL: SEDIMEN IARY ROCKS; SEISMOLOGY: SILICA SOLUEIL ITY: SILICATES; SODIUM CHLORIOES; SOLUSILIFY: STFCNTIUM SULFATES; SURFACE EQUIPMEN'; SUSPENDEO SOLIOS: ELEVATEO TEMPLRATUPE; TEF.FERATURE OEFENDENCE; LCW TEMPE RATUFE.

TITLE- INTRODUCTION TC OILFIELC WATER TECHNCLCGY.

AUTHOR- OSTROFF, A.E. ISOCONY MOBIL OIL CO.. INC., PRINCETOY, N.J. (USA). FIELD RËSEARCH LAE.). 


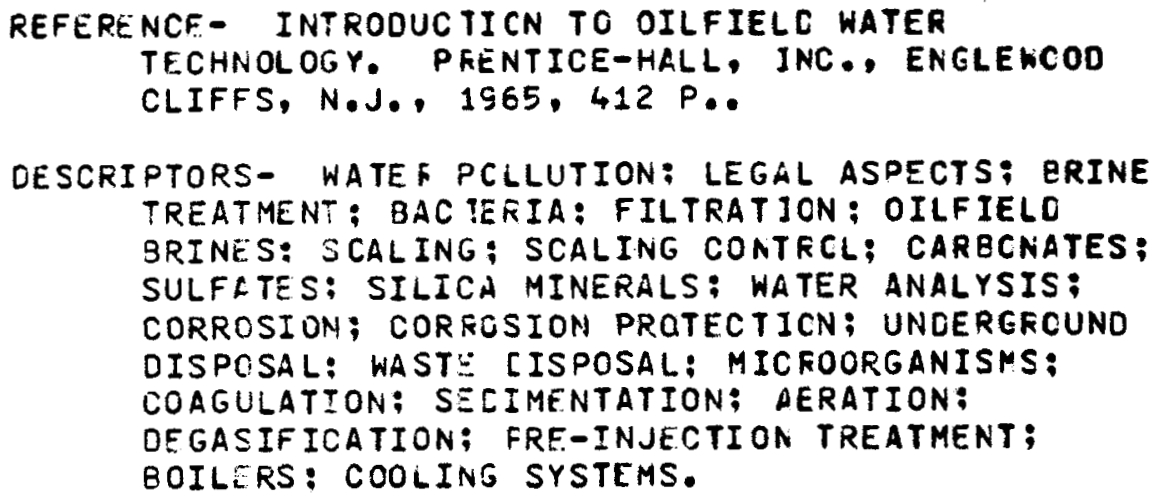

AWWA 71

BR INE TREATMENT/SFENT FLUIC OISPOSAL BR INE TREATMENT/SCALINE BF. INE TREATMENT/CCRFOSION

TITLE- WATER QUALITY ANO TREATMENT. A HANCECCK OF PUBLIC WATER SUFFLIES.

AUTHOP- THE AMERICAN WATER WORKS ASSOCIATION, INC.. REFERENCE- WATER QUALITY AND TREATMENT. A HANDBOCK OF PUBLIC WATER SUPPLIES. 3RC ED., MCGKAW-HILL BOOK CO.. NEW YOFK, N.Y. (USA), 1971, 654 P..

DESCRIPTORS - WATER QLALITY; BRINE TREATMENT; FLOCCULATION; FILTRATION; CHEMICAL REACTIONS; CORROSION: OESALINATION: WASTE MANAGEMENT.

191

STEVCVICH 75 BP. INE TREATMENT/SCALING BRINE TREATMENT/CCRFOSION

BR INE TREATMENT/SFENT FLUIC CISPOSAL

TITLE- GEOTHERMAL ENEFGY.

AUTHOR - STEVOVICH, V.A. [INFORMATICS INC., ROCKVILLE, MC. (LSA)).

REFERTNCE- GEOTHERMAL ENERGY. AC/A-D22 054, INFOFMATICS INC., R.OCKVILLE, MD., NOV 1975, 523 F.. 


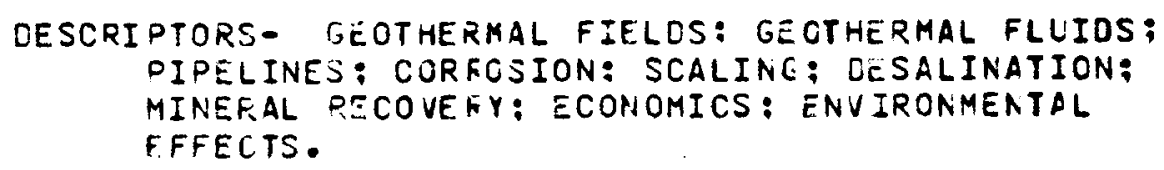
PIPELINES: CORFOSION: SCALINE: DESALINATION: MINEFAL RECOVEFY: ECONOMICS: ENVIRONMENTAL FFFECTS.

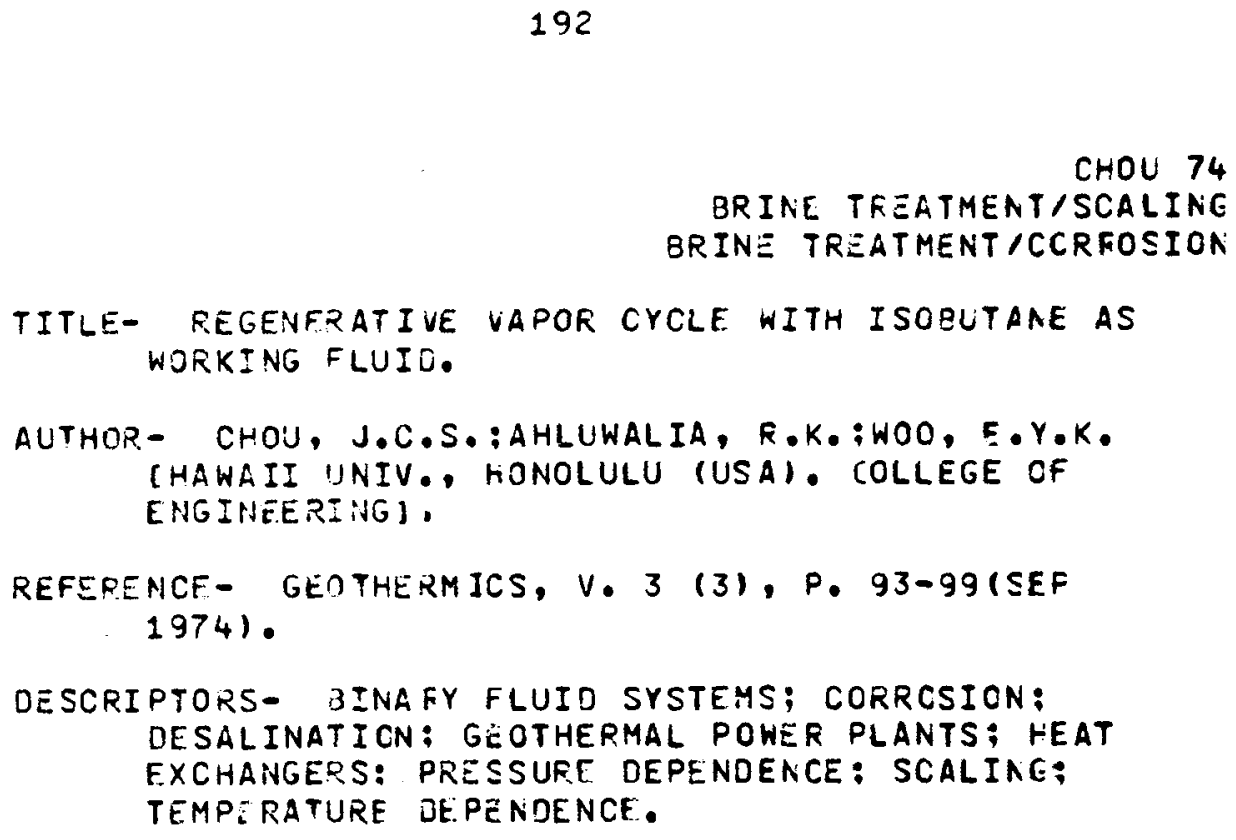

193

YANAGASE 70

BRINE TREATMENT/SCALING

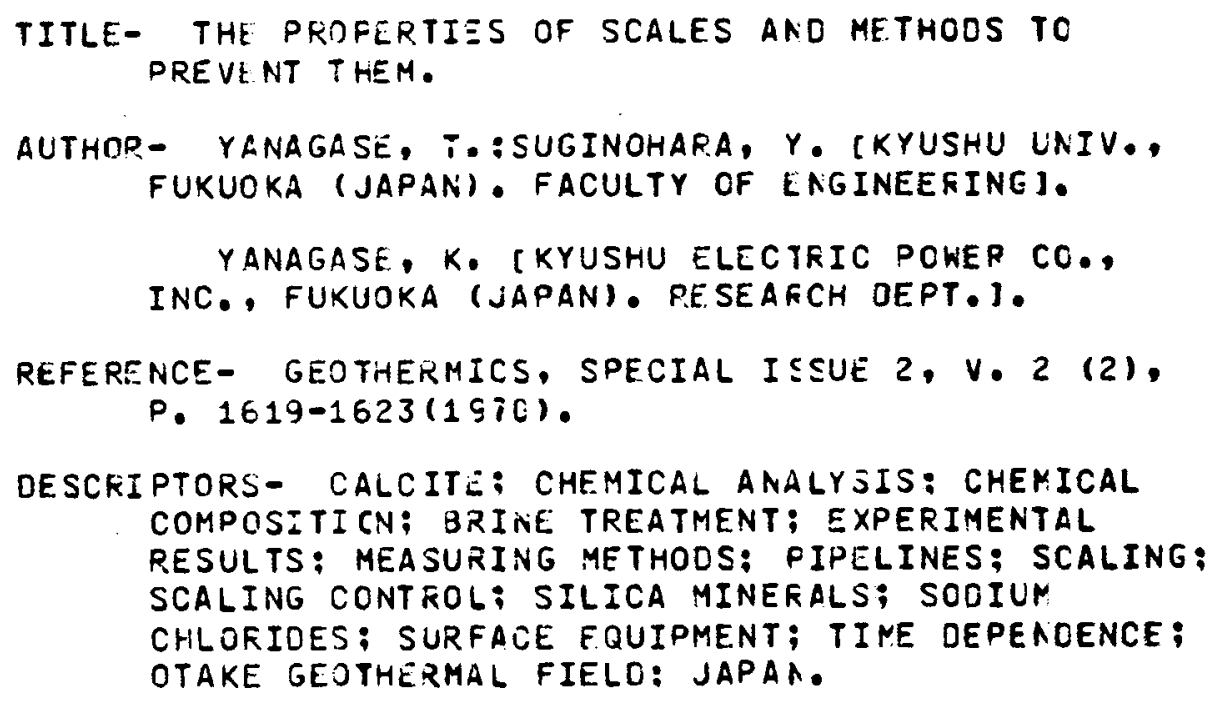


REHLAGE 76

BR INE TREATMENT/SCALING

BFINE TREATMENT/CCRRCSION

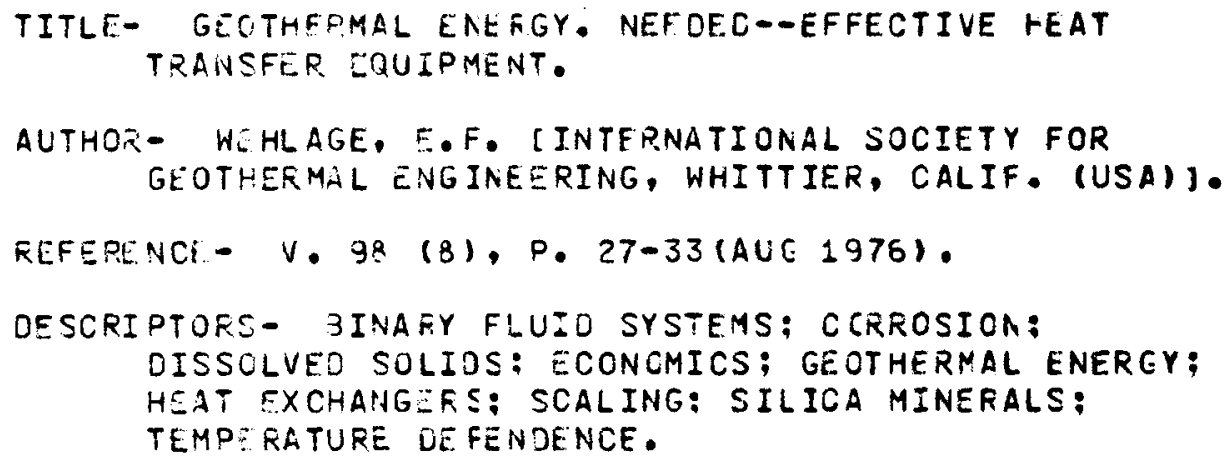

195

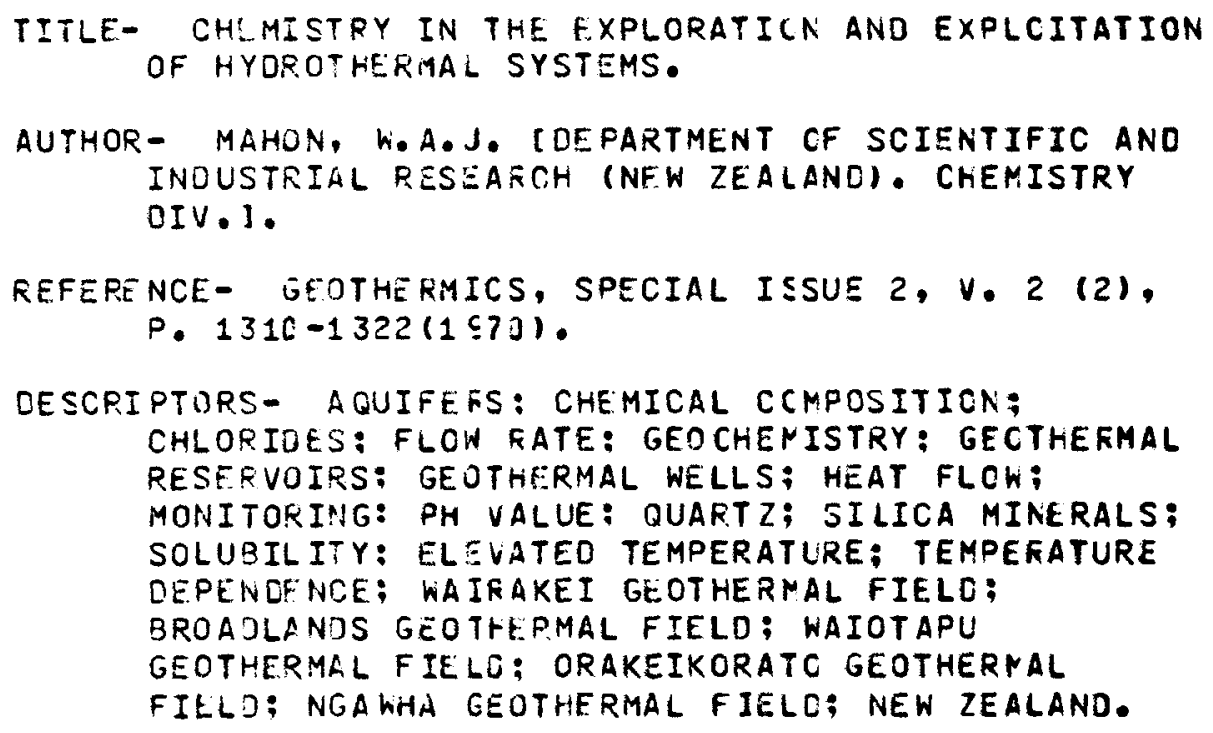

196 


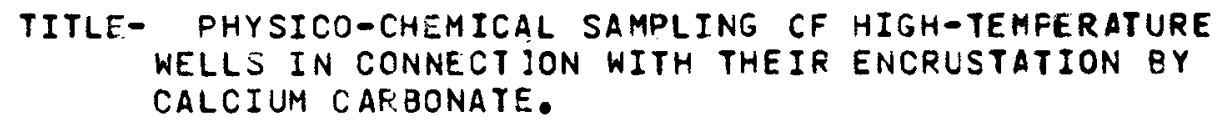
WELLS IN CONNECT JON WITH THEIR ENCRUSTATION BY CALCIUM CARBONATE.

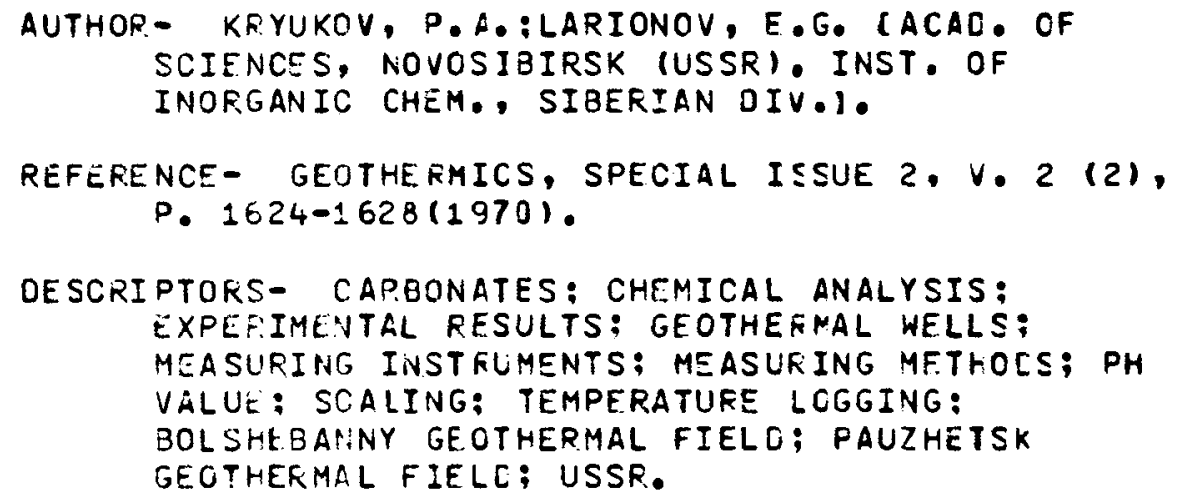

197

ELLIS 75

BR INE. TREATMENT/SCALING

TITLE- GEOTHEPMAL SYSTEMS AND POWER DEVELOPMENT.

AUTHOP- ELLIS, A.J. (CEPARTMENT OF SCIENTIFIC AND INDUSTRIAL FESE /PCH, PETONE (NEK ZEALANC). CHEMISTRY OIV.I.

REFERENCE- AM. SCI., V.63, P. 510-52i(SEP-OCT 1975$).$

DESCRI PTORS- CARBCNATES; CHEMICAL COMPOSITICN: BRINE TREATMENT: GEOCHEMISTFY: GEOTHERMAL ERINES: GEOTHEPMAL ENEREY; GEOTHERMAL FIELOS; GEOTHERMAL POWER PLANTS; GEOTHERMAL WELLS: GP.OUND SUBSIOENCE; HEAT TRANSFER;

POLYMERIZATION; FRE.CIPITATION: RESEFVOIF PROPERTI:S: SCALING: SILICA RINEFALS: TEMPE RATURF. GRACIENTS.

198

QUONG 76

BR INE TREATMENT/SCALINE

TITLE- THE LLL GEOTHERMAL INQUSTRIAL SUPPCRT PRCGRAM IN CHEMISTPY ANE MATERIALS FCF FY7GT ANE FY77.

AUTHOR- QUONG, R. CCALIFORNIA UNIV., LIVERMCRE (USA). LAWRENCE (IVERMORE LAB.). 
REFERENCE- THE LLL GEOTHERMAL INOUSTRIAL SUPPORT PROGRAM IN CHEMISTRY AND MATERIALS FOR FYT6T AND FY77. UCID-17209, CALIFCRNIA UNIV., LAWRENCE LIVERMCRE LAB., LIVËRMORE, CALIF., 1976,24 P..

DESCRIPTOKS- BRINE TFEATMENT: BRINES: CHEMICAL ANALYSIS: CHEMICAL COMPOSITICN; CORECSICN; CORROSION MONITCFING: CORROSION FESISTANT ALLOYS: DISSOLVEC SOLIDS; EXPERIMENTAL FESULTS: FAILURES: FIELO STUDIES; INJECTION WELLS; MEASURING INSTFLIFNTS; MEASUFING METHOLS; MONITORING: PH ACJUSTMENT; PH DEPENCENCE: POLYMERIZATION; FRECIPITATION; CHEMICAL REACTION KINET ICS: SCALE COMFCSITION; SCALING; SCALING CONTROL: SILICA MINERALS: SUSPENDEO SOLIDS; TEMPERATURE OEPENOENCE; IMPERIAL VALLEY.

ROTHBAUM 76

BRINE TREATMENT/SCALING

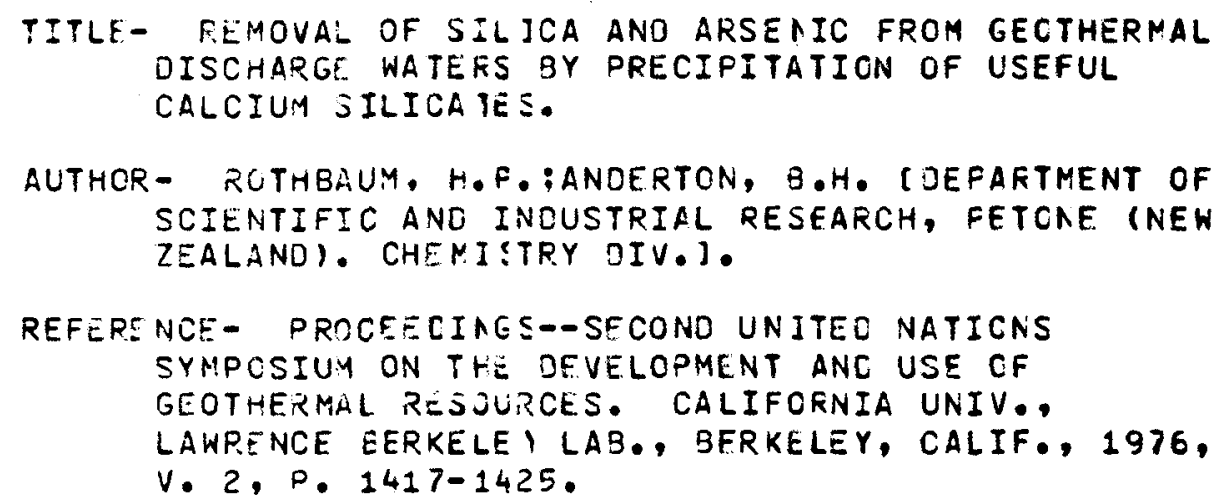

REFERENCE- PROCEECINES--SECOND UNITED NATICNS SYMPOSIUY ON THE DEVELOPMENT ANC USE CF GEOTHERMAL RESJURCES. CALIFORNIA UNIV., LAWPENCE EERKELE I LAB., BFRKELEY, CALIF., 1976, V. 2, P. 1417-1425.

DESCRIPTORS- CHEMICAL ANALYSIS: CHEMICAL COMPOSITICN: BFINE TREATMENT: COLLOIOAL SILICA: DEMINERAL IZATION: EXPERIMENTAL RESULTS: MEASURING METHOCS; FLOCCULATICN; FLCCCULATING AGENTS: GECTHERKAL BRINES; MINERAL RECCVERY: POLYMERIZATICN: SILICA MINERALS; SILICATES: WAIRAKEI GEOTHERMAL FIELD: BRCADLANOS GEOTHERMAL FIELC: NEW ZEALANC.

200 


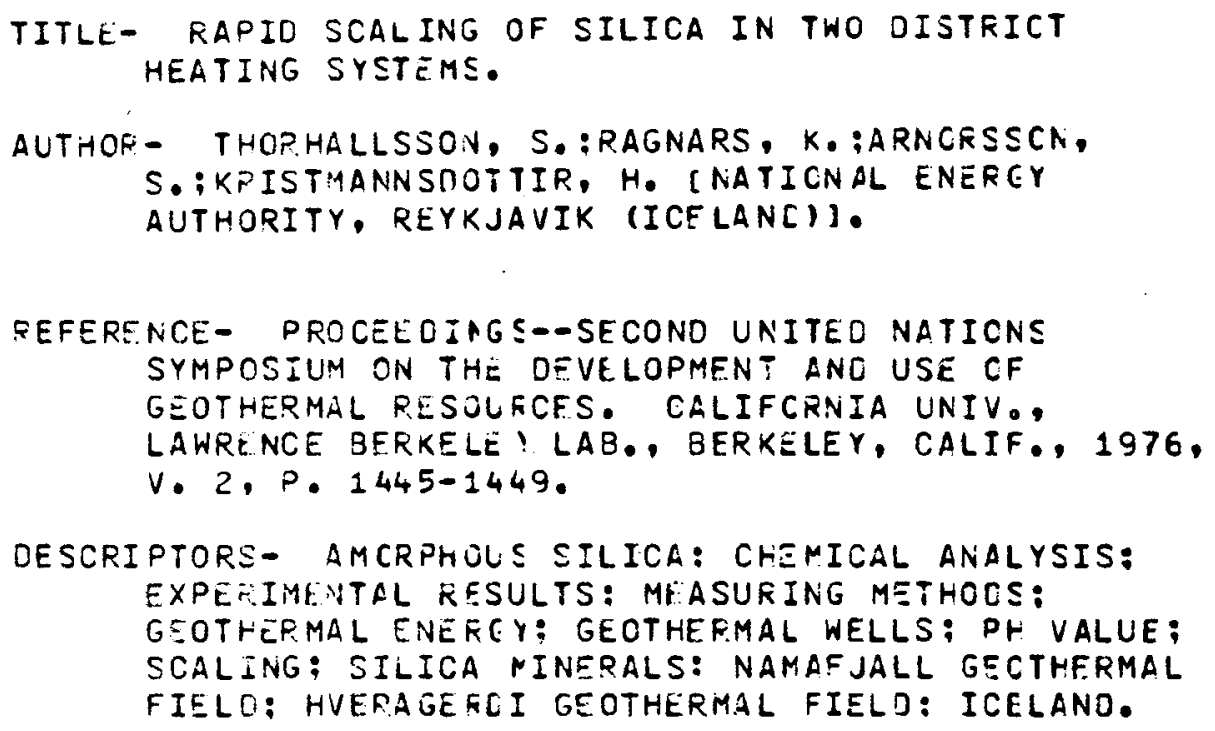

201

EPA 72

3R INE TREATMENT/SFENT FLUIC CISPOSAL

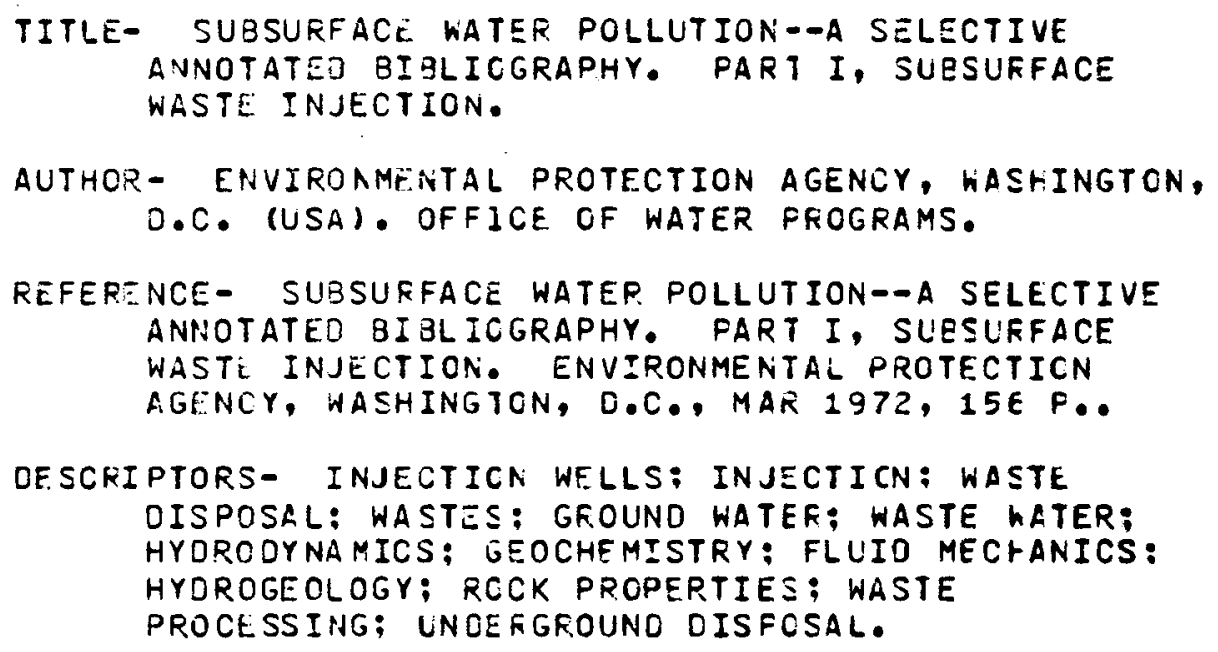

202 


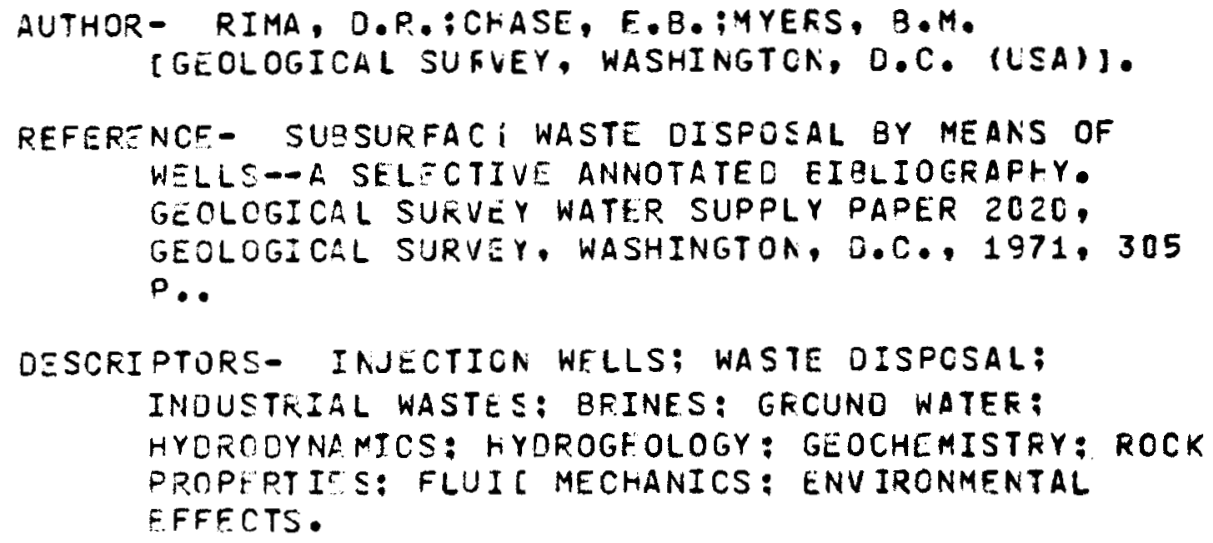

203

TOFFLEMIRE 70

BRINE TREATMENT/SPENT FLUIC CISPOSAL

TITLE- DETP-WELL IAJE(TION (LITERATURE REVIEW).

AUTHOR - TOFFLEMIRE, T.J. [WATER POLLUTION CCATROL

FECEFATIUN, WASHINGTON, D.C. (USA)].

REFERENCE- J. WATER, FOLLUT. CONTFCL FED., V. 42 (E), P. 1231-1:35(1 5 :0)

DESCPIPTCRS- INDUSTRIAL WASTES: DEEP WELLS:

INJECTION WELLS: WASTE WATER; PRE-INJECTION

TPEATMENT: WASTE DISPOSAL: GEOLOGY.

204

YOSHIDA 69

BR INE TREATMENT/SCALING BRINE TREATMENT/CCRROSION

TITLE- CORROSIOA CONTHOL IN GECTHERMAL STEAN TURBINES.

AUTHOR- YOSHIOA, H.:HCASHI, J.;MI IAZAKI, M. TTOKYO SHIBAURA ELECTRIC CO., YOKOHAMA (JAFAN). TUF.BINE WORKSI.

REFERENCE - PROCEEOINGS OF THE AMERICAR POKER CONFERENCE, 1968. AMERICAN FOHER CONFERENCE, CHICAGO, ILL.. $1569, V .30, P .965-973$. 
DESCRIPTORS - CHEMICAL COMPOSITION ; CORRCSICN ; CORROSION PROTECIION: CORROSICN FESISTANT ALLOYS: EXPERIMENTAL RESULTS; GEOTHERMAL FLUIOS: GEOTHERMAL POWER PLANTS: MEASURING METHODS: PITTIAG CORROSION: SCALING; SILICA MINERALS: STRESS CORROSICN: TURBINES: MATSUKAWA GEOTHERMAL FIELC: JAPAN.

205

\section{CARTER 74 BRINE TREATMENT/CCRAOSION}

TITLE- CORROSION! RESISTANCE OF SOME COMMEFCIALLY AVAILABLE METALS ANO ALLOYS TC GEOTHERMAL BRINES.

AUTHOR - CARTEF, J.P.: CRAMER, S.O. LBUREAU OF MINES, COLLIE PAKK, Mi. (USA). COLLEGE PAKK

METALLURGY RESEARCH CENTERI.

REFEFENCE- COPRCSION FROBLEMS IN ENEFGY CONVERSION AND GENEPATION. THE ELECTROCHEMICAL SCCIETY. CORFOSION OIV., PRINCETON, N.J., 1974, F. $24 \Omega-250$.

DESCRIPTORS- COFROSION; CORROSION RESISTANT ALLOYS; DISSOLVEO SOLIOS: EXPERIMENTAL RESULTS; GEOTHERMAL BRINES; IRON OXICES; MEASURING METHOOS: MOUERATE PRESSURE; FITTING COFECSION: STRESS CORROSION; ELEVATED TEMPEFATURE; EAST MESA KGFA: NILANL: IMPERIAL VALLEY: USA.

206

TITLE- SULUBILITY GF CXYGEN IN GECTHERMAL RFINES.

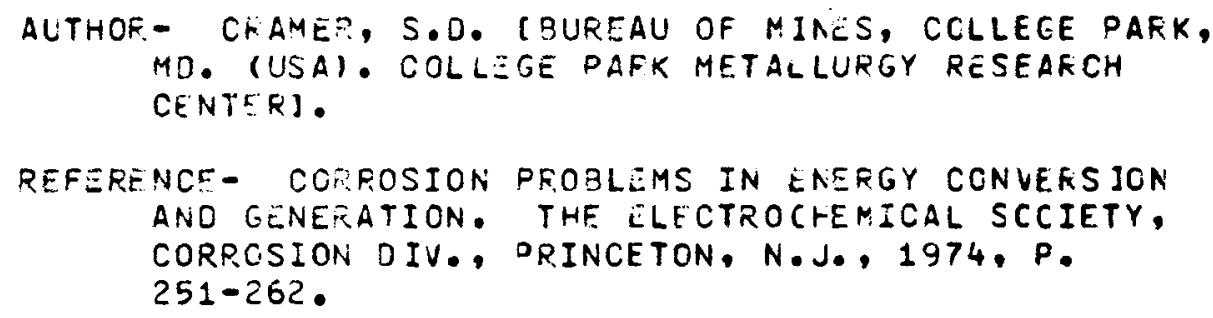




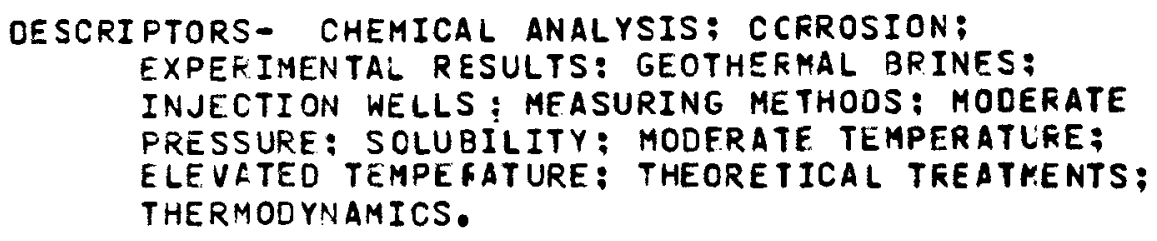

207

HERMANASSON 70

BRINE TREATMENT/SCALING BRINE TREATMENT/CCRROSION

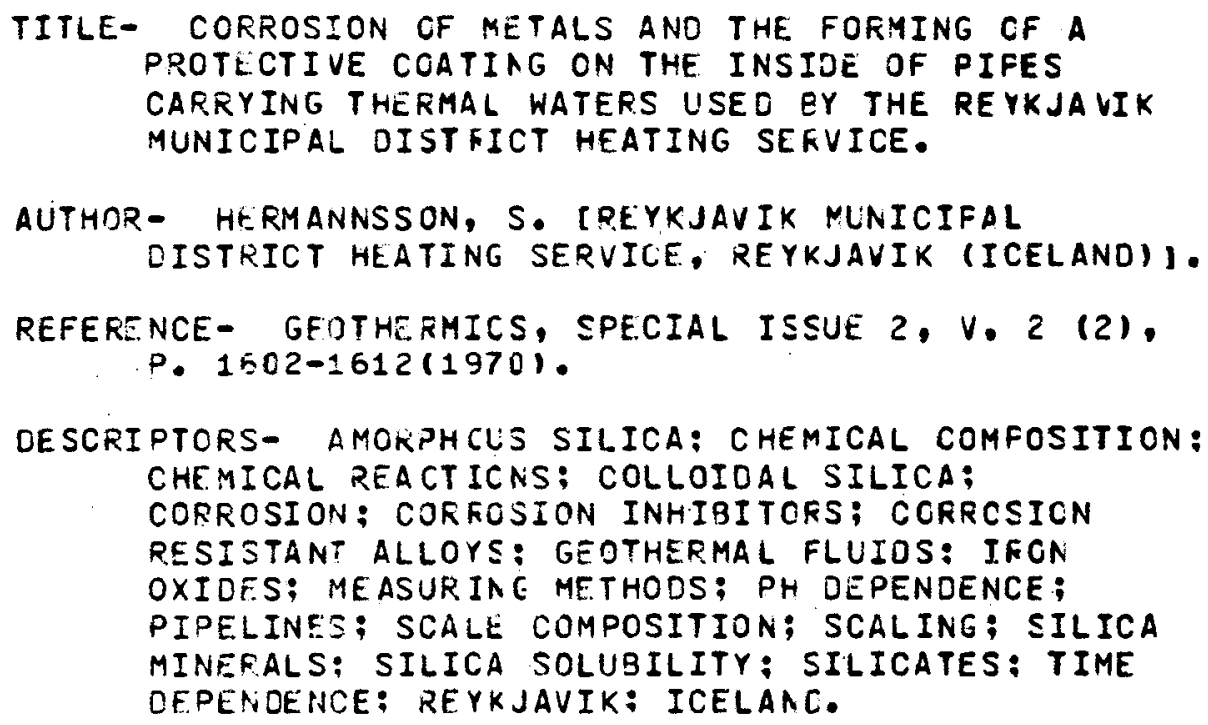

208

MAFSHALL 57

BF INE TREATMENT/CCRROSICN

TITLE- CORROSION BY LCW-PRESSURE GEOTHERMAL STEAM.

AUTHOP- MARSHALL, T.:HUGILL, A.J. IOEPARTMENT OF SCIENTIFIC AND INOUSTFIAL RESEARCH, WELLINGTON (NEW ZEALANCI. OCMINION LAB.].

PEFER:NCL- COFROSION, V. 13. P. 329T-337T (MAY 1957).

UESCRIPTORS- CREMICA COMPOSITION: CORROSION: CORROSION FESI STANT ALLOYS: EXPERIMENTAL FESULTS: MEASUFING METHODS: FLOW RATE: GEOTHERMAL FLUJCS: STRESS COFFOSION; WAIFAKEI GEOTHEPMAL FIELO; NEW ZEALANL. 


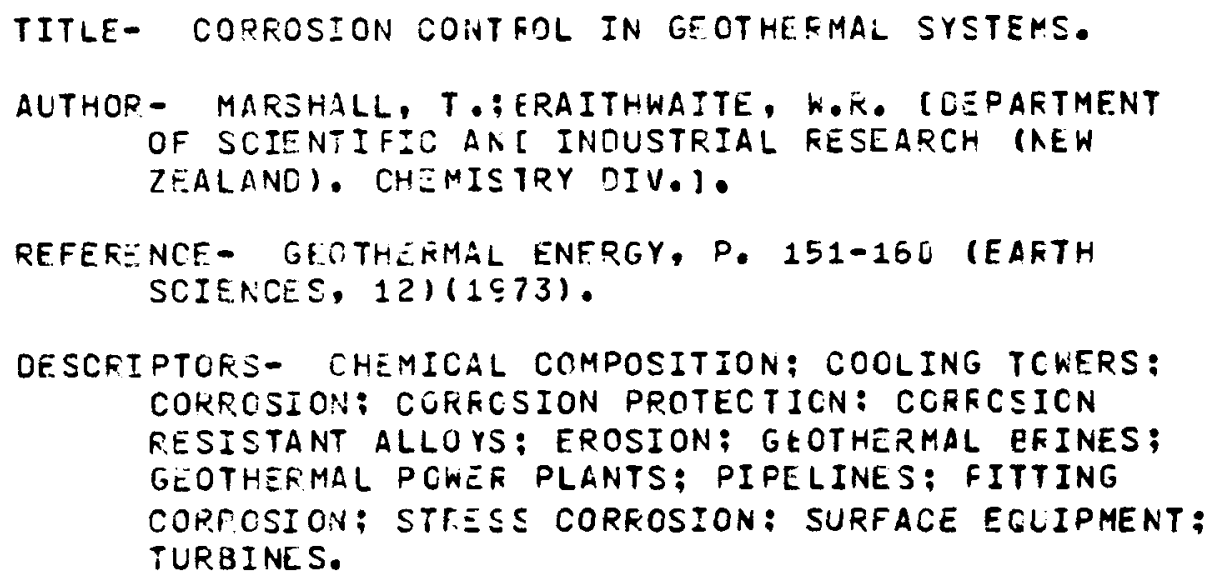

AKIBA 70

BRINE TREATMENT/SCALING BRINE TREATMENT/CCRFOSION

TITLF- MECHANICAL FEATURES OF A GECTHERMAL PLANT.

AUTHOR- AKIBA, M. ITCKYO SHIBAURA ELECTRIC CC., LTD., (JAPAN). TUFBINE. ENGNG. JEPT. .

REFERENCE- GEOTHEKMICS, SPECIAL ISSUE $2, V .2$ (2), P. 1521-1529(1 $77 \mathrm{G})$.

DESCFIPTOPS - CHEMICAL COMPCSITION: CORROSICN ; GEOTHERMAL POWEF PLANTS; SCALE COMPCSITION; SCALING: STRESS CORROSION: SLFFACE EQUIFMENT; TURBINE BLADES: TURBINES: MAISUKAWA GECTHERMAL FIELO; CERFO FEIETO GEOTHERMAL FIELO; CEYSERS GEOTHEPMAL FIELE; JAPAN.

211

ANCERSON 70

BR INE TREATMEAT/SCALING BR INE TREATMENT/CORROSION

TITLE- A VAPOR TUREINE GEOTHERMAL FOWER FLANT. 


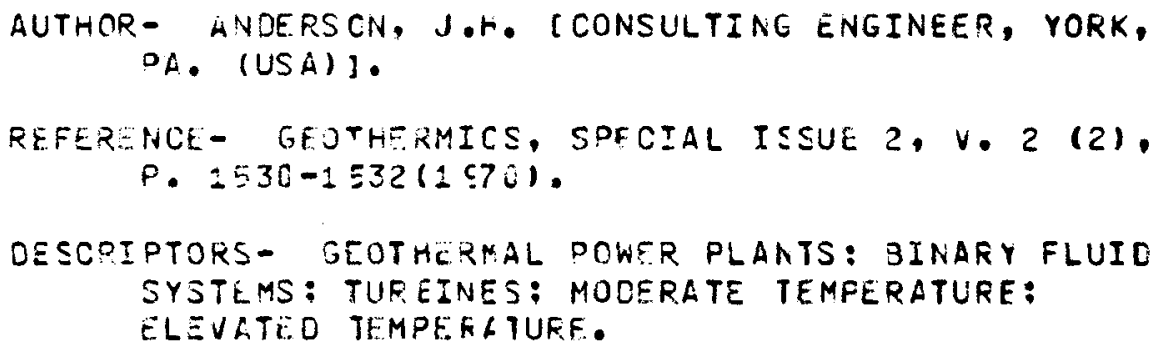

TITLE- GEOCHEMISTRY CF THE WATERS OISCHARGEC FROM DRILLHOLES IN THE OTAKE ANC HATCHOBARU AREAS.

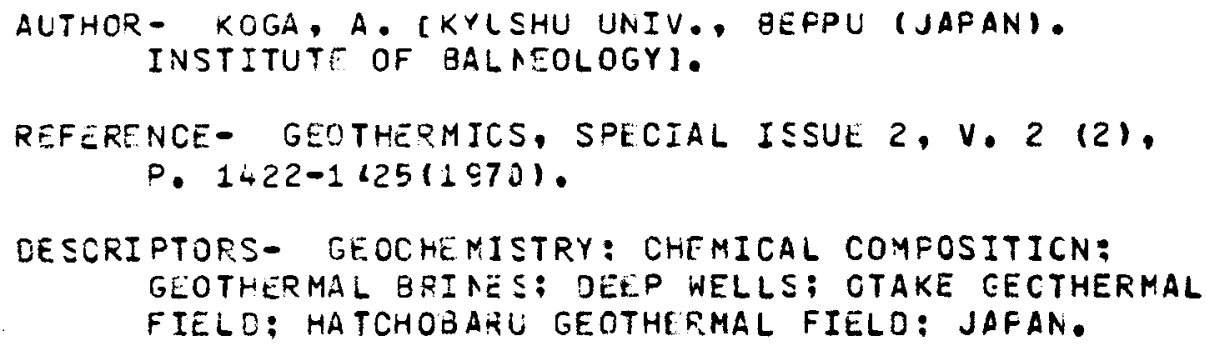

213

NASHIKO 70

BE INE TREATMENT/SCALING BRINE TREATMENT/CCRROSION

TITLE- NEW SUPPLY SYSTEMS OF THER PAL WATERS TO A WIDE AREA IN JAFAN.

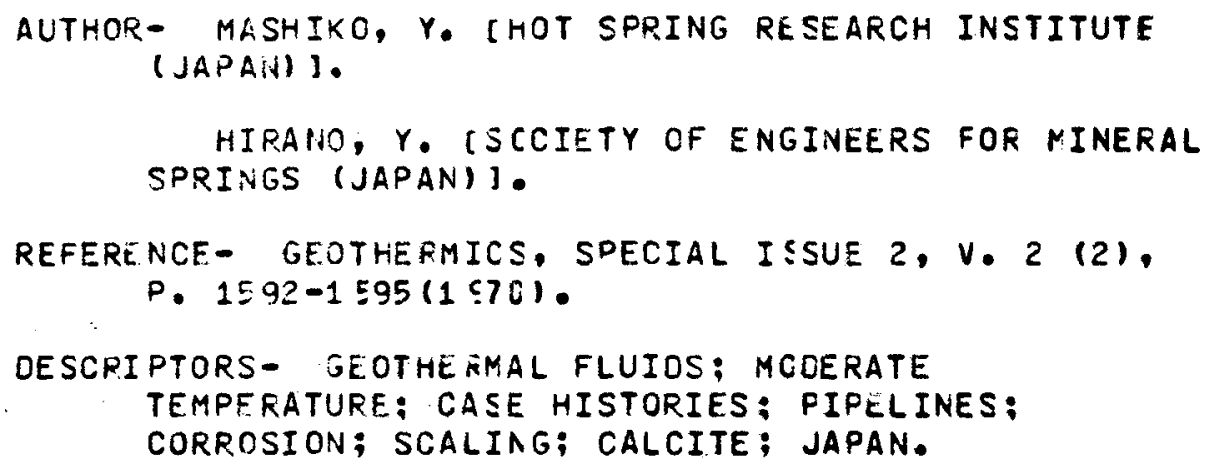


SHCHEREAKOV 70 BRINE TREATMENT/SCALING BR INE TREATMENT/SFENT FLUIC CISPOSAL

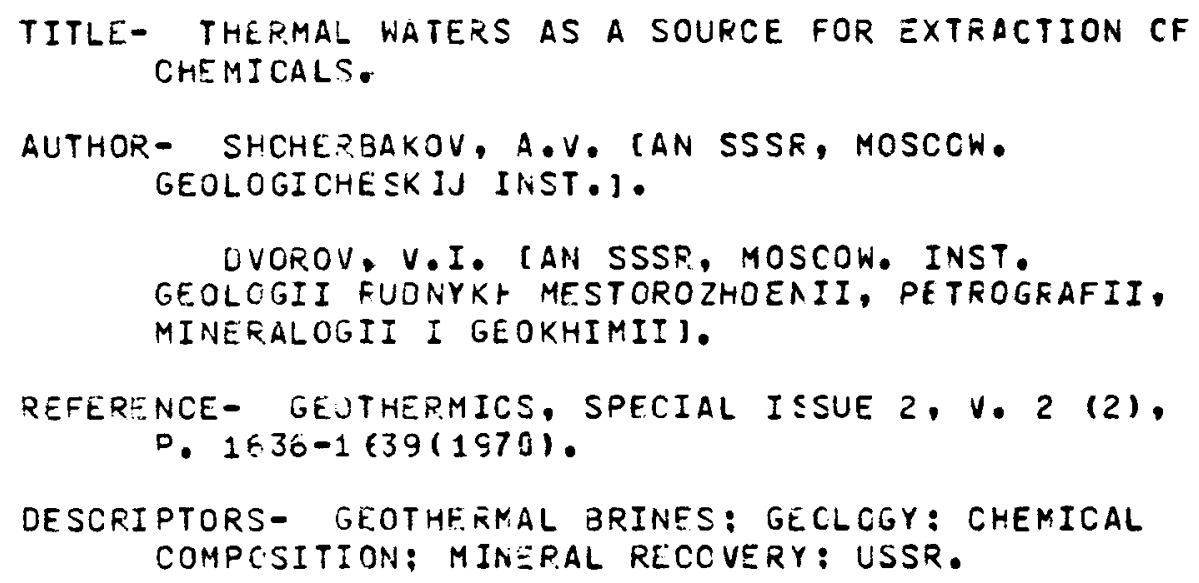

216

TITLE- COFROSION STULIES AT THE GEYSERS POWEF PLANT. ABSTRACT NO. $10 E$. 


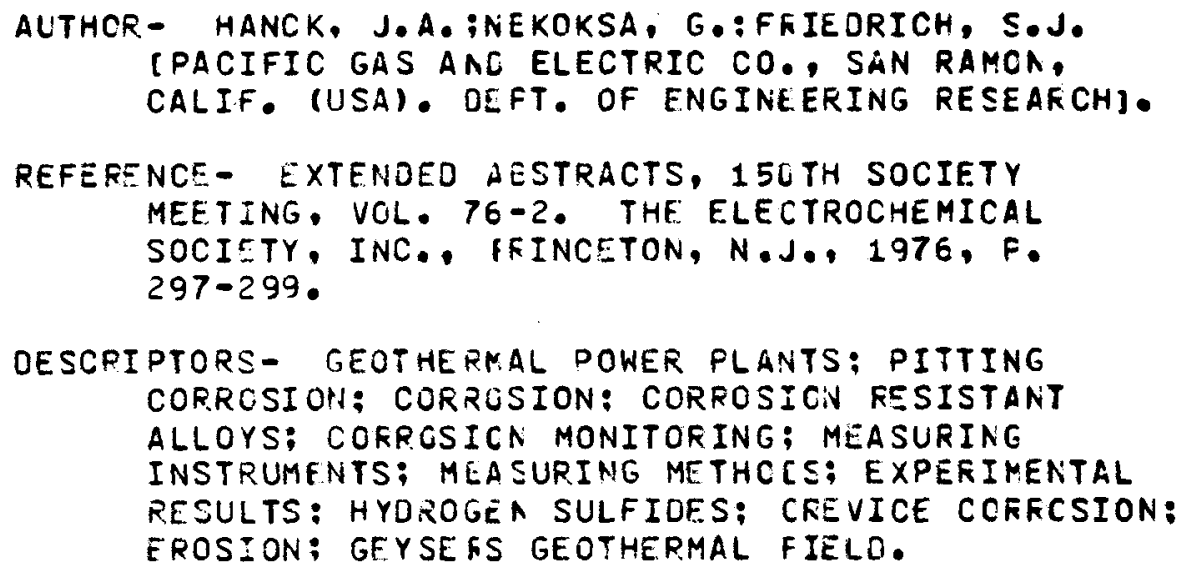

217

RLOCE $S 76$

BRINE TREATMENT/CCRFOSION

TITLE- CORROSION ME CHANISMS OF CAREON STEEL IN AQUEOUS HZS SOLUTIONS. ABSTRACT NO. 107.

AUTHOR- RHODES, P.R. [SHELL DEVELOFMENT CO., HOUSTON, TEX. (LSA)I.

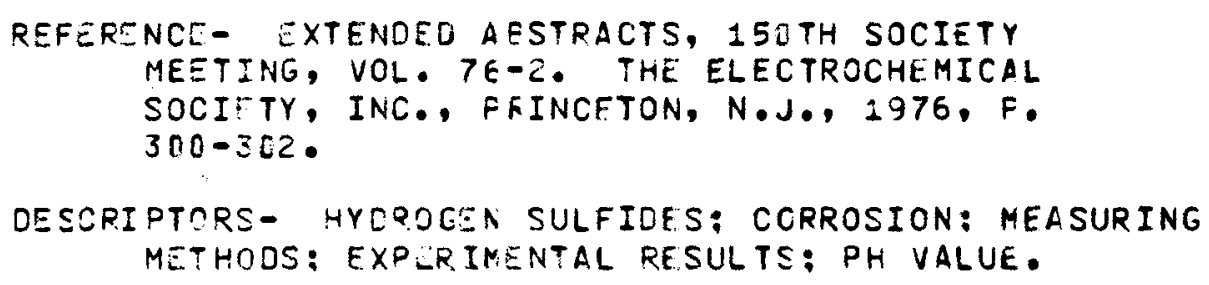

218

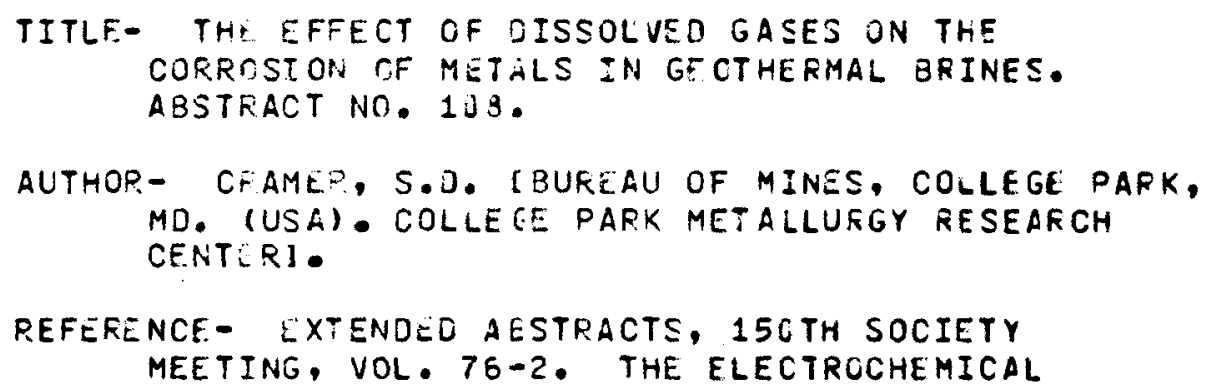


SOCIETY, INC., FFINCETON, N.J., 1976, P. $3[3-3 C 4$.

DESCRIPTDFS- CORROSICN： GEOTHERMAL BRINES: MEASURING METHOOS: EXPËRIMENTAL RT SULTS: FH VALUE: CHEMICAL COMFCSITION: CREVICE CCRRCSICA; STRESS COPROSION: ËAST MESA KGFA; SALTCN SEA

GTOTHERMAL FIELL.

219

BRINE TREATMENTICCRFOSION

TITLE- THE ROLE OF CHEMICAL COMPONENTS IN GECTHERMAL BRINFS ON THE CORROSION OF METALS. AESTFACT NO. 109.

AUTHOR - SHANNON, C.W. IBATTELLE FACIFIC NCRTHWEST LASS., FICHLANC, WASH. (USAII.

REFERENCE- RXTENDED AESTRACTS, $150 T H$ SOCIETY MEETING, VOL. 7E-2. THE ELECTROCMERICAL SOCIETY, INC., FFINCETON, N.J., 1976, P. $3 C 5-3 C 6$.

OESCPIPTORS- CHEMICAL COMPOSITION: CHEMICAL P.EACTIONS : GEO ITERMAL BFINES; CORROSION; CORFOSION RESISTANT ALLOYS: MEASURING METHODS: EXPERIMENITAL RESULTS: HYOROGEN SULFIOES; PH VALUE: MODERATE TEMPERATURE: ELEVATEO TEMPERATURE.

220

POSEY 76

BFINE TREATMENT/CCRFOSION

TITLE- ELECTROCHEMICAL ASPECTS OF CORROSICN CF IRON AND STEFLS IA SYNTHETIC BRINES. ABSTRACT NO. 110 .

AUTHOR- POSEY, F.A. :FALKO, A.A. [CAK RIOGE NATIONAL LAB., TENN. (USA). CHEMISTRY CIV.).

REFFRENCE - EXTENDEC AESTRACTS, $150 T H$ SOCIETY MEETING, VOL. 76-2. THE ELECTROCHEMICAL SOCIETY, INC., PEINCETON, N.J., 1976, F. $307-308$. 


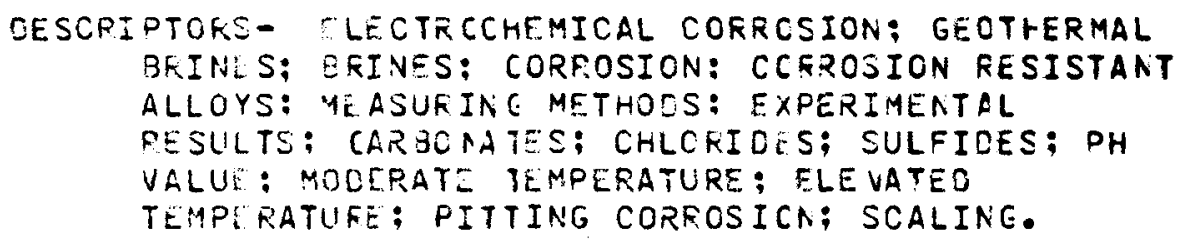

TITLE- EXPERIMENTAL EVALUATION OF THE GECCHENISTRY OF GEOTHERMAL SYSTEMS.

AUTHOP- DOWIS, W.F.:EAPNES, H.L. CFENNSYLVANIA STATE UNIV., UNIVER̃SITY PAFK (USA). DEPT. OF GEOSCIENCESI.

DEFEFENCE- EXTENDEO AESTRACTS, 15UTH SOCIETY MEETING, VOL. TE-2. THE ELECTROCHEMICAL SOCIETY, INC.. FFINCETON, N.J., 1976, AESTRACT No. $111, P, 309-510$.

CESCRIPTORS- GEOTHERNAL SYSTEMS; GEOCHEMISTEY; FXPEFIMENTAL MOLELS: DYNAMIC SYSTEMS: EFINES; GECTHERMLL FLUIIS; ROCKS; ROCK-FLUID INTEFACTIONS; NINERALS; SCLUBILITY; SILICA MINERALS: SCALIAG: PRECIPITATION; SILICA CHEMISTRY; QUAFTZ; CHEMICAL FEACTION KIAETICS; HEAT EXCHANGERS; LASL.

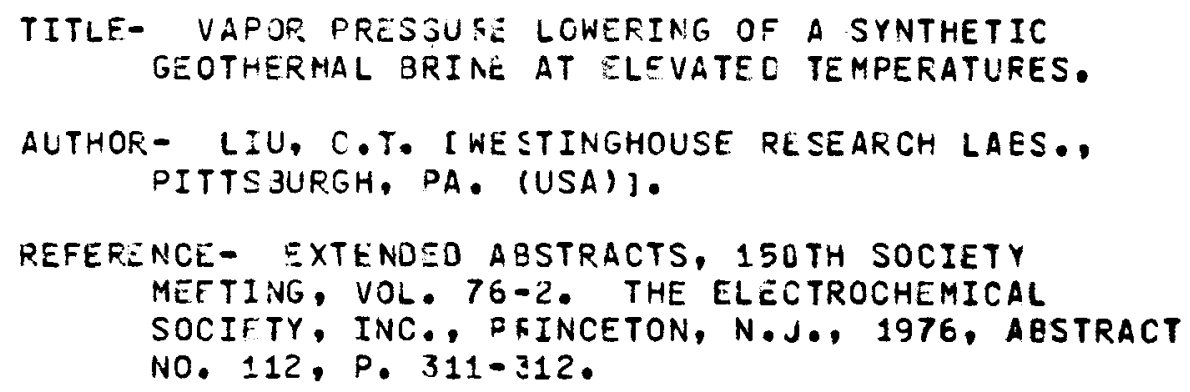


OESCRI PTORS- THERMOOYAAMIC PEOPERTIES; GEOTHEFMAL BRINES: VAPOP PRESSURE: OSMOTIC COEFFICIENT: TEMPERATURE DEPEADENCE: MOCERATE TEMPERATURE; ELEVATED TEMPERA IURE; CONCENTKAT ION DEPENDENCE; SOOIUM CHLORIDES: EXPERIMENTAL RESULTS.

223

CFAMER 76B

BRINE TREATMENT/CCRFOSION BR INE TREATMENT/SCALING

TITLE- THE THERMOOYNAPICS OF GASES DISSOLVEC IN BRINZS.

AUTHOF- CRAMER, S.O. (BUREAU OF MINES, COLLEEE PARK, MO. (USA). COLLEGE PARK METALLURGY FESEAFCH CENTERJ.

REFERENCE- EXTENDED AESTRACTS, 150 TH SOCIETY MEETING, VOL. 76-2. THE ELECTROCHEMICAL SOCIRTY, INC., FFINCETON, N.J., 1976, AESTRACT NO. 113 , P. 313-314.

DESCRIPTORS- THERMODYMAMICS: DISSCLVED GASES; GEOTHERMAL BRINES; OXYGEN: CARBON DICXICE; METHAME: SCLUBILITY: TEMPERATLRE OEPENIENCE: MODERATE. TEMPERA TURE: ELEVATEC TEMPEFATLFE; CONCENTRATIGN DE FENDENCE; ENTFOPY; ENTHALPY; SALTING-OUT EFFECT: SCALING: COFROSION: EXPË.KIMEINTAL FESULTS.

224

STAEHLE 76 BRINE TREATMENT/CCRKOSICN

TITLE- EFFECTS CF HYCROGEN SULFIDE ENVIFCNMENTS ON THE PERFORMANCE CF MATEFIALS.

AUTHOR - STAEHLE, R.W.:AGPAWAL, A.K. COHIO STATE UNIV., COLUMBUS IUSA). DFPT. CF METALLLEEICAL ENG INEERING].

REFERENCE - EXTENDEO AESTRACTS, $15 U T H$ SOCIETY MEETING, VOL. 76-2. THE ELECTROCHEMICAL SOCIETY, INC., FFINCETON, N.J., 1976, AESTRACT NO. 114 , P. 31 E. 


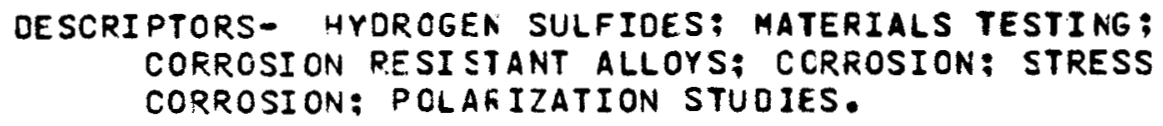

225

\author{
HEREMANN 76 \\ BRINE TREATMENT/CCRFOSION
}

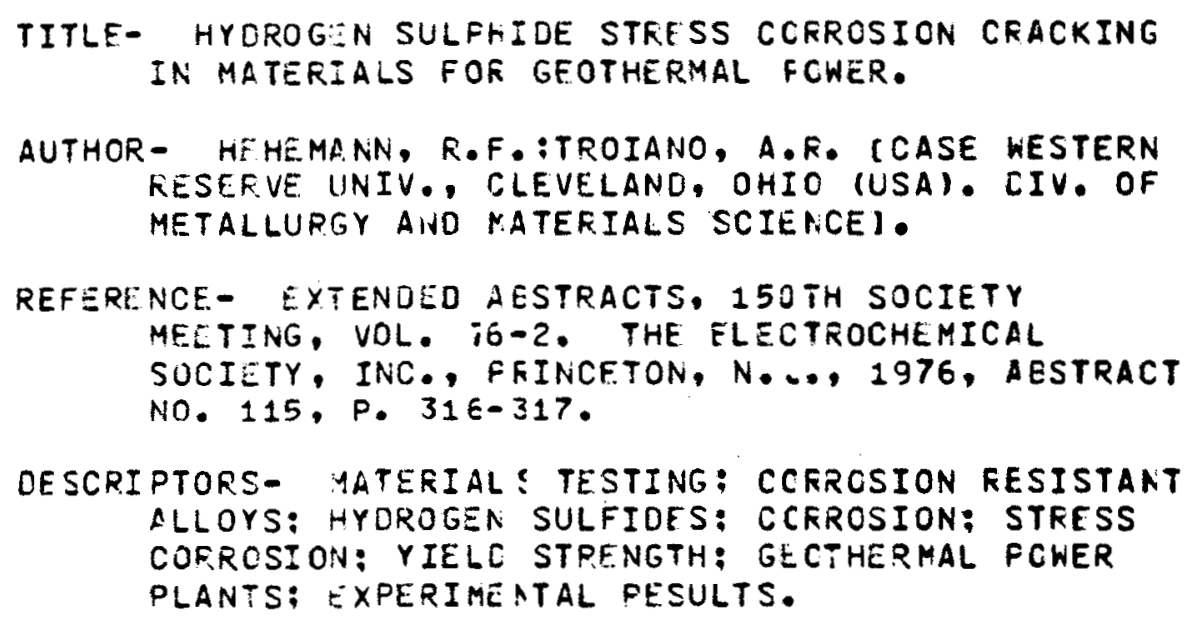

226

TITLE- THE INETIATICN AND GFOWTH CF LOCALIZEO CORROSION ON STAINLESS STEELS IN CHLOFICE SOLUTIONS.

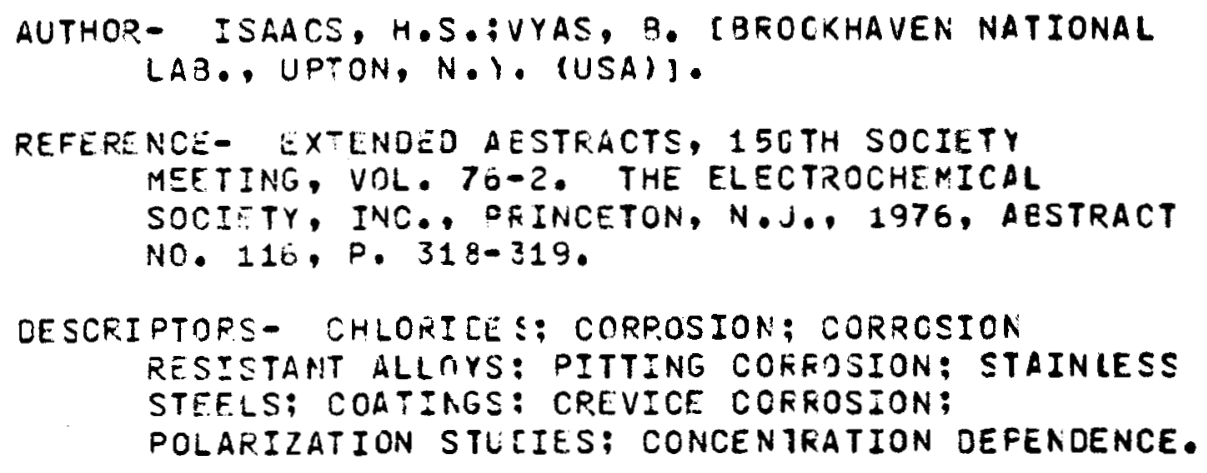


FESSALL 76

BPINE TREATMENT/CORFOSION

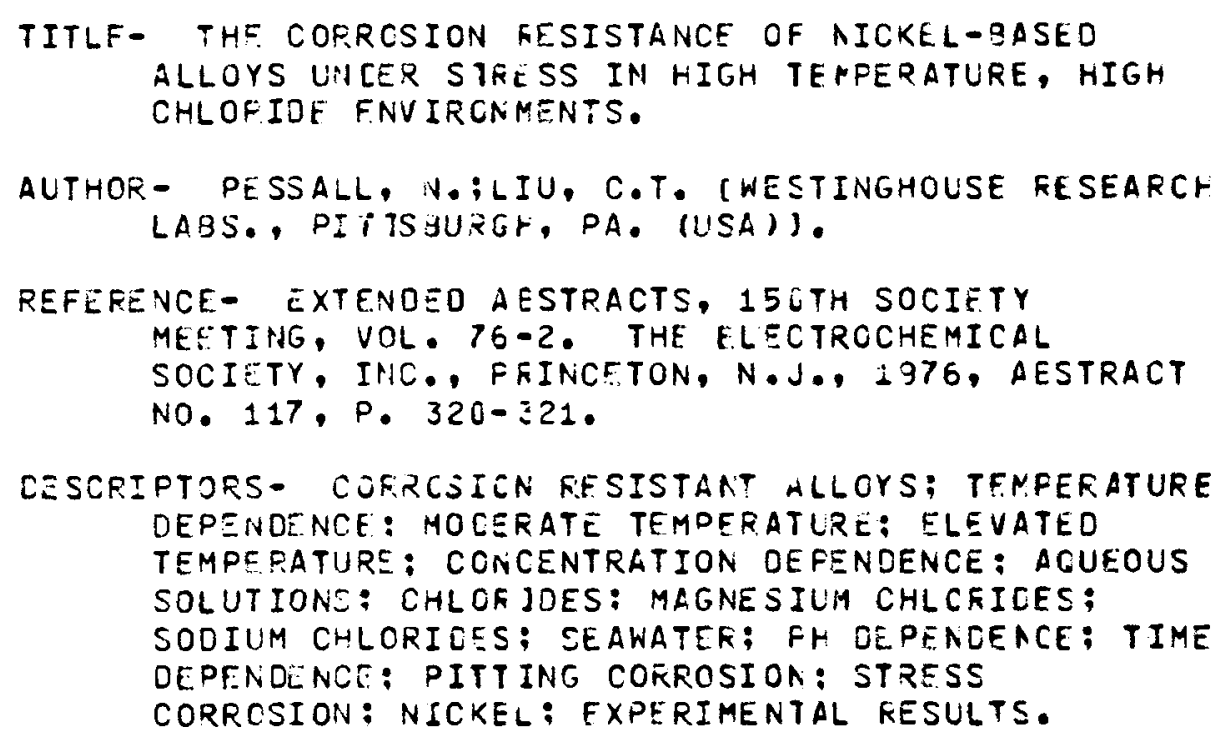

TITLE- EVALUATION CF CORROSICN IN A GEOTHERMAL WELL LINER.

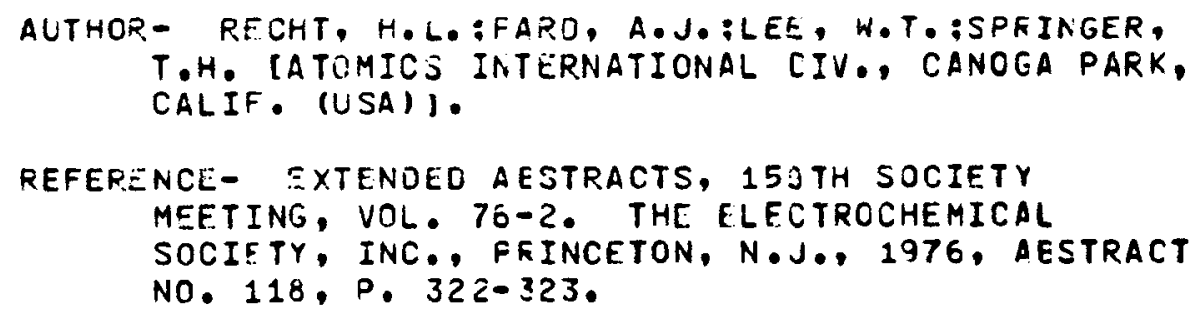

DESCRIPTORS - CORROSICN: GEOTHERMAL WELLS; HELL CASINGS: GEOTHERMAL FLUIOS: [ISSOLVEO SCLIOS; WELL LOGGING: ELEVATEO TEMPERATURE; METALLOGRAPHY; METALS: PIFELINES; PITTING CORROSIOIV: CORROSION RESISTANT ALLOYS: EXPERIMENTAL RESULTS. 


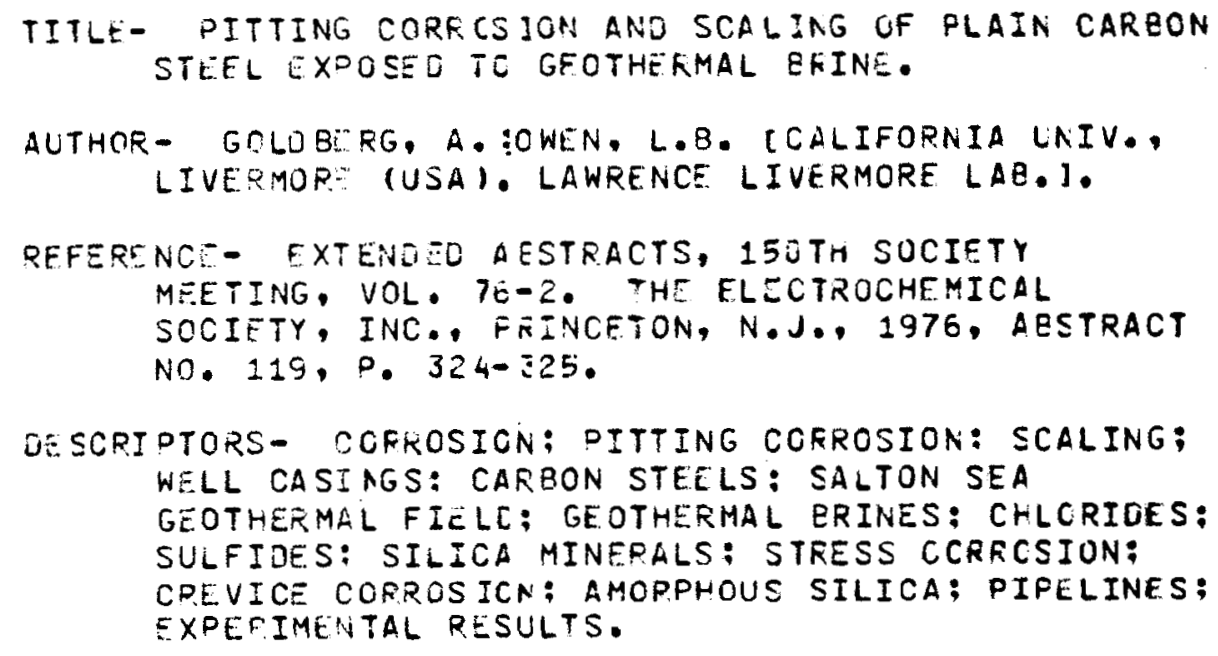

TITLE- METALLURGICAL EVALUATION OF MATERIALS FOR GEOTHERMAL POWER PLANT APPLICATIONS.

AUTHOR- TONEY, S.:COHEN, M. CGENEFAL ELECTFIC CO, LYNN, MASS, (USA). MEOIUM STEAR TUREINE OEPY.I.

CRON, C.J. CURION OIL CO., BREA, CALIF. (USA). UNION DIL RESEARCH CENTER).

REFERENCE - EXTENDED AESTRACTS, $150 T H$ SOCIETY MEETING, VOL. 76-2. THE ELECTKCCHEMICAL SOCIETY, INC., FEINCETON, N.J., 1976, AESTRACT ND. 119A, P. 3ZE-327.

DESCRIPTORS- MATERIALS TESTING: GECTHERMAL POWER PLANTS; CORROSICN FESISTANT ALLOYS: CCRECSION; STRESS CORROSICN; TUFBINES; TEAT EXCHANGERS: NEW MEXICO; GEOTHERMAL FLUIOS: NATURAL STEAM; TIME DEPENOENCE; FATIGUE; AMORP HOUS SILICA; 
TITLE- CORPOSION ANC METAL PROTECTION.

AUTHOR- ROSENFELO, I.L. (ED.) (AN SSSR, MOSCCH. INST. FIZICHESKCJ KHIMII).

RCFERENCE- COPROSZCA AND METAL PRCTECTION. INDIAN NATIONAL SCIENTIFIC DOCUMENTATION CENTRE, NEW DELHI, 1975, 378 P.. TRANSLATION OF - KCEFOZIYA I ZASHCMITA METALLOV., MOSKVA, 1970, TRANSLATEO FROOM RUSSIAN.

DESCKIPTORS - CORROSICN: CORROSION INHIBITORS: CORROSION PROTECIION: CORROSICN FESISTANT ALLOYS: PITTING CORROSION: STRESS CORROSION; METALS: STAINLESS STEELS: ELECTROCHEMICAL CORROSION: ELECJFDLYTES: SEAWATER: SULFLFIC ACID: NITRIC ACIC; HYDPOCHLCFIC ACID; HYCROGEN SULFIDES: OIL WELLS: DRILL PIFES: COATINES: POLYMER COATINES.

TITLF- POLYMER-CONCAEE IF COMPOSITES FOR ENEOCY RELATEO SYSTEMS. PROGPESS REPORT NO. 1 , APRIL-JUNE 1374.

AUTHOR- KUKACKA, L. E. AUSKERN, A.;FONTANA, J. [BROOKHAVEN NATI (NAL LAB., UPTON, N.Y. (LSA). DEPT. OF AFPLIE[ SCIENCE].

REFEFENCE- POLYMER-CLACRETE COMPOSITES FCR ENERGY RELATED SYSTEMS. PROGRESS REPCRT NO. 1 , APRIL-JUNE 1374. SNL 19152, ERCOKHAVEA NATICNAL LAB., LFTON, N.Y., 1974 , INFORMAL REPORT, 9 P..

DESCRIPTORS - COOLINS 10WERS: GEOTHERMAL BRINES: WELL CEMENTING: MATERIALS TESTING: SALTON SEA GEOTHERMAL FIELC: COATINGS: GEYSERS: GECTHERMAL POWEF PLCNTS; PCLYMER-CONCKETE MATERIALS; GEOTHERMAL WELLS; HIGH TEMPEFATURE: CESALTING PLANTS: WASTE FRCCESSING; PIFELINES. 


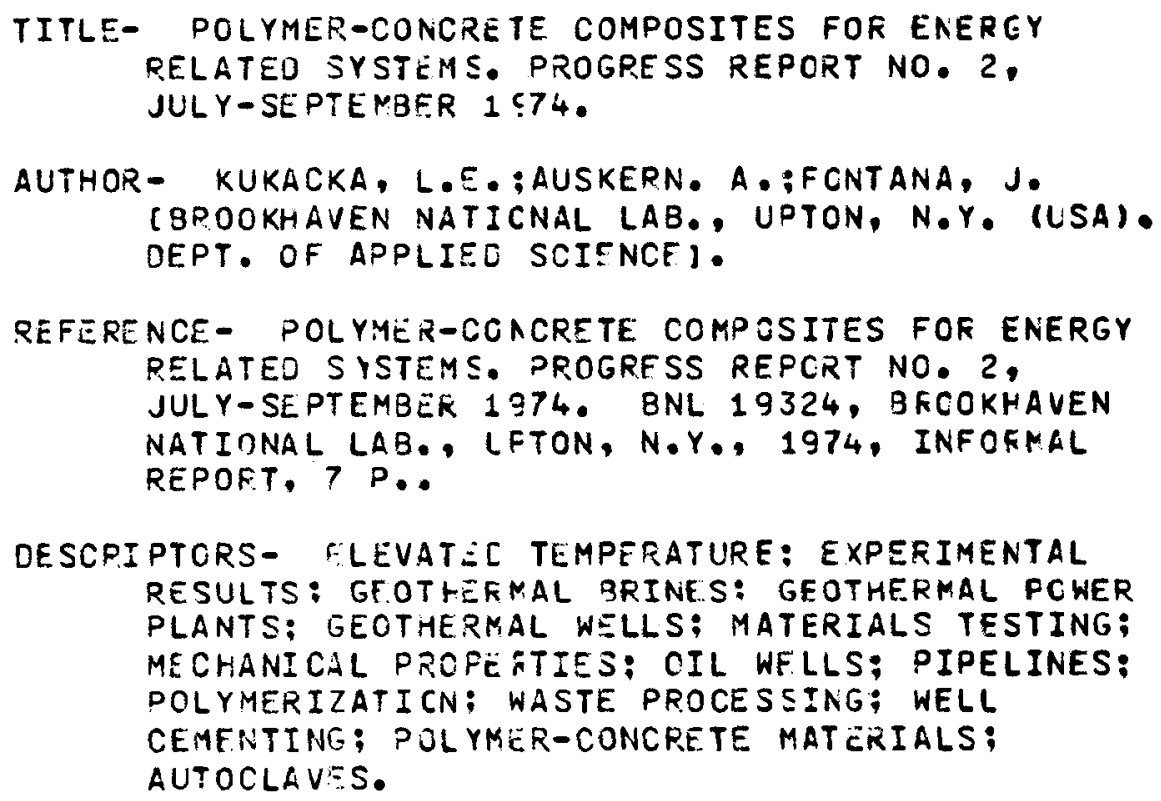

234

KLKACKA $74 C$

BRINE TREATMENT/SCALINE BRINE TREATRENT/CCRFOSION

TITLE- POLYMER-CONCRE TE COMPOSITES FOR ENEREY RELATED SYSTEMS. PF.OGRESS REPCRT NO. 3 , OCTOBER-OECE PBEF 1974.

AUTHOP- KUKACKA, L.E. :AUSKERN. A.:FONTANA, J. IBROOKHAVEN NATI INAL LAB., UPTON, N.Y• (USA). DEPT, OF APPLIEC SCIENCEI.

REE ERENCE- POLYMER-CCACRETE COMPCSITES FCF ENERGY RELATEO SYSTEMS. PROGRESS REFORT NO. 3 , OCTOBEF-DECERBER 1974. BNL 19746, BRCOKHAVEN NATIONAL LAB., LFTON, N.Y., 1974,16 P..

DESCRIPTORS - ELEVATEC TEMPERATURE ; EXPERIMENTAL RESULTS: GEOTH:RMAL BFINES: GEOTHERMAL FOWER PLANTS; GEOTHEFMAL WFLLS; HIGH TEMPEFATLRE; MECHANICAL PROFERTIES; OIL WELLS; PIFELINES; TIME DEPCACENCE: WASTE PROCESSING: WELL 
APRIL-JUNE 1975. BNL 2L336, EROOKHAVEN

NATIONAL LAB., LFTON, N.Y.. 1975, 13 D..

\begin{abstract}
DESCFIPTORS- TLEVATEC TEMPERATURE: EXPERIMENTAL FESULTS: FIELO STUOIES: GEOTHERMAL BRINES; GEOTHERMAL POWEF PLANTS: GEOTHERMAL WELLS: MATEFIALS TESTING; MECHANICAL PRCPERTIES: MATURA! STIAM: CIL WELLS: PIFELINES: PCLYMERIZATION: TIME OEPENOENCE: WASTE MANAGEYENT: WASTE PROCESSING: WELL CASINES: WELL CEHENTING: FOLYMER-CONCFETE MATERIALS: GEYSERS GFOTHERMAL FIELD: NFW MEXICO: AUTOCLAVFS: THERMAL ANALYSIS.
\end{abstract}

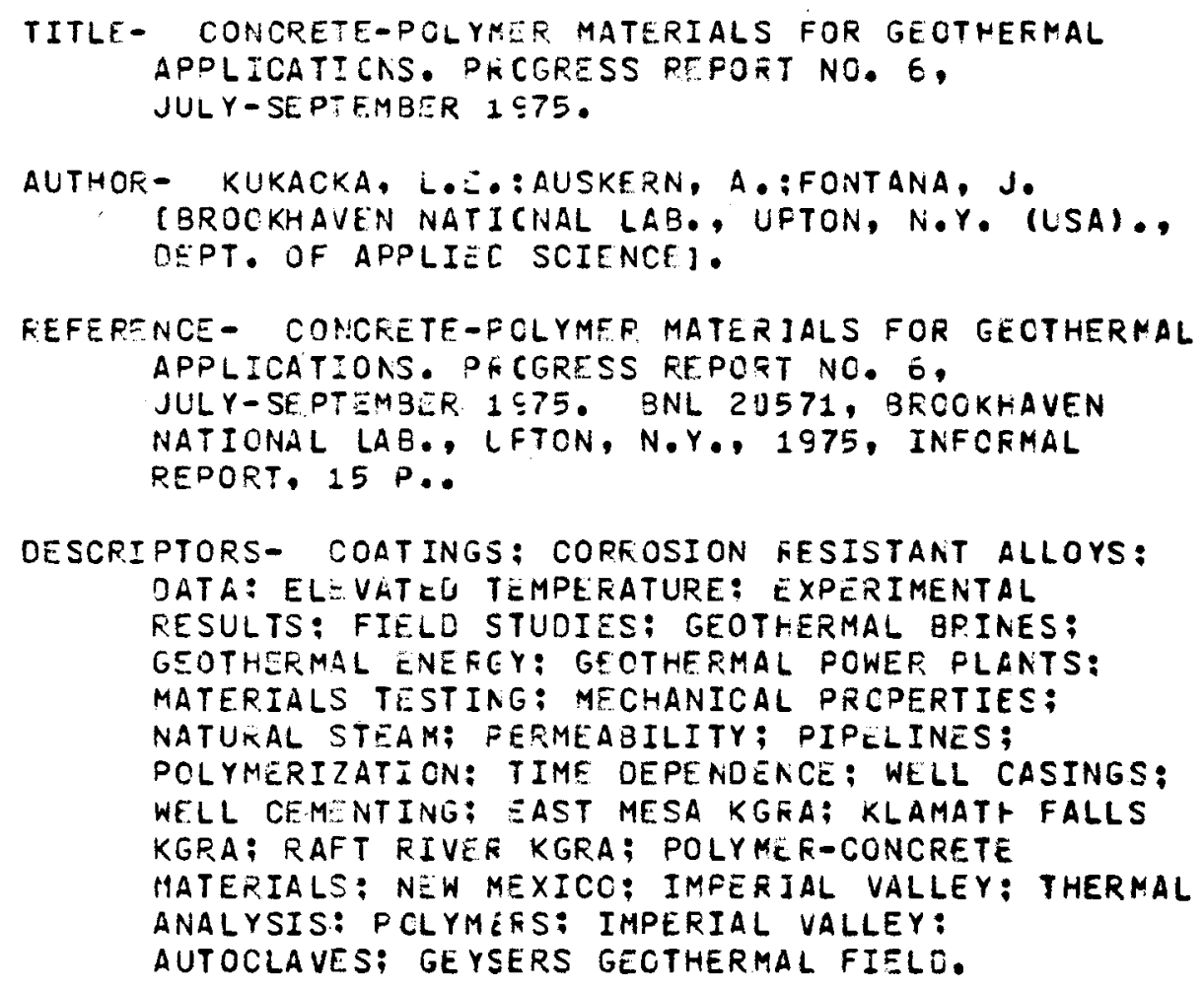




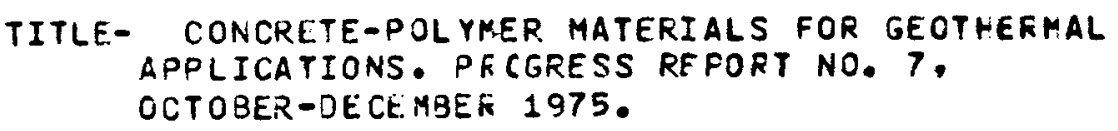

AUTHOR - KUKACKA, L.E.:FONTANA, J.:HORN, W.:AMARO, J. [BROOKHAVEN NATICNAL LAB., UPTON, N.Y. (USA). DEPT. OF APPLIE[ SCIENCE].

REFERENCE- CONCFETE-PCLYMER MATERIALS FOF GECTHERMAL APPLICATIONS. PRCGRESS REPORT NO, 7. OCTOBER-OECE PBEF 1975. BNL 20865 , 8FOOKHAVEN NATIONAL LAB., LFTON, N.Y., 1S75, INFOFMAL REPORT, 22 P..

DESCRIPTORS- COATINGS: CORROSION: ELEVATEO TEMPERATURE; EXFERIMENTAL RESULTS; FIELC STUDIES: GEOTHERMAL FLUIOS: GEOTHERMAL FOWER PLANTS: GEOTHERMAL WELLS: MATERIALS TESTING; MECHANICAL PFCPERTIES; PERMEABILITY: PH AOJUSTMENT: PIFELINES: SCALINE: SCALING CONTFOL: WELL CASINGS: WELL CEMENTING: POLYMER-CONCRETE HATERIALS; THERMAL ANALYSIS; POLYMEPS: GEYSERS GEOTHERMAL FIELO: AUTCCLAVES: NEW MEXICO: KLAMATH FALLS KGEA; EAST MESA KGRA; FAFT RIVER KGRA.

TITLE- COACPETE-POLYMER MATERIALS FOR GECTHERMAL APPLICATIONS. PFCGRESS REFORT NO. 8 , JANUARY-MAR.CH 1976 .

AUTHOR - KUKACKA, L.E.:FONTANA, J.:HORN, H.:AMARO, J. (BR.OOKHAVEN NATI CNAL LAB., LFTON, N.Y. (USA). DEPT. OF APPLIE[ SCIENCE].

REFEFENCE- CONCRETE-FCLYMER MATERIALS FOR GECTHERMAL APPLICATICNS. PFCGRESS REPORT NO. 6 , JANUARY-IAARCH 19i6. BNL 21244, BROCKHAVEN NATIONAL LAB., LFTON, N.Y., 1976, INFORHAL REPOPT, $\$ 8$ P..

DESCRIPTORS- CORROS ICN: CORFOSION RESISTANT ALLOYS: ECONOMICS: BLECTROCHEMICAL CCRROSION: FLEVATEO TEMP RATURE: FIELD STUOIES: GEOTHERMAL FLUIDS; GEOTHERMAL PCHEF PLANTS: GEOTHERMMAL SYSTEMS; MATERIALS TESTING; MECHANICAL PROPERTIES; NATUEAL STEAM; FH AOJUSTMFNT; PCLYMERIZATION; 
SCALING: WELL CASINGS: WELL CEMENTING: POLYMER-C CNCRE IE MATERIALS: PCLYMERS: THERMAL ANALYSIS; GEYSERS GEOTHERMAL FIELO; IMPERIAL VALLEY: KLAMATH FALLS KGRA; RAFT RIVER KGRA.

240

KUKACKA $76 \mathrm{E}$

BR INE TREATMENT/SCALING BRINE TREATMENT/CCRFOSION

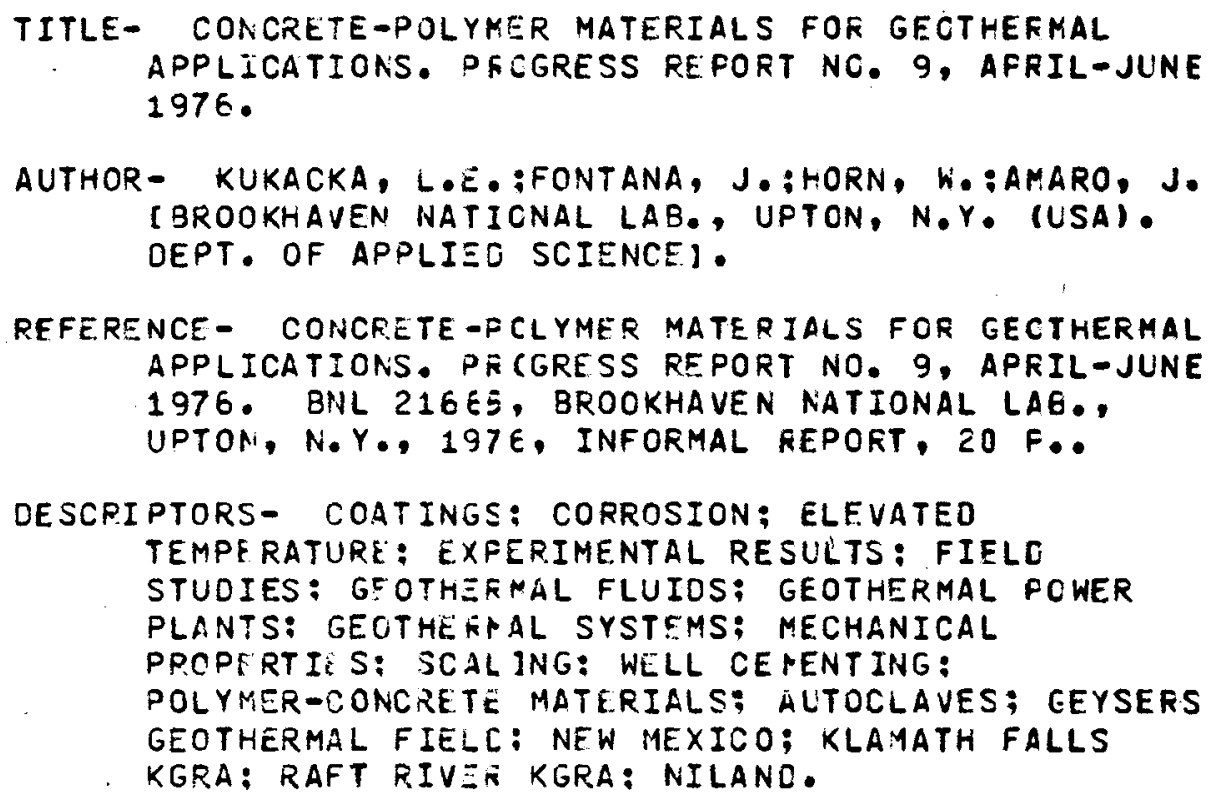

241

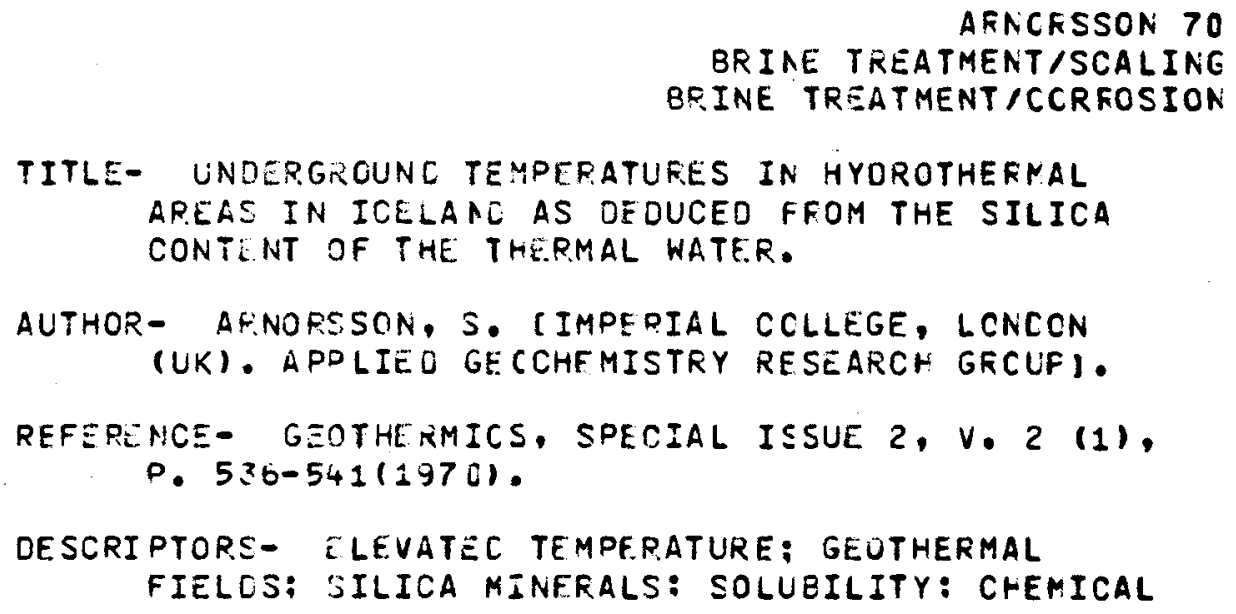


EQUILIBRIUM: CHALCFDONY; QUAFTZ; PRECIFITATICN: MEASURING METHCCS: EXFEFIMENTAL FESLLTS; OEEF WELLS: ICELAND.

242

[CRINCC 70

BRINF TKEATMENT/SCALINE BRINE TREATMENT/CCRROSION

TITLE- THE GEOCHEMISTFY CF THE KIZILOERE CECTHERMAL FIELD, I:I THE FFAMEWORK OF THE SARAYKOY-CENIZLI GEOTHEPMAL AREA.

AUTHOR- DOMINCO, - Q IU.N. GEOTHERMAL ENEREY SURVEY OF WESTERN ANATCLIA, ANKARA (TURKEY)].

SAMILGIL, E . CMTA INSTITUTE, ANKARA

REFCFENCE- GEOIHEFHICS, SPECIAL ISSUE $2, v, 2(1)$, P. $553-550(1970)$.

DESCRIPTORS- GEOCHEMISTRY: GEOTHEFMAL FLUICS: GEOTHERMAL RESEFVOIPS: RESERVCIR PRCPERTIES; MODERATE TEMFERATURE: HYDROLCGY: CHEMICAL EQUILIBRIUM; CALCITE: CHEMICAL ANALYSIS; MEASURING RETHCES: EXPERIMENTAL RESULTS; DEEP WELLS: KIZILDEFE GEOTHERMAL FIELC; TURKEY.

243

ELLIS 70

BRINE TREATMEAT/SCALING

BR INE TREATMENT/CCRFOSION

TITLE- QUANTITATI VE INTERPEETATICN OF CHEMICAL CHARACTERISTICS CF HYDPOTHERMAL SYSTEMS.

AUTHOR- ELLIS, A.J. (CEPARTMENT OF SCIENTIFIC ANO INOUSTRIAL RESEAFCH, PETONE (NEH ZEALANC). CHEMISTRY OIV.I.

REFERENCF- GEOTHERMICS, SPECIAL ISSUE $2, V \cdot 2(1)$, P. 516-528(1976).

DESCRIPTORS - CHEMICAL EQUILIBRIUM; CHEMICAL REACTIONS: CHEMICAL COMPOSITICN: CONCENTRATION OEPENDENCE: ELEVATED TEMPERATLRE; GEOCHEMISTRY; PH VALUE; GEOTHIFMAL FLUIDS; DEEP WELLS; TEMPE RATURF DEPENOENCF: CALCITE; PRECIFITATION; SALINITY: SULF JEES. 
HAYASHIDA 70

EPIAE TREATMEAT/SCALINE

BRINE TREATMENT/CCREOSION

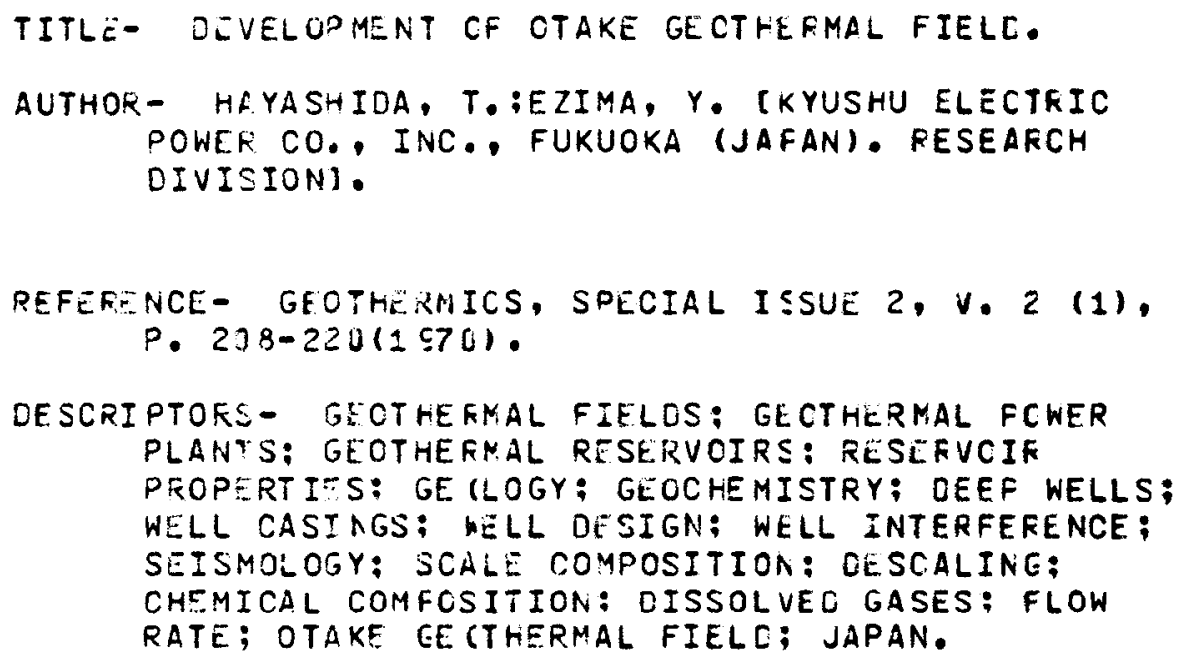

245

TITLE- THE PROOUCTICA OF CHEMICALS FROM BRINE AND SEAWATER USING GEOTHERMAL ENERGY.

AUTHOR- LINDAL, 9. I CCNSULTING ENGINEER, REYKJAVIK (ICELAND) ].

REFEFENCE- GEJTHERMICS, SPECIAL ISSUE $2, V .2(1)$, P. $910-917(197()$.

DESCRIPTORS- MINERAL FECOVERY: GEOTHERMAL REINES: SEAWATER: GEOTHERMAL ENERGY: FEYKJANES GEOTHERMAL FIELE; ICELAND; CHEMICAL COMPOSITION: CHEMICAL REACTICNS: ECONOMICS. 


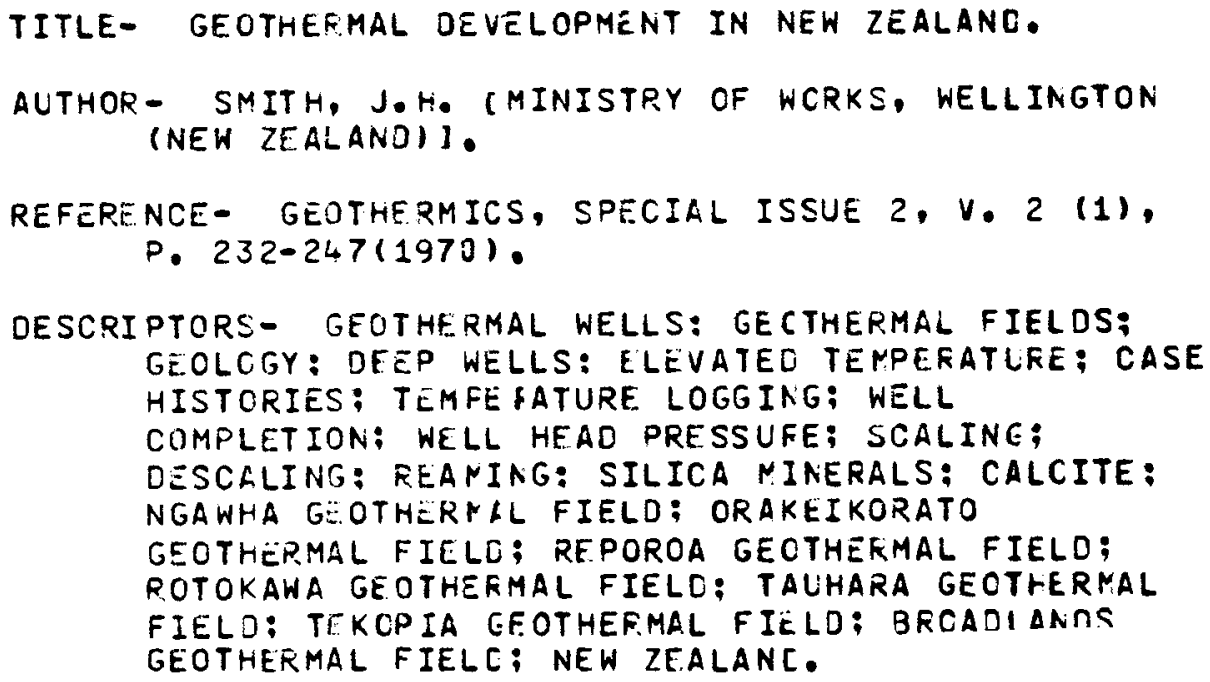

TITLE- SCALE CEPOSITICN AND CONTRCL RESEARCH FOR GEOTHERMAL UTILIZATION. THE ABOVE ARTICLE HAS ALSO APPIARE IN IN (1) PROC.-ENO U.N. SYMP. ON THE CEV. AND USE OF GEOTHEFMAL RESOURCES, SAN FPANCISCO, CALIF, MAY 2E-23, 1975, ANC (2) PROC.-WWRKSHCF ON MATERIALS FECBLEMS ASSOCIATEO WITH THE OEV. OF GEOTHERMAL ENERGY SYSTEMS, EL CENTFO, CALIF, MAY 16, 1975.

AUTHOR- WAHL, E.: YEN, I.K. IGARRETT RESEARCH ANO OEVELOPMENT CO. INC., LA VEFNE, CALIF. (USA) I.

REFERENCE- SCALE CEFOSITION ANO CCATRCL FESEAFCH FOF GEOTHERMAL UTILIZATION. GRE 75-050, GAFRETT RESEARCH AND DEVELOPMENT CO., LA VERNE, CALIF., MAY 1975,15 P..

DESCRIPTORS- AMCRPHCLS SCALE: ERINES: CALCITE: CHEMICAL CCMPOSITION: CHEMICAL ZOUILIERILM: CHEMICAL REACTICN KINETICS; LXPFRIHENTAL RESULTS: GECTREFRAL BFINES: PATHEMATICAL MODELS: MEASUFINE METHODS: PH VALUE: FRESSURE DEPENDENCE: SCALE COMPOSITION: DESCALINE; SCALING; SILICA NINEF.ALS; SILICATES; TEMPEFATURE DEFENDENCE: TIME DEPENOENCE: EAST MESA KGRA. 
WONG 70

BR INE TREATMENT/SCALING

BRINE TREATMENT/CCRROSION

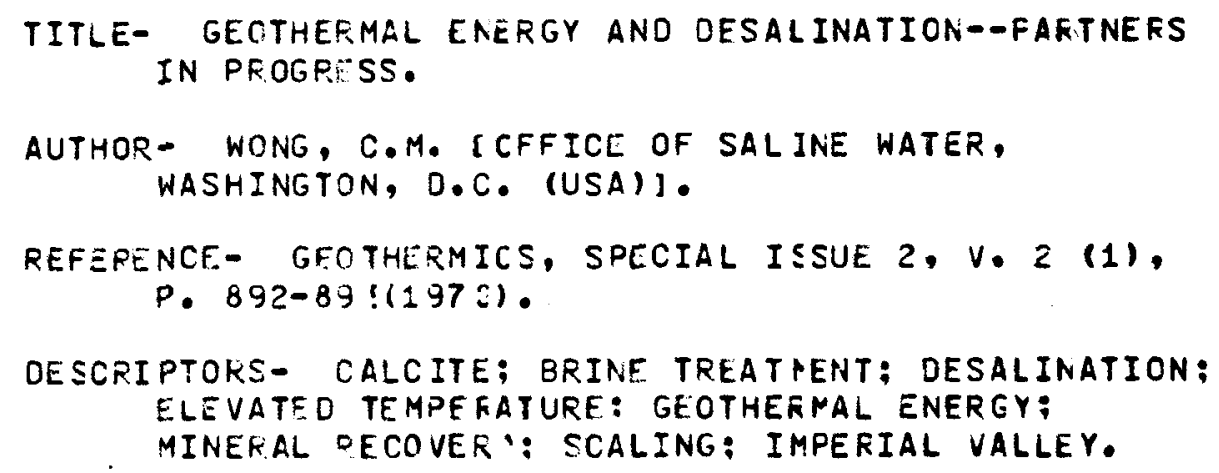

249

\author{
AFMSTEAC 70 \\ BRINE TREATMENT/SCALINE \\ BR. INE TREATRENT/CCRROSION
}
TITLE- UTILIZATION CF STEAM ANC HIGH ENTHALFY WATER (FOR ELECTRIC FOWER GENEFATICA AND CTHER PURPOSESI.

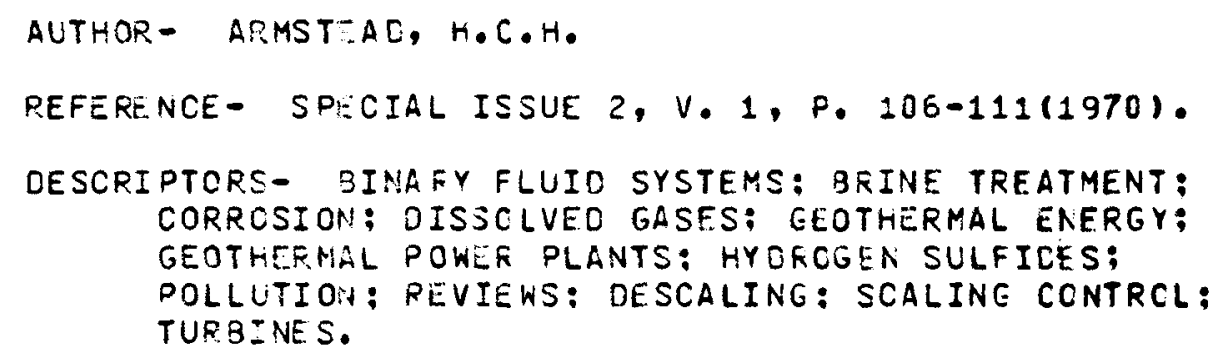

250

TITLE- CHEMICAL ASPECTS OF THE ENUIRONMENTAL IMPACT OF GE OTHEERML PCWER. 


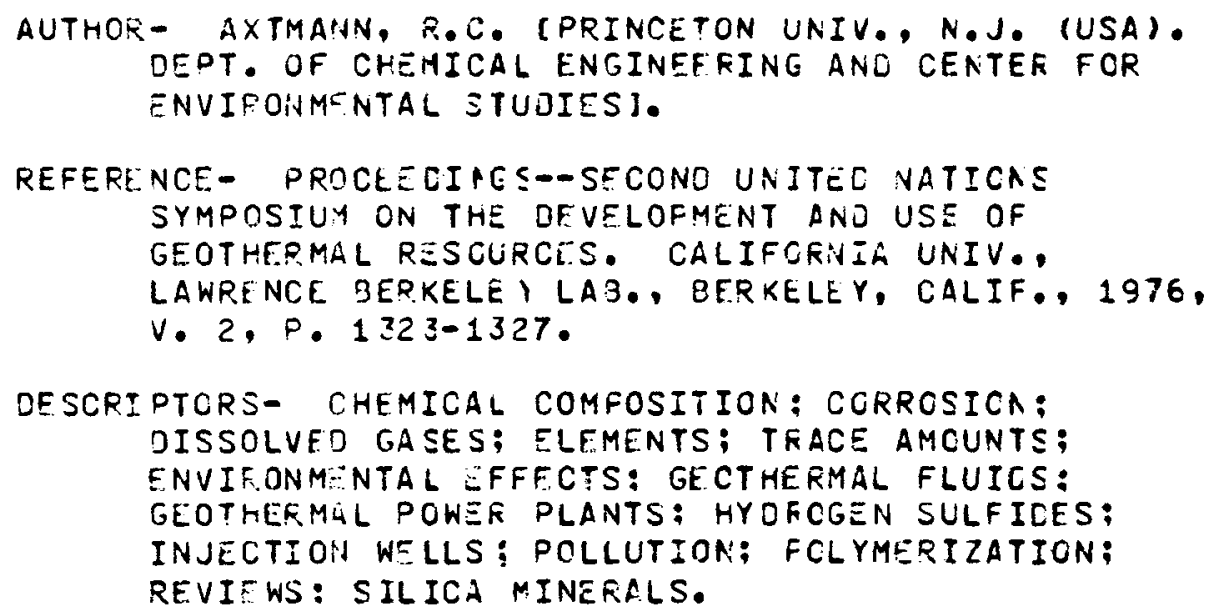

251

ERACBURY 70

BRINE TREATMENT/SCALING BRINE TREATMENT/CCRROSION

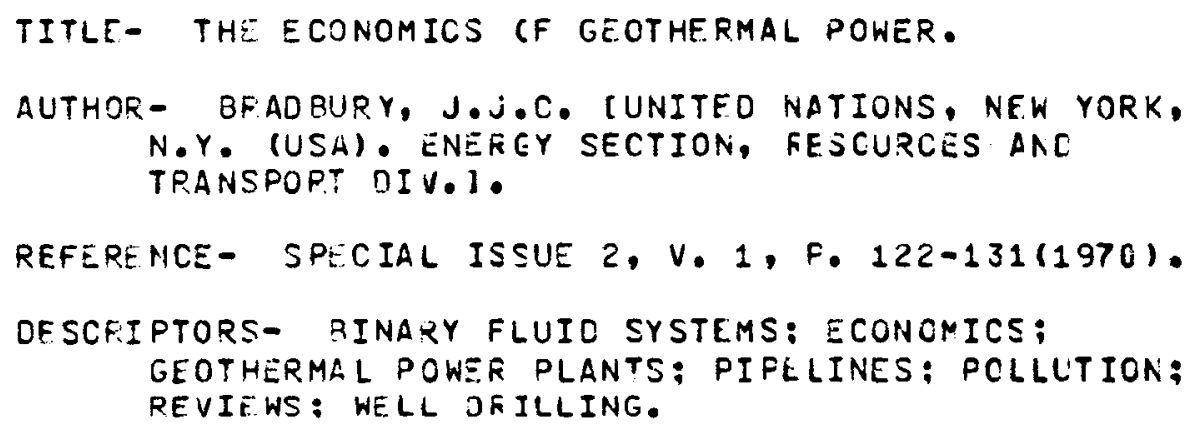

TITLE- THE STATUS OF WORLD GEOTHERMAL DEVELCFMENT. AUTHOR - FACCA. G. REFERENCE- SPECIAL JSSUE 2, V. 1, P. 8-23(1970). DESCRIPTORS - BINAFY FLUID SYSTEMS: ECONCMICS; GEOTHERMAL POHER PLANTS: REVIEWS. 


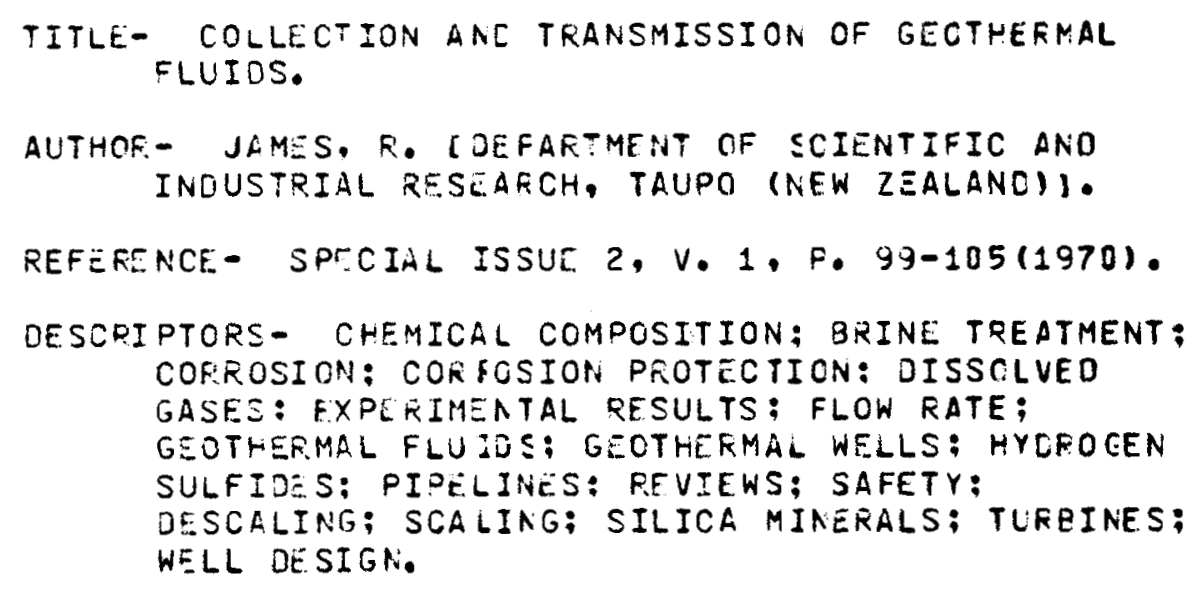

254

WHITE 70

BRINE TREATMENT/SCALINE BRINE TREATMENT/CCRFOSION

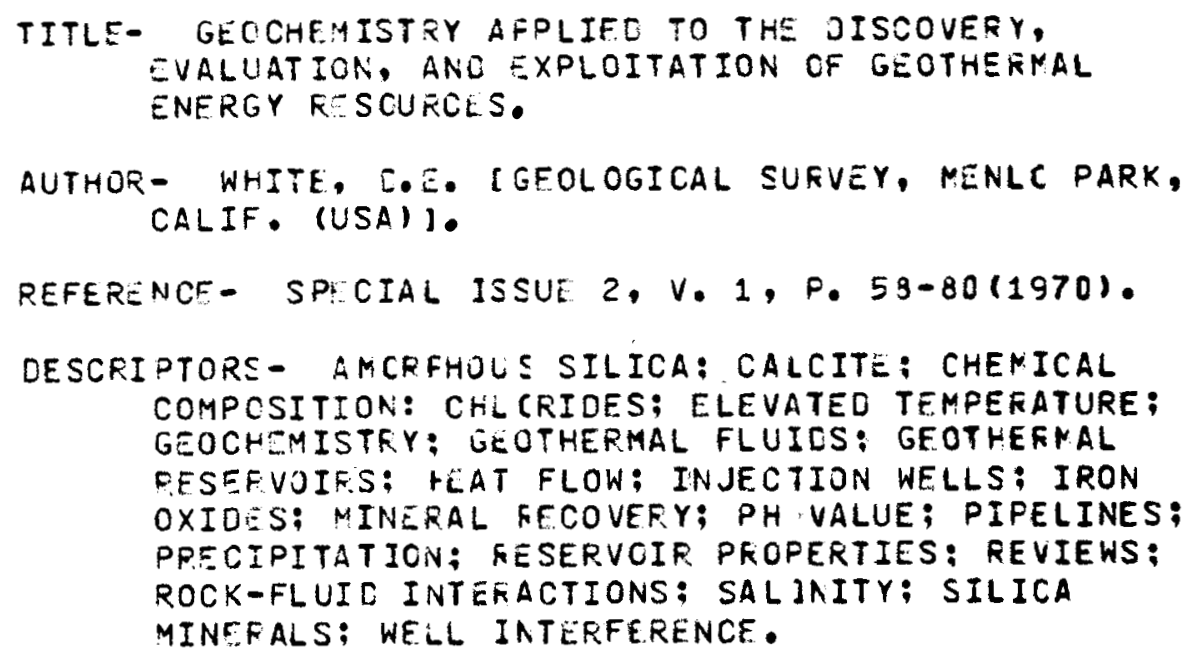

255 
AUTHOR- BARNES, H.L. :FIMSTIOT, J.C. CPENNSYLVANIA STATE: UNIV., UNI IERSITY PARK (USA). DEFT. OF GEOSCIENCE $S$.

HALL, B.A. (EC.)

REFERENCE- SFCOND WCKKSHOP ON MATEFIALS PFOELEMS ASSOCIATED WITH THF DEVELOPMENT OF GEOTHERMAL ENERGY SYSTEPS. PROCEEDINGS OF THE WOFKSHOP HELD MAY 16-18, 1975 AT EL CENTFO, CALIFORNIA. GEOTHERMAL RESOLRCES CCUNCIL, DAVIS, CALIF., $1976, P .1-13$.

DESCRIPTORS- AMORPHOLS SILICA: CAFEONATES: CHEMICAL FQUILIBRIUM: CHEMICAL REACTICA KINETICS: CHEMICAL REACTICNS: CONCENTRATION DEFEACENCE; CRISTOBAL ITE; IISPOSAL FORMATIONS; ELEVATED TEMPERATURT: EXFERIMENTAL RESLLTS; FOULING; GEOTHERMAL POWER PLANTS; GEOTHERMAL RESEFVOIES; MEASURING METHOCS: MODERATE TEMPERATURE: PH VALUE: PIFELINES; PLUGGING; FFECIPITATICN; OUARTZ; SALINITY: SCALING; SCALING CONTKCL: SILICA MINERALS: SILICA CHEMISTRY: SILICA SOLUBILITY: SCLLEILITY; TEMFEFATURE CEFEADENCE.

$25 \epsilon$

EISHOP 76

ORINE TREATMENT/SCALING TITLE- GEOTHEFMAL TEST BY SAN OIEGC GAS AND ELECTRIC
CO..

AUTHOR- BISHOP, H.K. ISAN OIEGO GAS ANO ELECTRIC

CO.. CALIF. (USA)].

HALL, B.A. (EE.)

PEFERENCE- SECOND WCFKSHOP ON MATEFIALS PROELEMS ASSOCIATED WITH THE DEVELOPMENT OF CEOTRERMAL ENERGY SYSTERS. PROCEEOINGS CF THE WOAKKSHOP HFLO MAY 16-18, 1975 AT EL CENTFO, CALIFORNIA. GEOTHEFMAL RESCLRCES COUNCIL, DAVIS, CALIF.. 1976 , P. 13-67.

OESCRIPTORS- IINAFY FLUID SYSTEMS: CHEMICAL COMPOSITION: COFROSION: DISSCLVED GASES: OISSOLVEO SOLIOS: ELEVATEC TEMPERATURE: EXPEFIMENTAL RESULTS: FLOW RATE: GEOTHERMAL BRINE S: GEOTHERMAL POWER PLANTS: GECTHEFMAL WELLS; HEAT EXCHANGERS; MOCERATE PRESSLRE; PITTING CCFRCSICN; RESEFVOIR FRCPEPTIES; SCALING: SCALING CONTROL: SCRLGEERS: SILICA MINEFALS: IMPFEIALL VALLEY: NILAND: HEEEF GEOTHERMAL FIELL. 


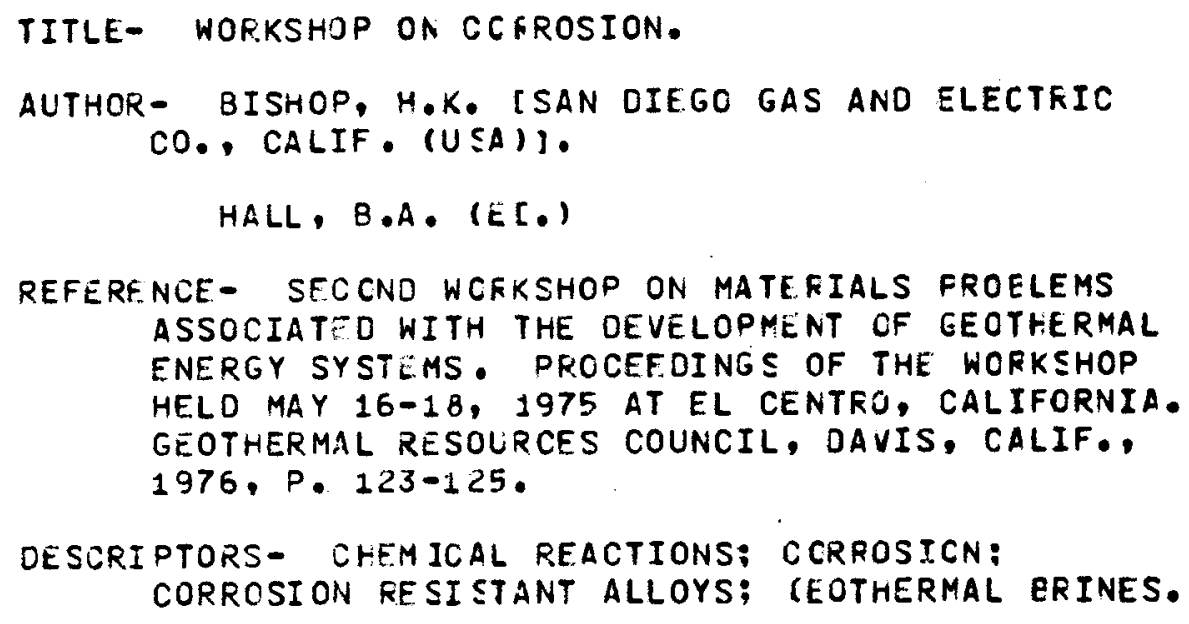




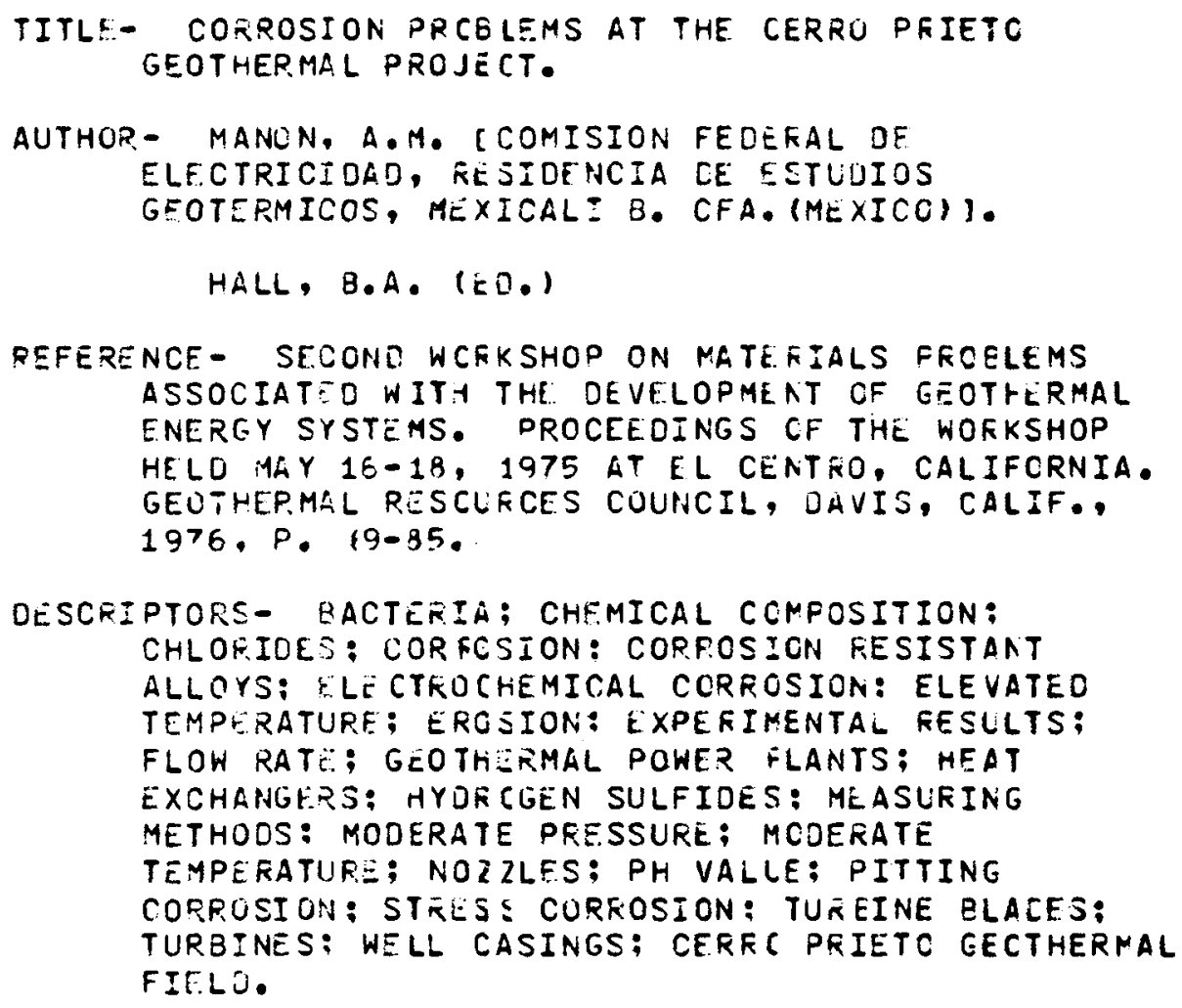

260

MAUREF 76

BRINE TREATMENT/CCRROSION

TITLE- NEW AUSTENITIC ANO FERRITIC STAINLESS STEELS FOR GEOTHERMAL AFPLICATIONS.

AUTHOR - MAURER, J.R . [ALLEGHENY LUCLUM STEEL CORP., BRACKENRIDGE, FA. (USA). RESEARCH CENTER).

HALL, B.A. (E[.]

REFERENCE - SECONO WORKSHOP ON MATERIALS PROELEMS ASSUCIATED WITH THE OEVELOPMEAT OF GECTHERMAL ENERGY SYSTEMS. PROCEEDINGS OF THE WOFKSHOP HELD MAY :5-18, 1975 AT EL CENTRO, CALIFORNIA. GEOTHERMAL RESCURCES COUNCIL, DAUIS, CALIF., 1976, P. 1C5-119.

DESCRIPTORS- CHLORICES: CORROSION RESISTANT ALLOYS: CREVICE CORROS ICN; OESALTING PLANTS;

ELECTROCHËMICAL CORROSION; EXPERIMENTAL 
RESULTS: GEOTHEEPAL POWFR PLANTS: MEASLRING METHODS: PITTIAC CORROSION; STAINLESS STEELS; STRESS CURROSION: TEMPERATURE DEPENCENCE.

261

MALRER 76E BP.INE TREATMENT/CCRROSION

TITLE- WORKSHOP ON METALS FABRICATICN.

AUTHOR- MAURE?, J.R. LALLEGHENY LUCLUM STEEL CORP., BRACKENRIOGE, FA. (USA). RESEARCH CENTEF).

HALL, B.A. (EC.)

REFERENCE- SECOND WCFKSHOP ON MATEFIALS PROELEMS ASSOCIATED WITH THE DEVELCPMENT CF GEOTHERMAL ENERGY SYSTE HS. PROCEEOINGS CF THE WOFKSHOP HELD MAY 16-18, 1975 AT EL CENTFO, CALIFCRNIA. GEOTHERMAL RESCLRCES COUNCIL, DAVIS, CALIF., 1976, P. 133-13E.

DESCRIPTORS - GEOTHEFMAL POWER PLANTS; MATERIALS TESTING.

262

NEECHAM 76E

BR INE TREATMENT /CCRFOSION

TITLE- MATERIALS FESEAPCH AND OEVELOPMENT PFCERAM FOP. GEOTHERMAL EAVIFONMENTS.

AUTHOR- NEEOHAM, P.3., JR. (BUREAU OF MINES, COLLEGE PARK, MD. (USA). COLLEGE PARK METALLUREY

RESFARCH CENTEFI.

HALL, B.A. (IEO.)

REFERENCE- SECOND WCFKSHOP ON MATERIALS PRCELEMS ASSOCIATED WITH THE DEVELOPMENT OF GEOTHERMAL ENERGY SY STEMS. DROCEEDINGS CF THE WORKSHOP HELO MAY :6-18, 1975 AT EL CEATRO, CALIFCRNIA. GEOTHERMAL RESOLIFCES COUNCIL, DAVIS, CALIF., 1976 , P. 15-62.

DESCRIPTORS- BRINES: CARBONATES: CHEMICAL ANALYSIS: CORROSION: CORFOSION RESISTANT ALLOYS: CFEVICE CORROSION: DESALTING PLANTS; OISSOLVED GASES; ELEVATED TFMPERATURE; FIELD STUDIES: GEOTHERMAL BRINES: GEOTHERMAL POWER PLANTS: GEOTHERMAL 
WELLS: PITTING CCRROSION; SCALE COMPOSITION; SCALING; SOLUBILITY; STRESS CORROSICN;

TEMPERATURE DE FEADENCE: SALTON SEA GEOTHERMAL

FIELO; EAST PESA KGRA.

263

WAHL 76

BR INE TREATMENT/SCALING

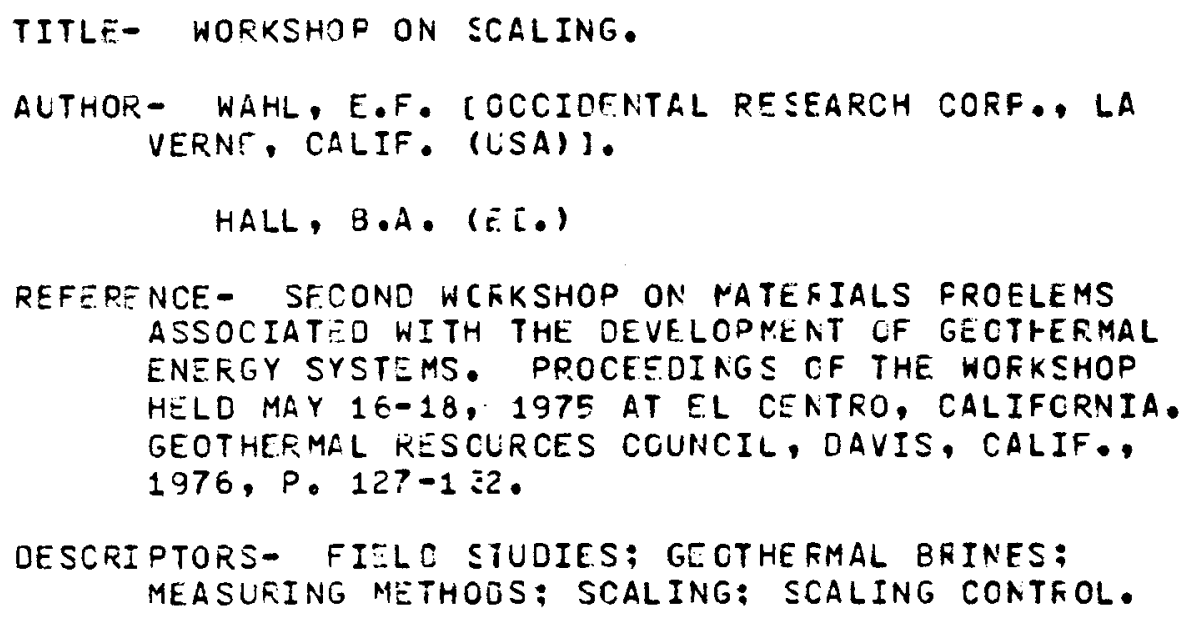

264

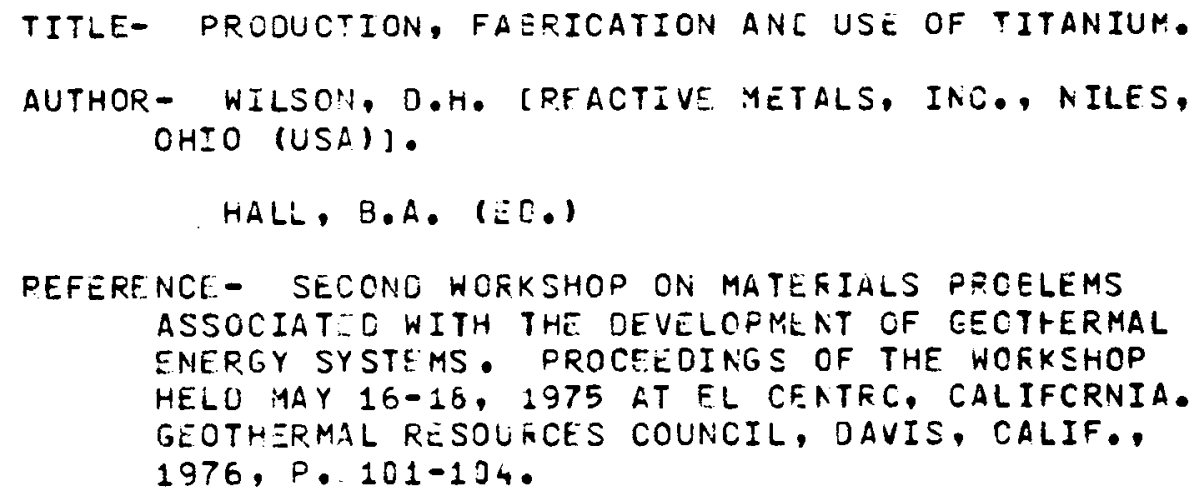

UESCRIPTORS - CORRCSICN: CORFOSION RESISTANT ALLOYS. 
ALSTIA 76

BR INE TREATMENT/SCALING BRINE TREATMENT/CORFOSION

\author{
TITLE- PROSPECTS FOR ADVANCES IN ENERGY CONVERSION \\ TECHNOL OGIES FOF GEOTHERMAL ENERGY OEVELOPMENT. \\ AUTHOR- AUSTIN, A.L. (CALIFORNIA UNIV., LIVEFMORE \\ (USA). LAWRENCE LIVERMORE LAB.) • \\ REFERENCE - PROCECOINGS--SECOND UNITED NATICNS \\ SYMPOSIUM ON THE DEVELOPMENT AND USE OF \\ GEOTHERMAL RESOLRCES. CALIFORNIA UNIV., \\ LAWRENCE GERKELEY LAB., BERKELEY, CALIF., 1976, \\ V. 3, P. 1925-1935. \\ OESCRIPTORS- 3 INAFY FLUID SYSTEMS: ECONOMICS; \\ ELEVATED TEMPE FATURE: FLASHING; FLOW RATE: \\ GEOTHERMAL BRINES: GEOTHERMAL FIELOS: \\ GEOTHEFMAL POWEF PLANTS: MODERATE PRESSLRE; \\ NOZZLES: SURFACE EQUIPMENT: THERMOOYNAMIC \\ PROPERTIES; TOTAL FLOW SYSTEN; TURBINES.
}

266

BR. INE TREATMENT/CCRFCSION

TITLE- MATERIAL ANE CCRPOSION TESTING AT THE EEYSERS GEOTHEPMAL PCWEI PLANT.

AUTHOR- DODJ, F.J.:JCHNSON, A.E.:HAM, W.C. CFACIFIC GAS ANO :LECTRIC CO., SAN RARCN, CALIF. (USA). DEPT. OF ENGINEERING RESEARCHI.

REFERENCE- PROCEEDI AGS--SECONO UNITED NATIONS SYMPOSIUM ON THE DEVELOPMENT AND USE OF GEOTHERMAL RESCLRCES. CALIFCENIA UNIV., LAWRENCE BERKELEY LAB., BERKELEY, CALIF., 1976, V. 3, P. 1959-19E3.

DESCRIPTORS - CHEMICAL COMPOSITION: PH AOJUSTMENT: CORRUSION: CORRCSION RESISTANT ALLOYS: CREVICE CORROSION: OISIOLVEO GASES; EXPEKIMENTAL RESUITS: FIELO STUDIES; FLOW RATE; EEOTHERMAL BRINES; GEOTHEFNAL POWER PLANTS: HYCROGEN SULFIOES: FITTING CORROSICN: STAINLESS STEELS; TURBINE 3LACES: GEYSERS GEOTHERMAL FIELC. 
FERAELIUS $7 E$

BP INE TREATMENT/SCALINE

BRINE TREATMENT/SFENT FLUIE CISPOSAL

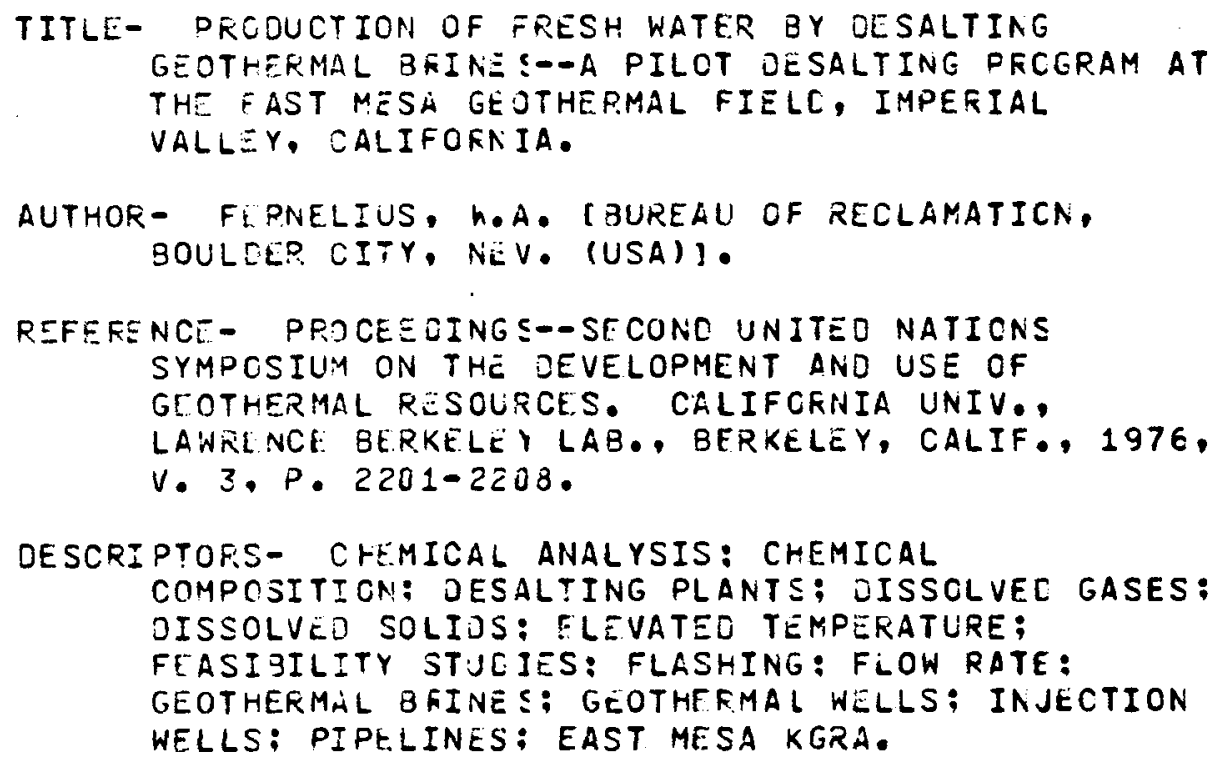

HANCK 768

BRINE TREATMENT/CCRFOSION

TITLE- CORPOSION RATE MONITORING AT THE GEYSERS
GECTHER.AL POWEK PLANT.

AUTHOR- HANCK, J.A.:NEKOKSA, G. [FACIFIC GAS AND ELECTRIC CO., SAA RAMON, CALIF. (USA). CEPT. OF ENG INEERING RESEARCH].

REFERENCE- PROCEEDIAGS--SFCOND UNITED NATIONS SYMPOSIUM ON THE JEVELOPMENT ANO USE OF GEOTHERMAL RESCLRCES. CALIFCRNIA UNIV.. LAWRENCE BERKELEY LAB., BERKELEY, CALIF., 1976, V.3, F. $1 \subseteq 79-1 \subseteq B$ L.

DESCRIPTORS- CATHCOIC DEPOLARIZATION: CHEMICAL ANALYSIS: CORPOSION: CORROSICA MONITCRING: CORROSION RESISTANT ALLOYS: CREVICE CORFOSION; ELECTROCHEMICAL CORROSION: ELEVATED TFMPERATURE: ERCSION: FIELO STUCIES: FLCW RATE: GEOTHERMAL BRINES: GEOTHERMAL POWER PLANTS; HYOROGEN SULFICES: MEASURING INSTRUMENTS: 
MEASURING MFTHCES: MODERATE FRESSURE; FF VALUE: PITTING CCRROSICN; STAINLESS STEELS; GEYSERS GEOTHERMAL FIELC.

269

LCMBARD 76

BP. INE TREATMENT/SCALING

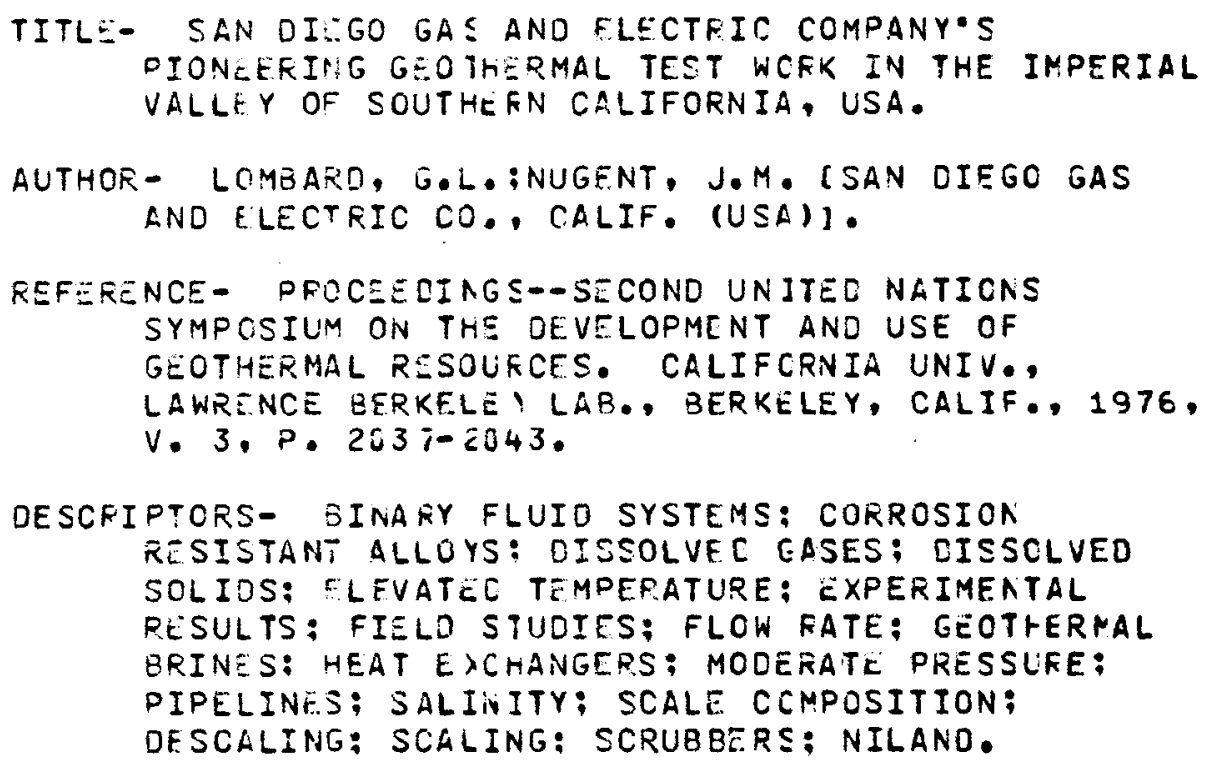

270

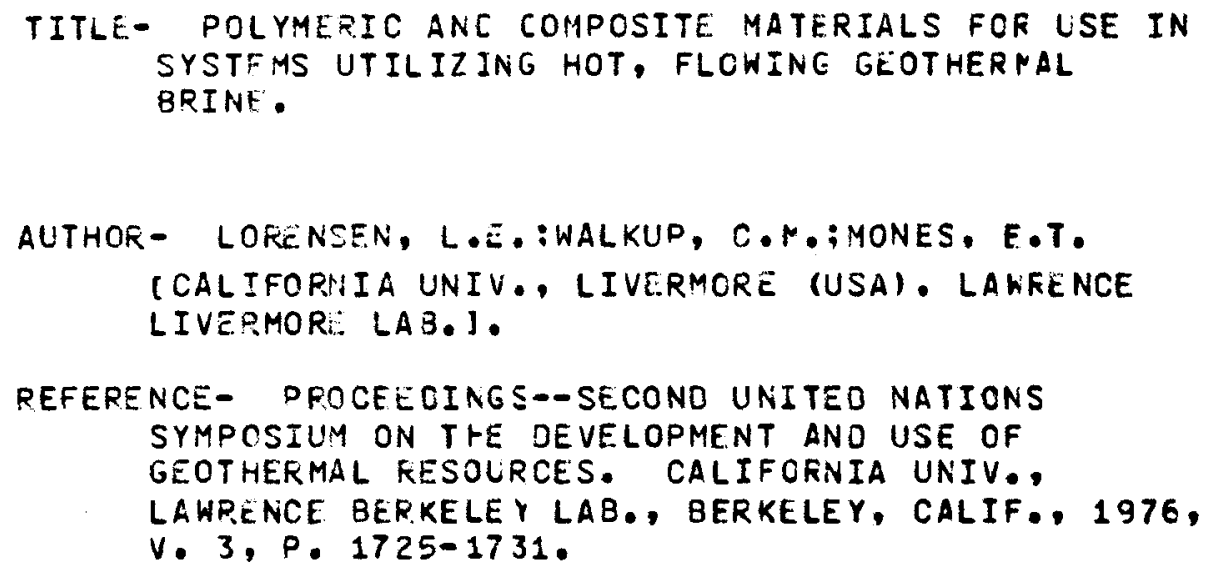


DESCRI PTORS - ELEVATEO TEMPERATURE; EROSION: EXPERIMENTAL PESULTS: FIELD STUDIES: GEOTHERMAL BRINES: MATERIALS TESTING; NOZZLES; SCALING; STAINLESS STEELS; TOTAL FLOW SYSTEM.

271

MATHIAS 76

BRINE TREATMENT/SCALING BR. INE TREATMENT I SFENT FLUIC OISPOSAL

TITLE- THE MESA GEOTHEPMAL FIELD--A FRELIMINAFY EVALUATION OF FI VE GEOTHERMAL WELLS.

AUTHOR - MATHIAS, K.E. [BUREAU OF RECLAMATION, BOUL[ER CITY, NEV. (USA)].

REFEPE NCE - PFOCEECINGS--SECOND UNITED NATIONS SYMPOSIUM ON THE DEVELOPMENT ANE USE OF GEOTHERMAL RESOLFCES. CALIFCFNIA UNIV., LAWRENCE BIPKELEY LAB., BERKELEY, CALIF.. 1976, V. $3, P .1741-1747$.

DESCRIPTORS- CHEMICAL COMPOSITION: BRINE TFEATMENT: DESALTING PLANTS: FLEVATED TEMPERATURE: FLOW RATE: GEDTHERMAL FIELDS: GEOTHERMAL WELLS; IHJECTION WELLS: MEASURING INSTRUMENTS; MODEFATE PFESSURE: MONITORING: PRESSURE DECLINE: SCALIAG: WELL CASINGS: WELL COMPLETION; EAST MESA KGRA.

272

TCLIVIA 76 BRINE TREATMENT/CCRFOSION

TITLE- CORROSION OF TURBINE MATEKIALS IN GECTHERMAL STEAM ENVIRONMEA 1 IN CERPO FFIETO, MEXICO.

AUTHOR- TOLIVIA, E. $\mathrm{M}$. [FEOERAL ELECTRICITY COMMISSION, MEXICO, D.F. (MEXICO)].

HOASHI, J.:MIYAZAKI, M. (ICKYO SHIBALEA ELECTRIC CO., LTC., YOKCHAMA (JAPAN)).

REFERENCE- PROCEELINGS--SECOND UNITEO NATIONS SYMPCSIUY ON THE DFVELOPMENT ANO USE CF GEOTHERMAL RESCUFCES. CALIFCENIA UNIV.. LAWRENCE BERKELEY LAB., BERKELEY, CALIF., 1976, V. 3,P. $1815-182 i$. 
DESCRIPTORS - CHEMICAL COMPOSITION: CORROSION: CORROSION RESISTANT ALLOYS: CEEVICE CORFOSION; ELEVATED TEMPERATURE: EROSICN: FIELO STLOIES: FLOW RATE: GEOTHERMAL BRINES: GEOTHERMAL POWER PLANTS: MATERIALS TESTING; MEASURING METHODS; MOOERATE PRESSURE; PITTING CCRROSION; STAINLESS STEELS: STRESS CCRROSION: TIME DEPENCENCE: TURBINES; CERRO PRIETO GEOTHERMAL FIELC.

273

VIDES 76

BR INE TREATMENT/SPENT FLUIC CISPOSAL

TITLE- RECENT STUOIES OF THE AHUACHAPAN GEOTRERMAL FIELD.

AUTHOR - VIDES. A. [CONSULTORA TECNICA S.A., SAN SALVADOR (EL SALVADOR)).

REFERENCE- PROCEEIIAGS--SECOND UNITED NATIONS SYMPCSIUM ON THE DEVELOPMENT AND USE OF GEOTHEFMAL RESOURCES. CALIFORNIA UNIV., LAWRENCE BERKELEY LAB., BERKELEY, CALIF., 1976, V. 3, P. 1851-1854.

DESCRIPTORS - CHEMICAL COMPOSITION: DEEP WELLS: FLCW RATE: GEOCHEMISTRY: GEOLOGY; GEOTHERMAL FIELCS: GEOTHERMAL RESERVOIRS; GE OTHËRMAL WELLS; INJECTION WELLS; MODTRATE PRESSURE; MOLERATE TEMPFRATURE: FESERVOIP PROPEFTIES: WASTE OISPOSAL: WASTE WATER; WELL CASINGS: WELL CHARACTERISTICS; AHUACHAPAN GEOTHERMAL FIELD.

274

YASUTAKE 76

BRINE TREATMENT/SCALINE BRINE TREATMENT/CORFOSION

TITLE- RESULTS ANO ITFROVEMENTS OF WATER TREATMENT IN THE COOLING WATER SYSTEM (F OTAKE GECTHERMAL POWER PLANT.

AUTHOR- YASUTAKE, H. [KYUSHU ELECTRIC POWER CO.. INC., OITA (JAPAN) . OTAKE GE (THERMAL PCHER PLANT].

HIRASHIMA, M. (KYUSHU ELECTRIC POWEF CO., INC. . FUKUOKA (JAPAN) . RESEARCH OEPT.). 


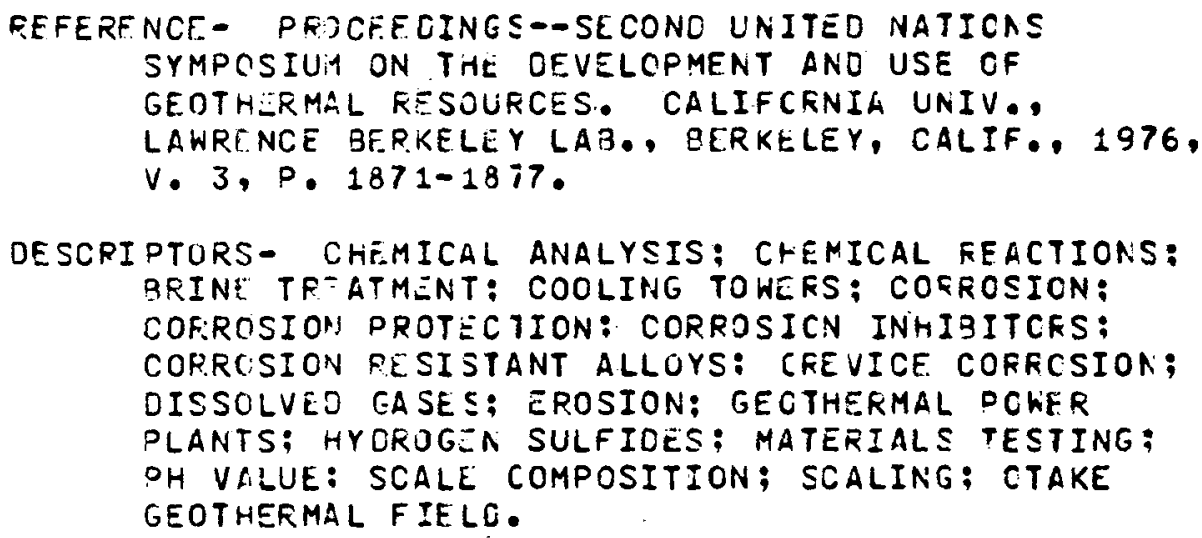

275

EARNES 75

BRINE TPEATMENT/SCALING BRINE TREATMENT/CCRROSION

TITLE- CORROSION ANE SCALING.

AUTHOR- BARHES, H.L. [PENNSYLVANIA STATE UNIV., UNIVERSITY PARK, PA. (USA). CEPT. OF GEOSCIENCESI.

HALL. B.A. (EO, )

REFERENCE- MATEFIALS FROBLEMS ASSCCIATEC WITH THE OEVELUPMENT OF GEOTHERMAL ENERGY RESOUFCES. GEOTHERMAL RESOLRCES COUNCIL, DAVIS, CALIF., MAY 1975, P. 2S-31.

DESCRIPTORS- AMORPHOIS SILICA: CHLORIDES: CCRFOSION: CORPOSION FE.JISTANT ALLOYS: GEOTHERMAL ERINES; HIGH PRESSURE: HIGH. TENPERATUFE: HYOROGEN SULFIDE: S: IOAIC STRENGTH: MATERIALS TESTING: PH ADJUSTMENT: PH VALUE: OUARTZ: SCALING; SILICA MINEFALS; SULUBILITY; STAINLESS STEELS; STRESS CORROSION: SULFIOES: TEMPERATURE DEPENDENCE.

276

EERTHELOT 75

BR INE TREATMENT/SCALINE BRINE TREATMENT/CORROSION

TITLE- SALTON SEA GESTHERMAL FIELC. 


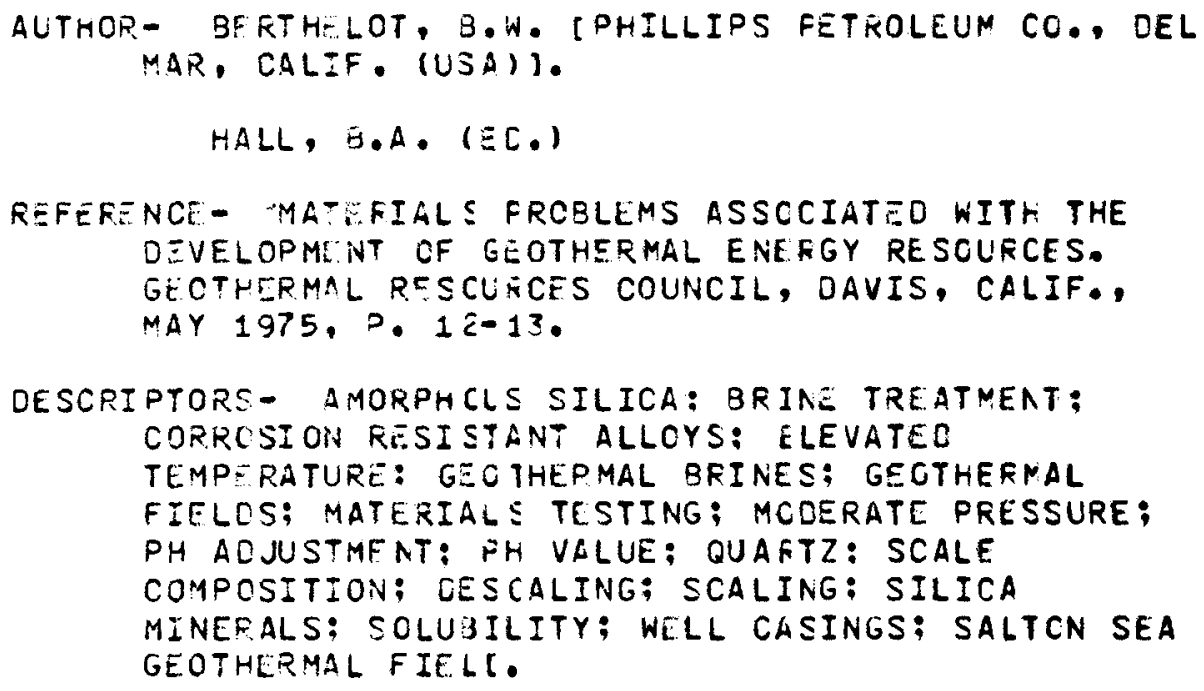

TITLF- SALTON SEA GEO IHERMAL FIELC.

AUTHOK- BISHOP, H.K. CSAN OIEGO GAS ANO ELECTFIC

CO., CALIF. (USA)].

HALL, 3.A. (EE.)

REFERENCE - MATEFIALS FROSLEMS ASSOCIATEO WITH THE DEVELOPMENT CF GEOTHERMAL ENEFGY RESCUFCES. GEOTHEPMAL RESOLRCES COUNCIL, DAVIS, CALIF.. MAY 1975. P. 14-15.

DESCRIPTORS - BINAFY FLUID SYSTEMS: BRINE TREATMENT: CORROSION: OISSCLVED GASES: ELEVATEO TEMPERATURE: FIELO STUDIES: FLCW RATE: GEOTHERMAL BRI PES; HEAT EXCHANGERS: HYCFOGEN SULFIDES: INJECTION WELLS: MODERATE PRESSURE: PH ADJUSTMENT: FIPELINES: REAMING: SALINITY: SCALE COMPOSITICN; DFSCALING; SCALING: SILICA MINEFALS: STAIALESS STEELS: SALTCN SEA GEOTHERMAL FIELE. 


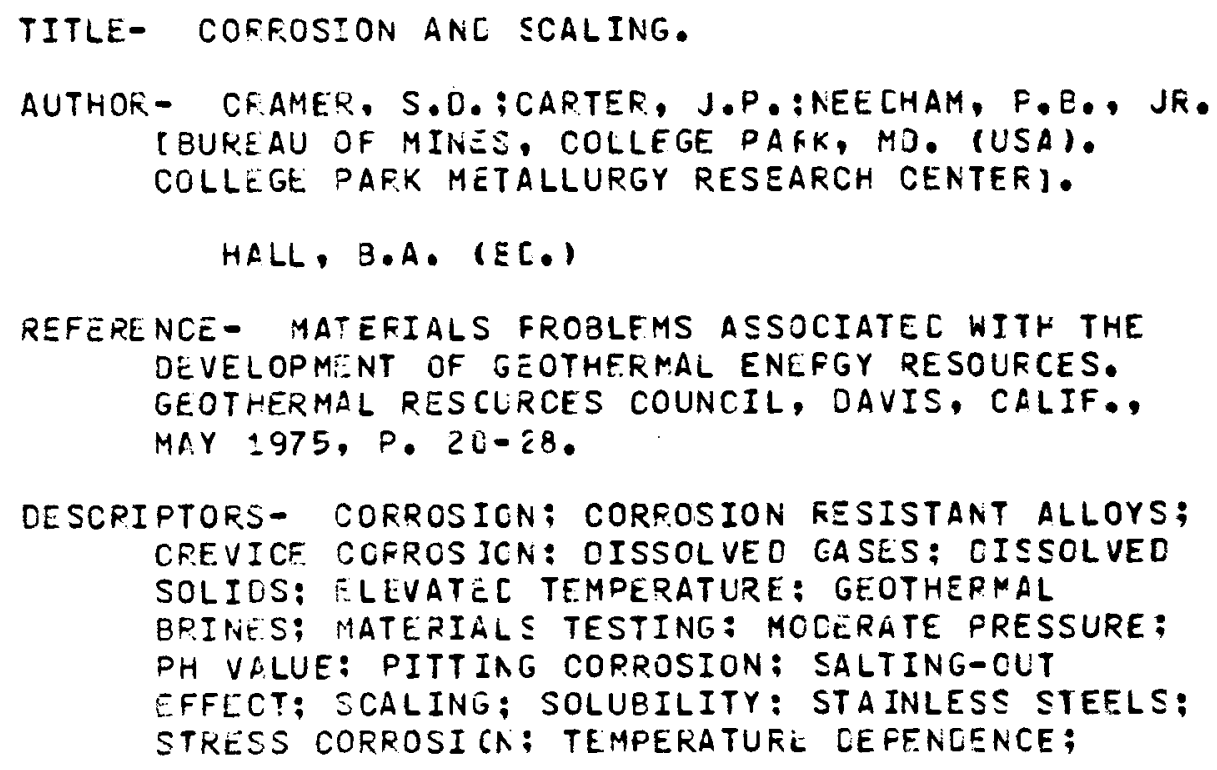

HUTCHINSON 75

BRINE TKEATKENT/SCALING BF. INE TREATRENT/CCRRCSION

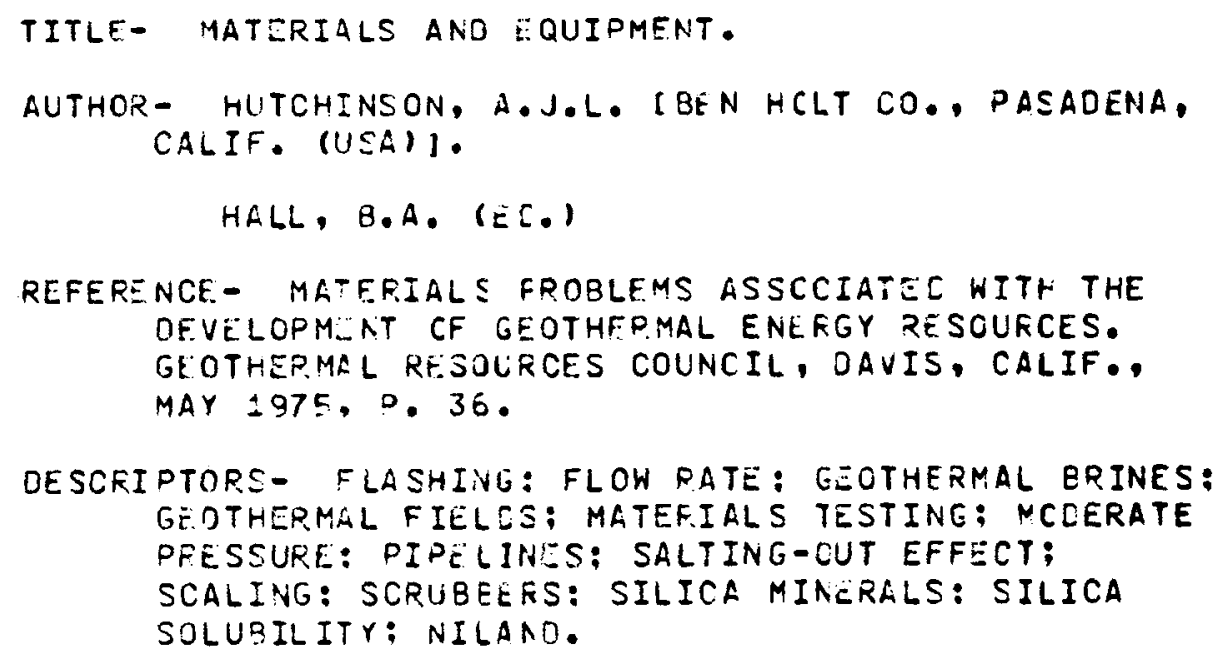


TITLE- KIZILDERE (TURKEY) GEOTHERMAL FIELC.

AUTHOR - KUWADA, J.T. [ROGERS ENGINEERING CO.. INC.. SAN FRANCISCO, CALIF. (USA) I.

HALL, B.A. (EC.)

REFERENCE - MATERIALS FROBLEMS ASSCCIATEC WITH THE DEVELOPMENT CF GEOTHERMAL ENERGY RESCUFCES. GEOTHERMAL RCSOLRCES COUNCIL, DAVIS, CALIF., MAY 1975, P. 18-19.

OESCRIPTORS- CALCITE; CARBONATES ; CORROSION; OISSOLVEO SOLIO:: ELEVATED TEMPERATURE; FIELC STUOIES: FLOW RATE: GEOTHERMAL BRINES: GEOTHERMAL FIELES; GEOTHEFMAL WELLS: HEAT EXCHANGERS: HEAT TRANSFER; PRECIPITATICN; REAMING: SCALING: STAINLESS STEELS: STFESS CORROSION; KIZILOERE: GEOTHERMAL FIELG: TURKEY.

281

MARSH 758

BR IAE TREATMENT/SCALING BRINE TREATMENT/CCRFOSION

TITLE- SALTON SEA GEOTHERMAL FIELO.

AUTHOR- MARSH, G.A. CUNION OIL CO. OF CALIF., BREA (USA) - RESEAFCH CENTERI.

HALL, B.A. (EC.)

REFEPENCE- MATEFIALS FROBLEMS ASSCCIATED WITH THE OEVELOPMENT OF GEOTHERMAL ENERGY RESOUFCES. GEOTHEPMAL FESOLFCES COUNCIL, DAVIS, CALIF.. MAY $1375, P, 10-11$.

DESCRIPTORE- AMORPHOLS SILICA: CHLCRIUES: CORFOSION: CORROSION RESI STANT ALLOYS: ELEVATEC TEMPERATURE: GECTHERMAL BFINES; GEOTHERMAL WELLS: IRUN OXILES: MATERIALS TESTING: MCOERATE PRESSURE: PITTING CORFOSION: SCALING: TEMPERATURE DEFENDENCE; SALTON SEA GEOTHERMAL FIELC. 
TITLE- SALTON SFA EOCIHERMAL FIELC.

AUTHOR- REEJ, M.J. IEEOLOGICAL SUEVEY, MENLC FARK. CALIF. (USA)\}.

HALL, B.A. (EC.)

FEFERENCE- MATEFIALS FROBLEMS ASSCCIATEC WITH THE DEVFLOPMNNT OF GEOTHERMAL ENLRGY RESCURCES. GEOTHERMAL RESOLRCES COUNCIL, DAVIS, CALIF., MAY 1975 , D. 8-9.

DESCRIPTORS - AMORPHCLS SILICA: CHEMICAL FEACTION KINETICS: CHLORIDES: CORROSION: CORROSICN RESISTAN? HLLOYE; CKEVICE CORIOOSION: CISSOLVEC SOLIDS: TLEVATEC. TEMPEPATURE: FLCW KATE: GCOTHEPMAL BEINE :: GLOTHERMAL FIELOS: SCALING; SILICA MINERALS; SILICA SOLUAILITY; SULFIDES; SALTON SIA GEOTHERMAL FIFLD.

283

TITLE- COPROEION ANC SCALING.

AUTHDR - FEED, M.J. [GEOLOGICAL SURVEY, MENLC FARK. CALIF. (USA)1.

HALL, B.A. (E[.)

REFERENCE- MATEFIALS FROBLEMS ASSCCIATEC WITH THE OEVELOPMENT CF GEOTHEFMAL ENEFGY RESCLICES. GEOTHERMAL RESOLRCES COUNCIL, OAVIS, CALIF., MAY $1975, P .32-33$.

DESCRIPTORS - CALCITE: BRINE TREATMENT: CHLCEICES; DISSOLVLO SOLIDS; ELEVATED TEMPERATUGE: GEOTHERMAL BRIAES: GEOTHERMAL FIELOS: MEASURING INSTFUMENTS: PH ADJUSTMENT; REAMING; SCALING CONTFOL: SILICA MINERALS: CERFO PRIETO GEOTHERMAL FIELC. 
TITLE- HEBER GEUTHERMAL FIELE.

ALTHOF- SCHREMP, F.W. ICHEVPON OIL FIELO RESEARCH

CO., LA HABRA, (ALIF. IUSA)].

HALL, B.A. (EC.)

REFEFENCE- YATEFIALS PROBLEMS ASSCCIATEC WITH THE DEVELOPM NT OF CEOTHERMAL ENERGY RESOURCES. GEOTHERMAL RESCLRCES COUNCIL, DAVIS, CALIF., MAY 1975, P. IE-17.

DESCOIPTORS - DARBONATES; BRINE TREATMENT; CCKROSION; OISSOLVED SCLIJS: ELEVATED TEMPERATURE: GEOTHERMAL BRIM!S; GECTHEFMAL FIELOS: GEOTHERMAL WELLS: HEAT EXCHANGERS: INJECTION WELLS; MATERIALS TFSTING: MEASURING INSTRLMENTS: PITTING CORROSICN: SCALINE: SULFIOSS: HEEBER GEOTHERMAL FIELO.

285

SNCCGRASS 75 BRINE TREATMENT/SCALINE BF.INE TREATMENT/CCRROSION

TITLE- MATERIALS ANO EQUIPMENT.

AUTHOR- SNOOGOASS, J.S. [RFYNOLDS METALS CO., FICHMOND, VA. (ISA)\}.

ANUERSON, D.B. CINTERNAT I CNAL NICKEL CO., INC.. NEW YORK (USA)].

HODGE, F. G. [CABOT COFP., KOKOMO, INC. (USA). STELLITE [IV.].

KOMP, M.E. (UNITEO STATES STEEL CORF., MONROEVILLE, PA. (USA). APPLIEO RESEARCH LAB.1.

FFANSON, I. [AIPCO VACUUM METALS, LeETSOALE, PA. (USA)].

HALL, B.A. (EC.)

REFERENCE - MATERIALS FROBLEMS ASSOCIATEO WITH THE DEVELOPMENT OF GEOTHERMAL ENERGY RESOURCES. 
GEOTHERMAL RESOLRCES COUNCIL, DAYIS, CALIF.,

MAY 1975, P. 34-35.

DESCRIPTORS- CHLORICES: CORROSION: CORRCSION

RESISTAN: ALLOYS; GEOTHERMAL ERINES: PITTING CORROSIOH: SCALING: STAINLESS STEELS: STRESS CORROSIOH.

286

VETTER 76B

BRINE TREATMENT/SCALING

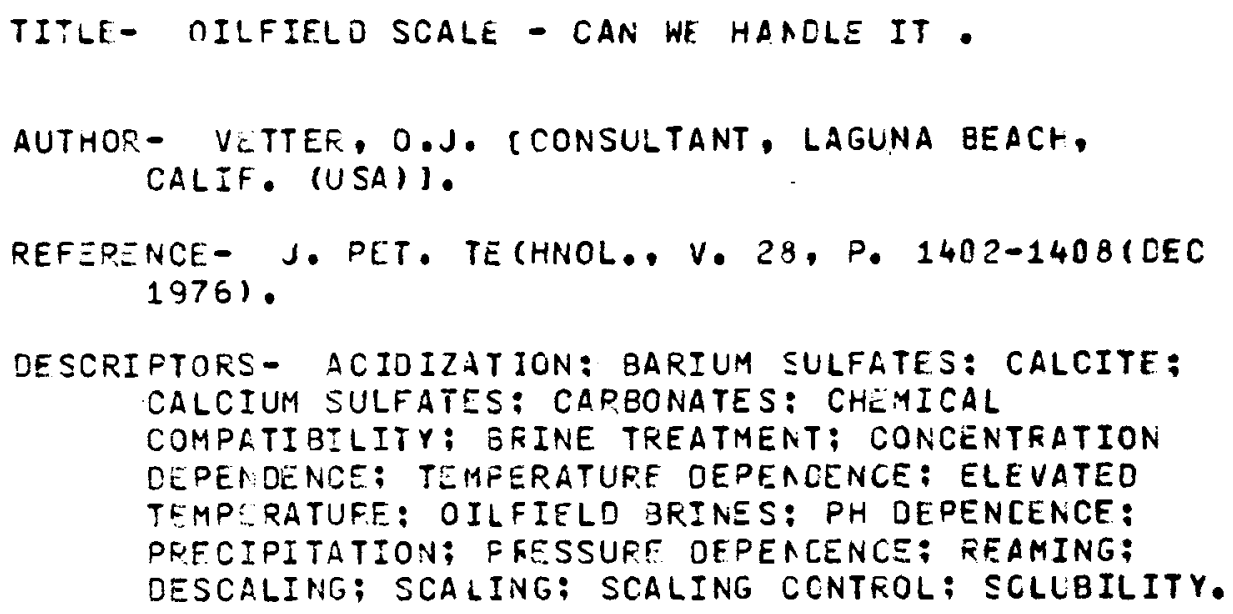

287

HATCH 70

BRINE TREATMENT/SCALING

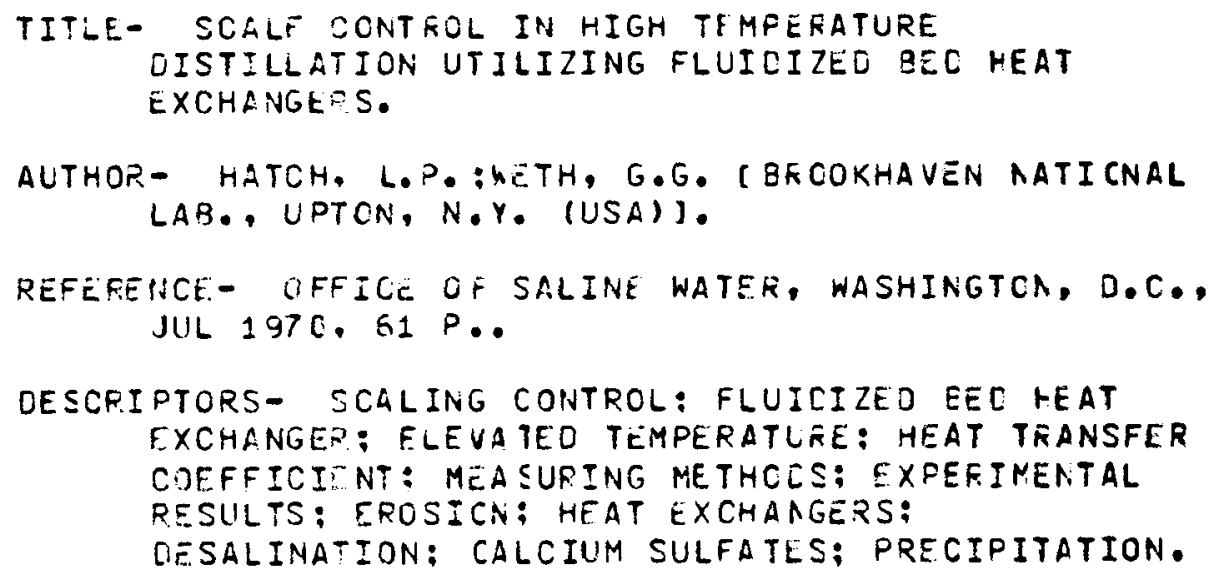




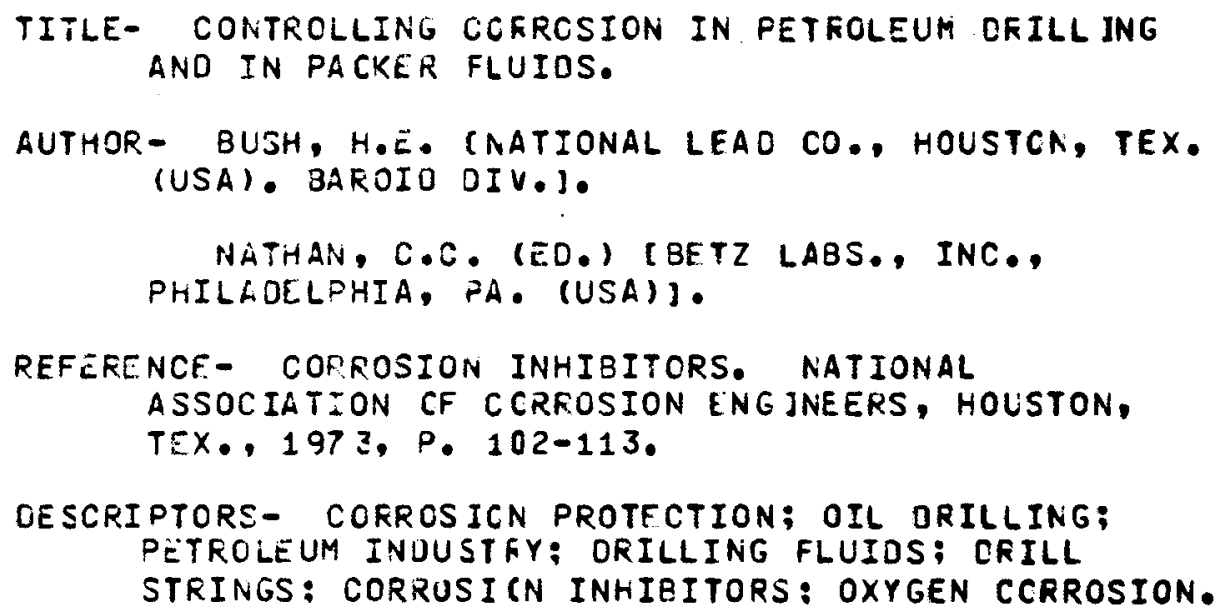




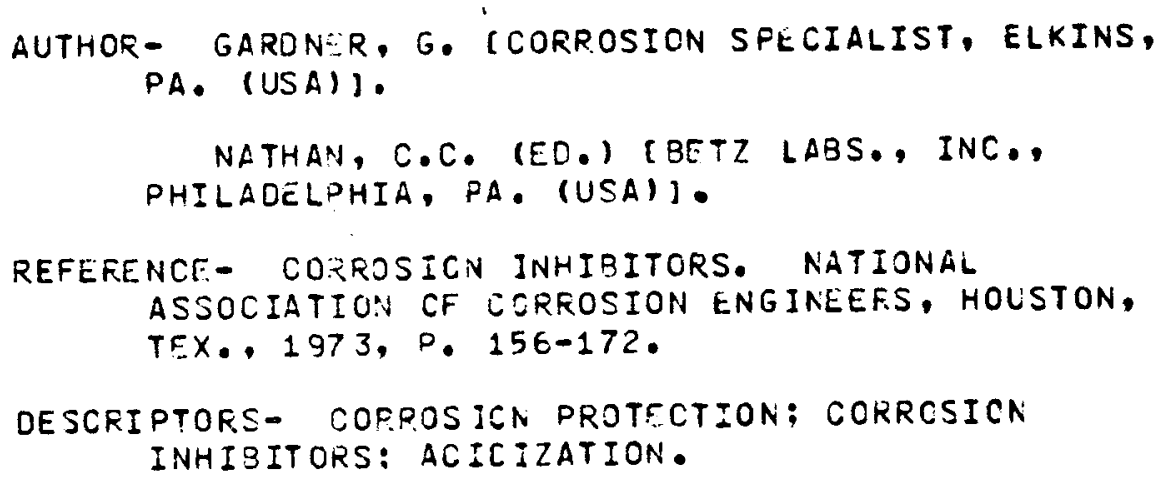

291

TITLE- SCOPE AND IMPGFTANCE OF INHIBITOR TFCHNOLOGY.

AUTHOR- HAMNER, N.E. (NATIONAL ASSCCIATICN CF CORROSION ENGINEERS, HOUSTON, TEX. (USA)).

NATHAN, C.C. (EO.) (BË.TZ LABS., INC., PHILACELPHIA, FA. (USA)].

REFERENCE - CORRCSION INHIBITORS. NATIONAL ASSOCIATION OF CCRROSION ENG JNEERS, HCUSTON, TEX. , 1973, P. 1-E.

DESCRIPTORS- CORROSICN PROTECTION: CORROSICN INHIBITORS: METALS: ALLOYS.

292

HAMNER 738

BRINE TREATMENT/CCRROSION

TITLE- INHIBITORS IN CRGANIC COATINGS.

AUTHOR- HAMNEP, N.E. (NATIONAL ASSOCIATICN CF CORROSION ENGINEERS, HOUSTON, TEX. (USAI).

NATHAN: C.C. (ED.) (BETZ LABS., INC., PHILAOELPHIA, FA. (USA) I.

REFERENCE- CORROSION INHIBITORS. NATIONAL ASSOCIATION CF CCPROSION ENGINEERS, HOLSTON, TEX., 1973, P. 190-195. 


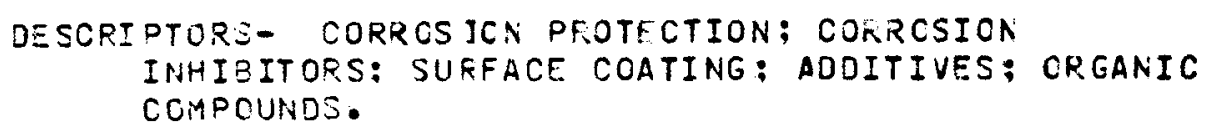

293

HAMNER $73 \mathrm{C}$

BRINE TREATMENT/CCRFOSION

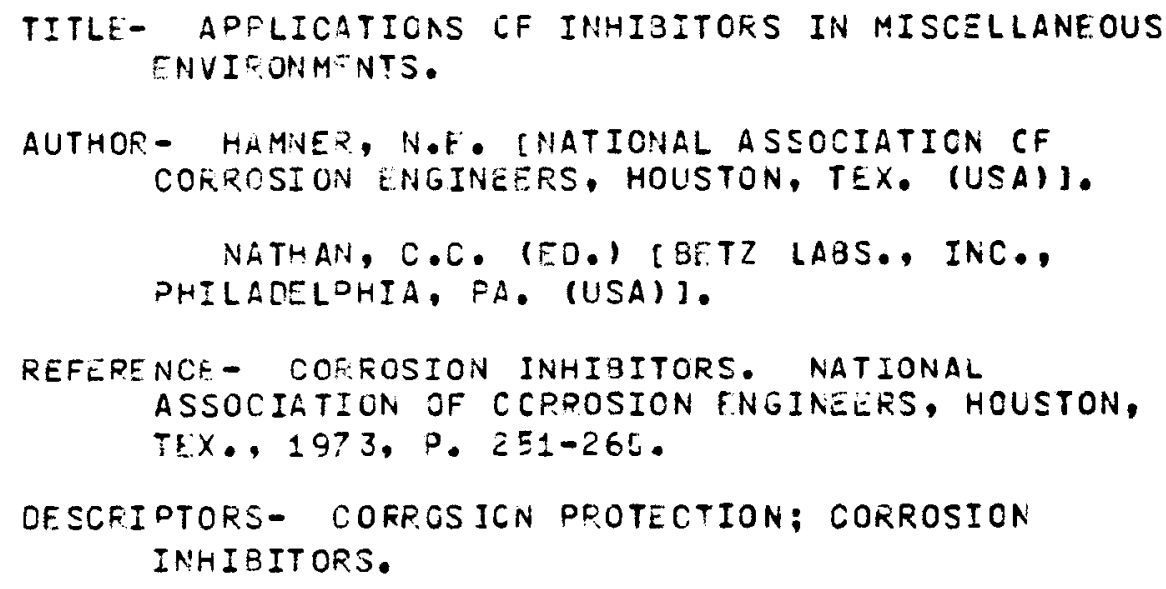

294

BR INE TREATMENT/CORROSION

TITLE- INHIBITORS FJF POTABLE WATER.

AUTHOR - HATCH, E. 3. [CALGON COFP., PITTSEUREH, PA. (USA)\}.

NATHAN, C.C. (ED.) (BETZ LABS., INC.,

PHILADELPHIA, PA. (USA)].

REFERENCE- CORRDSION INHIBITORS. NATIONAL ASSOCIATION OF CCRROSION ENGINEERS, HOLSTON, TEX.., 1973 , P. 114-125.

DESCRIPTORS- CORPOS ICN PROTECTION; CORROSION

INHIBITORS; DRINKING WATER: VATER POLLUTION. 
TITLE- INHIBITICN OF COOLING WATER.

AUTHOR- HATCH, G. 3. [CALGON CORP., PITTSBURGH, PA. (USA) 1 .

NATHAN, C.C. (ED.) [BETZ LABS., INC.,

PHILLDELPHIA, FA. (USA)].

REFERENCE- CORROSION INHIBITORS. NATIONAL

ASSOCIATION OF CCRROSION ENG INEEES, HOLSTON, TEX. , 1973, P. 126-147.

DESCRIPTORS- CORROSICN PROTECTION: CORROSION

INHIBOTORS: COCLING SYSTEMS.

296

KAAACK 73

BRINE TREATMENT/CCRROSION

TITLE- INHIBITORS FOR TEMPORARY PFCTECTICN.

ALTHOR- KNAACK, D.F.:BROOKS, D. [E.F. HOUGHTCA CO.,

PHILA.OELPHIA, FA. (USA)\}.

NATHAN, C.C. (ED.) [BETZ LABS., INC.,

PHILAOELPHIA, FA. (USA)].

REFERENCE - CORROSION INHIBITORS. NATIONAL

ASSOCIATION CF CCFROSION ENGINEERS, HOUSTON,

TEX., 1973, P. $220-227$.

DESCPIPTORE- CCFROSICN PROTECTION: CORRCSION

INHISITORS: COATINGS: PAINTS.

297

METCALF 73

BF INE TREATMENT/CORROSION

TITLE- INHIBITION ANC CORROSION CCNTRCL PRACTICES FOR BOILER WATERS. 


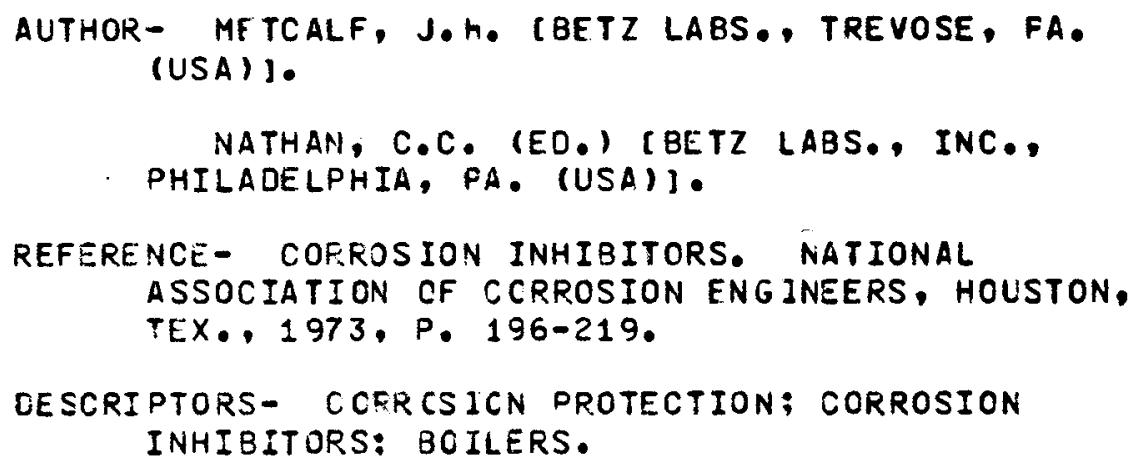

TITLE- COFROSION INHIBITORS IN REFINERIES ANC PETRCCHEMICAL FLANTS-PART 1.

AUTHOR- NATHAN, C.C. $($ CO,) [BETZ LABS., INC., PHILADELPHIA, PA. (USA)].

REFEFENCE - COFROSION INHIBITORS. NAT IONAL ASSOCIATICN CF CORROSION ENGINEERS, HCLSTON, $T E X ., 1973, P .42-54$.

DESCFIPTORS- CORRUSICN PROTECTION ; CORRCSION INHIBITORS: FETRCLEUM INOUSTFY. 


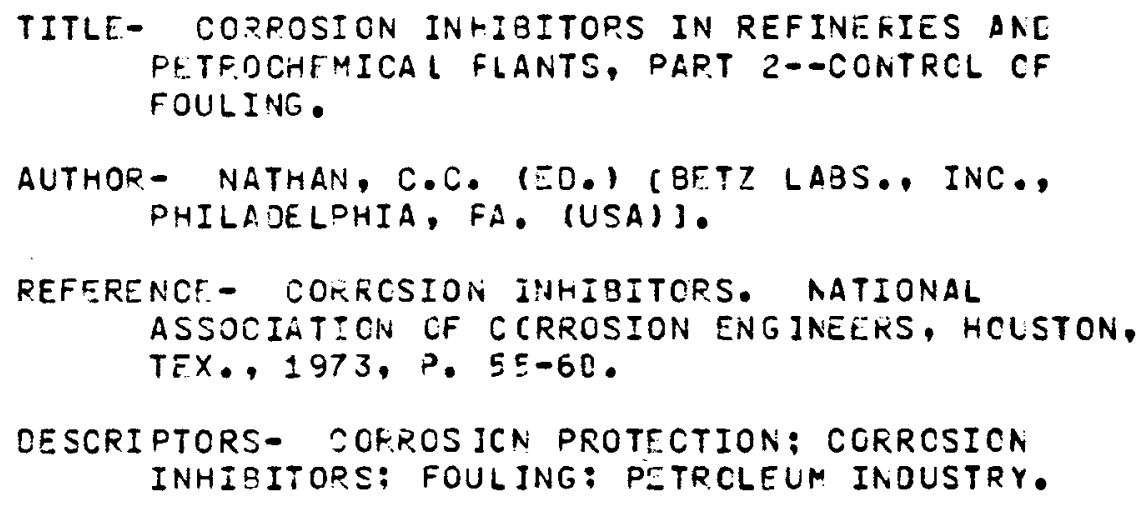

301

NESTLE 73

BRINE TREATMENT/CCRFOSION

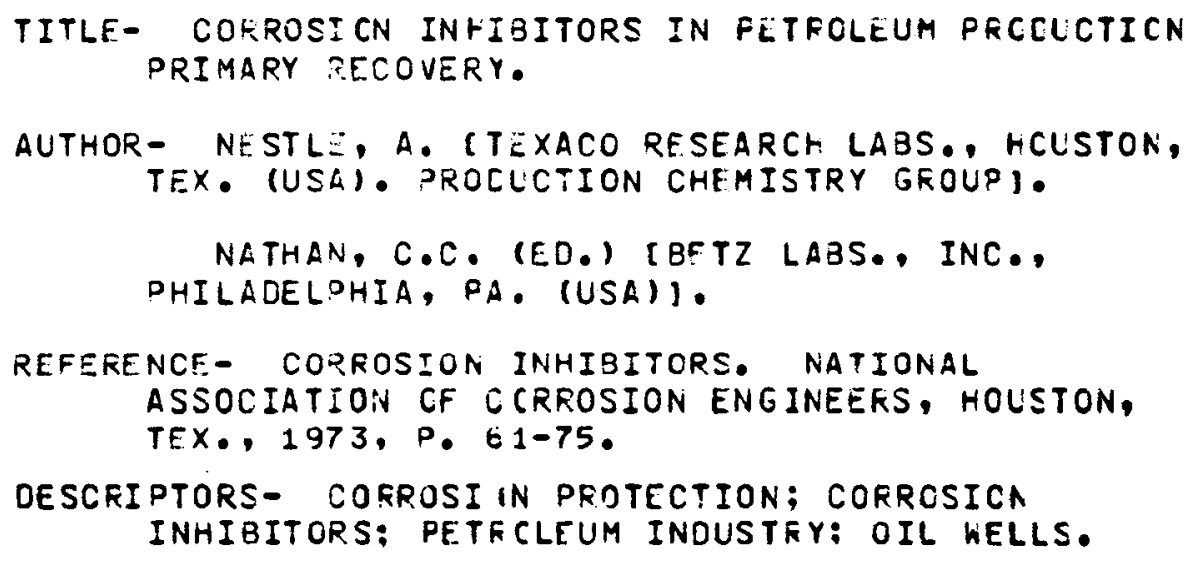

302

TITLE- INHIBITCRS IA DESALINATION SYSTEMS.

AUTHOR- OAKES, 3.D. COOW CHEMICAL CO., FREEPCET, TEX. (USA)]. 
NATHAN, C.C. (ED.) (BETZ IABS., INC., PHILADELPHIA, FA, (USA)\}.

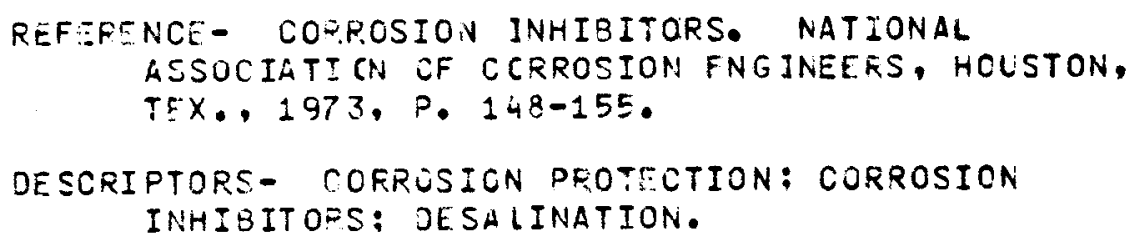

303

FARKER 73

BFINE TREATMENT/CCRFOSION

TITLE- CONTROL OF INTERNAL CORFOSICN CF PIPELINES CAPRYING REFINEC PETROLEUN PRCOUCTS.

ALTHOP- PARKER, I.M. [PLANTATION FIPE LINE CC., ATLANTA, GA. (US\&)].

NATHAN, C.C. (E.D.) [BETZ LABS.. INC., PHILAOELPHIA, PA. (USA))

REFERENCE - CORROSION INHIBITORS, NATIONAL ASSOCIATION OF CORROSION ENGINEEFS, HOLSTON, TEX. , 1973, P. 89-94.

DESCRIPTCRS- CORRCS ICN PROTECTION; COFROSION INHIBITCPS: FETFCLEUM INDUSTKY: PIPELINES.

304

TITLE- INHIEITION OF ALUMINUM.

AUTHOR- ROEBUCK, A. F. [FULLERTON, CALIF, (USA)]. NATHAN, C.C. (ED.) [BETZ lABS., INC., PHILADELPHIA, FA. (USA)).

REFERENCE - CORROSION INHIBITORS. NATIONAL ASSOCIATICN CF CCRROSION ENGINEEFS, HOUSTON, TEX., 1973, P. 240-244.

OESCRIPTORS - CORROSICN PROTECTION: CORROSION INHIBITORS: ALUMINUM: ALLOYS. 
TITLE- INHIBITION OF CORROSION FROM CAUSTIC ATTACK.

AUTHOR- ROEBUCK, A.H. (FULLERTON, CALIF, (USA)]•

NATHAN, C.C. (ED.) (BETZ LABS., INC., PHILADELPHIA, FA. (USA) I.

REFCRENCF- COFROSION INHIEITORS. NATIOHAL ASSOCIATICN CF CCRROSION ENGINEERS, HOLSTON, TEX., 1973, P. 245-250.

DESCRIPTORS- CORROSICN PRCTECTION; CORROSION INHIBITOR.S: ALLCYS.

TITLE- METHODS FOR EVALUATION ANC TESTING OF COR.KOSION INHIBI TORS.

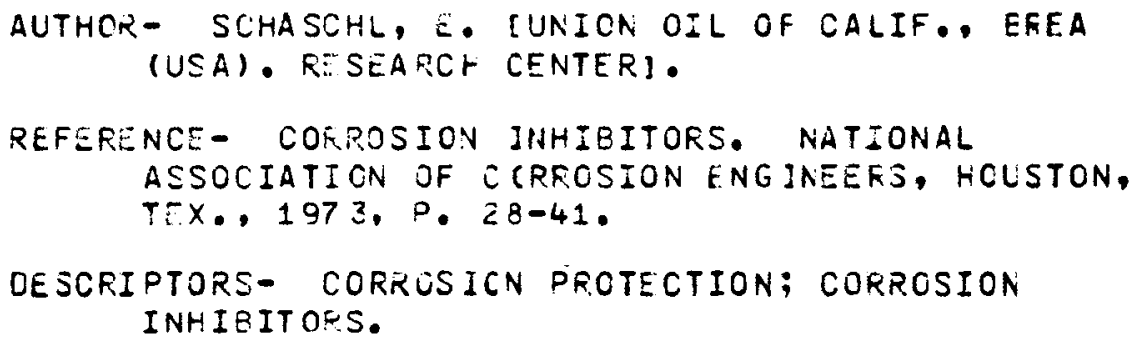

307

\section{BRINE TREATHENT}

TITLE- MICROBICLOGICAL CORROSION AND ITS CONTEOL.

AUTHOR- SHARPLEY, J.M. CVIRGINIA CCMMONWEALTH UNIVERSITY, FRECEFICKSBURG (USA).

NATHAN, C.C. (ED.) [BETZ LABS., INC., PHILADELPHIA, FA. (USAI). 
REFERENCE - CORROSION INHIBITORS. NATIONAL ASSOCIATION OF CCRROSION ENGINEERS, HOUSTON, TEX. , 1973 , P. 228-235.

DESCRI PTORS- CORROSICN PROTECTION: MICROORGANISMS: BIOLOGICAL FOULING.

308

EARLCUGHER 57

BR INE TREATMENT/SCALING

TITLE- SEQUESTERING AEENTS FOR PREVENTION OF SCALE DEPOSITION IN CIL WELLS.

AUTHOR- EARLOUGHER, R.C. IEARLGUGHER ENGINEERING, TULSA, OKLA. (USA)).

LOVE, W.W. COUWELL, INC., TULSA, OKLA.

REFERENCE - J. PET. TECHNOL., P. 17-20 (APR 1557).

DESCRIPTORS- SCALING: SCALING CONTFCL; OIL WELLS;

INJECTION WELLS: SEQUESTERING. AGENTS;

309

\section{BFINE TREATMENTICORFOSION}

TITLE- PROCESS CORRCSION AND CCRRCSICN INHIEITORS IN THE PETROLEUM INCUSTR.Y.

AUTHOR- HEUSLEF, R.H.;STANSKY, C.A.;NEVINS, A.J. [UNIV. OIL PROD. CO., DES PLAINES, ILL. (USA)).

REFERENCE- NACE, INTEFNATIONAL CORFOSION FORUM. NACE, HOUSTON, TEX., 1974, 40 P..

OESCRIPTORS- CORROSICN PROTECTION; CORROSION

INHIBITORS: FETF CLEUM INDUSTFY.

310

VETTER 72

BR INE TREATMENT/SCALING 


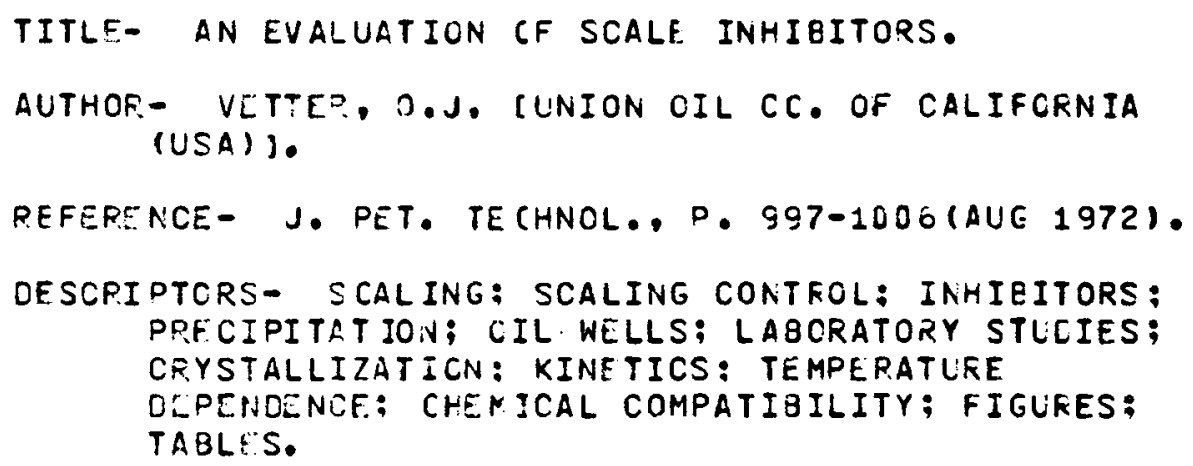

TITLE- WATER SCLUELE CORROSION INHIBITORS--A DIFFERENT APPFOACH TO INTERNAL PIPELINE CORR.CSION CONTKOL.

AUTHOR - PETTUS, P.L. :STRICKLAND, L.N. CBAROIC DIV., $N$ L IND. INC., HCUSTON, TEX. (USA)].

REFERENCE- NACE, IN IEFNATICNAL CORFOSION FORUM. NACE, HOUSTON, TEX, 1974, 11 F..

DESCFIPTORS - CGFROSICN PROTECTION; CORROSION

INHIBITORS; PIFELINES; PETROLEUM INELSTFY.

312

MATHIAS 74

BRINE TREATMENT/SCALINE

TITLE- PRELIMINARY RESULTS OF GECTHERMAL WELLS. MESA 6-1 AND MESA 6-2 EAST MESA KERA, IMPERIAL VALLEY, CALIFORNIA.

AUTHOR- MATHIAS, K. E. CBUREAU OF RECLAMATION, BOULEER OITY, NEY. (USA)].

REFERENCE- GEOTHERMAL ENERGY, $V_{0}=(6), P, 8-17$ (JUN 19741 .

DESCRIPTORS- $5 A S T$ MESA KGRA: CALIFORNIA: GEOTHERMAL WELLS; HEAT FLCW: GEOPHYSICAL SURVEYS: SCALING: CHEMICAL ANALYSIS; PIPELINES; BRINE TREATMENT. 
MILLER 76

BRINE TREATMENT/CCRFOSION

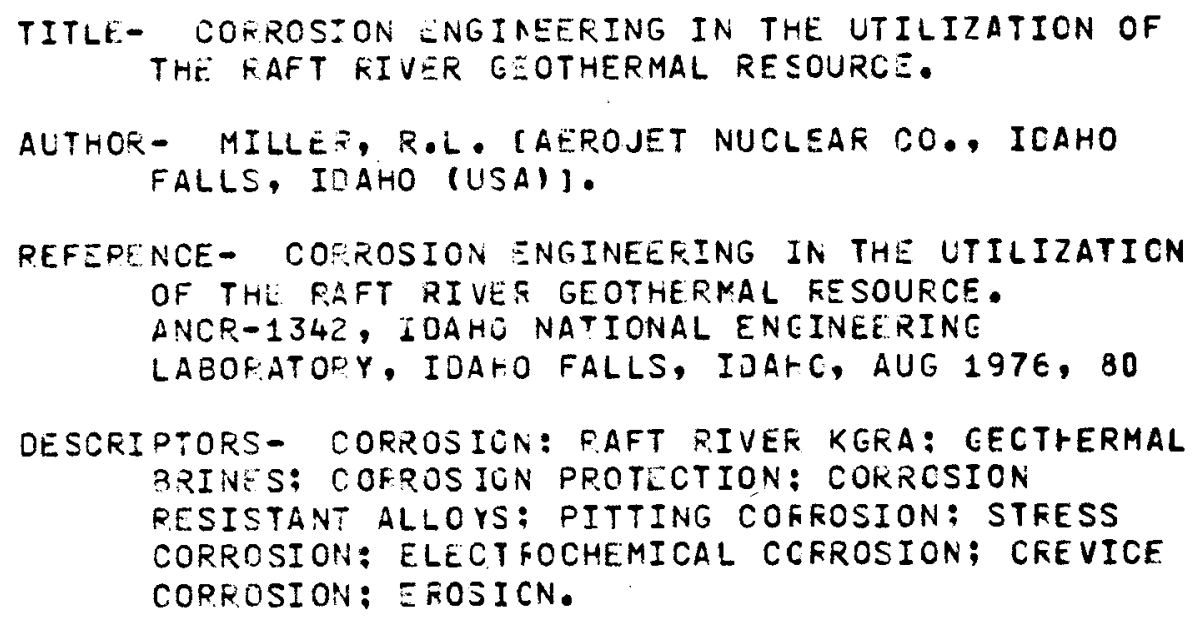




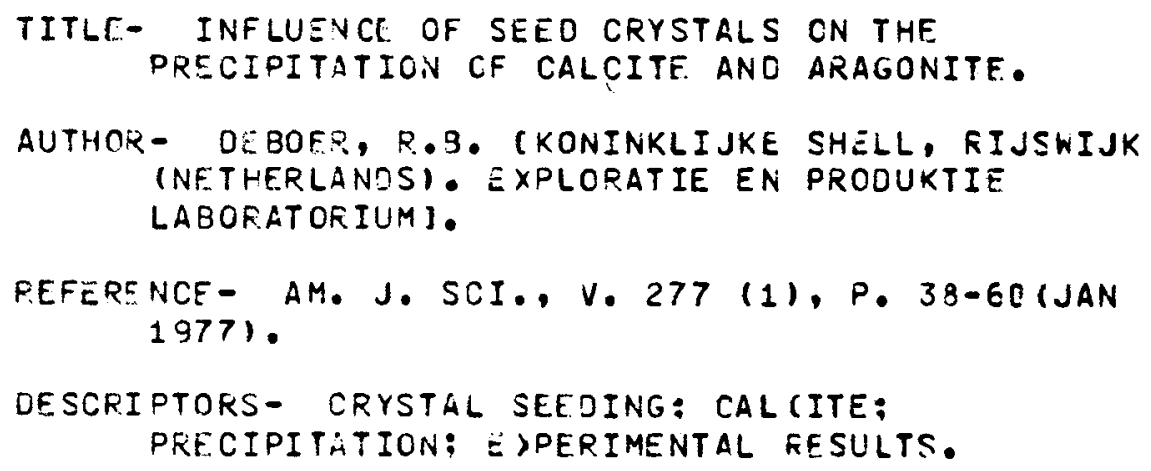

317

GAUPP 74
BRINE TREATMENT/CCREOSION BR INE TREATMENT/SCALING

TITLE- CORROSION AND SCALE CONTROL.

AUTHOR- GAUPP, F.H.:AYGREN, J.A. ICREH CHEMICAL CORP. (USA)\}. 
TITLE- CORROSICN TESTING OF HIGHLY ALLOYEC MATERIALS FOR OEEP, SCUR GAS WELL FAVIFCNMENTS.

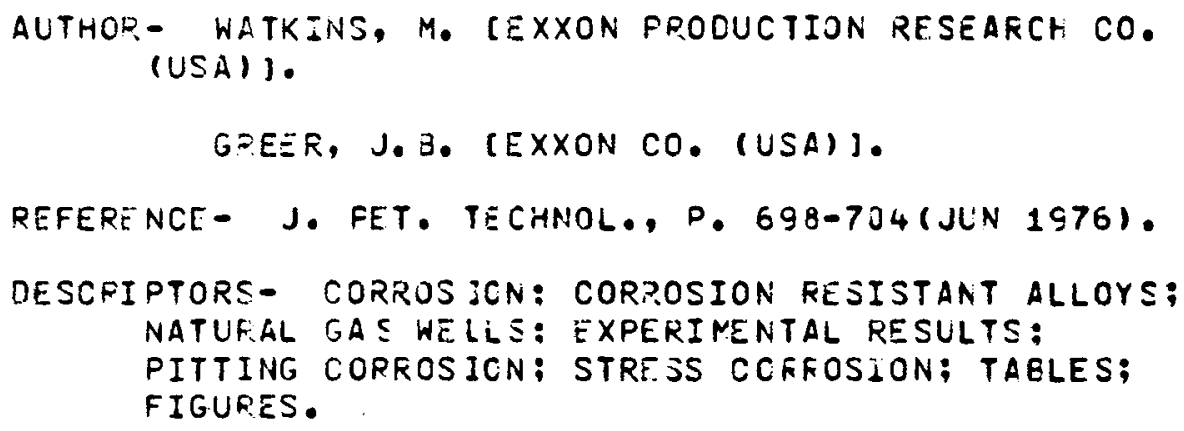

321

ELLIS 63

BRINE TKEATMENT/SCALING

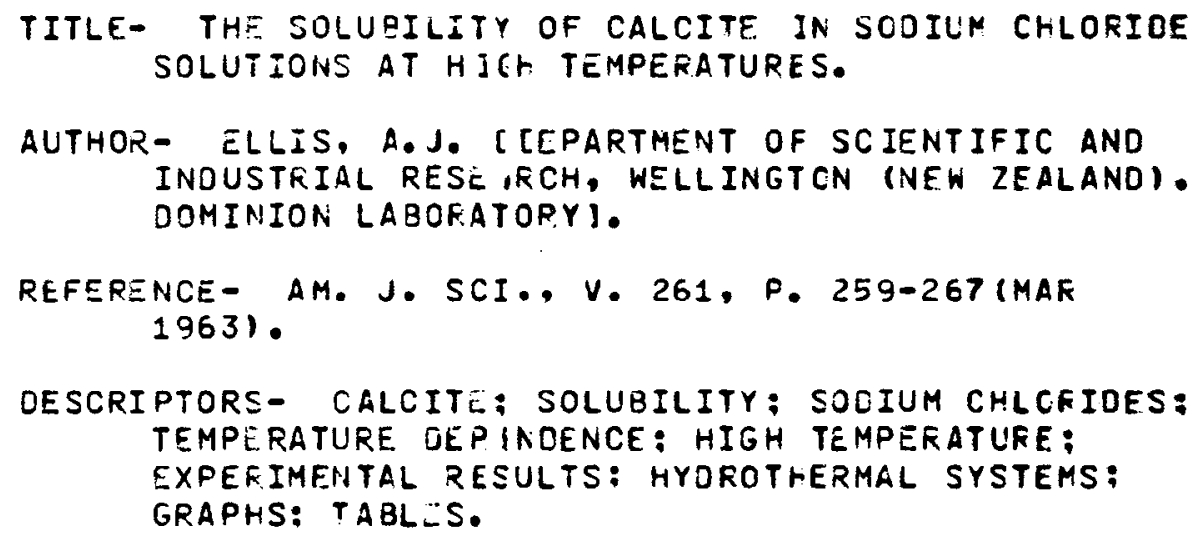

322 


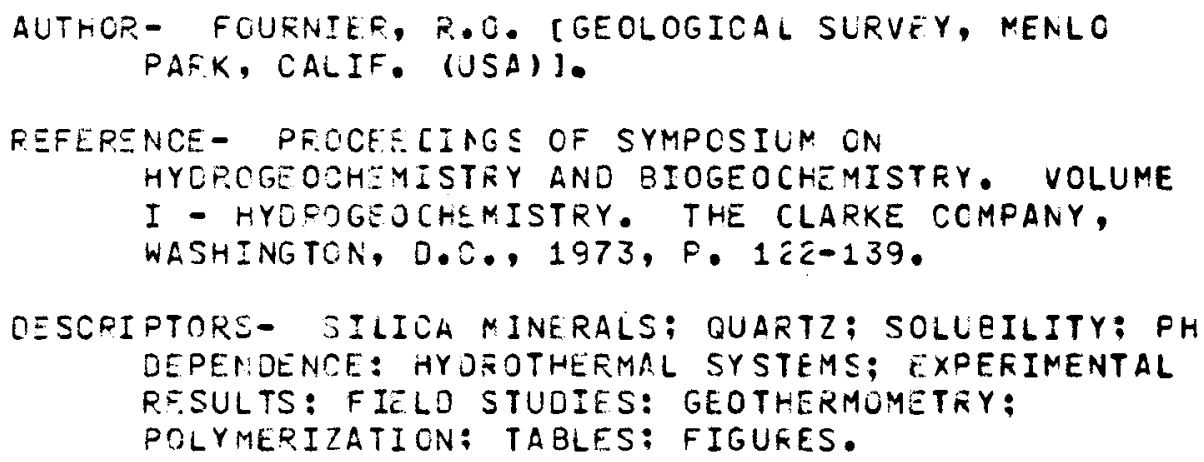

323

FOGERS 55

BRINE TREATMENT/CCRROSION

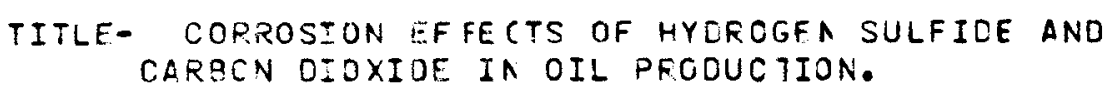

324

LYON 74

BRINE TREATMENT /CCRFOSION BRINE TREATMENT/SCALING

TITLE- A RECOMMENOED RESEARCH PROGRAM IN GECTHERMAL CHE MISTRY.

AUTHOR- LYON, R.N. [CAK RIUGE. NATICNAL LAB., TENN. (USA)!.

KOLSTAD, G.A. IUSAEC DIVISION OF PHYSICAL RESEARCH, WASHINGTON, D.C. (USA)I. 


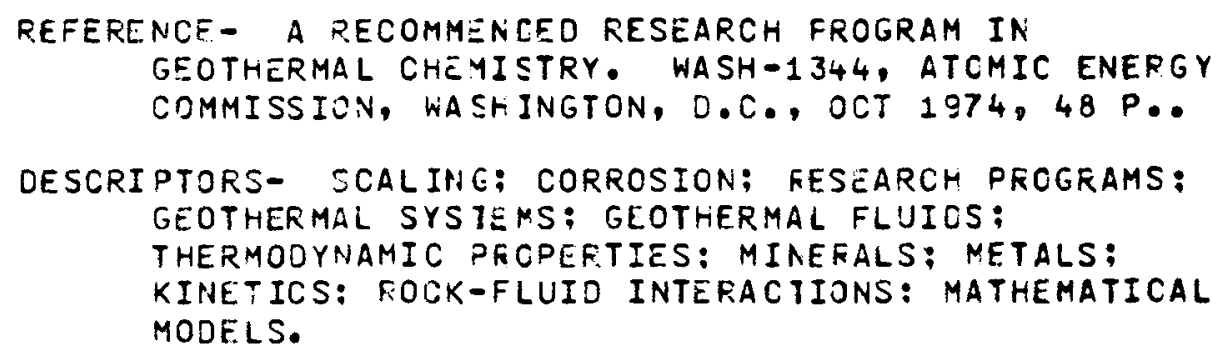

TITLE- CONTINOUS TUEE CLEANING IMPFOVES PERFCRMANCE OF CONDENSTRS ANI HEAT EXCHARGERS.

AUTHOK- KERN, W.I. CAMERTAP CORP., MINEOLA, N.Y. (USA) ].

REFFFENCE- CHEM. ENG.. V. 82 (22), P. 139-144(1975).

DESCFIPTORS - SCALING: STEAM CONOENSERS: HEAT

EXCHANGERS; TUFEINES; SCALING CONTFOL.

326

COPSON 51
BRINE TREATMENT/CCRROSION

TITLE- LITERATURE SURVEY ON CORFGSION IN NELTKAL UNAERATED CIL WELL BRINES.

AUTHOR- COPSON, H.R. [INTEFNATIONAL NICKEL CC., BAYONNF, N.J. (LSA). RESFARCF LAB.l.

FEFERENCE- CORROSICN, V. 7, F. 123-127 (APF 19E1).

DESCRIPTOFS- COFRCSICN: OILFIELC ERINES: REVIFWS; CORROSI OH INHISITDFS. 
TITLE- PROBLEMS RELATED TO OPERATIAG THERMAL WELLS SUBJECT TO SCALING IN HUNGARY.

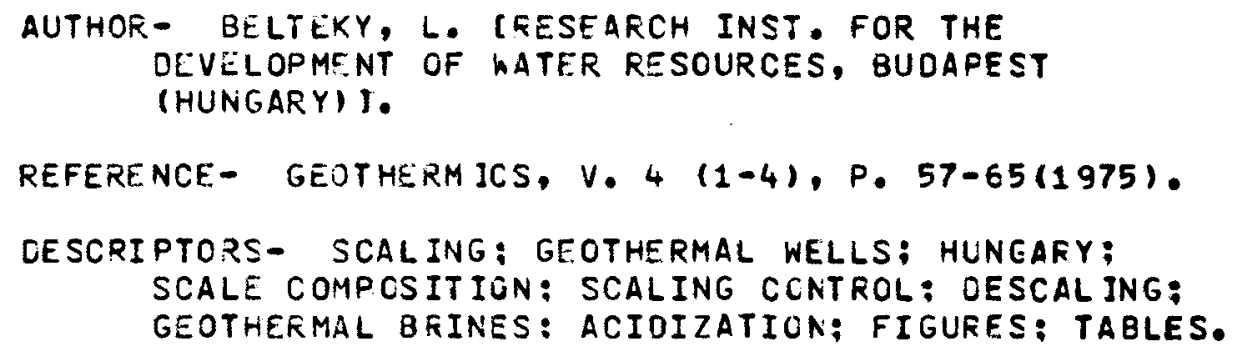

SAKAI 76

BRINE TREATMENT/CCRFOSION

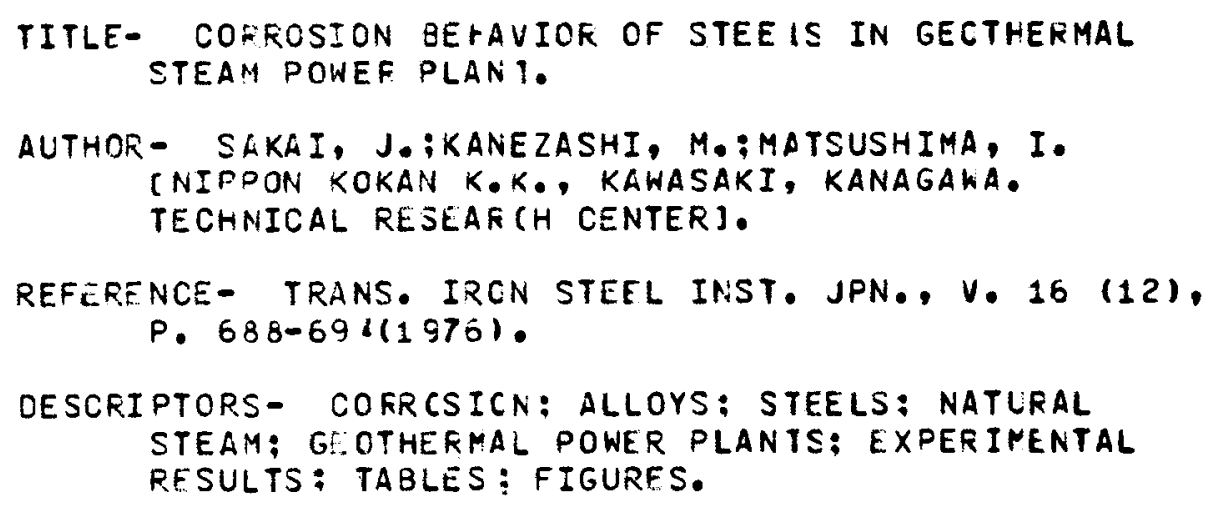

329

TSKHVIRASHVILI 72

BFINE TREATMEAT/CORROSION

TITLE- ON CORIOSICN CF METALS IN GEOTHERMAL FCWER PLANTS.

AUTHOR- TSKHVIRASHVILI, D.: VAFOIGCRELI, O. LGEORGIAN INST. OF ENERGY, TBILISI (USSE)).

ACOLSIN, P. (NATIONAL HEAT ENGINEERING INST., MOS COW (ISSRI).

REFEFENCE - GEOTHERMICS, V. 1 (3), F. 113-118(1972)•

DESCRIPTORS - CORROSICN; CORROSION PROTECTION:

METALS; GEOTHE FMAL POWER PLANTS: GEOTHERMAL 
FLUIOS: CHEMICAL ANALYSIS: EXPERIMENTAL P.FSULTS: GRAPHS: TABLES.

TITLE- GEQTHERMAL MATEFIALS STUDIES. METALLUFGY DIVISION OUAETEFLY P.EPOFT--AFRIL-JUNE 1976.

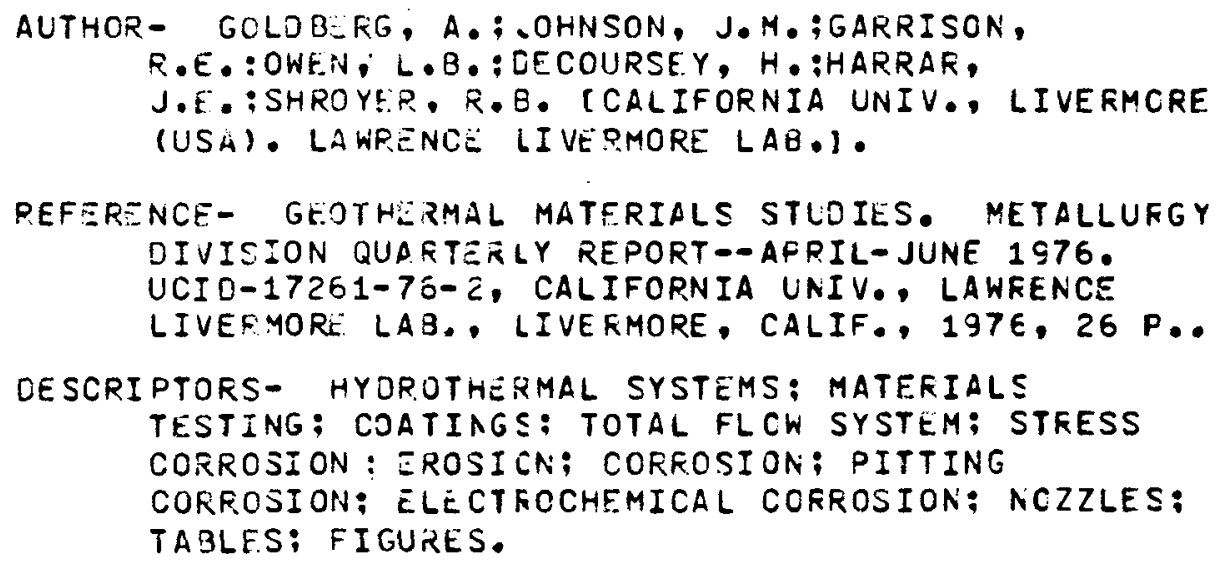

TITLE- CURROSIVITY OF GEOTHERMAL BFINES. PRCGRESS FEPORT FOR PCRICC ENOING JUNE 1976.

AUTHOR- POSEY, F.A.;FRLKO, A.A. CCAK RIDGE NATIONAL LAB., TENN. (USA). CHEMISTRY GIVISICN) •

REFERENCE- CORRCSIVITY OF GECTHERMAL BRINES. PROGRESS REPORT FOR. PERIOC ENOING JUNE 1976. ORNL/TM-5 188, OAK RIDGE NATIONAL LABCRATCRY, OAK FIDGE, TENA.. DEC 1976, 33 P..

OESCRIPTORS- GEOTHERMAL BRINES: CORROSION: CCERCSIVE EFFECTS: STEELS: ELECTROCHEMICAL CORROSION: PITTING CORROSICN: EXPERIMENTAL RESULTS: LABOFATORY EQUIFMENT: GRAPHS: FIGURES. 


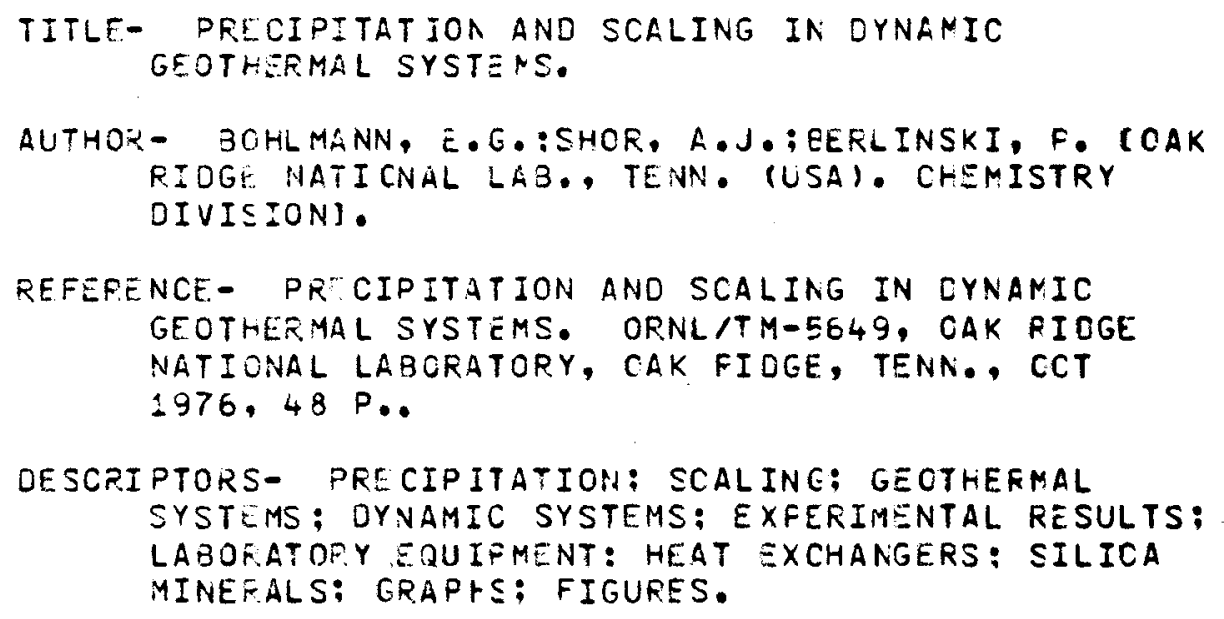

333

MC CCWELL 76 BR INE TREATMENT/SCALING BRINE TREATMENT/CCRROSION

TITLE- SCPUBBING OF CHLLRIICES IN CAREY-OVER WATER FROM GEOTHERMAL WELL. SEPARATCRS.

AUTHOR- MC DOWELL, G.C. COEPARTMENT OF SCIENTIFIC AND INUUSTRIAL FESEARCH, C/MCW, TAUFO (NEW ZEALANOII.

FEFERENCE- PROCEEDINGS--SECOND UNITED NATIONS SYMPOSIUM ON THE DEVELOPMENT ANO USE OF GEOTHERMAL RESOLRCES. LAWRENCE BERKELEY LAB., UNIV. OF CALIFOFNIA, BERKELEY, CALIF., 1976, $\mathrm{V}$. $3, P .1737-1740$.

DESCRIPTORS- GEOTHERMAL WELLS; WAIKAKEI GEOTHERMAL FIELO: GCOTHERMAL FLUIDS; CHLCFIOES; SCFLBBING; STEAM SEPAFATORS.

334

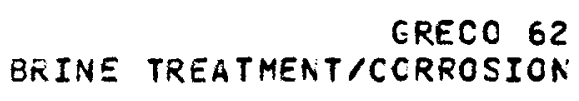

TITLE- CORROSION OF IFON IN AN H2S-CO2-H2O SYSTEM. 


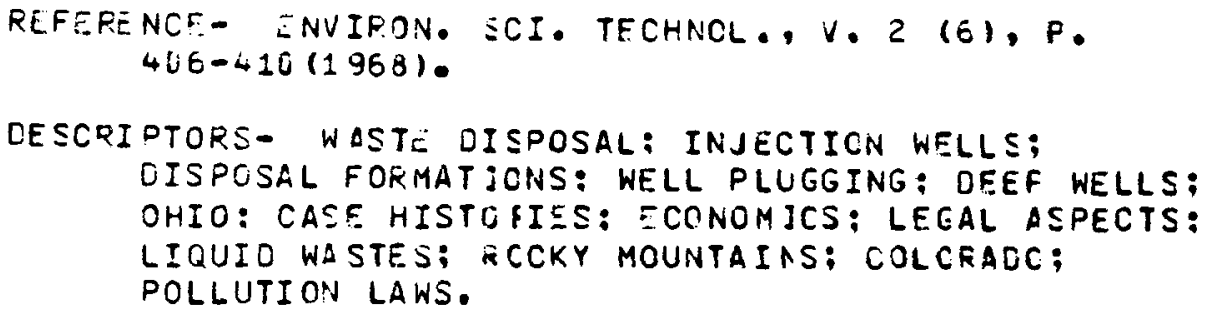

340

VETTER 70

BRINE TREATMENT/SCALING

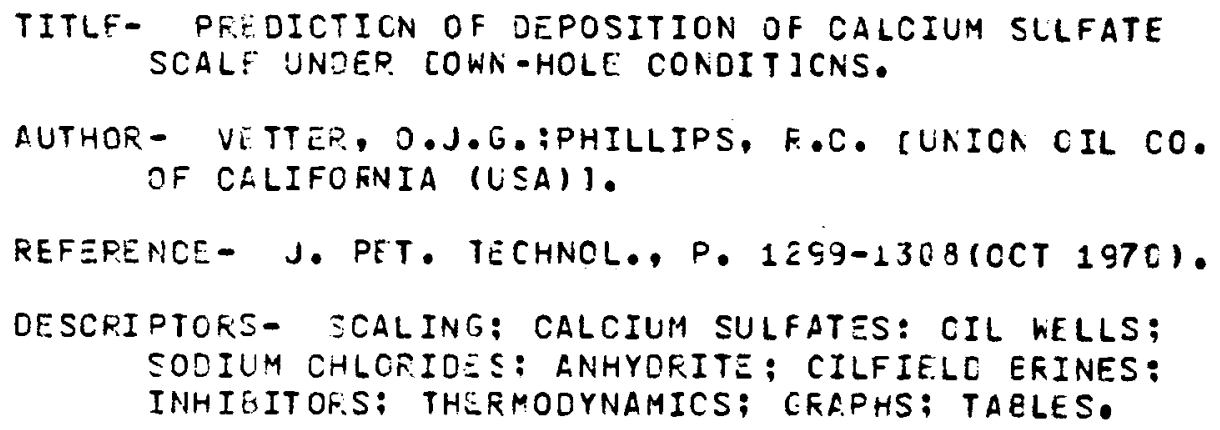

341

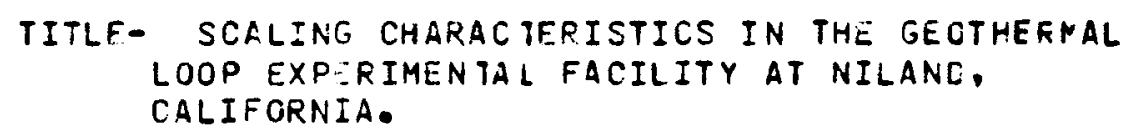




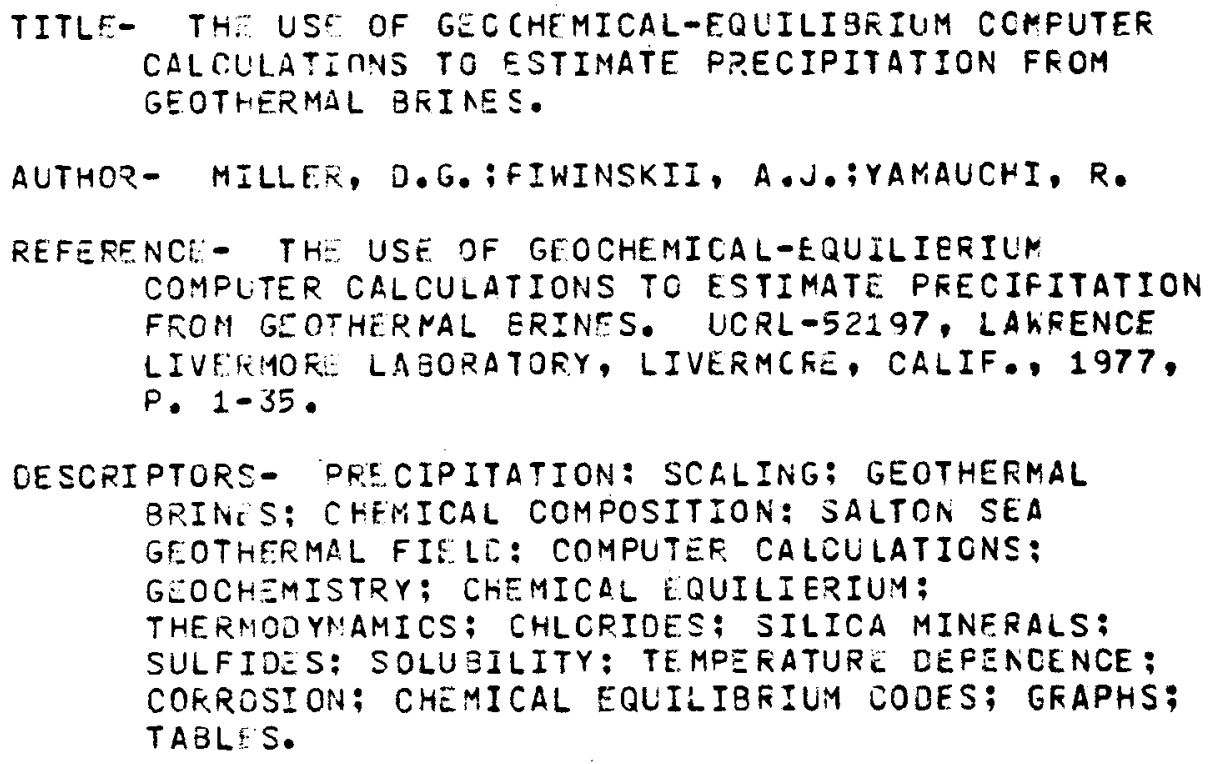

343

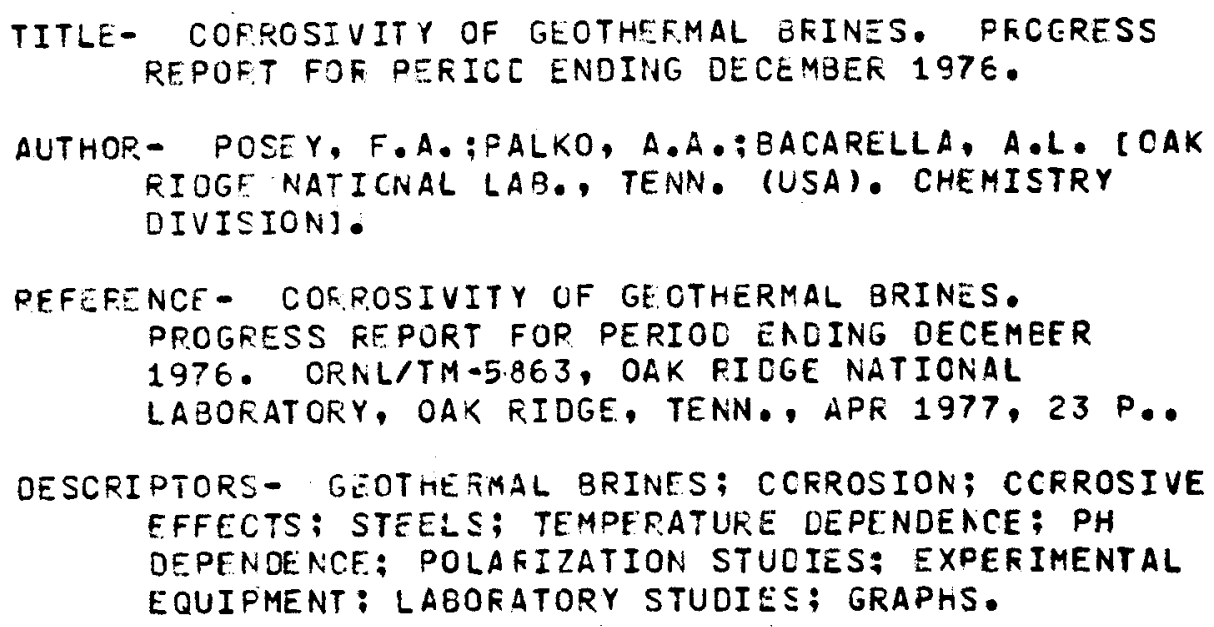


TITLE- REMOVAL OF SILICA FROM WATEF EY COLD FROCESS. AUTHOR- BETZ, L.D.:NOLL. C.A.:MAGUIRE, J.J. C K.H. AND L.D. GETZ., PHILADELPHIA, PENN. (USAI).

REFERENCE - INO. ENG. CHEM.. V. 32, P. 1320-1323 10CT 19401 .

DESCRIPTORS- SILICA MINERALS; DESCALING; BOILERS; PH DEPENDENCE: TEMFERATURE DEPENOENCE; ALUMINUM HYDROXIDES: LABCFATORY STUDIES.

345

TITLE- REMOVAL OF SILICA FROM WATEF BY HCT FFCCESS. AUTHOR- BETZ, L.O.;NOLL, C.A.;MAGUIRE, J.J. Ih.H. AND L.D. BETZ, PHILADELPHIA, PENN. (USA)].

REFERENCE - INO, ENG. CHEM.. V. 32, P. 1323-1329 1OCT 19401 .

DESCRIPTORS- SILICA MINERALS; DESCALING; BOILERS; MAGNESIUM INORGANIC COMPOUNDS: TEMPERATURE DEPENDENCE: PH CEPENDENCE: LABORATORY STUDIES.

346

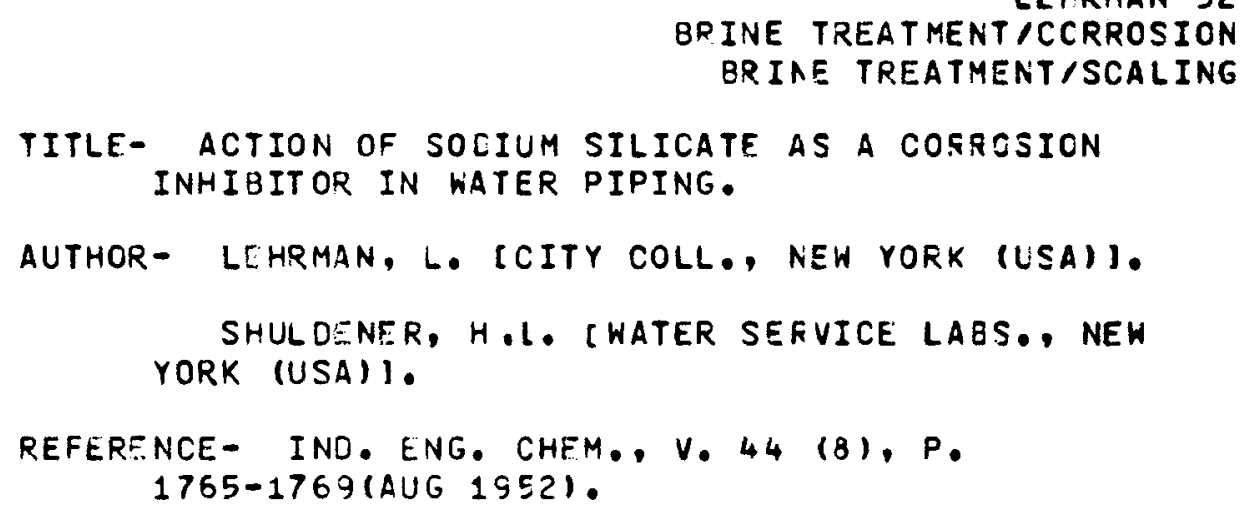




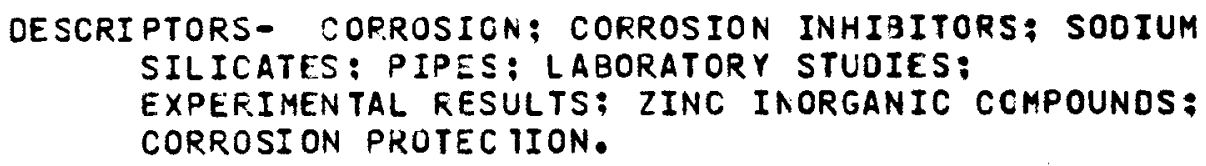

\section{7}

MIOKIFF 76

BRINF. TREATMENT/SCALING

TITLE- AMORPHOUS SILICA SCALE IN COOLING WATERS.

AUTHOR- MIDKIFF, W. S. ILOS ALAMOS SCIENTIFIC LAB.,

N. MEX. (USA)) .

FOYT, H.P. (WATER TREATMENT SPECIALIST).

REFERFNCE - AMORPHOUS SILICA SCALE IN COCLING WATERS. LA-UR-75-2313, LOS ALAMOS SCIENTIFIC LAB., LOS ALAMOS, N: MEX., 1976, 22 P..

DESCRIPTORS- SILICA MINERALS: AMORPHOUS STATE; COOLING TOWERS; DESCALING: SCALING CONTRGL; WATER. TREA TMENTS: CORROSION INHIBITORS; CHELATING $\triangle G E N$ IS: FIGURES; X-RAY DIFFRACTION.

348

TITLE- CHEMICAL FIXATION OF OXYGEN.

AUTHOR - PYE, D.J. C COK CHEMICAL CC.. PITTSELRG,

CALIF. IUSA). GREAT WESTERN DIVISIONI.

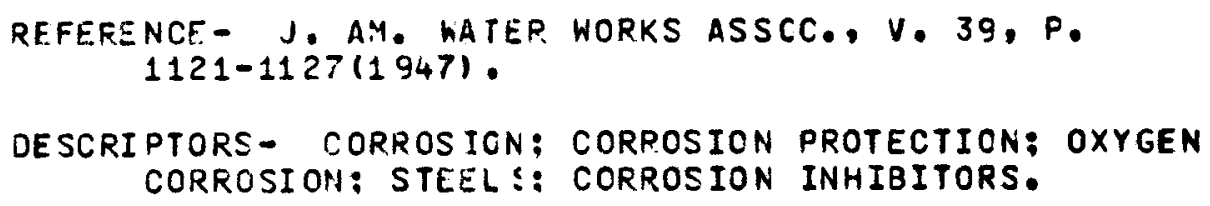

